CRISTIANE OLIVEIRA REIMBERG

\title{
COMUNICAÇÃO, EDUCAÇÃO E SAÚDE: \\ a Ação da Pastoral da Criança para a Cidadania na Arquidiocese de São Paulo
}




\section{COMUNICAÇÃO, EDUCAÇÃO E SAÚDE: a Ação da Pastoral da Criança para a Cidadania na Arquidiocese de São Paulo}

Dissertação apresentada ao Programa de Pós-Graduação em Ciências da Comunicação, Área de Concentração Interfaces Sociais da Comunicação, Linha de Pesquisa Políticas e Estratégias de Comunicação, da Escola de Comunicações e Artes da Universidade de São Paulo, como exigência parcial para obtenção do Título de Mestre em Ciências da Comunicação, sob a orientação da Prof. Dra. Alice Mitika Koshiyama. 
Reimberg, Cristiane Oliveira

Comunicação, Educação e Saúde: a ação da Pastoral da Criança para a cidadania na Arquidiocese de São Paulo / Cristiane Oliveira Reimberg. -- São Paulo: C. O. Reimberg, 2009.

271 p. + anexos.

Dissertação (Mestrado) Programa de Pós Graduação em Ciências da Comunicação. Área de Concentração: Interfaces Sociais da Comunicação - Escola de Comunicações e Artes da Universidade de São Paulo.

Orientadora: Prof. Dra. Alice Mitika Koshiyama.

1. Movimentos sociais e Igreja 2. Cidadania 3. Políticas de Comunicação 4. Comunicação Popular. I. Título.

CDD 21. ed. -302 
FOLHA DE APROVAÇÃO

Cristiane Oliveira Reimberg

COMUNICAÇÃO, EDUCAÇÃO E SAÚDE: a

Ação da Pastoral da Criança para a Cidadania

na Arquidiocese de São Paulo

Dissertação apresentada à

Escola de Comunicações e Artes

da Universidade de São Paulo

para a obtenção do título de mestre

em Ciências da Comunicação

Aprovada em:

Banca examinadora:

Prof. Dr:

Instituição:

Assinatura:

Prof. Dr:

Instituição:

Assinatura:

Prof. Dr:

Instituição:

Assinatura: 
A todas as crianças do Brasil, especialmente para aquelas que não têm seus direitos respeitados, e a todos aqueles que acreditam que é possível agir em defesa da infância, assim como fazem os voluntários e voluntárias da Pastoral da Criança. 


\section{Agradecimentos}

Primeiramente agradeço à Prof. Dra. Alice Mitika Koshiyama pela orientação desse trabalho nesses três anos. Cada comentário foi essencial para o desenvolvimento da pesquisa assim como para os ajustes finais, levantando questões que eu, algumas vezes, não tinha percebido. Não posso deixar de agradecer pela dedicação e disposição a ajudar. Obrigada pelo conhecimento partilhado, pelos autores apresentados e pelo exemplo que você é.

Aos meus pais, José e Lourdes, por sempre terem me incentivado a estudar, me animado nos momentos difíceis da pesquisa, pela preocupação constante, por me ouvirem e pela contribuição que cada um deu ao seu modo a esse trabalho. E a minha irmã, Leiliane, pelo apoio e preocupação, ajudando-me quando necessário e me ouvindo sempre.

Às professoras que me deram aulas na ECA. Cada uma deixou sua marca na minha pesquisa: a Prof. Dra. Rosana de Lima Soares com a questão da identidade; a Prof. Dra. Maria Otília Bocchini com conceitos sobre texto acessível e também dicas de leituras; a Prof. Dra Nancy Nuyen Ali Ramadan, sugerindo autores para uma discussão jornalística e sobre gêneros em relação ao Jornal Pastoral da Criança; a Prof. Dra. Ecléa Bosi, com a questão da memória. Mais uma vez devo agradecer a Alice, como professora, suas aulas foram fundamentais para tratar a cidadania. Também agradeço às aulas do Prof. Dr. Jesús MartínBarbero, que contribuíram com textos e novas ideias para essa pesquisa.

Aos amigos e amigas, especialmente, a Margarida Maria Adamatti, pelas dicas preciosas e a amizade de todas as horas; a Paula Bosi pelo apoio de sempre; Márcia Augusta de Paula por me ouvir nos momentos de desespero; a Cristina Sato, pela convivência durante o mestrado e a constante troca de ideias.

Também agradeço a editora da Revista Proteção, Daniela Bossle, a João Batista e Alexandre Gusmão, pelas folgas concedidas e o diálogo constante que vivencio na editora, permitindo conciliar a pesquisa acadêmica e a carreira de jornalista.

Para finalizar, um agradecimento especial a todas as pessoas que me concederam entrevistas e possibilitaram que essa pesquisa se realizasse. Sem as voluntárias e voluntários da Pastoral da Criança nada disso seria possível. Cito ainda o nome de algumas pessoas da Pastoral da Criança, que me ajudaram muito além das entrevistas: Maria do Rosário Gazzola, Selma Leite, a ex-assessora da Pastoral da Criança Aline e a estagiária da assessoria de imprensa, Amanda. Essas quatro pessoas sempre me socorreram quando precisei. Muito obrigada! 
Sozinhos, ficamos livres, mas não podemos exercitar a nossa liberdade. Com o grupo, encontramos os meios de multiplicar as forças individuais, mediante a organização. É assim que nosso campo de luta se alarga e que um maior número de pessoas se avizinha da consciência possível, rompendo as amarras da alienação. É também pela organização que pessoas inconformadas se reúnem, ampliando, destarte, sua força e arrastando, pela conviç̧ão e o exemplo, gente já predisposta mas ainda não solidamente instalada nesses princípios redentores.

Milton Santos 


\section{Resumo}

Esse estudo retrata a ação da Pastoral da Criança na Arquidiocese de São Paulo, analisando como funciona na prática o processo educativo e comunicativo idealizado pela organização. Autores que trabalham a relação entre comunicação, cidadania, jornalismo, educação popular e saúde da criança estão presentes no campo teórico. Na pesquisa de campo, ouvimos 61 pessoas que atuam na entidade sobre as ações que realizam, o uso que fazem do Jornal Pastoral da Criança e como veem ou vivem a questão da cidadania. Ainda entrevistamos outras dez pessoas ligadas à Coordenação Nacional ou programas específicos, das quais destacamos a fundadora da Pastoral da Criança, Zilda Arns, e a jornalista responsável pelo jornal, Sonia Prati. Paralelamente às entrevistas, optamos por uma pesquisa participante, com o intuito de aprofundar nosso conhecimento sobre as práticas estabelecidas no cotidiano do voluntariado. Também analisamos a acessibilidade do texto do Jornal Pastoral da Criança, além de relacionar as respostas de leitoras e leitores com o conteúdo apresentado nas matérias, buscando ver se havia uma contribuição efetiva para a construção da cidadania. Nesse percurso, pudemos perceber as políticas comunicativas da Pastoral da Criança e seus efeitos nas comunidades. Realiza-se uma comunicação popular ao mesmo tempo em que se preocupa com a imagem da organização na mídia. O diálogo é a base do processo educativo e da comunicação estabelecida pela Pastoral da Criança, que procura ouvir representantes do voluntariado de diversas formas e incentivar a participação no sistema comunicativo, tanto no jornal quanto na internet e no programa semanal de rádio que desenvolve. Nesse processo educadoras são também educandas assim como as receptoras das mensagens podem também construí-las. O caminho trilhado possibilita que reflexão e ação caminhem juntas rumo à construção da cidadania nas comunidades.

Palavras-chave: construção da cidadania, políticas de comunicação, comunicação e educação, comunicação popular, saúde e desenvolvimento infantil, Pastoral da Criança, Jornal Pastoral da Criança. 


\begin{abstract}
This study shows the action of Pastoral of Child in Archdiocese of São Paulo, analyzing how it works in practice the educational and communicative process designed by the organization. Authors that work the relationship between communication, citizenship, journalism, popular education and health of the child are present in the theoretical. In field research, we heard 61 people about the actions they perform working in the entity, their use of the Journal Pastoral of the Child and how they see or live with issues of citizenship. Also interviewed ten people linked to the National Coordination or specific programs, of which highlight the founder of Pastoral of Child, Zilda Arns, and the journalist and publisher of the journal, Sonia Prati. In same time, we chose a participant research, in order to deepen our understanding of established practices by voluntary daily. We also analyzed the accessibility of the text of the Journal Pastoral of the Child, and relate the responses of readers with the content displayed in the reports, trying to see if there was an effective contribution to building citizenship. Along the way, we can realize the communication policies of the Pastoral of the Child and its effects on communities. There is a popular communication while, in the same time, it is concerned with the organization's image in the media. Dialogue is the basis of the educational and communicative process established by the Pastoral of Child, which seeks to hear the voluntaries of the various forms and encourage the participation in the communication system, both the newspaper and the Internet and the weekly radio program that develops. In this process teachers are also educative as well as the recipients of messages can also build them. The path trodden enables reflection and action go hand in hand to the construction of citizenship in the communities.
\end{abstract}

Keywords: construction of citizenship, political communication, communication and education, popular communication, health and child development, Pastoral of the Child, Journal of Pastoral of the Child. 


\section{Sumário}

Introdução.

Capítulo I - A Pastoral da Criança e o envolvimento da Igreja Católica nas questões sociais

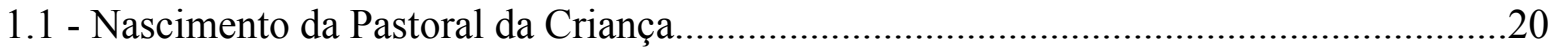

1.2 - As raízes da educação praticada pela Pastoral da Criança............................................23

1.3 - Os reflexos do Golpe na ação social da Igreja...........................................................26

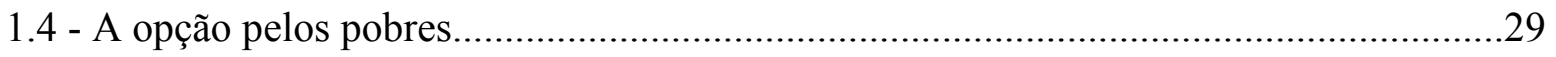

1.5 - O legado da Teologia da Libertação.................................................................................

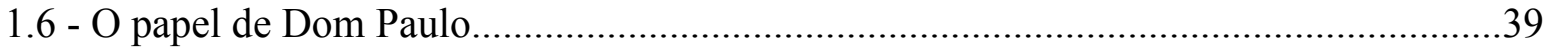

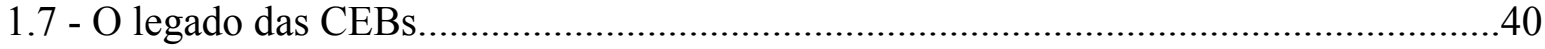

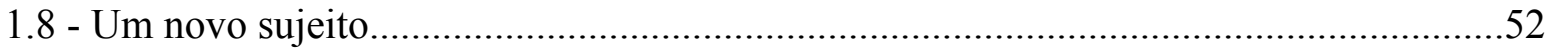

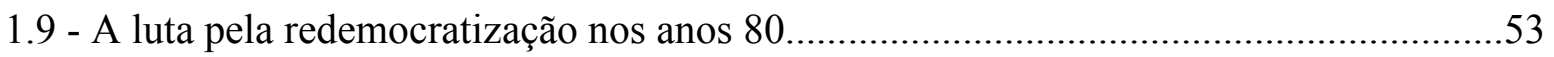

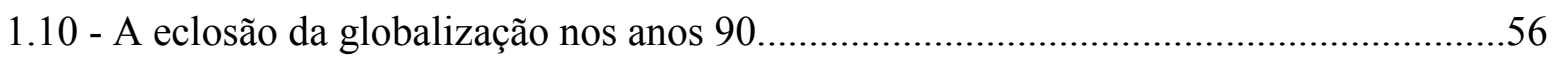

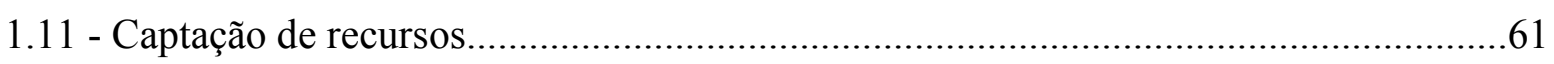

Capítulo II - A comunicação praticada pela Pastoral da Criança.................................69

2.1 - Complexidade das ações comunicativas.......................................................................69

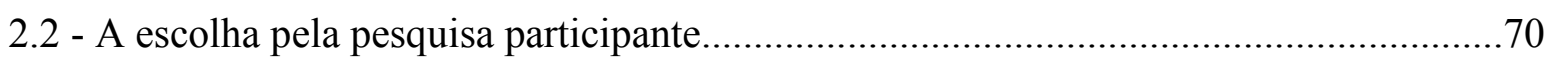

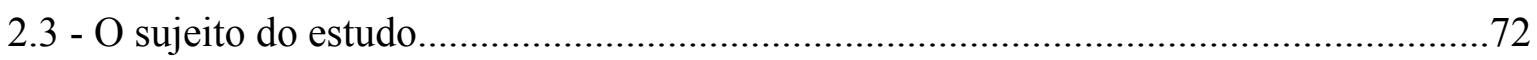

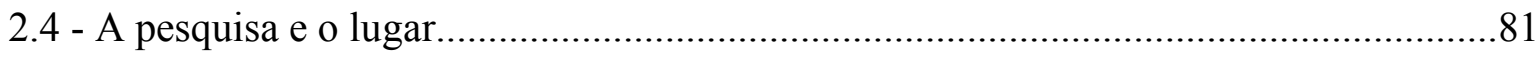

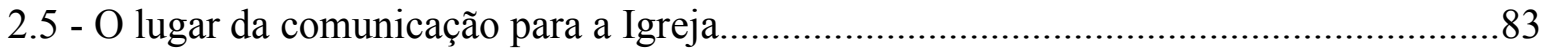

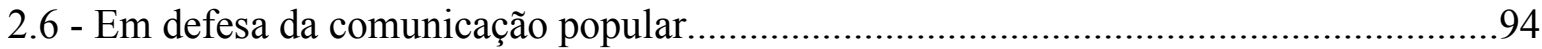

2.7 - Uma questão de comunicação organizacional...............................................................110

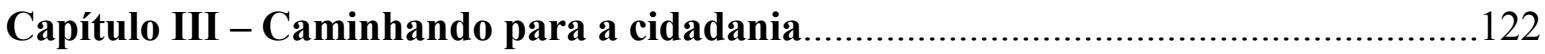

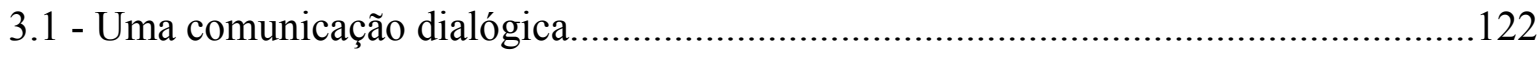

3.2 - A relação entre a comunicação e a educação................................................................131

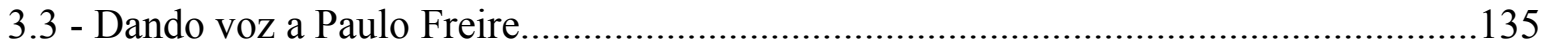


3.4 - Uma comunicação que educa e liberta.

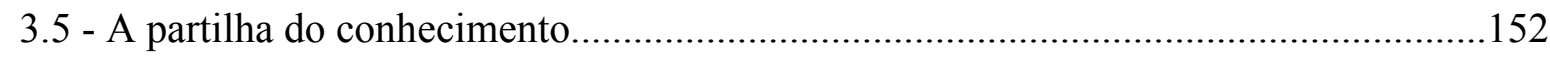

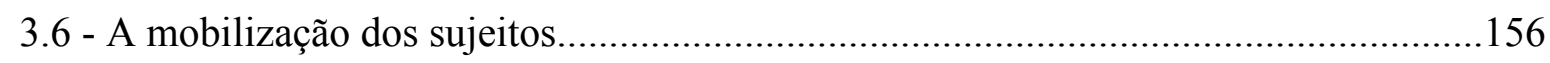

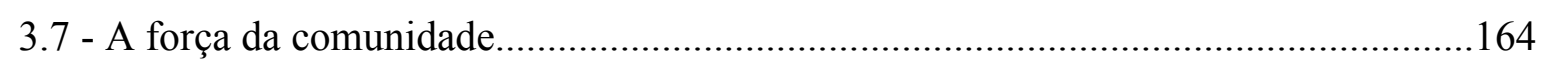

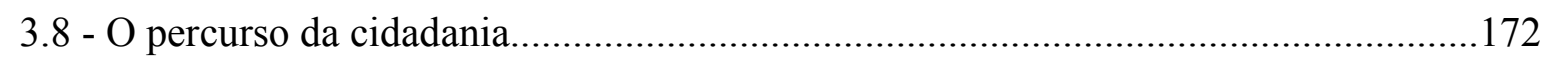

3.9 - A cidadania para a Pastoral da Criança................................................................. 179

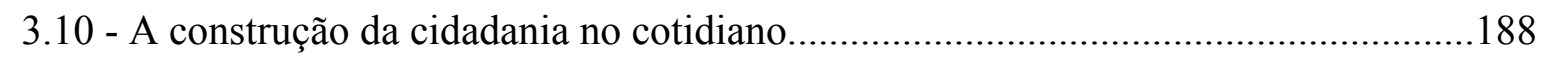

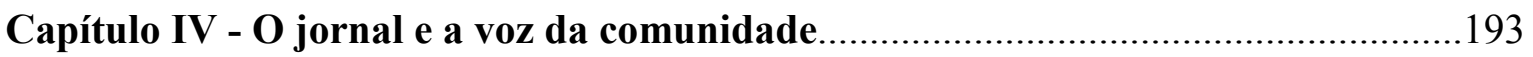

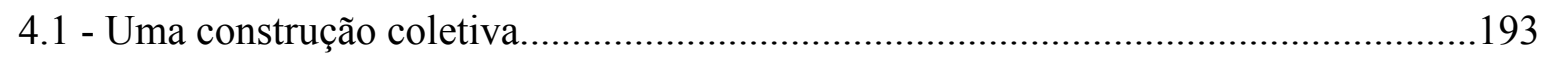

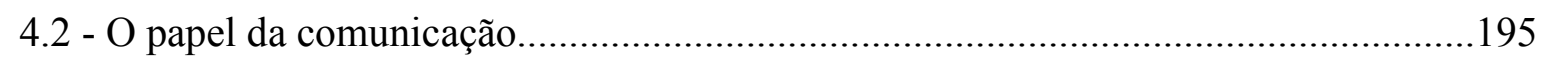

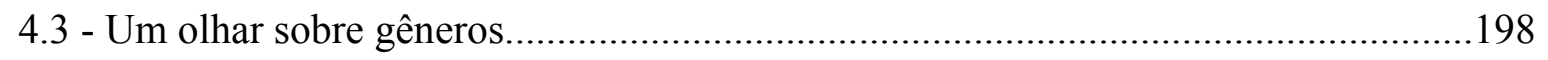

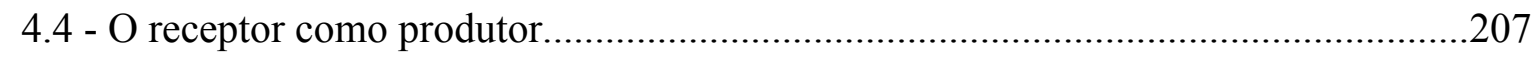

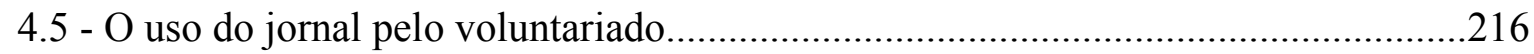

4.6 - A contribuição do jornal para a cidadania.............................................................22

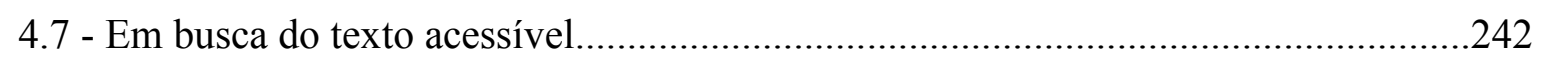

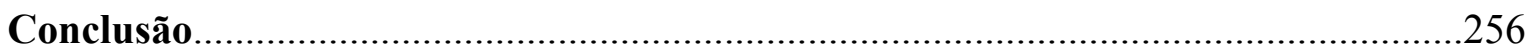

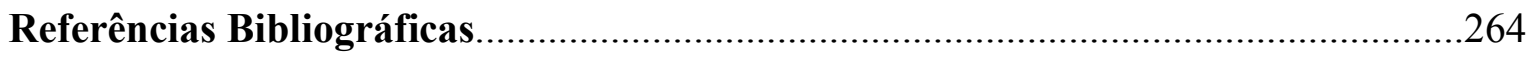

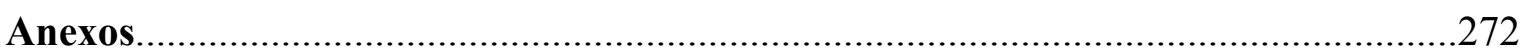

Anexo I - Entrevistadas e entrevistados ligados à Coordenação Nacional........................272

Anexo II - Entrevistadas e entrevistados ligados à Arquidiocese de São Paulo.................274

Anexo III - Imagens de atividades da Pastoral da Criança.............................................285

Anexo IV - Páginas do Jornal Pastoral da Criança .......................................................287 


\section{Introdução}

Neste estudo avaliamos como a Pastoral da Criança delineou um processo educativo e comunicativo que contribui para a construção da cidadania nas comunidades em que atua. Para tanto, optamos por estudar a região da Arquidiocese de São Paulo, que se divide em seis setores: Belém, Brasilândia, Ipiranga, Lapa, Santana e Sé. Assim incluímos em nosso corpo de pesquisa toda a região norte, oeste e central da capital paulista, além de parte da zona sul e leste.

Para realizá-lo, atuamos em diferentes frentes. Uma dessas linhas foi a pesquisa participativa, na qual assumimos um papel no grupo e passamos a participar de reuniões, encontros e atuar em questões ligadas à comunicação, a partir das orientações de Curitiba. Esse papel de comunicadora é realizado por outras pessoas na Pastoral da Criança, em diferentes regiões do Brasil. Isso nos permitiu conhecer a fundo o processo educativo, baseado na multiplicação do conhecimento e ver a práxis do voluntariado na cidade de São Paulo. Presenciamos como ação e reflexão caminham juntas.

Outra atuação consistiu em realizar entrevistas semiabertas com voluntários e voluntárias da Pastoral da Criança, mas também com membros da Coordenação Nacional. Na Arquidiocese de São Paulo, falamos com 61 pessoas, 10 membros de cada uma das seis regiões episcopais (Belém, Brasilândia, Ipiranga, Lapa, Santana e Sé) e a coordenadora da Pastoral da Criança na Arquidiocese de São Paulo. Essa área é denominada pela entidade como SP1. Ainda no nível arquidiocesano, entrevistamos a coordenadora do Programa de Geração de Renda em Serviços Domésticos, Silvana Aparecida Gonçalves, além de uma mãe de criança atendida pela Pastoral - Maria José de Araújo - e uma avó - Roseli Bueno Neri. O intuito foi entender como funcionava essa ação da Pastoral da Criança, que capacita pessoas e encaminha para o trabalho.

Também entrevistamos a coordenadora nacional da Pastoral da Criança, irmã Vera Lúcia Altoé, por duas vezes; a fundadora da Pastoral da Criança, Zilda Arns, por três vezes; a jornalista responsável pelo Jornal Pastoral da Criança, Sonia Prati; e o coordenador estadual da Pastoral da Criança/SP, José de Anchieta. Ainda conversamos com dois multiplicadores estaduais de São Paulo, que fazem parte da equipe nacional, para entender melhor o funcionamento da prática educativa desenvolvida pela Pastoral da Criança - Isaac Elias Filho e Maria Lúcia de Campos Guerra Caldin; e com a nutricionista da organização, para entender 
as ações desenvolvidas para a nutrição da criança, Caroline Dallabona. No total, foram entrevistadas 71 pessoas.

Para entender a configuração da comunicação e a educação na Pastoral da Criança, analisamos as 61 entrevistas realizadas na Arquidiocese de São Paulo, relacionando-as com a recepção do Jornal Pastoral da Criança. Procuramos perceber de que forma ele é lido, quais partes contribuem mais para a ação e como ele é utilizado. Assim pudemos avaliar se ele contribui para o processo educativo da Pastoral da Criança. Paralelamente observamos o conteúdo da publicação, entre os meses de fevereiro de 2008 e junho de 2009 , mapeando as seções do jornal e como a cidadania é retratada nelas. Também buscamos ver a acessibilidade do texto, como necessidade fundamental para uma contribuição efetiva.

O projeto surgiu a partir de monografia $^{1}$ realizada no curso de pós-graduação em jornalismo social na Cogeae (Coordenadoria Geral de Especialização, Aperfeiçoamento e Extensão), da PUC/SP, entre os anos de 2004 e 2006. Na época, realizamos um estudo comparativo sobre o conteúdo do Jornal Pastoral da Criança e a cobertura da Folha de S.Paulo sobre a Pastoral da Criança. Para tanto, foram analisados os exemplares de setembro de 2003 a agosto de 2004 do Jornal Pastoral da Criança, e os exemplares de $2001^{2}$ e do período de setembro de 2003 a agosto de 2004 da Folha de S.Paulo. Constatamos que o jornal da entidade realizava uma comunicação popular que contribuía para a educação em saúde, enquanto a Folha de S.Paulo fazia uma cobertura personalista focada na dimensão política de Zilda Arns.

Mas essa análise foi centrada no conteúdo. Era preciso aprofundar os conhecimentos sobre as características do jornal e avaliar se na prática essa formação em saúde realmente existia. Vimos que seria necessário estabelecer critérios para analisar essa comunicação. Mais do que isso, seria preciso realizar um estudo de recepção. Ouvir as leitoras para saber o que ocorria na ação cotidiana. Fomos descobrindo ao longo da realização desta pesquisa de mestrado que não bastava falar do jornal e dar voz aos leitores, era preciso conhecer todo o processo educativo da Pastoral da Criança. Foi dessa necessidade que surgiu a opção pela pesquisa participante. Por meio dela, pudemos conhecer o sistema educativo e as políticas de comunicação da entidade. Somente com esse conjunto foi possível avaliar se havia na Pastoral

\footnotetext{
1 "Dois olhares sobre a relação entre jornalismo e a Pastoral da Criança: a comunicação popular do jornal da entidade e a cobertura jornalística da Folha de S.Paulo".

${ }^{2}$ Escolhemos esse ano para avaliar a Folha de S.Paulo também devido à indicação da Pastoral da Criança ao Prêmio Nobel. Já o Jornal Pastoral da Criança de 2001 não foi analisado porque ele havia passado por uma reformulação em setembro de 2003. Assim optamos por duas análises, uma do período pós-reforma do Jornal da Pastoral e da Folha nesse mesmo período, fazendo-se uma comparação; e outra apenas da Folha no período em que ocorreu a primeira indicação da Pastoral da Criança ao Nobel.
} 
da Criança na Arquidiocese de São Paulo uma comunicação e educação que contribuíam para a construção da cidadania nas comunidades. Dessa forma, descobrimos a comunicação popular, educativa e dialógica, na qual voluntários e voluntárias são educandos e educadores, e também leitores e comunicadores.

Mas por que a Pastoral da Criança? O que nos levou a escolher essa organização? Como dissemos, essa escolha é consequência de uma opção anterior, nossa pesquisa na PUC/SP. Naquela época, fazíamos o curso de especialização em jornalismo social e desde o início, em 2004, desejávamos estudar algum tema que relacionasse comunicação e criança. Isso porque fazíamos um trabalho voluntário na Igreja Católica com crianças e adolescentes desde 1995, discutindo temas da atualidade e relacionando com o evangelho. Queríamos então fazer um estudo em que pudéssemos relacionar a nossa formação de jornalista com a ação educativa voluntária que desenvolvíamos, voltada às crianças.

A primeira ideia foi falar sobre o Estatuto da Criança e do Adolescente (ECA). Na aula de projeto, já em 2005, a professora Margarethe Steinberger ressaltou que precisávamos encontrar um enfoque jornalístico novo para a questão. Como não conseguíamos desenvolver esse novo olhar, passamos a pesquisar na internet vários temas ligados à infância e encontramos o site da Pastoral da Criança.

Apesar de realizar ações com crianças e pré-adolescentes em uma paróquia ${ }^{3}$ da diocese de Santo Amaro, no Grajaú ${ }^{4}$, havia 10 anos na época, não conhecíamos a Pastoral da Criança, apesar de já ter ouvido falar da organização. A dimensão do trabalho social realizado e o sistema comunicativo desenvolvido nos impressionaram e optamos por realizar a pesquisa. Mas o tempo de estudo nessa pós-graduação lato sensu não nos permitia fazer uma pesquisa de campo. Assim quando acabamos o trabalho de análise comparativa do conteúdo do Jornal Pastoral da Criança com a cobertura da Folha de S.Paulo chegamos à conclusão de que esse estudo deveria ser aprofundado. No mestrado, por meio da pesquisa de campo, analisamos como essa comunicação se realizava efetivamente nas comunidades e se realmente a informação sobre saúde, direitos e deveres surtia efeito. Procuramos ver se na prática havia uma comunicação de caráter educativo, que contribuía para a construção da cidadania.

Esse nosso interesse também é justificado pela dimensão do trabalho da Pastoral da Criança. A organização foi criada em 1983 pela médica sanitarista Zilda Arns em Florestópolis. Naquela época, o local contava com uma mortalidade infantil de 127 por mil.

\footnotetext{
${ }^{3}$ Paróquia Nossa Senhora Aparecida.

${ }^{4}$ Distrito da zona sul de São Paulo, que segundo estimativas da SEADE (Fundação Sistema Estadual de Análise de Dados) do ano de 2008, tem uma população de 430.669 habitantes. A paróquia fica no bairro Parque Grajaú, que pertence ao distrito.
} 
Passados 24 anos, as estatísticas de 2007 no local apontavam o número de 28 mortes em cada mil crianças nascidas. Qual o papel da organização nessa história? A mobilização de pessoas da comunidade, especialmente as mulheres, foi fomentada pela Pastoral da Criança. A ação de pessoas da região multiplicaria o conhecimento entre a comunidade, agindo em prol do desenvolvimento integral da criança e reduzindo a mortalidade infantil.

Dados de 2007, divulgados pela Pastoral da Criança em 2008, apontam o acompanhamento de uma média mensal de 1.816.261 crianças menores de seis anos e 94.987 gestantes em 4.066 municípios de todos os estados brasileiros. Isso significa que há Pastoral da Criança em todas as 263 dioceses da Igreja Católica no país. São 6.414 paróquias e 42.319 comunidades acompanhadas por 261.962 pessoas voluntárias. No total, 1.407 .743 famílias são visitadas mensalmente.

Os números alcançados pela Pastoral da Criança impressionam, mas certamente a estrutura montada pela organização assim como a mobilização dessas voluntárias, já que 92\% são mulheres, é ainda mais marcante. Para começar, passam por uma capacitação de 15 encontros com três horas cada. Nessa formação, conhecem o Guia do Líder, um livro com 304 páginas que traz informações sobre como realizar as visitas domiciliares às famílias e explicações sobre a saúde da gestante e da criança nas diferentes fases de desenvolvimento.

Esse é apenas o começo do processo educativo. Ao terminar o curso, as voluntárias recebem o nome de líderes. Elas desenvolverão um papel de liderança na comunidade e multiplicarão o conhecimento com as famílias que acompanhará. A situação das crianças é relatada no Caderno do Líder e também apresentada para a Coordenação Nacional através das Folhas de Acompanhamento e Avaliação das Ações Básicas de Saúde e Educação na Comunidade (FABs).

$\mathrm{Na}$ comunidade, as líderes se reúnem com a coordenadora para avaliarem e refletirem o trabalho que vem sendo feito, as dificuldades enfrentadas, tudo baseado no método "ver, julgar e agir", acrescido de mais dois tópicos "avaliar" e "celebrar". É a chamada "Reunião de Reflexão e Avaliação”. Essas reuniões também ocorrem em nível paroquial, chamado de ramo pela Pastoral da Criança e também no setor. Há assembleias setoriais, regionais e

\footnotetext{
${ }^{5}$ Números relativos ao ano de 2007 e publicados no informativo especial do ano de 2008 "Promovendo a vida plena para todas as crianças", produzido pela entidade. Os dados também estão disponíveis em http://www.pastoraldacrianca.org.br/htmltonuke.php?filnavn=pastcri-dev/arquivos_genericos/portal/tabela.html , o que foi verificado no dia 10/08/2008, às 21 h40.
} 
estaduais. Os coordenadores ou coordenadoras de cada instância ${ }^{6}$ são escolhidos por meio de eleição através de lista tríplice.

Percebe-se toda uma estrutura educativa que tem a comunicação como grande aliada. A Pastoral da Criança produz um jornal mensal com tiragem de 280 mil exemplares, o Jornal Pastoral da Criança. Também produz o programa de rádio semanal Viva a Vida com 15 minutos de duração e que é retransmitido por 2063 emissoras ${ }^{7}$. No caso da cidade de São Paulo, o material é editado por uma voluntária da Brasilândia e transmitido dentro de um programa sobre pastorais na rádio Nove de Julho, às quartas-feiras, entre às $17 \mathrm{~h} 30 \mathrm{e} 18 \mathrm{~h}$. A Pastoral da Criança possui ainda site e blog${ }^{8}$. Outra iniciativa é o novo projeto de comunicação popular que começou a ser desenhado em 2008.

Essa estrutura fomenta a ação, contribuindo para a construção da cidadania nas comunidades. As discussões não se limitam às visitas e ao desenvolvimento das crianças. As pessoas passam a conhecer seus direitos e deveres, sendo estimuladas a pensar em políticas públicas e participar de conselhos comunitários. Esse trabalho, o número de voluntárias e voluntários, a quantidade de crianças acompanhadas e a estrutura de educação e comunicação justificam a importância de se estudar a Pastoral da Criança.

O informativo especial do ano de 2008 "Promovendo a vida plena para todas as crianças", produzido pela entidade, usa títulos como "A partilha que salva" e "Transformação Social" para definir a ação da Pastoral da Criança. "A partilha do conhecimento ajuda a promover o desenvolvimento integral da criança e a melhoria da qualidade de vida das famílias. O Guia do Líder é a base da capacitação e o texto de referência dos voluntários que se dedicam a Pastoral da Criança." (PASTORAL DA CRIANÇA, 2008, p.3)

Essa ação ultrapassou o território brasileiro e já está presente em outros 19 países, com a Pastoral da Criança Internacional: Paraguai (1994), Angola (1996), Colômbia (2001), Timor Leste (2001), México (2002), Moçambique (2002), Argentina (2003), Bolívia (2003), Panamá (2003), Filipinas (2004), República Dominicana (2004), Uruguai (2004), Honduras (2005), Guatemala (2005), Venezuela (2005), Guiné (2007), Guiné-Bissau (2007), Haiti (2008) e Guiné-Conacry (2008).

O reconhecimento internacional é outro ponto a se destacar em relação à Pastoral da Criança. O que fica evidente a partir dos prêmios que a instituição já recebeu: Rey de España

\footnotetext{
${ }^{6}$ Isso ocorre nos setores como é o caso do SP1, que abrange a arquidiocese de São Paulo. Também ocorrem com as coordenadoras das regiões episcopais e com o coordenador estadual.

${ }^{7}$ Dados de 2007.

${ }^{8} \mathrm{O}$ endereço do site da Pastoral da Criança é http://sites.pastoraldacrianca.org.br/pastoraldacrianca/ , já o blog pode ser acessado em um link no próprio site ou diretamente no endereço: http://sig.pastoraldacrianca.org.br/wordpress/
} 
de Derechos Humanos (Governo Espanhol/2005); Objetivos de Desenvolvimento do Milênio (Governo Brasileiro e PNUD/2005); Direitos Humanos e Cultura da Paz (UNESCO/2000); Prêmio Criança e Paz e Maurice Pate (Unicef/1991 e 1993); entre outros. Também foi indicada pelo governo brasileiro ao Prêmio Nobel da Paz de 2001 a 2004.

A fundadora da Pastoral da Criança, Zilda Arns, também recebeu várias condecorações: Prêmio Empreendedor do Ano - Responsabilidade Social (Ernst \& Young/2008); Woodrow Wilson (Woodrow Wilson Foundation/2007); Opus Prize (Opus Prize Foundation/2006); Heroína da Saúde Pública das Américas (OPAS/2002); $1^{\circ}$ Prêmio de Direitos Humanos (USP/2000); Personalidade Brasileira de Destaque no Trabalho em Prol da Saúde da Criança (Unicef/1998), entre outros. (PASTORAL DA CRIANÇA, 2008, p.5)

Sem dúvida, esse reconhecimento passa pela comunicação e depende dos seus efeitos nas comunidades. É esse universo de comunicação criado pela Pastoral da Criança que estudamos, analisando a recepção de voluntários e voluntárias e o reflexo que essa comunicação popular tem para a construção da cidadania e uma conscientização sobre a saúde. Assim, buscamos avaliar as interfaces sociais da comunicação da entidade, relacionando as estratégias de comunicação, a produção jornalística através do jornal da entidade e seus reflexos nas comunidades atendidas pela Pastoral em parte da cidade de São Paulo.

Dessa forma, objeto de nossa pesquisa foi a recepção e o conteúdo comunicacional da Pastoral da Criança através do jornal da entidade, confrontando-se a organização política da Pastoral da Criança e a necessidade de uma comunicação popular com um texto acessível, que tenha características educativas para que os conceitos de saúde e cidadania passem a fazer parte do repertório e das ações das líderes e coordenadoras.

O objetivo geral desse trabalho é estudar a relação entre a comunicação praticada pela Pastoral da Criança e a educação para a cidadania na Arquidiocese de São Paulo. Um dos objetivos específicos é ver como a entidade faz uso dessa comunicação como parte do processo educativo para a saúde e cidadania em parte da capital paulista, principalmente, através do uso que voluntários e voluntários fazem de seu jornal. Assim quisemos olhar para essas pessoas e ouvi-las. Também esteve entre nossos objetivos específicos relacionar esse uso com o conteúdo da publicação, mapeando temas e a acessibilidade do texto.

Como objetivo teórico, tentamos relacionar as práticas de comunicação da Pastoral da Criança com diferentes vertentes do estudo da comunicação, especialmente, a comunicação popular e a recepção, mas também com uma perspectiva educativa a partir dos conceitos de Paulo Freire. Já o objetivo prático foi ver o uso da comunicação no processo educativo nas 
próprias comunidades a partir de um trabalho de campo realizado nas mesmas, com estudo da recepção e do conteúdo do jornal da entidade.

Como hipótese, estabelecemos que essa rede de comunicação da Pastoral da Criança dá subsídios para as comunidades e motiva o desenvolvimento da ação de voluntários e voluntárias, contribuindo para a construção da cidadania. Através dela se conscientiza sobre direitos e se fortalece a ação e o papel da mulher nas comunidades, possibilitando a edificação de uma identidade entre os membros, apesar de limitações advindas da Igreja, como o fato de não se pensar com liberdade a questão da sexualidade, por exemplo.

Nesse processo, o jornal da entidade é uma das maiores fontes de informação. O Jornal Pastoral da Criança existe desde 1985. Começou como trimestral, depois bimestral e desde setembro de 2003 se tornou mensal. Algumas edições com encartes especiais saem com 24 páginas, quando não há encarte, são 16. Tem formato tablóide e tiragem de 280 mil exemplares. Ele é destinado aos líderes da Pastoral, às comunidades acompanhadas e aos parceiros da entidade.

Observando o jornal, percebe-se que ele mostra os acontecimentos das comunidades, com espaço para o voluntariado mandar seus textos e publicá-los, na seção Comunidades. Também apresenta uma seção chamada Aprendendo Mais, dedicada a questões da saúde, com abordagem explicativa. Também há textos sobre direitos e deveres. O jornal encontra-se ainda na internet no formato PDF, podendo ser visto da mesma forma que o impresso.

Um estudo encontrado sobre a Pastoral da Criança que aborda a comunicação é o de Elson Faxina - "Participação e Subjetividade em Movimentos Sociais", dissertação de mestrado apresentada na ECA/USP, em 2001. No entanto, seu tema central é a construção e a legitimação do sujeito nos movimentos sociais a partir da Pastoral da Criança. Faxina (2001) verificou que os leitores, na maioria das vezes, procuram matérias que falem das comunidades e se ver no jornal. O pesquisador entrevistou 60 líderes e coordenadoras locais da entidade, de diferentes partes do Brasil. Também é interessante destacar que ele trabalhou como responsável pelo jornal no final dos anos 80 e nos anos 90 .

Outro estudo centrado na Pastoral da Criança e que aborda a comunicação foi realizado por Aline Fernanda Lima - "O Jornal Pastoral da Criança como Instrumento de Promoção de Cidadania”, como dissertação de mestrado apresentada no Programa de PósGraduação em Comunicação Social da Universidade Metodista de São Paulo, em 2007. A pesquisadora entrevistou 18 voluntárias da Arquidiocese de Aparecida/SP e cinco membros da Coordenação Nacional da Pastoral da Criança. 
Verifica-se que, tanto o Jornal Pastoral da Criança como os demais veículos de comunicação da Pastoral da Criança e a própria estrutura comunicativa da entidade se mostram como canais alternativos para a promoção do trabalho da pastoral e para a mobilização das comunidades, respondendo pela construção de espaços comunitários de debate sobre as questões que afligem a criança brasileira e a sociedade como um todo. Também geram oportunidade de informação e comunicação para as comunidades na busca da realização dos seus problemas. Podemos destacar, por exemplo, o enfoque em assuntos como direitos da criança e da gestante, dicas sobre ações básicas de saúde e de cidadania. (LIMA, 2007, p.162)

Outro pesquisador que estudou a Pastoral da Criança foi Juciano de Sousa Lacerda, com a dissertação de mestrado em Ciências da Comunicação: "Redes digitais de solidariedade social. As estratégias e táticas de produção de significação em redes sociais de comunicação midiatizadas pelo digital. Um estudo de caso da Recomsol - Rede de Comunicadores Solidários à Criança”, realizada em 2003 na Universidade do Vale do Rio dos Sinos/RS. Não chegamos a ler a dissertação, mas consultamos dois artigos do autor que falam do Jornal Pastoral da Criança, produzidos na época em que realizava essa pesquisa. Lacerda (2002a, p.11-12) avalia que a seção Comunidades é o " "carro chefe' do Jornal da Pastoral”, caracterizando-a como "o lugar mais estratégico" no "processo de midiatização, para a interação entre a Pastoral da Criança" e o voluntariado. Aponta um discurso pedagógico na publicação. Ainda mostra que o leitor fala em forma de notícias nessa seção a partir de mecanismos reguladores estabelecidos (LACERDA, 2002b).

O nosso estudo se diferencia dos demais, primeiro, pelo local da análise: a Arquidiocese de São Paulo. Assim conseguimos abranger grande parte da cidade de São Paulo, exceto os extremos sul e leste, os quais pertencem às dioceses de Campo Limpo e Santo Amaro, e São Miguel Paulista, respectivamente. Ao optar pela arquidiocese de São Paulo, conseguimos entrevistar pessoas de diferentes bairros do centro, das zonas norte e oeste, mas também sul, com localidades do setor Ipiranga, e leste, com bairros do setor Belém. Vale lembrar que as regiões episcopais da arquidiocese de São Paulo abrangem, cada uma, vários distritos, que por sua vez reúnem vários bairros.

Outra diferença de nosso estudo é que ele não se limita a ouvir as pessoas como fez Faxina (2001) e Lima (2007), avaliando a recepção, ou analisar o jornal como Lacerda (2002a,b). Nossa pesquisa analisa a produção jornalística da entidade e a recepção desse material nas comunidades atendidas pela Pastoral da Criança na cidade de São Paulo, além de fazer uma pesquisa de campo. Buscamos entender a relação da política de comunicação da entidade com a necessidade de uma comunicação popular, avaliando os resultados que isso traz na prática para as coordenadoras e líderes. Para tanto, relacionamos a pesquisa 
participante com o estudo de recepção e do conteúdo produzido, avaliando a dimensão educativa da ação e sua contribuição para a construção da cidadania. Conseguimos assim ampliar a análise e ainda comparar os resultados alcançados com o que Faxina (2001), Lima (2007) e Lacerda (2002a,b) já haviam descoberto.

A pesquisa bibliográfica para esse trabalho baseou-se principalmente em contribuições de estudiosos sobre movimento social, cidadania, comunicação popular, jornalismo, educação, estudos de recepção e acessibilidade do texto. Estabelecemos três vertentes para a pesquisa: Análise histórica dos movimentos sociais a partir dos anos 70 e sua relação com a Igreja, especialmente com a Pastoral da Criança; Estudo comunicacional: comunicação popular, jornalismo, comunicação organizacional e estudos de recepção, relacionando comunicação e o papel educativo, além de avaliar a acessibilidade do texto; e A questão da cidadania que trouxe conceitos de educação, direitos e identidade.

Contamos com contribuições importantes de diversos autores. Na primeira vertente, por exemplo, Sader (1988), Frei Betto (1981), Puntel (1994), Lima (1981) e Faxina (2001). Já na segunda, destacamos Peruzzo (1998) e Puntel (1994) para a análise de comunicação popular e, para uma perspectiva educativa da comunicação, Marques de Melo (1981), Soares (1988), e Kaplún (1998). Para os conceitos de jornalismo, autores como Abramo (1988), Chaparro $(1998,2007)$ e Dines (1986). A recepção foi avaliada a partir dos conceitos de Martín-Barbero (2002, 2006), Lopes (2005), Sousa (2002), Hall (2006) e mais uma vez Kaplún (1998). Já para a acessibilidade, utilizamos Kato (1985), Kleiman (2007) e Bocchini e Assunção (2006) e Bocchini (1994). Na última vertente teórica, apontamos a contribuição de autores como Manzini-Covre (1993), Martín-Barbero ${ }^{9}$, Gentilli (1995), Heller (1989), Santos (2007, 2008) e para a questão da educação Freire (1977, 1992, 1996, 2005, 2008).

Essas vertentes e os resultados da pesquisa foram trabalhados nos quatro capítulos dessa dissertação. O primeiro intitulado como "A Pastoral da Criança e o envolvimento da Igreja Católica nas questões sociais" procura mostrar a história da Pastoral da Criança e a relação das práticas da organização com os movimentos sociais e a ação da Igreja Católica no Brasil, especialmente a Teologia da Libertação e as Comunidades Eclesiais de Base (CEBs). Também procuramos apontar a reconfiguração dos movimentos sociais nos anos 80 e 90, e como a Pastoral da Criança se coloca nesses momentos.

\footnotetext{
${ }^{9}$ Diversos textos que fazem parte de uma apostila usada pelo professor doutor Jesús Martín-Barbero no curso "Novas sensibilidades: entre urbanias e cidadanias", ministrado na ECA/USP, entre os dias 15 e 19 de setembro de 2008 .
} 
O segundo capítulo - "A comunicação praticada pela Pastoral da Criança" - procura delinear as ações comunicativas da Pastoral da Criança. Para tanto fazemos uma análise a partir da perspectiva da comunicação popular e de estudos que mostram a face educativa da comunicação. Também pontuamos como a Igreja Católica tem visto ao longo dos anos a comunicação e como isso é trabalhado pela Pastoral. Ainda fazemos uma breve análise da comunicação da organização sem perder de vista o viés popular e educativo da comunicação realizada para e com o voluntariado.

Já o terceiro capítulo - "Caminhando para a cidadania" - continua a olhar para a comunicação, aprofundando o estudo sobre seu teor educativo e sua relação dialógica, vendo o direito de comunicar e de conhecer como uma forma de se educar e se conscientizar sobre os problemas sociais. Essa partilha de conhecimento educa e liberta, mobilizando os sujeitos para construir a cidadania em suas comunidades a partir das práticas cotidianas.

Por fim, o último capítulo - "O jornal e a voz da comunidade" - apresenta os resultados do estudo de recepção e dá voz a leitoras e leitores, que mostram como usam o Jornal Pastoral da Criança e de que forma o conteúdo contribui para a ação. Também olhamos para o jornal e a configuração das seções, mapeando assuntos abordados que têm relação com a cidadania e avaliando a acessibilidade do texto.

Ainda colocamos alguns anexos no final do trabalho, que procuram mostrar um pouco do que foi relatado durante a dissertação. Assim, selecionamos algumas fotos das reuniões e encontros acompanhados. Também anexamos a lista com dados das 71 entrevistadas e entrevistados durante a pesquisa. Para encerrar, apresentamos algumas páginas do Jornal Pastoral da Criança. 


\section{Capítulo I - A Pastoral da Criança e o envolvimento da Igreja Católica nas questões sociais}

\section{1 - Nascimento da Pastoral da Criança}

A Pastoral da Criança conseguiu destaque no cenário nacional por mobilizar mulheres das comunidades em que atua para agir em prol da saúde de crianças até seis anos. Todo esse trabalho é subsidiado por uma atividade intensa de capacitação, somada a políticas de comunicação e a valorização da ação dessas mulheres, chamadas de líderes. Considerada um organismo de ação social da Conferência Nacional dos Bispos do Brasil (CNBB), a entidade é, sem dúvidas, sob essa óptica, a pastoral de maior mobilização da Igreja Católica no país.

Não há outro movimento voltado para as questões sociais que tenha mais voluntários. Eram 261.962 em 2007, espalhados por 4.066 municípios de todos os estados brasileiros. Essas pessoas acompanhavam uma média mensal de 1.816.261 crianças menores de 6 anos. Isso em todas as 263 dioceses da Igreja Católica no Brasil, chegando a 6.414 paróquias e 42.319 comunidades. Dos que abraçaram a chamada "missão" da Pastoral da Criança, 141.869 eram líderes comunitários, ou seja, visitam as famílias para acompanhar o desenvolvimento das crianças, enquanto 120.093 são membros das equipes de apoio. Há 1.407.743 famílias acompanhadas mensalmente assim como 94.987 gestantes. $^{10}$

É importante ressaltar que, em 2007, 92\% das líderes eram mulheres. Essa participação das mulheres é uma marca dos movimentos sociais e organizações que os fomentam, como confirma Peruzzo:

As mulheres vão quebrando o tabu de uma vocação que restringe suas atividades aos afazeres domésticos e passam a envolver-se ativamente em movimentos sociais. Sua participação, geralmente superando a dos homens, não se limita só as organizações especificamente femininas, mas estende-se a praticamente todas as outras e às comunidades eclesiais de base, assumindo até posições de liderança. (PERUZZO, 1998, p.70).

\footnotetext{
${ }^{10}$ Números relativos ao ano de 2007 e publicados no informativo especial do ano de 2008 "Promovendo a vida plena para todas as crianças", produzido pela entidade. Os dados também estão disponíveis em http://www.pastoraldacrianca.org.br/htmltonuke.php?filnavn=pastcri-dev/arquivos_genericos/portal/tabela.html , o que foi verificado no dia 10/08/2008, às 21 h40.
} 
O principal objetivo da Pastoral da Criança, realizado por essas mulheres, é agir em prol do desenvolvimento integral da criança, como pode ser visto pelo lema da entidade: "para que todas as crianças tenham vida e vida em abundância" "1 . A história da criação da entidade é contada tanto no site da Pastoral da Criança como em informativos especiais ${ }^{12}$. Esse começo nos remete ao ano de 1982, quando o então diretor executivo do Unicef, James Grant, sugeriu ao, na época, cardeal arcebispo de São Paulo, Dom Paulo Evaristo Arns que a Igreja Católica poderia ensinar às mães ações como o preparo do soro oral.

Dom Paulo procurou sua irmã, Zilda Arns:

Expliquei a ele que, a partir da minha experiência em saúde pública, como médica pediatra e sanitarista, o que mais faltava às mães era o conhecimento e a solidariedade fraterna. Assim não bastava ensinar as mães a usarem o soro oral. Também seria preciso ensiná-las sobre a importância do pré-natal, aleitamento materno, vigilância nutricional, vacinação, desenvolvimento integral das crianças, relações humanas, afim de que elas soubessem e fossem estimuladas a cuidar de seus filhos para que "crescessem em sabedoria e graça” (Lc 2,52). (PASTORAL DA CRIANÇA, 2008, p. 4)

Dessa conversa, nasce a Pastoral da Criança, fundada em 1983 com a aprovação da CNBB. A ação começou em Florestópolis, que faz parte da Arquidiocese de Londrina, norte do Paraná. Nessa época, a mortalidade infantil na cidade era de 127 mortes por mil nascidos vivos. A população local era formada em maioria por boias-frias, profíssão de $74 \%$ das famílias.

Ao descrever esse início do trabalho, Zilda Arns afirma ter desenvolvido uma metodologia comunitária que teve como inspiração o evangelho e o milagre da multiplicação de pães. Segundo o evangelista São João, dois peixes e cinco pães saciaram a fome de cinco mil homens, sem contar as mulheres e crianças. "Assim se organizariam as pequenas comunidades para multiplicar o saber e a solidariedade, com espírito de FÉ e VIDA”, conta a fundadora. A ideia era ter um "sistema de informação simples" que pudesse ser entendido pelos líderes e os estimulasse a serem "agentes de transformação social”. (PASTORAL DA CRIANÇA, 2008, p. 4)

A multiplicação é uma palavra fundamental para a Pastoral da Criança. Assim como é a educação e a comunicação. Observando o funcionamento da entidade, vemos que para uma pessoa se tornar uma líder precisa passar por uma capacitação de 15 encontros de três horas.

\footnotetext{
${ }^{11}$ A frase é retirada da Bíblia: JO 10, 10

12 Estamos usando o informativo especial "Promovendo a vida plena para todas as crianças" , de 2008, e também informações obtidas através da pesquisa participante, que desenvolvemos durante o mestrado para mostrar como é a prática educativa e comunicativa da entidade.
} 
Nessa formação, ela aprende o que é a Pastoral da Criança, suas ações, como fazer as visitas às famílias e tantas outras informações sobre saúde presentes no Guia do Líder. A última edição desse guia, de 2007, conta com 304 páginas contendo textos, fotos e ilustrações. Já o Caderno do Líder serve para anotar dados sobre a saúde de cada criança acompanhada e também tem o uso explicado no guia. Essa voluntária, muitas vezes, trabalhou antes como apoio nas atividades. Em uma das reuniões que a pesquisadora participou em São Paulo a atuação de apoio foi definida por uma voluntária como um estágio, no qual a pessoa conhece a Pastoral da Criança e vê se quer mesmo participar do grupo.

A líder é capacitada por uma capacitadora, de preferência da comunidade em que vive, que ainda é ou foi líder. Essa capacitadora teve formação dada por uma multiplicadora ${ }^{13}$. É uma prática educativa na qual educandas e educadoras se misturam como na educação defendida por Paulo Freire. Os encontros de multiplicadores ou as capacitações também mostram um ambiente participativo, em que se compartilha o conhecimento. Todos são estimulados a falar e participar das atividades. Não se trata de uma educação bancária ${ }^{14}$. $\mathrm{O}$ mesmo vemos nas reuniões de reflexão e avaliação entre coordenadores ou nos encontros com as lideranças. Discutem-se os problemas que afetam as famílias, a saúde da mãe e da criança, os limites da ação da voluntária e como vencer as dificuldades. Essa prática é aliada ao que a Pastoral da Criança chama de mística, que envolve leituras bíblicas, reflexões ou dinâmicas que tratam da fé e da espiritualidade.

Não é possível entender esse trabalho realizado pela Pastoral da Criança sem olhar para o passado da Igreja Católica e o seu envolvimento com o movimento social. Não é possível ver as ações educativas e não se lembrar de Paulo Freire. Não é possível participar de uma reunião e não pensar nas CEBs (Comunidades Eclesiais de Base). Seria imaginável o nascimento da Pastoral da Criança em uma Igreja Católica que não tivesse tido esse passado? Quais são as raízes dessa ação praticada nos dias atuais? É isso que buscaremos observar ao longo desse capítulo.

\footnotetext{
${ }^{13}$ Optamos por usar as palavras no feminino já que a maioria das líderes são mulheres assim como grande parte do voluntariado, correspondendo a $92 \%$ da liderança em 2007.

${ }^{14}$ Freire (2005, p.65-66) explica que a educação, muitas vezes, caracteriza-se pela narração de conteúdos. O sujeito é como um narrador. Os objetos são os educandos, que apenas ouvem, tratados como recipientes a serem preenchidos pelo educador. Recebem depósitos, que precisam ser guardados e arquivados. "Dessa maneira a educação se torna um ato de depositar, em que os educandos são os depositários e o educador o depositante. Em lugar de comunicar-se, o educador faz 'comunicados' e depósitos que os educandos, meras incidências, recebem pacientemente, memorizam e repetem. Eis aí a concepção 'bancária', em que a única margem de ação que se oferece aos educandos é de receberem os depósitos, guardá-los e arquivá-los ".
} 


\section{2 - As raízes da educação praticada pela Pastoral da Criança}

Freire (2008, p.67) defende uma educação que leve o povo à reflexão "sobre si mesmo, sobre seu tempo, sobre suas responsabilidades, sobre seu papel”. Faz isso no exílio, em um momento que o Brasil vivia sob a ditadura militar. Fala em uma época datada, mas podemos afirmar que essas características devem ser buscadas em qualquer época. Também apontava a necessidade de uma educação que colocasse o povo em constante diálogo, um com o outro $(2008$, p.98) e o levasse a "uma nova postura diante dos problemas de seu tempo e de seu espaço" (2008, p.101).

(...) teria o homem brasileiro de ganhar a sua responsabilidade social e política, existindo essa responsabilidade. Participando. Ganhando cada vez maior ingerência nos destinos das escolas do seu filho. Nos destinos do seu sindicato. De sua empresa, através de agremiações, de clubes, de conselhos. Ganhando ingerência na vida do seu bairro, de sua Igreja. Na vida de sua comunidade rural, pela participação atuante em associações, em clubes, em sociedades beneficentes. (FREIRE, 2008, p.100)

Essa participação defendida por Freire nos anos 60, também faz parte do discurso e da prática da Pastoral da Criança, como presenciamos na pesquisa participante realizada, o que será relatado no próximo capítulo dessa dissertação. O Jornal Pastoral da Criança, do qual trataremos no quarto capítulo, também traz textos que falam de conselhos de saúde, da criança e do adolescente, incentivando a participação do voluntariado. O mesmo foi visto nas reuniões presenciadas.

O arcebispo Aldo di Cillo Pagotto, presidente do Conselho Diretor da Pastoral da Criança, afirmou:

Priorizamos visitas às famílias pobres, atendidas ou não pelos órgãos públicos. Articulamo-nos com os Conselhos de Saúde. Selamos parcerias, exercendo a concidadania e o controle social de políticas públicas especificamente voltadas à mãe e à criança nas áreas de saúde, educação, capacitação para o trabalho e renda. Damos assistência aos mais empobrecidos ou em conflito com a lei, reorientando mulheres em presídios femininos. Abraçamos missões populares e práticas especiais junto a migrantes em locais de busca de oportunidades. Perplexos, enxergamos na sociedade na qual nos inserimos, terríveis contradições, provenientes da ausência de valores éticos e morais, bem como da miséria e da exclusão. (PASTORAL DA CRIANÇA, 2008, p.2) 
Por sua vez, nesse mesmo informativo, Zilda Arns fala em promoção da saúde e cidadania, melhoria das políticas públicas e democratização do saber ao retratar a ação da Pastoral da Criança.

As visitas às famílias, de que fala o bispo, são, na maioria das vezes, feitas por uma pessoa da comunidade, que também vive dificuldades parecidas, mas assumiu um papel de sujeito. São casos como de Michaele Gonçalves Souza, de 13 anos, apoio da Pastoral da Criança, que entrevistamos e vive em Heliópolis, a maior favela de São Paulo ${ }^{15}$, na região do Ipiranga, zona sul. Ou de Ana Paula de Lima Silva, 28 anos, que é coordenadora de uma comunidade da Pastoral da Criança na Favela da Vila Prudente, bairro da zona leste de São Paulo.

Freire (2008, p.62-63) fala da necessidade do povo passar de espectador do processo a participante através de uma tomada de consciência. Deixa a posição de inferioridade e passa a ter autoconfiança. Não aceita a posição de objeto. Vimos essa consciência ao entrevistar essas jovens. Assim Ana Paula analisa a situação e a ação local: "A maioria dos líderes mora lá. Tem tráfico e todos os problemas de uma favela, mas o nosso trabalho é bem recebido lá dentro. A dificuldade é da realidade por si própria: há famílias bem carentes, falta acesso às coisas, a energia é precária, os becos são apertadinhos".

Certamente essa postura de sujeito tomada pelas líderes passa pela capacitação, pelas reuniões mensais de avaliação nas comunidades, pelas visitas. Essa educação que valoriza o debate traz características da educação libertadora defendida por Freire desde os anos 60. Para o autor (2005, p.67), “a razão de ser da educação está no seu impulso inicial conciliador. Daí que tal forma de educação implique a superação da contradição educador-educando, de tal maneira que se façam ambos educadores e educando”. A estrutura de capacitação da Pastoral, as dinâmicas das reuniões e encontros assim como o diálogo entre líderes e mães remetem a essa igualdade no compartilhamento do saber, como sugere Paulo Freire.

As ideias de Paulo Freire sobre educação, que passaram a circular pelo mundo nos anos 60, começaram ainda nos anos 40, a partir de um trabalho de educação para adultos. Como relata Lima (1981, p. 23), Freire militava no movimento Ação Católica, trabalhando com a população pobre do Recife. No início dos anos 60 , criou um método de alfabetização de adultos em 40 horas. É criador da metodologia das palavras geradoras ${ }^{16}$, que hoje é usada

\footnotetext{
15 Segundo informações da Prefeitura, o local contava com 100 mil habitantes em 2006. Disponível em $<$ http://portal.prefeitura.sp.gov.br/noticias/empresas_autarquias/cohab/2006/01/0003, verificado em 28/02/2009, às $17 \mathrm{~h} 05$

16 "Palavras geradoras são aquelas que, decompostas em seus elementos silábicos, propiciam, pela combinação desses elementos, a criação de novas palavras", define Freire (2008, p.120). O autor explica que essas palavras
} 
pela Pastoral da Criança em programas de alfabetização para líderes ou familiares das crianças acompanhadas.

Lima (1981, p.38) conta que a Ação Católica foi criada pelo Papa Pio XI, em meados da década de 20. Com a participação de leigos, veio para o Brasil em 1935, seguindo o modelo italiano, que era centralizador e autoritário. Em 1945, por não ter eficácia, foi reestruturada seguindo o modelo franco-belga. Para o seu desenvolvimento, contou com o apoio dos dominicanos. Deu origem a movimentos estudantis em 1950: Juventude Universitária Católica (JUC) e Juventude Estudantil Católica (JEC).

Esse período também é retratado por Sader (1991, p.150-151). A partir dos anos 50, a Igreja Católica passa a sofrer uma perda de influência junto à população mais pobre. É nesse contexto que surge a ligação de grupos de leigos da Ação Católica ${ }^{17}$ a lutas populares, como faziam a JUC e a Ação Católica Operária. O autor também destaca a criação do Movimento de Educação de Base (MEB), no Nordeste em 1961 e que setores do clero de Pernambuco criam sindicatos rurais. $\mathrm{O} \mathrm{MEB}^{18}$ era inspirado no método de educação de Paulo Freire.

Lima (1981, p.46-47) destaca o fato de que essa organização com base na Igreja Católica, que foi criada pela CNBB, tinha o apoio do governo federal. Havia programas de alfabetização para a população rural com utilização de rádio-escolas, que contavam com pessoas no local treinadas e usavam emissoras de rádio da Igreja. Os participantes eram membros e ex-membros da Ação Católica.

Esses movimentos de educação deixaram um legado, que permitiram a Pastoral da Criança trilhar um caminho voltado para a educação e questões sociais. A utilização de rádio, por exemplo, iniciada pelo MEB nos anos 60, desde 1990 faz parte da vida da Pastoral da Criança. Também se usa o rádio para ações de caráter educativo. Mais de duas mil emissoras de rádio no país retransmitem o programa Viva a vida, que a entidade produz. A maioria dos programas traz informações sobre saúde. Eles são utilizados na íntegra ou em partes, uma prática que é incentivada para que cada localidade dê a cara de sua região ao programa.

\footnotetext{
são escolhidas a partir do universo vocabular do grupo a ser alfabetizado. Desenvolvia-se a partir dessas palavras um "processo de alfabetização pela conscientização".

${ }^{17}$ Em 1947, passa a ser orientada pelo então padre Helder Câmara, que mais tarde se tornaria bispo e ajudaria a organizar a criação da CNBB em 1952. A Ação Católica vai aos poucos voltando seu olhar para as classes populares e dando início a uma política pastoral de educação popular que contava com o apoio da juventude de classes médias urbanas. (ANDRADE, 1989, p. 47-48)

18 Anteriormente ao MEB, em 1960, Paulo Freire e outros intelectuais criam o MCP (Movimento de Cultura Popular) no Recife. Era influenciado por ideias socialistas e cristãs. Buscava conscientizar as pessoas. (LIMA, 1981, p.46)
} 
Outra semelhança entre o MEB e a Pastoral da Criança é que o movimento dos anos 60 utiliza o método "ver, julgar e agir", já a Pastoral usa a mesma metodologia acrescentado os termos “avaliar" e “celebrar". Segundo Lima (1981, p.38), a Juventude Universitária Católica, nos anos 50, já tinha o "ver, julgar e agir" como seu lema.

A metodologia é utilizada pela Pastoral da Criança durante as reuniões de reflexão e avaliação, que ocorrem mensalmente nas comunidades.

Durante a reunião, os líderes avaliam os progressos de suas ações, utilizando a metodologia do 'Ver, Julgar, Agir, Avaliar e Celebrar'. Nesse encontro, eles observam a realidade das famílias que acompanham, julgam as causas e conseqüências de determinada situação, unem esforços e avaliam quais alternativas podem ajudar a família ou a comunidade. (PASTORAL DA CRIANÇA, 2007, p. 9)

O acréscimo da palavra "celebrar" se deve a outra ação da Pastoral da Criança: o Dia de Celebração da Vida. Uma vez por mês líderes, mães e crianças se reúnem para comemorar as conquistas e "buscar soluções para melhorar a qualidade de vida delas" (PASTORAL DA CRIANÇA, 2007, p.9). No encontro, o local é enfeitado como uma festa, há lanche e um momento de espiritualidade. As crianças são pesadas, o que é anotado no cartão de cada uma. Por sua vez, essa informação, assim como as colhidas nas visitas, vão para o Caderno do Líder. Já na reunião de avaliação, as líderes e a coordenadora da comunidade vão preencher as Folhas de Acompanhamento e Avaliação das Ações Básicas de Saúde e Educação na Comunidade (FABS). Esse material é enviado para a Coordenação Nacional, em Curitiba e registrado em um sistema de informações.

Percebe-se, dessa forma, que as práticas educativas da Pastoral da Criança e mesmo suas ações têm muito das características do que começou a ser trabalhado pela Igreja Católica nos anos 50 e 60. As atividades dos anos seguintes continuam usando esses processos educativos, que vão sendo retrabalhados até chegar ao que a Pastoral da Criança é hoje.

\section{3 - Os reflexos do Golpe na ação social da Igreja}

Com o golpe de 64, segundo Sader (1991, p.151), as iniciativas mais populares são reprimidas. Setores conservadores da Igreja Católica abandonam os grupos perseguidos. Por outro lado, militantes católicos se lançam a atividades que se opunham à ordem vigente, retomando a mística de cristãos perseguidos. 
O golpe, no entanto, não impediu que as reflexões da Ação Católica e o Concílio Vaticano II (1962 - 1965) mudassem a forma de inserção católica nos movimentos sociais. Wanderley (1985, p.22) aponta que na passagem para os anos 60, com raras exceções, "eram os setores de classe média que iam ao povo, na maior boa vontade, prestar serviços, ajudas, animação etc. (...) Predominava uma perspectiva de alguém de fora que ia ao povo".

Conforme o regime militar vai suprimindo os canais de participação popular, o povo busca novos espaços para se organizar e, nessa busca, encontra a Igreja (FREI BETTO, 1981, p.22). Como explica Sader (1991, p.151), com o Ato Institucional $n^{\circ} 5$, que marca o auge da repressão, setores conservadores da Igreja perdem poder. Já os agentes pastorais ligados a organizações populares encontram apoio da CNBB. Além disso, o Concílio Vaticano II estimula essas ações voltadas às classes populares ${ }^{19}$ ao falar da Igreja como povo de Deus e estimular a participação em grupos comunitários.

Camargo, Souza e Pierucci (1980, p.60-61) também acreditam que, a partir de 1964, a Igreja progressista desenvolveu ações concretas. Em São Paulo, por exemplo, apoiou movimentos e instituições contidos ou perseguidos pelo Estado e atuou através das Comunidades Eclesiais de Bases. Também atuou na luta contra a tortura praticada pelos militares e na defesa de presos políticos e comuns.

Os três autores chamam atenção, no entanto, para o fato de que apesar de existir essa ação progressista, alguns setores do clero apoiaram a instauração do governo militar, substituindo inclusive bispos na CNBB que eram ligados à Ação Católica. No entanto, existiam aqueles religiosos que já haviam se oposto ao regime e eram perseguidos.

Andrade (1989, p.50-51) explica que já havia um conflito direto dentro da hierarquia da Igreja entre conservadores e progressistas, antes mesmo do golpe. O apoio aos militares não pôde, no entanto, continuar devido aos atos do governo e vai se transformando em resistência, até que em 1968 com a reunião em Medellín, a "Igreja Católica assumiu o papel de principal instituição a fazer oposição ao governo autoritário". A CNBB tornou-se o espaço de resistência e oposição ao governo, assumindo o trabalho junto aos oprimidos, seja através das CEBs, seja através da liderança de "manifestações da sociedade civil em benefício dos presos políticos, pelos direitos humanos e mais tarde pela anistia”.

\footnotetext{
${ }^{19}$ Wanderley (1985, p.12) explica que a partir de 1964 quando se falava de popular, usava-se o termo classes populares. Segundo o autor, estudos mostram que classes populares ou classes subalternas são "todos aqueles que sofrem o processo de exploração econômica, dentro da fábrica, da empresa rural e urbana, todos aqueles que sofrem um processo de expropriação dos meios de produção no campo, que vão pouco a pouco sendo engolidos pelo capitalismo e se transformando em proletários, em bóias-frias; e aqueles que são dominados social e politicamente pelo sistema: um pequeno comerciante, um pequeno proprietário rural, um artesão, um produtor autônomo, um trabalhador por conta própria".
} 
Por outro lado, o Concílio Vaticano II pregava uma ampliação da participação dos leigos. A Igreja Católica ainda enfrentava problemas como o fechamento de seminários e perda de fiéis com a expansão de outras igrejas, principalmente, pentecostais. Diante dessa situação, a partir da segunda metade dos anos 60, os documentos da Igreja já falavam de comunidades de base no Brasil, num esforço que reconhece a crise da paróquia e a necessidade de renovação. (Camargo; Souza; Pierucci, 1980, p.63-65)

Camargo, Souza, Pierucci (1980, p.60) apontam ainda que a configuração capitalista também contribuiu para a ruptura entre Estado e Igreja. O primeiro dispensa a ideologia religiosa e se legitima a partir do crescimento econômico e da segurança nacional. Cresce, nesse cenário, a pobreza, e o catolicismo se depara "em sua prática cotidiana, com a massa de explorados e excluídos". Dessa forma, parcela da Igreja Católica busca se relacionar com essa população através de "um novo pensamento teológico que procura se fundamentar na análise sociológica da realidade social e na releitura dos Evangelhos".

Isso terá força porque, como acredita Gohn (1997, p.229-230), a religião é um valor importante para o homem pobre latino-americano. O Concílio Vaticano II fez a Igreja Católica mudar o eixo de sua política na América Latina. Tanto que os movimentos populares que obtiveram mais destaque na região foram os que estavam ligados à Teologia da Libertação, ala progressista da Igreja Católica. Com o Concílio, ela se volta para a sociedade civil, passando a ser um agente ativo na organização social através de pastorais e Comunidades Eclesiais de Base. As ditaduras militares se tornam um inimigo a combater até que com a redemocratização esse alvo perde sentido.

A renovação da Igreja, iniciada com o Vaticano II e levada a efeito na América Latina a partir da reunião de Medellín, em 1968, fez com que a hierarquia eclesial se aproximasse sempre mais das classes populares, das quais o Estado se encontrava cada vez mais distanciado. A Igreja passou a ser "a voz dos que não têm voz", emprenhando-se resolutamente na campanha de denúncia às torturas e pela defesa de direitos humanos. $O$ terror repressivo estendeu-se sobre ela: religiosos foram condenados por tribunais militares; padres foram assassinados pela polícia, um bispo foi seqüestrado e seviciado por grupos direitistas. O povo redescobriu a Igreja, não apenas como seu espaço de expressão e nutrição da fé, mas também como espaço de organização e mobilização. (FREI BETTO, 1981, p.22) 


\section{4 - A opção pelos pobres}

Esse olhar voltado para as classes populares que ganha força no Concílio Vaticano II traz a opção pelos pobres, que é a base da Teologia da Libertação. O fato de dar voz para o povo falar e não apenas receber o "conhecimento" dos intelectuais que iam até o povo também tem muito a ver com a ação que Paulo Freire praticava. Isso é visto também no trabalho que a Pastoral da Criança começou a desenvolver em 1983.

As líderes são pessoas da comunidade em que atuam. Elas discutem seus problemas. Delas saem as coordenadoras da comunidade e do setor. Algumas também são indicadas por coordenadoras para serem capacitadoras ou multiplicadoras, conforme mostram ter facilidade em falar com as pessoas e partilhar conhecimentos. Há encontros entre setores, regiões, estados e o nacional, onde a Coordenação Nacional ouve representantes de todo o país e ao mesmo tempo essas representantes trocam experiências. A Pastoral da Criança fez uma opção pelos pobres. Atua nas comunidades carentes e fomenta discussões que levam a construção da cidadania.

Se essa opção ainda existe hoje, apesar do forte conservadorismo presente na Igreja e do distanciamento da Teologia da Libertação, é porque historicamente essas sementes foram lançadas e deram frutos. Em 1968, dando continuação ao processo do Concílio Vaticano II, ocorre a $2{ }^{\text {a }}$ Conferência dos Bispos Latino-americanos em Medellín.

O tema do encontro dos bispos foi "A igreja na atual transformação da América Latina, à luz do Concílio Vaticano II" (DALE, 1985, p.92). Os documentos do encontro definem, segundo Camargo, Souza e Pierucci (1980, p.66), duas linhas principais de ações: a opção pelos pobres e as Comunidades Eclesiais de Base. Os autores destacam algumas conclusões, que se assemelham com a linha adotada pela Pastoral da Criança ainda hoje:

1)“Defender, segundo o mandato evangélico, os direitos dos pobres e oprimidos (...). Alentar e favorecer os esforços do povo para criar e desenvolver suas próprias organizações de base, pela reivindicação e consolidação de seus direitos e busca de uma verdadeira justiça" (Conclusões de Medellín 2, 22 e 27).

2) "A comunidade cristã de base é o primeiro e fundamental núcleo eclesial, que deve, em seu próprio nível, responsabilizar-se pela riqueza e expansão da fé, como também pelo culto que é sua expressão. É ela, portanto, célula inicial da estruturação eclesial e foco de evangelização e atualmente fator primordial de promoção humana e desenvolvimento" (Conclusões de Medellín 15, 10). (CAMARGO; SOUZA; PIERUCCI, 1980, p.66) 
As frases acima trazem características das Comunidades Eclesiais de Base (CEBs). No entanto, o trabalho da Pastoral da Criança também valoriza a ação na base: comunidade. $\mathrm{Na}$ sua ação, também informa sobre direitos e como buscá-los. Primeiro no processo educativo da líder, que é da comunidade e teve sua capacitação por alguém da região também. Depois com as líderes visitando as famílias. O aprendizado aumenta nessas visitas. Não são apenas as mães que aprendem, as líderes também, e levam suas dúvidas para as reuniões. É uma construção permanente do conhecimento.

Esse formato tem suas raízes no passado. Por exemplo, quando vemos que a posição assumida em Medellín ganhou força na Conferência dos Bispos Latino-americanos em Puebla (1979), no México. Os bispos deram orientações para a opção pelos pobres e marginalizados. Também assumiram uma posição de defesa dos direitos humanos. "Passou-se de uma Igrejahierárquica para uma Igreja-comunidade, já que os bispos aprovaram o movimento crescente das comunidades eclesiais de base”. Há uma clara posição em Puebla a favor da participação. As atividades da Igreja "deveriam ser partilhadas em comunidade, com o povo como participante ativo no processo de evangelização e não como meros espectadores da mensagem cristã”. (PUNTEL, 1994, p.81)

Certamente a experiência da Igreja com as CEBs, que existem até hoje, serviu de exemplo para a ação comunitária da Pastoral da Criança. $\mathrm{Na}$ pesquisa participante, encontramos na Pastoral da Criança pessoas que tiveram essa vivência, como a coordenadora do projeto de comunicação popular, a jornalista e freira Núbia Maria da Silva.

O leigo, que é valorizado pelas CEBs e depois pela Pastoral da Criança, antes foi valorizado pelo Concílio Vaticano II. "Esta realidade foi fundamental na renovação da Igreja. O Concílio foi a porta aberta pela qual a Igreja começou a dinâmica transformadora que trouxe consigo a estruturação das CEBs" (GOMES, 1987, p.22).

Gomes (1987, p.24-26) aponta outros fatores como favoráveis ao surgimento das CEBs no Brasil. Um deles é a criação, em 1965, de catequistas populares na diocese de Barra do Piraí, no Rio de Janeiro, que depois se espalhou para outras localidades. Esses catequistas reuniam o povo para a oração, o culto e a leitura da Palavra de Deus, valorizando a participação de leigos na Igreja. A outra ação seria o Movimento de Educação de Base, com a catequese radiofônica, na diocese de Natal, no Rio Grande do Norte.

Esse movimento surgiu devido à preocupação com os problemas sociais da região, primeiro, atendendo às necessidades mais urgentes da população, depois, partindo para a conscientização do povo. Assim, espalhou-se para outras regiões do Nordeste. A outra questão que serviu para a articulação das CEBs foi a elaboração de Planos Nacionais de 
Pastoral $^{20}$, que visam a participação dos leigos e a renovação paroquial, sendo precedidos pela Ação Católica. Isso levou a busca de questionamentos e ao aperfeiçoamento da ação dos cristãos na realidade.

Acreditamos que a experiência do "círculo de cultura" 21 , iniciada por Paulo Freire no Movimento de Cultura Popular do Recife, também deixou o seu legado às CEBs e as reuniões da Pastoral da Criança. Nessa experiência, formavam-se grupos de debates. A programação, como relata Freire (2008, p.111), era feita a partir dos próprios grupos, que eram entrevistados pelos educadores. Essa ação resultava na enumeração de problemas a serem discutidos. Foi a partir desse trabalho, que veio a metodologia de alfabetização de Paulo Freire.

Desde logo, pensávamos a alfabetização do homem brasileiro, em posição de tomada de consciência, na emersão que fizera em nossa realidade. Num trabalho com que tentássemos a promoção da ingenuidade em criticidade, ao mesmo tempo em que alfabetizássemos.

Pensávamos numa alfabetização direta e realmente ligada à democratização da cultura, que fosse uma introdução a essa democratização. Numa alfabetização que tivesse no homem, não esse paciente do processo (...), mas o seu sujeito. (...) Pensávamos numa alfabetização que fosse em si um ato de criação capaz de desencadear outros atos criadores. (FREIRE, 2008, p. 112)

O debate, como nos círculos de cultura, é uma característica essencial tanto das CEBs quanto da Pastoral da Criança. Nas reuniões e capacitações em que participamos, em diferentes esferas, todos são convidados a falar e dar sua opinião.

\section{5 - O legado da Teologia da Libertação}

A base teórica de parte das ações da Igreja voltadas para os pobres nos anos 60 foi a Teologia da Libertação.

A teologia da libertação encontra suas origens no início a década de 60 , quando a Igreja oficial começava a reavaliar seu papel tradicional na sociedade. Esta nova tendência refletia-se nas encíclicas do papa João XXIII,

\footnotetext{
20 Esses planos eram elaborados pela CNBB. O primeiro deles, 1965-1970, consagrou a expressão "Comunidades Eclesiais de Base". Os seguintes, 1971-1972 e 1973-1974, refletiram sobre as CEBs e avaliaram suas realizações. (GOMES, 1987, p. 27).

${ }^{21}$ Freire (2008, p.111) define o círculo de cultura: "Em lugar de professor, com tradições fortemente 'doadoras', o Coordenador de Debates. Em lugar de aula discursiva, o diálogo. Em lugar de aluno, com tradições passivas, o participante de grupo. Em lugar dos pontos e de programas alienados, programação compacta, 'reduzida' e 'codificada' em unidades de aprendizado".
} 
Mater et Magistra (1961) e Pacem in Terris (1963), que destacavam a necessidade de mudanças estruturais e o direito humano a uma forma decente de existência e à participação na educação e na política. João XXIII acentuava que a Igreja era uma comunidade de iguais e que devia comprometer-se com o desenvolvimento, entendido como mudanças na sociedade. (PUNTEL, 1994, p.73)

Puntel (1994, p.74-75) destaca ainda que a teologia da libertação teve como "pano de fundo teórico" o Vaticano II, que instiga a Igreja a dialogar com o mundo. Com a Conferência de Medellín, há uma denúncia das injustiças e um estímulo aos bispos à mudança. A teologia da libertação é usada "para responder às urgentes necessidades de uma sociedade predominantemente empobrecida" (1994, p.78). Assim a palavra "libertação" aparece constantemente nos textos de Medellín, mostrando a necessidade dos latino-americanos se libertarem da opressão.

Segundo Sader (1991, p.164-165), os pobres passam a serem vistos como sujeitos conscientes de sua própria libertação. Essa libertação se opõe à opressão, trabalhando valores como solidariedade e egoísmo, justiça e miséria, serviço comunitário e fechamento individualista, capacidade crítica e alienação, luta e conformismo. A libertação dos discursos pastorais tem como meta o Reino de Deus iniciado na própria Terra. Buscam-se novos valores nas ações humanas dentro das comunidades.

Já para Scherer-Warren (1987, p.70), a teologia da libertação é concebida como uma nova maneira de fazer teologia, na qual a práxis é o elemento chave. A autora usa Clodovis Boff $^{22}$ para explicar que a "práxis é considerada como o conjunto de práticas visando à transformação da sociedade ou à produção da História". Há assim uma orientação, “em última análise, para a formação de movimentos sociais com vistas à libertação das formas de opressão impostas pelo capitalismo".

Essa nova forma de fazer teologia também é destacada por Puntel (1994, p.84) e é caracterizada por interpretar o evangelho "à luz do contexto social". O que "significa trabalhar junto às pessoas e colaborar para sua libertação de toda espécie de opressão ou dependência”. O ser consciente assume a sua história e transforma. Há um processo de conscientização. Nisso, a autora destaca a influência de Paulo Freire no catolicismo da América Latina, que, por meio da ala progressista, incorpora sua metodologia e suas idéias (1994, p.90). A emancipação parte do povo, que adquire uma consciência crítica, nos moldes de conscientização e diálogo defendidos por Freire (1994, p.93). Quase quatro décadas

\footnotetext{
${ }^{22}$ BOFF, Clodovis. Teologia e prática: teologia do político e do produto. Petrópolis: Vozes, 1978.
} 
depois, também presenciamos esse alinhamento entre evangelho e realidade nas reuniões da Pastoral da Criança.

Voltando a esse passado, para entender essas influências, vemos que a Igreja para participar desse processo de libertação do povo latino-americano teve que se comprometer com as classes populares. Na Teologia da Libertação, isso significou romper com os interesses das classes dominantes. “A Igreja não pode servir ao mesmo tempo ao Deus que faz justiça aos oprimidos e aos senhores do capital, que mantêm a opressão. Pretender reconciliar estes pólos antagônicos é ignorar a natureza e o caráter do conflito que travam" (FREI BETTO, 1981, p.12). Mais do que entrar nas classes populares, a Igreja deve ainda aprender com o povo. Além disso, a construção da salvação deve se efetuar nesse mundo e não esperar por um plano espiritual.

Não basta uma libertação pessoal e interior do homem que não transforme as estruturas eivadas do pecado em que ele vive e pelas quais se sente condicionado. Por isso esta libertação tem necessariamente um alcance político, dentro de um contexto econômico e social. (FREI BETTO, 1981, p. 14)

A Teologia da Libertação procura aliar a elaboração teórica frente aos mecanismos de opressão e sua reflexão com o caminhar do povo e a religiosidade. "O conhecimento proveniente das Ciências Sociais participa, neste caso, como mediador entre a reflexão teológica e a prática efetiva" (SCHERER-WARREN, 1987, p.70-71). A autora também chama a atenção para alguns pontos essenciais dessa corrente teológica da Igreja Católica: opção ideológica a favor dos pobres e oprimidos, com uma "dimensão metasocial" que traz o ponto de vista da religião e a criação de uma práxis inovadora por partir da cultura popular através da religiosidade do povo. Ela ainda destaca que essa teologia se voltou muito mais para a prática do que para a teoria. Também aponta a importância de dois documentos da Igreja para a questão: Documento de Medellín (1968) e Documento de Puebla (1979).

Um ponto a ser lembrado é que embora se faça a opção pelos marginalizados, isso não significa a realização de um paternalismo, "mas sim uma inserção num processo de autoidentificação com os pobres, significa também tornar-se parceiro político do oprimido na luta libertadora". (SCHERER-WARREN, 1987, p.74)

Iokoi (1996, p.211), por sua vez, destaca dois teólogos como os "mais ativos propositores" da teologia da libertação: Gustavo Gutiérrez e Leonardo Boff. O primeiro propõe, segundo a autora, "uma reflexão crítica da práxis histórica como teologia libertadora", aproxima-se do marxismo e constata a "necessidade da superação das condições desiguais", 
com a libertação não só econômica, mas também da "opressão cultural, ideológica, simbólica" (1996, p.212-213). Assim estar com Deus é buscar a libertação total.

Já em relação a Boff enfatiza a procura de elementos da crítica na própria religião. $\mathrm{Na}$ vida presente, há os elementos para libertação e para opressão. Essa última é fruto de escolhas, do conflito e do arbítrio. Já a liberdade "supõe a realização de si mesmo nas determinações existencial, social e política", e a "fé surge dentro do processo de libertação". (IOKOI, 1996, p.214-215)

É sob o manto da Teologia da Libertação que está reunida toda a reflexão teológica que embasa as CEBs e esse novo modo de ser Igreja. Como explica Andrade (1989, p.52), essa reflexão parte da história da opressão vivenciada na América Latina, considerando a fome, a miséria e os direitos fundamentais da vida. "A Igreja elaborou um discurso que deslocou a reflexão sobre a dominação do plano transcendental para o plano da história. Esta nova concepção do cristianismo exige nas práticas sociais uma postura de compromisso e participação". Com um discurso político e religioso, através da Teologia da Libertação, a Igreja tem que "mudar suas formas de poder, de inserção social, de discurso e de prática". No entanto, há uma reação na própria Igreja, os progressistas a favor da Teologia da Libertação e os conservadores contra.

Puntel (1994, p.96) destaca a preocupação que o Vaticano teve com a Teologia da Libertação, reprovada pelo então responsável da Congregação pela Doutrina e Fé, o então cardeal Ratzinger, já nos anos 80, pelo temor de que a práxis tivesse como força propulsora a análise marxista. No entanto, a teologia da libertação tem como "moldura" o Cristo libertador (1994, p.118).

Embora a teologia da libertação ainda seja uma teoria controvertida, nas últimas três décadas muitas das fontes de inspiração para as atividades da Igreja latino-americana dela provieram. Esta nova maneira de pensar a fé, à luz da conjuntura social influenciou também as atividades da Igreja no campo da comunicação. (PUNTEL, 1994, p.99)

A autora chega a essa conclusão quando finaliza sua pesquisa em 1989. Logo fala dos anos 60, 70 e 80. A Pastoral da Criança, que nasce em 1983, está sob essa influência. A opção pelos pobres feita pelo Vaticano II, reforçada em Medellín e Puebla e fortalecida pela teologia da libertação, ainda vive na Pastoral da Criança. A organização atua em localidades pobres, leva informação às famílias, promove o debate e conscientiza. Dessa forma, há uma libertação da falta de conhecimento e também da opressão. Nas reuniões, sempre se fala da importância da participação em conselhos, da busca de direitos. Um participante complementa o outro. Há 
o diálogo defendido por Freire e uma tomada de consciência. Os problemas sociais estão presentes nas discussões como a violência doméstica e sexual, a agressão às crianças, o respeito às famílias visitadas. Esses são só alguns dos temas que vimos ser debatidos. Em uma reunião na região episcopal da Lapa, em março, uma das voluntárias ressaltou a importância de que todos na Pastoral da Criança sejam cristãos incomodados. Nessa pesquisa, entrevistamos vários desses cristãos. Foram 61 entrevistados, voluntárias e voluntários na Pastoral da Criança, na região da Arquidiocese de São Paulo. Vimos outros falando nas diversas reuniões que acompanhamos em diferentes regiões de São Paulo.

Essa observação participante nos dá subsídio para dizer que apesar do rumo conservador tomado pela Igreja, inclusive com Ratzinger, hoje como papa Bento XVI, algumas ideias da teologia da libertação ainda vivem assim como a prática educativa de Paulo Freire encontra eco na ação da Pastoral da Criança. Esse conservadorismo já é mostrado por Puntel (1994, p.28), que destaca “o aumento dos obstáculos dentro da Igreja, como instituição, ao criar espaços para a participação interna". No entanto, ressalta:

Apesar da oposição da hierarquia tradicionalista, a Igreja popular, inspirada na teologia da libertação, prossegue com suas práticas junto ao povo, baseadas em atividades democráticas. É nesse sentido que a Igreja popular representa um desafio para a Igreja como instituição. Apesar disso, o processo participativo foi implantado e suas influências parecem irreversíveis. (PUNTEL, 1994, p.28)

Segundo Heck (2009), a teologia da libertação continua viva até hoje, na vida concreta tanto das pessoas quanto das comunidades. "Isso não se consegue destruir de um dia pro outro. E se faz e acontece em práticas e ações de fé e política, caminhando com e sem a paróquia, com e sem a diocese, avançando na mística do povo e tornando viva a fé”. É nesse sentido que vemos a contribuição da teologia da libertação para a Pastoral da Criança. Ela está viva nas práticas sociais.

Boff (1998, p.80) explica que para a Igreja e a teologia libertarem não é necessário uma "ideologia revolucionária ou socializante". Mas é preciso que a Igreja "faça sua leitura, à luz da óptica da fé, do fenômeno político-econômico, da marginalização, da opressão e da libertação. E urge uma práxis libertadora como unidade vital entre leitura e ação, ortodoxia e ortopraxia".

O autor ainda explica que o "Reino de Deus não se restringe a uma região da existência humana como a do espírito". Ele possui uma característica global e abrange toda a "realidade criada inserida no mistério de Deus. E não é libertação da dor, da alienação, das 
injustiças, da morte". Conclui, assim, que o reino de Deus não é uma "realidade apenas futura". Na verdade, essa realidade já está presente.

Porque tudo pertence ao Reino, não pode deixar de valorizar também sua faceta política e econômica, que hoje, dentro de nosso arranjo vital, desempenha um fator de significada relevância. Na sua primeira aparição pública Jesus recalcou a mordência concreta do Reino. Não é só reconciliação com Deus. É também exorcitação de tudo o que escraviza o homem: é libertação dos aprisionados, luz para os cegos, liberdade para os oprimidos, saúde para os leprosos e ano da graça do Senhor (cf. Lc 4,18-21; Mt 11,3-5). Na superação destas opressões é que o Reino se mediatiza e está em nosso meio (cf. Lc 17,21). Ora, para nós hoje libertação dos aprisionados significa todo o aparato da justiça; luz para os cegos, a organização da saúde pública com os meios mais sofisticados; e ano da graça do Senhor, a concretização da justiça social, especialmente concernemente à atribuição mais eqüitativa dos bens e ao gozo dos direitos humanos fundamentais. Tudo isso é advento do reino dentro das condições da história... (BOFF, 1998, p.81-82)

A Pastoral da Criança traz em si essa mistura da mística da fé e do engajamento social. Esse envolvimento fica visível no incentivo para que voluntários sejam membros de conselhos ou participem de discussões junto ao poder público. Por exemplo, em abril de 2009, a coordenadora da Pastoral da Criança na Arquidiocese de São Paulo, chamada SP 1, e a coordenadora da Pastoral da região SP 2, que abrange as dioceses de Santo Amaro, Campo Limpo, São Miguel Paulista e alguns municípios da grande São Paulo, foram recebidas pelo secretário municipal de saúde. O intuito da reunião era discutir o alto índice da mortalidade infantil na região do Marsilac, extremo sul de São Paulo, como também outros problemas de saúde da cidade, presenciados pelas líderes da Pastoral da Criança. O índice, por exemplo, do Marsilac é de 40 mortes por mil nascidos vivos, enquanto a média de mortalidade entre as crianças acompanhadas pela Pastoral da Criança é de 11.

Nas reuniões da Pastoral da Criança, os momentos de fé sempre vêm acompanhados de discussões sobre problemas sociais, seja a violência, o não respeito ao direito à saúde, a desnutrição ou a obesidade infantil. De certa forma há a práxis, mas a reflexão não parte da teoria e sim das experiências cotidianas, que impulsionam as ações dos voluntários. São sujeitos agindo na história.

A teologia da libertação traz essa base teórica que explica as ações da Pastoral da Criança. Boff (1998, p.71) explica que um novo horizonte pode ser criado pela "consciência histórica da libertação". A economia, a política, a medicina, a psicologia, a religião e a teologia podem ser lidas a partir da óptica de opressão e de libertação. "Toda fé e toda 
teologia, pela simples razão de serem o que são, possuem em si mesmas uma dimensão libertadora ou opressora" (1998, p.73).

(...) uma reflexão mais essencial e radical que vê a própria teologia como articulação histórica da revelação do Mistério de Deus no processo humano. Esta revelação não ocorre apenas no âmbito religioso, mas na totalidade das manifestações da história dentro se sua epocalidade própria, no nosso caso sob o signo da libertação. A teologia consiste então na tentativa de tematizar ao nível da linguagem e da comunidade de fé essa realidade que afeta a todos, mas que na religião é conscientizada, decifrada e celebrada. (BOFF, 1998, p.72)

O autor ainda coloca a fé cristã como adesão ao mistério de Deus, que se comunica na história e na ressurreição de Cristo. "É na captação concreta do momento histórico em seu sentido radical como pro-vocação ao homem para uma decisão totalizante de sua vida" (BOFF, 1998, p.73). Mais adiante completa: "Praticar a verdade no sentido bíblico (cf. Jo 3,21; 1Jo 3,19) consiste em transformar de tal forma a vida que esta se deixa empapar pela realidade de Deus sentida e sofrida dentro da própria existência” (BOFF, 1998, p.74).

Na ressurreição de Cristo, está a libertação dos homens. "Com isso, toda a existência, a luta secular dos oprimidos e dos opressores (manifestações da morte dentro da vida) e o sentido da história são iluminados" (BOFF, 1998,p.75). Esse discurso do Cristo no oprimido ainda se mantém vivo. A ação da Pastoral da Criança não se baseia na caridade, as voluntárias são chamadas a ver Cristo nas crianças pobres e a ajudar às famílias a conhecerem aspectos da saúde, a saber seus direitos e assim ir mudando o modo de vida. É o que pode ser visto na fala do bispo auxiliar da Arquidiocese de São Paulo e responsável pela Região Episcopal Ipiranga, Dom Tomé Ferreira da Silva, durante a homilia em uma missa ocorrida no final de novembro, no II Encontrão de Valorização do Líder: "Nós vemos nas crianças atendidas pela Pastoral da Criança a pessoa de Jesus Cristo. Agora iniciamos a caminhada para o Natal de Jesus. Temos que nos rejuvenescer, reproduzindo em nós a mesma vida de Jesus Cristo".

Para Boff (1998, p.76), “a fé cristã somente é verdadeira se continuamente como Deus na encarnação, assumir o diferente dela, o mundo, a realidade mais adversa". O autor vai mais longe afirmando que viver "a libertação contra todas as formas de opressão" constitui o cristão e não "a prática de atos religiosos" (1998, p.78). Ainda critica que o "pretenso despolitismo da teologia ou da Igreja não deixa também de ser uma posição política porque legitima o status quo ao invés de questioná-lo”.

Hoje na América latina se vive o tempo intenso e urgente (Assmann) da história da salvação sob o signo da libertação das escravizações sociais que assolam o homem, marginalizam milhões e esmagam a dignidade humana. 
Isso não possui apenas uma dimensão sociológica e política É a forma como a libertação e a opressão, a graça e a des-graça chegam à nossa consciência histórica e desafiam o engajamento de nossa fé. Uma Igreja e uma teologia que por temor da politicagem e por medo da contestação e da repressão se negam a ver no fenômeno da marginalização sua dimensão também de fé e de teologia... (BOFF, 1998, p.79)

Obviamente que a Pastoral da Criança não chega a esse nível de crítica, como Leonardo Boff, mas fica claro, a partir de nossa pesquisa de campo, que há uma reflexão sobre a marginalização, a pobreza e uma ação visando transformar a vida das pessoas, ainda que não se questione a igreja conservadora. No entanto, na prática, vemos ações progressistas na Pastoral da Criança e uma necessidade de ser "cristãos incomodados" como ouvimos uma multiplicadora dizer na Assembleia Anual da Lapa, no mês de março de 2009. Esse cristão incomodado é chamado a agir contra as injustiças, a questionar.

A Pastoral da Criança age nas famílias pobres. Nesse sentido, uma afirmação de Boff (1998, p.87) explica bem para quem e como essa ação deve olhar. "Na verdade, o pobre é um empobrecido (...) roubado e defraudado do fruto do seu trabalho e de sua dignidade. Este empobrecimento cria um apelo para o amor cristão (...) para criar condições de superação desta situação". Assim o teólogo conclui que fazer isso "é mergulhar no conflito social" e “fazer uma escolha política".

A libertação exige que se deixe de lado a "teologia abstrata e constituída de um sistema fechado de conceitos". O que se fará:

mediante uma nova experiência e uma práxis diferente de fé e da Igreja. Então, sim, poderá nascer uma teologia libertada de seu cativeiro intrasistêmico. Nascida da práxis, iluminá-la-á, deixar-se-á questionar e enriquecer por ela, e destarte manter-se-á permanentemente e dialeticamente a unidade de teologia e vida cristã. (BOFF, 1998, p.89)

Vale lembrar que o teólogo brasileiro Leonardo Boff foi proibido de lecionar e escrever sobre a teologia de abril de 1985 a março de 1986. O livro "Igreja: Carisma e Poder" foi declarado perigoso à doutrina da fé. A questão era que Boff criticava "a monopolização do poder da Igreja e seu uso indevido pela estrutura hierárquica”. Em 1992, Leonardo Boff deixa a Ordem Franciscana e o exercício do sacerdócio, atuando como teólogo laicizado. Leonardo Boff era um dos maiores expoentes da Teologia da Libertação. (PUNTEL, 1994, p.95) 


\section{6 - O papel de Dom Paulo}

Se vamos apontar as influências que percebemos nas atividades da Pastoral da Criança, não podemos deixar de falar de Dom Paulo Evaristo Arns. Primeiro, porque a iniciativa da criação do organismo de ação social partiu dele. Segundo porque ele foi um dos protagonistas na ação da Igreja voltada para os pobres.

Sader (1991, p.147-148) aponta que no fim dos anos sessenta e durante os anos setenta começam a surgir as primeiras CEBs da periferia de São Paulo. Ele cita como exemplo um grupo de jovens da Capela do Socorro, zona sul da capital, ligados a uma comunidade de base em 1968. O desenvolvimento das CEBs também ganhou força por meio de Dom Paulo Evaristo Arns, que se tornou arcebispo da Arquidiocese de São Paulo. A Igreja Católica também se engajou na alfabetização usando o método Paulo Freire com a atividade em 80 paróquias da região sul, aliando-se o aprendizado à vida prática dos alunos para despertar um olhar crítico e a consciência.

Outra iniciativa narrada por Sader (1991, p.148-149) foi o Centro Pastoral Vergueiro, uma criação do padre Giorgio Calegari para resgatar a memória das lutas populares através de arquivos que poderiam ainda dar subsídios aos novos movimentos. Em 1973, por exemplo, Dom Paulo lança a Operação Periferia, que visa à criação de centros comunitários nos bairros pobres. Eram lugares nos quais se possibilitavam a profissionalização, regularização documentos, instruções religiosas e espaços de lazer. As paróquias da periferia passam a se envolver com as necessidades das populações locais.

Essa ação foi precedida pela criação do Movimento das Pastorais de Periferia Urbana em São Paulo, também por Dom Paulo Evaristo Arns em 1971 (GOHN, 1995, p. 107). A ação pastoral da arquidiocese paulistana, entre 1978 e 1979, priorizava a Pastoral do Mundo do Trabalho, a Pastoral dos Direitos Humanos, a Pastoral da Periferia e as CEBs (CAMARGO; SOUZA; PIERUCCI, 1980, p.60-61).

É esse mesmo Dom Paulo, que valorizava as ações sociais e o papel da comunidade, que vai procurar sua irmã, Zilda Arns, em 1982 para colocar em prática uma ação que leve informação para as mães, visando à redução da mortalidade infantil. Como um incentivador das Pastorais Sociais e das CEBs, não se pode negar que elas também deixaram a sua contribuição para o modo como a Pastoral da Criança se desenvolveu. 


\section{7 - O legado das CEBs}

Puntel (1994, p.214-216) se baseia em diversos autores para concluir que o nascimento das CEBs teve a contribuição de três movimentos. O primeiro foi a catequese popular, que ocorria no início dos anos 50, em Barra do Piraí. Leigos se reuniam para rezar e ler a Bíblia, e muitos passaram a coordenar a comunidade e a organizar o ensino religioso. $\mathrm{O}$ segundo, o Movimento de Natal de Dom Eugênio Salles, usava programas de rádio para "alfabetizar e despertar a consciência crítica sobre os problemas da população. O curioso é que o movimento surgiu para "estabelecer centros de tratamento para doenças e para a desnutrição. Vemos ai uma motivação parecida com a Pastoral da Criança, que surge para combater a desnutrição infantil e vai ampliando o seu trabalho.

O terceiro ponto seria o Movimento Popular de Cultura e o Movimento de Educação de Base. O MPC foi criado por Paulo Freire e trazia os círculos de cultura. As ideias do educador foram assumidas por pessoas da Igreja e trabalhadores. Já o MEB, criado pela CNBB, baseia-se na metodologia de Paulo Freire. Essas formas de atuar em comunidades antecedem a prática das $\mathrm{CEBs,} \mathrm{mas} \mathrm{trazem} \mathrm{em} \mathrm{si} \mathrm{muito} \mathrm{do} \mathrm{que} \mathrm{as} \mathrm{comunidades} \mathrm{de} \mathrm{base} \mathrm{vão}$ fazer. "As CEBs combinaram e articularam a ampla participação dos leigos na busca de uma sociedade construída sobre relações sociais mais ativas, igualitárias e participativas" (PUNTEL, 1994, p.224)

As Comunidades Eclesiais de Base, segundo Frei Betto (1981, p.16-17), multiplicaram-se pela zona rural e na periferia das cidades, chegando a 80 mil e congregando 2 milhões de pessoas no Brasil em 1981. Eram pequenos agrupamentos organizados em torno de uma paróquia, no caso urbano, ou de uma capela, no caso rural, por iniciativa de leigos, padres e bispos. As primeiras CEBs surgiram ainda na década de 1960.

O autor também explica o uso do termo comunidade: "porque reúnem pessoas que têm a mesma fé, pertencem à mesma Igreja e moram na mesma região", vivendo problemas comuns em relação à sobrevivência, moradia e condições de vida. Essas características podem ser aplicadas em parte à Pastoral da Criança, pois também reúnem pessoas com a mesma fé e da mesma região, no entanto, traz um discurso ecumênico. $\mathrm{Na}$ pesquisa, chegamos a entrevistar uma coordenadora de ramo $^{23}$ da Pastoral da Criança, que é evangélica. Suas três filhas, também evangélicas, ajudam nas ações como apoio. Elas são moradoras do bairro

\footnotetext{
${ }^{23}$ Termo usado pela Pastoral da Criança para designar a coordenação de uma paróquia, que pode reunir mais de uma comunidade.
} 
Terceira Divisão, Iguatemi, pertencente à Região Episcopal do Belém, zona leste de São Paulo. Também entrevistamos uma multiplicadora da Pastoral da Criança, na Região Episcopal da Brasilândia, que é evangélica e frequenta a Igreja Universal do Reino de Deus.

Frei Betto ainda explica os termos eclesiais, por estarem congregadas na Igreja, e de base, por ter pessoas que trabalham com as próprias mãos. Essas duas elucidações se aplicam a Pastoral da Criança, pois mesmo com um discurso ecumênico, faz parte da Igreja Católica e é um organismo social da CNBB. A entrevistada evangélica da região do Belém, por exemplo, relatou que costuma passar o jornal da Pastoral para o padre e para a secretária paroquial. Eles cuidam da distribuição. A ação depende do apoio do padre para dar certo. Quanto à explicação para base, também na Pastoral da Criança a ação é movida pelas mãos de pessoas das comunidades.

Esse papel fica claro na frase dita por Zilda Arns na Comemoração dos 25 anos da Pastoral da Criança no estado de São Paulo (2008): "Não desanimem nunca. Vocês têm um tesouro, que precisam passar a diante. A nossa Pastoral da Criança é missão de vida”. Eram mais de 15 mil voluntários na Praça da Basílica de Nossa Senhora Aparecida, no interior do estado. No mesmo palco, o bispo da diocese de São José do Rio Preto, Dom Paulo Mendes Peixoto teve um discurso parecido:

A gente tem muito a agradecer pelo bem que a Pastoral da Criança faz a todas as famílias que são assistidas por tantos líderes e tantas líderes no Brasil inteiro. Hoje é um dia para dar graças a Deus e dar os parabéns não só a Dra. Zilda, mas a todos aqueles que estão à frente de um trabalho da Pastoral da Criança em suas comunidades. Estão a serviço da esperança, sendo discípulos e missionários de Jesus Cristo para que todos tenham vida. (Zilda Arns)

Outra característica das CEBs que permanece na Pastoral é a flexibilidade do número de participantes. Sader relata que (1991, p.156-160) as reuniões das Comunidades Eclesiais de Base podiam ser semanais, quinzenais ou mensais, com um número de 10 a 30 pessoas. Havia um estímulo para que todos participassem ativa e conscientemente. Geralmente, elas surgiam por iniciativa de um agente pastoral e em torno de motivações religiosas. O tema variava entre uma leitura bíblica, de um folheto litúrgico ou de aspectos práticos da comunidade. Para tanto, o debate utilizava-se do método "ver-julgar-agir"24. O objetivo era uma reflexão crítica voltada para a prática, na qual cada um fazia observações sobre o tema (ver), para depois

\footnotetext{
${ }^{24}$ Segundo Gomes (1987, p.30), esta metodologia desenvolvida pela Ação Católica, muito usada pela Juventude Operária Católica e pela Juventude Universitária Católica, mais tarde se tornou o método dos Círculos Bíblicos (grupos de estudo sobre a Bíblia). Ganhou foro de cidadania nas grandes Conferências do Episcopado LatinoAmericano, em Medellín e Puebla".
} 
contrastar a realidade com valores cristãos (julgar) e concluir com o que podia ser feito diante do problema (agir).

Como já relatamos, a metodologia usada pela Pastoral da Criança continua a mesma, acrescida do item avaliar, que tem a ver com as reuniões mensais para analisar o trabalho, e celebrar. Também não há um número fixo de líderes nas comunidades. Há locais que podem ter apenas duas líderes e outros mais de 10. Também há a presença de apoio nas comunidades, denominação para aquelas que ainda não passaram pela capacitação, mas ajudam na Celebração da Vida. As reuniões de avaliação na comunidade são mensais, mas há as reuniões de coordenadores em diferentes esferas. O uso da Bíblia e de leituras é outra semelhança assim como discussões de problemas das comunidades, mas centradas em questões ligadas à criança e à mãe. O que não impede que outros temas sociais sejam trazidos ao debate como violência e diversos problemas sociais que façam parte da realidade da comunidade.

Já sobre as CEBs, Frei Betto (1981, p.24) relata que, nas reuniões, a palavra de ordem era a libertação. Isso ajudava a "comunidade a passar de uma consciência social reformista para a consciência da transformação social, da modificação do modo de produção capitalista". Observando as ações da Pastoral da Criança, podemos afirmar que há uma conscientização para que as voluntárias e as mães das crianças atendidas conheçam seus direitos, podendo exigir que esses existam de fato, mas não se chega a pensar em uma mudança do sistema capitalista.

Sader (1991, p.161-162), por sua vez, destaca que os próprios membros das CEBs decidiam suas ações. Havia uma autonomia, mas as relações eclesiásticas eram fundamentais para o seu desenvolvimento. Seus representantes participavam dos conselhos paroquiais. A Igreja, por sua vez, fornecia agentes pastorais e capacitação dos membros, oferecendo ainda uma legitimação teológica. Por outro lado, elas atuavam em seu meio, participando de mutirão para criar um salão paroquial, de mobilização para reclamar da falta de ônibus, de reivindicação para coleta de lixo, da defesa dos direitos dos moradores de loteamento clandestino, da saúde, da educação, entre outros.

$\mathrm{Na}$ Pastoral da Criança, as ações são definidas pela Coordenação Nacional. No entanto, essas decisões contam com a participação de representantes de todo o Brasil. Os materiais também são elaborados ouvindo membros. Por exemplo, em 2008, a Pastoral da Criança começou um novo projeto voltado para a comunicação popular. Para realizá-lo, contratou uma freira jornalista, irmã Núbia, que tem muita vivência com movimentos sociais e com as CEBs. Ela coordenou um projeto piloto no Nordeste e elaborou uma cartilha sobre o tema. 
O material foi apresentado para os coordenadores estaduais, para a coordenadora nacional da Pastoral da Criança, Irmã Vera Lúcia Altoé e para o presidente do Conselho Diretor da Pastoral da Criança, Dom Aldo Di Cillo Pagotto durante a Assembleia Nacional, em 03/12/08, na cidade de Curitiba. Eles deram sugestões, pois avaliaram que a linguagem não estava adequada. O material foi reescrito. Já em fevereiro de 2009, cinco jornalistas foram convidados a ir para Curitiba integrar o projeto. Cada um representando uma região e todos com algum envolvimento com a Pastoral da Criança. Fomos convidadas a representar o Sudeste. Também havia uma jornalista de Porto Alegre/RS, outra de Brasília/DF, um de Ilhéus/BA e uma de Ji-Paraná/RO.

Lá cada um pôde conhecer o desenvolvimento do projeto piloto e durante dois dias debater o conteúdo do material. Também ficou combinado que cada jornalista mandaria observações sobre o conteúdo por e-mail e até março realizaria uma capacitação em comunicação popular em uma comunidade da sua região. Assim mais cinco pessoas aplicariam o material como teste. Para só depois do resultado e de novo debate, o material ser publicado e uma nova política de comunicação popular estabelecida.

Esse exemplo mostra que, apesar das ações da Pastoral da Criança serem definidas pela Coordenação Nacional, há uma construção coletiva e um debate permanente em torno delas. O Guia do Líder, por exemplo, é constantemente discutido nas capacitações, inclusive se estimulando uma avaliação crítica do material, para que voluntárias e voluntários mostrem o que não está bom.

Outra característica apontada por Frei Betto (1981, p.18-20), que pode ser comparada a Pastoral da Criança, é que os membros das CEBs eram geralmente pessoas que ganhavam até quatro salários mínimos, morando em casas alugadas na periferia ou em favelas; na zona rural, em pequenos sítios ou à beira de cidades que forneciam mão-de-obra para o trabalho agrícola. Dados de 2003 apontam que dos 155 mil voluntários da Pastoral da Criança da época, cerca de 122 mil moravam em favelas e palafitas nos grandes bolsões de pobreza (COELHO, 2003).

Em nossa pesquisa, encontramos desde pessoas voluntárias que viviam em favelas como outros com formação superior, que moravam próximos à favela e iam até lá realizar as visitas domiciliares. Presenciamos, por exemplo, esse último caso no bairro da Saúde, Região Episcopal do Ipiranga, onde uma fisioterapeuta e uma professora universitária faziam esse trabalho.

Frei Betto (1981, p.18) ainda explica que nas CEBs os animadores são chamados de agentes pastorais, que podem ser padres, religiosas ou leigos, formados na própria 
comunidade. O papel desses agentes é assessorar as comunidades para que o "povo seja sujeito de sua história”. Na Pastoral da Criança, as líderes e coordenadoras são da própria comunidade, assim como se incentiva que toda comunidade tenha sua capacitadora, o que nem sempre acontece.

Migrantes e oprimidos, os membros das comunidades, se outrora buscavam na religião um sedativo para os sofrimentos, encontram agora um espaço de discernimento crítico frente à ideologia dominante e de organização popular capaz de resistir à opressão (FREI BETTO, 1981, p.20).

A Pastoral da Criança também oferece um espaço crítico, de organização popular voltada às questões de saúde pública, da criança e das mães. Além de toda a formação voltada para esses temas, acompanhamos ações junto a Prefeitura de São Paulo sobre tuberculose e outras com o Ministério da Saúde. Vimos casos de pressões em nível local, como nos postos de saúde e subprefeitura, exigindo informações no cartão da gestante.

No entanto, parece que a autonomia era maior nas CEBs, que não contavam com uma coordenação nacional estruturada como a Pastoral da Criança, a qual prepara materiais e diretrizes para serem seguidas por todos, ainda que essa preparação consulte coordenadores estaduais e regionais, seja através dos encontros ou dos dados enviados.

Segundo Camargo, Souza e Pierucci (1980, p.69-77), as CEBs assumiam modalidades diversificadas. Estavam sempre reformulando seus objetivos, ações, métodos a partir do que era imposto pela sociedade e pelas necessidades das próprias comunidades. Assim, as pessoas iam lutando por seus direitos básicos. Tudo era escolhido de forma democrática, por voto. As tarefas eram divididas de acordo com a possibilidade de cada um em se dedicar ao cumprimento, de tal maneira que se mobilizavam os membros da comunidade e até outros moradores do bairro. Também havia reuniões para se avaliar o que foi feito, a repercussão da ação e as dificuldades encontradas. Essas reuniões podem ser comparadas com as reuniões de reflexão e avaliação.

Pela descrição dos autores, as ações das CEBs eram decididas apenas localmente e os objetivos variavam. Já a Pastoral da Criança tem uma atuação definida em nível nacional: agir em prol da saúde das crianças de até seis anos dentro de suas famílias. No entanto, há outras ações, que são políticas nacionais, como de geração de renda e de alfabetização. A partir das diretrizes nacionais, cada comunidade ou região fará suas ações e terão o apoio de materiais e financeiro da Pastoral da Criança. Já os comentários dos autores sobre divisão de tarefas e reuniões de avaliação são parecidos com a instituição estudada. 
Mas nas CEBs havia uma crítica bem mais acentuada ao sistema capitalista, enquanto na Pastoral da Criança os discursos são centrados na questão dos direitos e deveres e da necessidade de políticas públicas, que devem ser cobradas e acompanhadas.

Voltam-se então as Comunidades Eclesiais de Base para os problemas
decorrentes do crescimento econômico excludente, para as relações de
trabalho, para as instituições sindicais e políticas. Esboça-se, desta maneira,
um ideal democrático que não se limita ao protesto urbano ou a uma
concepção liberal do Estado e da sociedade civil. Vislumbra-se a construção
de uma democracia igualitária e liberta das injustiças inerentes ao
capitalismo. Embora de forma incipiente, tornam-se as CEBs participantes
das mais gerais - e mais determinantes lutas e tensões que encaminham as
mudanças econômicas e sociais do país. (CAMARGO; SOUZA; PIERUCCI,
1980, p.76)

Nesse cenário, Frei Betto (1981, p.22-24) estabelece três etapas percorridas pelas CEBs. A primeira centrada na motivação religiosa, procurando no evangelho "as pistas para sua atividade social". Depois, vem a etapa dos movimentos populares (como clube de mães, movimento do custo-de-vida, loteamento clandestinos, grupos de teatros), que surgiam com os participantes das comunidades, através de suas reflexões sobre os problemas do bairro, da família e do trabalho. A terceira seria a participação dos membros no movimento operário por meio da oposição sindical e de "sindicatos autênticos".

“Assim, a Comunidade Eclesial de Base abria-se ao movimento popular, ajudando a criar ou a fortalecer formas de organização popular autônomas, desvinculadas do Estado e da Igreja" (1981, p.24). Ele ainda explica que "mesmo não havendo uma consciência de classe, percebe-se nos movimentos populares um forte sentimento de justiça e a consciência, cada vez mais explícita, dos direitos do povo" (1981, p.25).

Faxina (2001, p.141-142) averiguou a mesma característica na Pastoral da Criança: "não há uma consciência de classe ou de exploração social, geralmente". Mas há o entendimento de que existem problemas sociais e que eles podem ser agentes transformadores, enfrentando-os. Além disso, há a percepção de que todos têm direito à vida $\mathrm{e}$ à dignidade humana. Outro ponto considerado pelo autor é que a Pastoral deve ampliar sua intervenção no campo dos direitos civis, políticos e sociais, buscando-se uma cidadania $\operatorname{ativa}^{25}$ (FAXINA, 2001, p.189).

\footnotetext{
25 "Busca-se o exercício de uma cidadania ativa, na forma como explica Chaú (1984), lembrando que a cidadania passiva é aquela outorgada pelo Estado e se diferencia da cidadania ativa, na qual o cidadão, portador de direitos e deveres, é essencialmente criador de direitos para abrir novos espaços de participação política" (FAXINA, 2001, p.191)
} 
Voltando-se para a análise de Frei Betto sobre as CEBs, percebemos que a motivação religiosa de que ele fala também existe também na Pastoral da Criança. Além de sempre haver o momento de fé nos encontros, seja com leitura bíblica ou um canto de reflexão, a fé sempre aparece nas publicações:

Nossos voluntários praticam a solidariedade e o amor, desenvolvendo ações concretas para que as crianças, gestantes e suas famílias tenham oportunidade de alcançar a vida plena. Procure a coordenação da Pastoral da Criança mais próxima e venha participar dessa rede de solidariedade. 'Cada vez que o fizeres a um desses meus irmãos mais pequeninos, a mim o fareis' MT 24,40. (PASTORAL DA CRIANÇA, 2008, p.20)

Em nossa pesquisa, verificamos que as voluntárias são incentivadas a participarem de conselhos e se mobilizarem em torno das questões da saúde e da criança. Há o sentimento de justiça e de direitos do povo, também sem consciência de classe. Mas não há envolvimento com o movimento sindical nem dos movimentos populares como ocorreu nos anos 70 e 80 . É uma nova forma de se relacionar. Naquele período não havia os conselhos como hoje nem práticas participativas no governo. Na verdade, isso é uma consequência das lutas passadas pela democracia, para as quais as CEBs foram fundamentais.

Podemos ver isso através dos relatos de Wanderley (1985, p.13-14). Os movimentos de bairro são impulsionados pelas $\mathrm{CEBs}^{26}$. Isso também é motivado pela situação gerada pelo próprio sistema capitalista, pois à medida que ele avança nas zonas urbanas, "o capital se apropria do solo urbano, e a cidade passa a ser mercadoria”. Assim, a especulação imobiliária e o encarecimento do solo urbano agravam a "periferização", e as pessoas das classes menos favorecidas passam a morar em bairros periféricos, onde não há condições mínimas de sobrevivência como transporte, luz elétrica, água encanada, saúde ou educação. "Pouco a pouco, esses trabalhadores vão passar a lutar coletivamente por transporte, por luz, por água, e nascem movimentos ligados à reivindicação desses bens coletivos". Nesse contexto, a mulher vai ter papel fundamental na liderança desses movimentos.

São em locais como esse, na periferia, que a Pastoral da Criança começa sua atuação em São Paulo, o que se mantém até hoje. As mulheres também foram e continuam sendo protagonistas na ação da Pastoral da Criança, como vimos anteriormente.

\footnotetext{
${ }^{26}$ Para Peruzzo (1998, p.46), as CEBs não são um movimento social, apesar de atuarem no universo desses movimentos e terem muito a ver com ele. Elas "são animadoras e fomentadoras de grupos sociais populares e sindicais". A atuação se dá "no nível da conscientização, da denúncia, do assessoramento jurídico e político, da articulação, da formação, da sistematização e divulgação de informações". No entanto, ela faz a ressalva de que essa não é uma questão "clara, pois, principalmente nos primeiros anos de sua práxis, as comunidades eclesiais de base e as pastorais sociais (pastoral da terra, pastoral operária) caracterizaram-se bastante enquanto movimentos, apesar de serem essencialmente motivadoras dos mesmos".
} 
Voltando às CEBs, para Singer (1980, p.85-106), funcionavam como organizadoras dos movimentos de bairro. Assim, as Comunidades Eclesiais de Base caracterizavam-se pela vida comunitária embasada em valores cristãos como igualdade e solidariedade entre as pessoas, assumindo as reivindicações locais e criando uma nova sociabilidade que negava o caráter competitivo do capitalismo. Elas não aceitavam as desigualdades sociais, e que essa desigualdade fosse explicada pela diferença entre indivíduos, ou seja, "o pobre como responsável por sua pobreza". Visava à participação da população nas instituições governamentais através da luta por direitos.

Um fato que também deve ser destacado nas ações das CEBs é a pedagogia de trabalho, que também lembra a pedagogia usada pela Pastoral da Criança. O agente, ou militante, precisa se reeducar para educar as classes populares, realizando uma troca de conhecimentos:

No contato agente-base, um e outro se reeducam, como bem o demonstra Paulo Freire em Pedagogia do Oprimido. (...) Destrói-se aquela imagem idílica do povo, como se ele fosse um barril vazio pronto a ser enchido pelas idéias explosivas dos agentes de classe média. (...) Dentro de um trabalho organizado, emerge a consciência do oprimido, aprendendo o avesso da estrutura social e partindo para uma prática transformadora (FREI BETTO, 1981, p.38-39).

Outro ponto importante para a comparação foi citado por Gomes (1987, p.27-28): os encontros interclesiais de base, que avaliam a trajetória das comunidades. Esses eventos foram fundamentais para o desenvolvimento das CEBs. O material vindo delas é analisado teologicamente, pastoralmente e sociologicamente. O primeiro deles ocorreu em Vitória, no ano de 1975, com o tema "Uma Igreja que nasce do Povo pelo Espírito de Deus", no qual as CEBs se restringiam em enviar relatórios para serem avaliados. Já no segundo, em 1976, passam a participar como ouvintes. No terceiro, em 1978, são as próprias CEBs que preparam o encontro. É com esse envolvimento que prosseguem outros encontros pela década de 80 .

Todos os anos, os representantes das CEBs reúnem-se em suas respectivas dioceses e, a cada três ou quatro anos, há um Encontro Nacional das CEBs, com a presença de bispos, teólogos, sociólogos e mais de quinhentos representantes de todo o Brasil. Esses encontros constituem uma oportunidade importante para a hierarquia tomar o pulso do povo, ouvindo e compreendendo seus problemas e necessidades. Juntos refletem sobre situações concretas, como a da terra ou do sistema econômico vigente. À luz da fé, mas dentro do contexto histórico das CEBs, examinam e adotam orientações para o futuro. Essas orientações são, por sua vez, passadas para todos os representantes das CEBs, nas diferentes regiões do país. (PUNTEL, 1994, p.227) 
Na Pastoral da Criança, também há uma dinâmica de encontros e assembleias nacionais e regionais. A assembleia nacional reúne todos coordenadores estaduais. Estados com maior número de dioceses como São Paulo e Minas Gerais levam, além do coordenador, mais dois representantes. Também há os chamados Encontros Nacionais, nos quais a Coordenação Nacional se reúne com grupos de estados e discute os temas a serem trabalhados no ano. Isso também permite que todos tenham os mesmos objetivos.

No caso de São Paulo, o estado se reúne sozinho com os representantes da Coordenação Nacional. É sempre o último estado a ter assembleia e geralmente recebe oito representantes da Coordenação Nacional. Participam dessa reunião coordenadores de 46 setores e de oito núcleos. Em 2009, esse encontro ocorreu em Jundiaí, no mês de julho. O tema central desse ano é a obesidade infantil, que vem atingindo crianças de várias classes sociais. Segundo Dallabona (2009), o problema é que as crianças deixaram de comer frutas e legumes para se alimentar com produtos industrializados (informação verbal) ${ }^{27}$.

Também ocorrem anualmente assembleias por setores. A Arquidiocese de São Paulo tem seis setores para a Pastoral da Criança, que correspondem as regiões episcopais: Belém, Brasilândia, Ipiranga, Lapa, Santana e Sé. Essas assembleias duram 16h e a cada dois anos servem para eleger o coordenador do setor. Quem vota são os coordenadores de área e de ramo (paróquias). Forma-se uma lista tríplice, da qual o bispo da região ratifica um coordenador e um vice. Também há a assembleia da arquidiocese, na qual a cada dois anos se escolhe a coordenadora arquidiocesana da Pastoral da Criança, ratificada pelo arcebispo Dom Odilo Scherer. Em todos os casos, os coordenadores podem ser reeleitos quatro vezes.

Essas assembleias e encontros se caracterizam por possibilitarem uma discussão na qual todos são livres para falar, apresentar dificuldades e criticar problemas sociais. $\mathrm{Na}$ assembleia da Lapa, por exemplo, no dia 22/03/2009, parte da discussão girou em torno da Campanha da Fraternidade, que tratou da questão da segurança pública em 2009, com o lema “a paz é fruto da justiça". Dessa forma, os coordenadores presentes falaram da violência verbal, e não apenas física, da violência dos meios de comunicação que lucram com uma indústria do medo e da violência do cotidiano, como a exploração sexual. Destacou-se a necessidade do diálogo para implantar uma cultura da paz e se obter mudanças através da educação. Quem preparou o material sobre o tema foi uma multiplicadora da região e

\footnotetext{
${ }^{27}$ Informação fornecida pela nutricionista da Pastoral da Criança Caroline Dallabona em entrevista realizada pela autora durante capacitação em alimentação e hortas caseiras no Centro de Formação Sagrada Família, no Ipiranga, em 14/03/09.
} 
conforme ela foi expondo, todos complementavam com informações e davam suas opiniões de forma dinâmica.

Vale lembrar ainda que em cada um desses seis setores ocorre reunião mensal com todos os coordenadores. As líderes participam quando enviadas pelos coordenadores. Também há reuniões mensais de áreas com coordenadores de ramo (comunidades) e as reuniões de avaliação nas comunidades com as líderes. Outra reunião mensal é das coordenadoras dos seis setores (regiões episcopais) com a coordenadora arquidiocesana. Participamos de diversas reuniões, assembleias e encontros e sempre vimos esse caráter participativo. Também é feito um "encontrão" anual com todas as líderes por setor. Outro ponto interessante é que a maioria das coordenadoras, exceto dos seis setores e da arquidiocese, continua atuando como líder e visitando as famílias.

Faxina (2001, p.136-139), que teve a Pastoral da Criança como objeto de estudo, também vê semelhanças entre as CEBs e a Pastoral. Ele destaca a fé como impulso para as ações e a classifica como "mantenedor do equilíbrio entre desafios e alegrias, entre cansaço e esperança". Dessa forma, acredita que os voluntários recuperam um dos principais eixos das CEBs, que é unir fé e vida. A fé não aparece como "consolidação de um sujeito individualista" e, sim, permeada de uma preocupação de "construção de relações humanas solidárias". O autor ainda relata que, como também verificamos em nossa pesquisa, acontecem formas de manifestação religiosa como cânticos, orações ou leituras bíblicas nas reuniões da Pastoral.

Destacamos novamente nisso semelhanças com as CEBs, que também se utilizavam desses recursos nas reuniões. Ainda se pode fazer um paralelo entre as líderes comunitárias e os agentes pastorais das CEBs, que, na maioria das vezes, também acabavam sendo pessoas da própria comunidade. Fica clara ainda uma preocupação em ambos os casos para que se valorize a linguagem do povo e sua cultura, além da preocupação com a realidade e os problemas da família ou da comunidade.

Para se ter uma idéia, vale lembrar que, segundo Frei Betto (1981, p.55), as reuniões são consideradas um meio de comunicação entre as Comunidades Eclesiais de Base e estão abertas “à realidade concreta de seus membros e é em função dessa realidade que ela encontra seu dinamismo e sua razão de ser".

Por sua vez, afirma Faxina (2001, p.205):

No caso da Pastoral da Criança (...) seus coordenadores locais e líderes comunitários são pessoas que têm público próprio, assimilam os ensinamentos que recebem e os traduzem, a partir de seu conhecimento 
acumulado, de seu lugar de ação, de suas necessidades, enfim, adapta-os à cultura local, de forma que sejam entendidos e assimilados por seu público próprio. Essa possibilidade de reedição de uma mensagem permite sua adequação à realidade local e, portanto, a incorporação das práticas cotidianas de determinado grupo.

Outra semelhança é o valor dado para formação. Segundo Faxina (2001, p.211), na época de sua pesquisa, eram realizados pela Pastoral da Criança 40 mil cursos de capacitação a cada ano, que incluem tanto novos voluntários como reciclagem daqueles que já atuavam na entidade. São mais de 600 mil pessoas capacitadas. Por sua vez, Frei Betto (1981, p.56) afirma que os agentes das CEBs participavam periodicamente de encontros ou treinamentos promovidos pela coordenação pastoral. Sendo que os encontros eram as reuniões das comunidades para aprofundamento espiritual, para debater o plano pastoral da diocese ou a integração ao tema da Campanha da Fraternidade. Já os treinamentos formavam membros das comunidades. No caso da Pastoral da Criança, a Campanha da Fraternidade sempre é trabalhada em reuniões assim como no jornal da entidade.

Se olharmos para o passado das CEBs, veremos algumas dificuldades. Segundo Frei Betto (1981, p.40) a participação das pessoas era boa na hora de rezar, cantar, ler e meditar o evangelho, mas quando se falava em miséria, fome, opressão, sindicato, algumas pessoas se afastavam. Haveria ainda

uma defasagem entre a proposta libertadora do agente, feita em geral de forma colonialista, e a reação da comunidade, desconfiada dos que querem manipulá-la. É como se os membros da comunidade preferissem continuar acomodados em sua opressão a se arriscarem na busca de uma transformação cujo alcance eles não conseguem apreender (1981, p.70).

Outro problema segundo o autor são dois desvios que aconteciam e deviam ser evitados: o populismo eclesial e o vanguardismo eclesial. No primeiro caso, permite-se que apenas o povo fale sem que os agentes questionem ou analisem a situação do povo. É o que ele chama de anti-intelectualismo exacerbado. Já o vanguardismo eclesial julga o povo incapaz e acredita ser autossuficiente. $\mathrm{O}$ agente, nesse caso, acredita não ter nada a que aprender com o povo, querendo apenas politizá-lo o mais rápido possível e dirigi-lo. (FREI BETTO, 1981, p.41-44).

Uma das formas para mobilizar o povo era partir de interesses imediatos como água encanada, luz para o bairro, transporte, entre outros. "É através de ações concretas, em função desses interesses imediatos, que a base popular chega a absorver e entender a força de sua união, a luta pela justiça, a busca de um mundo novo" (FREI BETTO, 1981, p.46). Ele 
explica ainda que o discurso genérico sensibiliza a consciência popular, mas não o mobiliza. Por isso que é importante ouvir o povo, que conhece a história da opressão pela sua própria vivência.

Se observarmos a Pastoral da Criança, também veremos limitações. Na Assembleia da Arquidiocese de São Paulo, ocorrida em 05/04, uma multiplicadora do Belém avaliou que nem sempre os ramos (paróquias) fazem a reunião de reflexão e avaliação. Além disso, quando acontece um problema que deveria ser resolvido em conjunto nessa reunião, não se faz isso e se leva a questão para a coordenadora do setor. Já entre as 61 pessoas da arquidiocese entrevistadas para a pesquisa houve um consenso em apontar como a maior dificuldade o fato de que seria preciso ter mais voluntárias e voluntários. Muitas pessoas chegam a dizer que farão a capacitação, mas acabam desistindo.

Olhando para o passado das CEBs, vemos ainda outra questão que reflete na atuação social da Igreja. Camargo, Souza e Pierucci (1980, p.78) apontam que as CEBs, em relação à própria sociedade que pretendiam mudar, "sofriam limitações oriundas da inércia da tradição eclesiástica. E, como tantas associações da sociedade civil, debatem-se entre projetos alternativos sem um modelo claro de postura ética e ação política”.

Acreditamos que nesse sentido, a Pastoral da Criança tem um modelo claro que vem da Coordenação Nacional e é retrabalhado pelas bases. No entanto, pode haver limitação sim caso um padre não apoie a ação da Pastoral da Criança. A ação política é incentivada a partir da participação em conselhos e em debates públicos.

Já no caso das CEBs, com a abertura política, a Igreja e as CEBs ainda perdem a "hegemonia na oposição ao regime". "As Comunidades Eclesiais de Base já não são o espaço privilegiado de organização popular e seus membros participam agora das formas autônomas de mobilização do povo e dos instrumentos de luta da classe trabalhadora" (FREI BETTO, 1981, p.81). Ocorre uma modificação no papel das CEBs, que têm reduzido seu alcance político, o que não significa que elas estejam superadas. Para Frei Betto, as CEBs e os movimentos populares autônomos se completam.

Atualmente ainda existem CEBs. Os Interclesiais continuam ocorrendo. Nesse ano de 2009, o $12^{\circ}$ Interclesial das Comunidades Eclesiais de Base ocorreu no mês de julho, em Porto Velho, Rondônia. O tema é "CEBs: Ecologia e Missão" e o lema "Do Ventre da Terra, o Grito que vem da Amazônia" O texto-base, segundo o arcebispo de Porto Velho, Dom 
Moacyr Grechi, traz subsídios sobre etnias, religiões e culturas diferentes, além de tratar da devastação da Amazônia ${ }^{28}$.

Acreditamos que as CEBs continuam vivas não só nas CEBs que ainda restaram, mas também na Pastoral da Criança, que como as comunidades de base, trilhou um caminho que opta pelos pobres, com uma visão crítica e conscientizadora, na qual o leigo é sujeito da transformação.

\section{8 - Um novo sujeito}

Sader (1991, p.26-29) relata que em 1978, os grupos populares entraram na cena pública, reivindicando seus direitos. Houve uma revalorização de práticas sociais no cotidiano popular com o impacto dos movimentos sociais. Gestados nos anos 70, os movimentos sociais passaram a serem vistos pelas suas linguagens, pelos lugares onde se manifestavam, pelos seus valores e pela emergência de novas identidades coletivas. Nasce um sujeito coletivo como afirmação de setores sociais até então excluídos. São "novos personagens em cena", lutando pelo "direito a ter direitos".

Se há movimentos operários e populares, não podemos esquecer a ação das CEBs. Brant (1980, p.14-16), por exemplo, destaca o papel central da Igreja, através das Comunidades Eclesiais de Base, na organização pela moradia na periferia de São Paulo. Outras pastorais também se voltaram para os trabalhadores e marginalizados, estimulando movimentos.

Por sua vez, Sader (1991, p.144) aponta como na Igreja, as CEBs têm como "matriz discursiva" a Teologia da Libertação, com raízes na cultura popular e apoiada em uma organização bem implantada. A esquerda conta com a "matriz discursiva" marxista que enunciava um corpo teórico em relação à luta e exploração no capitalismo. Já os discursos do novo sindicalismo são os mais ligados aos conflitos e temas relativos ao mundo do trabalho e à exploração dos trabalhadores.

Toda essa articulação dos anos 70, que é consequência das ações dos anos 50 e 60 , possibilita a configuração de um novo sujeito. A noção de sujeito, como explica Sader (1991, p.52-54), vem associada a um projeto. Também há a ideia de autonomia como elaboração da

\footnotetext{
${ }^{28}$ Essas informações foram verificadas em http://www.cebs12.org.br/index.asp, em 26/03/2009, às $22 \mathrm{~h} 22$.
} 
própria identidade e de projetos coletivos de mudanças sociais através de experiências. "Configura-se um sujeito coletivo no qual se elabora uma identidade e se organizam práticas que permitem que seus membros defendam seus interesses e expressam suas vontades, constituindo-se em suas lutas".

Esse novo sujeito de que fala Sader, que lutará pela democracia nos anos 80, é o sujeito que observamos na Pastoral da Criança. A organização social, surgida em 1983, traz esse projeto coletivo de mudança social, primeiro através da experiência de Florestópolis. Essa experiência se múltipla por outras regiões até chegar aos impressionantes números atuais: mais de 260 mil voluntários, 4.066 municípios de todos os estados brasileiros e média mensal de 1.816.261 crianças menores de seis anos acompanhadas.

Sem dúvida esses voluntários, como vimos na pesquisa participante, formam uma identidade através da Pastoral da Criança. A ação conjunta visa à mudança de vida da criança e da família, que terão conhecimentos para uma alimentação adequada, informações para exigirem direitos, como saúde e educação, também se trabalham questões do âmbito familiar, como a violência doméstica. Por sua vez, essas voluntárias adquirem uma consciência crítica, mobilizam-se, agem em prol da mudança social. É uma luta organizada, com práticas estabelecidas e discutidas desde a base.

\section{9 - A luta pela redemocratização nos anos 80}

Para entender o período em que nasce a Pastoral da Criança é preciso olhar para o processo de redemocratização vivido pelo país nos anos 80. Gohn (1997, p.226) destaca que o final dos anos 70 e os anos 80 se caracterizaram, na América Latina, pela redemocratização. As políticas internas dos países latino-americanos foram redirecionadas a partir da mobilização e pressão da sociedade civil e política. Nesse cenário, os regimes militares foram substituídos por civis, seja através de negociação no parlamento, seja através de vias eleitorais. Já os movimentos sociais cresceram em quantidade e ganharam diferentes tipos, alcançando visibilidade devido à luta pela redemocratização ou por causas específicas.

Os novos movimentos sociais, que surgiam no final da década de 70 no Brasil, caracterizavam-se por serem movimentos sociais populares urbanos, grande parte também ligado à Igreja Católica e sua Teologia da Libertação. 
A denominação buscava contrapor os novos movimentos sociais aos ditos já velhos, expressos no modelo clássico das sociedades amigos de bairro ou associações de moradores. O que estava no cerne da diferenciação eram práticas sociais e um estilo de organizar a comunidade local de maneira totalmente distinta (GOHN, 1997, p. 281).

Vale lembrar a divisão que Cardoso (1994, p.81-82) faz da trajetória dos movimentos sociais no período. A primeira fase engloba a década de 70 e o início dos anos 80 , sendo denominada como "a emergência heróica dos movimentos". Há a ideia de espontaneidade e de autonomia. Os movimentos nesse período "apareciam como algo dominante, novo, de caráter mais puro, muito mais importante, que iriam ocupar um espaço vazio", o qual se encontrava dessa forma devido à ditadura militar, que bloqueava os canais de representação. A autonomia deles rompia com as relações clientelistas e com o sistema político vigente. Era uma participação antiestado, antipartido, antissistema político.

A segunda, nos anos 80 , é quando ocorre a "institucionalização da participação dos movimentos, da relação desses movimentos com o Estado". Há um novo contexto político, que consiste no início da "redemocratização",29, com a abertura de novos canais de comunicação e participação que estavam bloqueados. Isso se inicia em 1982 com as eleições estaduais. Os movimentos passam a se relacionar com as agências públicas, mas esse processo é parcial, atingindo apenas algumas áreas. Um exemplo é a criação de conselhos em algumas áreas específicas como a saúde, mas outras são deixadas de lado como a educação.

Foi o grande momento em que todos os conselhos de participação começaram a ser criados, desde o conselho da mulher até o conselho do negro, de habitação, de saúde e, agora mais recentemente, o conselho da criança, criado pelo Estatuto da Criança e do Adolescente. Há uma ampliação do modo de gerir as áreas de políticas públicas com a aceitação e abertura de espaços novos onde os movimentos sociais entram - tudo isso de um modo muito parcelado. (CARDOSO, 1994, p.83)

É interessante notar que a participação em conselhos da saúde, da mulher e da criança é estimulada pela Pastoral da Criança, seja por meio de matérias no jornal da entidade ou das reuniões. Na pesquisa de campo, vimos voluntários que faziam parte de diferentes conselhos e como eles traziam as discussões desses para os outros membros da Pastoral da Criança, sempre estimulando a participação de todos no debate e que cada um em sua comunidade buscasse uma participação ativa.

\footnotetext{
${ }^{29}$ Cardoso (1994) utiliza o termo entre aspas porque acredita que o processo de democratização não chegou ao fim.
} 
Se isso é possível hoje, deve-se a esse cenário que começa a ser construído nos anos 80 e ganha ainda mais força após a Constituição estabelecida em 1988.

\begin{abstract}
Desse modo, a experiência da visibilidade deste "outro" agora autonomamente organizado e disputando o sentido do espaço público - os sindicatos antes legalmente controlados, os trabalhadores pobres e excluídos sociais, as pessoas discriminadas por gênero, cor, idade, etnia, opção sexual, as pessoas destituídas de seu meio pela ação predadora do capital - impactou fortemente a cultura política do país. Modificou a forma de exercício do poder local e das grandes cidades, envolveu a virada secular da Igreja, gerou uma nova esquerda política e partidária, introduziu um novo vocabulário político em cujo centro, pela primeira vez, estava a palavra "cidadania", influiu fortemente nos dispositivos da nova Constituição (pós-ditadura militar) dando peso e consistência à palavra "direitos" e introduziu o que mais tarde se configuraria como o "modelo participativo" local de negociação e deliberação pública e política. (PAOLI, 2002, p.404)
\end{abstract}

No entanto, vale ressaltar que havia limitações. Cardoso (1994, p.89) aponta que apesar da abertura para a participação institucional, há dificuldades para essa participação na administração pública devido à própria identidade, espontaneidade e particularidade dos movimentos. Esses tinham diferentes reivindicações, e as agências públicas não sabiam lidar com essa situação. Pensava-se que com os conselhos se conseguiria um consenso para o estabelecimento de programas, mas os movimentos tinham dificuldades em definir representantes, critérios e o equilíbrio entre recursos e políticas. Segundo alguns autores, verificaram-se o esvaziamento dos conselhos e uma mobilização menor que a esperada, apesar de haver casos bem sucedidos.

Outro ponto a ser considerado sobre o período é que houve o aparecimento de entidades aglutinadoras dos movimentos sociais populares. Isso se aprofundou nos anos 90 com a disseminação das ONGs. (GOHN, 1997, p.285) Deve-se considerar também que com as eleições municipais de 1988 e o crescimento dos partidos políticos, ocorreu uma busca desses partidos de interação com as bases e, assim, com as comunidades, associações de moradores e outros grupos sociais (ANDRADE, 1989, p.44-45). As modificações na política impuseram a partir da metade da década de 80 uma reformulação das posturas dos movimentos sociais:

As mudanças, como o aproveitamento de muitas lideranças para um trabalho político partidário; as instâncias de diálogo e colaboração mútua que os governos estaduais criaram em alguns lugares; a grande mobilização exigida como forma de pressão na elaboração da Constituição brasileira, tudo isto colaborou para um arrefecimento dos movimentos sociais, que ao verem antigos aliados chegando ao poder, sem apresentar nenhuma correspondente mudança real, permaneceram perplexos e tardaram a enfrentar o desafio 
agora imposto de continuarem organizados e mobilizados, sem deixar de estar ao mesmo tempo acessíveis a novas formas de articulações: as negociações, composições, barganhas, etc. que a pluralidade dos interesses e dos grupos envolvidos está a exigir. (ANDRADE, 1989, p.45-46)

Com a transição democrática, os movimentos sociais se tornaram interlocutores privilegiados do Estado, que se democratizava e buscava mudar sua face repressiva (GOHN, 1997, p.313). Dessa forma, a autora descreve o ano de 1982 a 1995 como a "época da negociação e a era dos direitos":

Esta fase corresponde a um período de intensa movimentação social, dado pelas características da conjuntura política e bastante ampliado pela dimensão dos problemas sociais, pelo aumento do contingente populacional do país e pela facilidade de divulgação e reprodução das ações coletivas pelos meios de comunicação de massa. (GOHN, 1995, p.123)

Para entender a importância dos anos 80 para o nascimento da Pastoral da Criança, podemos recorrer mais uma vez a Gohn (1995, p.124), que caracteriza o período como fundamental "para a compreensão da construção da cidadania dos pobres no Brasil, em novos parâmetros". A autora acredita que "embora com o estatuto de cidadãos de segunda categoria, os pobres saíram do submundo e vieram à luz como cidadãos dotados de direitos". Esses direitos, coloca, estão na Constituição, mas muitas vezes são negados na prática.

Podemos ver a Pastoral da Criança como um movimento institucionalizado não só pela Igreja, mas também com relações com o Estado, já que desde 1985 o Ministério da Saúde é parceiro técnico e financeiro da Pastoral da Criança. No entanto, não apenas olha para os pobres como dá voz e subsídios para que eles mesmos superem os problemas de desnutrição da comunidade. Esse empenho em combater a mortalidade infantil não se trata apenas de uma medida higienista como sugere Brolhani (2004, p.188). Em nossa pesquisa de campo, vimos debates e articulações de ação visando à construção da cidadania. Parte do voluntariado não só se vê como sujeito de direito, como age para que as pessoas das famílias visitadas também se vejam assim. Mesmo os que não têm essa visão, vivenciam a cidadania na prática.

\subsection{0 - A eclosão da globalização nos anos 90}

Os anos 90 se caracterizaram por um acirramento das desigualdades no cenário do capitalismo nos países ocidentais conforme mostra o panorama traçado por Gohn (1997, 
p.227). Desde os anos 70/80, ocorre uma redivisão internacional do trabalho, a produção passou a ser fragmentada visando vantagens fiscais e econômicas para uma maior acumulação, as fronteiras nacionais perderam importância. Além disso, o trabalho informal cresceu assim como o desemprego, e os sindicatos perderam poder de forma generalizada. Os que não foram demitidos tiveram que se adequar ao trabalho, sendo multiespecializados. Tudo isso se aprofunda nos anos 90, e essa década passou a ser chamada de "era" da globalização e caracterizada por políticas neoliberais.

Outra característica apontada pela autora sobre o período é que o Estado não precisa mais dos movimentos para se legitimar como não repressor. Os movimentos progressistas que sobreviveram querem participar das políticas públicas através de uma nova forma democrática, a pública não-estatal. É importante salientar que a partir dessa década, os movimentos populares progressistas e a Teologia da Libertação perderam o apoio irrestrito da Igreja Católica. Isso aconteceu porque a Igreja tem revisto suas doutrinas e práticas sociais, mudando os rumos e diretrizes de suas ações em relação à participação popular na política nacional. A Teologia da Libertação ${ }^{30}$ deixou de ser "uma política para ser uma linha de resistência”. (GOHN, 1997, p.313-314)

A própria Pastoral da Criança, apesar de vermos vários pontos trabalhados que lembram a teologia da libertação e a ação das CEBs, em nenhum momento se diz adepta dessa teologia, no entanto, no seu discurso e na sua prática encontramos essa influência, seja através

\footnotetext{
${ }^{30}$ Vale lembrar que as limitações à Teologia da Libertação tiveram como grande expoente o então prefeito da Congregação para a Doutrina da Fé, Cardeal Joseph Ratzinger, hoje Papa Bento XVI. Em 06 de agosto de 1984, o Cardeal Ratzinger trouxe a público o texto "Instrução sobre certos aspectos da teologia da libertação" (disponível http://www.vatican.va/roman_curia/congregations/cfaith/documents/rc_con_cfaith_doc_19840806 theologyliberation en.html em 27/04/2009, às $16 \mathrm{~h}$ - em inglês). Ele avalia que a luta de classes como a lei fundamental da história foi aceita pela teologia da libertação como um princípio. Critica a identificação do reino com a libertação humana como um processo de autorredenção do homem por meio da luta de classes, o que, em sua avaliação, é colocado como oposição à fé da Igreja, tal como foi reafirmado pelo Concílio Vaticano II. Trazendo a discussão para a atualidade, conforme noticiado em março de 2007 pela Adital (disponível em http://www.adital.com.br/site/noticia.asp?cod=26675\&lang=PT, em 26/04/09, às 21h13) a Congregação para a Doutrina da Fé notificou o teólogo da libertação Jon Sobrino sobre a proibição de que ministre aulas em qualquer centro católico "até que revise suas conclusões". Na página do vaticano (disponível em http://www.vatican.va/roman curia/congregations/cfaith/documents/rc con_cfaith doc 20061126 notificationsobrino po.html, em 26/04/09, às 21h10), podemos ver uma notificação da Congregação da Doutrina da Fé sobre as obras de Jon Sobrino: "Jesucristo liberador. Lectura histórico-teológica de Jesús de Nazaret" (Madrid, 1991) e "La fe en Jesucristo. Ensayo desde las víctimas" (San Salvador, 1999). Chama-se "atenção para certas proposições que não são conformes à doutrina da Igreja. Tais proposições têm a ver com: 1) os pressupostos metodológicos enunciados pelo autor, onde ele funda a sua reflexão teológica, 2) a divindade de Jesus Cristo, 3) a encarnação do Filho de Deus, 4) a relação entre Jesus Cristo e o Reino de Deus, 5) a auto-consciência de Jesus Cristo e 6) o valor salvífico da sua morte", afirma o texto.
} 
da opção pelos pobres, seja pelo uso de práticas educativas de Paulo Freire e pela mesma metodologia das CEBs - "ver, julgar e agir". Mas isso é aliado às tendências dos anos 90, como veremos a seguir.

Ferreira (1999, p.129) acredita que o neoliberalismo "modificou drasticamente os cenários mundiais nas mais diferentes esferas das sociedades". Houve uma mundialização da cultura, a economia se globalizou, a tecnologia da comunicação possibilitou o encurtamento do espaço e possibilitou um novo conceito de tempo. Por outro lado, houve o crescimento da pobreza.

Ocorre a retirada do Estado da esfera social. As políticas sociais passam a ser preteridas pelo Estado. Tudo isso justificado pela necessidade de uma retomada do crescimento econômico e como estratégia de desenvolvimento. Por sua vez, as relações de trabalho perdem espaço na luta dos trabalhadores. O foco passa a ser a manutenção do emprego e não mais as condições de trabalho dentro de uma categoria. Ao mesmo tempo, a mídia se torna um grande agente de pressão, e as ONGs ganham confiança na gerência dos recursos públicos. (GOHN, 1997, p.296)

Gohn (1997, p.298-301) destaca ainda que a globalização leva a novas formas de gerir o sistema sócio-econômico nacional e internacional. Nesse contexto, há uma prioridade do mercado sobre o Estado. No entanto, não é um mercado da economia liberal. Trata-se de um mercado oligopolizado, gerenciado por regras estatais que estimulam ou retraem a economia formal ou informal, segundo os interesses de maior lucratividade. Enfim, do mercado comandado pela ideologia neoliberal. O capital financeiro atua desvinculado do processo produtivo, especulativo e volátil, que migra em busca de melhores taxas de lucro e retorno imediato. Não há compromisso de desenvolvimento com as nações em que investem. Outra característica do período é que o Estado busca reformar o sentido de suas ações, transferindo grande parte de suas responsabilidades para a iniciativa privada. Dessa forma, há enxugamento da máquina estatal, privatizações e revisão das leis previdenciárias.

Os programas de ajuste econômico e social configuram políticas neoliberais, que trazem um novo tipo de relação entre Estado e sociedade civil baseada numa concepção minimalista do Estado e da democracia. Diante disso, "a sociedade civil é obrigada a assumir as responsabilidades sociais evitadas agora pelo Estado neoliberal”. Por outro lado, há níveis de pobreza, violência, exclusão social sem precedentes. (ALVAREZ; DAGNINO; ESCOBAR, 2000, p.15) No caso da Pastoral da Criança, ela assume a bandeira da mortalidade infantil, partindo depois para o desenvolvimento integral das crianças de até seis anos. 
A globalização e o neoliberalismo não só intensificaram a desigualdade econômica como redefiniram de modo significativo o terreno políticocultural no qual os movimentos sociais devem empreender atualmente suas lutas. Com efeito, as políticas neoliberais esmagadoras que varreram o continente em anos recentes parecem, em alguns casos, ter enfraquecido os movimentos populares e abalado as linguagens existentes de protesto, colocando os movimentos a mercê de outros agentes articuladores, de partidos conservadores e narcotráfico a igrejas fundamentalistas e consumismo transnacional. (ALVAREZ; DAGNINO; ESCOBAR, 2000, p.45-46)

Por outro lado, esses autores apontam que a globalização abriu novas possibilidades aos movimentos sociais, como facilitar a promoção de uma política de democratização nãoterritorial de questões globais. As novas tecnologias de comunicação como a internet, por sua vez, permitiram um "ativismo político à distância". Essas novas tecnologias são fundamentais para a disseminação do trabalho da Pastoral da Criança, que utiliza tanto esse meio como a produção de jornais e programas de rádio.

Outro ponto que nos remete a Pastoral da Criança é relatado por Gohn (1997, p.240): os movimentos locais que não se articularam em redes nacionais ou regionais se enfraqueceram nos anos 90. Por outro lado, aqueles que trabalharam com demandas globais como reivindicações culturais dos indígenas, ecológicas, pela paz, por direitos humanos, entre outros, fortaleceram-se. Surgiram ações internacionais em meio ambiente, direitos humanos, para trabalhar com mulheres, crianças e jovens. Foram desenvolvidas estruturas e infraestruturas de apoio, capacitaram-se tecnologicamente, utilizando recursos como a internet e criando estruturas nacionais.

Olhando para a Pastoral da Criança, vemos que logo após a criação, Zilda Arns já busca disseminar a iniciativa por todo o Brasil através da CNBB. A ação para combater a mortalidade infantil também tem um forte apelo internacional. As estruturas citadas pela autora também estão presente na capacitação, que além de ocorrer presencialmente, em algumas situações utiliza a internet, como no caso da capacitação de voluntários para assessoria de imprensa.

Outro aspecto que vale ressaltar é que ainda nos anos 90 a metodologia da Pastoral da Criança é implementada em outros países do mundo (PASTORAL DA CRIANÇA, 2008, p.18). O primeiro foi o Paraguai, em 1994. Dados do segundo semestre de 2007, apontavam para 7.370 crianças atendidas e 1723 voluntários. Outro país que conta com a Pastoral da Criança e tem um sistema de informação implantado, baseado no brasileiro, é a Colômbia. No 
país desde 2001, são 806 voluntários acompanhando 12.548 crianças. Esses dados são do quarto semestre de 2007.

Outros países contam com a Pastoral da Criança como a Angola, desde 1996. Nos anos 2000, outros países passam a desenvolver a ação da Pastoral da Criança: Colômbia (2001), Timor Leste (2001), México (2002), Moçambique (2002), Argentina (2003), Bolívia (2003), Panamá (2003), Filipinas (2004), República Dominicana (2004), Uruguai (2004), Honduras (2005), Guatemala (2005), Venezuela (2005), Guiné (2007) e Guiné-Bissau (2007). Em 2008, mais dois países ganharam Pastoral da Criança: Haiti e Guiné-Conacry. São 19 países com a Pastoral da Criança Internacional.

Atualmente Zilda Arns é coordenadora internacional da Pastoral da Criança. Em 18 de novembro de 2008, foi oficializada a organização internacional. A cerimônia ocorreu em Montevidéu, no Uruguai. O país foi escolhido para a nova instituição por apresentar uma legislação que permite apoiar iniciativas em outros países. A coordenação da Fundação Internacional terá a colaboração voluntária de brasileiros e uruguaios. $^{31}$ No Brasil, as entidades filantrópicas não podem ajudar outros países (PASTORAL DA CRIANÇA, 2008, p. 18). No discurso abaixo, Zilda Arns fala sobre alguns momentos vividos pela Pastoral da Criança em outros países:

Fiquei profundamente emocionada quando fui a Guiné-Bissau no ano passado, mulçumanos, batistas, Assembleia de Deus formando capacitação da Pastoral da Criança. Lá $43 \%$ são mulçumanos, $10 \%$ são católicos e os outros são de outras religiões e outras devoções nativas. Todos irmanados trabalhando com alegria, agradecendo a Deus e salvando vidas naquela pobreza e miséria, cheia de malária, tuberculose e AIDS, tantas doenças, diarreia e tudo mais. Juntos salvando vidas, visitando as famílias, rezando juntos na sua devoção. Para mim, foi uma emoção enorme. Em Angola, estive duas vezes, especialmente durante a guerra em 1997. Capacitei 17 mulheres para começar a Pastoral da Criança. Naquela guerra onde os pais morriam, e os filhos ficavam órfãos. Não tinham o que comer. Havia um campo de mães que estavam amamentando. Elas, desnutridas, dava para contar os ossos do tórax. Quando respiravam, a gente via os ossos se mexerem. Elas desnutridas dando de mamar. Eu visitei famílias lá que não tinham o que comer. As dificuldades enormes no parto. Muitas mães morriam no parto porque hospital não tinha de graça, e o povo não tinha como pagar hospital. Agora outros países da África querem a Pastoral da Criança. Fui convidada agora para a Assembleia dos Bispos da África, que vai ser em Angola, para falar para todos os bispos para implantar a Pastoral da Criança. (informação verbal) ${ }^{32}$

\footnotetext{
31 Disponível em http://www.pastoraldacrianca.org.br/htmltonuke.php?filnavn=pastcridev/arquivos_genericos/portal/noticias/fundacao_pci.html, em 27/04/09, às 17h43.

${ }_{32}$ Informação fornecida por Zilda Arns em discurso na comemoração de 25 anos da Pastoral da Criança, em Aparecida do Norte/SP, no dia 20/09/2008.
} 


\subsection{1 - Captação de recursos}

A Pastoral da Criança, como dito anteriormente, recebe recursos financeiros do Ministério da Saúde desde 1985. Nesse começo, isso não foi bem visto por muitos progressistas:

A Pastoral da Criança já nasceu sob o signo da contradição, por estruturar-se
de maneira diametralmente oposta ao pensamento presente no campo
político brasileiro e ao novo desenho da presença da Igreja Católica no
mundo - portanto, no Brasil. Como não poderia deixar de ser, seu
surgimento dividiu na época as opiniões dos responsáveis pelas Pastorais
Sociais da CNBB e de muitas outras lideranças religiosas ligadas aos setores
classificados de progressistas, que viam como uma contradição a parceria
entre a Igreja e o Estado na busca da superação dos problemas relativos à
criança. Ainda hoje há resquícios desse desentendimento. (FAXINA, 2001,
p.129)

Esse tipo de parceria feita pela Pastoral da Criança se deve ao cenário dos anos 80 descrito abaixo:

Os movimentos, que antes negavam tudo que viesse do governo, começaram a aceitar a idéia de discutir com ele. Foram, assim, abrindo espaço no interior do Estado, que passou a reconhecê-los como interlocutores e a mostrar-se mais sensível às reivindicações. Com isso, tornou-se mais candente a necessidade de formação, agora especializada, com vistas à competência para negociar melhor, propor e debater questões e programas públicos, numa relação de igualdade entre as partes. (PERUZZO, 1998, p.42)

Já nos anos 90 Peruzzo (1998, p.43) explica que as organizações sociais passaram a procurar parcerias com “órgãos públicos municipais, estaduais e federais, empresas, organizações não governamentais (ONGs) e outras instituições”. É uma forma de ter mais eficiência para resolver "problemas concretos" e uma maneira de criar canais para propostas, contribuindo para formular e executar projetos e interferir nas políticas públicas.

O que ocorre nos anos 90, além do cenário neoliberal e globalizado, é que o modelo de movimento social dos Estados Unidos chega ao Brasil através de ONGs internacionais. Esse modelo configura um movimento-organização, que enfatiza a autoestruturação. Isso se dá através de uma política interna de captação de recursos, constituição de uma base de adeptos, articulação com a sociedade civil e política através de parcerias e política de qualificação de quadros. Essas características descritas por Gohn (1997, p.240) também são percebíveis na estrutura da Pastoral da Criança. 
Os movimentos sociais populares perdem sua força mobilizadora, pois as políticas integradoras exigem a interlocução com organizações institucionalizadas. Ganham importância as ONGs por meio de políticas de parceria estruturadas com o poder público (GOHN, 1997, p.297).

No caso da Pastoral da Criança, essa articulação política e de parcerias permite que ela receba colaboração financeira de empresas e do Estado $^{33}$ :

\begin{tabular}{|c|c|}
\hline \multicolumn{2}{|c|}{ Fontes de Recursos Financeiros entre $01 / 10 / 2007$ e 30/09/2008 } \\
\hline Ministério da Saúde & $\mathrm{R} \$ 21.600 .000,00$ \\
\hline Doação Cartão HSBC Solidariedade & $\mathrm{R} \$ 3.639 .624,00$ \\
\hline Criança Esperança & $\mathrm{R} \$ 2.763 .990,00$ \\
\hline Doações de Companhias de Energia & $\mathrm{R} \$ 2.303 .571,00$ \\
\hline Resultado Financeiro das Aplicações & $\mathrm{R} \$ 2.211 .334,00$ \\
\hline Doações em nível nacional & $\mathrm{R} \$ 1.085 .340,00$ \\
\hline Parcerias Estados/Municípios & $\mathrm{R} \$ 2.160 .213,00$ \\
\hline Resultado Financeiro das Aplicações & $\mathrm{R} \$ 2.211 .334,00$ \\
\hline Doações em nível nacional & $\mathrm{R} \$ 1.085 .340,00$ \\
\hline Governo do Estado de São Paulo & $\mathrm{R} \$ 1.000 .000,00$ \\
\hline Doações/Promoções - Setor e Estado & $\mathrm{R} \$ \quad 838.873,00$ \\
\hline Governo do Estado do Paraná & $\mathrm{R} \$ \quad 597.000,00$ \\
\hline SEBRAE & $\begin{array}{ll}\mathrm{R} \$ & 557.739,00\end{array}$ \\
\hline Parcerias Estados e Municípios & $\mathrm{R} \$ \quad 501.978,00$ \\
\hline Gol Linhas Aéreas & $\mathrm{R} \$ \quad 500.000,00$ \\
\hline Gerdau Aços & $\mathrm{R} \$ \quad 416.670,00$ \\
\hline Total de recursos financeiros & $\mathrm{R} \$ 38.016 .119,00$ \\
\hline
\end{tabular}

Além de calcular os valores financeiros, a Pastoral da Criança também calcula o que a doação em trabalho de cada voluntário representa monetariamente. Para chegar a esses valores usa a seguinte metodologia: usam uma média de horas que cada voluntário doa e quanto isso corresponde ao valor do salário mínimo. Nos dados de 01/10/2007 a 30/09/2008,

\footnotetext{
33 Disponível em http://www.pastoraldacrianca.org.br/htmltonuke.php?filnavn=../pastcridev/arquivos_genericos/portal/recursos_recebidos2.html, 27/03/2009, às 17h47.
} 
o salário mínimo era de $\mathrm{R} \$ 415,00$. Assim, considera-se o valor de $\mathrm{R} \$ 50,00$ por líder ( $24 \mathrm{~h} / \mathrm{mês}), \mathrm{R} \$ 8,00$ por membro da equipe de apoio da comunidade (4h/mês) e $\mathrm{R} \$ 134,00$ por coordenador de ramo, setor ou estado (66h/mês).

\begin{tabular}{|l|l|}
\hline \multicolumn{2}{|c|}{ Valor monetário representativo do Voluntariado entre 01/10/2007 e 30/09/2008 } \\
\hline Líderes & $\mathrm{R} \$ \quad 83.742 .657,00$ \\
\hline Coordenadores & $\mathrm{R} \$ 11.727 .834,00$ \\
\hline Apoios & $\mathrm{R} \$ 11.582 .018,00$ \\
\hline Total representativo & $\mathrm{R} \$ 107.052 .509,00$ \\
\hline
\end{tabular}

Já os dados de recursos financeiros recebidos pela Pastoral da Criança de 01/10/2006 a 30/09/2007 totalizaram $\mathrm{R} \$ 37.705 .111,45$. Esse valor dividido para cada mês e pela média mensal de 1.816.261 crianças acompanhadas em 2007 dá um gasto de R\$1,71 reais por criança. (PASTORAL DA CRIANÇA, 2008, p.15)

Segundo Gohn (1997, p.17), a parceria com setores públicos e privados traz outra característica: ações voltadas para obtenção de resultados, que substitui a ação coletiva de pressão e reivindicação, antes presente na maioria dos movimentos sociais. As ONGs passam a organizar movimentos populares a partir de seus projetos. Os movimentos sociais que permaneceram foram os de caráter mais global (1997, p.339) e se tornaram mais qualificados. Por meio das ONGs, passaram a ter infraestrutura própria e recursos tecnológicos. Isso é obtido pelas ONGs através de projetos, financiados por outras ONGs, por programas governamentais ou pela própria comunidade (1997, p.315).

As organizações sociais, com vistas a uma eficácia ainda maior na busca de soluções para problemas concretos, formam parcerias com órgãos públicos municipais, estaduais e federais, empresas, organizações não governamentais (ONGs) e outras instituições. Com isso, a participação dos movimentos torna-se mais efetiva, criando-se canais que potencializam as práticas de apresentação de propostas, da contribuição para a formulação e execução de projetos e programas e de interferência positiva para que as políticas públicas sejam direcionadas em conformidade com as necessidades e os anseios da população. (PERUZZO, 1998, p.43)

Os processos descritos por Peruzzo (1998) e Gohn (1997) mostram uma realidade das ONGs, que também é vivenciada pela Pastoral da Criança, que recebe doações de muitas empresas. Por um lado, os recursos possibilitam a ampliação do trabalho, mas, por outro, há limitações e o caráter mercantil. Como fica a questão da cidadania e da crítica à realidade 
social, a transformação, se o próprio mercado financia a ação? Trata-se de responsabilidade social ou apenas marketing social? Até onde essa ajuda financeira não tira a autonomia da entidade? Por outro lado, como custear as ações sem o financiamento? Certamente, são muitas questões que não devem ser desconsideradas.

(...) a filantropia empresarial tem seu lado de bom negócio. Entre a entrada de dinheiro voltada para finalidades filantrópicas e os seus destinatários finais (os pobres), começam a proliferar um bom número de instituições mediadoras, configurando uma divisão de trabalho especializada e interna a esta atividade, que constantemente abre "nichos de mercado" (para usar a linguagem empresarial) que configuram um setor importante para a realização do lucro mercantil. (PAOLI, 2002, p.396)

Gohn (1995, p.126) ainda coloca que as políticas de parceria de organismos sociais com o Estado e empresas privadas mostram uma orientação voltada para a “desregulamentação do papel do Estado na economia e na sociedade como um todo, transferindo responsabilidades do Estado para as 'comunidades' organizadas”. Além da questão dos recursos, também vemos na Pastoral da Criança essa transferência de responsabilidade para a redução da mortalidade infantil, o que foi se ampliando para outras ações também como de alfabetização, geração de renda e educação.

Outra característica apontada por Paoli (2002, p.378) que cabe a Pastoral da Criança é o fato das entidades ainda serem movimentadas pelo "ativismo social do voluntariado" e por um sentimento de solidariedade. A sociedade civil que era impulsionada por "movimentos sociais autônomos e politizados" passa a ser por "organizações não-governamentais profissionalizadas". Desloca-se, assim, "o ativismo político pela cidadania e justiça social para o ativismo civil voltado para a solidariedade social”.

No caso da Pastoral da Criança, acreditamos que a solidariedade é um fato marcante, mas vimos tanto nas entrevistas quanto na pesquisa de campo, por parte da liderança, uma busca pela cidadania, pela participação política por meio dos conselhos e uma crítica forte às injustiças sociais. Talvez esse seja um diferencial da Pastoral da Criança, que mistura características das ações sociais progressistas da Igreja com uma estrutura profissional como das ONGs.

Gohn (1997, p.306-311) acredita que as ações que mobilizaram muitas pessoas nos anos 90 passaram a perder seu marco coletivo e, crescentemente, veem-se presas ao individualismo. Baseadas na solidariedade e não em projetos político-partidários como nos anos 80 , as ações coletivas se caracterizam muito mais como campanhas ou como assistência do que como movimentos sociais. Outra novidade é que as reivindicações populares deixam 
de se centrar nas questões de infraestrutura ligadas ao consumo coletivo como moradia, educação e transportes para focar na sobrevivência física dos indivíduos. O intuito é garantir suportes mínimos de sobrevivência como a alimentação ou a terra para produzir alimentos. As políticas para a área social também se diferenciam ao privilegiar questões temáticas, como a fome, o desemprego, a moradia, os sem-teto, os sem-terra, ao invés dos atores sociais organizados em movimento.

Portanto o "novo" dos movimentos sociais se redefine novamente nos anos 90, e isto se faz em duas direções. Primeiro deslocando o eixo das reivindicações do plano econômico, em termos de infra-estrutura básica para o consumo coletivo, para suporte mínimo de mercadorias para o consumo individual, em termos de comida. Retoma-se a questão dos direitos sociais tradicionais, nunca dantes resolvidos no país. Segundo, o plano moral ganha o lugar central como eixo articulatório das lutas sociais. (GOHN, 1995, p.125)

Ainda vemos um caráter coletivo na Pastoral da Criança, apesar de ser baseada também na solidariedade. Há um foco na sobrevivência das famílias, mas também uma preocupação em debater questões coletivas, principalmente sobre SUS, direitos das crianças e educação. Há uma preocupação em não ser um movimento assistencialista e sim que busca conscientizar as famílias para promover o desenvolvimento integral das crianças.

Para Faxina (2001, p.36-37), há um cenário de disputa pela "apropriação" dos movimentos sociais, permeado de diferentes concepções do papel da sociedade civil. No entanto, cresce a importância dos movimentos, que ganham uma nova possibilidade: a atuação conjunta do Estado, do mercado e da sociedade civil, resguardadas suas diferenças, para a solução de problemas sociais. Deve-se, no entanto, cuidar para que os movimentos não se institucionalizem a ponto de se tornarem "braço do próprio corpo estatal".

Para que essas experiências de parcerias ocorram sem a perda de identidade dos movimentos sociais em questão, cada esfera da realidade social precisa ter muito claro qual é a sua fatia de poder e responsabilidade social, na implementação das ações emparceiradas. É preciso ter claro que essa tarefa não é assim tão fácil como, às vezes, pretendemos que seja. Contudo o entendimento de que a solução de certas demandas sociais serão mais eficientes quanto melhor forem estabelecidas parcerias entre a sociedade política e a sociedade civil, tem se tornado muito claro nas áreas de saúde, educação e direitos da criança e do adolescente. Neste sentido, surgem dois tipos de parcerias, uma para a definição de políticas públicas e controle social dos recursos públicos, através de conselhos e outros instrumentos; outra, através de entidades que se apropriam de recursos públicos para realizar a tarefa de organizar a sociedade para encontrar a saída para seus próprios problemas. (FAXINA, 2001, p.37) 
O autor ainda avalia que é um desafio para os movimentos sociais construir uma agenda própria que paute os acontecimentos ao seu redor para a busca de soluções de problemas. É preciso também ir além do determinismo da estrutura social imposta pelo mercado para serem sujeitos com capacidade de intervenção na sociedade. (FAXINA, 2001, p.38). Por outro lado, afirma que a para os líderes comunitários há o entendimento, diante desses recursos em maioria governamentais, que a ação da Pastoral da Criança é prevenir doenças enquanto ao governo cabe cuidar de sua cura:

A ação da Pastoral da Criança previne os problemas de saúde e resolve aquilo que pode ser solucionado no âmbito familiar e comunitário, desobstruindo os serviços públicos de saúde que, com isso podem atender melhor os casos que realmente necessitam de atendimento profissional da área médica. Este entendimento político é importante ao analisar as conquistas da Pastoral da Criança, para não ser confundida como apêndice do Estado, ou como substituição de uma tarefa do Estado através do uso de 'mão-de-obra barata' chamada voluntariado. (FAXINA, 2001, p.179)

Faxina destaca (2001, p.42) ainda uma baixa participação em eventos de massas como passeatas, caminhadas, greves e protestos nos anos 90. Peruzzo (1998, p.73-75) também fala da dificuldade do povo brasileiro participar de movimentos sociais. No entanto, é interessante notar que embora a participação seja uma dificuldade para os movimentos sociais e as entidades que os fomentam, isso não acontece na Pastoral da Criança.

O próprio Faxina (2001, p.134) aponta que a Pastoral da Criança apresenta um crescimento permanente de voluntários, de no mínimo, 10\% ao ano. Em 1999, houve um crescimento de $18 \%$, fechando o ano de 2000 com 145 mil voluntários no Brasil. Para o autor, vários fatores explicam essa questão, mas um deles é que "trabalhar com criança não exige, a priori, uma tomada de decisão política mais efetiva, bastando o comprometimento emocional com a causa" (2001, p.163).

Podemos perceber que o crescimento continua, se em 2000 havia 145 mil voluntários, o ano de 2007 fechou com um total de 261.962 voluntários. Isso mostra um crescimento de aproximadamente $80 \%$ no número de voluntários entre os anos citados.

Outra característica dos anos 90 são as mobilizações coletivas em forma de campanhas, como aquelas contra a fome ou contra a violência, por exemplo. Por outro lado, os movimentos sociais dos anos 70 e 80 entram em crise seja de militância, de mobilização ou de credibilidade junto às políticas públicas e à própria população. Surgem movimentos centrados em figuras carismáticas como o Ação da Cidadania contra a Fome, de Betinho. (GOHN, 1995, p.125) 
Esse exemplo pode ser estendido à Pastoral, que apesar de surgir ainda na década de 80, também está centrada em torno de uma figura carismática: Zilda Arns. O carisma de Dra. Zilda foi presenciado em vários momentos da pesquisa. Na comemoração dos 25 anos da Pastoral da Criança em Aparecida/SP, realizada em 20 de setembro de 2008, a médica mal conseguia andar. O tempo todo era parada por voluntárias da Pastoral, que queriam entregar presentes, abraçá-la, tirar fotos.

Gohn (1997, p.236) ainda complementa que os intelectuais também estão inseridos no cenário dos movimentos sociais latino-americanos. "São pessoas de grupos sociais distintos dos demandatários e têm se constituído em interlocutores básicos dos movimentos junto a agências governamentais e à mídia em geral". Mas a autora acredita que isso "não obscurece o dado da presença majoritária dos estratos populares nos movimentos sociais".

Na Pastoral da Criança, essa interlocução é feita pela médica Zilda Arns, que em 2008 deixou de ser coordenadora da entidade, mas continua na ativa como fundadora e coordenadora internacional. Essa capacidade de interlocução fica clara não só pelo apoio financeiro público e privado, como em reuniões com governantes. Foi em uma dessas reuniões com o governador de São Paulo, José Serra, que Zilda Arns pôde articular o apoio para a Pastoral da Criança. O estado doou 1 milhão de reais para o projeto. Mas também é feita por coordenadoras como a já citada reunião com o secretário de saúde para falar sobre problema da mortalidade infantil em São Paulo e outros problemas de saúde, que ocorreu em16/04/09.

Gohn (1997, p.252) acredita que embora alguns atores individuais possam se destacar mais, eles atuam como representantes e veículos de expressão dos movimentos; suas mensagens e ideologias também são do movimento a que pertencem. "O líder não fala por si e sim pelo coletivo". Nós concordamos com a autora e presenciamos essa característica na Pastoral da Criança.

Assim vemos hoje a Pastoral da Criança como um organismo da Igreja, que tem um líder carismático, mas isso não impede que tenha se desenvolvido um sistema democrático que permite que as voluntárias sejam ouvidas nas diferentes esferas que formam a Pastoral da Criança. A estrutura entre coordenadores não é vista como uma prática autoritária e sim como uma maneira de através das reuniões e dos diálogos fazer com que todos possam ser ouvidos. Se por um lado temos uma Coordenação Nacional, com uma estrutura administrativa como a das ONGs e o recebimento de doações do Estado e de empresas, por outro temos uma prática educativa "freireana", que valoriza o diálogo, a autonomia e a libertação do indivíduo. Essa libertação, como defende Freire, não ocorre sozinha, e sim através do coletivo. Esse coletivo 
que forma a Pastoral da Criança tem uma identidade que os unem e uma visão crítica e consciente dos problemas sociais, que não são só discutidos, mas vividos na prática, vivenciando, assim, a práxis de que fala Paulo Freire em suas obras. 


\section{Capítulo II - A comunicação praticada pela Pastoral da Criança}

\section{1 - Complexidade das ações comunicativas}

As ações comunicativas da Pastoral da Criança são fundamentais para a reflexão da líder e para promover um constante aprendizado. O jornal, os guias e os programas de rádio têm um caráter educativo. Trazem informações sobre saúde e cidadania, muitas vezes, de forma didática. No caso do jornal, percebemos que os textos são construídos de forma que a voluntária reflita sobre a sua ação e o seu lugar no mundo, visualizando os problemas que atingem a sociedade em relação à criança.

Outra característica é que o jornal tem metade das páginas reservadas para receber textos das comunidades. Dessa forma, a publicação acaba sendo feita para e pelas comunidades, caracterizando-se pela prática de uma comunicação popular. Até mesmo o programa de rádio pode ser visto assim, pois apesar de já estar pronto, incentiva-se que cada localidade produza seu próprio programa, usando as partes do material que achar interessante. O Cd dos programas é mandado para as comunidades e também está disponível no site da Pastoral da Criança. A cidade de São Paulo voltou a utilizar o programa Viva a Vida em 2009, através do trabalho de uma coordenadora de ramo do setor Brasilândia, Rosangela Maria Santos da Silva, de 44 anos. Ela usa trechos do material da Pastoral, editando-o e acrescentando informações, o que é apresentado semanalmente na Rádio Nove de Julho.

Outra novidade da comunicação na Pastoral da Criança foi o estabelecimento de uma formação em comunicação popular. $O$ intuito é que cada comunidade tenha o seu comunicador popular. Para tanto, foi realizado um projeto piloto no Nordeste pela jornalista e freira Núbia Maria da Silva. Ela elaborou um material, como já citamos no primeiro capítulo dessa dissertação, que foi discutido em assembleia com os coordenadores estaduais e depois apresentado em fevereiro de 2009 para cinco jornalistas das diferentes regiões do país, onde estivemos presentes. Além de dar sugestões para o manual, aplicamos a formação na Brasilândia, na capital paulista.

Essa realização tem muito a ver com a opção de pesquisa que fizemos. Quando optamos por estudar o papel da comunicação na Pastoral da Criança, já conhecíamos o jornal da entidade, o site e o programa Viva a Vida. Diante de diferentes ações, seria impossível, 
querer aprofundar os nossos estudos sobre o Jornal Pastoral da Criança e deixar todo o resto de lado. Era preciso olhar o todo, conhecer o todo, para depois aprofundar o específico.

Classificamos a comunicação popular da Pastoral como educativa porque vimos que cada atividade se complementa, ampliando os conhecimentos do líder. Mas isso não poderia ser visto somente analisando os textos do jornal. Era preciso ir até a base para ouvir esse receptor que também é produtor. No entanto, só ir à base realizar entrevistas não bastava. $\mathrm{O}$ universo da Pastoral da Criança é complexo demais para ser esclarecido somente com as entrevistas. Tínhamos que conhecer mais. Só nos restava, então, estar presente, ouvir, observar, fazer. Partimos assim para a pesquisa participante.

\section{2 - A escolha pela pesquisa participante}

A opção por esse tipo de pesquisa começou a brotar quando fomos ao escritório da Pastoral da Criança, na Arquidiocese de São Paulo, em dezembro de 2007. Na ocasião pegamos alguns exemplares do Jornal Pastoral da Criança e falamos sobre nossa pesquisa com a coordenadora da entidade na Arquidiocese de São Paulo, Maria do Rosário Gazzola de Souza, explicando que realizaríamos entrevistas e gostaríamos de estar presente em algumas reuniões. Imediatamente ela nos convidou a auxiliá-la como comunicadora voluntária. Teríamos que orientá-la em relação à assessoria de imprensa em nível local, acompanhando eventos e escrevendo textos sobre os mesmos para o jornal da arquidiocese - O São Paulo. Esses textos também passaram a ser publicados no site da Pastoral da Criança e, em alguns casos, foram encaminhados pela coordenadora para o Jornal Pastoral da Criança.

Seria essa uma forma de conhecer melhor a entidade e suas práticas? Ou poderia comprometer a pesquisa? Como manter a suposta neutralidade acadêmica estando dentro do grupo? Participar das reuniões como pretendíamos já caracterizava a observação participante. Mas era possível ir além e ajudar nas ações? Como conciliar o voluntariado com a pesquisa de forma a enriquecê-la? Antes de aceitar, era preciso pesquisar mais para fazer uma escolha consciente e fundamentada, que nos ajudaria a entender a complexidade da comunicação dentro da Pastoral da Criança.

Para Peruzzo (2005, p.125), a pesquisa participante possibilita a inserção do pesquisador no ambiente natural da ocorrência do fenômeno e sua interação com a situação investigada. A partir da definição de diversos autores, caracteriza a pesquisa participante: 
a) a presença constante do observador no ambiente investigado, para que ele possa "ver as coisas de dentro";

b) o compartilhamento, pelo investigador, das atividades do grupo ou do contexto que está sendo estudado, de modo consistente e sistematizado - ou seja, ele se envolve nas atividades, além de co-vivenciar "interesses e fatos"; c) a necessidade, segundo autores como Mead e Kluckhohm, de o pesquisador assumir o papel do outro para poder atingir "o sentido de suas ações” (HAGUETE, 1990, p.63). (PERUZZO, 2005, p.126)

O intuito, segundo a autora, desse tipo de pesquisa é alcançar um caráter qualitativo com profundidade. As finalidades para a área de Comunicação Social seriam observar fenômenos ligados a experiência popular de comunicação; realizar estudos de recepção; e contribuir para a melhoria da comunicação dos grupos pesquisados. Todas essas características vão ao encontro dos objetivos que trazemos nesse trabalho.

A pesquisa participante pode se apresentar em três modalidades: observação participante, pesquisa participante e pesquisa-ação. Na observação participante, o pesquisador se insere no grupo, participa das atividades, mas não assume um papel dentro do grupo. (PERUZZO, 2005, p.131) Aceitando a proposta da coordenadora da Pastoral da Criança na Arquidiocese de São Paulo, nós assumiríamos um papel cooperativo no grupo e faríamos uma pesquisa participante.

Trata-se de opção que exige muita maturidade intelectual; acentuada capacidade de distanciamento, a fim de não criar vieses de percepção e interpretação - o que não quer dizer neutralidade; e responsabilidade para com o ambiente pesquisado, de modo a não interferir demasiadamente no grupo ou criar expectativas que não poderão ser satisfeitas, até pela circunstância de sua posição transitória no grupo. (PERUZZO, 2005, p.137).

Acreditamos que assim pudemos conhecer de forma aprofundada todo o sistema de comunicação da entidade nas suas diferentes esferas. Seja com o contato com a coordenação nacional, seja com a vivência local através da Arquidiocese de São Paulo.

Em geral, a motivação é compreender de modo sistemático e com base científica os processos de comunicação existentes, como forma de identificar suas inovações, virtudes e avanços, mas também as falhas e os desvios de práticas comunicacionais, levantar as práticas participativas e de gestão, entender os mecanismos de recepção de mensagens e auscultar as aspirações dos receptores de modo a aperfeiçoar o trabalho desenvolvido nos meios de comunicação grupais ou mediáticos de alcance comunitário ou local. Paralelamente, poderá ter a preocupação de documentar a história das experiências consideradas relevantes e dignas de serem registradas e dadas a conhecer a outros públicos - como o acadêmico - e ao conjunto da sociedade. (PERUZZO, 2005, p.138) 
Como recomenda a autora, buscamos usar técnicas complementares para coletas de dados como entrevistas, análise documental e estudo de dados secundários como informações já disponibilizadas pela Pastoral da Criança. Os pressupostos teóricos, a metodologia, a confluência de técnicas são importantes para obtenção de resultados científicos válidos. Dessa forma, pretendeu-se evitar que a interferência do pesquisador no grupo e ao mesmo tempo as influências do grupo no pesquisador comprometesse a pesquisa.

Esse tipo de pesquisa não acredita na neutralidade da ciência como pressuposto epistemológico, mas se declara favorável ao distanciamento investigativo de modo a não se confundir o que realmente ocorre com conceitos prévios ou intenções valorativas do pesquisador. (PERUZZO, 2005, p.144)

\section{3 - O sujeito do estudo}

Peruzzo (2005, p.140) explica que na pesquisa participante o objeto de estudo é transformado em sujeito. No caso de nosso trabalho, não é possível fazer um estudo que abranja a relação de todos os 261.962 voluntários da Pastoral da Criança com a comunicação e como essa ação comunicativa educa para a cidadania. Tivemos, então, que delimitar o nosso sujeito.

Assim decidimos realizar a pesquisa participante na Arquidiocese de São Paulo, que é formada por seis regiões episcopais: Belém, Brasilândia, Ipiranga, Lapa, Santana e Sé. Cada uma dessas regiões corresponde a um setor da Pastoral da Criança e conta com uma coordenadora. Elas se reúnem mensalmente.

A cidade de São Paulo ainda conta com outras três dioceses, Campo Limpo, Santo Amaro e São Miguel Paulista, que abrangem os extremos sul e leste da capital, e ficaram fora do nosso estudo. Concentramos nossa pesquisa na arquidiocese que abrange bairros de todas as zonas da capital paulista: sul, leste, oeste, norte e central, tendo uma maior representatividade de amostra.

Em cada região episcopal, nós entrevistamos a coordenadora de setor da Pastoral da Criança e mais nove voluntárias, que podiam ser líderes, coordenadoras de ramo (paróquias), multiplicadoras ou até mesmo exerciam todas essas funções, totalizando 60 entrevistas. Também entrevistamos a coordenadora da Pastoral da Criança na Arquidiocese de São Paulo, Maria do Rosário Gazzola de Souza; a fundadora da Pastoral da Criança, Zilda Arns; a 
coordenadora nacional da Pastoral da Criança, Vera Lúcia Altoé; o coordenador estadual da Pastoral da Criança em São Paulo, José de Anchieta; a jornalista responsável pelo Jornal Pastoral da Criança, Sonia Prati. Foram realizadas entrevistas semiabertas, que são trabalhadas no terceiro e no quarto capítulo desse estudo. Também entrevistamos um multiplicador e uma multiplicadora estadual e uma nutricionista.

Segundo Duarte (2005, p.66), a entrevista semiaberta conta com um roteiro de questões voltadas para o interesse da pesquisa. Busca tratar da amplitude do tema. Explora ao máximo cada resposta. É conduzida em parte pelo entrevistado, valorizando seu conhecimento, mas ajustada ao roteiro do pesquisador.

As entrevistas com as voluntárias possibilitaram que tentássemos delinear a recepção do jornal da entidade, além de analisar a comunicação como um todo na Pastoral da Criança na cidade de São Paulo. Um dos intuitos foi saber como o jornal é percebido pelo grupo e como elas enxergam a cidadania.

Nós montamos inicialmente o seguinte roteiro:

1 - Você recebe o jornal da Pastoral da Criança todo mês?

2 - Você costuma ler o jornal? Por quê?

3 - Qual parte do jornal você mais gosta de ler? O que há de interessante?

4 - Você recorda alguma matéria que foi importante para você exercer sua atividade?

5- Quais assuntos você mais gosta de ler? Quais não gosta?

6 - Nos últimos números que você leu, alguma notícia chamou sua atenção? Se a pessoa citar algo, perguntar por que gostou.

7 - Você acha que o jornal mostra para as líderes o que elas querem e precisam saber?

8 - O que é cidadania para você?

9 - O jornal contribui para a sua cidadania? De que forma?

10 - Função, tempo na Pastoral, idade, formação, descrição das atividades.

Mas logo na primeira entrevista percebemos que algumas questões podiam ser condensadas. Além disso, na prática, mostrou-se ser mais produtivo para a entrevista começar com a pessoa falando quem ela era, como conheceu a Pastoral da Criança, as atividades que desenvolvia, para só depois falarmos sobre o jornal e a percepção de cidadania da entrevistada. Paralelamente a isso, analisamos o conteúdo do Jornal da Pastoral da Criança, a partir dos conceitos de cidadania e texto acessível. 
Já nas entrevistas com coordenadores do nível nacional, estadual e regional, buscamos conhecer melhor a dinâmica do grupo. Em uma dessas conversas, Zilda Arns ressaltou a importância do jornal que chega a regiões da Amazônia, onde o acesso só é possível após dias de viagens de barco. O Jornal Pastoral da Criança passa a ser o único veículo informativo do local. Já a coordenadora da Pastoral da Criança, irmã Vera Lúcia Altoé, explica que as líderes costumam ler, no geral, algumas matérias em casa, e as que têm a ver com situações da comunidade são debatidas nas reuniões mensais.

I Indagada ${ }^{34}$ sobre a importância do jornal para a formação da líder, irmã Vera destaca que o "esse jornal é um meio de formação contínua da Pastoral da Criança na nossa liderança. Tudo que surge de novo e mesmo orientações para as líderes são feitas através do jornal”. Quando a pergunta é sobre a contribuição do veículo para a construção da cidadania, a coordenadora nacional responde:

Eu penso que muito porque a gente se constrói através da leitura e do conhecimento. Então esse jornal tem ajudado muito as líderes. Algumas até escrevem para o jornal dizendo que o material as ajudou. É um subsídio muito forte para nós da Pastoral da Criança e constrói realmente a cidadania. Elas têm novas maneiras de pensar e de julgar em cima do que foi escrito e a partir de reflexões pessoais. (Vera Lúcia Altoé)

Já o coordenador estadual de São Paulo da Pastoral da Criança, José de Anchieta ${ }^{35}$, afirma que o jornal é importante porque "traz toda a vida da pastoral em nível de Brasil". Dessa forma, é mostrada "a realidade de diversos pontos e como as situações são resolvidas". A líder consegue ter "uma noção geral de todo o trabalho do Brasil". Para ele, é através da informação do jornal que a liderança vai se formando e capacitando. "O ponto forte da Pastoral é a comunicação, e há algumas comunidades do Brasil em que o único jornal que chega à comunidade é o Jornal da Pastoral da Criança".

Uma das dificuldades que Anchieta aponta é a falta de costume de ler que a população brasileira tem. "Mas não podemos desistir por isso. O Jornal Pastoral da Criança é um instrumento forte e eficaz na nossa ação", pondera. Em relação à contribuição do jornal para a construção da cidadania, o coordenador estadual é categórico: "Com certeza, porque se o nosso povo não tem informação, não tem cidadania. A cidadania vem através da informação, e o jornal da Pastoral da Criança tem o intuito de informar, mostrar diretrizes e caminhos. É um meio de inclusão social”.

\footnotetext{
${ }^{34}$ Entrevista concedida à autora no Encontro da Coordenação Nacional com o Estado de São Paulo, dia $07 / 07 / 2008$

${ }^{35}$ Também entrevistamos o coordenador estadual José de Anchieta durante o Encontro da Coordenação Nacional com o Estado de São Paulo, dia 07/07/2008.
} 
Em relação à pesquisa participante, acompanhamos algumas reuniões e encontros relativos à formação tanto da cidade quanto do estado de São Paulo, como apresentamos nos quadros abaixo. São atividades em todos os setores, além de observarmos os diferentes encontros, aproveitávamos para realizar as entrevistas com as voluntárias, atingindo assim pessoas de diferentes bairros.

\begin{tabular}{|c|c|}
\hline \multicolumn{2}{|r|}{ Atividades Acompanhadas - 2008} \\
\hline Fevereiro/2008 & $\begin{array}{l}\text { - Acompanhamento de Missa de Cinzas na Catedral da } \\
\text { Sé, acompanhando líderes e mães da Pastoral da } \\
\text { Criança. Elaboração de matéria a pedido da } \\
\text { coordenadora da Pastoral na Arquidiocese de São Paulo. } \\
\text { - Elaboração de matéria sobre tuberculose a partir de } \\
\text { parceria da Pastoral da Criança com a Vigilância } \\
\text { Sanitária da prefeitura de São Paulo a pedido da } \\
\text { coordenadora da Pastoral na Arquidiocese de São Paulo. } \\
\text { - Ida ao escritório da Pastoral da Criança em São Paulo } \\
\text { para entender como ela se organiza na Arquidiocese. }\end{array}$ \\
\hline Março/2008 & $\begin{array}{l}\text { - Acompanhamento da Via Sacra da Pastoral da Criança } \\
\text { com a presença de Zilda Arns. Além de acompanhar a } \\
\text { manifestação em favor das crianças, realização de } \\
\text { entrevista com a fundadora para entender a Pastoral da } \\
\text { Criança em São Paulo. Local: Pátio do Colégio, Setor } \\
\text { Sé. } \\
\text { - Acompanhamento do Encontro de Multiplicadores. } \\
\text { Fundamental para entender a dinâmica de formação e o } \\
\text { diálogo existente. Local: Centro Missionário José } \\
\text { Allamano, Horto Florestal, Setor Santana. } \\
\text { Entrevista com um multiplicador e uma multiplicadora. }\end{array}$ \\
\hline Abril/2008 & $\begin{array}{l}\text { - Elaboração de texto evento Via Sacra com Dra. Zilda a } \\
\text { pedido da coordenadora da Pastoral na Arquidiocese de } \\
\text { São Paulo. } \\
\text { - Elaboração de texto sobre Encontro dos Multiplicadores } \\
\text { a pedido da coordenadora da Pastoral na Arquidiocese }\end{array}$ \\
\hline
\end{tabular}




\begin{tabular}{|c|c|}
\hline & de São Paulo. \\
\hline Maio/2008 & $\begin{array}{l}\text { - Acompanhamento da Assembleia Anual da Pastoral da } \\
\text { Criança na Arquidiocese de São Paulo. Local: Centro, } \\
\text { Setor Sé. }\end{array}$ \\
\hline $\begin{array}{l}\text { Abril/2008 } \\
\text { Agosto/2008 }\end{array}$ & $\begin{array}{l}\text { - Participação na capacitação em assessoria de imprensa } \\
\text { via moodle para os voluntários de comunicação da } \\
\text { Pastoral da Criança. }\end{array}$ \\
\hline Junho/2008 & $\begin{array}{l}\text { - Elaboração de texto sobre Assembleia de maio a pedido } \\
\text { da coordenadora da Pastoral na Arquidiocese de São } \\
\text { Paulo. } \\
\text { - Levantamento de veículos de comunicação católicos } \\
\text { com a coordenadora Maria do Rosário e com a } \\
\text { assessora de imprensa da Coordenação Nacional para } \\
\text { envio de material preparado por Curitiba sobre encontro } \\
\text { de julho. }\end{array}$ \\
\hline Julho/2008 & $\begin{array}{l}\text { - Acompanhamento do Encontro da Coordenação } \\
\text { Nacional com o estado. Elaboração de texto sobre o } \\
\text { evento a pedido da coordenadora da Pastoral na } \\
\text { Arquidiocese de São Paulo. Local: Centro Missionário } \\
\text { José Allamano, Horto Florestal, Setor Santana. } \\
\text { - Entrevistamos Irmã Vera Lúcia Altoé. } \\
\text { - Entrevistamos o coordenador estadual José de Anchieta. } \\
\text { - Assessoria: atendimento a uma jornalista do jornal } O \\
\text { Globo via telefone, que entrevistou irmã Vera, durante o } \\
\text { Encontro. }\end{array}$ \\
\hline Agosto/2008 & $\begin{array}{l}\text { - Ida ao curso de serviços domésticos do Programa de } \\
\text { Geração de Renda da Pastoral da Criança em São Paulo, } \\
\text { por duas vezes, para conhecer a ação. Local: Centro, } \\
\text { Setor Sé. }\end{array}$ \\
\hline Setembro/2008 & $\begin{array}{l}\text { - Ida à cidade de Aparecida com a Romaria de } 25 \text { anos da } \\
\text { Pastoral da Criança. Acompanhamos todo o evento, } \\
\text { auxiliamos na assessoria de imprensa e realizamos } \\
\text { entrevistas com Zilda Arns e irmã Vera Lúcia Altoé }\end{array}$ \\
\hline
\end{tabular}




\begin{tabular}{|c|c|}
\hline & $\begin{array}{l}\text { sobre a Pastoral da Criança em São Paulo. Elaboração } \\
\text { de texto cobrindo o evento a pedido da coordenadora da } \\
\text { Pastoral na Arquidiocese de São Paulo }\end{array}$ \\
\hline Outubro/2008 & $\begin{array}{l}\text { - Elaboração de texto sobre serviços domésticos a pedido } \\
\text { da coordenadora da Pastoral na Arquidiocese de São } \\
\text { Paulo - versão } 1 .\end{array}$ \\
\hline Novembro/2008 & $\begin{array}{l}\text { - Ida ao espaço para brincadeiras de uma comunidade da } \\
\text { Pastoral da Criança, que teve brinquedos e reforma } \\
\text { doados pela Duracell. A coordenadora Maria do Rosário } \\
\text { concedeu entrevista ao Programa Domingo Legal do } \\
\text { SBT, que foi levado através da assessoria da Duracell. } \\
\text { Local: Lauzane Paulista, Setor Santana. } \\
\text { - Elaboração de texto sobre o espaço a pedido da } \\
\text { coordenadora da Pastoral na Arquidiocese de São Paulo. } \\
\text { - Entrevistamos nove voluntárias da Pastoral da Criança } \\
\text { no Setor Santana. } \\
\text { Entrevistamos a coordenadora da Pastoral da Criança } \\
\text { na Arquidiocese de São Paulo. } \\
\text { Ida ao Encontrão de Líderes do Ipiranga. Local: Cúria } \\
\text { da Região Episcopal Ipiranga, Setor Ipiranga. } \\
\text { Entrevistamos dez voluntárias da Pastoral da Criança no } \\
\text { Setor Ipiranga. }\end{array}$ \\
\hline Dezembro/2008 & 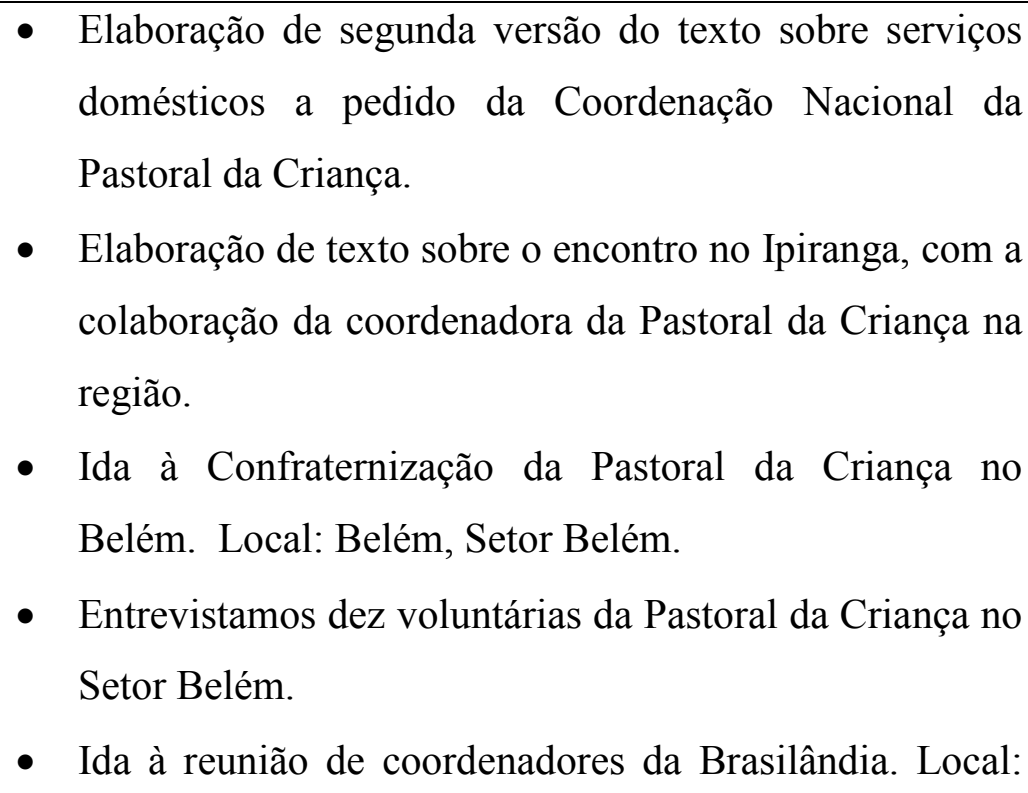 \\
\hline
\end{tabular}




\begin{tabular}{|l|l|}
\hline \multirow{2}{*}{$\begin{array}{l}\text { Cúria da Região Episcopal Brasilândia, Setor } \\
\text { Brasilândia. }\end{array}$} \\
$\qquad \begin{array}{l}\text { Entrevistamos sete voluntárias da Pastoral da Criança } \\
\text { no Setor Brasilândia. }\end{array}$ \\
\hline
\end{tabular}

\begin{tabular}{|c|c|}
\hline & es Acompanhadas - 2009 \\
\hline Fevereiro/2009 & $\begin{array}{l}\text { - Participação na Reunião de Comunicação Popular em } \\
\text { Curitiba com a Coordenação Nacional sobre novo } \\
\text { projeto a ser implantado. } \\
\text { - Entrevista com a jornalista responsável pelo Jornal } \\
\text { Pastoral da Criança. }\end{array}$ \\
\hline Março/2009 & $\begin{array}{l}\text { - Reunião com a coordenadora da Pastoral da Criança na } \\
\text { Arquidiocese de São Paulo sobre o projeto de } \\
\text { comunicação popular. } \\
\text { - Acompanhamento da Capacitação de Alimentação e } \\
\text { Hortas Caseiras. Local: Centro de Formação Sagrada } \\
\text { Família, Setor Ipiranga. } \\
\text { - Entrevista com uma voluntária do Setor Santana e com } \\
\text { a nutricionista da Pastoral da Criança. } \\
\text { - Elaboração de texto sobre a Capacitação a pedido da } \\
\text { coordenadora da Pastoral da Criança na Arquidiocese de } \\
\text { São Paulo. } \\
\text { - Ida à reunião de coordenadores do Setor Sé. Local: } \\
\text { Centro, Setor Sé. } \\
\text { Entrevistamos oito voluntárias da Pastoral da Criança } \\
\text { - no Setor Sé. } \\
\text { - Agendamento de entrevista da coordenadora Maria do } \\
\text { Rosário com o site Comunicação Católica. } \\
\text { Ida à Assembleia da Lapa. Local: Parque Continental, } \\
\text { Setor Lapa. }\end{array}$ \\
\hline
\end{tabular}




\begin{tabular}{|c|c|}
\hline & $\begin{array}{l}\text { como projeto piloto. Local: Paróquia Santa Terezinha } \\
\text { do Menino Jesus, Jardim Maggi, Setor Brasilândia. } \\
\text { - Entrevistamos três voluntárias da Pastoral da Criança no } \\
\text { Setor Brasilândia. }\end{array}$ \\
\hline Abril/2009 & $\begin{array}{l}\text { - Acompanhamento da Assembleia Eletiva da Pastoral da } \\
\text { Criança na Arquidiocese de São Paulo, onde a } \\
\text { coordenadora Maria do Rosário foi reeleita. Local: } \\
\text { Centro de Formação Sagrada Família, Setor Ipiranga. } \\
\text { - Elaboração de texto noticiando a assembleia da } \\
\text { Arquidiocese e a da Lapa a pedido da coordenadora da } \\
\text { Pastoral da Criança. }\end{array}$ \\
\hline Maio/2009 & $\begin{array}{l}\text { - Acompanhamento de reunião da Pastoral da Criança } \\
\text { com membros da área técnica da Secretaria de Saúde. }\end{array}$ \\
\hline Junho/2009 & $\begin{array}{l}\text { - } \text { Elaboração de texto sobre a reunião na Secretaria de } \\
\text { Saúde a pedido da coordenadora da Pastoral da Criança } \\
\text { na Arquidiocese de São Paulo. } \\
\text { - Ida à Celebração da Vida em comunidade da Bela Vista, } \\
\text { Setor Sé. } \\
\text { - Entrevistamos duas voluntárias da Pastoral da Criança } \\
\text { no Setor Sé. } \\
\text { - Acompanhamos Dra. Zilda até o programa do Ronnie } \\
\text { Von, na TV Gazeta. A fundadora falou sobre a história e } \\
\text { o funcionamento da Pastoral da Criança. } \\
\text { Entrevistamos Dra Zilda Arns sobre o jornal da Pastoral } \\
\text { da Criança. } \\
\text { Acompanhamos a Peregrinação da Criança e do } \\
\text { Adolescente, organizada pela Pastoral da Criança e pela } \\
\text { Pastoral do Menor. }\end{array}$ \\
\hline
\end{tabular}

Buscamos observar o uso na prática do Guia do Líder da Pastoral da Criança. O livro de 304 páginas traz diversas orientações sobre saúde, com textos e ilustrações. Também vimos como se organizam as reuniões, encontros, capacitações e em todos presenciamos um espaço aberto ao diálogo. Com a pesquisa participante tivemos noção de todo o conjunto da 
comunicação, que como dissemos vai além do jornal e dos materiais produzidos, como guia e programas de rádio. A comunicação é trabalhada em cada reunião, nos cursos de formação, nos encontros realizados.

Em cada local no qual estivemos presentes, ficávamos, na maior parte do tempo, como observadora. Nos intervalos, conversávamos com as voluntárias e os voluntários. Em alguns encontros, aproveitamos para realizar entrevistas para a dissertação. Era uma forma de falar com pessoas de diferentes comunidades, otimizando tempo, já que assembleias, encontros, reuniões costumam trazer diversas pessoas de um mesmo setor ou de vários setores da Arquidiocese de São Paulo. No caso de capacitações e encontros estaduais, tivemos a oportunidade de ter contato com membros da Pastoral da Criança de outras cidades do estado.

Quanto à elaboração de textos, não acreditamos que isso atrapalhou a dinâmica da pesquisa nem influenciou no funcionamento da Pastoral da Criança porque essa prática faz parte da organização comunicacional da Pastoral da Criança. Em diferentes cidades, há profissionais que auxiliam a Pastoral da Criança na assessoria de imprensa. Em Curitiba conhecemos os jornalistas que foram chamados para o Projeto de Comunicação Popular e eles também desenvolvem ações nesse sentido. A ideia da Pastoral da Criança nesse momento é retomar o contato com todos os assessores voluntários para saber quais continuam atuando nas comunicações locais.

Nesse sentido, participamos do curso promovido pela assessoria de imprensa da Pastoral da Criança sobre comunicação. O curso era virtual. Tínhamos que semanalmente ler textos que falavam sobre a comunicação na entidade. A cada módulo realizávamos exercícios e escrevíamos textos de análise de mídia. Os textos lidos ajudaram a entender como a entidade vê a questão da comunicação organizacional.

Quanto aos textos que produzimos a pedido da coordenadora da Pastoral da Criança na Arquidiocese de São Paulo, Maria do Rosário, eram encaminhados para o jornal O São Paulo, da Arquidiocese, que não é tema dessa pesquisa. Além disso, o material era colocado pela assessoria de comunicação da Pastoral da Criança no site, que também não está no centro de nossa pesquisa. Apesar de olhamos a comunicação na Pastoral da Criança como um todo, nossa análise se aprofunda no Jornal Pastoral da Criança. Quando a coordenadora Maria do Rosário julgava interessante, encaminhava os textos para a jornalista responsável pelo Jornal Pastoral da Criança. No entanto, o jornal recebe os textos em forma de rodízio para que todas as regiões do Brasil possam enviar matéria.

A Pastoral da Criança da Arquidiocese de São Paulo apareceu no Jornal Pastoral da Criança em algumas edições. No mês de abril e de maio de 2008, com textos feitos pela 
coordenadora Maria do Rosário sobre tuberculose e enviados antes do momento em que passamos a acompanhar as ações. Em junho de 2008, com texto elaborado pelo Setor Lapa de evento de outubro de 2007 e parte da matéria que fizemos da Via Sacra da Criança em março de 2008. Já em julho de 2008, com texto que elaboramos sobre a Capacitação de Multiplicadores, ocorrida em março de 2008. No mês de agosto de 2008, texto elaborado por voluntária do Setor Lapa. Por sua vez, em setembro de 2008, texto elaborado e enviado pelo Setor Santana e com texto enviado e elaborado pelo Setor Brasilândia. Em novembro de 2008, parte do texto que elaboramos sobre a comemoração de 25 anos da Pastoral da Criança foi publicada, enquanto que no site foi colocada a cobertura na íntegra. O Setor Santana elaborou e enviou texto mais uma vez, publicado na edição única de dezembro de 2008 e janeiro de 2009. Já o Setor Lapa produziu matéria para a edição de abril de 2009. Em junho de 2009, foi publicado texto que elaboramos sobre obesidade infantil.

Nossa presença não impediu que os setores da Arquidiocese de São Paulo continuassem enviando textos para os jornais. Quanto aos textos que produzíamos, eram feitos a partir do que conversávamos com a coordenadora Maria do Rosário. Tentávamos colocar no papel o que ela e os outros voluntários viviam nos eventos. Cabia a coordenadora encaminhar ao Jornal Pastoral da Criança, se julgasse necessário, e o texto só seria publicado a partir das regras de envio de matérias para as comunidades. Por isso acreditamos que essa relação não prejudicou a pesquisa, pelo contrário, permitiu que vivenciássemos na prática a dinâmica do Jornal Pastoral da Criança e conhecêssemos melhor como a comunicação é organizada pela entidade.

\section{4 - A pesquisa e o lugar}

O lugar de nossa pesquisa é a Arquidiocese de São Paulo, que apesar de englobar bairros de todas as zonas da cidade, deixa de lado os bairros mais ao sul e mais ao leste. Mas não foi sempre assim. Primeiro, o título de Arquidiocese foi recebido pela Igreja de São Paulo em 1908, a pedido do bispo Dom Duarte Leopoldo e Silva à Santa Sé ${ }^{36}$.

A Arquidiocese de São Paulo ao longo desses mais de cem anos de existência passou por algumas transformações. Uma de grande impacto foi a sua divisão em 1989, criando as

\footnotetext{
${ }^{36}$ As informações sobre a Arquidiocese de São Paulo foram retiradas do jornal da arquidioce $O$ São Paulo, edição especial sobre o centenário da mesma, publicado em 07 de julho de 2008.
} 
dioceses de Campo Limpo, Santo Amaro, São Miguel Paulista e Osasco. Segundo o jornal $O$ São Paulo, "era o fim de todo um projeto de pastoral urbana sugerido a dom Paulo pelo Papa Paulo VI".

Dom Paulo Evaristo Arns foi arcebispo de São Paulo entre 1970 e 1990. Franciscano, era chamado de arcebispo da esperança e defensor dos direitos humanos. Uma de suas primeiras decisões foi vender o palácio episcopal e, com o dinheiro, comprar terrenos na periferia para serem construídos centros comunitários. Era a chamada "Operação Periferia", entre os anos 70 e 80 . Nos locais, migrantes e suas famílias eram abrigados, dava-se ainda suporte à organização de movimentos sociais. Outro destaque ocorreu em 1972, quando criou a Comissão de Justiça e Paz para lutar pelos direitos humanos durante a ditadura militar.

A Arquidiocese de São Paulo, sob o comando de Dom Paulo Evaristo Arns, tinha grande inclinação ao social. E apesar da ideia da Pastoral da Criança ter sido lançada a Zilda Arns por ele, a vinda da Pastoral da Criança para São Paulo envolve outras personagens, responsáveis por disseminar essa ação na cidade.

A história da Pastoral da Criança no estado de São Paulo começa em duas cidades: Bragança Paulista e na própria cidade de São Paulo ${ }^{37}$. Em Bragança, começou porque uma freira francesa, irmã Piarret, veio ao Brasil para trabalhar na cidade, mas antes passou por Brasília, onde a missionária conheceu Zilda Arns e a Pastoral da Criança. O entusiasmo foi tanto que a freira implantou a Pastoral da Criança em Bragança Paulista.

$\mathrm{Na}$ mesma época, em outro episódio, Dom Luciano Mendes de Almeida pediu que Zilda Arns fosse fazer uma palestra no bairro do Belém, na capital. O padre Júlio Lancelotti estava presente e a levou para conhecer algumas favelas, onde começariam o trabalho da Pastoral da Criança. A enfermeira Alice Yano, que era do Ipiranga, também se interessou. Assim Alice Yano e Irmã Piarret foram as primeiras capacitadoras do estado de São Paulo, formando as primeiras líderes comunitárias. A fundadora da Pastoral da Criança, Zilda Arns, relembra esse começo, na entrevista que nos concedeu em setembro de 2008:

Quando a gente muda de rumo sempre há resistência. Por exemplo, a Igreja não estava acostumada a ter voluntariado permanente, a pesar criança, a recuperar desnutridos, ao soro caseiro, mas eu diria até que as resistências não foram tão fortes aqui em São Paulo. Eu me hospedava na casa de Dom Paulo e me convidavam para dar palestras nas regiões para padres. Então não foi tão difícil. Já nas favelas, em todo o país, não só em São Paulo, a migração é muito grande. As pessoas mudam de um lugar para outro. Então,

\footnotetext{
37 As informações sobre a Criação da Pastoral da Criança em São Paulo foram dadas por Zilda Arns em entrevista que realizamos após a Comemoração dos 25 anos da Pastoral da Criança, em Aparecida do Norte, em 20/09/2008. Essa entrevista foi feita quando já havíamos retornado para a cidade de São Paulo.
} 
quando já estava organizado, as pessoas mudavam e tínhamos que organizar de novo. (Zilda Arns)

Dos bairros do Belém e do Ipiranga da capital paulista e da cidade de Bragança a semente da Pastoral da Criança foi se espalhando por outros bairros e cidades. Considerando apenas o nosso lugar de pesquisa, a Pastoral da Criança tem, segundo dados de 2008, 17.315 crianças cadastradas na Arquidiocese de São Paulo e 2.488 voluntárias e voluntários ${ }^{38}$. Eles estão espalhados pelas Regiões Episcopais: Belém - 608 pessoas voluntárias e 3.871 crianças acompanhadas; Brasilândia - 475 pessoas voluntárias e 3.581 crianças acompanhadas; Ipiranga - 256 pessoas voluntárias e 1.609 crianças acompanhadas; Lapa - 243 pessoas voluntárias e 1.492 crianças acompanhadas; Santana - 766 pessoas voluntárias e 6.016 crianças acompanhadas; Sé - 140 pessoas voluntárias e 746 crianças acompanhadas. Eram 265 comunidades cadastradas e 149 ramos (paróquias). Sobre todo o trabalho da Pastoral da Criança, irmã Vera Lúcia Altoé, coordenadora nacional da Pastoral da Criança, afirmou ${ }^{39}$ :

\begin{abstract}
A Pastoral da Criança nesses 25 anos alcançou uma credibilidade muito grande graças ao trabalho, desde o início, da fundadora da Pastoral, Zilda Arns. Cada vez ganhamos mais espaço para que esse trabalho seja realizado. Contamos hoje com mais de 260 mil líderes voluntárias que de casa em casa vão executando esse trabalho. Elas se reúnem uma vez por mês para fazer a Celebração da Vida e celebrar os avanços das crianças durante esse tempo. Também podemos destacar um forte compromisso de nossas lideranças em participar de algumas ações e, sobretudo, avaliar isso no dia da Celebração da Vida e na Reunião de Avaliação e Reflexão. Temos uma alegria muito grande em saber que muitas crianças foram salvas graças a esse trabalho. Estamos atendendo hoje um total de 1 milhão e 800 mil crianças, mas isso é apenas $20 \%$ das crianças até seis anos de todo Brasil. O nosso desafio é avançar em pelo menos $50 \%$ esse número, pois temos muitas crianças que necessitam de uma acolhida e estão fora da Pastoral. Também precisamos ter mais líderes. Queremos que outras pessoas somem força conosco em nossa missão. (Vera Lúcia Altoé)
\end{abstract}

\title{
2.5 - O lugar da comunicação para a Igreja
}

Essa credibilidade de que fala irmã Vera certamente foi alcançada pelas ações que a Pastoral da Criança realiza e os resultados que alcança, mas também tem muito a ver com o

\footnotetext{
${ }^{38}$ Dados fornecidos por e-mail pela Coordenação da Pastoral da Criança na Arquidiocese de São Paulo, em 18/06/2009, sobre o ano de 2008.

39 Entrevista concedida a autora no Encontro da Coordenação Nacional com o Estado de São Paulo, dia 07/07/2008.
} 
papel que a comunicação tem para esse organismo da Igreja. O modo como a Pastoral da Criança trabalha a comunicação pode ser relacionado de alguma forma com a comunicação defendida pelos documentos da Igreja? Há uma história da comunicação na Igreja e experiências que antecederam o que a Pastoral da Criança faz hoje?

A nossa pesquisa participante mostrou que a Pastoral da Criança vai além do que a comunicação da Igreja coloca e do que já realizou. Mas isso não significa que os documentos da Igreja e a própria história da comunicação na Igreja não tenham contribuído para que a Pastoral da Criança construísse esse universo comunicativo.

Marques de Melo (1981, p.18) aponta quatro fases da comunicação na Igreja Católica: “censura e repressão (de Inocêncio VII ao século XIX), aceitação desconfiada (de Leão XIII ao Decreto Inter Mirifica), deslumbramento ingênuo (da Communio et Progressio a Medellín), avaliação crítica (Puebla)”.

Nessa primeira fase, há o extremo controle da palavra escrita. Já a segunda tem como um dos marcos a convocação do Concílio Vaticano II pelo Papa João XXIII. Com o decreto Inter Mirifica passa a usar os meios de comunicação para divulgar sua mensagem. Na fase seguinte, a referência é a instrução pastoral Communio et Progressio, que avança sem a desconfiança anterior no uso do rádio e da televisão. A quarta fase supera o deslumbramento que houve em Medellín e faz uma avaliação crítica da comunicação. Em toda essa história, as mudanças na ação comunicativa da Igreja se relacionam com as transformações em sua estrutura eclesial. (MARQUES DE MELO, 1985, p.62-64) Dessa forma,

Faz uma autocrítica em relação aos posicionamentos anteriores e busca novos padrões, resgatando as práticas do cristianismo primitivo, em certo sentido vivenciadas intensamente pelas comunidades eclesiais de base em todo o Continente. A Igreja passa a incentivar, a patrocinar, a respaldar experiências de comunicação do próprio povo. Facilita de modo que os seus meios de comunicação sejam voz dos que não têm voz e cria condições para que o povo de Deus, organizado em comunidades, passe a ter voz através dos seus próprios meios populares de comunicação, rompendo o silêncio milenar a que esteve condenado o nosso povo. (MARQUES DE MELO, 1985, p.63)

Como caracteriza Marques de Melo (1985, p.66), havia a identificação de uma oposição entre comunicação dialógica e evangelização eletrônica. A Igreja trabalhava, "não apenas para dar voz aos que não têm vez, mas sobretudo para que os sem-voz e vez" construíssem "seus próprios meios de comunicação" e pudessem "emitir sons ... de sua própria vivência..." 
Esses dois pontos relatados pelo autor estão presentes na comunicação da Pastoral da Criança. O Jornal Pastoral da Criança é esse espaço com lugar reservado para suas voluntárias falarem de suas ações, ou seja, dá voz aos “sem-voz e vez". O passo além começou esse ano com o projeto de comunicação popular, que pretende capacitar as voluntárias para serem comunicadoras populares em suas comunidades, criando seus próprios meios, seja através de boletins, cartazes, jornal mural ou teatro. Como no passado, começa a incentivar que elas construam seus meios.

Uma análise de Marques de Melo (1985, p.68) aponta uma contradição, o que, de certa forma, tem a ver com os dias atuais, sobre o uso da mídia. A diferença é que hoje não há por parte da Igreja, como instituição, essa defesa tão clara das formas dialógicas.

Embora reconheça o caráter massificante da reprodução simbólica que opera através dos mass media, a Igreja ainda persiste utilizando-os como se tal dimensão não tivesse sido constatada e autocriticada. Ou seja, ela proclama e pratica internamente formas dialógicas, horizontais, interativas de comunicação; externamente, prossegue ocupando espaços no rádio, na televisão, na imprensa, no cinema para difundir mensagens evangélicas, à maneira dos demais mercadores de bens e serviços que se valem desses recursos potencialmente abrangentes da moderna tecnologia. (MARQUES DE MELO,1985, p.68)

No caso da Pastoral da Criança, trabalham-se as duas vertentes: comunicação de massa e comunicação popular. Está na mídia, por meio de sua assessoria de imprensa, que distribui releases, articula entrevistas para reportagens em TVs e trabalha para que as ideias e ações da Pastoral da Criança cheguem à sociedade. O que chama atenção, nesse caso, é a organização da entidade e o cuidado para que suas mensagens não sejam distorcidas. Por outro, no seu trabalho de comunicação interna, produz o jornal e programas de rádio que primam em promover a cidadania e levar informações educativas sobre saúde, com espaços e estímulos para que sua leitora e seu leitor -voluntários - também sejam produtores. Assim, tenta conciliar o que antes já foi visto como oposto.

Já a comunicação da Igreja como um todo está presente não só nas emissoras católicas como também frequenta a mídia em geral com padres que cantam e aparecem nos mais diversos tipos de programas, vendo essa como uma oportunidade de evangelizar, chegando ao grande público. Nesse caso, parece não haver a mesma organização da Pastoral da Criança.

Em relação à comunicação popular, algumas paróquias continuam produzindo seus boletins assim como as dioceses, apesar de não haver um discurso oficial que defenda essa comunicação de forma explícita. Apesar disso, há encontros como o Mutirão de Comunicação da América Latina e Caribe, que estava previsto para julho desse ano, mas em função da 
propagação do vírus H1N1, o evento foi adiado para fevereiro de 2010. Organizado pela CNBB, acontece desde 1998 no Brasil e de 2001 em nível latino-americano. São experiências de comunicação da Igreja, dos movimentos sociais e das organizações. Talvez não haja uma experiência que tenha a dimensão da comunicação popular da Pastoral da Criança, produzindo 280 mil jornais e os distribui por todo Brasil, ou do programa de rádio Viva a Vida que passa em mais de 2000 emissoras de rádio. Mas são iniciativas muito importantes para as expressões locais.

Se olharmos os momentos vividos na Igreja e suas ações em relação à comunicação, veremos que o Vaticano II foi fundamental para que a comunicação assumisse um novo lugar na Igreja. Foi a primeira vez que um concílio geral da Igreja discutiu a questão da comunicação, aprovando o decreto Inter Mirifica, em 4 de dezembro de 1963. Esse assegura o dever e o direito da Igreja utilizar instrumentos de comunicação social. (PUNTEL, 1994, p.53) Apresentou uma visão otimista da comunicação em relação às questões sociais e apontou o direito à informação como "intrínseco à sociedade humana" (1994, p.58-59). Já o artigo 12 foi o mais polêmico ao analisar "o dever da autoridade civil de defender e tutelar uma verdadeira e justa liberdade de informação", o que foi interpretado por alguns como ir “contra a liberdade de imprensa" (1994, p.60).

\footnotetext{
Embora o papa Paulo VI afirme que o Inter Mirifica não "foi de pouco valor", os comentaristas concordam com o fato de que, se este decreto tivesse sido discutido mais no final do concílio, após as muitas sessões consagradas à Igreja no mundo moderno e à liberdade religiosa, o texto do Inter Mirifica teria sido particularmente mais enriquecido. (...) Infelizmente o decreto olhou o passado e não o futuro, olhou para dentro e não para fora. (...) Apesar das tantas limitações (...) pode ser considerado um divisor de águas em relação à mídia, e não um fim em si mesmo. (...) Fez um avanço em relação aos documentos anteriores, ao conferir à sociedade o direito à informação...” (PUNTEL, 1994, p.61-62)
}

Outro documento que a autora destaca é a instrução pastoral Communio et Progressio, promulgada por Paulo VI em 1971, considerando-a o mais avançado documento da Igreja sobre comunicações (PUNTEL, 1994, p.64). "Reforça o direito de informar e ser informado" e a importância de que os meios de comunicação sejam "instrumentos para a educação, a cultura e o lazer". Ainda recomenda a "capacitação de comunicadores e de ouvintes ou espectadores" e "a cooperação entre cidadão e as autoridades". Também fala da necessidade do diálogo da Igreja com o mundo e de que a opinião pública é necessária para alimentar o diálogo. (PUNTEL, 1994, p.64-66) 
Puntel (1994, p.24-27) avalia que nos anos 60, 70 e 80, a Igreja Católica na América Latina trilhou um caminho próprio para a comunicação a partir dos documentos do Vaticano. Havia "preocupação em dar ao povo as bases necessárias para compreensão de suas realidades dentro do quadro da libertação".

Os documentos de Medellín e Puebla são os marcos que deram rumo à Igreja
no que concerne às perspectivas da comunicação. A análise do documento
de Medellín revela uma postura ingênua e um encantamento diante das
novas tecnologias da comunicação. A importância desse documento, no
entanto, está em suas conclusões despertarem uma nova mentalidade na
Igreja e, por extensão, em suas relações com os processos de comunicação.
Puebla (1979) já demonstra um avanço em relação à posição de Medellín, já
que não apenas reconhece que a comunicação social está condicionada pela
realidade sócio-cultural, mas também denuncia o controle e a manipulação
ideológica exercidos através da mídia pelos grupos de poder político e
econômico. A mais significativa contribuição do documento de Puebla, no
entanto, é que com ele a Igreja, sem rejeitar os meios de comunicação de
massa, enfatiza a comunicação popular como um processo alternativo,
levando em conta um procedimento dialogal e participativo de comunicação.
(PUNTEL, 1994, p.25)

Marques de Melo (1981, p.11-13) destaca ainda que em Medellín se acreditava "nas potencialidades múltiplas das mensagens evangélicas disseminadas através da imprensa, rádio, TV e cinema. É quase uma proclamação da onipotência e onipresença daqueles meios". O documento coloca os meios de comunicação como os únicos capazes de alcançar todos os homens, mas existe a consciência de que pertencem aos donos do poder, que não querem transformar a sociedade. Puebla vai além criticando o monopólio e a manipulação, despertando para uma comunicação dialógica e buscando uma linguagem próxima à realidade do povo (1981, p.15-17).

O documento de Puebla supera claramente muitas dessas ambigüidades. Ele traduz a certeza de que a opção preferencial pelos pobres, assumida pela hierarquia eclesiástica e respaldada pela prática libertadora das comunidades eclesiais de base, não comporta atitudes conciliatórias frente às classes dominantes. Reconhecendo que estas têm a voz ativa dentro da sociedade e sufocam as iniciativas de resistência das classes subalternas, a Igreja se propõe a fazer eco das suas reivindicações através dos seus próprios meios de comunicação. (MARQUES DE MELO, 1981, p.13)

Puntel (1994, p.26) ainda destaca dois documentos da Igreja latino-americana como significativos para a discussão que ocorria na época sobre a Nova Ordem Mundial da Informação e da Comunicação (NOMIC): Quito (1982) e Embu (1982). Ambos enfatizam a comunicação popular "como o caminho mais eficiente para devolver o acesso e a 
participação". Tratava-se do direito de comunicar, conforme recomendava o Relatório Mac Bride, da UNESCO, em 1980, com a participação das pessoas de forma ativa e não como sujeitos passivos da comunicação (1994, p.15-16).

O Documento de Embu fala de comunicação alternativa como o resultado da ação dos oprimidos, que "vão criando formas diferentes de comunicação e expressão não verticalistas, às quais os representam e os inter-relacionam (...)" Diversos termos procuram identificar essas formas: "comunicação horizontal, grupal, participativa, popular, de base, comunitária" (DE 30), cuja característica, como comunicação alternativa, é "ter um caráter libertador, na medida em que se propõe a representar os interesses e os propósitos das classes populares" (DE 30). "Este tipo de comunicação popular libertadora constitui parte do processo de construção da NOMIC" (DE 30). (PUNTEL, 1994, p. 167)

A Igreja contribui, assim, para a construção de um novo conceito de comunicação na América Latina e, nesse contexto, a teologia da libertação teve grande influência:

Dentro da perspectiva "libertadora", a palavra participação é uma palavrachave em todas as atividades inspiradas pela teologia da libertação. Esta tese conclui que essa teologia tem um efeito de caráter ideológico no desenvolvimento da comunicação alternativa: ela ajuda as pessoas a tornarem-se, através de um processo participativo, agentes de transformação. Nesse sentido, a comunicação assume um papel "libertador" na criação de um espaço democrático para desenvolver o potencial e a mobilização dos setores populares no trabalho de transformação social. (PUNTEL, 1994, p.27)

É interessante notar como a Igreja esteve dentro do processo de comunicação popular, seja nessas discussões, seja na prática da comunicação popular nas CEBs. O documento de Embu, por exemplo, fala da necessidade da Igreja possibilitar a participação em seus meios e também capacitar o povo para produzir seus próprios meios (PUNTEL, 1994, p.172-173).

Esses pontos apregoados nos anos 80 são colocados em prática pela Pastoral da Criança. O Jornal Pastoral da Criança foi criado em 1985, justamente nessa época em que se defendia o direito de comunicar. Segundo Zilda $\mathrm{Arns}^{40}$, a Pastoral da Criança já estava começando a se expandir para o Brasil nesse período. A ação era mantida pelo UNICEF. "A Pastoral da Criança era muito valorizada pelo UNICEF porque tinha os mesmos objetivos: reduzir a mortalidade infantil, a desnutrição, promover os direitos das crianças, mas faltava uma comunicação porque o Brasil é muito grande”, relembra a fundadora. Naquele tempo, a Pastoral da Criança contava com Zilda Arns e uma secretária, trabalhando integralmente para

\footnotetext{
${ }^{40}$ Entrevista concedida a autora dessa dissertação em 25/06/2009, na cidade de São Paulo.
} 
a organização. "Então eu e o UNICEF chegamos a conclusão de que um jornal para que as pessoas trocassem experiências entre si seria muito útil."

Nesse início, a expansão estava voltada, principalmente, para o nordeste, que tinha a mortalidade muito grande. "Havia comunidades onde 50\%, 60\% das crianças eram desnutridas". Assim Zilda Arns passou a escrever os artigos, para haver uma troca de experiência entre as comunidades, e contava com o apoio do jornalista do UNICEF, que editava o material em um jornal de quatro páginas.

O convênio com o Ministério da Previdência, que cuidava da parte de assistência médica naquela época, por meio do INAMPS, possibilitou a impressão periódica do jornal, que em 1986 se tornou trimestral; depois bimestral. Entre os anos de 1987 e 1988, o jornalista Elson Faxina passou a fazer o Jornal Pastoral da Criança, trabalhando por cerca de oito anos a comunicação da entidade com um enfoque na participação dos voluntários.

Naturalmente o jornal foi progredindo, aumentou o número de páginas,
começou a sistematizar mais o jornal através das dioceses, porque o objetivo
principal era a troca de experiência e a educação continuada. Nós tínhamos
os encontros regionais, tínhamos milhares de capacitações pelo Brasil a fora,
mas para atualizar os recursos humanos, o voluntariado, animá-los,
precisávamos ter notícias das bases. No começo eram 10 dioceses que
apareciam uma vez por ano, agora é mais frequente. Como a equipe
aumentou, pedimos a contribuição de outros para escreverem. Então
começou a Voz do Pastor, pelo bispo do Conselho Diretor. Desde o começo
da Pastoral da Criança, sempre tinha um artigo meu. Normalmente animando
o voluntariado e reforçando as ações básicas de saúde, nutrição, educação e
cidadania. Isso foi se aperfeiçoando. (Zilda Arns)

Essa prática das comunidades enviarem notícias para o jornal começa nos anos $80 \mathrm{com}$ Elson Faxina. "Só que no começo só as dioceses maiores que mandavam notícias", afirma Zilda Arns. Assim nos anos 90, o jornalista começou a organizar treinamentos em comunicação, o que possibilitou mais participação. O jornalista fazia cursos em uma cidade maior, e os comunicadores de todas as cidades vizinhas iam até lá. Esses comunicadores enviavam as experiências de suas comunidades para o jornal. "Os comunicadores tiveram um importante papel na Pastoral. Nós dávamos bastantes cursos de rádio, para jornalistas e outras pessoas. Muitos locais não tinham jornalistas profissionais, então, o voluntariado aprendia a fazer entrevistas e se comunicar mais", relata a fundadora da Pastoral da Criança.

A articulação para que todas as dioceses do Brasil participassem, por meio de suas comunidades, foi feita constantemente. Também foram sendo criados espaços para participação dos técnicos, visando atualizar e dar uma educação contínua para voluntários e voluntárias. Esse direito de comunicar permanece vivo no jornal, que em setembro de 2003 se 
tornou mensal. Nesse período, também mudou a metodologia de envio de notícias para a publicação, visando garantir que todas as regiões do Brasil participassem.

Em 2008 começou uma ação voltada para a capacitação em comunicação popular, primeiro no Nordeste; depois, já em 2009, com um novo projeto piloto em cada região do país. Uma forma de retomar a capacitação em comunicação que era feita por Elson Faxina nos anos 90. Passados 26 anos do encontro de Embu/SP, a Pastoral da Criança tenta colocar em prática o direito de comunicar defendido no documento gerado naquela época.

Também é interessante notar os papéis que as CEBs tiveram nesse passado, que refletem no tipo de comunicação praticado pela Pastoral da Criança. Soares (1988, p.351) relata que nos anos 70 as experiências das CEBs em comunicação comunitária influenciaram os bispos reunidos em Puebla. Nas conferências de comunicação promovidas pelo Decos/Celam (Departamento de Comunicação Social/Conselho Episcopal Latino-americano) na segunda metade dos anos 70, a novidade era a participação de leigos. Além disso, baseados nas teorias de Paulo Freire, buscavam a "comunicação social como meio adequado de diálogo e participação". (1988, p.353) Já nos anos 80, o autor avalia que houve um aprofundamento teórico das conquistas de Puebla, como os documentos de Quito e Embu, mas não como discurso oficial da Igreja (1988, p.362).

Na prática, essas experiências deram voz ao povo. Puntel (1994, p.241-242) conta um pouco da história do CEMI (Centro de Comunicação de São Miguel), em São Paulo, para articular trabalhos pastorais em 1983. Produzia o jornal mensal Grita Povo!, que falava tanto dos problemas sociais locais como de ações pastorais. Se olharmos hoje para o Jornal Pastoral da Criança, vemos que ele mantém características parecidas. Também fala de questões sociais, não com a diversidade de temas que apareciam no Grita Povo!, mas focando em problemas mais relacionados à saúde e informações sobre direitos e deveres, convivência familiar. Por outro lado, tem o espaço reservado para a fé e também para os relatos enviados pelas comunidades da Pastoral da Criança.

Gomes (1987, p.6) também estudou o jornal Grita Povo! e avalia que se tratava de um projeto de comunicação popular, jornalismo popular e jornalismo católico. Havia "um referencial alternativo de enfrentamento com a lógica de dominação do sistema capital”, e o jornal se colocava a serviço de pastorais sociais como a operária, o movimento dos sem terra, a luta por direitos humanos (1987, p.14). A comunicação e o jornalismo popular estão inseridos em um contexto alternativo que luta por transformações sociais (1987, p.59). Já o jornalismo católico "se pretende possuir um projeto popular, deve (...) assumir a realidade de 
um jornalismo popular. Isto significa inserir-se num contexto alternativo e contribuir para a transformação social" (1987, p.116).

Já Bocchini (1988, p.34) pesquisou a legibilidade visual em cartilhas de política da Igreja Católica, entre 1981 e 1982, e constatou esforço dos produtores "para reduzir as dificuldades lingüísticas e discursivas", mas a qualidade visual era precária. Ainda constatou que em alguns casos as comunidades deram sua opinião e ofereceram contribuições para as equipes responsáveis pela publicação (1984, p.100).

A produção de cartilhas da Igreja, se, por um lado, atesta seu desejo de prestar serviços aos oprimidos, revela por outro, o quanto ela ainda é novata no conhecimento dos destinatários de suas publicações, o quanto ainda desconsidera as necessidades desses a quem se dirige, talvez porque ainda pese, até mesmo sobre essa Igreja mais progressista, mais voltada para os trabalhadores, a visão ideologizada dos pobres, por parte de uma instituição que passou séculos envolvida quase que exclusivamente com classes dominantes e letradas. (BOCCHINI, 1988, p.197)

Soares (1994, p.267-269) pesquisa a comunicação "de resistência" no movimento popular ligado à Igreja no início dos anos 90. Conclui que esse tipo de comunicação continua existindo nas CEBs e no movimento popular, caracterizando-se por produções compromissadas com os interesses dos mais pobres, das minorias étnicas e sociais. Havia uma aproximação com fóruns que discutem políticas de comunicação, uso de técnicas radiofônicas e de vídeos. Para o autor, a comunicação popular cria uma consciência na comunidade e apesar do movimento conservador se expandir pela Igreja Católica, essa comunicação se mantém atuante, mas desarticulada. Falta ampliar o seu público, sendo a exceção projetos ligados a carências emergenciais de setores específicos, como ecologia, saúde pública, criança de rua.

Os exemplos usados pelo autor nos dão uma pista sobre a aceitação que a Pastoral da Criança tem e a articulação que conseguiu criar, já que defende uma questão de saúde pública, mas também de infância: a saúde de crianças até seis anos e seu pleno desenvolvimento no contexto familiar. Nessa defesa, a Pastoral da Criança soube usar o legado deixado pelos anos 70 e 80 para fazer uma comunicação popular articulada.

Se olharmos para a maneira como a Igreja tem visto a comunicação nas duas últimas décadas, veremos que a forma como a Pastoral da Criança trabalha a comunicação vai além das premissas oficiais. Puntel (1994, p.177) afirma que o documento de Santo Domingo, conferência dos bispos da América Latina ocorrida em 1992, "resume e direciona a compreensão da comunicação para o 'uso' dos meios”. 
Já a Carta Apostólica O Rápido Desenvolvimento, de João Paulo II (2005) afirma que o Inter Mirifica permanece atual mesmo diante do rápido desenvolvimento das tecnologias de comunicação. Assim reforça o uso dos meios de comunicação pela Igreja para difundir o evangelho e a integração da "mensagem salvífica na 'nova cultura' que os poderosos instrumentos de comunicação criam e amplificam" (2005, p.5, n.2). Ainda aponta que "os meios de comunicação social podem e devem prover a justiça e a solidariedade, transmitindo de modo cuidadoso e verdadeiro os acontecimentos, analisando integralmente as situações e problemas, dando voz às diversas opiniões" (2005, p.7, n.3).

O texto do papa João Paulo II (2005) não incentiva a comunicação popular, focando-se mais na importância dos meios de comunicação social no geral. Ressalta que é preciso discernimento, fala em direito sem chegar a defender o direito em comunicar ou algo que lembre um receptor que seja também produtor. Em alguns momentos, exagera sobre o papel dos meios de comunicação:

(...) podemos pedir ao Senhor que nos leve a compreender como se comunicar com Deus e com os homens através dos maravilhosos instrumentos de comunicação social. (...) os meios de comunicação se revelam uma oportunidade providencial para atingir os homens em qualquer latitude, superando barreiras de tempo, de espaço e de língua... (João Paulo II, 2005, p.10, n.5)

Apesar de várias vezes falar positivamente dos "poderosos meios", que podem contribuir para a "difusão do Evangelho" (2005, p.12, n.6), o papa também alerta sobre limitações. Coloca que "o desenvolvimento positivo dos meios de comunicação a serviço do bem comum é responsabilidade de todos e de cada um" (2005, p.19-20, n.10). Ainda aponta que "sem uma formação adequada corre-se o risco de que eles, em vez de estarem a serviço das pessoas cheguem a instrumentalizá-las e condicioná-las inadequadamente" (2005, p.20, n.11) e acredita ser necessário "chamar a atenção sobre o acesso aos meios de comunicação e sobre a participação co-responsável na sua gestão".

No momento em que fala da opinião pública, cita o direito de se expressar de forma limitada: o direito canônico reconhece "em determinadas condições o direito à expressão da própria opinião" $(2005$, p.22, n.12). O lado positivo está na afirmação de que a "comunicação deve tender a um diálogo construtivo para promover na comunidade cristã uma opinião pública retamente informada e capaz de discernimento" (2005, p.22, n.12). O papa ainda olha a internet como forma de interatividade e de maior informação, mas também destaca a importância de jornais, revistas, rádios e TVs católicas (2005, p.15-16, n.9). 
Acreditamos que a Carta Apostólica não avançou em relação ao Inter Mirifica por não tratar da questão do direito de comunicar. Também não aponta uma abertura para a participação popular nos meios de comunicação na Igreja e se foca no uso dos meios para a evangelização. Seria um documento muito mais rico se tratasse da importância de se usar os grandes meios de comunicação ao mesmo tempo em que incentivasse a comunicação popular. Outro fator importante seria explorar uma comunicação que defendesse valores como a igualdade social e de oportunidades para os seres humanos, orientando a Igreja para também contribuir para a reflexão sobre a saúde, a educação e a cidadania.

Outro documento que podemos citar é o texto conclusivo da V Conferência Geral do Episcopado Latino-Americano e do Caribe, ocorrida em maio de 2007, na cidade de Aparecida/SP. Há apenas um texto com sete notas - Pastoral da comunicação Social voltado para a comunicação. Além disso, o termo aparece em outras dezenove notas ao longo do livro. Não há referências à prática da comunicação popular nem ao direito de comunicar.

Há uma perspectiva crítica da "comunicação de massa". Se por um lado aponta a possibilidade do tempo real, por outro destaca que essa comunicação é incapaz de "preencher o vazio produtivo em nossa consciência" e que "em muitas ocasiões a informação transmitida pelos meios só distrai” (n.38). Ainda critica a exploração publicitária dos meios (n.48) e influência negativa sob os jovens (n.318).

No entanto, apesar das críticas, defende o uso dos meios de comunicação para a difusão do Evangelho (n.485) e que se valorize a "nova cultura da comunicação" (n.486a). Assim faz algumas recomendações aos bispos. Apenas um item se aproxima da promoção de uma comunicação popular: "Promover a formação profissional na cultura da comunicação de todos os agentes e cristãos" (n.486b). Mas não detalha como seria essa formação. Até mesmo quando fala da necessidade da Igreja "apoiar e otimizar (...) a criação de meios de comunicação social próprios, tanto nos setores televisivos e de rádio, como nos sites de Internet e nos meios impressos" (n.486d), não aponta qual seria o papel dos leigos nisso. Só mais a frente que apontam a necessidade de "desenvolver uma política de comunicação capaz de ajudar tanto as pastorais de comunicação como os meios de comunicação de inspiração católica a encontrar seu lugar na missão evangelizadora da Igreja” (n.486i).

Pede ainda que se otimize "o uso dos meios de comunicação católicos, fazendo-os mais atuantes e eficazes, seja para a comunicação da fé, seja para o diálogo entre a Igreja e a sociedade" (n.497b). Também aponta a necessidade de "atuar com (...) jornalistas, comunicadores e apresentadores, (...) professores, líderes comunitários e religiosos" (n.497c). Mas ambos os itens com enfoque na comunicação de "valores evangélicos". 
Percebemos assim uma preocupação para usar a comunicação como um espaço para a evangelização e para a fé. Não se mostra um interesse em promover uma comunicação popular efetiva em que o povo fale de suas necessidades. Outro ponto defendido pelos bispos latino-americanos é a presença da Igreja "nos meios de comunicação de massa (...) para introduzir neles o mistério de Cristo" (n.486e).

Já uma questão que avaliamos como positiva é o olhar dos bispos para a internet, apesar de vê-la apenas como instrumento de evangelização. Chegam inclusive a sugerir formas de combater a exclusão digital.

Os meios de comunicação, em geral, não substituem as relações pessoais nem a vida comunitária. No entanto, os sites podem reforçar e estimular o intercâmbio de experiências e informações que intensifiquem a prática religiosa através de acompanhamentos e orientações. (n.489) Visto que a exclusão digital é evidente, as paróquias, comunidades, centros culturais e instituições educacionais católicas poderiam ser estimuladoras da criação de pontos de rede e salas digitais para promover a inclusão, desenvolvendo novas iniciativas e aproveitando, com olhar positiva, as que já existem. $\mathrm{Na}$ América Latina e no Caribe existem revistas, jornais, sites, portais e serviços on line de conteúdos informativos e formativos, além de orientações religiosas e sociais diversas, tais como "sacerdote", "orientador espiritual", "orientador vocacional", "professor", "médico", entre outros. Existem inumeráveis escolas e instituições católicas que oferecem cursos à distância de teologia e cultura bíblica. (n.490) (DOCUMENTO DE APARECIDA, 2007)

\section{6 - Em defesa da comunicação popular}

O diferencial da Pastoral da Criança em relação ao lugar dado à comunicação está justamente em aliar esses dois mundos: a inserção na mídia com discernimento e o investimento em comunicação popular, voltada não só para a fé, mas também para questões sociais como a saúde e informações sobre direitos. Acreditamos que ao usar os instrumentos de comunicação sem dar a eles um sentido de justiça, apenas para a evangelização, a Igreja leva a uma fé vazia por não estar aliada à ação.

Já a Pastoral da Criança faz uma clara opção em defesa da comunicação popular, executando o direito das líderes em comunicar, ao enviarem notícias para o jornal, e ouvindo os representantes eleitos das regiões para pautar os assuntos que aparecerão em relação à saúde, educação e cidadania. Podemos dizer o mesmo do programa de rádio Viva a vida, que traz informações que giram em torno dessas temáticas como entrevistas com especialistas ao 
mesmo tempo em que se incentiva que cada emissora de rádio ou cada voluntário reconstrua o programa a partir da realidade de sua região.

A comunicação popular, segundo Peruzzo (1998, p.113-121) começou a se desenvolver nos anos 70 e 80 . Alguns autores usam o termo alternativo, mas a expressão "imprensa alternativa", no Brasil, é usada para definir os periódicos que se tornaram uma opção de leitura crítica em relação à grande imprensa, que era censurada e ao mesmo tempo configurava monopólios informativos. Também chamada de nanica, configurava uma imprensa de oposição frente ao regime ditatorial. Outros termos utilizados para classificar a comunicação popular são comunitária, participativa, dialógica, horizontal.

Assim a autora opta por classificar a comunicação dos movimentos sociais como “popular-alternativa". É a comunicação que luta por melhores condições de existência para o povo mediante movimentos de base organizados. Essa corrente se posiciona de dois modos diferentes. Uma surgida em 80 que concebe a comunicação popular como libertadora e crítica, capaz de levar à transformação social através de conteúdos críticos e reivindicatórios, colocada em antagonismo à comunicação de massa. É denominada como "populista esquerdizante" 41 .

A outra vertente aparece no início dos anos 90 e tem uma posição mais dialética e flexível, já que acredita que a comunicação popular pode contribuir para a democratização dos meios de comunicação e da sociedade. Ela percebe que não consegue levar a uma transformação imediata devido às limitações, contradições e sua inserção na grande diversidade cultural. Além disso, não se contrapõe à comunicação de massa. Essas duas linhas de pensamento coexistem. Peruzzo (1998, p.119) ainda complementa que a "comunicação popular alternativa" é uma realização da sociedade civil que se constitui historicamente, podendo sofrer transformações e ocupar novos espaços e tecnologias de informação como rádio, TV e internet.

Acreditamos que a Pastoral da Criança pratica uma comunicação popular alternativa que se enquadra nessa postura mais dialética e flexível apontada por Peruzzo (1998, p.119). Tanto que há a equipe de profissionais voltados para essa comunicação popular, preparando o Jornal Pastoral da Criança e os programas de rádio Viva a Vida, e outra mais voltada para a assessoria de imprensa e a comunicação externa.

\footnotetext{
${ }^{41}$ Segundo Peruzzo (1998, p.119), a denominação "populista esquerdizante” foi dada por Jorge Gonzáles em seu texto "A razão e o coração nos tão falados tempos de cólera: oralidade, modernidade e meios" In: HAUSSEN, Doris F. (org.). Sistemas de comunicação e identidades da América Latina. Porto Alegre, INTERCOM/EDIPURGS, 1993.
} 
Já Gomes (1987) trabalha a definição de comunicação popular a partir de diversos autores. Assim, um dos pontos que levanta é que a comunicação popular supõe a quebra da lógica da dominação, realizando-se a partir do povo e de seus códigos (1987, p.49). É um instrumento dos setores dominados para expressarem sua realidade, acontecendo de forma horizontal, dialógica e participativa, não havendo a dicotomia entre emissor-sujeito e receptor-objeto, pois ambos são sujeitos que se comunicam (1987, p.53).

Puntel (1994, p.133), por sua vez, explica que a comunicação popular "refere-se a um novo tipo de comunicação ‘do povo’ na América Latina”. Pode comunicar através de diversos meios, que passavam por jornais mimeografados, teatro popular, posters, vídeos feitos com as comunidades. "O povo participa do processo de produção, escolhendo o que produzir, como produzir e onde apresentar a produção visual".

Para melhor compreender a comunicación popular, é preciso fazer uma distinção de outras experiências de comunicação, que também recebem o nome de "popular". O termo "popular" refere-se freqüentemente a produtos da indústria cultural de massa (...), pode significar simplesmente "ter uma ampla aceitação", mas também implica um contraste com a cultura elevada... No entanto, o termo "popular" é também relacionado à palavra "povo" e, na América Latina, os substantivos pueblo ou povo e o adjetivo popular começam a denotar um movimento de emancipação. (...) Assim, "povo" representa o oprimido, o sem defesa, não importando quem seja camponeses, trabalhadores, mulheres, crianças, negros, desempregados, etc. Para explicitar o significado de "popular", como um movimento de emancipação, isto é, visto dentro da perspectiva desenvolvida pela filosofia educacional de Paulo Freire... (PUNTEL, 1994, p.193-194)

Outra autora que aborda a questão da comunicação popular é Festa (1984, p.232), que acredita que esse tipo de comunicação não se restringe a meios e técnicas, mas também a processos culturais que se articulam através de redes populares com sentidos e símbolos sociais e políticos diferenciados da classe dominante. Constitui a busca de outra sociedade a partir das organizações sociais.

Em suma, a comunicação popular refere-se ao modo de expressão das classes populares de acordo com a sua capacidade de atuar sobre o contexto social na qual ela se reproduz. Contexto de enfrentamento com o projeto de dominação capitalista. Nesse contexto, a comunicação popular é o agente da definição do projeto popular, que vai conformando a inter-relação entre grupos e classes populares e a sua incapacidade atual de articular alianças políticas. Daí porque ela se expressa em espaços determinados como nas CEBs, sindicatos, grupos de mulheres, centros de educação e comunicação popular, grupos culturais, movimento de favelados, etc. (FESTA, 1984, p.170) 
Os destaques ficam por conta da criação de vários centros de documentação, educação popular e comunicação em todo o país nos anos 70, apoiados pela Igreja, para "uma educação popular mais comprometida com o nível de consciência da classe subalterna". Assim produziam

folhetos, cadernos de estudo, material para reflexão, cartazes, volantes, audiovisuais, filmes, programas de rádio, etc., material para grupos de mães, favelados, operários, comissões de direitos humanos, alfabetização, etc., além de um material novo para as campanhas, novenas, festas litúrgicas, etc. (FESTA, 1986, p. 18)

As Comunidades Eclesiais de Base (CEBs) também foram fundamentais para o desenvolvimento da comunicação popular. Faziam boletins diocesanos, folhetos litúrgicos, cordel e cadernos de formação. Preparado sob a coordenação e supervisão dos agentes pastorais, os temas eram sugeridos pela comunidade, que também avaliava o material produzido antes que ele fosse finalizado. Um dos critérios para a aprovação era a certeza de que a comunidade havia entendido o material produzido (FREI BETTO, 1981, p.53).

O texto recolhe, em forma de notícias, reflexões, orações, versos, contos, narrações ou análises, aquilo que a comunidade vive e fornece espontaneamente. Se destinados às próprias comunidades, o código de elaboração obedece às exigências da intelecção popular. $O$ conteúdo conceitual é transmitido através da descrição visual. (...) Escreve-se como o povo fala: contando o caso, como o Evangelho o faz em parábolas. $\mathrm{Na}$ publicação popular, esse código é enriquecido por ilustrações, desenhos ou fotos. As descrições e ilustrações procuram refletir a situação vivida pelos leitores. O texto é para eles como um espelho no qual reencontram sua verdadeira fisionomia. (FREI BETTO, 1981, p.54-55)

As características apontadas por Frei Betto sobre a comunicação nas CEBs lembram a comunicação popular desenvolvida hoje pela Pastoral da Criança. O Jornal Pastoral da Criança conta com uma jornalista responsável por sua publicação - Sonia Prati. No entanto, a seção Comunidades é feita somente com textos enviados por comunidades da Pastoral da Criança de todo o Brasil. Assim o próprio povo fala. No total, a publicação costuma ter 16 ou 24 páginas. $\mathrm{O}$ aumento ocorre quando se publica algum suplemento especial. Entre os meses de fevereiro de 2008 e junho de 2009, de um total de 16 jornais ${ }^{42}$, 13 tiveram oito páginas para a seção Comunidades. Já as edições de maio de 2008 e abril de 2009 tiveram 10 páginas dedicadas aos textos enviados pelos setores. A edição de setembro de 2008, por sua vez, teve um espaço de 12 páginas para as comunidades.

\footnotetext{
${ }^{42}$ Os meses de dezembro de 2008 e janeiro de 2009 contaram com uma única edição devido a uma reforma sofrida pelo jornal. As mudanças são analisadas no capítulo 4 de nossa dissertação.
} 
Para Peruzzo (1998, p.122), a comunicação popular pode ser compreendida por diversos processos, já que não há uma uniformidade metodológica na execução dessa comunicação e na produção de seus veículos. Enquanto alguns abrem espaço para que realmente haja uma comunicação participativa, outros só o fazem ocasionalmente e ainda há aqueles que nem chegam a fazê-lo. É necessário, assim, para a autora, que se promova a participação de maneira mais ampliada, já que muitas vezes elas ficam restritas a algumas lideranças (1998, p.143).

Concretamente, a participação popular na comunicação comunitária pode significar, numa gradação crescente: o simples envolvimento de pessoas, geralmente ocasional, no nível das mensagens, ou seja, dando entrevistas, avisos, depoimentos e sugestões ou cantando, pedindo a inserção de música e aderindo a concursos; elaborar matérias (notícias, poesias, desenhos); compartilhar a produção global do jornalzinho, do programa de rádio etc.; tomar parte na definição da linha política, do conteúdo, do planejamento, da edição, do manejo de equipamentos; compartilhar o processo de gestão da instituição comunicacional como um todo. (PERUZZO,1998, p.142-143)

Uma das conclusões de Peruzzo (1998, p.297-299) é que a participação da comunidade é maior em relação às mensagens. Isso ocorre através de entrevistas, depoimentos, avisos, cartas ou sugestões. Ela avalia que o aprendizado do processo participativo é lento e que a comunicação participativa passa "pela questão da cultura, pelas necessidades e pelas oportunidades vividas". Dessa forma, como a cultura é dinâmica, os padrões vão se alterando.

No caso do Jornal Pastoral da Criança, foi criada uma metodologia própria para garantir a participação de comunidades de diferentes regiões do Brasil. Para Faxina (2001, p.213), o maior desafio em se produzir os materiais de comunicação da Pastoral da Criança é manter uma comunicação que seja efetivamente popular já que eles precisam ter abrangência nacional.

Foi pensando em vencer essa dificuldade e permitir que diferentes regiões estivessem no jornal, que se desenvolveu um processo participativo no qual as mais de 300 dioceses que possuem Pastoral da Criança no Brasil foram divididas em oito grupos. Cada mês a seção Comunidades é dedicada a uma dessas áreas, conforme explica a jornalista Sonia Prati ${ }^{43}$ :

O líder tem uma participação no jornal enquanto comunidade. Cada diocese, que faz parte de determinado grupo, recebe uma carta. Elas têm um calendário de quando podem mandar a notícia. Nós mandamos com

\footnotetext{
43 Sonia Prati, jornalista responsável pelo Jornal Pastoral da Criança, nos concedeu entrevista no dia
} 10/02/2009, em Curitiba/PR. 
antecedência um envelope já selado, tudo pronto, o setor digita ou envia a cartinha notícia e manda para a Coordenação Nacional da Pastoral da Criança ou manda também por e-mail. Na assembleia de 2007 e também no Congresso da Pastoral da Criança ficou acertado que o líder mandaria a notícia via coordenador do setor, porque o líder mandava direto a notícia para o Jornal Pastoral da Criança. O que acontecia? Muitas vezes a coordenação do setor não sabia que no próprio setor estava acontecendo aquela realidade que o líder tinha mandado. Então se convencionou que o líder pode mandar notícia direto para o jornal, mas antes ele tem que entrar em acordo com o coordenador de setor. (Sonia Prati)

A jornalista responsável pelo Jornal Pastoral da Criança ainda explica que além de poder mandar a notícia a cada oito meses, conforme o seu grupo, o coordenador de setor também pode enviar texto quando há uma celebração especial ou uma festa comemorativa maior. Isso para que a notícia não fique tão defasada quando aparecer no jornal. Apesar de Sonia Prati relatar esse cuidado, lendo as notícias das comunidades, vimos essa diferença entre o tempo do acontecimento e o período em que aparece no informativo, como no caso de uma notícia do Setor Lapa. A comemoração ocorreu em outubro de 2007, mas só foi noticiada em junho de 2008.

O espaço entre o fato e a publicação provavelmente deve ter ocorrido devido ao rodízio de oito meses entre os setores. Não acreditamos que o sistema de rodízio seja negativo por esse fato, mas seria preciso estudar novas formas para que não houvesse uma distância tão grande entre o fato e a publicação. Talvez orientando as coordenadoras para que mandem notícias recentes. Outra forma seria aliar a comunicação do jornal com a internet, assunto que está em discussão na Pastoral da Criança. A própria carta poderia trazer orientações nesse sentido, já que funciona como um lembrete para a coordenadora participar do jornal ao mesmo tempo em que fornece envelope selado, forma de incluir pessoas que não dominam a internet para mandar a notícia por e-mail.

A jornalista aponta outro problema. Algumas coordenadoras mandam notícias dos ramos (paróquias) maiores, já os menores não aparecem. Para evitar isso, a equipe recomenda que a questão do espaço do jornal seja muito discutida entre a coordenação de setor e os coordenadores de ramos e de área, "para que haja um diálogo". Assim coordenadoras ou coordenadores vão construindo soluções: revezamento, cada vez entra uma paróquia do setor; síntese de suas paróquias; outros relatam eventos gerais que foram para diocese toda.

A líder também encontra outros espaços no jornal em que pode participar sem depender da coordenação do setor a que pertence. Um desses locais é a Pergunta do líder, no qual é possível enviar uma pergunta ou uma dúvida sobre qualquer tema. Por exemplo, uma questão sobre o aleitamento materno, alguma parte das FABs (Folhas de Acompanhamento e 
Avaliação Mensal das Ações Básicas de Saúde e Educação na Comunidade) que não entendeu. A resposta será dada, via jornal, pelo setor técnico da Pastoral da Criança.

Outro espaço que podemos identificar como exemplo de uma comunicação popular em que o receptor também é construtor da notícia é a seção Testemunho. Nela a líder com uma caminhada na Pastoral da Criança tem espaço para falar de sua história ou vivências na pastoral. Essa seção foi apontada pela jornalista Sonia Prati como um dos espaços em que a líder aparece, mas ela também deu outros exemplos durante a entrevista:

O líder entra diretamente no jornal quando ele colabora com a receita. Ele dá ideia para o Diálogo. Eles dizem - "na minha comunidade os líderes estão com muito baixa autoestima, estão desmotivados, então eu gostaria que o jornal colocasse um tema sobre isso". Os líderes entram no Mural de Recados. (Sonia Prati)

Sobre essa seção, em que a líder pode dar um pequeno depoimento sobre a Pastoral da Criança, relatar um fato ou fazer um comentário, Sonia Prati relembra uma história curiosa, que mostra o potencial do jornal da Pastoral. Uma líder mandou em Rondônia um aviso no Mural de Recados. No Rio Grande do Sul, outra líder, ao ler o Mural, reconheceu a líder de Rondônia, que havia deixado o estado do sul havia quase 30 anos. Durante todo esse período, as amigas não tinham se visto nem tinham notícias uma da outra. O Mural de Recados foi o que fez com que elas se reencontrassem.

Assim resume a participação da líder:

O líder é nossa prioridade, tem sempre um espaço no jornal. Para mandar notícias como setor, ele sempre entra em contato com a coordenadora diocesana do setor. Para mandar notícias individuais, tem o espaço próprio deles: Testemunho, Pergunta do Líder, Mural de Recados, as Notas. São sempre espaços para o líder independente da coordenação do setor. (Sonia Prati)

Percebe-se uma preocupação sobre a concretização de uma comunicação popular efetiva, na qual se desenvolve um trabalho em que o público leitor - as voluntárias e voluntários - são também produtores das notícias. As líderes e coordenadoras não só podem escrever textos que serão publicados pelo jornal como são incentivadas a isso. A carta enviada para o setor é um exemplo desse incentivo. O próprio jornal também faz isso. No início da seção Comunidades, de cada edição, explica-se que o "caderno" é o espaço para os setores apresentarem as atividades que a Pastoral da Criança desenvolve em suas comunidades. Ressalta-se que o Brasil foi dividido em oito grupos e relata qual grupo se apresenta na edição. Especificamente no jornal de junho de 2009, publicou-se um box sobre a importância 
de escrever o nome da comunidade e do setor nas fotos enviadas assim como escrever no envelope e na página da notícia que o material enviado é para o jornal. Isso é feito porque há pessoas que enviam notícias sem a identificação e elas acabam se perdendo, como vemos no depoimento a seguir:

Eu mandei minha notícia e por que não saiu? O que aconteceu? Falta identificação na maioria das vezes. É muito difícil você escrever dentro de uma realidade específica com um público geral. Ele esquece, mesmo o coordenador quando vai escrever, que ele vai para fora do contexto dele. Então não coloca a cidade, às vezes não coloca a comunidade, o nome da paróquia completo. A identificação fica muito difícil. Mesmo porque quando os envelopes chegam à Coordenação Nacional da Pastoral da Criança, existe uma equipe que abre as cartas e separa por setores. Quando chega para mim, só vem o conteúdo das cartas, eu não tenho acesso aos envelopes. Se na notícia não estiver a comunidade, a diocese, o nome das pessoas, eu não tenho como identificar. Também recebemos fotos sem identificação atrás. Não tenho como saber de onde é. Mesmo quando vem por e-mail, muita gente empresta e-mail para a líder, para a coordenadora ou para alguém mandar. Às vezes eu consigo mais informações por aquele e-mail, outras não. Outro problema que também acontece muito é o envio da notícia no meio de FABs, de prestação de contas, com outros materiais. Essa notícia, essa folhinha, fica perdida no meio de uma caixa de FABs ou no meio de prestação de contas. Para digitar as FABs, a folhinha perdida pode ser confundida com um relatório, pois não está escrito "para o jornal". Então a gente orienta que sempre escrevam "para o jornal". Nós fazemos muitos esforços para descobrir a notícia e quando a notícia vem direto da comunidade, a gente entra em contato com o coordenador do setor para perguntar daquela notícia. Porque às vezes o líder quando escreve alguma coisa de uma família que acompanha, ele é tão transparente que na simplicidade dele, escreve tudo. Quem recebe tudo isso tem que ter o bom senso de preservar, prevendo o que pode acontecer quando essa história for para a comunidade. Você tem que medir a repercussão que essa história, que saiu em nível nacional, vai ter quando voltar para aquela cidade pequena. É com esse olhar, com esse espírito que você tem que montar o jornal da Pastoral da Criança. (Sonia Prati)

A jornalista ainda explica que houve uma discussão no Jornal Pastoral da Criança sobre o que seria notícia para o jornal. "Tivemos que mudar o olho, mudar a concepção do que é notícia para o nosso público alvo, o líder.” Isso porque se considerou necessário saber o que significava a notícia para as líderes. "É ele se retratar e se ver retratado no jornal, ele lê aquela matéria da sua comunidade e dizer - 'Puxa nosso Brasil inteiro sabe o que estamos fazendo aqui'." A definição de Sonia Prati ilustra o significado da notícia na comunicação popular praticada pela Pastoral da Criança.

Nós recebemos muitas cartas e muitos e-mails. Não há censura, o que o setor decidiu publicar, se ele mandou para o jornal como notícia, a palavra final é dele. Não sou eu ou qualquer outra pessoa que vai dizer essa notícia não 
serve, não, porque se o grupo de líderes de um setor decidiu que essa é a notícia que eles querem que saia no jornal, eles querem se ver através daquela notícia, aquela notícia vale. Então não há uma censura. Há apenas o seguinte, quando não cabe, fica para o próximo. Isso nós avisamos na abertura da seção Comunidades. (Sonia Prati)

Outro ponto importante na produção do Jornal Pastoral da Criança é a escolha dos temas retratados. Tanto o jornal quanto o rádio são voltados para a formação contínua. Assim, conforme explica a editora, os dois veículos trazem a mesma temática. Observa-se o calendário litúrgico, do qual se abordam as festas mais importantes, como a Páscoa e o Natal. Consideram-se as atividades das líderes, por exemplo, um mês antes da realização do mutirão das gestantes, quando as líderes são incentivadas a buscarem mulheres grávidas para orientálas, o jornal aborda o fato. As campanhas do Ministério da Saúde também pautam matérias: tuberculose, hanseníase, dengue. Outros temas que costumam ser retratados são o tabagismo, o aleitamento materno, a semana do voluntariado.

Todos esses textos aparecem na seção Aprendendo Mais, o espaço voltado para essa formação contínua, já que apresenta temas sobre saúde, cidadania e educação. Apesar de esses materiais serem produzidos pela Coordenação Nacional, muitas vezes por técnicos, a escolha da temática também passa pelos voluntários. Em todos os encontros regionais, as coordenações de todos os setores apontam o que gostariam de ver no Jornal Pastoral da Criança. Assim são definidos os temas de forma comum com os programas de rádio, de maneira que se aprofundem os temas abordados pelo Guia do Líder.

Procura-se ainda fixar temas para os próximos três anos. O que não impede que coisas novas sejam colocadas. Por exemplo, a edição de abril de 2009 trouxe um encarte bíblico de quatro páginas porque na assembleia da Pastoral da Criança, nos encontros regionais, decidiuse que era necessária a "formação contínua na parte da mística". "Não é um instrumento fechado, pelo contrário, absolutamente dinâmico e aberto para mudanças”, define Sonia Prati.

Os canais de participação criados pela Pastoral da Criança mostram como se desenvolver um veículo de comunicação popular para pessoas de tantas comunidades diferentes. As alternativas criadas possibilitam uma comunicação horizontal, em que se busca a reflexão sobre os problemas vivenciados nas comunidades. Isso porque quando se fala dos problemas de saúde, dos direitos que devem ser buscados, dos problemas de convivência familiar, aborda-se a realidade que as líderes presenciam em suas visitas. O jornal funciona como um recurso informativo e educativo, que pode levar a reflexão. Até mesmo porque muitas das voluntárias entrevistadas em nossa pesquisa acabam utilizando o jornal para 
debates nas reuniões de avaliação e reflexão da comunidade. Toda essa prática não foge da definição apresentada por Puntel em sua pesquisa sobre os anos 80:

A comunicación popular começa por uma análise da própria situação social de cada um, que transforma as consciências e conduz à ação, ao envolvimento e à luta. Esses movimentos locais constituem muitas vezes, o primeiro passo para estabelecer-se a comunicação alternativa, horizontal e a estrutura organizacional entre a população urbana e rural. A comunicação, portanto, não é vista como algo que acontece entre "emissor" e "receptor", mas como um processo participativo, que se torna um símbolo de oposição ao modelo autoritário, vertical e hierárquico da elite dominante, da comunicação controlada, típico das sociedades contemporâneas. (PUNTEL, 1994, p.197)

Nesse sentido, a comunicação popular, como coloca Faxina (2001, p.99), é um espaço de expressão democrática, que possibilita a abertura de novos canais para aqueles que, muitas vezes, não podem expor suas ideias e reivindicações nos meios de comunicação de massa. Opinião parecida com a de Fernández (2000, p.298) que descreve a propagação da comunicação na América Latina como "a proliferação de meios de informação e comunicação alternativos, como resposta frente ao monopólio da palavra por parte dos que usufruem também do poder político e econômico".

O diferencial no período pós 2000 seria a internet como instrumento que dá voz aos receptores, possibilitando que qualquer pessoa com computador e acesso à rede possa se tornar um produtor de informação. Claro que há fatores limitantes como a exclusão digital e problemas como a falta de alfabetização ou a educação de má qualidade. No entanto, é inegável que se abre um leque muito rico a ser explorado pelos movimentos sociais e pelos cidadãos para a democratização da informação.

No caso da Pastoral da Criança, ela parece ter percebido o potencial da rede, mas sua exploração ainda não é ideal. Há um blog ${ }^{44}$ dos comunicadores da Pastoral da Criança desatualizado. Criado em 2007, teve cinco postagens. Em 2008, treze. Em 2009, nenhuma ${ }^{45}$. Certamente seria enriquecedor um blog atualizado diariamente que trouxesse a ação da Pastoral da Criança em diversas partes do país, como um espaço aberto para publicar histórias dos voluntários.

Já em 2009, outro blog foi criado com o intuito de trazer notícias sobre a campanha que orienta para os bebês dormirem de barriga para cima. Esse recebe notícias sobre a campanha de diferentes comunidades do país com matérias sobre a campanha que saíram na

\footnotetext{
${ }^{44}$ http://compastoraldacrianca.blogspot.com/

${ }^{45}$ Isso até 29/05/09, quando entramos no blog pela última vez.
} 
mídia. É um começo de uma ação interativa e popular que usar a internet. O ideal seria um blog aberto para todas as notícias das comunidades. Mas de certa forma, esse espaço também começa a ser construído no site, que está sendo reformulado ${ }^{46}$.

Antes o site da Pastoral da Criança trazia apenas um sistema de informação em que era possível acessar relatórios de todo o país e dados. As noticias dos comunicadores não era facilmente achadas nas páginas, isso quando saia, pois não havia uma política para isso. Com a reformulação, isso começa mudar e o site abre a possibilidade de também ser um espaço de comunicação popular. Agora existem categorias para as notícias: nacionais, internacionais, locais e outras. Essa última traz notícias de outros meios e informações que podem ter um cunho social, por exemplo, um concurso sobre o ECA (Estatuto da Criança e do Adolescente) ou um texto com dados do IPEA mostrando que os pobres pagam mais impostos. Já as locais trazem notícias enviadas por comunicadores de comunidades de diferentes regiões. Essas mudanças começaram a ser visualizada em junho de 2009 .

O layout do site ficou melhor com as categorias locais, nacionais, internacionais e outras. Os links também ficam em local de destaque. Quando assessores voluntários enviam notícias para serem publicadas, elas são incluídas em "locais" ou "nacionais", dependendo da abrangência. Seria interessante ainda estimular o envio de notícias ao site e transformá-lo em um espaço participativo como o jornal.

Ao que tudo indica, a Pastoral da Criança caminha para isso. Segundo a jornalista Sonia Prati será criado um link na internet, para colocar as notícias completas enviadas ao Jornal Pastoral da Criança, no caso daquelas que são muito grandes e não tem espaço para saírem na íntegra. Assim no próprio texto impresso viria um indicativo de "Leia Mais" e o endereço. Mas isso ainda não está "formalizado", segundo a assessoria. Por outro lado, no site é possível acessar todas as edições do jornal assim como ouvir os programas de rádio

Também seria interessante explorar o espaço da internet no curso de comunicação popular que a Pastoral da Criança está desenvolvendo. Essa formação leva a prática das raízes da comunicação popular, com práticas de teatro, cartazes, jornal mural, bibliodramas. Ações bem parecidas com as desenvolvidas pelas CEBs:

Esta comunicação popular pode tomar forma de textos escritos (geralmente jornais mimeografados) que falam de serviços ou lutas populares, contendo também orações, poesias, fábulas, relatos elaborados pelos próprios membros da comunidade sobre suas vidas, suas lutas, por melhores

\footnotetext{
${ }^{46} \mathrm{O}$ endereço do site da Pastoral da Criança é http://sites.pastoraldacrianca.org.br/pastoraldacrianca/, já o blog pode ser acessado em um link no próprio site ou diretamente no endereço:

http://sig.pastoraldacrianca.org.br/wordpress/
} 
condições e sobre outras pessoas e seus problemas. Pode ainda incluir petições a serem enviadas a autoridades ou cartas a autoridades civis e religiosas. A variedade de jornais murais, cartazes, panfletos, desenhos, ilustrações, tudo feito pelas comunidades, espelha o que os grupos vivem, pensam e desejam como parte importante de suas preocupações. Música, teatro, dramatização e audiovisuais baseados na experiência local têm mais efeito sobre a comunidade do que os que lhes são externos, por razão de identidade social. (PUNTEL, 1994, p.237-238)

A descrição acima sobre as CEBs de um modo geral expressa bem a comunicação popular da Pastoral da Criança que presenciamos em nossa pesquisa de campo. Assim como Puntel (1994) fala da inclusão de petições a autoridades, presenciamos ações desse tipo na Pastoral da Criança na cidade de São Paulo. Em abril de 2009, a coordenadora da Pastoral da Criança do setor SP1 (Arquidiocese de São Paulo) e a coordenadora do setor SP 2 (Dioceses de Campo Limpo, São Miguel Paulista, Santo Amaro e outros municípios vizinhos) enviaram uma carta ao secretário de saúde do município de São Paulo, Januário Montone, apontando as necessidades em saúde observadas pelas líderes da Pastoral da Criança. O secretário, como já relatamos, atendeu as coordenadoras em abril. A partir de então, iniciaram-se os contatos com a área técnica da saúde.

A coordenadora da Pastoral da Criança na Arquidiocese de São Paulo foi recebida em maio por técnicos da secretaria. O encontro marcou o início de um diálogo, que deve ocorrer constantemente. A inclusão do gráfico da curva uterina no cartão da gestante foi uma das principais reivindicações apresentadas pela coordenadora da Pastoral da Criança. Isso porque esse gráfico permite que a gestante acompanhe visualmente a saúde do seu bebê e se o desenvolvimento está normal. Diante disso, a coordenadora substituta e assessora técnica do Gabinete de Atenção Básica a Saúde, Rosana Castanho Sant'Anna, se mostrou aberta à mudança. Ela se dispôs a levar a reivindicação ao Programa Mãe Paulistana.

Também propôs a troca de informações sobre os problemas de cada região da capital paulista, presenciados pelas líderes da Pastoral da Criança. A cidade de São Paulo conta com cerca de quatro mil voluntários e voluntárias. São $2498^{47}$ espalhados pela Arquidiocese de São Paulo, e o restante dividido entre as dioceses de Campo Limpo, São Miguel Paulista e Santo Amaro.

A parceria é uma prática buscada pela coordenação da Pastoral da Criança na cidade de São Paulo e estimulada pela Coordenação Nacional. Outro exemplo é a ação com a secretaria de saúde em atenção à tuberculose. Além de técnicos realizarem palestras para as

\footnotetext{
${ }^{47}$ Dado referente a média do primeiro trimestre de 2009, apresentada pela coordenadora da Pastoral da Criança na Arquidiocese de São Paulo, Maria do Rosário, aos técnicos da prefeitura.
} 
líderes da Pastoral da Criança, a ação conjunta possibilitou a reversão de um quadro de tuberculose na aldeia indígena do Jaraguá.

Esse novo contato com a secretaria de saúde possibilitará palestras técnicas sobre os serviços na área para os articuladores de saúde da Pastoral da Criança, que vão aos hospitais recolher dados. Eles estudam as razões das mortes de crianças e discutem a questão com as comunidades para que não ocorram novos casos. Na maioria das vezes, são mortes por causas evitáveis. A intenção da coordenação da Pastoral da Criança na Arquidiocese de São Paulo é participar dos Conselhos de Saúde. Além de enviar informações sobre as demandas de saúde das crianças e gestantes nas comunidades atendidas pela Pastoral da Criança para a secretaria de forma constante.

Já as práticas de comunicação popular apontadas por Puntel (1994, p.237-238) como jornais murais, cartazes, panfletos, desenhos, ilustrações, teatro feitos pelas comunidades começaram a ganhar espaço na Pastoral da Criança em 2008. Trata-se do projeto de comunicação popular. O primeiro passo foi desenvolver projeto piloto no Nordeste, pegando uma comunidade rural e uma urbana, e uma cartilha de comunicação popular. Para tanto, a Pastoral da Criança contratou uma jornalista: Núbia Maria da Silva.

Missionária franciscana, irmã Núbia já havia atuado junto a CEBs e ao MST. Na Pastoral da Criança, participava no Maranhão, utilizando o programa de rádio Viva a vida na rádio educadora. Para tanto, ela reelaborava o programa da Pastoral a partir da realidade local. A ideia era fazer algo interativo. Na apresentação da cartilha, explica-se que Jesus "optou por um processo dialógico de comunicação que fala para o homem inteiro". A testagem começou em outubro de 2008 em uma comunidade de Lagoa Salgada/RN.

O material foi apresentado em Assembleia Nacional da Pastoral da Criança em dezembro de 2008. Também foi enviado a cinco jornalistas de diferentes regiões do Brasil: Jiparaná/RO, Brasília/DF, Ilhéus/BA, São Paulo/SP e Porto Alegre/RS. Fomos convidados a representar o sudeste, apresentando sugestões para a melhoria da cartilha e aplicando uma capacitação em uma comunidade de São Paulo.

Para tanto, estivemos em fevereiro de 2009 em Curitiba, onde conhecemos as experiências de irmã Núbia e os objetivos do projeto de comunicação popular. A Pastoral da Criança já desenvolvia uma ação para que profissionais de comunicação atuassem como voluntários, mas faltava uma ação que potencializasse o líder como comunicador. Assim surgiu a proposta da capacitação em comunicação popular.

A ideia é dar uma formação em capacitação popular para as líderes que tenham interesse, que consiste em um curso de dois dias (16h) e conta com a cartilha como subsídio. 
A líder se tornará uma comunicadora popular e poderá formar um grupo com pessoas de sua comunidade, que serão os comunicadores comunitários e não precisam ser voluntários da Pastoral da Criança. Dessa forma, eles poderão desenvolver ações comunicativas nas bases, de acordo com suas realidades. Esse projeto também pretende atrair a participação dos jovens.

Trazer os jovens para a Pastoral da Criança é um desejo também manifestado por Zilda Arns em outras ocasiões. Isso aconteceu, por exemplo, na comemoração dos 25 anos da Pastoral da Criança, em Aparecida do Norte/SP, no mês de setembro de 2008:

Vamos fazer uma forcinha para atrair a juventude para a Pastoral. Ela dá vida nova para a Pastoral da Criança, e a Pastoral também ensina muito. Esses jovens, quando casarem, saberão cuidar muito melhor das crianças. Os jovens precisam de ocupação e como voluntários semeiam a paz na comunidade, no Brasil e no mundo. (Zilda Arns)

Em Curitiba, esse desejo foi manifestado novamente na reunião sobre o projeto de comunicação popular. A cartilha apresenta técnicas como jornal mural, cartazes, teatro, boletins, bibliodramas, o que é vivenciado na formação com exercícios práticos. No entanto, como o intuito é atrair os jovens, falta uma parte que trabalhe a internet. Segundo a Pastoral da Criança, esse enfoque ainda não será trabalhado. Pretende-se trabalhar com materiais básicos, que não exijam recursos e possam ser realizados em qualquer lugar do país.

Em relação à cartilha, apresentamos algumas sugestões à irmã Núbia. A primeira delas ainda em Curitiba. Havia o uso constante da palavra "transmissão" para definir a comunicação, apesar de em alguns lugares se falar em trocar informações. Acreditamos que “transmitir" passa o sentido de uma comunicação vertical, na qual o receptor é preenchido pelas informações assim como a educação bancária criticada por Paulo Freire.

Freire (1996, p.23) explica que educar

não é transferir conhecimentos, conteúdos, nem formar é ação pela qual um sujeito criador dá forma, estilo ou alma a um corpo indeciso e acomodado. Não há docência sem discência, as duas se explicam e seus sujeitos, apesar das diferenças que os conotam, não se reduzem à condição de objeto, um do outro. Quem ensina aprende ao ensinar e quem aprende ensina ao aprender.

Acreditamos que a pedagogia defendida por Paulo Freire é a que deve ser usada nas atividades comunicativas da Pastoral da Criança, respeitando-se o repertório das classes populares e aprendendo com ele. A partir desse debate, a jornalista Sonia Prati sugeriu que se usasse a palavra "partilhar" no lugar de "transmitir".

Depois enviamos o arquivo da cartilha, em março de 2009, com outras sugestões: como uso de frases diretas e mais curtas, uso de palavras mais comuns ou explicando termos 
que as pessoas podem não conhecer. Por exemplo, quando se fala em visão antropológica da Bíblia e não se explica do que se trata. Isso porque nem todas as pessoas sabem o significado do termo antropológico. Também sugerimos cortar alguns trechos que achamos repetitivos ou muito longos.

Em relação às definições de comunicação, questionamos duas delas. Uma que dizia que comunicação “é o ato ou processo de transmissão de mensagens a receptores por intercâmbio de símbolos". Sugerimos que se colocasse "compartilhar mensagens entre emissores e receptores através do uso de símbolos". Também apontamos que o item que afirmava - "é o propósito de afetar o comportamento do receptor no desejo de produzir certos efeitos sobre a maneira de sentir, pensar e agir. Ter a missão de convencer!" - trazia uma definição muito publicitária. Sugerimos que se trocasse o termo convencer por conscientizar e criticamos o uso de "afetar o comportamento".

Sobre o processo comunicacional, apresentava-se o seguinte esquema:

\section{PROCESSO COMUNICACIONAL \\ Emissor - (fonte) Canal - (mensagem) - Receptor (Público)}

Sugerimos um esquema em círculo entre o emissor, o canal e o receptor, mostrando que a comunicação não é apenas o emissor passar a mensagem para o receptor, mas sim ter um retorno sobre o que foi passado. Seria interessante frisar que essa mensagem é retrabalhada pelo receptor, que interage com a mensagem e transforma o significado a partir de sua vivência, repertório, cultura. E isso acontece até mesmo com a informação.

Todas as sugestões recebidas por Irmã Núbia, tanto dos jornalistas convidados quanto dos coordenadores estaduais, estão servindo de base para que ela reconstrua o texto da cartilha. Além disso, os jornalistas convidados saíram de Curitiba incumbidos de realizar uma testagem em uma comunidade de sua cidade.

No nosso caso, pedimos para que a coordenadora da Pastoral da Criança na Arquidiocese de São Paulo, Maria do Rosário, falasse com as coordenadoras e escolhesse uma comunidade. Assim ela nos sugeriu realizar a capacitação em comunicação popular no setor Brasilândia. Fomos ao bairro Jardim Maggi, na comunidade Santa Teresinha do Menino Jesus, nos dias 28 e 29 de março de 2009.

A participação foi articulada pela coordenadora da Pastoral da Criança na paróquia, Rosangela. O padre apoiou a iniciativa e incentivou que membros de diferentes pastorais participassem. Foram 17 pessoas. Havia representantes da Pastoral da Criança, da Catequese, 
da Saúde, dos Ministros. A idade variou bastante. Tínhamos desde um líder da Pastoral da Criança com 67 anos até duas meninas de 11 anos, que ajudam a Pastoral da Criança como apoio. A comunidade saiu comprometida com a ação. Decidiram montar um teatro na celebração da vida, com os mais jovens, e um informativo com a participação de todas as pastorais para a comunidade, que passou a ser publicado mensalmente, com quatro páginas.

Consideramos uma troca de experiência muito rica. As pessoas que participaram relataram no final da tarde de domingo que também haviam gostado. Para montar a capacitação, utilizamos a cartilha de comunicação popular. Fizemos um resumo de quatro páginas, explicando o que era e como fazer: bibliodrama, teatro, jornal mural, boletim, cartaz e foto-relato.

A orientação da Pastoral da Criança era que fizéssemos oficinas práticas para que as pessoas pudessem realmente utilizar os recursos da comunicação popular após o curso, dando continuidade ao que foi aprendido. Para a parte espiritual, usamos a técnica do bibliodrama, que a cartilha apresenta como uma maneira de entender o texto bíblico com a razão e o coração.

Assim fizemos a leitura, repetidas vezes, de um texto bíblico (Mt 15, 21-28), sugerido na cartilha. No exercício do bibliodrama, as pessoas ficavam com os olhos fechados, ouvindo. Depois, conforme se repetia a leitura, passavam a desenhar. Os desenhos serviam de subsídio para o debate, que começava na realidade bíblica e depois partia para a realidade da comunidade. O interessante é que com atividades assim, as pessoas que estavam caladas e pouco participativas, soltaram-se e falaram sobre seus dramas, tanto da vida pessoal quanto nas limitações da comunidade e problemas sociais.

Toda a formação misturou exercícios para a voz, respiração, alongamento, debates constantes e trabalhos em grupos, tudo conforme a cartilha de comunicação popular orientava e seguindo a experiência do Nordeste relatada por irmã Núbia, adaptada à realidade de São Paulo. No domingo, os grupos produziram aquilo com que mais se identificaram. Algumas senhoras fizeram cartazes. Era perceptível que algumas tinham dificuldades de escrever, mas uma ajudando a outra conseguiram produzir materiais se preocupando com as informações básicas, para que não ficasse dúvida na pessoa que lesse. Outro grupo produziu um boletim. Os mais jovens, teatro. Todos os trabalhos foram apresentados no final do dia, seguido de uma roda de conversa.

Eles refletiram como poderiam usar os recursos de comunicação na sua comunidade e como enfrentar problemas sociais que se deparavam no dia-a-dia. Por exemplo, casos de mães que usam drogas e deixam os filhos sozinhos, até na rua. Debateram como ganhar a confiança 
da família e como agir em casos de maus tratos. O interessante é que quatro dos voluntários da Pastoral da Criança também fazem parte do Conselho Tutelar, o que mostra um envolvimento com as questões sociais em outras esferas.

A ideia desse projeto é que depois a comunidade continue realizando ações de comunicação popular. Na Brasilândia, isso tem acontecido. De maio a julho de 2009, foram publicados boletins mensais com notícias de todas as pastorais. A comunidade pretende continuar fazendo o boletim, que tem o apoio do padre.

Essas ações comunicativas da Pastoral da Criança, sejam através do Jornal Pastoral da Criança e suas metodologias, sejam através do projeto de comunicação popular, caracterizam uma comunicação participativa. Segundo Puntel (1994, p.260), “o processo participativo, incentivado nas comunidades de base, contribui para a criação de práticas mais democráticas e participativas, habilitando as comunidades a tornarem-se agentes de transformação da sociedade". Acreditamos que o mesmo pode ser dito sobre a Pastoral da Criança. Trata-se de um movimento nacional, abrangente, mas que cria mecanismos para a participação local das comunidades.

Também acreditamos que essas práticas remetem à pedagogia de Freire (1996, p.26), pois "nas condições de verdadeira aprendizagem os educandos vão se transformando em reais sujeitos da construção e da reconstrução do saber ensinado, ao lado do educador, igualmente sujeito do processo". É isso que acontece com as líderes e os líderes comunitários da Pastoral da Criança. Através dos meios de comunicação da Pastoral e dos cursos de capacitação, trocam informações sobre saúde e cidadania para agirem. Essa educação considera o seu meio e sabedoria, possibilitando a construção do saber ensinado, que vai ser reconstruído diversas vezes. Isso porque a líder também é uma educadora, que vai passar o aprendido para as mães, que por sua vez vão multiplicar o conhecimento na família e assim na comunidade, num processo educativo no qual todos são sujeitos importantes para a disseminação das informações, construindo a cidadania de forma coletiva.

\section{7 - Uma questão de comunicação organizacional}

Peruzzo (1998, p.130-132) afirma que a comunicação popular e a comunicação massiva não são excludentes e sim complementares. Assim os meios de comunicação popular não são forças que superam os meios massivos, apesar de sua importância política. No 
entanto, a mídia não consegue suprir a necessidade das comunidades e dos movimentos sociais em termos de comunicação. O que ocorre é que apesar de seu poder de manipulação e de estar a serviço dos interesses da classe dominante, ela também contribui para a sociedade e para o interesse público. Além disso, a comunicação popular também pode se valer deles. Inclusive, um ponto que a autora ressalta é que a comunicação popular poderia usar melhor um recurso da mídia massiva, que é o entretenimento, o lúdico e o humor, aliando isso aos valores culturais de onde estão inseridos.

Essa postura de opor os meios populares massivos sofreu uma profunda revisão nos anos noventa, em função das mudanças que ocorrem na sociedade. Apesar de serem campos de conflitos e terem suas especificidades, sob a ótica do receptor não se estabelece esse antagonismo. Por outro lado, muitas das metas e linguagens antes restritas ou acessíveis apenas aos meios alternativos começaram a ser incorporadas na programação da mídia convencional, seja por iniciativa desta ou por pressão de organizações da sociedade civil. Além do que, entidades e grupos dos movimentos populares passaram a ocupar espaços nos grandes veículos, para transmitir suas mensagens e os programas por eles produzidos, e mesmo a deter a posse de canais de comunicação como jornais e rádios de alcance local ou até regional. (PERUZZO, 1998, p.132)

No caso da Pastoral da Criança, busca-se realizar ações nessas duas áreas. Ao mesmo tempo em que se articula o novo projeto de comunicação popular e se desenvolve essa prática participativa no jornal e no programa de rádio, existe uma área de comunicação externa que divulga as ações da Pastoral da Criança junto à mídia. Também atende as solicitações de jornalistas, radialistas, programas de TV, de rádio, sites da internet com o objetivo de divulgar e promover a missão da Pastoral da Criança.

É interessante apontar que essa visibilidade na mídia contribui para a ação da Pastoral da Criança. Uma de nossas entrevistadas na Arquidiocese de São Paulo foi Nuri Mary de Oliveira Baptista, da região Brasilândia. Evangélica, ela conheceu o trabalho da Pastoral da Criança a partir de uma entrevista de Zilda Arns no Domingão do Faustão. Nury já sentia vontade de fazer um trabalho de cunho social. Em sua igreja, costumava visitar casas para evangelizar, mas isso não a completava. No programa de TV, ela viu que a ação era ecumenica, então, resolveu procurar sua irmã, Débora Mara de Oliveira Soares, católica e voluntária da Pastoral. Nuri já está há quatro anos na organização e acumula várias funções: multiplicadora, capacitadora, coordenadora de área e líder.

Outros exemplos da contribuição da mídia para a ação da Pastoral passa pelas reportagens que retratam a organização. Matérias do Jornal Nacional falaram do trabalho da entidade em 2008. Em 2009, reportagem no mesmo programa abordou a campanha para os 
bebês dormirem de barriga para cima realizada pela Pastoral da Criança. Essa campanha também apareceu na novela das $21 \mathrm{~h}$ da Rede Globo, Caminho das Indías, quando o bebê da protagonista vestia uma roupa com o símbolo da campanha e no diálogo se explicava como o bebê deve dormir. Também em 2009, tanto Zilda Arns quanto o coordenador nacional adjunto da Pastoral da Criança, Nelson Arns Neumann, deram entrevistas em diferentes programas da TV Gazeta ${ }^{48}$.

Já a área de Comunicação Interna elabora o Jornal da Pastoral da Criança e os programas de rádio Viva a Vida, que consideramos como exemplos de comunicação popular. Ainda é responsável pelos materiais específicos para campanhas com temas relativos à saúde e pela arte-final e projeto gráfico dos materiais educativos, como o Guia do Líder, o informativo Dicas, os Laços de Amor (envelope contendo cartões com informações para a gestante sobre temas como riscos, alimentação e pré-natal).

Ambas as áreas contam com profissionais de comunicação. No caso da comunicação externa, há ainda assessores de imprensa voluntários que atuam junto às coordenações estaduais ou setoriais. Percebe-se uma visão organizacional da comunicação, com profissionais que dão subsídios aos materiais produzidos e ao mesmo criam estratégias para a participação dos leitores na construção do texto, sem se esquecer de cuidar também da imagem da instituição na mídia.

Segundo Kunsch (1997, p.55), “a comunicação tem um papel fundamental nas organizações modernas e nas instituições públicas e religiosas". Há a formação de um "novo comportamento institucional", estimulado pelos ideais democráticos. Assim, a "Igreja tem que assumir uma nova postura, aproximando-se mais da sociedade (...) por meio de um serviço planejado de comunicação que atue com eficiência”.

Dessa forma, a autora defende uma comunicação organizacional para a Igreja, conceituando-a como "um processo dinâmico por meio do qual as organizações se relacionam com o meio ambiente interno e externo, utilizando as mais variadas técnicas e instrumentos para atingir seu universo de públicos e a opinião pública" (Kunsch, 1997, p.56). Para tanto, desenvolve-se uma comunicação integrada que abrange a comunicação institucional, publicitária e interna. "O termo 'comunicação organizacional' (...) envolve todas as organizações e não só as empresas” (KUNSCH, 2005, p.24).

\footnotetext{
${ }^{48}$ Em 25 de junho, Zilda Arns foi entrevistada à noite pelo apresentador Ronnie Von. Já no dia 12 de agosto, o médico Nelson Arns Neumann foi ao Programa Mulheres, no período da tarde, para falar sobre a campanha que explica a forma correta dos bebês dormirem. A TV Gazeta é uma emissora da Fundação Cásper Líbero, que abrange o estado de São Paulo.
} 
Com a redemocratização do país, sobretudo a partir da reabertura política iniciada em 1985, as instituições e organizações começaram a entender melhor a necessidade de serem transparentes e que suas relações com a sociedade deveriam dar-se pela vias democráticas. (KUNSCH, 2005, p.21)

Acreditamos que a Pastoral da Criança realiza, em parte, essa comunicação organizacional ao desenvolver ações voltadas tanto para seu público interno - as voluntárias, e externo - a sociedade em geral. Há uma comunicação integrada em que a Pastoral reforça seus valores de solidariedade e de promover uma educação em saúde voltada para o desenvolvimento integral das crianças. A Pastoral da Criança se preocupa com sua imagem e cultiva um relacionamento com a mídia, preocupando-se com a comunicação externa.

No entanto, diferentemente das organizações de que fala Kunsch, a Pastoral da Criança ao realizar uma comunicação popular permite o conflito; já em uma empresa se procura eliminar tudo o que for contraditório. As comunicações nas empresas também costumam ser verticais, de cima para baixo. Na Pastoral, presenciamos uma comunicação horizontal, na qual tanto em reuniões quanto no jornal há espaço para o conflito e o debate.

Podemos citar dois exemplos que mostram como o debate faz parte da Pastoral da Criança. Na Assembleia da Lapa, em março, quando se falava dos diferentes tipos de violência, um dos multiplicadores presentes falou da exploração sexual de que muitas mulheres e meninas são vítimas. Prontamente uma das coordenadoras respondeu que isso acontece por vontade das mulheres. Outras coordenadoras presentes discordaram e começaram dar exemplos de como as mulheres são enganadas ou forçadas a fazer o que não querem. $\mathrm{O}$ conflito gerou um debate positivo.

Também podemos usar o Jornal Pastoral da Criança. Na edição de junho de 2008 (p.14), uma mãe acompanhada pela Pastoral da Criança fez a seguinte pergunta: "Posso continuar amamentando meu filho se estou esperando outro bebê?". A resposta foi dada pela enfermeira da Pastoral da Criança, Sonia Schram:

Sim. Uma nova gestação não prejudica o leite, ainda que mude um pouquinho de gosto, a criança às vezes estranha, mas logo se acostuma. A amamentação não costuma prejudicar o bebê que está se formando. Lembre que é preciso fazer o pré-natal em toda a gravidez. Aproveite e converse sobre esse assunto na consulta.

Na edição de dezembro/2008 e janeiro/2009, a informação dada foi questionada. Em um jornal de empresa, dificilmente haveria espaço para um trabalhador questionar algo que saísse em um informativo interno. Até mesmo na mídia, seja impressa ou eletrônica, quando algum leitor questiona uma informação, esse questionamento não é divulgado ou quando é, 
isso é feito em um espaço inferior, sem o mesmo impacto da publicação anterior, e depois de uma edição no material enviado. Já no jornal da Pastoral ocorreu justamente o contrário. $\mathrm{Na}$ página 12 da mesma seção anterior, Aprendendo Mais, o questionamento ganhou meia página. A primeira informação, veiculada em junho de 2008, tinha apenas uma coluna de sete linhas. Por isso, vemos na comunicação da Pastoral da Criança esse espaço para o conflito, para o diálogo, de forma horizontal e não vertical. A seguir transcrevemos o texto na íntegra:

\section{Pergunta do Líder}

"Sou líder da Pastoral da Criança na Arquidiocese de Maringá, mais especificamente na cidade de Mandaguari - Paróquia Nossa Senhora Aparecida. Ao ler o jornal da edição de junho/2008, me deparei com a reportagem da Saúde (p.14), em que uma mãe acompanhada pela Pastoral da Criança, pergunta a enfermeira Sonia sobre a amamentação: "Posso continuar amamentando meu filho se estou esperando outro bebê?". A resposta causou certa confusão entre as líderes e assim consultamos um profissional da área médica que atende voluntariamente a Pastoral da Criança e sua resposta está divergindo com a resposta da enfermeira Sonia. O médico foi taxativo dizendo que não é possível amamentar outra criança estando grávida. Portanto, pedimos que no jornal respondam esse assunto, para esclarecimentos. Desde de já agradecemos a atenção. Lucilene”.

Realmente, não existe impedimento para a mãe continuar amamentando. Há dados da La Leche League mostrando que a maioria dos bebês desmama, espontaneamente, quando a mãe engravida.

Sabe-se que a interrupção não deve ser abrupta e que, se o bebê não é muito jovem, isto é, se a gravidez não ocorreu nos primeiros meses após o parto, o benefício para o bebê não é tão grande e o ideal seria a mãe ir reduzindo gradativamente a amamentação, antes do novo bebê nascer.

É mais uma questão de bom senso, ir reduzindo e desmamar, para o bebê não sentir que o novo irmão tomou seu lugar. A interrupção ocorreria bem antes do nascimento.

Entretanto, não há indícios de problemas para o novo bebê, quando o outro irmão segue mamando, mas existe a recomendação que, se a mãe não desmamou antes, o primeiro bebê a mamar deverá ser o mais jovem.

Em congresso, já ouvi falar que a flora bacteriana da boca do bebê mais velho seria diferente daquela do recém-nascido, mas não achei nada concreto a respeito de conseqüências... O mais importante é que a mãe fique tranqüila e sem culpa para decidir.

Que possa discutir com o profissional que a está assistindo, sem pressões, pois é comum receber a orientação de interromper o aleitamento imediatamente.

A mãe deve saber que o desmame não deve ser abrupto e que faz parte do crescimento do bebê. Espero que tenha contribuído. Um abraço,

Elaine Arbernaz

Especialista internacional em Aleitamento Materno (Iblce Certification

Examination pela

International Board Of Lactation Consultant Examiners),

Sua tese de doutorado em Epidemiologia foi neste tema e é revisora 
do Jornal de Pediatria e dos Cadernos de Saúde Pública (FIOCRUZ).

Vemos que com a comunicação popular, a Pastoral da Criança educa. Essa educação precisa do contraditório, pois só assim se pode construir um novo conhecimento. Por isso vemos essa comunicação como dialógica, seguindo os princípios de Paulo Freire. No entanto, a Pastoral da Criança também se preocupa com sua imagem na mídia e isso possibilita levar sua mensagem para outras pessoas. Com a comunicação externa, ela valoriza sua imagem, o que permite sustentar a credibilidade do seu trabalho.

Kunsch (1997, p.56) lista alguns itens necessários para uma comunicação organizacional eficaz, que acreditamos, em parte, serem praticados pela Pastoral da Criança, como "uma linguagem comum de todos os setores" e um "comportamento organizacional homogêneo". Mas esse homogêneo na Pastoral não significa que não haja liberdade para o questionamento e sim que existe uma homogeneidade de ação: a busca do desenvolvimento integral das crianças. Essa questão faz parte do discurso de todas as pessoas do grupo. Há uma linguagem comum nesse sentido. A formação realizada pela Pastoral da Criança faz com que as líderes não só recebam informações sobre saúde ou aprendam a realizar as visitas, como também cria uma identificação entre todas em defesa das crianças, com a missão de salvar vidas, sempre citada. Para isso, todas recebem os mesmos materiais educativos e comunicacionais.

Outro item citado que presenciamos na Pastoral é o "sistema integrado de comunicação", no qual os setores trabalham de forma conjunta, "respeitando os objetivos de cada setor" e ao mesmo tempo seguindo "os objetivos gerais da organização". A Pastoral da Criança tem uma política de comunicação e a divisão entre a comunicação interna e externa. A diferença em relação às outras organizações é que essa "comunicação interna" é horizontal. Existe o diálogo entre a produção do rádio e do jornal, o envolvimento dos jornalistas responsáveis pelos dois materiais com o novo projeto de comunicação popular, que é tocado por outra jornalista. Ao mesmo tempo, há uma interligação desses com a assessoria de imprensa. E todo esse processo conta com a participação de voluntários e voluntárias, seja com o envio de textos, as sugestões de pautas em encontros ou escrevendo para o jornal, como também dando entrevistas para a mídia em sua região.

Kunsch defende a "valorização da gestão participativa nos processos de comunicação organizacional" (1997, p.56), o que fica claro na opção da Pastoral da Criança pela comunicação popular, bem mais do que podemos visualizar em outras instâncias da Igreja ou 
em empresas, que no fundo possuem relações verticais. Essa escolha tem a ver com os próprios objetivos e ações da Pastoral da Criança, que são horizontais.

A reformulação desse setor tem que passar por um processo de participação que envolva os dirigentes e todos os públicos estratégicos com os quais o relacionamento da Igreja é fundamental, de bispos às comunidades de base e aos fiéis. (...) O papel de uma Assessoria de Comunicação na estrutura organizacional da Igreja é pensar estrategicamente como a Comunicação pode ajudar a instituição no que tange ao cumprimento de sua tarefa, ao alcance de seus objetivos, à realização de suas ações e aos serviços prestados, que devem atender às expectativas pessoais e sociais, isto é, do cidadão e da sociedade. (KUNSCH, 1997, p. 57)

Todos esses aspectos já são vivenciados pela Pastoral da Criança. A comunicação faz parte das discussões da Assembleia Nacional, que conta com um bispo, coordenadores estaduais e a coordenação nacional. O jornal é usado em algumas comunidades nas reuniões, nas visitas. A formação de multiplicadores, que forma os que vão dar os cursos de capacitação para os capacitadores, tem o momento para que todos opinem sobre o Guia do Líder, como presenciamos no Encontro de Multiplicadores em março de 2008. Além de se apresentar o conteúdo, discutia-se se havia algo que precisava ser mudado, quais eram os pontos positivos do material. As multiplicadoras do Encontro, que trazia pessoas de todo o estado de São Paulo, também escreveram um texto relatando esses aspectos e dando sua opinião, o que seria passado para a Coordenação Nacional.

Outro ponto defendido por Kunsch (1997, p.57) no âmbito organizacional, que acreditamos ser praticado pela Pastoral da Criança é a valorização do local e do regional, ao mesmo tempo em que se pense institucionalmente. Lógico que é preciso que essa estrutura e visão institucional não contradigam nem impeçam a participação efetiva do voluntariado nem destrua o diálogo entre as bases, pelo contrário, isso deve fazer parte dessa visão institucional e da proposta da Pastoral da Criança.

Um exemplo de ação que valoriza o regional é a ação de assessores de imprensa voluntários. Eles atuam nos setores auxiliando a coordenação local em relação à comunicação, por exemplo, orientando em relação a entrevistas, elaborando textos, atendendo à imprensa e encaminhando para falar com as voluntárias. Há um contato direto com a área de comunicação externa da Pastoral da Criança, que conta com duas jornalistas e uma estagiária.

Além disso, a assessoria organiza para esses assessores uma capacitação, da qual participamos entre os meses de abril e agosto de 2008. A formação ocorria via moodle, uma ferramenta da internet controlada pela Pastoral da Criança a qual todos assessores tinham acesso via senha. Lá encontravam os textos de cada etapa da formação, que deviam ser lidos a 
cada período. Após havia um prazo para entregar os exercícios propostos ao final de cada "aula", que trazia subsídios sobre a função da assessoria de comunicação e informações sobre a Pastoral da Criança, aprofundando o conhecimento dos voluntários sobre a organização.

O Módulo I da capacitação explicava como a comunicação da Pastoral da Criança é organizada, a área de comunicação institucional (externa) e a interna, os materiais produzidos. Também falava sobre os comunicadores voluntários da Pastoral da Criança, que se articulam desde 2003. Apresentava entre os objetivos desses voluntários: "multiplicar, nas comunidades de todo o país, mensagens de Fé e Vida por meio de informações sobre saúde, educação, nutrição, cidadania"; "aproximar e atrair mais pessoas para a missão da Pastoral da Criança" e "contribuir para fortalecer e motivar a expansão da Pastoral da Criança"; "promover a união das pessoas nas comunidades e fortalecer o espírito comunitário"; "promover e fortalecer políticas públicas direcionadas à criança e à gestante de famílias pobres”.

Também havia algumas informações sobre o papel do comunicador popular, que atuava divulgando informações nas comunidades. Na época do curso, ainda não havia começado o projeto de capacitação em comunicação popular desenvolvido pela jornalista irmã Núbia. Sobre a função do voluntário em assessoria de imprensa, afirmava-se:

ajuda a promover a imagem e o trabalho da Pastoral da Criança nos meios de comunicação de massa: rádios, televisões, jornais, revistas e sites. Ele irá buscar novas possibilidades de interlocução da Pastoral da Criança com a mídia local, tanto nos meios convencionais de comunicação, quanto nos meios comunitários e ligados à Diocese e às Paróquias. Também irá colaborar para fortalecer a ação dos demais comunicadores voluntários e assessorar a coordenação de Setor nos assuntos relacionados à comunicação. O voluntário deve ter conhecimento profissional na área de comunicação social; ser indicado pela Coordenação de Setor; e ter o compromisso de exercer esta função, ao menos, por 12 meses.

Da mesma forma, apresentava informações sobre a missão da Pastoral da Criança "Promover o desenvolvimento integral das crianças pobres, da concepção aos seis anos de idade, em seu contexto familiar e comunitário, a partir de ações preventivas e que fortaleçam o tecido social e a integração entre as famílias e a comunidade”. E a partir das explicações sobre o trabalho da Pastoral da Criança, relacionavam-se definições sobre a assessoria de imprensa e se procurava mostrar o que a Pastoral da Criança tem a dizer à sociedade. Assim explicava

O trabalho do Assessor de Comunicação está associado à figura do portavoz, aquele que sempre fala em nome do responsável ou presidente de uma empresa, organismo ou entidade. Ele é, geralmente, um jornalista, 
publicitário ou relações públicas que elabora os textos e prepara programas e roteiros de divulgação da entidade. $\mathrm{O}$ assessor de imprensa voluntário da Pastoral da Criança, acima de tudo, precisa ser uma pessoa que tenha identificação com a causa da organização e disponibilidade de usar as suas habilidades e experiência profissional para defendê-la e trabalhar por ela.

Também apresentava itens sobre a relação com a imprensa: "o relacionamento com a imprensa pode trazer inúmeros benefícios para a instituição, se for bem conduzido, mas também pode trazer grandes transtornos se for negligenciado". Considerava-a "um dos melhores canais para levar mensagens à sociedade". Além de ressaltar que "a imprensa é um meio de comunicação sob o qual a organização não exerce nenhum controle" e que "as informações que chegam até ela serão apresentadas ao público a partir da ótica do repórter e da edição feita pelo veículo". O que se apontava como forma de credibilidade, mas também poderia dar "margem para má interpretação de informações e dados". Outras informações foram trabalhadas como o Guia do Lider da Pastoral da Criança.

Já no Módulo II se trouxe mais dados sobre os meios de comunicação no país e ações de assessoria de imprensa na Pastoral da Criança. Explicava-se também como funciona o Sistema de Informação da Pastoral da Criança, que permite consultar dados da organização em nível regional e nacional pelo site. O Módulo III, por sua vez, contava a história da criação da Pastoral da Criança, além de trazer explicações sobre controle social ${ }^{49}$ e o jornalismo como meio de controle social.

Nesse sentido, colocava como meta dos comunicadores da Pastoral "potencializar a influência que a Pastoral da Criança tem sobre a mídia para democratizar o espaço, ampliando os temas e as formas com que as discussões são abordadas”. Assim listava alguns assuntos relacionados à sua área de atuação:

Desigualdade social; Distribuição de renda; Políticas públicas nas áreas da saúde, educação, assistência social e segurança alimentar e nutricional; Orçamentos públicos (nas mesmas áreas acima) municipais, estaduais e nacional; Continuidade e a avaliação de resultados de políticas públicas sociais; Desenvolvimento humano; Direitos da criança e o estatuto da criança e do adolescente; Mortalidade infantil; Desnutrição; Alimentação enriquecida (multimistura de alimentos frescos).

\footnotetext{
${ }^{49} \mathrm{O}$ texto explicava que "Controle Social é a prática exercida pela sociedade que tem o objetivo de fiscalizar os recursos públicos, debater e dialogar com o governo, propor programas, projetos e outras iniciativas que visem a melhor aplicação dos recursos públicos em benefício da população. (...) pode ser exercido individualmente, por qualquer cidadão, ou por grupos organizados em fóruns populares, movimentos sociais e sindicais, organizações da sociedade civil, entre outros. Além dos conselhos, os cidadãos ou grupos organizados, em certos momentos, podem encontrar outros caminhos para a participação, inclusive com ações que envolvem o Ministério Público e a justiça".
} 
Havia ainda o blog dos comunicadores, em que a assessora colocava alguns textos enviados pelos voluntários. No entanto, essa atualização, como já explicamos, não era constante e também deixou de ser usado após a formação. O ideal seria que esse blog tivesse atualizações diárias com participação ativa dos comunicadores e que fosse divulgado no próprio jornal da Pastoral como também em outros espaços da internet, como a comunidade no Orkut formada por voluntários. Seria uma forma de ampliar a participação e criar novos espaços de comunicação.

Martín-Barbero aponta a internet como "um cibermundo em que emerge um novo espaço público mundial",50. É uma tecnologia que traz novos modos de percepção e linguagem, deslocalizando saberes ${ }^{51}$. Como vimos, apesar das limitações, a Pastoral da Criança está inserida nesse contexto com site, blog e comunidade no Orkut. A presença na rede pode possibilitar uma troca entre as diferentes comunidades do Brasil e as experiências em outros países, o que parece ocorrer principalmente no Orkut, uma comunidade virtual na qual se debate diversos temas relativos à ação do grupo e permite interatividade entre voluntários de diferentes regiões. Em 13 de outubro de 2008, a comunidade no Orkut contava com 3.901; já em 16 de junho de 2009, o número havia subido para 4537 membros.

Também em junho de 2009, a Pastoral da Criança lançou outro blog ${ }^{52}$, como relatamos anteriormente. O intuito é divulgar a campanha da Pastoral lançada nesse mês para prevenção da morte súbita, assim recomenda que os bebês durmam de barriga para cima. A primeira mensagem postada foi do médico Nelson Arns Neumann, pedindo que as pessoas enviassem informações via e-mail sobre como cada local vem trabalhando a questão da morte súbita. Essa proposta amplia a participação dos líderes em mais um espaço de comunicação, o que é extremamente positivo. Além do blog temático da campanha, seria interessante que a Pastoral tivesse um blog para as líderes contarem suas histórias. Ao mesmo tempo, seria necessário trabalhar a divulgação desses espaços no jornal da entidade, no programa de rádio e na comunidade que os voluntários criaram no Orkut.

Mas outro ponto precisa ser levantado. Se há um espaço virtual a ser ocupado em prol da cidadania, há um batalhão de excluídos digitais que precisam ser incluídos. Na Pastoral da Criança, há ação de alfabetização para aqueles que não sabem ler nem escrever, no entanto,

\footnotetext{
${ }^{50}$ MARTÍN-BARBERO, Jesús. Pensar juntos espacios y territórios. Esse texto e os seguintes fazem parte de uma apostila de textos trabalhados pelo professor doutor Jesús Martín-Barbero no curso "Novas sensibilidades: entre urbanias e cidadanias", ministrado na ECA/USP, entre os dias 15 e 19 de setembro de 2008.

${ }^{51}$ MARTÍN-BARBERO, Jesús. Entre urbanias y ciudadanías.

${ }^{52} \mathrm{http}$ ://sig.pastoraldacrianca.org.br/wordpress
} 
não há nada voltado para os "analfabetos digitais". Essa questão deve ser trabalhada pelos movimentos sociais.

Martín-Barbero aponta que $70 \%$ dos usuários das redes digitais vivem nos Estados Unidos ou na Europa. Também há diferença entre o uso da internet por ricos e pobres nos países em desenvolvimento como Brasil. Há ainda, segundo o autor, um processo que conecta o considerado válido informacionalmente ao mesmo tempo em que se desconecta o que não é considerado válido como estratégias de campo, experiências dos imigrantes, memória cultural dos velhos ${ }^{53}$. Assim, vemos pessoas excluídas do uso da tecnologia, a qual não tem acesso, como também são invisíveis para os que têm acesso, por não aparecerem como informação na rede. É importante que os movimentos sociais se articulem para mudar essa realidade.

O texto chama atenção para uma consciência do valor da diferença, do pluralismo e da diversidade coexistindo com uma uniformização dos imaginários cotidianos. A diversidade cultural das comunidades e a consciência do direito à diferença devem aparecer na internet. Para tanto, Martín-Barbero fala em alfabetização virtual e alternativas de acesso comunitário. Pensando na Pastoral da Criança, da mesma forma em que há projeto de alfabetização baseado no método de Paulo Freire, poderiam ser criadas iniciativas de alfabetização digital tendo a mesma perspectiva freireana, atualizada para as novas tecnologias.

Por outro lado, os movimentos sociais e organizações como a Pastoral da Criança deveriam se articular para que o poder público ampliasse as alternativas de acesso. Em São Paulo, há projetos tanto em nível estadual, o Acessa SP, como municipal, o Telecentro. Mas essas iniciativas precisavam ser ampliadas e ter uma maior participação das comunidades em que estão instaladas. A necessidade de ampliação fica clara com o crescente número de lan houses na periferia. Ligar a ação dos movimentos sociais às novas tecnologias permitiria também ampliar a participação dos jovens na Pastoral da Criança e em outros movimentos sociais que se apropriem da rede, buscando-se uma linguagem mais próxima desse público.

Como afirma Moraes (2000, p.145), "as vozes da sociedade civil que se somam no ambiente on line representam grupos de pessoas identificados com causas $\mathrm{e}$ comprometimentos comuns, não importando o porte das ONGs à que se vinculam". O autor ainda destaca a velocidade com que a mensagem é veiculada pela internet. Um dos exemplos que usa é Conferência Nacional dos Bispos do Brasil, que interligou pela internet as dioceses, facilitando "o planejamento, a implementação e a avaliação das ações pastorais em todo o território nacional" (2000, p.151).

\footnotetext{
${ }^{53}$ MARTÍN-BARBERO, Jesús. Cultura y nuevas mediaciones tecnológicas.
} 
Moraes (2000, p.153) defende o potencial da internet, que possibilita "práticas comunicacionais interativas, descentralizadas e não submetidas aos mecanismos habituais de seleção e hierarquização adotados pela grande mídia". Vê, dessa forma, um uso do espaço virtual como "esfera pública de comunicação", que pode informar, fortalecendo a cidadania e questionando as "hegemonias constituídas".

As ferramentas da Web podem propiciar aos movimentos sociais uma intervenção ágil em assuntos específicos, acentuando-lhes a visibilidade pública. Outro fator positivo é a constituição de comunidades virtuais por afinidades eletivas. Formam-se, assim, coletivos em rede, por aproximações temáticas, anseios e práticas comuns de cidadania. Eles compartilham ações sociopolíticas, tendo em vista o fortalecimento dos laços comunitários e de uma ética por interações, assentada em princípios de diálogo, de cooperação e de participação. (MORAES, 2000, p.154)

Ações buscando a inclusão digital e ampliando os espaços de participação das voluntárias na internet fariam com que a Pastoral da Criança contribuísse ainda mais para a democratização da informação. Mais do que isso, as líderes teriam outros espaços para ampliar sua formação e exercer o direito de se comunicar. Parece que esse caminho começou a ser trilhado esse ano. Agora é necessário aprofundar as ações, explorar mais as ferramentas tecnológicas e possibilitar uma formação entre o voluntariado para usá-las. 


\section{Capítulo III - Caminhando para a cidadania}

\section{1 - Uma comunicação dialógica}

A comunicação na Pastoral da Criança, como temos apresentado, possibilita uma formação contínua das líderes e também permite que elas exerçam o direito de se comunicar. Essa comunicação popular educa e liberta a partir do momento que leva à reflexão sobre direitos e deveres. As líderes conhecem a cidadania e a vivenciam na sua atividade voluntária.

Segundo Peruzzo (1998, p.302), a busca pelo alargamento da cidadania pelos movimentos sociais pode ser impulsionada pela comunicação popular, que surge "como uma necessidade e se realiza articulada às práticas sociais. Ela contribui com maior ou menor intensidade para a democracia, dependendo dos instrumentos, das formas e da metodologia que utiliza".

A autora nos mostra que a definição de comunicação popular passou por modificações ao longo dos anos. No início, havia a ideia de que era uma "comunicação simples, de circulação limitada, produzida quase artesanalmente por grupos populares”. Depois, passou-se a focar em seu conteúdo, que deveria ser "crítico e libertador", voltado às "classes subalternas”. Em seguida, veio a noção de produção conjunta, dialógica, na qual a pessoa é um "sujeito pleno". Essa comunicação popular se desenvolve no "bojo de uma educação popular libertadora", na qual se luta pela vida e contra as condições de existência degradantes. Conscientiza, mobiliza, educa e informa, ao mesmo tempo, que é uma manifestação cultural do povo. (PERUZZO, 1998, p.123-125)

Acreditamos que a comunicação popular vivenciada pela Pastoral da Criança tem essa característica educativa e libertadora. Esse tipo de comunicação tem suas raízes em Paulo Freire. Segundo Marques de Melo (1981, p.8), a questão de uma pedagogia da comunicação constitui o elemento orientador da produção educativa de Freire e é fundamental para o sentido libertador de sua pedagogia do oprimido.

Essa pedagogia da comunicação fica clara quando Freire pensa o homem como um ser de relação com o mundo, o que evidencia uma proposta educacional fundamentada na comunicação (1981, p.23). Assim pensa uma pedagogia que instaure o diálogo e proporcione um novo conteúdo programático da educação, ultrapassando a compreensão ingênua do mundo e desenvolvendo a crítica (1981, p. 23). 
(...) no cerne da Pedagogia do Oprimido está inevitavelmente o problema da comunicação: o homem que se comunicando com a natureza, consigo mesmo e com os outros homens, descobre a sua própria humanidade. Conhecer-se a si mesmo, em sua contextualização, é descobrir-se como oprimido. A Pedagogia do Oprimido insere-se na luta do homem pela sua humanização. (...) Aí PF torna mais explícita a natureza da sua Pedagogia da Comunicação: implicando na comunhão do educador e do educando, afigura-se como uma pedagogia aberta, em permanente reelaboração. Quanto mais intensa essa comunicação, mais rica a interação entre os participantes. É também uma pedagogia libertadora. Pela comunicação, conduz a libertação. (...) Comunicação e liberdade são fenômenos coincidentes. Não dicotomizados. A comunicação só se faz autenticamente com liberdade. Por sua vez, a liberdade só se conquista com comunicação. (MARQUES DE MELO, 1981, p.32)

Essa comunicação dialógica de Paulo Freire é praticada pela Pastoral da Criança, as líderes se descobrem comunicando-se com outras líderes seja nas capacitações ou nas reuniões de avaliação. Nesse diálogo, problematizam a comunidade e discutem formas de superação. Essa educação continua nas visitas às famílias.

O encontro de multiplicadores, ocorrido entre os dias 28 e 30 de março de 2009, na cidade de São Paulo, é um exemplo da existência desse diálogo. Enquanto se discutia o Guia do Lider, tanto o multiplicador que coordenava o encontro quanto os outros participantes falavam não só sobre os temas do material como também dos problemas que se deparavam na atividade voluntária.

Um dos assuntos abordados foi a importância de se visitar os serviços de saúde, destacando-se a necessidade de trabalhar juntos e da comunidade se organizar para a conquista de direitos. Ao se levantarem essas questões em encontros, parte-se para uma conscientização das necessidades da comunidade e de como mudar a realidade. Como levantou uma das participantes do encontro: "Ficou mais fácil de trabalhar, aproximando-se do grupo, o capacitador assume um compromisso com Jesus Cristo e a transformação da sociedade".

O método "ver, julgar e agir" é levantado durante toda a reunião. A participação é grande, todos têm espaço para falar. Quando alguém levanta alguma dúvida, não é apenas quem coordena a capacitação que responde. O mesmo ocorre quando o responsável por alguma parte do curso levanta uma questão, como quando o palestrante Waldemar Caldin perguntou sobre o que eram os indicadores para o desenvolvimento integral das crianças. Vários multiplicadores vão respondendo, de forma bem dinâmica e vão construindo esse conhecimento juntos, dialogando, cada participante dando exemplos reais que são 
vivenciados. Assim vão trocando experiências e entendendo as informações do guia juntos, em um diálogo entre iguais, que têm raízes no passado.

Na defesa do diálogo como prática pedagógica para superar a compreensão mágica ou ingênua do mundo e na reserva quanto aos processos de comunicação vertical e autoritário da burguesia, da Igreja ou dos grupos revolucionários cupulistas estão as chaves para o entendimento de uma nova postura teórica cristã frente à cultura e ao fenômeno da comunicação social. (...) no catolicismo radical de Paulo Freire residiam as bases para uma nova teoria da comunicação (...) aquela que sustenta a verdadeira comunicação como o diálogo entre iguais... (SOARES, 1988, p.331-332)

Soares (1988, p.340) avalia ainda que, após Puebla, houve um esforço para se elaborar teorias de comunicação na Igreja que considerassem a comunicação dialógica. As propostas pedagógicas de Paulo Freire nascem na fronteira entre a Igreja e a sociedade e estão na base dessa renovação. Assim o autor cita trechos da Carta aos Comunicadores, da Equipe de Reflexão da CNBB (1984):

A comunicação humana é um fenômeno essencialmente dialogal. Isso implica a troca de experiências entre os envolvidos no processo de comunicação. Por ser diálogo, trata-se de um processo de produção e recepção de sentido entre as pessoas, superando a mera informação de dados. Implica, ainda, compartilhar o mesmo lugar social, onde o código, a mensagem e os pontos de referência estejam igualmente distribuídos entre os parceiros de comunicação.

Onde só uma pessoa domina o conteúdo, o código, o meio, não há interação e não há liberdade, por isso, não há comunicação. Desse modo acontece um processo verticalista e opressor de comunicação, os interesses devem ser comuns e a busca de sentido deve ser comunitária. (...) Comunicar é ser o outro de certo modo.... (SOARES, 1988, p.378-379)

É interessante ressaltar que o Jornal Pastoral da Criança nasce justamente em 1985, primeiro com Zilda Arns escrevendo e logo depois com o jornalista Elson Faxina por oito anos. Essa comunicação tem característica dialógica e educativa, como vemos no trecho a seguir $^{54}$ :

O Faxina começou a descentralizar. Cada técnico escrevia sobre um tema: a nutricionista, a enfermeira, a médica. $\mathrm{O}$ fundamental para a organização da Pastoral da Criança é a motivação. Não posso imaginar a Pastoral da Criança sem o jornal, porque o Brasil é imenso, como é que vamos nos comunicar? Então o jornal ajuda muito. Já fui ao Alto Solimões e estavam no barco os jornais que aquelas comunidades ribeirinhas todas iriam receber. $\mathrm{O}$ pessoal lendo o jornal. Isso serviu de motivação para alfabetização de muitas líderes.

\footnotetext{
${ }^{54}$ Entrevista realizada pela autora dessa dissertação com Zilda Arns em 25/06/2009.
} 
No início, por exemplo, no Norte e Nordeste do país, metade das líderes não sabia ler nem escrever. Tinha comunidade do Pará que de 18 líderes, apenas uma sabia ler e escrever. Os outros não sabiam. Então, os cursos de alfabetização mais o jornal com as reuniões e as capacitações foram crescendo e realizando uma promoção humana extraordinária das mulheres, porque $92 \%$ dos que trabalham na Pastoral são mulheres, que mais educadas transformam a família e a comunidade, melhora todo o tecido social. (Zilda Arns)

A comunicação pode contribuir para a educação. Na análise de Marques de Melo (1981, p.41-42), Paulo Freire chama atenção para a função massificante dos veículos de comunicação, que contribuem para alienar o cidadão. No entanto, recomenda o uso dessas mensagens para educação popular como forma de desenvolver um espírito crítico. Chega a apontar, a partir da experiência em Guiné-Bissau, o uso do rádio e do jornal, citando a possibilidade de uma página que falasse sobre os círculos de cultura: avanços, dificuldades e soluções encontradas. Já o rádio levaria ao ar trechos dos debates.

Essas recomendações de Freire são as que vemos no Jornal Pastoral da Criança que dedica grande parte de suas páginas às comunidades. Essa é a seção mais citada pelas entrevistadas e entrevistados de nossa pesquisa. Foram ouvidas 61 pessoas, das quais 41 citaram as matérias sobre as comunidades como a preferida ou como uma das que auxiliam na realização das atividades na Pastoral da Criança. É o que vemos, por exemplo, na afirmação da líder e capacitadora Irene Pira de Lima, de 57 anos, que atua no Imirim (Setor Santana): "Mostra também os outros estados, o que eles fazem. Sempre um empurrão, um incentivo. A gente pensa, não está dando certo o que estamos fazendo aqui, mas olha lá, e eles têm menos recurso que a gente e estão fazendo." Opinião parecida tem a coordenadora de ramo Maria José da Silva, de 36 anos, da Aclimação (Setor Sé):

Gosto também daquela parte onde as pessoas falam o que está acontecendo dentro da comunidade. Acho que é uma maneira da gente saber o que está acontecendo com as pessoas que estão trabalhando no mesmo projeto da gente, em outras famílias, em outras cidades, em outros estados. Acho que é bom a gente saber que não é só a gente que está fazendo algo, mas as outras pessoas também estão fazendo algo pelas mesmas causas.

Outro ponto importante a ser destacado é o valor educativo dado ao jornal. Como avalia Zilda Arns, o jornal contribui para a cidadania e permite uma formação contínua. Isso porque "difunde informações e com a troca de experiência voltada para dentro da Pastoral, ele anima a comunidade, porque uma dificuldade que uma comunidade tem, a outra já teve. Então eles trocam experiências e isso é muito interessante". Outro ponto destacado pela fundadora 
da Pastoral da Criança é que "as pessoas se sentem promovidas porque o que a Pastoral da Criança faz desde o início é a multiplicação do saber e da solidariedade". A composição do jornal, para ela, "é feita de forma que haja promoção humana pela partilha do saber e pela partilha da solidariedade".

Essa multiplicação e educação se dão a partir de uma série de ações, conforme explica Zilda Arns. Primeiro a "mudança de comportamento" é trabalhada desde o início com “educação individual na visita domiciliar". Assim o "Guia do Líder é apresentado para a mãe, discutido na visita". A outra parte dessa educação ocorre no Dia da Celebração da Vida, em que se pesam as crianças, com "uma educação grupal”. Essa educação é complementada pelos meios de comunicação da Pastoral: o jornal e o programa de rádio. "Os três instrumentos de educação, quando usados ao mesmo tempo para um assunto, possibilitam um reforço, pois se podem coincidir temas importantes no jornal, no programa de rádio e no trabalho nas comunidades". Além disso, o Jornal Pastoral da Criança contribuiu para a educação:

O jornal serviu muito para a alfabetização, porque as pessoas eram alfabetizadas e, muitas vezes, por não ter o que ler, esqueciam. Então o jornal servia como reforço para a alfabetização de jovens e adultos. Isso começou um pouco depois do jornal na Pastoral da Criança. A alfabetização era coordenada pela pedagoga Maria Helena Arns, minha irmã. O jornal serviu de base também para a Celebração da Vida. Eles gostavam muito de ver um artigo, a minha carta, alguma notícia para terem algum assunto para discutir com as mães. Também na reunião mensal de avaliação e reflexão tiravam uma parte do jornal para a reflexão e reforço das lideranças. Creio que foi um programa muito bem sucedido, o jornal por todo o Brasil. Hoje são 280 mil exemplares que chegam aos mais longínquos rincões. Andam de barco para entregar os jornais. E todo o voluntariado, cerca de 270 mil voluntários, todos têm acesso a comunicação da Pastoral. (Zilda Arns)

Mesmo em São Paulo é possível ver casos assim. A líder Josefa Gonçalves Leite, 58 anos, da Lapa, afirma ter encontrado na Pastoral da Criança a motivação para aprender ler e escrever. Como tem dificuldades, o filho lê com ela os materiais como o Guia do Líder e o Jornal Pastoral da Criança. A contribuição do jornal para a formação é reconhecida por outras entrevistadas da pesquisa como a atual coordenadora do setor Lapa, Dalila Aparecida da Costa, 54 anos:

O jornal contribui bastante e vem para reciclar a ação. A gente fez a capacitação do guia em 2007, com uma metodologia que você começa a ter uma nova visão. $\mathrm{O}$ trabalho fica mais unido. Essas etapas fazem crescer, amadurecer o trabalho. E as líderes, que já tinham sido capacitadas e fizeram só a reciclagem, é uma forma de terem a formação contínua, é a proposta da Pastoral. Se ela lê o jornal, está sendo reciclada. Com as opiniões e os 
depoimentos do jornal, abre um campo de visão. Você vê que não é só na sua comunidade em que está acontecendo determinada situação, em outra comunidade também acontece. Não é só aqui na minha paróquia ou do vizinho, acontece no Brasil todo.

Essa comunicação que educa nos remete mais uma vez a Paulo Freire. Na Pastoral da Criança, comunicação e educação caminham juntas e dependem das relações e participações dos sujeitos numa maneira bem parecida com a avaliação que Venício Artur de Lima (1981) faz de Freire.

\begin{abstract}
Enfatizando que a comunicação significa co-participação dos Sujeitos no ato de pensar, que o objeto do conhecimento não pode se constituir no termo exclusivo do pensamento mas, de fato, é seu mediador, e que o conhecimento é construído através das relações entre seres humanos e o mundo, Freire está, na verdade, definindo a comunicação como a situação social em que as pessoas criam conhecimento juntas, ao invés de transmitilo, dá-lo ou impô-lo. A comunicação é uma interação entre Sujeitos iguais e criativos. Mas esta interação é de natureza tal que necessita estar fundada no diálogo. (LIMA, 1981, p.64)
\end{abstract}

Lima (1981, p.65) destaca que em Freire há uma relação de igualdade no processo significativo compartilhado pelos sujeitos. Outro ponto do pensamento de Freire é que o homem com voz é sujeito de suas opções (1981, p.66). A comunicação, assim, educa e liberta.

\begin{abstract}
A ação cultural dialógica para a liberdade e a revolução dialógica são os caminhos propostos por Freire para que os homens e as sociedades possam reconquistar sua verdadeira voz num mundo desumanizado. (...) Uma vez que a característica fundamental de nossa época é a dominação, o objetivo a ser atingido pela ação cultural deve ser a libertação. A dominação [ou desumanização] se caracteriza por ser um processo "que marca não apenas aqueles cuja humanidade foi roubada [os oprimidos], mas também os que a roubaram" [os opressores]. Assim, no processo de libertação [ação cultural revolucionária] "os oprimidos não devem, ao procurar restaurar a humanidade, se transformar, por sua vez em opressores de seus opressores, mas sim restaurar a humanidade de ambos." Freire identifica a libertação como "o processo [ou luta] pela humanização", ou seja, "pela emancipação do trabalho, pela superação da alienação, pela afirmação dos homens enquanto pessoas". (LIMA, 1981, p.66-67)
\end{abstract}

Acreditamos que a Pastoral da Criança contribui para essa libertação, que nasce do diálogo. Primeiro a líder com a capacitadora, que trocam informações e saberes. O mesmo podemos dizer das líderes e das mães, e das mães e a família. A própria estrutura da Pastoral fala em multiplicação do conhecimento. Esse conhecimento em saúde, que tem bases científicas, é multiplicado a partir da realidade local e seus problemas, que são refletidos nas 
reuniões de avaliação. A alienação é superada, pois se passa a ter uma visão crítica da realidade, conhecendo os direitos e exigindo-os. Lima (1981, p.69) destaca que Freire acredita no "desenvolvimento de uma confiança mútua" entre os dialogadores. Vimos isso em nossa pesquisa de campo na Pastoral da Criança em São Paulo. Há a criação desse elo entre voluntárias, mães e crianças.

No já citado encontro de Multiplicadores, ocorrido em março de 2008, uma das atividades foi a divisão dos presentes em grupos para debater alguns pontos da ação na Pastoral da Criança e depois apresentar ao restante do grupo. Uma das questões levantadas foi o fato de que a líder deve fazer a visita sem pressa e conquistar a família, criando um vínculo de confiança. Também foi apontado como importante respeitar a família, pois se está no ambiente dela, assim como formar um laço de amizade.

Esse elo de confiança também foi percebido nas entrevistas realizadas com os voluntários e voluntárias dos setores, como podemos observar no depoimento da coordenadora e líder da Pastoral da Criança no setor Belém, Maria Vaz Couto Martine, sobre o contato com as famílias: "É muito interessante. Eu tenho amizade com as pessoas, então, já chego lá conversando, batendo papo, como se fosse amiga, porque elas já estão como amigas da gente. Fica mais fácil."

Como vemos, essa força dialógica está não só na relação de confiança, mas no próprio testemunho. A líder, que geralmente é uma pessoa da comunidade, como a própria mãe não apenas fala, mas age em conjunto.

Na Pedagogia do Oprimido, ao identificar a organização das massas populares como um dos elementos constitutivos da teoria dialógica da ação cultural, Freire enfatiza a necessidade de que os líderes testemunhem "o fato de que a luta pela libertação é uma tarefa comum". Em algumas circunstâncias, assinala Freire, é através do testemunho que se pode estabelecer uma relação dialógica entre os líderes e os oprimidos. (LIMA, 1981, p.71)

As ações dos líderes devem corresponder às expectativas dos oprimidos, e essa liderança não deve perder o contato com o povo e se fechar numa relação antidialógica e manipulatória, apesar desse risco existir (LIMA, 1981, p.71). Acreditamos que esse cuidado deve ser tomado pela Pastoral da Criança. As líderes passam por diversas capacitações, reuniões e reflexões, ampliam seus conhecimentos e visão de mundo, mas não devem por isso deixar de ver as necessidades das famílias acompanhadas e tentar compreender essa realidade. Não devem chegar às casas como possuidoras de um conhecimento que deve ser transmitido. 
Freire (1992, p.25) conta uma história que ocorreu no início de sua carreira, quando trabalhava no Sesi, em Recife/PE, que nos faz refletir sobre essa necessidade de entender o outro. Ele falava para trabalhadores sobre a importância de uma relação dialógica entre pais, mães, filhos e filhas, que substituísse os castigos violentos. "Meu erro estava, primeiro, no uso de minha linguagem, de minha sintaxe, sem um esforço maior de aproximação dela à dos presentes. Segundo, na quase desatenção à realidade dura da imensa audiência que tinha em frente a mim”. Ao terminar a exposição, um homem de 40 anos pediu a palavra.

\begin{abstract}
"Agora, eu queria dizer umas coisas ao doutor que acho que meus companheiros concordam." Me fitou manso mas penetrantemente e perguntou: "dr. Paulo, o senhor sabe onde a gente mora? O senhor já esteve na casa de um de nós?" Começou então a descrever a geografia precária de suas casas. A escassez de cômodos... Falou da falta de recursos para as mais mínimas necessidades. Falou do cansaço do corpo, da impossibilidade dos sonhos com um amanhã melhor. (...)

- Pois bem, doutor, sua casa (...). Deve de ter um quarto só para o senhor e sua mulher. Outro quarto grande é pras três meninas. Tem outro tipo de doutor que tem um quarto pra cada filho e filha. Mas o senhor não é desse tipo, não. Tem outro quarto para os dois meninos. Banheiro com água quente. (...) Uma coisa é chegar em casa, mesmo cansado, e encontrar as crianças tomadas banho, vestidinhas, limpas, bem comidas, sem fome, e a outra é encontrar os meninos sujos, com fome, gritando, fazendo barulho. E a gente tendo que acordar às quatro da manhã do outro dia pra começar tudo de novo, na dor, na tristeza, na falta de esperança. Se a gente bate nos filhos e até sai dos limites não é porque a gente não ame eles não. É porque a dureza da vida não deixa muito pra escolher. (FREIRE, 1992, p.26-27)
\end{abstract}

Ao estar com sua esposa Elza, comentou que havia sido tão claro e não foi compreendido. Elza respondeu: "Não terá sido você, Paulo, quem não os entendeu? (...) Creio que entenderam o fundamental de sua fala. O discurso do operário foi claro sobre isto. Eles entenderam você mas precisavam de que você os entendesse" (1992, p.28). O relato mostra a importância de se levar em conta a realidade da comunidade e de ouvir o outro, não com a sua verdade, mas aberto a verdade do outro. Segundo o autor, é preciso que o educador ou educadora respeite o "saber de experiência feito ..., somente a partir do qual é possível superá$10 "$.

A líder é a educadora da Pastoral da Criança. Ela quem levará à comunidade os conhecimentos adquiridos nas capacitações, reflexões, materiais de comunicação como o jornal. Mas também não pode desprezar o saber da experiência. Um exemplo disso foi a discussão da Capacitação em Alimentação e Hortas Caseiras ocorrida no Ipiranga e reunindo voluntárias e voluntários de todo o estado de São Paulo, em 14/03/09. Além de apresentar o guia que a Pastoral da Criança desenvolveu sobre o tema, a nutricionista Caroline Dallabona 
mostrava que o uso do material sempre vai depender da realidade local. Cada participante falava de sua região e como se poderia trabalhar o conteúdo do guia a partir das necessidades das mães. Um dos pontos sugeridos é que os alimentos trabalhados na comunidade devem ser levados conforme a possibilidade de cada um e que ao trabalhar a questão da alimentação, isso deve ser feito como um momento de troca entre mães e líderes.

Frases como "é preciso ter troca de experiências" e "considerar as diferenças de cada pessoa preparar os alimentos" surgiam no debate ao mesmo tempo em que eram reforçadas pelo guia. Sugestões de roteiros, críticas a receitas e relato de vivências fazem parte da capacitação, que é marcada pelo diálogo constante. O objetivo dessa capacitação é preparar os multiplicadores, que prepararão os capacitadores, que por sua vez, prepararão os líderes nas comunidades para trabalhar a alimentação saudável com as famílias. Uma das preocupações é o aumento da obesidade entre as crianças, pois as famílias deixam de comer cereais, frutas e legumes para consumir produtos industrializados.

O interessante é notar que mesmo nos intervalos da capacitação voluntários e voluntárias continuavam conversando sobre os temas discutidos na formação e falando das dificuldades que encontram, da maneira que devem falar com as famílias, de como considerar a realidade local e apresentar coisas novas. Vão surgindo ideias dos pequenos grupos que se formam nesse bate-papo informal. Falam, por exemplo, da necessidade de usar a Celebração da Vida não só para pesar crianças, mas como um momento de conversarem com as mães, falarem dos problemas que vivenciam, apesar disso nem sempre ocorrer e por isso ser necessário abordar nas capacitações para que ocorra nas comunidades.

Vemos que há por parte dos voluntários e voluntárias uma preocupação em realizar uma educação como a defendida por Freire, que considera o saber e a realidade local, mas também quer uma superação. Ocorre essa comunicação dialógica, de caráter social e comunitário. "Somente Freire - dentre os demais membros da corrente dialógica - é categoricamente social, nossa intenção é enfatizar a enorme diferença que o separa do individualismo" (LIMA, 1981, p.73).

Tanto as obras de Paulo Freire quanto as suas ações práticas influenciaram a forma de se fazer comunicação na Igreja e a teologia da libertação, como já vimos. Por consequência também influenciaram a forma de fazer comunicação popular, primeiro, nas CEBs, depois, na Pastoral da Criança. No exílio, o autor também levou sua influência a outros países e autores, espalhando sementes para uma educação dialógica. 


\section{2 - A relação entre a comunicação e a educação}

Um dos autores estrangeiros, influenciado por Paulo Freire, é Mario Kaplún que faz uma relação entre a comunicação e a educação. Para ele, toda ação educativa implica em um processo comunicativo. Assim procura desenvolver uma comunicação participativa e problematizadora. Os meios de comunicação podem ser usados como instrumentos para uma educação popular que transforma. A comunicação deve suscitar nos que recebem a mensagem uma recriação, uma invenção. (KAPLÚN, 1998, p.11-13, p.17 e p.24)

Na avaliação de Kaplún (1998, p.25), da mesma forma em que há uma educação bancária, existe uma comunicação bancária, que apenas transmite a informação. É o comunicador que emite sua mensagem e conteúdos, a partir de sua visão, para um leitor, um espectador ou um ouvinte, que não sabe e tem apenas a função de receber a informação. Trata-se de um monólogo de quem escolhe o conteúdo e sabe, para o receptor, que recebe e não sabe.

Acreditamos que na Pastoral da Criança, o receptor da mensagem não é apenas o que recebe. Ele ajuda a construir a informação a partir das reuniões e capacitações, em que aprende, mas também é ouvido e fala. O que ele pensa e vive ajuda a escolher os temas do Jornal Pastoral da Criança e do programa de rádio Viva Vida. A mensagem é reconstruída e discutida nas reuniões e nas visitas. Como vemos nos depoimentos de diferentes voluntárias e voluntárias nos seis setores episcopais da Arquidiocese de São Paulo:

Belém - Maria de Moreira do Amor Divino, 45 anos, coordenadora de ramo e líder, bairro Terceira Divisão: "A gente leva e lê em casa. Tem novidade que a gente usa na Celebração da Vida. A gente aconselha as mães a lerem. Leva o jornalzinho e deixa a mãe ler para ela ter noção do que é uma vida saudável, controlar e cuidar da alimentação da pessoa".

Brasilândia - Eron Gonçalves de Aguiar, 45 anos, coordenador de área no Jaraguá: "Na formação, a gente faz a leitura do jornal. Vemos três tópicos do jornal e deles escolhemos um. Recentemente, vimos uma notícia do interior de São Paulo e vamos usar agora na celebração de sábado. Os seminaristas aderiram a Pastoral da Criança e fizeram um dia de roda de conversa da Pastoral da Criança. Isso estava no jornal e nós lemos, com o grupo que estava formando. A gente resolveu pegar esse modelo e fazer a roda de conversa na Paróquia Perpétuo Socorro. No domingo de manhã, fui, falei com padre, convidamos as mães das áreas carentes e marquei para sábado agora a roda de conversa sobre a Pastoral".

Ipiranga - Cecília Valverde, 43 anos, coordenadora da Pastoral da Criança no Setor Ipiranga: "No setor nós entregamos na reunião mensal 
para cada coordenadora de ramo para que elas levem o jornal para sua equipe e trabalhem as receitas, o fé e vida. Cada paróquia trabalha com o jornal dentro de sua realidade. A gente faz mais orientação de como usar as dicas, de como usar esse jornal. (...) O jornal todo, em si, é muito informativo, tem líderes e coordenadoras que até xerocam parte da saúde que ele trabalha, saúde bucal, tuberculose e levam nas visitas domiciliares, leem para as mães e deixam uma cópia para elas. Essas informações de saúde são super importantes".

Lapa - Jairo Fedel, 49 anos, multiplicador do Setor Lapa: "Além da leitura individual, a gente incentiva nas reuniões de reflexão e avaliação, os temas propostos no jornal, nós discutimos em cima deles. Às vezes coincide de alguma problemática que está tendo em nossa comunidade, vir a ter alguma reportagem ou artigo. A gente coleta até dados e incentiva bastante a liderança com o jornal, é um trabalho muito bom".

Santana - Cinira Fidalgo Serafim, coordenadora de ramo no Lauzane: "Os jornais são distribuídos para as líderes. No dia da reunião das FABs, a gente entrega um para cada líder e cada uma lê. Quando tem alguma coisa interessante a gente discute nas nossas reuniões".

Sé - Elizabeth Valente Lorenzano, 61 anos, coordenadora de ramo e líder em Perdizes: "Dou o jornal para o pároco, para o vigário, para as líderes e apresento para as mães. Sempre tem uns dois ou três exemplares no dia da pesagem. A gente tira muitas ideias, receitas ou comentários. Agora mesmo eu fiz um cartaz para a campanha da fraternidade e tirei basicamente os depoimentos que tinham no jornal da Pastoral".

Vemos pelo depoimento uma comunicação horizontal, dialógica, com caráter educativo, que valoriza a reconstrução da mensagem pelo receptor. É uma opção interessante, pois como alerta Kaplún (1998, p.26-27) ao criticar a comunicação autoritária e vertical que vê o emissor como protagonista, caracterizando-a como unidirecional:

En la medida en que sigamos asumiendo el clásico papel de emisores, de poseedores de la verdad que dictamos esa verdad a los que "no saben", en la medida en que sigamos depositando informaciones e ideas ya "digeridas" en la mente de nuestros destinatarios, por libertadores y progresistas que sean los contenidos de nuestros mensajes, continuaremos siendo tributarios de una comunicación autoritaria, vertical e unidireccional. (KAPLÚN, 1998, p.27)

Para uma comunicação educativa, o autor traz algumas sugestões como consulta aos destinatários e suscitar neles um processo pessoal. Nesse sentido, vimos que a Pastoral da Criança desenvolveu mecanismos para ouvir os voluntários em seus encontros regionais, além de possibilitar a participação no jornal e incentivar que os voluntários reconstruam o programa de rádio. O que nos permite dizer que ela pratica essa comunicação educativa. 
Kaplún (1998, p.32) apresenta alguns pontos que devem ser observados por quem quer realizar uma comunicação popular efetiva. Se primeiro ele chama atenção para os que enfatizam o conteúdo e o transmitem para os que "não sabem", depois fala dos que usam a comunicação para persuadir, por exemplo, os camponeses "atrasados" a abandonar suas técnicas e adotar novas.

Acreditamos que uma comunicação popular que se proponha a educar não deve estar preocupada em convencer os seus "receptores" e sim em gerar um debate entre iguais, uma partilha de conhecimentos e uma construção conjunta de ações que melhorem a comunidade. Esse deve ser o papel das líderes na Pastoral da Criança.

Como explica o próprio Kaplún (1998, p.45), as mensagens libertadoras, conscientizadoras, problematizadoras vão "contra a corrente" do sistema, da ideologia dominante. Os mecanismos que este emprega para reforçar seus valores são inoperantes quando se trata justamente de questionar e mudar valores. Não se "vende" criticidade, solidariedade, libertação, com os mesmos recursos que se vende Coca-Cola.

Para o autor (1998, p.44 e p.47-49), a comunicação educativa ao colocar ênfase no processo, também atende aos conteúdos e resultados. Esse tipo de comunicação se baseia na educação libertadora de Paulo Freire, que educa para a democracia e transformação da sociedade. Não é uma educação para informar e sim para transformar a realidade.

Acreditamos que a comunicação e a educação na Pastoral da Criança têm esse caráter transformador. A forma como a Pastoral da Criança aborda a saúde é um exemplo, que mostra a construção conjunta do conhecimento visando uma mudança. Uma das questões trabalhadas é a necessidade de que a gestante tenha acesso aos dados de sua curva de altura uterina. Isso foi debatido no Encontro de Multiplicadores de março de 2008. Voluntárias e voluntários relataram como é o cartão da gestante em sua região. Na cidade de São Paulo, por exemplo, não há o gráfico desenhado. Com o gráfico preenchido pelo médico, é possível a mãe visualizar se o crescimento do bebê no ventre está adequado e se não há desnutrição.

Uma das multiplicadoras relatou que mesmo quando o Ministério da Saúde enviava o cartão com o gráfico, os médicos não preenchiam e que "devem lutar para as mulheres terem acesso a essa informação, da mesma forma que lutaram pelo soro caseiro, que foi difundido pela Pastoral da Criança". Esse mesmo tema foi tratado na reunião com as coordenadoras das regiões episcopais da Arquidiocese de São Paulo no dia 10/12/2008. Na ocasião, foi entregue uma carta, desenvolvida por um multiplicador de políticas públicas que estava no encontro de março de 2008. 
Cópias dessa carta deveriam ser entregues para as coordenadoras e coordenadores de ramo (paróquias) e de comunidade para serem levadas aos postos de saúde. Já as coordenadoras das regiões episcopais levariam às regionais da secretaria de saúde e subprefeituras. A coordenadora da Pastoral na Arquidiocese de São Paulo ficou responsável pelo contato com o secretário de Saúde. A carta explicava que a inclusão do gráfico era necessária para que as mães acompanhassem se o desenvolvimento do bebê estava dentro dos padrões estabelecidos pelo Ministério da Saúde. Essa informação também é importante para as líderes poderem acompanhar a gestação das mães, visando uma nutrição adequada. Ainda ressaltava que “ $60 \%$ das crianças no período perinatal morrem por causas evitáveis".

Vimos essa carta ser entregue e discutida na Confraternização da Pastoral da Criança no Belém, no dia 13/12/2008. Na ocasião, a coordenadora da Pastoral da Criança na Arquidiocese de São Paulo afirmou:

O desafio da Pastoral da Criança da Pastoral da Criança começou há 25 anos. Era diminuir a mortalidade infantil. No começo a causa era a desnutrição e a diarreia. Agora o desafio está em acompanhar a gestante, porque muitas mortes ocorrem na primeira semana de vida. Se a gestante tem, por exemplo, infecção urinária, isso pode causar mortalidade infantil, caso não faça um pré-natal. Se a gestante é bem orientada, os problemas são sanados. Por isso, estamos trabalhando para que haja o gráfico de curva uterina no cartão da gestante. (Maria do Rosário)

O mesmo tema foi retratado pela coordenadora do Setor Brasilândia, na última reunião com coordenadores do ano, em 18/12/2008. Os coordenadores foram relatando suas experiências como Eron Gonçalves de Aguiar, que disse ter falado sobre o gráfico com uma enfermeira do Hospital Nova Cachoeirinha. Ela respondeu que isso dizia respeito ao médico e o paciente. Algo parecido com o que ouvimos em princípio na reunião com os técnicos da secretaria de saúde em 20/05/2009, quando afirmaram que o médico tinha essa informação no prontuário.

A grande questão é o direito da mãe visualizar e entender essas informações que dizem respeito à saúde do bebê. Isso foi apontado em maio de 2009 como foi debatido na reunião local da Brasilândia. A multiplicadora Débora Mara de Oliveira Soares explicou que a mortalidade neonatal é muito grande e é necessário para a gestante ter essa informação no cartão para entender como está a saúde do bebê.

O debate levou o grupo a levantar a necessidade de se trabalhar outras questões de saúde e como cada área poderia buscar a administração regional. Percebe-se como a educação se dá através do diálogo e da troca de experiências. Dessa forma, a educação é um processo 
permanente, em que o sujeito vai se descobrindo, elaborando, reinventando, fazendo seu conhecimento. É um processo de ação-reflexão-ação, que parte da experiência para uma construção conjunta, na qual educador-educando é um facilitador da análise e reflexão. (KAPLÚN, 1998, p. 50)

Como explica Kaplún (1998, p.51), o que importa, mais que ensinar coisas e transmitir conteúdos, é que o sujeito aprenda a aprender; que se faça capaz de raciocinar por si mesmo, de superar as constatações meramente empíricas e imediatas dos feitos que a rodeiam (consciência ingênua) e desenvolver sua própria capacidade de deduzir, de relacionar, de elaborar sínteses (consciência crítica). Esse modelo se baseia na participação ativa do sujeito, no processo educativo e forma para a participação na sociedade, porque somente participando, envolvendo-se, investigando, fazendo perguntas e buscando respostas, problematizando e problematizando-se, chega-se realmente ao conhecimento.

\section{3 - Dando voz a Paulo Freire}

As obras de Paulo Freire nos mostram como deve ser uma comunicação que educa e liberta. Muitos pontos levantados já são praticados pela Pastoral da Criança. Mas algumas práticas poderiam ser melhoradas, trabalhando-se os conceitos de Freire e se fazendo uma reflexão teórica sobre o que já ocorre na prática.

Numa dessas obras, Comunicação ou extensão?, Freire (1977) faz uma crítica à extensão e define a comunicação. Publicada pela primeira vez em 1969, no Chile, analisa o problema de comunicação entre o técnico e o camponês. Assim avalia que na ação extensionista se vai até o outro, inferior, para normalizá-lo. Extensão tem a ver com "transmissão, entrega, doação, messianismo, mecanicismo, invasão cultural, manipulação". Não há um “que-fazer educativo libertador”, nem a busca de “seu Ser Mais”. (1977, p. 22-23)

A persuasão não é conciliável à educação "como prática da Liberdade". Isso porque implica em um "sujeito que persuade" e um "objeto sobre o qual incide a ação de persuadir" (1977, p.24). A “extensão educativa” é vista como "domesticação": Educar e educar-se, na prática da liberdade, não é estender algo desde a "sede do saber", até a "sede da ignorância" para salvar, com este saber, os que habitam nesta. 
Ao contrário, educar e educar-se, na prática da liberdade, é tarefa daqueles que sabem que pouco sabem - por isto sabem que sabem algo e podem assim chegar a saber mais - em diálogo com aqueles que, quase sempre, pensam que nada sabem, para que estes, transformando seu pensar que nada sabem em saber que pouco sabem, possam igualmente saber mais. (FREIRE, 1977, p.25)

Reconhecer que não se sabe tudo e que o outro tem o seu saber. Eis um ponto que presenciamos em nossa pesquisa de campo na Pastoral da Criança em São Paulo. No Encontro de Multiplicadores, uma das participantes levantou que um dos problemas é que as mulheres têm muitos filhos. Outra participante respondeu que não devemos julgar os outros, que devemos "entrar dentro da vida da pessoa" e contou casos de mulheres que são violentadas pelo marido.

Nesse mesmo encontro, ao se debater a capacitação, ressaltou-se a importância do consenso com o grupo assim como o fato de se sentarem em círculo, que mostra a situação de igualdade entre os participantes. Nisso, incentivou-se que os multiplicadores devem fazer as capacitações baseadas no diálogo. Explicou-se que o próprio Guia do Líder foi fruto de discussão em todo o país e que o material serve para orientar o trabalho, mas a discussão é importante porque quando um tem dúvida, o outro pode levantar uma solução.

Vemos um cuidado para que a educação praticada pela Pastoral da Criança não tenha o caráter extensivo. "O sujeito que estende é, enquanto ator, ativo, em face de 'espectadores' em que deposita o conteúdo que estende" (FREIRE, 1977, p.26). Nem nas capacitações, reuniões e encontros as líderes podem ser vistas dessa forma, como as mães não podem ser vistas assim nas visitas. A multiplicação do conhecimento aplicada pela Pastoral da Criança só será alcançada valorizando os saberes locais, e a superação só faz sentido se partir da construção conjunta do conhecimento, na qual todos são sujeitos.

Daí que se torne indispensável à superação da compreensão ingênua do conhecimento humano, na qual muitas vezes nos conservamos. Ingenuidade que se reflete nas situações educativas em que o conhecimento do mundo é tomado como algo que deve ser transferido e depositado nos educandos. Este é o modo estático, verbalizado de entender o conhecimento...

Conhecer na dimensão humana, que aqui nos interessa, qualquer que seja o nível em que se dê, não é o ato através do qual um sujeito, transformado em objeto, recebe dócil e passivamente os conteúdos que outro lhe dá ou impõe. (...)

Conhecer é tarefa de sujeitos, não de objetos. E é como sujeito e somente enquanto sujeito, que o homem pode realmente conhecer.

Por isto é que, no processo de aprendizagem, só aprende verdadeiramente aquele que se apropria do aprendido, transformando-o em apreendido, com o que pode, por isto mesmo, reinventá-lo; aquele que é capaz de aplicar o 
aprendido-apreendido a situações existenciais concretas. (FREIRE, 1977, p.27-28)

Essa deve ser a forma de conhecimento multiplicada pela Pastoral da Criança. "Na situação educativa, educador e educando" assumem "o papel de sujeitos cognoscentes, mediatizados pelo objeto cognoscível que buscam conhecer" (1977, p.28). Essa ação entre sujeitos também deve ser repetida nos meios de comunicação da Pastoral da Criança, que têm um caráter educativo e de formação contínua. A opção pela comunicação popular, criando formas de participação, mostra que as voluntárias e voluntários não são apenas "receptores", mas também produtores. São sujeitos da ação, o que vai ao encontro da educação defendida por Freire. Também são sujeitos da reflexão, o que ocorre nas reuniões de avaliação. A ação também está presente no trabalho desenvolvido pelas lideranças com a família. São seres "do trabalho e da transformação do mundo". São seres "da 'práxis'; da ação e da reflexão" (FREIRE, p.1977, p.28)

Para Freire (1977, p. 33-34), o objetivo fundamental de uma educação popular é "através da problematização do homem-mundo ou do homem em suas relações com o mundo e com os homens, possibilitar que estes aprofundem sua tomada de consciência da realidade na qual e com a qual estão". Desenvolve-se, então, a "ação transformadora da realidade".

Isto demanda um esforço não de extensão mas de conscientização que, bem realizado, permite aos indivíduos se apropriarem criticamente da posição que ocupam com os demais no mundo. Esta apropriação crítica os impulsiona a assumir o verdadeiro papel que lhes cabe como homens. O de serem sujeitos de transformação do mundo, com a qual se humanizem. (FREIRE, 1977, p.36)

Se por um lado pode haver uma crença de que as mães não sabem nada ou são culpadas por determinada situação, sempre que uma opinião dessa se manifesta em alguma reunião, alguém faz o contraponto. Na Assembleia da Lapa, em 22/03/2009, ao debaterem as diversas formas de violência, citaram exemplos como a exploração sexual. Uma das voluntárias presentes afirmou que isso acontece quando a pessoa quer. Imediatamente todos questionaram que não e começaram dar exemplos de mulheres que são enganadas, violentadas, que não tem informação.

Assim como a Pastoral da Criança precisa considerar o saber das voluntárias e voluntários, esses precisam considerar o saber e a realidade das famílias, que por sua vez também precisam aceitar essa troca. Todos devem ser vistos como sujeitos da transformação. Mas pode ocorrer tanto das líderes desacreditarem no potencial das mães, como o contrário, 
de acordo com a fala da líder Josefa Gonçalves Leite, de 55anos, que convidou uma voluntária de fora da comunidade para ajudá-la:

Desde o ano passado, estou conversando com a Do Carmo para ir junto, porque a gente tem um momento de chamar uma pessoa de fora para dar uma palestra, para que as mães entendam o nosso trabalho. Por viver perto de onde elas moram, acham que a gente faz por fazer ou se mostrar e não dão muita atenção. (Josefa Leite)

Paulo Freire nos alerta sobre o que leva a esses problemas: "uma inegável descrença no homem simples".

Uma subestimação do seu poder de refletir, de sua capacidade de assumir o papel verdadeiro de quem procura conhecer: o de sujeito desta procura. Daí a preferência por transformá-lo em objeto do "conhecimento" que se lhe impõe. Daí este afã de fazê-lo dócil e paciente recebedor de "comunicados", que se lhe introjetam, quando o ato de conhecer, de aprender, exige do homem uma postura impaciente... Uma busca que, por ser busca, não pode conciliar-se com a atitude estática de quem simplesmente se comporta como depositário do saber. (FREIRE, 1977, p.46)

Tanto a prática educativa da Pastoral da Criança em relação às líderes, quanto das líderes em relação às mães devem ser pautadas nessa busca conjunta, na qual todos são sujeitos, visando à conscientização e a transformação da realidade de líderes e mães. Essa transformação pode ser vista seja na luta coletiva para a implementação de políticas públicas como também em mudanças na vida da pessoa, seja líder ou mãe. As reuniões e capacitações são fundamentais, como mostra a fala do coordenador estadual da Pastoral da Criança, durante o Encontrão de Líderes do Ipiranga, em 29/11/2008:

Temos que discutir os problemas na Reunião de Avaliação e Reflexão, pois assim poderemos saber quais são as políticas públicas necessárias e poder mudar a realidade com justiça. Toda vez que não olhamos para quem tem fome, tem sede, esteve preso, deixamos de olhar para Jesus. A Pastoral da Criança chega a lugares onde nenhum pastor foi. Temos essa responsabilidade. (José de Anchieta)

Já um exemplo de mudança é a coordenadora de ramo Maria José da Silva, de 36 anos, do setor Sé. Há sete anos na Pastoral da Criança, Maria já foi acompanhada pela Pastoral da Criança quando era gestante e enquanto sua filha era pequena. Acabou se tornando líder. Hoje faz faculdade de fisioterapia. Sobre a Pastoral da Criança afirma: 
Para mim, a Pastoral da Criança foi e é muito importante, porque eu comecei como família acompanhada. Então isso me levou a querer saber um pouquinho mais sobre o porquê era feito esse trabalho. Como as lideres faziam? É importante levar essa experiência. (Maria José da Silva)

Transformação também é o que a ação da Pastoral da Criança significa para Josefa Gonçalves Leite, da Lapa. Não alfabetizada, nunca teve a oportunidade de ir para a escola. Por muito tempo, ajudou na Pastoral da Criança como apoio. Vem frequentando o curso de alfabetização da Igreja, mas tem dificuldade para aprender a ler e escrever. Mesmo assim, conseguiu há dois anos realizar o seu sonho: ser líder da Pastoral da Criança. As visitas são feitas em dupla. Para as anotações, ela conta com a ajuda do filho que preenche o Caderno da Líder para ela, assim como lê com ela o Guia do Líder e o Jornal Pastoral da Criança. Sem o ensino formal, Josefa tem a sabedoria do mundo e a vontade de aprender:

Eu vim das cinzas. Minha história é muito longa, renasci muitas e muitas vezes. Aqui em São Paulo meu trabalho está sendo bom. É uma Pastoral que me deu vida, além dela ser celebração de vida para as crianças, porque agora a minha prioridade é estudar e cada vez que eu estou em reunião, eu aprendo mais. A gente vai amadurecendo e se educando porque nunca estamos sabido de tudo. Todo dia ela me faz renascer. (Josefa Leite)

"Nunca estamos sabido de tudo". A frase de Josefa ilustra bem o pensamento de Paulo Freire, em que educandos e educadores devem reconhecer que sempre tem mais a aprender. Traz em si a sabedoria de Sócrates: "Só sei que nunca sei". E assim a mulher que nunca teve a oportunidade de ir à escola vai construindo seu conhecimento. Esse passa pela leitura do mundo: "A leitura e a escrita das palavras, contudo, passa pela leitura do mundo. Ler o mundo é um ato anterior à leitura da palavra" (FREIRE, 1992, p.79)

A base dessa transformação também é o diálogo, que problematiza, critica e assim insere o ser humano em sua realidade como sujeito da mudança. "O que se pretende com o diálogo é a problematização do próprio conhecimento em sua indiscutível reação com a realidade concreta na qual se gera e sobre a qual incide, para melhor compreendê-la, explicála, transformá-la”. (FREIRE, 1977, p.52)

Isso é feito a partir de uma "práxis verdadeira, que demanda a ação constante sobre a realidade e a reflexão sobre essa ação". É isso que as líderes fazem, como educadoras agem ao visitar as famílias, ao pesar as crianças, a orientar sobre saúde e direitos. As reuniões de avaliação são os momentos de reflexão sobre a ação. Elas aprendem nas capacitações, mas aprendem mais ainda quando agem e depois refletem.

É um pensar e um aprender conjunto, que passa pela comunicação como diálogo: 
Todo ato de pensar exige um sujeito que pensa, um objeto pensado, que mediatiza o primeiro sujeito do segundo, e a comunicação entre ambos, que se dá através dos signos lingüísticos.

(...)

O sujeito pensante não pode pensar sozinho; não pode pensar sem a coparticipação de outros sujeitos no ato de pensar sobre o objeto. Não há um "penso", mas um "pensamos". É o "pensamos" que estabelece o "penso" e não o contrário.

Esta co-participação dos sujeitos no ato de pensar se dá na comunicação. (FREIRE, 1977, p.66)

Assim na comunicação não há sujeitos passivos, a comunicação é diálogo, e a “educação é comunicação, é diálogo, na medida em que não é transferência de saber, mas um encontro de sujeitos interlocutores que buscam a significação dos significados". Nesse contexto, é importante que para uma comunicação eficiente, "a expressão verbal de um dos sujeitos seja percebida dentro de um quadro significativo comum ao outro sujeito". (FREIRE, 1977, p.67-69)

Podemos concluir que a Pastoral da Criança deve ter em suas capacitações e materiais de comunicação uma linguagem compreensível pelas líderes, que por sua vez devem falar com as mães compartilhando os mesmos signos. Isso é facilitado pelo fato de que, na maioria das vezes, mães e líderes pertencem a mesma comunidade.

Essa comunicação deve ter um caráter humanista, que rejeita a manipulação e "só é verdadeiro enquanto se dá na ação transformadora das estruturas em que eles se encontram 'coisificados', ou quase 'coisificados'." Nesse humanismo, homens e mulheres "podem superar a situação em que estão sendo um quase não ser e passar a ser um estar sendo em busca do ser mais". (FREIRE, 1977, p.74)

Assim, na práxis, ação e reflexão "se iluminam constante e mutuamente". A prática, “implicando na teoria da qual não se separa, implica também numa postura de quem busca o saber, e não de quem passivamente o recebe" (FREIRE, 1977, p.80). As líderes são educandas da Pastoral da Criança e educadoras das mães; algumas se tornam educadoras de outras líderes. Mas tanto como educandas e educadoras devem ter em vista a problematização.

Segundo Freire (1977, p.81-83), a tarefa do educador "é de problematizar aos educandos o conteúdo que os mediatiza, e não a de dissertar sobre ele". O "educador reconstrói, permanentemente, seu ato de conhecer". Essa "problematização é a reflexão que alguém exerce sobre um conteúdo, fruto de um ato, ou sobre o próprio ato, para agir melhor com os demais, na realidade". 
Acreditamos que a forma de multiplicação do conhecimento adotada pela Pastoral da Criança permite que isso ocorra, pois tanto as capacitações como os materiais de comunicação contam com a participação dos líderes, que o tempo todo tem em si os papéis de educador e educandos.

Os homens, em seu processo, como sujeitos do conhecimento e não como recebedores de um "conhecimento" de que outro ou outros lhes fazem doação ou lhes prescrevem, vão ganhando a "razão" da realidade. Esta, por sua vez, e por isto mesmo, se lhes vai revelando como um mundo de desafio e possibilidades; de determinismos e de liberdade, de negação e de afirmação de sua humanidade; de permanência e de transformação; de valor e desvalor; de espera na esperança da busca, e de espera sem esperança, na inação fatalista. (FREIRE, 1977, p.84)

\section{4 - Uma comunicação que educa e liberta}

Outra obra de Paulo Freire dos anos 60 é Educação como prática da liberdade. $\mathrm{Na}$ abertura, assinada pelo autor em 1965, também no Chile, Freire (2008, p.45) diz retomar "um pouco da história dos fundamentos e dos resultados" alcançados no Brasil a partir dos trabalhos de alfabetização que realizou aqui, como os círculos de cultura. Esses círculos lançaram suas sementes, e as reuniões da Pastoral da Criança apresentam várias características desses encontros assim como também apresentaram as CEBs.

Os homens do povo que tomaram parte dos círculos de cultura fazem-se cidadãos politicamente ativos ou, pelo menos, politicamente disponíveis para a participação democrática. Esta atualização política da cidadania social e econômica real destes homens excluídos pelas elites tradicionais contém implicações de amplo alcance. (WEFFORT, 2008, p.26)

Ao analisar uma experiência datada, vivenciada na prática da educação popular, antes do golpe, Freire (2008) delineia uma prática educativa com características universais, que ultrapassa as barreiras de tempo e espaço. Um dos pontos criticados pelo autor é o assistencialismo. "O assistencialismo faz de quem recebe a assistência um objeto passivo, sem possibilidade de participar do processo de sua própria recuperação”. Ainda alerta para a "violência do antidiálogo" dessa prática, que impõe à pessoa o "mutismo e passividade", sem oferecer condições para o desenvolvimento da consciência crítica. (FREIRE, 2008, p.65) 
Na Pastoral da Criança, as líderes não devem ser assistencialistas em relação às mães. Isso costuma ser tratado nas formações e reuniões. Por exemplo, se uma mãe está desempregada, pode ser encaminhada para a capacitação do programa de geração de renda em serviços domésticos. Todas as pessoas que passam pelo curso aprendem técnicas para lavar e passar roupas. Também têm aulas sobre economia na cozinha, higiene e manipulação de produtos de limpeza. Durante o curso, são encaminhadas para os locais de trabalho. O projeto é destinado para as mães e líderes da Pastoral da Criança, que estejam desempregadas.

Certamente o curso não tem um caráter libertador em relação à opressão, mas não se pode negar que gera uma transformação na vida das pessoas, que sem trabalho, não tem nem como conseguir o sustento de sua família. Isto é o que ouvimos de pessoas que passaram pelo curso em agosto de 2008: "Voltar ao campo de trabalho é uma grande coisa. É fazer parte da sociedade de novo. Sem trabalho, você é um desconhecido". A frase dita por Roseli Bueno Neri, moradora do bairro da Casa Verde, zona norte de São Paulo, mostra a importância de ter conseguido um trabalho aos 51 anos. Após a capacitação, ela trabalha em uma casa na Chácara Santo Antônio, zona sul, cuidando de três crianças. Antes disso, na casa de Roseli, todos estavam desempregados. Ela vive com os três filhos, a nora, o neto e a mãe dela de 83 anos.

A transformação também pode ser vista na fala de outra mãe da Pastoral da Criança, moradora de Parelheiros, extremo sul de São Paulo: Maria José de Araújo, de 31 anos, que vive com o marido e a filha. Como estava desempregada, uma voluntária da Pastoral da Criança lhe indicou o curso. Assim foi contratada para trabalhar na limpeza de um hospital em Santo Amaro, zona sul. "A Pastoral da Criança é muito importante na minha vida. É parte da minha família. Eu era calada, e as líderes me ensinaram um novo mundo”, relatou Maria José. De abril a outubro de 2008, 72 pessoas foram capacitadas. Dessas, 49 estão trabalhando, com registro em carteira.

Há uma troca de experiências e conhecimento baseada no diálogo, como avalia a coordenadora do curso, Silvana Aparecida Gonçalves: "Conseguir um trabalho é uma dificuldade em nosso país. Essas mães vêm de longe. Muitas chegam com a autoestima lá embaixo. Mas no terceiro dia de aula já vemos a mudança. No final, somos nós que aprendemos com elas". Mais uma vez acreditamos que o alcance desses resultados é o diálogo. Mas ainda falta ao curso um olhar crítico aos problemas sociais. Talvez pudesse ser feita uma ação levantando questões de cidadania e políticas públicas como já ocorre nas reuniões e capacitações do voluntariado. No entanto, não podemos negar que essa capacitação tem como base o diálogo. 
Para Freire (2008, p.68-69), a própria existência do ser humano está ligada ao diálogo: entre as pessoas, com o mundo e sobre o mundo. "É essa dialogação do homem sobre o mundo e com o mundo mesmo, sobre os desafios e problemas, que o faz histórico". Assim defende uma "educação dialogal e ativa, voltada para a responsabilidade social e política".

Sobre a sociedade brasileira, criticava o "mutismo do homem" e a "não-participação na solução dos problemas comuns". A colonização que tivemos resultou em uma falta de vivência comunitária. Os núcleos urbanos nascem de cima para baixo. (FREIRE, 2008, p.7880) Nos anos 60, via uma fase de transição e a voz do povo, o que levou à "rachadura" da sociedade (2008, p.86). A democracia como forma de vida precisa do debate das pessoas, que devem examinar os problemas comuns e se caracterizar pela participação (2008, p.88). Assim, defendia:

\footnotetext{
Uma educação que possibilitasse ao homem a discussão corajosa de sua problemática. De sua inserção em sua problemática. Que o advertisse dos perigos de seu tempo para que, consciente deles, ganhasse a força e a coragem de lutar... Educação que o colocasse em diálogo constante com o outro. Que o predispusesse a constantes revisões. A análise crítica de seus "achados". A uma certa rebeldia, no sentido mais humano da expressão. (FREIRE, 2008, p.98)
}

Acreditamos que as reuniões, capacitações e a ação das líderes buscam inseri-las em um debate democrático, que multiplica o conhecimento sobre direitos e deveres como também reflete sobre os problemas comuns das comunidades em relação às crianças e às famílias. Isso inclui saúde, alimentação, trabalho, moradia digna. Pontos que são discutidos pelas voluntárias.

No Encontro de Multiplicadores, em março de 2008, foi levantado que os líderes da Pastoral da Criança não podem ser um burocrata da informação como um médico sanitarista e devem ter um olhar humano para levar condições melhores para as pessoas. Também se debateu a importância de se trabalhar a cidadania e os direitos com as famílias. São os cristãos incomodados de que se falou na Assembleia da Lapa, que querem mudar a realidade, em março de 2009. A cidadania também esteve em pauta na Assembleia da Arquidiocese de São Paulo, em 05/04/2009, quando se falou da necessidade de que voluntários e voluntárias da Pastoral da Criança discutissem políticas públicas a partir das necessidades do dia-a-dia das comunidades e não como uma imposição.

Quando Paulo Freire fala em suas obras de "consciência crítica" e de "transformação da realidade" está também falando desses cristãos incomodados da Pastoral da Criança. Assim 
na sua experiência de educação popular antes mesmo dos anos 60 ele criou um "método ativo que fosse capaz de criticizar o homem através do debate de situações desafiadoras, postas diante do grupo" e que fossem "existenciais" para eles. Estabelecendo, então, um "método ativo, dialogal, participante”. (FREIRE, 2008, p.114-115)

Freire (2008, p.116) chega ao "conceito antropológico de cultura", em que distinguiria o mundo natural e o da cultura, mostrando "o papel ativo do homem em sua e com sua realidade”. Dessa forma, os círculos de cultura traziam situações existenciais a partir de temas geradores e debate. Em uma delas, o educador mostrou aos participantes um figura que ilustrava o próprio círculo de cultura. Os participantes, que estavam sendo alfabetizados, logo se identificavam e começavam o debate:

\footnotetext{
"A democratização da cultura", disse certa vez um desses anônimos mestres analfabetos, "tem que partir do que somos e do que fazemos como povo. Não do que pensem e queiram alguns para nós." (...) Em duas noites são discutidas estas situações, motivando-se intensamente os homens para iniciar, na terceira, a sua alfabetização, que é vista agora como uma chave para abrir a eles a comunicação escrita.

Só assim a alfabetização cobra sentido. É a conseqüência de uma reflexão que o homem começa a fazer sobre sua própria capacidade de refletir. Sobre sua posição no mundo. Sobre o mundo mesmo. Sobre o seu trabalho. Sobre seu poder de transformar o mundo. (FREIRE, 2008, p.150)
}

Vimos na Pastoral da Criança debates e reflexões tão ricas quanto do homem que foi alfabetizado por Paulo Freire. Esse ambiente crítico, de consciência de si mesmo, do mundo e dos problemas existentes dos círculos de cultura ocorrem também nas reuniões, capacitações e ações das líderes da Pastoral da Criança como também ocorreram e podem estar ocorrendo nas Comunidades Eclesiais de Base.

Como nas CEBs se ressaltou o método "ver, julgar e agir". Em várias reuniões vimos citarem ou usarem o método. No Encontro de Multiplicadores de março de 2008, por exemplo, a metodologia foi mais uma vez explicada. É preciso “ver” com os olhos de Jesus. O "julgar" é analisar como melhorar a situação e sem preconceitos. O "agir" é pensar de que forma podemos agir e fazer. O "avaliar" é ver o que fizemos e refletir. Já o "celebrar" é agradecer a Deus por partilhar com a família, é sair da visita dizendo como foi bom estar lá e falar o que a família precisa ouvir.

Puntel (1994, p.236) descreve as CEBs de forma que nos faz ver mais semelhanças com as ações desenvolvidas pela Pastoral da Criança. A autora aponta um "processo participativo de comunicação desenvolvido pelo grupo através de suas discussões", o que leva inclusive a "cursos de religião, de alfabetização e de higiene". Essas discussões estão 
presentes nas reuniões da Pastoral da Criança assim como cursos de alfabetização e o de serviços domésticos.

Mas nem todos percebem essas semelhanças entre as CEBs e a Pastoral da Criança ou da organização com os conceitos freireanos. Brolhani (2004) faz uma análise política da Pastoral da Criança a partir da autonomia dos movimentos sociais. Retrata as CEBs como um espaço privilegiado para "as primeiras reflexões sobre as contradições de gênero para mulheres de classe menos privilegiada e operárias" (2004, p. 59). Conclui que através das Comunidades mulheres até então oprimidas vão para o movimento social e há uma participação que leva a conquista da cidadania, apesar das "limitações de consciência feminista, devido muitas vezes a fatores do conservadorismo popular assim como a internalização e identificação com o papel tradicional da mulher expresso no catolicismo" (2004, p. 60).

\begin{abstract}
Nosso interesse em estudar a Pastoral da Criança foi em decorrência de compreender como a Igreja Católica está vinculada na transformação social nos dias de hoje, após o declínio das CEBs. Presumimos que a Pastoral da Criança no contexto de ambigüidade dos espaços religiosos atuais poderia ser uma forma alternativa da Igreja e estar vinculada a questões sociais. Este contexto é refletido com a convivência do discurso da Teologia da Libertação pelas CEBs e do movimento carismático mais identificado com formas de ação social de caridade e assistencialismo. As mulheres têm sido as principais agentes dessas transformações e assim procuramos mostrar o potencial libertador e/ou reprodutor desses contextos nas suas vidas. (BROLHANI, 2004, p.131)
\end{abstract}

Brolhani (2004, p. 188) afirma que o site da Pastoral da Criança diz que o trabalho da organização busca que as famílias se tornem "sujeitos de sua própria transformação pessoal e social". Classifica isso como "discurso próprio das CEBs em decorrência da influência de Paulo Freire”. Mas na prática de sua pesquisa em Campo Largo/PR concluiu que havia "formas pedagógicas mais tradicionais vinculadas às formas de ações de educação de saúde de herança higienista e feitas a partir de formas de pedagogia autoritária”.

Não vimos isso em São Paulo, onde os debates sobre o conteúdo e as questões sociais sempre estão presentes. Na Assembleia da Arquidiocese de São Paulo, em abril de 2009, por exemplo, discutiu-se a questão da violência, motivados pela Campanha da Fraternidade de 2009. Os presentes elencaram situações que vão além das agressões físicas, como não ser atendido em um hospital, falta de vaga na creche, falta de um espaço de lazer. Também presenciamos discussões sobre esse tema na Assembleia da Lapa e na reunião dos coordenadores do Setor Sé, ambas em março de 2009. 
Nesse encontro de abril, a questão das políticas públicas voltou a ser debatida. A Pastoral da Criança da Arquidiocese de São Paulo também tem um representante no Fórum de Atenção Integral à Saúde da Criança em Situação de Risco Social, da região central. Há parcerias com hospitais, atendimento fonoaudiológico e psicológico, que permitem o encaminhamento de crianças acompanhas pela Pastoral. Não apenas se discute como conseguir mudanças nas comunidades, como se estimula ações tanto em nível local como nas parcerias buscadas pela coordenação arquidiocesana da Pastoral da Criança.

No entanto, Brolhani (2004, p.198) avalia que ver a Pastoral da Criança como continuidade das atividades das CEBs pode ser uma visão parcial, pois se por um lado o discurso é ligado aos pressupostos da Teologia da Libertação, a prática não é mesma. Ela não vê o sentido de transformação nem conscientização das bases populares.

Na pesquisa participante que realizamos em São Paulo observamos similaridades com as CEBs e acreditamos que não há na Pastoral da Criança uma discussão que leve a uma revolução social ou política. Mas entendemos que existe sim a conscientização em prol de direitos e deveres, além do estímulo ao exercício da cidadania, através de participação em Conselhos, debates sobre questões sociais ligadas à saúde da criança e problemas vivenciados como violência doméstica, falta de diálogo e outros. Também presenciamos uma educação que vai ao encontro da pedagogia de Paulo Freire.

Talvez essas diferenças de interpretação se devam a três pontos que Brolhani (2004) coloca. A região estudada por ela não tem histórico de CEBs, o Movimento da Renovação Carismática está na região há 10 anos e as entrevistadas não tiveram uma educação política que as possibilitasse questionar a opressão de classe, gênero e raça, pois não participaram de movimentos populares nem mesmo católicos.

Já em São Paulo, vimos uma prática pedagógica freireana. Nesse sentido, outra obra de Paulo Freire importante para entendermos o papel da educação é Pedagogia do Oprimido, de 1968. Nela, aprofunda as discussões do livro anterior - Educação como prática da liberdade. Um dos pontos que aborda é a contradição entre opressores e oprimidos, mostrando como superá-la, fazendo-se com que os oprimidos descubram o opressor que carregam em si: “(...) os oprimidos, em vez de buscar a libertação na luta e por ela, tendem a ser opressores também, ou subopressores. A estrutura de seu pensar se encontra condicionada pela contradição vivida na situação concreta, existencial, em que se formam". (FREIRE, 2005, p.34-35) Trata-se de uma reflexão importante, pois as líderes não podem se tornar opressoras das mães ao sair da condição de oprimidas. 
A violência dos opressores, que os faz também desumanizados, não instaura uma outra vocação - a do ser menos. Como distorção do ser mais, o ser menos leva os oprimidos cedo ou tarde, a lutar contra quem os fez menos. E esta luta somente tem sentido quando os oprimidos, ao buscarem recuperar sua humanidade, que é uma forma de criá-la, não se sentem idealistamente opressores, nem se tornam, de fato, opressores dos opressores, mas restauradores da humanidade em ambos. (FREIRE, 2005, p.32-33)

Há uma necessidade de "superar a situação opressora". Para tanto, é necessário o "reconhecimento crítico" dessa situação, permitindo que ocorra uma "ação transformadora", que "possibilite a busca do ser mais". Precisam "expulsar o opressor de dentro de si":

Sua luta se trava entre serem eles mesmos ou serem duplos. Entre expulsarem ou não o opressor de "dentro" de si. Entre se desalienarem ou se manterem alienados. Entre seguirem prescrições ou terem opções. Entre serem espectadores ou atores. Entre atuarem ou terem a ilusão de que atuam na atuação dos opressores. Entre dizerem a palavra ou não terem voz. (FREIRE, 2005, p.38)

Diante disso, qual é a opção das líderes em sua atuação na Pastoral da Criança? Elas apenas seguem a prescrição da organização ou atuam e têm voz? Pela organização que presenciamos e o nível de discussões que acompanhamos nas reuniões e discussões acreditamos que elas atuam e têm voz. Claro que a reprodução do opressor pode se manifestar, pois por mais que se discuta a questão do preconceito, as próprias líderes estão vivenciando isso. O que não inviabiliza o trabalho nem o caráter transformador. Mais uma vez usamos Josefa Gonçalves Leite, não alfabetizada, que vive na Vila Jaguari, em Pirituba. Ao falar de sua atuação como líder, afirma: "Primeiro, a gente precisa ter fé; em segundo lugar, força de vontade; e, em terceiro, amar o que faz. Se não tiver, nós não vamos em frente, porque a gente luta com pessoas que mesmo que tenham estudo, são pessoas que moram em favela. Pessoas que não entendem coisa com coisa".

Ao fazer essa afirmação, Josefa reproduz um preconceito enraizado na sociedade, mas também fala do preconceito que ela mesma sofre por não ter estudo. Isso também não impede que ela lute por ter voz e para mudar a realidade, fazendo isso ela está lutando para expulsar esse opressor de si. Basta observar como ela vê os problemas sociais e mais adiante define cidadania. Há uma consciência social aliada à fé e vontade de mudar a realidade:

A gente tem que ter fé, tem que orar e tem que ter muita garra. Tem muita criança necessitada em nosso país e tem muita pobreza como você sabe. É dificultoso, mas não é nada difícil para Deus.

(...) 
Não é só pegar o título e votar, é ter o respeito, ser reconhecido não para se exaltar, mas a gente ter o respeito e respeitar os outros. Cidadania é isso, a gente respeitar, lutar, ter o conhecimento e não só votar. E na hora que nós tivermos uma reclamação para fazer, ter mais gente para reclamar.

Para Freire (2005, p.40), mesmo o opressor pode se solidarizar com o oprimido, o que exige em "com eles lutar para a transformação da realidade objetiva que os faz ser este 'ser para outro'." Acreditamos que a ação da Pastoral da Criança permite que pessoas de diferentes níveis de educação formal e econômico se unam em prol da transformação da realidade das famílias visitadas; o que inclui informação sobre saúde e direitos, mas também mudança de atitude.

Mais uma vez Freire $(2005$, p.42) ressalta a importância da práxis: "é reflexão e ação dos homens sobre o mundo para transformá-lo. Sem ela é impossível a superação da contradição opressor-oprimidos". Ainda alerta que "o mero reconhecimento de uma realidade que não leve a esta inserção crítica (ação já) não conduz a nenhuma transformação da realidade objetiva.

A educação libertadora se baseia no diálogo e traz em si a ação e a reflexão (FREIRE, 2005, p.43-44). Vemos essa prática na Pastoral da Criança, em que as líderes, na maioria das vezes, são da comunidade, vivenciando a ação (visitas e transformação da realidade) e a reflexão (reuniões de avaliação, capacitações, jornal, rádio e comunicação popular). Tanto uma quanto a outra, que presenciamos na pesquisa de campo ou nas análises, estão baseadas no diálogo.

A pedagogia do oprimido, como pedagogia humanista e libertadora, terá dois momentos distintos. $\mathrm{O}$ primeiro, em que os oprimidos vão desvelando o mundo da opressão e vão comprometendo-se, na práxis, com a sua transformação; o segundo, em que, transformada a realidade opressora, esta pedagogia deixa de ser do oprimido e passa a ser a pedagogia dos homens em processo de permanente libertação. (FREIRE, 2005, p.46)

O diálogo, nesse processo, é fundamental. Não se trata “de 'depositar' a crença da liberdade nos oprimidos". Como sujeitos, inserem-se lucidamente na realidade, na situação histórica, e constroem uma percepção crítica da situação e, na práxis, vão transformá-la. (FREIRE, 2005, p.61)

Também é importante que nessa prática pedagógica, seja através das capacitações, reuniões ou materiais de comunicação e educativos, não se faça uma educação "bancária", nem da Pastoral da Criança para as voluntárias, nem das líderes para as mães. "Na visão 
'bancária' da educação, o saber é uma doação dos que se julgam sábios aos que julgam nada saber" (FREIRE, 2005, p.67).

(...) a razão de ser da educação libertadora está no seu impulso conciliador. Daí que tal forma de educação implique a superação da contradição educador-educandos, de tal maneira que se façam ambos, simultaneamente, educadores e educandos.

$\mathrm{Na}$ concepção 'bancária' que estamos criticando, para qual a educação é o ato de depositar, de transferir, de transmitir valores e conhecimentos, não se verifica nem pode verificar-se essa superação. Pelo contrário, refletindo a sociedade opressora, sendo dimensão da 'cultura do silêncio', a 'educação' 'bancária' mantém e estimula a contradição. (FREIRE, 2005, p.67)

$\mathrm{Na}$ Pastoral da Criança, a base da educação é a multiplicação. No Encontro de Multiplicadores em São Paulo, no dia 29/03/2008, entrevistamos o multiplicador do estado Isaac Elias Filho e também perguntamos sobre o significado desse processo educativo pela multiplicação. “A Pastoral da Criança trabalha com líderes, capacitadores, multiplicadores e os coordenadores das diversas instâncias. Para a gente ter o líder, é preciso capacitá-lo. E para a gente ter o capacitador, é preciso de alguém que o capacite.” Esse é o multiplicador e se está trabalhando para que cada setor tenha o seu multiplicador. "Isso dá para o setor a possibilidade de aumentar o número de capacitadores, que colocarão os líderes em condição de fazer os trabalhos nas comunidades".

Já para o voluntariado se tornar líder é preciso passar por uma capacitação de 15 encontros, com duração de três horas cada. "Depois disso, há o processo de formação contínua nas reuniões mensais que ocorrem na comunidade ou setor da diocese. É uma oportunidade de eles retomarem as dificuldades que forem aparecendo", explica Elias Filho. Isso faz com que sempre haja uma renovação da discussão do conteúdo como forma de avançar e aprofundar o conhecimento. O jornal da Pastoral também dá sua contribuição para a formação, como relata o multiplicador:

A gente procura usar o material com o líder. Há várias seções como a Aprendendo Mais. Às vezes há uma seção específica com um tema em relação a desenvolvimento. Então a gente procura orientar os capacitadores e coordenadores para levar esse conteúdo e discuti-los, ou nas reuniões mensais, ou nas capacitações que estiverem acontecendo. O jornal tem bastante conteúdo: fala das comunidades, dos setores, das festas e tem o assunto que é mais específico e dirigido, que é a questão da espiritualidade e da mística como também tem as questões de saúde, educação e alimentação. 
Um dos pontos criticados por Freire (2005, p.68) é o fato de que "o educador escolhe o conteúdo programático; os educandos, jamais ouvidos nesta escolha, se acomodam a ele". Se observarmos as líderes e coordenadoras como educandas, elas são ouvidas pela Pastoral da Criança a partir dos diversos mecanismos de participação existentes: reuniões, encontros, assembleias, capacitações, jornal, relatórios enviados à Coordenação Nacional. No entanto, não há um mecanismo direto da Pastoral da Criança que ouça as mães acompanhadas. São as líderes que passam à Pastoral o que acontece. Em todo o processo de formação, percebe-se que há uma preocupação das líderes com o diálogo, mas talvez fosse necessário também criar mecanismos para uma maior participação das mães.

Há casos em que as próprias mães acabam virando líderes, no entanto, as líderes e coordenadoras da Pastoral da Criança poderiam organizar rodas de conversas com as mães, como já ocorre em algumas comunidades, da mesma forma a Pastoral poderia desenvolver um informativo direcionado para elas, além do Laços de Amor, que reúne diversos cartões com informações para as gestantes sobre saúde e cuidados na gravidez.

Seria interessante um jornal para as mães ou então que o próprio Jornal Pastoral da Criança passasse a ser distribuídos para elas e que contasse com uma seção em que as mães dessem seu testemunho e sua história, no moldes de Comunidades ou mesmo da coluna Testemunho, na qual uma líder conta sua experiência de vida com a Pastoral da Criança. Algumas líderes entrevistadas já separam matérias do Jornal Pastoral da Criança e levam nas visitas. Porém, se as comunidades recebessem jornais em quantidade suficiente para distribuir para as famílias, esse procedimento seria oficializado e o conhecimento se multiplicaria ainda mais.

Assim como defende Freire (2005, p. 69), a educação deve ser "estimulante do pensar autêntico, que não se deixa emaranhar pelas visões parciais da realidade, buscando sempre os nexos que prendem um ponto a outro, ou um problema a outro". Diferentemente da "concepção bancária" em que "a consciência é, em sua relação com o mundo, esta "peça' passivamente escancarada a ele, à espera de que entre nela" o mundo disciplinado pelo educador (2005, p.72). O que acontece é que "somente na comunicação tem sentido a vida humana". "O pensar do educador somente ganha autenticidade na autenticidade do pensar dos educandos, mediatizados ambos pela realidade, portanto, na intercomunicação". (2005, p.74)

A educação que se impõe aos que verdadeiramente se comprometem com a libertação não pode fundar-se numa compreensão dos homens como seres vazios a quem o mundo "encha" de conteúdos, não pode basear-se numa consciência especializada, mecanicistamente compartimentada, mas nos 
homens como "corpos conscientes" e na consciência como consciência intencionalizada ao mundo. Não pode ser a do depósito de conteúdos, mas a da problematização dos homens em suas relações com o mundo.

Ao contrário da "bancária", a educação problematizadora, respondendo à essência do ser da consciência, que é sua intencionalidade, nega os comunicados e existencía a comunicação. (FREIRE, 2005, p.77)

Nesse tipo de educação, caracterizada pelo diálogo: "ninguém educa ninguém, ninguém educa a si mesmo, os homens se educam entre si, mediatizados pelo mundo". Através do diálogo há "a superação de que resulta um termo novo: não mais educador do educando, não mais educando do educador, mas educador-educando com educandoeducador." Enquanto o educador educa, também é educado pelo educando, pois ambos são "sujeitos do processo". (FREIRE, 2005, p.78-79) E "quanto mais se problematizam os educandos, como seres no mundo e com o mundo, tanto mais se sentirão desafiados" (2005, p.80)

(...) na prática problematizadora, vão os educandos desenvolvendo o seu poder de captação e de compreensão do mundo que lhe aparece, em suas relações com ele, não mais como uma realidade estática, mas como uma realidade em transformação, em processo.

A tendência, então, do educador-educando como dos educandos-educadores é estabelecerem uma fórmula autêntica de pensar e atuar. Pensar-se a si mesmo e ao mundo, simultaneamente, sem dicotomizar esse pensar da ação. A educação problematizadora se faz, assim, um esforço permanente através do qual os homens vão percebendo, criticamente, como estão sendo no mundo com que e em que se acham. (FREIRE, 2005, p.82)

A transformação pode ocorrer porque "aprofundando a tomada de consciência da situação, os homens se 'apropriam' dela como realidade histórica, por isso mesmo, capaz de ser transformada por eles", homens e mulheres que se sentem sujeitos. Essa ação em "busca do ser mais" não pode se realizar "no isolamento", mas sim "na comunhão, na solidariedade dos existires”. Não há espaço para o individualismo. (FREIRE, 2005, p.85-86)

Mais uma vez vemos uma característica da Pastoral da Criança que é essa ação conjunta e solidária, em busca da efetivação dos direitos de cidadania do coletivo: a comunidade, que inclui as próprias líderes, as mães, as crianças e por extensão a família. A prática dialógica é fundamental para que essa transformação ocorra e a conscientização se dá por meio de uma prática comunicativa que educa e liberta.

"Existir, humanamente, é pronunciar o mundo, é modificá-lo. O mundo pronunciado, por sua vez, se volta problematizado aos sujeitos pronunciantes, a exigir deles novo pronunciar". Os seres humanos não se fazem no silêncio, "mas na palavra, no trabalho, na 
ação, na reflexão". Por isso esse "dizer a palavra verdadeira" é um direito de todas as pessoas. (FREIRE, 2005, p.90)

O diálogo é este encontro dos homens, mediatizados pelo mundo, para pronunciá-lo...

(...)

...o diálogo é uma exigência existencial. E, se ele é o encontro em que se solidarizam o refletir e o agir de seus sujeitos endereçados ao mundo a ser transformado e humanizado, não pode reduzir-se a um ato de depositar idéias de um sujeito no outro, nem tampouco tornar-se simples troca de idéia...(FREIRE, 2005, p.91)

\section{5 - A partilha do conhecimento}

No diálogo, "não há ignorantes absolutos nem sábios absolutos: há homens que, em comunhão, buscam saber mais". Trata-se de uma "relação horizontal", de "confiança entre sujeitos". Essa "confiança implica o testemunho que um sujeito dá aos outros de suas reais e concretas intenções”. (FREIRE, 2005, p.93-94) Vemos essa confiança entre as voluntárias e também entre as líderes e as mães da Pastoral da Criança. Como disse uma médica, voluntária da Pastoral da Criança, no Encontro dos Multiplicadores em março de 2008: "Entrar na casa do outro é uma conquista. Temos que cativar o outro e ter muito respeito. Nosso trabalho é diferente do agente de saúde. Nossa missão é dar uma vida mais digna para as pessoas. A gente não pode olhar o outro a partir da vida que a gente teve".

Para Freire (2005, p.96), o diálogo começa já na escolha do conteúdo programático. Propõe, assim, a investigação do "universo temático do povo ou o conjunto de seus temas geradores". Para tanto, usa-se uma metodologia dialógica para que se consiga, "ao mesmo tempo, a apreensão dos 'temas geradores' e a tomada de consciência dos indivíduos em torno dos mesmos". Pretende-se investigar o "pensamento-linguagem referido à realidade, os níveis de sua percepção desta realidade, a sua visão de mundo, em que se encontram envolvidos seus 'temas geradores'.” (2005, p.100-101)

É importante que a Pastoral da Criança tenha essa visão em relação às líderes e às mães. As voluntárias também devem ter essa postura investigativa sobre as mães. Para tanto, deve-se observar a realidade em que elas estão inseridas, suas visões de mundo e necessidades para saber quais os temas que devem ser debatidos nas reuniões e formações, o que deve ser abordado no jornal e no Guia do Líder. 
Como explica Freire (2005, p.102), chega-se ao tema gerador através da "experiência existencial" e de "uma reflexão crítica sobre as relações homens-mundo e homens-homens, implícitas nas primeiras". Os temas são geradores porque podem "desdobrar-se" em outros temas. Eles se encontram “encobertos pelas 'situações-limites', que se apresentam aos homens como se fossem determinantes históricas". Quando percebidos, esses temas exigem respostas transformadoras. Podem ser "localizados em círculos concêntricos, que partem do mais geral ao particular”. (FREIRE, 2005, p.108-109)

Ao observar uma sociedade, percebe-se que ela tem temáticas universais, mas também questões específicas. "Em um círculo mais restrito, observaremos diversificações temáticas, dentro de uma mesma sociedade, em áreas e subáreas em que se divide, todas, contudo, em relação com o todo de que participam”. (FREIRE, 2005, p.110)

Vemos nisso mais um desafio para a Pastoral da Criança, que além de descobrir esses temas geradores para incentivar suas discussões nas comunidades tem que lidar com o problema de falar com todo Brasil e as comunidades locais ao mesmo tempo. Então é fundamental que as líderes, coordenadoras e, principalmente, capacitadoras e multiplicadoras tenham liberdade e sejam incentivadas a descobrir esses temas em níveis locais, permitindo que o conteúdo nacional seja reconstruído e rediscutido a partir das necessidades e problemas das comunidades.

(...) a investigação do tema gerador, que se encontra contido no "universo temático mínimo" (os temas geradores em interação), se realizada por meio de uma metodologia conscientizadora, além de nos possibilitar sua apreensão, insere ou começa a inserir os homens numa forma crítica de pensarem seu mundo. (FREIRE, 2005, p.112)

(...)

Investigar o tema gerador é investigar, repitamos, o pensar dos homens referido à realidade, é investigar seu atuar sobre a realidade, que é sua práxis. (2005, p.114)

(...)

Os temas, em verdade, existem nos homens, em suas relações com o mundo, referidos a fatos concretos. Um mesmo fato objetivo pode provocar, numa subunidade epocal, um conjunto de temas geradores, e, noutra, não os mesmos, necessariamente. Há, pois, uma relação entre o fato objetivo, a percepção que dele tenham os homens e os temas geradores. (2005, p.115)

Como esclarece Paulo Freire (2005, p.117), é necessário investigar “o próprio pensar do povo". No caso da Pastoral da Criança, das voluntárias e mães. Essa investigação é feita com o povo, "como sujeito de seu pensar". "E se seu pensar é mágico ou ingênuo, será 
pensando o seu pensar, na ação, que ele mesmo se superará". Essa "superação não se faz no ato de consumir idéias, mas no de produzi-las e de transformá-las na ação e na comunicação".

É um "pensar crítico" sobre sua própria “condição de existir”, conscientizando-se. “A tarefa do educador dialógico é, trabalhando em equipe interdisciplinar este universo temático recolhido na investigação, devolvê-lo, como problema". Na "visão de mundo dos educandos" estão os "temas geradores". (FREIRE, 2005, p.118-119)

Vimos que a Pastoral da Criança desenvolveu mecanismos para ouvir as líderes seja no jornal ou nas reuniões. Quanto mais esses mecanismos forem ampliados e mais se ouvir as líderes, ao mesmo tempo em que se criem mecanismos para ouvir as mães, maior será a possibilidade de descobrir esses temas e colocá-los no jornal e programas de rádio da organização. Também é importante que no trabalho das líderes elas tenham liberdade para descobrir, refletir, debater e agir sobre os problemas de sua comunidade.

No caso de Paulo Freire (2005, p.120-128), primeiro os educadores se aproximavam das pessoas com uma conversa informal, falando de sua presença no local e objetivo, estimulando que alguns se tornassem auxiliares. Faziam reuniões, anotavam a forma de falar e de ser das pessoas da comunidade. Também faziam visitas nos ambientes de trabalho, nas organizações e reuniões locais, nas horas de lazer e nas casas. É preciso ver além das "situações limites": "o inédito viável". Com os dados, chegava-se a um conjunto de contradições, das quais eram eleitas algumas e codificadas em pinturas ou fotografias, representando situações conhecidas dos sujeitos, que iriam descodificá-las a partir de reflexão crítica, surgindo uma nova percepção.

Ocorriam círculos de investigação temática com no máximo 20 pessoas. As discussões eram gravadas e analisadas pela equipe interdisciplinar, com a presença do povo. Os temas surgidos em todo esse processo acrescidos de alguns que são vistos como fundamentais, ainda que não sugeridos pelo povo, eram trabalhados nos círculos de cultura. (FREIRE, 2005, p.130 e p.134)

Após elaborar o programa temático, confeccionava-se o material didático: fotografias, slides, cartazes, textos. Apresentavam-se entrevistas com especialistas e pequenas dramatizações. Discutiam-se artigos de revistas, jornais, capítulos de livro, o conteúdo editorial da imprensa e seus “comunicados". (2005, p.136-137)

Trazendo essa experiência dos anos 60 para a Pastoral da Criança vemos que as reuniões que já ocorrem podem ser usadas como momento de investigação temática, o que já ocorre de certa forma, mas pode ser aprofundado. Com a capacitação em comunicação popular, que está surgindo, os debates e o diálogo podem ser enriquecidos e o conhecimento 
ainda mais multiplicado. Vemos positivamente o fato da Pastoral da Criança transformar pessoas da comunidade em educadoras: as líderes. No entanto, é preciso estar atento para que não ocorra o seguinte problema:

\footnotetext{
(...) nos chamados "treinamentos de líderes" que, embora quando realizados sem esta intenção por muitos dos que os praticam, servem, no fundo, à alienação.

O básico pressuposto desta ação já é, em si, ingênuo. Fundamenta-se na pretensão de "promover" a comunidade por meio da capacitação dos líderes, como se fossem as partes que promovem o todo e não este que, promovido, promove as partes.

Na verdade, os que são considerados em nível de liderança nas comunidades, para que assim sejam tomados, necessariamente, refletem e expressam as aspirações dos indivíduos da comunidade.

(...)

No momento em que, depois de retirados da comunidade, a ela voltam, com um instrumental que antes não tinham, ou usam este para melhor conduzir as consciências dominadas e imersas, ou se tornam estranhos à comunidade, ameaçando, assim, sua liderança.

Sua tendência provavelmente será, para não perderem a liderança, continuar agora, com mais eficiência, no manejo da comunidade.

Isto não ocorre quando a ação cultural, como processo totalizado e totalizador, abarca a comunidade e não seus líderes apenas. Quando se faz através dos indivíduos como sujeitos do processo. (FREIRE, 2005, p.162)
}

Acreditamos que esse problema pode ocorrer na Pastoral da Criança, mas como exceção, não como regra. Isso porque qualquer pessoa da comunidade por ser líder, o que faz a pessoa se tornar uma líder não é a capacidade de liderança e sim o envolvimento dela com a ação em prol do desenvolvimento das crianças. A partir desse interesse, elas passam pela capacitação aliada com uma formação constante através das reuniões e materiais didáticos, de preferência sem sair da comunidade. Todo o conhecimento se dá a partir de muito diálogo e é através do diálogo que será levado para as famílias, buscando multiplicar o conhecimento, que é partilhado. As questões percebidas nas visitas ou levantadas pelas mães serão fruto de reflexão nas reuniões de avaliação, pois ação e reflexão caminham juntas na Pastoral da Criança.

Vemos a ação da Pastoral da Criança como dialógica, crítica e participativa, buscando transformar a realidade das comunidades e das famílias, através de um processo educativo voltado para a cidadania. Não há o sentido revolucionário de tomada de poder, mas uma busca para o reconhecimento dos direitos do cidadão numa verdadeira democracia composta por sujeitos de direitos. Essa transformação, em que se conhecem os direitos e se luta por sua efetivação, ocorre através dessa educação dialógica e participativa das voluntárias, ainda que 
elas muitas vezes não tenham consciência do que são políticas públicas ou de conceituar a cidadania, acabam vivenciando essas questões na prática.

Segundo Freire (2005, p.191), "na teoria dialógica da ação, os sujeitos se encontram para a transformação do mundo em co-laboração". Assim, "os sujeitos dialógicos se voltam sobre a realidade mediatizadora que, problematizada, os desafia. As respostas aos desafios da realidade problematizada é já a ação dos sujeitos dialógicos sobre ela, para transformá-la" (2005, p.193).

Outro destaque é a importância do testemunho, não como "um gesto no ar", mas sim como "uma ação, um enfrentamento, com o mundo e com os homens", que serve a organização (FREIRE, 2005, p.204). Esse testemunho é fundamental para a Pastoral da Criança, pois as líderes mostram para comunidade seu compromisso através dele. É a própria ação delas que cria a confiança com as famílias acompanhadas.

O autor (2005, p.205) ainda reconhece a importância da liderança, da disciplina, da decisão, dos objetivos, das tarefas a cumprir e contas a prestar para a organização. Mas esses quesitos não podem levar a coisificação das pessoas. Nesse sentido, a Pastoral da Criança consegue estabelecer esses pontos necessários para a organização ao mesmo tempo em que se estimula o diálogo, a participação e a reflexão sobre a ação realizada. “A teoria dialógica da ação nega o autoritarismo como nega a licenciosidade. E, ao fazê-lo, afirma a autoridade e a liberdade" (FREIRE, 2005, p.206). É através do diálogo que se faz a partilha do conhecimento.

\section{6 - A mobilização dos sujeitos}

A última obra de Paulo Freire (1992) que analisamos e comparamos com a prática educativa da Pastoral da Criança é Pedagogia da Esperança, publicada pela primeira vez em 1992 e considerada um reencontro com Pedagogia do Oprimido escrito em 1967, no Chile: “(...) discuto a esperança com que escrevi a Pedagogia do Oprimido” (1992, p. 65).

Um dos pontos que Freire (1992, p. 42) chama atenção é para "a relação entre a clareza política na leitura do mundo e os níveis de engajamento no processo de mobilização e de organização para a luta, para a defesa dos direitos, para a reivindicação da justiça”, que enfatiza em Pedagogia do Oprimido. Educadores e educadoras devem estar atentos a essas questões, que acreditamos estar presentes na educação praticada pela Pastoral da Criança. 
o educando precisa de se assumir como tal, mas, assumir-se como educando significa reconhecer-se como sujeito que é capaz de conhecer...

O educando se reconhece conhecendo os objetos, descobrindo que é capaz de conhecer, assistindo à imersão dos significados em cujo processo se vai tornando também significador crítico. (FREIRE, 1992, p.47)

Um ponto interessante retratado por Freire (1992, p.66) é a análise sobre as críticas que recebeu de norte-americanas entre 1970 e 1971 pelo uso de uma linguagem machista. É um ponto importante porque ainda hoje temos esse comportamento. A própria Pastoral da Criança, apesar de contar com 92\% de mulheres em sua liderança, muitas vezes, usa "os líderes" no Jornal Pastoral da Criança. O uso do masculino ou do feminino depende da comunidade que enviou o texto, em relação à seção Comunidades. Geralmente os textos técnicos, a coluna Palavra do Pastor e o editorial usam o masculino. A exceção é o texto de Zilda Arns, que começa sempre com "Querida (o) Líder, Querido (a) Coordenador (a)" ou "Querido (a) Líder, Querido (a) Coordenador (a)".

(...) consideravam em mim uma grande contradição. É que, diziam elas, com suas palavras, discutindo a opressão, a libertação, criticando, com justa indignação, as estruturas opressoras, eu usava, porém, uma linguagem machista, portanto discriminatória, em que não havia lugar para as mulheres. (FREIRE, 1992, p.66)

Em todo o livro, Freire usava termos como "homens", "eles", sempre no masculino. Elas perguntavam: "Por que não, também as mulheres?". Num primeiro momento, pensou: “Ora, quando falo homem, a mulher necessariamente está incluída”. Mas logo percebeu a questão ideológica que há por trás disso: “Como explicar, a não ser ideologicamente, a regra segundo a qual se há duzentas mulheres numa sala e só um homem devo dizer: 'Eles todos são trabalhadores e dedicados?' Isso não é, na verdade, um problema gramatical mas ideológico". (FREIRE, 1992, p.67)

Também reflete sobre a forma como viu e continuava vendo a educação:

Não há como não repetir que ensinar não é a pura transferência mecânica do perfil do conteúdo que o professor faz ao aluno, passível e dócil. Como não há também como não repetir que, partir do saber que os educandos tenham não significa ficar girando em torno deste saber. Partir significa pôr-se a caminho, ir-se, deslocar-se de um ponto a outro e não ficar, permanecer. (...) Partir do "saber de experiência feito" para superá-lo não é ficar nele. (FREIRE, 1992, p.70-71) 
Esse é um ponto importante, pois ressalta o fato do educando ter suas visões de mundo e seu saber. A líder, quando entra na Pastoral da Criança também o tem, isso deve ser considerado nas capacitações e no jornal. Assim como as líderes devem, em sua ação, partir do saber da mãe para superá-lo. São sujeitos se mobilizando para mudar a comunidade e aprendendo em conjunto, a partir de suas realidades.

...não podemos deixar de lado... o que educandos... trazem consigo de compreensão do mundo, nas mais variadas dimensões de sua prática na prática social de que fazem parte. Sua fala, sua forma de contar, de calcular, seus saberes em torno do chamado outro mundo, sua religiosidade, seus saberes em torno da saúde, do corpo, da sexualidade, da vida, da morte, da força dos santos, dos conjuntos.

(...)

O respeito, então, ao saber popular implica necessariamente o respeito ao contexto cultural. A localidade dos educandos é o ponto de partida para o conhecimento que eles vão criando do mundo. (FREIRE, 1992, p.86)

A neutralidade é outra questão que retoma. Não há educação neutra. Mesmo a que diz não ser política o faz para "amaciar a possível rebeldia dos injustiçados". Logo tem uma opção política nisso. "Respeitar os educandos, porém, não significa mentir sobre os meus sonhos... Respeitá-los significa, de um lado testemunhar a eles minha escolha, defendendo-a; de outro, mostra-lhes outras possibilidades de opção...”. (FREIRE, 1992, p.78)

Pedagogia do Oprimido também recebeu críticas em relação à questão da luta de classes. Primeiro por optar por oprimido, um conceito vago, e não usar "luta de classes". No entanto, o autor contou mais de 20 usos do termo. Depois passou a ser criticado por usar algo ultrapassado. Assim reflete:

Nunca entendi que as classes sociais, a luta entre elas, pudessem explicar tudo..., daí que jamais tenha dito que a luta de classes, no mundo moderno era ou é o motor da história. Mas, por outro lado, hoje ainda e possivelmente por muito tempo, não é possível entender a história sem as classes sociais, sem seus interesses em choque.

A luta de classes não é o motor da história mas certamente é um deles.

(...)

Fazendo-se e refazendo-se no processo de fazer a história, como sujeitos e objetos, mulheres e homens, virando seres de inserção no mundo e não da pura adaptação ao mundo, terminaram por ter no sonho também um motor da história. Não há mudança sem sonho como não há sonho sem esperança.

Por isso, venho insistindo, desde a Pedagogia do Oprimido, que não há utopia verdadeira fora da tensão entre a denúncia de um presente tornando-se cada vez mais intolerável e o anúncio de um futuro a ser criado, construído, política, estética e eticamente, por nós, mulheres e homens. (FREIRE, 1992, p. 91) 
Para fazer uma análise dos sistemas políticos, Freire (1992, p.96) pega alguns números do UNICEF, dos anos 90, que apontavam a morte de cerca de 30 milhões de crianças menores de cinco anos, anualmente, por causas que seriam evitadas em países desenvolvidos. Ainda havia uma estimativa de morte de 100 milhões de crianças por desnutrição e doenças como sarampo, pneumonia, tétano, coqueluche na década de 90. Diante desses dados, analisa:

Que excelência é essa que, no Nordeste brasileiro, convive com uma exarcebação tal da miséria que mais parece ficção: meninos, meninas, mulheres, homens disputando com cachorros famintos, tragicamente, animalescamente, detritos nos grandes aterros de lixo, na periferia das cidades, para comer. E São Paulo não escapa à experiência dessa miséria (...)

Para mim, pelo contrário, o que não prestava na experiência do chamado "socialismo realista, em termos preponderantes, não era o sonho socialista, mas a moldura autoritária - que o contradizia e de que Marx e Lênin também tinham sua culpa e não apenas Stalin -, assim como o positivo na experiência capitalista não era e não é o sistema capitalista, mas a moldura democrática em que ele se acha. (FREIRE, 1992, p.96)

Quando afirmamos que a Pastoral da Criança e suas voluntárias e voluntários lutam por uma transformação, o fazemos porque há uma ação para que esses números denunciados pelo UNICEF mudem, o que é feito desde a fundação da entidade. Mas não se age apenas para que as crianças não adoeçam e se alimentem bem. Essa ação educativa possibilita a discussão dos problemas locais com os quais mães e líderes se deparam no dia a dia: drogas, violência, falta de saneamento, entre tantos outros, como presenciamos. Há também uma tomada de consciência sobre os direitos e como cobrá-los do poder público. Não se pode negar uma ação em favor da cidadania e da efetivação da democracia. São sujeitos de ação agindo para melhorar a comunidade.

Não vimos em nenhuma reunião, por exemplo, falarem explicitamente do sistema capitalista ou do socialismo, mas eram constantes as discussões sobre os problemas sociais vivenciados e as injustiças, discutindo-se como superá-los. Por outro lado, o Jornal da Pastoral da Criança não só fala desses direitos como incentiva a participação em conselhos municipais e na discussão de políticas públicas.

Nas próprias entrevistas, com as 61 voluntárias e voluntários da Pastoral da Criança na Arquidiocese de São Paulo, ouvimos essas preocupações. É o que mostra a fala de duas líderes e coordenadoras comunitárias da Região Episcopal da Lapa. Elas atuam em uma favela em um terreno invadido do Jardim Felicidade. Lá não há água encanada nem luz elétrica. "Uma coisa muito difícil de encarar é você ir dar alimentação para uma criança e ela 
chegar com o rosto e a mão toda suja porque não tem água. Quero que essa realidade mude, você vai para casa e não consegue dormir de noite", afirma Maria Lúcia Bosco Pinheiro. Ainda relata outros problemas: "Das seis crianças que visitei ontem, cinco estão com bronquite. Por que tem bronquite?" Ela mesma responde: "Porque a casa é um barraco que fica no meio daquela lama. Ficam com o chinelinho no meio daquela água suja da avenida. Não me conformo. Eles têm que ter um pouco de dignidade". Situação essa que pode ser explicada pela análise de Milton Santos $^{55}$ :

O homem-cidadão, isto é, o indivíduo como titular de deveres e direitos, não tem o mesmo peso nem o mesmo usufruto em função do lugar que se encontra no espaço total. Para começar, o acesso às fontes de informação não é o mesmo, Ora, na fase atual da economia, ser desinformado equivale a estar desarmado diante das mutações tão rápidas que atingem a vida cotidiana de cada um. (...) À medida que se vai descendo para a periferia (em termos de acessibilidade, e não em termos geométricos) as autoridades e as administrações com as quais se é obrigado a transigir detêm cada vez menos o prestígio e os meios para uma ação eficaz e rápida. (SANTOS, 2007, p. 112)

Benedita Lopes Carvalho de Moraes, de 68 anos, também é líder nessa favela e coordenadora de uma comunidade na aldeia guarani do Jaraguá. Ela acredita que a ação da Pastoral da Criança contribui para a conscientização, mas vê necessidade de que se procure fazer com que as líderes entendam melhor as famílias:

O trabalho da Pastoral da Criança contribui bastante para a conscientização, mas acho que a gente precisa trabalhar mais na Pastoral o sentido das líderes estarem entendendo o povo carente. Às vezes elas trabalham, mas criticam muito o modo que eles vivem. Fico preocupada nesse sentido. Essas mães que criam os filhos de uma forma que a gente critica, também foram criadas dessa maneira. As crianças que a gente atende, vão ser dessa mesma maneira? As líderes precisam entender melhor o porquê algumas pessoas acabam morando numa favela, o porquê a pessoa é agressiva com os próprios filhos, isso deveria melhorar na Pastoral, o trabalho com a liderança nesse sentido. (Benedita de Moraes)

\footnotetext{
${ }^{55}$ Milton Santos (2007) faz outras análises interessantes sobre a relação entre cidadania e espaço. O autor explica que "é impossível imaginar uma cidadania concreta que prescinda do componente territorial". Avalia ainda que “o valor do indivíduo depende do lugar em que está e que, desse modo, a igualdade dos cidadãos supõe, para todos, uma acessibilidade semelhante aos bens e serviços, sem os quais a vida não será vivida com aquele mínimo de dignidade que se impõe. Isso significa, em outras palavras, um arranjo territorial desses bens e serviços que, conforme a sua hierarquia, os lugares sejam pontos de apoio, levando em conta a densidade demográfica e econômica da área e sua fluidez. Num território onde a localização dos serviços essenciais é deixada à mercê da lei do mercado, tudo colabora para que as desigualdades sociais aumentem". (SANTOS, 2007, p.144)
} 
Para Freire (1992, p.100), “a libertação dos indivíduos só ganha profunda significação quando se alcança a transformação". Entrar na Pastoral da Criança é uma das possibilidades de se envolver nessa mudança, que depende de uma ação conjunta e que na organização ganha corpo através das capacitações, materiais didáticos e comunicativos, reuniões, visitas e acompanhamentos das crianças. Essa práxis faz com que não se fique apenas na discussão ou na ação vazia. Não basta conhecer a realidade para transformá-la, como alertou Paulo Freire ao criticar sua obra: Educação como prática da liberdade:

O meu equívoco não estava obviamente em reconhecer a fundamental importância do conhecimento da realidade no processo de sua transformação. O meu equívoco consistiu em não ter tomado estes pólos conhecimento da realidade e transformação da realidade - em sua dialeticidade. Era como se desvelar a realidade significasse a sua transformação. (FREIRE, 1992, p.103)

Vale ainda destacar que Paulo Freire não nega o papel do intelectual, como também não nega a necessidade do conteúdo. "Não há, nunca houve nem pode haver educação sem conteúdo" (FREIRE, 1992, p.110), no entanto os educandos têm que participar dessa organização, ou seja, serem sujeitos da aprendizagem.

Se trouxermos isso para a Pastoral da Criança veremos esse papel nos técnicos da organização: médicos, nutricionistas, jornalistas, entre outros, que trabalham as informações sobre saúde, desenvolvimento e direitos seja do Guia do Líder, Jornal Pastoral da Criança e outros materiais. Também estão presentes nas capacitações e estruturação das mesmas. São intelectuais pensando o conteúdo, mas também criando formas de participação das voluntárias nessa formulação.

Não acreditamos que essa participação ou os materiais vindos da Coordenação Nacional signifiquem, como aponta Brolhani (2004, p.213), que a Pastoral da Criança tenha "relações hierárquicas autoritárias e conservadoras". A autora critica ainda a capacitação "pela transmissão de conhecimento" e "habilitação técnica". O que difere do que encontramos em São Paulo, onde vimos capacitações centradas na vivência, no debate, em atividades práticas e que levavam a questionar o Guia do Líder, suas dificuldades, como lidar com diferentes situações, numa troca de experiências. Já as hierarquias existentes, coordenadores e líderes, não impediram que os encontros acompanhados apresentassem relações participativas e horizontais.

Por exemplo, no Encontro de Multiplicadores de março de 2008, os participantes receberam uma folha em branco para escrever as dificuldades que tiveram na capacitação e 
em relação ao Guia do Líder e todo o conteúdo, para que na próxima reunião a coordenação pudesse responder a essas dificuldades.

Os materiais trazem conteúdos técnicos sobre saúde, mas isso não significa que por isso a educação seja baseada na transmissão e habilidade técnica, pois todo material produzido conta com um debate que ouve coordenadores estaduais, que por sua vez ouviram os dos setores, que têm contato constante com as comunidades e as líderes. As próprias capacitações, sejam as que envolviam os multiplicadores, os capacitadores ou líderes, mostraram um debate constante sobre as realidades locais e como trabalhar o material a partir do que vive a comunidade.

Isso não quer dizer que não haja limitação. Na nossa pesquisa de campo, verificamos que o debate fica bastante centrado na questão da saúde da criança e da mulher, das dificuldades vivenciadas pelas líderes e pelas mães. Mas, por outro lado, há o incentivo para a inserção no debate de políticas públicas.

Presenciamos um caráter democrático das reuniões que acompanhamos, nas quais sempre havia espaço para todos falarem, todas muito participativas e dialógicas. Claro que isso não impede que exista problema com autoritarismo em situações específicas. Chegamos a presenciar uma reunião de coordenadoras de setores que tentavam encontrar uma solução para uma coordenadora de um ramo, que queria as coisas apenas do seu jeito e não aceitava ajuda dos outros. Se havia autoritarismo por parte dessa coordenadora, acreditamos que o fato de a coordenadora do setor abrir o problema para um grupo com outras coordenadoras mostra uma tentativa de resolver a questão a partir de um conjunto de opiniões. Sem contar que ter uma preocupação em todas as reuniões com o acolhimento fraternal das famílias e em explicar aspectos técnicos de saúde não significa autoritarismo, assistencialismo ou tecnicismo. Pelo contrário, há debates constantes em diversos níveis para que isso não aconteça. Como o próprio Freire diz:

...a leitura do mundo não pode ser a leitura dos acadêmicos impostas às classes populares. Nem tampouco pode tal leitura reduzir-se a um exercício complacente dos educadores ou educadoras em que, como prova de respeito à cultura popular, silenciem em face do "saber de experiência feito" e a ele se adaptem.

A posição dialética e democrática implica, pelo contrário, a intervenção do intelectual como condição indispensável à sua tarefa. E não vai nisto nenhuma traição à democracia, que é tão contraditada pelas atitudes e práticas autoritárias quanto pelas atitudes e práticas espontaneístas, irresponsavelmente licenciosas. (FREIRE, 1992, p.107) 
O autor ainda destaca a "necessidade imperiosa de se familiarizar com a sintaxe, com a semântica", com as leituras de mundo, com a cultura popular. A Pastoral da Criança precisa conhecer esse universo para falar com as líderes para que elas possam multiplicar o conhecimento com as mães. Dando espaço para as líderes também falarem à Pastoral, seja nas reuniões, assembleias ou jornais, conhecem não só o universo das voluntárias, como constroem o conhecimento e a reflexão em conjunto, para com a ação de acompanhamento das crianças, mudar a realidade. Nisso tudo, o diálogo é fundamental, permitindo que sujeitos falem, reflitam e criticamente cheguem ao conhecimento.

O diálogo tem significação precisamente porque os sujeitos dialógicos não apenas conservam sua identidade, mas a defendem e assim crescem um com o outro. O diálogo, por isso mesmo, não nivela, não reduz um ao outro. (...) Implica, ao contrário, um respeito fundamental dos sujeitos nele engajados, que o autoritarismo rompe ou não permite que se constitua...

(...) A relação dialógica, porém, não anula, como vezes pensa, a possibilidade do ato de ensinar. Pelo contrário, ela funda este ato, que se completa e se sela no outro, o de aprender... (FREIRE, 1992, p.118)

Nas reuniões vimos essas preocupações para que os sujeitos construíssem o conhecimento com o diálogo. Na própria Assembleia da Arquidiocese de São Paulo, em abril de 2009, as coordenadoras de setores e multiplicadoras presentes ressaltaram a importância da formação contínua e que "as partes envolvidas se mantenham comunicando, todos falando a mesma língua". Ressaltaram que na Arquidiocese de São Paulo não há barreiras para se comunicar com a coordenação da Pastoral da Criança. Percebem uma maior valorização da coordenação comunitária e da base, o que tem gerado uma "relação igualitária com as líderes". Nessa mesma reunião, um dos multiplicadores presentes ressaltou a importância de estarem próximos das comunidades, visitarem, "valorizarem o diálogo". Grande parte da reunião girou em torno da importância de descentralizar as ações, com capacitações locais e da necessidade dos coordenadores conhecerem as diferentes regiões.

Isso mostra uma preocupação para que não se caia no autoritarismo de que fala Brolhani (2004), como também deve haver uma preocupação para não se achar que as mães não sabem nada. Sempre presenciamos uma consciência crítica sobre as injustiças sociais do país. Mesmo ao relatar famílias que tinham problemas com drogas, vimos líderes questionando que essas mães também eram vítimas de uma situação que envolvia diversos problemas.

Por todos esses debates, que presenciamos nas mais diferentes reuniões e fomos relatando ao longo do texto, pelo incentivo à participação, seja nos mecanismos e seções 
criados no jornal ou pelos debates para a construção dos materiais, acreditamos que na Pastoral da Criança é o povo que fala. As líderes são da comunidade em que atuam ou das redondezas e conhecem a realidade local. Também vemos uma ação preocupada em mudar a realidade, principalmente, com as discussões envolvendo políticas públicas.

A apostila do Encontro Regional da Pastoral da Criança no estado de São Paulo, entre os dias 07 e 11 de julho, reafirma esse propósito político, que coloca as "políticas públicas de qualidade" como um "direito de cada cidadão". Há inclusive uma ação que propõe "ter articuladores atuantes em cada Conselho Municipal de Saúde onde a Pastoral da Criança estiver implantada, para que eles possam interferir significativamente na diminuição da mortalidade infantil". Esses articuladores também precisam estudar as causas das mortes de crianças acompanhadas pela Pastoral e elaborar propostas para a comunidade e para o Conselho de Saúde, a partir da realidade local. Para participar das políticas públicas, a apostila sugere: "educação continuada, participar das capacitações"; "divulgar as informações ... na comunidade local"; "mobilizar a comunidade para que participe ativamente nas decisões do Conselho", "articular-se e exigir que seja cumprido o que está previsto na lei, sobre saúde".

Todas as ações da Pastoral da Criança, envolvendo o diálogo e a participação, nos permitem afirmar que há uma contribuição para a construção da cidadania, seja pela reflexão sobre os problemas sociais como pela articulação de ações visando à melhoria da vida na família e na comunidade, pela multiplicação do saber. Mobilizações essas feitas por sujeitos organizados a partir da Pastoral da Criança.

\section{7 - A força da comunidade}

O que faz a Pastoral da Criança contribuir para a cidadania? Certamente esse espaço dialógico e participativo é um fator preponderante, mas não é o único. A educação aliada à comunicação popular em várias comunidades possibilita a construção de um ambiente em que se olhe para os problemas sociais e se discuta direitos e deveres. A comunicação popular

é um espaço de expressão democrática, vinculada aos interesses dos segmentos subalternos da população, tanto em sua metodologia quanto em sua forma e em seu conteúdo. Isso se evidencia nos fatos de ela: significar a abertura de novos canais para segmentos sociais sem garantia de acesso aos meios massivos para expor suas idéias e suas reivindicações; ser portadora de uma nuance democrática, ser constituída pelo ambiente onde se situa e 
ajudar a constituí-lo; participar na manifestação dos conflitos entre classes sociais nos campos dos interesses e da hegemonia; dispor de material (cartilhas, manuais, folhetos) que, em grande parte, apresenta a participação como princípio e aspiração, ao mesmo tempo em que divulga metodologias para divulgá-la. (PERUZZO, 1998, p.126)

Nesse processo, há uma busca pelo alargamento da cidadania pelos movimentos sociais, o que pode ser impulsionado pela comunicação popular, que surge "como uma necessidade e se realiza articulada às práticas sociais. Ela contribui com maior ou menor intensidade para a democracia, dependendo dos instrumentos, das formas e da metodologia que utiliza". (PERUZZO, 1998, p.302)

No caso da Pastoral da Criança, Faxina (2001) avalia que ao cuidar da criança carente e desnutrida, há um despertar para a cidadania:

Da criança passa para a situação da mãe, depois da família, do desemprego, do saneamento básico, do bairro, da presença nos conselhos municipais discutindo políticas públicas... É como partir do imediato para o distante, do particular para o geral, do concreto para o abstrato, do palpável para o 'incompreensível', do humano individual para o humano grupal. (FAXINA, 2001, p.198)

Esse despertar ocorre nas comunidades, que são os espaços propícios para a realização da comunicação e da educação popular. Sejam como receptoras da mensagem, sejam como construtora da mesma. A comunicação popular seria uma alternativa para informar as comunidades sobre a questão da cidadania. Mas em um contexto de globalização e de sociedade de massas em que vivemos, o que seriam as comunidades?

A comunidade é uma unidade estruturada, organizada, de grupos, dispondo de uma hierarquia homogênea de valores e à qual o indivíduo pertence necessariamente, essa necessidade pode decorrer do fato de se 'estar lançado' nela ao nascer, caso em que a comunidade promove posteriormente a formação da individualidade ou de uma escolha relativamente autônoma do indivíduo já desenvolvido. (HELLER, 1989, p.70-71)

Heller (1989, p.66-67) faz uma diferenciação entre grupo e comunidade. A relação entre indivíduo e grupo pode se basear na casualidade. No entanto, quando os fatores deixam de ser casuais, na medida em que a individualidade constrói os grupos a que se pertencem, esses grupos se convertem em comunidades.

O pertencimento a uma comunidade pode acontecer em consequência de uma necessidade exterior, segundo a autora. Mas também pode partir de uma necessidade interna, 
uma escolha individual. Antes da sociedade burguesa, as comunidades eram naturais. Não podiam ser objeto de uma escolha livre. As possibilidades de individualidade e hierarquia de valores eram determinadas no nascimento. Com a burguesia, são abolidas as comunidades naturais como integrações sociais primárias. Nasce a possibilidade de escolher a integração. É possível "não se tornar indivíduo mediante a nossa comunidade, mas ser capaz de escolher uma comunidade graças ao fato de já ser indivíduo" (HELLER, 1989, p.68).

As voluntárias e voluntários da Pastoral da Criança escolhem pertencer ao grupo dentro da comunidade. O processo educativo utiliza a "multiplicação" do conhecimento, que é disseminado comunitariamente. Assim explica a fundadora da organização, em entrevista realizada em 25/06/2009:

Eu me inspirei no evangelho de São João que narra a multiplicação de dois peixes e cinco pães, que alimentaram cinco mil pessoas, sem contar mulheres e crianças. Como Jesus fez? Mandou que a multidão se organizasse em pequenos grupos de 50 a 100. Então a Pastoral da Criança organiza grupos comunitários, que identificam famílias com gestantes e crianças menores de seis anos, e identificam lideranças de qualquer religião ou qualquer partido político, não existe discriminação de nada. Organiza essa comunidade e depois procura capacitar as líderes dessas comunidades, aprendendo muito sobre cuidados com as crianças, com as gestantes, com as famílias e cidadania. Há a mística da fraternidade, do amor, do voluntariado e multiplicação desse saber, essa solidariedade entre as famílias vizinhas. (Zilda Arns)

Heller (1989, p.73-76) explica que a sociedade burguesa separou o fato de pertencer a uma classe e o fato de pertencer a uma comunidade. $\mathrm{O}$ homem se converteu em um ser social não necessariamente comunitário. Não é obrigatório pertencer a uma comunidade assim como a existência individual não está determinada pela existência social. E quando se pertence a uma comunidade, trata-se de uma comunidade construída, que foi escolhida livremente.

As comunidades organizadas tendo em vista determinados fins históricos solicitam sobretudo determinadas capacidades dos indivíduos. Por isso, os indivíduos cujas capacidades inatas são congruentes com as qualidades mais importantes para as metas de uma comunidade têm maiores possibilidades de desenvolver sua individualidade do que aqueles cujas capacidades e talentos inatos estão fora de tal tendência.

Portanto, dois motivos podem estar na base da escolha de comunidade: o valor axiológico objetivo da comunidade, seus momentos favoráveis à essência humana; e a intenção de explicitar nela e através dela a própria individualidade. (HELLER, 1989, p.79) 
Isso significa que o conteúdo axiológico desse indivíduo se manifestará no conteúdo axiológico da comunidade por ele escolhida, ou seja, eles têm os mesmos valores. Assim, segundo Heller (1989, p.80-83), o conteúdo axiológico da comunidade ganha legitimidade através da individualidade. Já uma comunidade com conteúdo axiológico negativo não desenvolverá a individualidade nem o valor do indivíduo. Quando ocorre o contrário e se encontra uma comunidade com conteúdo axiológico positivo, há o cenário para que a individualidade se desenvolva.

$\mathrm{Na}$ Pastoral da Criança, vemos que os valores da organização e os valores das voluntárias e voluntários são os mesmos. Há uma identificação entre a pessoa e a própria Pastoral da Criança. Ambos se misturam como vemos na fala da coordenadora de ramo e líder de 28 anos, que vive e atua na Favela da Vila Prudente:

\begin{abstract}
A Pastoral contribui nessa parte de acompanhamento, porque a família vive sozinha, sem nenhum apoio e vem encontrar esse apoio dentro da Pastoral da Criança com a gente. Na medida do possível, o nosso trabalho, além do acompanhamento para a criança, tem o trabalho com a família. Também tem o trabalho de evangelização, de mostrar que a Pastoral da Criança não é só o momento da visita, mas é um todo. A gente tem que trabalhar isso com todas as famílias. (Ana Paula de Lima Silva)
\end{abstract}

A identificação também está na fala das entrevistadas, como vemos no depoimento de Maria Vila Nova de Sousa, 55 anos, do Setor Brasilândia: "Passado um ano, nós já estávamos conseguindo entrar nessas casas e nos tornamos uma família. Agora somos a família da Pastoral. Temos muitas famílias que são como minha família.” Fica clara também a percepção de que o trabalho deles, na Pastoral da Criança, contribui para a melhoria da comunidade e da cidadania, como afirma Eron Gonçalves de Aguiar, 45 anos, também da Brasilândia: "Contribui muito, porque você consegue fazer um trabalho em uma área em que a pessoa não tinha esse conhecimento. Muitos não se viam inclusos na comunidade. Tinham vergonha de se expor, por achar que eram menos do que os outros".

É uma ação da comunidade em prol de seus membros. Das 60 pessoas ouvidas das seis regiões episcopais de São Paulo, 57 vivem na região em que atuam. Ou elas moram na própria comunidade carente ou moram no mesmo bairro e vão fazer a ação em alguma favela ou cortiço local. As outras três entrevistadas têm uma ligação com o bairro em que atuam. Uma mora em Santa Cecília e faz a ação em Perdizes, onde frequenta a paróquia. Já as outras duas moraram no bairro e se mudaram, mas têm parentes que ainda moram na região. É o caso da bióloga de 45 anos, que atua como líder e capacitadora em Pirituba e mora em Perdizes: 
Resolvi fazer alguma coisa dentro da comunidade em que eu vivi. A minha ex-sogra já trabalhava lá e me convidou para trabalhar em uma favela que fazia fundo com a escola que eu estudei. Eu achei interessante trabalhar e me dedicar um pouco para a melhoria do local onde eu fui criada. Quando você vai trabalhar com as pessoas da comunidade, há certa resistência. Então você vai fazer um trabalho de cativar essas pessoas. Mostrar para ela o quão satisfatório é ela fazer a mudança no local em que ela vive, só que para isso você também precisa mudar o comportamento dela. Primeiro você tem que fazer um trabalho de mudança nela, para depois ela conseguir mudar a comunidade. Eu acho que para pegar uma pessoa de fora, é complicado, porque não é a realidade que ela vive. As pessoas que são de fora se espantam com aquela realidade, não querem entrar na casa de pessoas humildes. Quem não é do meio, se espanta um pouco e não encara. Até mesmo pela resistência que você tem da comunidade te aceitar. Para você entrar, as pessoas têm que te aceitar. Você tem que conquistar, depois você consegue realizar o trabalho bem e fica conhecido na comunidade inteira. (Maria Amélia da Silva)

$\mathrm{Na}$ época em que Faxina (2001, p.124), realizou sua pesquisa sobre a Pastoral da Criança, as mulheres contabilizavam aproximadamente 95\% dos voluntários. As líderes e os líderes comunitários representavam a maior porcentagem de atores sociais da entidade, chegando a $89 \%$ e vivendo nos próprios bolsões de pobreza e miséria em que atuam (2001, p.13-14). O autor caracteriza ainda a Pastoral da Criança como um movimento “comprometido com a inclusão na agenda social dos deserdados da ordem política, econômica e social vigente, criando condições para que todas as pessoas tenham respeitados seus direitos de cidadãos" (2001, p.66).

Atualmente vemos que $92 \%$ do voluntariado da Pastoral da Criança é formado por mulheres. Em nossa pesquisa, também percebemos essa emergência das questões sociais e da cidadania. Há o valor do grupo formado pela Pastoral e a questão da identidade, que unem essas pessoas na comunidade em que atuam, visando à construção de melhores condições de vida. São mulheres pobres que se unem para ajudar outras mulheres que vivem em dificuldade. Ou então que vivem próximas a essas famílias e tendo melhores condições econômicas, não se conformam com a situação em que vivem outras pessoas da comunidade.

A atuação da líder comunitária é de fundamental importância. É ela que visitará as famílias, trabalhará as informações sobre os cuidados para se combater a desnutrição e outros cuidados para o desenvolvimento das crianças. Dela depende a divulgação dos direitos. Isso é percebido na fala da líder e capacitadora da Fazenda da Juta (Belém), que tem 46 anos de idade e 23 de Pastoral da Criança: 
O trabalho é conhecer as dificuldades das famílias, das gestantes, das crianças e tentar mostrar para essas famílias que elas podem buscar meios para resolver os problemas na questão da saúde, da alimentação, na questão social, então, não é a gente resolver os problemas, mas mostrar que as famílias podem resolver. (Vera Lúcia Rodrigues Mangela)

Já uma multiplicadora da região Brasilândia 44 anos, explica a ação da liderança e dá vários exemplos de como contribuem para a construção da cidadania:

A gente procura mostrar para as mães os direitos que elas têm, de ir ao médico, da gestante ter sua curva uterina marcada e que a maioria dos médicos não marca, a pressão arterial anotada. É um direito que ela tem. Às vezes o médico até verifica e não anota. Ela precisa saber como está. A gente ensina essas mães a terem esse olhar. Ela pode questionar, pedir, é um direito de saber sua situação real. A gente pega carteiras de vacinação de criança que só tem o primeiro nome, é tudo incompleto, é um documento da criança que contem registros de vacinas importantes, que podem mudar uma situação. Quanto à certidão de nascimento e todos os direitos, às vezes, eles não têm essa orientação, e a gente procura fazer essa parte. A gente está contribuindo para a cidadania, para serem alguém melhor. (Débora Mara de Oliveira Soares)

Outro exemplo nesse sentido é a afirmação da líder Maria de Fátima Rodrigues de Freitas, 43 anos, do setor Ipiranga: "a gente está alertando para as crianças tomarem vacinas, as mães irem atrás dos direitos, como uma melhor moradia, como fazer melhor. Não dá para mudar tudo, mas podemos melhorar a situação". Voluntários e voluntárias se identificam na busca dos mesmos ideais como afirma a capacitadora Aparecida Gonçalves de Jesus, de 62 anos: "Eu frequentava a missa, e o padre sempre dizia que não adiantava ficar falando, a gente tinha que fazer alguma coisa. Resolvi procurar o que fazer, e o pessoal estava montando o grupo da Pastoral da Criança, acabei gostando, era isso mesmo que eu queria”.

A importância da identificação e da liderança para a Pastoral da Criança pode ser entendida a partir da psicanálise. Freud (1997) explica que cada indivíduo é componente de diversos grupos, com os quais é ligado por processos de identificação e constrói seu ideal do ego a partir de vários modelos. Partilhando de diversas mentes grupais, o indivíduo pode se elevar a elas. Por outro lado, nesses processos de identificação e construção da própria identidade, o ideal do ego pode ser substituído pelo ideal do grupo, que por sua vez, é personificado em uma liderança. Esse líder é escolhido por dar uma impressão maior de força e de mais liberdade de libido, fazendo com que os outros membros do grupo tenham o ideal do ego corporificado nele e sejam levados por "sugestão", ou seja, identificação. 
Essa líder da Pastoral ganhará destaque na comunidade e será a ela que as outras mães recorrerão. Haverá um processo de aprendizagem e troca de informações. Mas também um processo de identificação. Os processos de identificações permeiam por toda a vida como mostra Freud (1997) quando trabalha a identificação da criança com o pai ou com a mãe e depois com as identificações nos grupos.

Todo esse processo relaciona o sujeito, os grupos e o outro para a construção da identidade através de identificações. O sujeito se identifica com o outro, que pode ser tomado como modelo, mas também com os grupos de qual faz parte. Essas identificações contribuirão para a identidade do sujeito. Assim, as mães através da Pastoral da Criança conseguem construir não só uma identidade como grupo, mas também uma identidade como sujeito.

Essa tomada de modelo possibilitará as mudanças de hábitos que promoverão a nutrição das crianças. O que se deve pensar é que quando se agrupam indivíduos por um lado, separam-se esses mesmos indivíduos de outros. Criam-se grupos que se diferem entre si nas maneiras de pensar, de agir e que podem construir estigmas diante dessas diferenças. Dessa forma, a Pastoral da Criança e suas voluntárias e voluntários devem estar atentos para que não ajam de forma excludente na comunidade e sim inclusiva.

Observando-se a proposta da entidade, fica claro que ela age em prol de pessoas estigmatizadas na sociedade: pessoas pobres, que passam fome, sofrem com a desnutrição, com o desemprego e tantos outros problemas. Ao combater esses problemas, tenta-se tirar dessas pessoas a marca do estigma, que está extremamente ligado às questões culturais, econômicas e políticas que estigmatiza o grupo. A Pastoral da Criança realiza trabalho com os "outsiders" 56 de nossa sociedade. Promover a saúde de crianças e ao mesmo tempo orientar familiares não só sobre cuidados e deveres como também sobre direitos faz com que a Pastoral da Criança contribua para a construção da cidadania nas comunidades por ela atendida.

Outro ponto a ser considerado nesse processo educativo que leva a construção da cidadania é que, apesar da comunidade ser o espaço ideal para que se desenvolva a comunicação e a educação popular, vivemos em uma sociedade que pode ser definida como uma sociedade de massas. Para Heller (1989, p.84), a sociedade de massas impossibilita a decisão individual, sem a qual não pode haver comunidade. "A massa é co-participação de muitos homens numa ação determinante". Dessa forma, um grupo ou comunidade jamais

\footnotetext{
${ }^{56}$ Termo utilizado por ELIAS (2000) para descrever grupo estigmatizado e inferiorizado como pior. Levando-se em conta que as pessoas atendidas pela Pastoral da Criança são aquelas que enfrentam problemas como desemprego, fome e miséria, achamos devida a apropriação do termo.
} 
pode ser uma massa. Isso porque estão sempre articulados e estratificados, ao contrário da massa, que "pode ser perfeitamente aparecer não-estratificada e não-articulada" (HELLER, 1989, p.69). Logo, a ação da Pastoral da Criança também deve se preocupar em fazer com que essas pessoas que vivem em comunidade não ajam como massa.

A sociedade de massa favorece

a estrutura interna na qual não se podem desenvolver nem a individualidade, nem a comunidade; a socialidade dos homens, então, passa a expressar-se desde o primeiro momento como se todos formassem uma multidão manipulada e como se por todos os lados dominasse uma atitude de dispersão. 'Sociedade de massas', portanto, é uma expressão metafórica para descrever uma sociedade conformista manipulada. (HELLER, 1989, p.70)

Mas nem todos têm uma visão negativa da sociedade de massas. Para Gentilli (2005, p.28), nela há a possibilidade de "participação ampla de todos os homens na vida social cotidiana, à emersão de uma massa de sujeitos que passa a desfrutar da possibilidade potencial de acesso ou fruição a bens (materiais ou culturais)" ou a direitos que antes eram "apenas privilégio das elites". Por outro lado, o autor acredita que esses mecanismos de inclusão são perversos. O que não impede que ele defenda a possibilidade de uma democracia de massas, que conta com a contribuição do jornalismo para o exercício do direito de informação do cidadão.

Acreditamos que apesar da possibilidade de aniquilamento das comunidades pela sociedade de massa, as comunidades sobrevivem. Um indivíduo pode ao mesmo tempo em que está inserido na massa em determinadas situações, ser membro ativo de uma comunidade em outras. Nesse cenário, o jornalismo contribuiria cumprindo seu papel de informar sobre questões de cidadania.

No entanto, esse papel não é exclusivo do jornalismo, que muitas vezes deixa essa questão de lado. É essencial que a comunicação popular esteja engajada em informar suas comunidades sobre direitos e deveres, contribuindo para a construção da cidadania. E é isso que vimos, a partir de nossa pesquisa de campo, na comunicação e educação fomentada pela Pastoral da Criança nas comunidades. Mais do que isso, a comunicação popular abre espaço para que a comunidade também exerça o seu direito de comunicar. Ela não só recebe informações a que antes não tinha acesso como tem a possibilidade de informar o que está acontecendo localmente. 


\section{8 - O percurso da cidadania}

O jornalismo e a comunicação popular podem estimular a construção da cidadania, ao informar os cidadãos sobre seus direitos. Mas nem sempre a cidadania teve o destaque de hoje. Lima (2006, p.13) afirma que por muito tempo ela esteve longe dos debates acadêmicos, começando a aparecer com a Constituição Cidadã de 1988. Manzini-Covre (1993, p.7-8) relata que nos anos 60 e 70 a cidadania tinha uma conotação pejorativa, associada à democracia americana.

Para Manzini-Covre (1993, p.11), cidadania é o próprio direito à vida em sentido pleno, um direito que deve ser construído coletivamente. Assim, ser cidadão significa ter direitos e deveres. Vai muito além do direito de votar, por exemplo, que deve vir acompanhado de condições econômicas, políticas, sociais e culturais. Nesse sentido, a Constituição é um recurso para os cidadãos encaminharem e conquistarem propostas mais igualitárias.

Só existe cidadania se houver a prática da reivindicação, da apropriação de espaços, da pugna para fazer valer os direitos do cidadão. Nesse sentido a prática da cidadania pode ser a estratégia, por excelência para a construção de uma sociedade melhor. Mas o primeiro pressuposto dessa prática é que esteja assegurado o direito de reivindicar os direitos, e que o conhecimento deste se estenda cada vez mais a toda população.

As pessoas tendem a pensar a cidadania apenas em termos dos direitos a receber, negligenciando o fato de que elas próprias podem ser o agente da existência desses direitos. Acabam por relevar os deveres que lhes cabem, omitindo-se no sentido de serem também, de alguma forma, parte do governo, ou seja, é preciso trabalhar para conquistar esses direitos. Em vez de meros receptores, são acima de tudo sujeitos daquilo que podem conquistar. Se existe um problema em seu bairro ou em sua rua, por exemplo, não se deve esperar que a solução venha espontaneamente. É preciso que os moradores se organizem e busquem uma solução capaz de atingir vários níveis, entre eles o de pressionar os órgãos governamentais competentes (MANZINI-COVRE, 1993, p.10)

A cidadania, explica a autora (1993, p.11-15), contempla direitos civis, sociais e políticos. Os civis são os direitos de se dispor do próprio corpo. Eles dependem da existência dos direitos políticos, que por sua vez, dependem de um regime democrático. Já os direitos sociais são aqueles que tratam do atendimento das necessidades humanas básicas como alimentação, habitação, saúde e educação. Muitas vezes são usados pelos detentores do poder para administrar a classe trabalhadora, que deve saber ocupar os espaços acenados para 
reverter esse quadro. Os direitos políticos, por sua vez, são os que abordam a deliberação do homem sobre sua vida, o direito da livre expressão do pensamento, da prática política, religiosa. Eles se relacionam com a convivência com outros homens em organismos de representações e deliberação dos direitos sociais e civis.

$\mathrm{Na}$ concepção de Gentilli (2005), o jornalismo e, no nosso entendimento, a comunicação popular podem contribuir nessas três dimensões de direitos:

um jornalismo produzido em condições de oferecer, da melhor maneira possível, uma forma de conhecimento do mundo, que permita ao cidadão as condições de escolha quando se tratar de direitos políticos, que ofereça as informações básicas (jornalismo de serviços) para o desenrolar o cotidiano de suas atividades, que pense a práxis profissional no contexto amplo da ampliação da cidadania, do pluralismo, da liberdade, da democracia. (GENTILLI, 2005, p.143)

Ao explicar a trajetória da cidadania, Manzini-Covre (1993, p.16-26) explica que a origem da cidadania vem da polis grega, onde havia uma democracia restrita aos homens livres, que eram considerados cidadãos. Já na sociedade feudal, não há o exercício da cidadania, que passa a ser retomada com o desenvolvimento da sociedade capitalista. As revoluções burguesas foram primordiais para isso, especialmente, a Francesa (1789). Ela traz a igualdade para todos perante a lei. Rompe-se com o direito obtido pelo nascimento. Instaura-se o Estado de Direito.

As revoluções burguesas estabelecem constituições que delimitam o poder dos governantes e condensam a idéia dos direitos e da cidadania. São cidadãos que partilham a mesma norma e podem usá-las para se defender.

Quero assinalar o duplo recorte da ascensão do capitalismo, que identifica o seu aspecto contraditório. De um lado, trata-se do processo - o mais avançado que a humanidade já conheceu - de saída do imobilismo da sociedade feudal. Nessa evolução, despontou a cidadania, em sua proposta de igualdade formal para todos. De outro lado, porém, delineia-se o processo de exploração e dominação do capital. (MANZINI-COVRE, 1993, p.20)

A cidadania se desenvolve com o capitalismo e a visão burguesa. A valorização do trabalho, que vem com a ética protestante, foi o primeiro marco para a existência da cidadania. A Igreja Católica deixa o centro do poder. Valoriza-se a racionalidade dos homens, que são iguais pelo trabalho e pela capacidade que têm. É uma visão burguesa que preza o individualismo e um tipo de cidadania. Assim, quando a burguesia deixa de ser revolucionária para assumir o poder, vincula os direitos humanos aos que têm propriedade. É dessa forma 
que se explica a dominação da burguesia. Já uma cidadania mais efetiva, estende os direitos a todos.

No entanto, Manzini-Covre (1993, p.30-36) completa que a cidadania não é uma categoria estritamente burguesa. Ela pode ser apropriada pelos trabalhadores, que devem usar os poderes executivo, legislativo e judiciário, assim como os meios de comunicação, para construir a cidadania e estendê-la a todos.

O marxismo também contribui para a construção do conceito de cidadania ao criticar o uso dos direitos pela burguesia para dominar grupos. A força de trabalho, por exemplo, serve para pressionar e fazer valer os direitos. Ela ainda aponta as características do que seria a cidadania plena, que vem sendo ameaçada por um conceito mais esvaziado e apoiado no consumismo e imobilismo.

Não pode haver cidadania se não houver um salário condigno para a grande
maioria da população. O Trabalhador, enquanto mercadoria, deve lutar para
obter certa equivalência na troca estabelecida com o capitalista e o Estado. É
preciso que ele tenha acesso aos bens que complementam sua vida
(habitação, saúde e educação) e que compõem os chamados direitos sociais.
Mas, antes é necessário que os trabalhadores tenham direitos políticos, e que
existam mínimas condições democráticas para reivindicar o seu direito de
ser cidadão e de, enquanto e tal, poder batalhar, por quaisquer de seus
direitos. Por outro lado, é preciso que esses trabalhadores possam ser
educados sobre a existência desses direitos, vendo dessa forma a amplidão
do que há para construir em termos de uma sociedade sempre melhor.
(MANZINI-COVRE, 1993, p.37)

Vale ressaltar ainda que a concepção de sociedade civil na qual se reconhece o outro como sujeito de direitos legítimos é resultado de lutas sociais de movimentos e organizações nos anos 70 e 80. Já nos anos 90, esses espaços são estimulados por ONGs cidadãs, que consistem em ser entidades sem fins lucrativos que promovem e desenvolvem comunidades carentes a partir de relações de direitos e deveres da cidadania. (GOHN, 1997, p.302-303)

Desde a década de 1980, o conceito de cidadania ocupa um dos centros do pensamento social e político brasileiro. Sua relevância certamente vem do modo como intervém no debate público sobre os agudos níveis de exclusão social e política do país, vinculando-se, desde sua (re)descoberta naquela década, como parâmetro crítico de uma dupla transformação pela qual o país passa desde então. De um lado, a noção retrabalhada de cidadania passou a pautar um primeiro desafio histórico, a passagem das formas recorrentemente autoritárias de governo para uma democracia ampliada. De outro, define a tragédia do processo neoliberal em curso que visa a desregulamentação público-estatal da economia de mercado, cujo funcionamento, agora cada vez mais livre de limitações públicas, aprofunda 
e sedimenta os mecanismos de exclusão social e política tradicionalmente presentes na história de modernização do país. (PAOLI, 2002, p.376)

Outro fator a ser considerado é que as agendas dos órgãos públicos contemplam a interação com a sociedade civil. No entanto, essa interação ocorre segundo interesses das elites ou dos grupos que estão no poder. (GOHN, 1997, p.318)

\begin{abstract}
A partir do início dos anos 90, o uso do termo "cidadania" se difundiu cada vez mais pela sociedade brasileira. Enquanto a noção redefinida continuou subjacente às lutas populares e às práticas políticas de partidos políticos como o PT, e ONGs como as congregadas na Associação Brasileira de Organizações Não Governamentais (ABONG), a cidadania esteve também por trás de campanhas de solidariedade voltadas para a mobilização da classe média, tais como a Ação da Cidadania contra a Fome, liderada por Hebert de Souza (Betinho), ou as associações de empresários progressistas, tais como a CIVES (Associação Brasileira de Empresários pela Cidadania). Essa difusão se acentua ao longo da década e hoje a apropriação do termo cidadania se generalizou, com sentido e intenções obviamente muito diferentes. (DAGNINO, 2000, p.84)
\end{abstract}

A novidade é que nos anos 90 a cidadania já presente na década anterior terá seu exercício pensado de forma coletiva através de grupos e instituições que se legitimaram juridicamente a partir de 88 . Não se trata mais de reivindicar, pressionar ou demandar. É a hora de fazer, de propor, de participar qualificadamente. A exclusão social também ganha nova roupagem no período com a violência generalizada, a desagregação da autoridade estatal e o surgimento de estruturas paralelas de poder. Esses pontos acabam tendo efeito sobre as estruturas organizativas da população. (GOHN, 1997, p.288)

Em alguns casos, os movimentos sociais não somente conseguiram traduzir suas agendas em políticas públicas e expandir as fronteiras da política institucional, como também lutaram de maneira significativa para redefinir o próprio sentido de noções convencionais de cidadania, representação política e participação e, em conseqüência, da própria democracia. (ALVAREZ, DAGNINO, ESCOBAR, 2000, p.16)

Dagnino (1994) procura aliar os movimentos sociais à cidadania. A noção de cidadania, segundo a autora, emerge a partir dos anos 80 e está ligada à experiência dos movimentos sociais, que por sua vez, também contribuiu para a construção da democracia. A partir dessa movimentação, aparecem novos atores sociais e direitos. Surge a concepção do “direito a ter direitos" e é visível a luta dos excluídos pelo sistema econômico: 
A nova cidadania, ao contrário da concepção liberal, não se vincula a uma estratégia das classes dominantes e do Estado para a incorporação política progressiva dos setores excluídos, com vistas a uma maior integração social, ou como condição jurídica e política indispensável à instalação do capitalismo. A nova cidadania requer (e até pensada como sendo esse processo) a constituição de sujeitos sociais ativos, definindo o que eles consideram ser os seus direitos e lutando pelo seu reconhecimento. Nesse sentido, ela é uma estratégia dos não-cidadãos, dos excluídos, uma cidadania 'de baixo para cima'. (DAGNINO, 1994, p.108)

Outro ponto a se destacar é que essa nova cidadania só é possível por causa das experiências dos movimentos sociais. "Na organização desses movimentos sociais, a luta por direitos - tanto o direito à igualdade como direito à diferença - constituiu a base fundamental para a emergência de uma nova noção de cidadania”. Essa noção organiza a construção de uma cultura democrática. (DAGNINO, 1994, p.104)

A nova noção de cidadania também redefine a ideia de direitos, partindo da concepção do "direito a ter direitos", não se limitando a conquistas legais ou a direitos previamente definidos. A nova cidadania deve transcender o foco de relação com o Estado, ou do Estado com o indivíduo, para uma relação com a sociedade civil. Outra questão que ela ultrapassa é a referência do conceito liberal da reivindicação de acesso, inclusão ao sistema político, para um direito mais efetivo de participação nesse sistema. Uma das formas dessa participação seria através dos conselhos populares e do orçamento participativo. "Essas experiências apontam para uma nova fase dos próprios movimentos sociais, representada pelo seu esforço de adequação à institucionalidade democrática, que revela uma alteração qualitativa nas suas práticas”. (DAGNINO, 1994, p.108-110) Vemos essa questão de participação em conselhos ser cada vez mais trabalhada na Pastoral da Criança assim como a inserção na discussão de políticas públicas.

Também na América Latina a experiência dos movimentos sociais está levando a uma redefinição no que se entende por cidadão, não apenas em relação aos direitos à diferença. Isto implicaria uma perda de substância no conceito de cidadania manipulado por juristas: mais do que como valores abstratos, os direitos são importantes como algo que se constrói e muda com as práticas e discursos. A cidadania e os direitos não falam unicamente da estrutura formal de uma sociedade; indicam, além disso, o estado da luta pelo reconhecimento dos outros como sujeitos de "interesses válidos, valores pertinentes e demandas legítimas". Os direitos são reconceitualizados como "princípios reguladores das práticas sociais, definindo as regras das reciprocidades esperadas na vida em sociedade através da atribuição mutuamente consentida (e negociada) das obrigações e responsabilidades, garantias e prerrogativas de cada um". (GARCIA CANCLINI, 2005, p.36) 
No entanto Dagnino (2000, p.81) alerta que as práticas autoritárias e clientelistas certamente encontram espaços no campo dos movimentos sociais, os quais se caracterizam pela diversidade e heterogeneidade, mas isso não nega as mudanças trazidas por eles. A autora trabalha ainda com a relação desses movimentos com a democracia e articulação deles com partidos políticos, sindicatos, com a Igreja e com ONGs.

Manzini-Covre (1993, p.63-74) destaca, por sua vez, que os movimentos sociais são espaços para lutas que ampliarão a cidadania da população carente. No entanto, é preciso estar atento. As organizações podem ter seus interesses originais desvirtuados. Sindicatos que deviam lutar pelos trabalhadores, passam a geri-los. Um exemplo é o sindicalismo de resultado.

As organizações podem ainda ser cooptadas por partidos políticos. Se respeitarem os movimentos e o diálogo, os partidos podem ajudar as organizações a serem efetivas. $\mathrm{O}$ problema é quando passam a manipular o movimento e usá-lo para interesses partidários. Os canais de representação, como sindicatos e partidos, devem atuar em prol dos interesses coletivos dos representados.

Os sujeitos devem agir e lutar por seus direitos. Esse é o pressuposto básico para a cidadania.

Em suma, insisto sobre os contornos da cidadania plena. O primeiro passo é aquela revolução interna, na qual o rompimento com o autoritarismo e com o consumismo começa em cada uma das subjetividades - em cada um de nós, portanto, a todo momento - e da qual extraímos a força subjetiva de se sobrepor ao cotidiano e, pouco a pouco, ao mundo, ao capitalismo. Externamente em termos da sociedade global, devem ser mantidas as condições mínimas de democracia como espaço para avançar.

Então, torna-se possível o desenvolvimento daquela ação social de conteúdo coletivo dos trabalhadores, no campo econômico, para obter os bens e direitos a que fazem jus. E também, o exercício da ação social no nível político, como construção da democracia em seu sentido mais amplo - de uso da persuasão, do argumento, de construção da justiça, liberdade, igualdade. Retomo aqui, pela última vez, a dubiedade da cidadania: de um lado, a cidadania esvaziada, consumista; de outro a cidadania plena, dos que atuam nos vários níveis sociais, para atingir o nível mais abrangente do mundo, avançando nessa ação como sujeitos em direção à utopia. (MANZINI-COVRE, 1993, p.74)

Já para Garcia Canclini (2005), a cidadania deve ser repensada como "estratégia política":

Repensar a cidadania como "estratégia política" serve para abranger as práticas emergentes não consagradas pela ordem jurídica, o papel das 
subjetividades na renovação da sociedade e, ao mesmo tempo, para entender o lugar relativo destas práticas dentro da ordem democrática e procurar novas formas de legitimidade estruturadas de maneira duradoura em outro tipo de Estado. Implica tanto reivindicar os direitos de aceder e pertencer ao sistema sócio-político como o direito de participar na reelaboração do sistema, definindo portanto aquilo de que queremos fazer parte. (GARCIA CANCLINI, 2005, p.36)

A cidadania passa a envolver não só a questão dos direitos como também das responsabilidades e do pertencimento. Não são apenas os direitos políticos, civis e sociais que contam, mas também o direito à individualidade: "os desejos do indivíduo enquanto sujeito". (FAXINA, 2001, p.76-90)

Cidadania não é coisa de um reivindicar e outro dar, conceder, mas é acima de tudo conquista de espaço. A cidadania tornou-se, assim, o grande ícone que a sociedade civil dispõe para fazer valer os seus direitos e conquistar seu real espaço no jogo democrático viciado pela disputa interna entre os detentores dos poderes políticos e econômico. E este é o ganho dos movimentos sociais ao apropriarem-se do conceito de cidadania - assim como o de democracia -, buscando provocar um deslocamento semântico de como era entendida antes pela ideologia liberal. Com isso, cidadania passa a ser uma conquista, mais do que uma concessão; uma alteração do estado natural das coisas, mais do que uma mera arrumação interna do status quo vigente - conforme costuma ocorrer nas negociações políticas restritas aos grupos no poder - e exige um reposicionamento do Estado e suas instituições no âmbito da definição e implementação de políticas públicas. (FAXINA, 2001, p.73)

A afirmação de Faxina (2001) vai ao encontro de Manzini-Covre (1993), para quem a cidadania depende da ação dos sujeitos e dos grupos nos quais os mesmos estão inseridos, além das condições globais da sociedade.

A categoria cidadania permite avançar no pressuposto dialético marxista: os Homens fazem História, segundo determinadas circunstâncias estruturais - o que significa não pender nem para os sujeitos, nem para as estruturas. Nisso reside a possibilidade de fazer a ligação entre os desejos e as necessidades dos homens, enquanto indivíduos (subjetividades) e enquanto sujeitos grupais no bairro, nas fábricas, sindicatos, partidos, até chegar ao âmbito global da sociedade. (MANZINI-COVRE, 1993, p.63)

A "revolução" por uma sociedade melhor passa pela subjetividade das pessoas. É necessário agir com a consciência de que a democracia se constrói a todo instante nas relações sociais. Para a autora, essa revolução individual depende de três propiciadores: terapia, religião ou uma viagem poética, artística. Seriam formas de trazer para o individuo a força 
necessária para lidar com mundo e avançar no caso da terapia. Ou forças para ajudar o mundo agora, no caso da religião. E a arte preocupada com o Universo.

Os meios de comunicação, por exemplo, veiculam estilos de vida como a forma de viver. Entretanto, cada indivíduo deve ter sua forma de viver...

Essa revolução interna é traço essencial para a existência da cidadania. A violência perpassa o cotidiano das pessoas de inúmeros segmentos, em especial da população mais carente: mulheres, presos, negros, crianças e idosos. Há um sofrimento que tem lugar no âmbito privado e não vem a público, a não ser que essas pessoas tomem consciência de seus direitos como cidadãos e se organizem para lutar por eles. É preciso criar espaços para reivindicar os direitos, mas é preciso também estender o conhecimento a todos, para que saibam da possibilidade de reivindicar. (MANZINICOVRE, 1993, p.65-66)

\section{9 - A cidadania para a Pastoral da Criança}

Jesús Martín-Barbero ${ }^{57}$ afirma que a escola não é mais o lugar onde circula o saber, que passa por vários locais. Diante dessa realidade, é preciso transformar o modo de aprender e produzir o conhecimento. O autor pensa o mundo atual relacionando o tempo, o espaço, o movimento das migrações, tanto em um mesmo país como entre outros, com os fluxos e as mediações. Está em jogo o local e o global. As culturas já não podem sobreviver se forem cercadas de muros, pois não há identidade viva a não ser se transformando. Dessa forma, os fluxos desestabilizam o nacional e surgem novas formas de estar junto, reorganizando a circulação dos saberes, que são fragmentados.

Ao mesmo tempo, vivemos uma diversidade na democracia que não pode ser ignorada pelo sistema político. O mundo globalizado também é o lugar onde emergem as diferenças. São cidadãos vivendo a cidadania de maneiras diferentes porque não são iguais entre si. $\mathrm{O}$ Estado se vê confrontado por mulheres, indígenas, regiões com consciência e em busca de direitos.

Configura-se ainda um "presente autista", no qual não há perspectiva de futuro nem contextualização de um passado. Já não há relato, porque o que constrói sentido é algo que dura. Os jornais colocam coisas que sempre parecem iguais, e o jornalismo ficou sem relato e sem continuidade. As notícias são cada vez menores para concorrer com a internet e a TV.

\footnotetext{
${ }^{57}$ Esses conceitos foram discutidos no curso "Novas sensibilidades: entre urbanias e cidadanias", ministrado pelo professor doutor Jesús Martín-Barbero, na ECA/USP, entre os dias 15 e 19 de setembro de 2008. Os temas foram aprofundados pelos textos de autoria do professor, que fizeram parte da apostila do curso.
} 
Não há tempo para construir sentido. Os cidadãos não entendem o que está passando e se acostumaram a não entender. "Y sin um mínimo horizonte de futuro no hay posibilidad de pensar cambios, con lo que la sociedad patina sobre una sensación de sin-salida. Asistimos a una forma de regresión que nos saca de la historia y nos devuelve al tiempo de los contantes retornos...",58

Nesse cenário, com todas as características acima citadas, vemos como a comunicação e a educação, dentro de um movimento social, podem contribuir para uma nova construção do conhecimento, que leve à cidadania. É o que acontece na Pastoral da Criança. Nas 61 entrevistas $^{59}$ que realizamos, pudemos verificar como as voluntárias e os voluntários da Pastoral da Criança percebem a cidadania.

Levantamos os itens a partir das respostas sobre a pergunta "O que é cidadania para você?". Algumas pessoas citaram mais de um item em sua resposta. Nas respostas foram levantados os seguintes pontos: uso dos termos direitos ou deveres para explicar a cidadania; citação de exemplos de direitos; cidadania como solidariedade; cidadania como ação; cidadania como igualdade social ou percepção da realidade; cidadania como levar informação ou conhecimento.

Abaixo tabela com o número de vezes que cada uma dessas explicações aparece em cada região episcopal da cidade: Belém, Brasilândia, Ipiranga, Lapa, Santana e Sé. Também acrescentamos a esse quadro a opinião da coordenadora da Pastoral da Criança na Arquidiocese de São Paulo:

Cidadania é a gente saber que tem deveres e direitos e passar isso para as pessoas, que ela é uma cidadã e que ela tem direito a essa cidadania. A liderança, muitas vezes, faz um trabalho de políticas públicas e orienta sobre a cidadania das pessoas e não tem conta disso, não percebe o papel dela de cidadã e que ela faz com que a líder ou aquela mãe veja o papel importante dela numa cidade, numa comunidade, que ela tem os direitos e também os deveres. (Maria do Rosário Gazzola de Souza)

\begin{tabular}{|c|c|c|c|c|c|c|c|c|c|}
\hline \multicolumn{10}{|c|}{$\begin{array}{l}\text { Percepções sobre a cidadania das } 61 \text { pessoas entrevistadas na Arquidiocese de São } \\
\text { Paulo, que atuam na Pastoral da Criança }\end{array}$} \\
\hline $\begin{array}{l}\text { Explicações } \\
\text { para }\end{array}$ & $\mathrm{O}$ & Belém & Brasilân- & Ipiranga & Lapa & Santana & Sé & $\begin{array}{l}\text { Coorde- } \\
\text { nação }\end{array}$ & $\begin{array}{l}\mathrm{T} \\
\mathrm{O}\end{array}$ \\
\hline
\end{tabular}

${ }^{58}$ MARTÍN-BARBERO, Jesus. Dislocamientos del tiempo y nuevas topografias de la memória.

59 Foram dez entrevistadas e entrevistados nas seis regiões episcopais de São Paulo: Belém, Brasilândia, Ipiranga, Lapa, Santana e Sé. Além da entrevista com a coordenadora da Pastoral da Criança na Arquidiocese de São Paulo. 


\begin{tabular}{|l|l|l|l|l|l|l|l|l|}
\hline $\begin{array}{l}\text { significado da } \\
\text { cidadania: }\end{array}$ & & dia & & & & $\begin{array}{l}\text { Arqui- } \\
\text { diocese } \\
\text { SP }\end{array}$ & $\begin{array}{l}\text { A } \\
\text { L }\end{array}$ \\
\hline $\begin{array}{l}\text { Uso dos termos } \\
\text { direitos ou } \\
\text { deveres }\end{array}$ & 5 & 5 & 2 & 5 & 4 & 6 & 1 & 28 \\
\hline $\begin{array}{l}\text { Citação de } \\
\text { exemplos de } \\
\text { direitos }\end{array}$ & 3 & 2 & 2 & 7 & 3 & 4 & & 21 \\
\hline $\begin{array}{l}\text { Cidadania } \\
\text { como } \\
\text { solidariedade }\end{array}$ & 3 & 3 & 4 & 2 & 2 & 1 & & 15 \\
\hline $\begin{array}{l}\text { Cidadania } \\
\text { como ação }\end{array}$ & 2 & 3 & 2 & 4 & 3 & 2 & & 16 \\
\hline $\begin{array}{l}\text { Cidadania } \\
\text { como } \\
\text { igualdade } \\
\text { social } \\
\text { percepção da } \\
\text { realidade } \\
\text { comonecimento } \\
\text { ou informação }\end{array}$
\end{tabular}

Se transformarmos esses números em porcentagem, podemos afirmar que o termo direito e deveres apareceu em aproximadamente $46 \%$ das respostas. Os exemplos de direitos foram usados por $34,5 \%$ das 61 entrevistadas e entrevistados. A cidadania foi definida como ação por $26 \%$ dos ouvidos. Já $24,5 \%$ apontaram a cidadania como solidariedade, ajudar o próximo ou a comunidade. Para 19,5\% uma das características da cidadania é levar a informação ou o conhecimento. Cerca de $10 \%$ acreditam que a cidadania é igualdade social ou percepção da realidade. Essas características levantadas assim como a ação das voluntárias e voluntários estão de acordo com a forma com que Milton Santos vê a cidadania: 
O simples nascer investe o indivíduo de uma soma inalienável de direitos, apenas pelo fato de ingressar na sociedade humana. Viver, tornar-se um ser no mundo, é assumir com os demais, uma herança moral, que faz de cada qual um portador de prerrogativas sociais. Direito a um teto, à comida, à educação, à saúde, à proteção contra o frio, a chuva, as interpéries; direito ao trabalho, à justiça, à liberdade e uma existência digna.

(...) $\mathrm{O}$ respeito ao indivíduo é a consagração da cidadania, pela qual uma lista de princípios gerais e abstratos se impõe como um corpo de direitos concretos individualizados. A cidadania é uma lei da sociedade que, sem distinção, atinge a todos e investe cada qual com a força de se ver respeitado contra a força, em qualquer circunstância.

A cidadania, sem dúvida, se aprende. É assim que ela se torna um estado de espírito, enraizado na cultura. (...) Ameaçada por um cotidiano implacável, não basta à cidadania ser um estado de espírito ou uma declaração de intenções. Ela tem o seu corpo e os seus limites como uma situação social, jurídica e política. (...) para ter eficácia e ser fonte de direitos, ela deve se inscrever na própria letra das leis, mediante dispositivos institucionais que assegurem a fruição das prerrogativas pactuadas e, sempre que aja recusa, o direito de reclamar e ser ouvido. (SANTOS, 2007, p.19-20)

Em nossa pesquisa, se olharmos as respostas em cada região, vemos que nas dez entrevistas realizadas no Belém, por cinco vezes, foram citados os termos "direitos" ou “deveres” para definir cidadania, como na definição da líder Vera Lúcia Rodrigues Mangela: "Cidadania é conhecer os seus direitos, saber o que você pode realizar dentro de sua comunidade, dentro do seu município".

A questão dos direitos apareceu exemplificada por três vezes. Nesses casos, as entrevistadas também foram incluídas no item anterior, por também usarem os termos direitos ou deveres. Vemos uma percepção crítica da realidade, dos direitos e deveres, independentemente do nível de escolaridade formal:

Fernanda Tobias Cipriano, 21 - multiplicadora e líder - cursando educação física: "É você fazer suas obrigações e deveres. Cidadania para uma mãe é ela ter direito a trabalhar para sustentar seu filho, ter uma estrutura de saúde. Não adianta ela querer, se o posto não vai atender".

Selma Leite Galindo da Silva, 39 anos - líder e multiplicadora - Ensino Médio: "A cidadania é saber os meus direitos e meus deveres, saber os meus limites, onde começa a minha liberdade e onde termina. É ter um lugar legal para se viver, ter direito à água, saneamento, eu como pessoa existir. A gente frequenta esses lugares e vê que a pessoa não tem a dignidade delas, às vezes nem banheiro dentro de casa tem. Cidadania é a pessoa existir."

Aparecida Troqui Raffanini, 58 anos - coordenadora da região Belém Ensino Fundamental: "A cidadania é ter o direito de viver honestamente. Ter o direito de ser gente na vida, porque às vezes a pessoa não é respeitada. Ter direito a parte pública, médica, que precisa de mais atenção. Nós que 
fazemos a cidade, nós somos o povo e se esse povo não tem uma vida digna não é considerado ninguém."

Também por três vezes a cidadania foi percebida como solidariedade, como na fala de Maria Vaz Couto Martine, 57 anos: "É uma ajuda mútua, que a gente vive junto e é muito importante". Já como ação foi citada por duas vezes, como explicou Sandro Morate Ihana, 35 anos: "É ser uma pessoa de bem e engajada em alguma coisa". A cidadania ainda foi percebida como igualdade social e percepção da realidade em dois momentos:

\footnotetext{
Ana Paula de Lima Silva, 28 anos - atua na Favela da Vila Prudente: "Para mim cidadania é a gente poder viver em um ambiente onde todos sejam iguais, onde não tenha exclusão. Ai a gente pode dizer que vive em um país de cidadania, onde não tenha desigualdade e todos vejam cada um como o todo. Porque eu sou da favela e aquela que mora ali em cima é assim. Então, onde todos sejam iguais independente de onde cada um vive."

Irene Lopes Carderine, 65 anos - atua em Favelas de São Mateus: “É estar junto com todos, colaborando, falando das dificuldades que nós temos, porque ser cidadão é você ver a realidade de onde você vive."
}

Já na Brasilândia verificamos os mesmos itens nas respostas, acrescido de mais um: cidadania como levar informação ou conhecimento. Essa é a percepção de Adervisto Mariano Neto, 66 anos, líder e coordenador comunitário do Jardim Maggi: "saber como lidar com as pessoas, levar as novidades, saber o que está acontecendo no dia a dia. Não só ficar para si." Esse modo de ver cidadania também traz em si a visão de percepção da realidade.

A definição de cidadania com os termos direitos e deveres apareceu por cinco vezes, como na resposta de Marilza Damaciano Lopes Barbosa, 55 anos, coordenadora do Setor Brasilândia: "Cidadania, para mim, é você ser responsável, ter direitos e deveres. Fazer o que deve ser feito". Outro exemplo é a o que diz a multiplicadora Débora Mara de Oliveira Soares, de 44 anos: "É ter os seus direitos garantidos, usufruir daquilo que a lei determina para ele, ser considerado como cidadão, sem preconceito".

A citação de exemplos de direitos apareceu em duas falas da Brasilândia. A percepção de cidadania de Eron Gonçalves de Aguiar, 45 anos, mistura esse item com o anterior: "Cidadania, para mim, vem de cidadão. Uma vez que você tem o seu direito respeitado ou você corre atrás dos seus direitos, você consegue uma documentação que falta para uma criança, ai começa a cidadania, ele se torna um cidadão".

Tanto a cidadania como solidariedade quanto como ação apareceu por três vezes entre os entrevistados da Brasilândia. O líder Marcos Antonio Lopes, 44 anos, afirma que cidadania 
é "o trabalho que nós fazemos, um ato de cidadania é muito importante". Já Maria Vila Nova de Sousa, coordenadora comunitária e líder no Morro Doce, de 55 anos, traz em sua definição esses dois pontos: "Cidadania, para mim, é a gente valorizar o outro, o bairro que você mora, procurar ajuda para o seu bairro, para as famílias, estar junto, não pensar: eu não estou nem ai, porque não está acontecendo comigo".

Também realizamos dez entrevistas no setor Ipiranga. O conceito que mais apareceu nas respostas sobre o significado da cidadania foi o de solidariedade, por quatro vezes. É o que vemos na fala de Adelina da Conceição Rio Branco, líder com 70 anos de idade e 23 de Pastoral da Criança: "Na cidadania, que eu saiba são todos iguais. Então se você sabe que uma pessoa necessita, você vai, ajuda. A gente presta socorro em tudo. Tudo que a gente puder ajudar, a gente ajuda". Visão parecida tem a menina Michaele Gonçalves Sousa de 13 anos, que atua como apoio em Heliópolis: "Cidadania para mim é quando a gente ajuda os outros da maneira que pode. Não adianta você querer fazer tudo sozinho. Você precisa de todo mundo."

Ainda apareceram por duas vezes os seguintes conceitos: cidadania como direitos e deveres, citando esses termos; exemplificação de direitos; cidadania como ação; e cidadania como passar informação ou conhecimento. Os exemplos a seguir mostram cada um desses itens, respectivamente:

Maria de Fátima Rodrigues de Freitas, 43 anos - líder (Saúde): "Cidadania é você saber dos seus direitos e deveres e correr atrás daquilo que você acredita".

Ana Maria Torres de Barros, 48 anos - líder (Parque Bristol): "É ser um cidadão digno, com uma moradia decente, ter alimentação, vestimenta, o necessário, o básico".

Helena de Souza Silva, 27 anos - líder (Vila Santa Cristina): "Cidadania é atuar na sociedade, não só pensando em si, mas no coletivo e nos indivíduos".

Joana Nepomuceno de Santana, 73 anos - líder (Água Funda): “Tem muita gente que não sabe muita coisa e a gente explica".

Como ocorrido nas outras regiões episcopais, há pessoas que trazem em sua resposta vários conceitos. É o que aconteceu na fala sobre cidadania de Solange Martone Rocha, 45 anos, coordenadora de ramo, que abordou a solidariedade, a ação e levar conhecimento:

É o que a gente faz na Pastoral da Criança. A gente está ajudando, não só ajudando o próximo no sentido de humanidade, mas também no sentido de 
encaminhar a pessoa para algum lugar. Não é só ir lá à frente e falar a palavra de Deus. É importante, mas algo mais concreto Ele vai gostar muito mais do que se eu ficasse o dia inteiro na igreja rezando. Isso para mim é cidadania, você ir atrás, passar o seu conhecimento e não deixá-lo guardado numa gaveta. (Solange Rocha)

Já na Lapa o uso de exemplos de direitos apareceu em sete das dez entrevistas. Cinco pessoas usaram os termos direitos e deveres. A cidadania como ação apareceu em quatro respostas. O conceito de solidariedade e a cidadania como levar conhecimento e informação apareceram por duas vezes. Por uma vez, apareceu o conceito de igualdade social e percepção da realidade. A maioria das pessoas misturou mais de um conceito em sua resposta.

Selecionamos três exemplos. O primeiro usa tanto o termo "direito", dá exemplos sobre direitos e passa a ideia de necessidade de igualdade social. Já o segundo exemplo mostra a cidadania como direito e dever, mas também como ação. O último apresenta a cidadania como solidariedade, ação e levar a informação.

Benedita Lopes Carvalho de Moraes, 68 anos - líder em favela no Jardim Felicidade e coordenadora de uma comunidade na aldeia guarani do Jaraguá: "Cidadania, para mim, é a pessoa ter o direito de ir e vir, de ter moradia, de ter registro de nascimento, ter saúde, lazer. Tudo isso faz parte da cidadania. A pessoa tem direito a tudo. Ela tem que saber os direitos dela e cumprir com os deveres. Então acho que no meio carente a cidadania é precária. Nos postos de saúde, são discriminados, a gente tem que ir lá para que a criança seja atendida, para retirar um remédio porque a mãe não tem carteirinha; nas escolas, às vezes tem vaga para alguém da vila e não tem para quem mora na favela; então, isso prejudica a cidadania, porque os cidadãos precisam ter direitos plenos. Como Jesus disse para que todos tenham vida e vida plenamente, como cidadão, todos têm que ter direitos plenos".

Jairo Fedel, 49 anos - multiplicador do setor Lapa: "Cidadania, para mim, é você ter reconhecimento dos seus direitos e também dos seus deveres, enquanto membro de uma sociedade, enquanto cidadão, e participar ativamente tanto das atividades de sua comunidade, independente da sua religião. Participar para que todos tenhamos uma condição de vida melhor. É o agente político. Você pode participar de muitas maneiras. Uma delas é pela Pastoral da Criança. Outra na Sociedade Amigos do Bairro. Existem várias maneiras para você participar como cidadão. É você agir permanente como agente político, como cidadão na sociedade".

Margot Helena Noske Schutz, 71 anos, coordenadora e líder no Rio Pequeno: "Cidadania é a gente se interessar pelos problemas dos outros e ajudar a melhorar a vida da pessoa que está com dificuldade, orientar. Às vezes a mãe fala que precisava disso e daquilo, a gente orienta onde ela deve ir, dá o endereço que precisa. Acho que é assim. O pouco que a gente faz. A gente fala da paz na família. É muito importante. Fala do brincar, do dialogar, para deixar de assistir televisão para escutar o filho. Tudo isso a gente conversa com as mães nas visitas". 
Também ouvimos dez pessoas que atuam na Pastoral da Criança na Região Episcopal Santana. A líder e capacitadora Maria Teresa de Abreu tem 15 anos de Pastoral da Criança e é uma das entrevistadas. Para explicar cidadania, usou tanto o termo direito como deu alguns exemplos:

Cidadania é o direito de ir, de vir, de conversar, de falar, de ser registrado, de ter seus direitos atendidos, poder votar, poder dizer o que é certo e o que é errado. Ser um cidadão livre com direito à escola, à saúde, à educação, a todos os incentivos que existem para o progresso e emancipação da pessoa. (Maria Teresa de Abreu)

A definição de cidadania usando os termos direitos ou deveres apareceu em quatro respostas. Já a exemplificação de direitos ocorreu três vezes. A cidadania vista como solidariedade esteve em duas entrevistas. A ação foi usada por três vezes. A percepção da cidadania como igualdade ou realidade social apareceu uma vez. Por quatro vezes, a cidadania foi mostrada como levar informação ou conhecimento. Selecionamos exemplos que mostram cada uma dessas situações, respectivamente. $O$ último traz em si a cidadania vista tanto como percepção da realidade, levar conhecimento, mas também usa o termo direito e exemplos.

Vera Lúcia Vieira Figliuoleo, coordenadora do estado de São Paulo da Ação Brinquedos e Brincadeiras - 6 anos de Pastoral da Criança: "Para mim, cidadania é quando eu percebo como posso exigir os meus direitos e que eu também reconheça que tenho os meus deveres, que eu saiba como ir atrás desses meus direitos. Para mim é muito importante estar ciente disso, porque muitas famílias não conhecem. A Pastoral tenta nas nossas visitas, mês a mês, passar para essas famílias para que elas percebam o que elas podem fazer para que elas cresçam como família, como comunidade.

Maria Aparecida dos Santos Viana, coordenadora comunitária - 5 anos de Pastoral da Criança: "Cidadania é você ter onde morar, morar com dignidade. Ser pobre não é morar no lixo. Você precisa ter um teto para morar, e o pai trabalhar, não ganhar cesta básica, trabalhar para trazer comida para casa, não viver de cesta básica. Isso para mim não é cidadania".

Cinira Fidalgo Serafim, coordenadora de ramo - 6 anos de Pastoral da Criança: "Um pouquinho que você dê para uma pessoa como uma família, ajudando, pelo menos em afeto. Isso é cidadania".

Ivone Cataguene Cardoso, líder - 5 anos de Pastoral da Criança: "Cidadania é tudo isso que eu faço e nós fazemos na Pastoral. Participo de várias atitudes para as pastorais, que fazem um serviço comunitário como esse, e trabalhamos com o ser humano. O povo é carente, e a nossa parte é essa." 


\begin{abstract}
Arlete Della Coleto Agostinho, líder - 8 anos de Pastoral da Criança: "Para mim, eu queria que as mães tivessem essa noção de que elas têm direitos no estado, na cidade, nas comunidades em que elas vivem e elas desconhecem. Elas têm medo de buscar as coisas que podiam melhorar a situação de vida. Elas têm direitos e onde se amparar, no que diz respeito à violência em casa, do marido. Também que elas tivessem noção do que é cuidar da criança sem violência. Se você fala um tom mais alto você já está sendo violento com as crianças. Às vezes você chega para visitar a mãe, e ela está aos berros com a criança. É tão curto o tempo da mãe com a criança, e ela não está sabendo aproveitar. Ela não teve a orientação, não buscou o conhecimento. Às vezes a Pastoral oferece e ela desconhece. Em relação à saúde, tem tanta mãe com problema sério de saúde, descontente com aquela vida até miserável. É um trabalho nosso enquanto líder estar orientando as mães. Isso ajuda um pouquinho elas conquistarem a cidadania. Para mim, cidadania é crescimento".
\end{abstract}

Já no setor Sé o uso dos termos direitos ou deveres para definir a cidadania apareceu em seis entrevistas. A citação de exemplos de direitos apareceu em quatro falas. Selecionamos um exemplo que usa esses dois quesitos e também passa a ideia de igualdade social e percepção da realidade, usado por um coordenador de ramo e líder de 54 anos:

Cidadania é o direito à vida. Ter uma parte social, ter educação. São os direitos que o ser humano deveria ter, baseados na Constituição, direito à educação, à saúde e tudo mais. A Pastoral ajuda muito nesse sentido, de mostrar para as mães como devem cuidar da criança; os direitos que elas têm de ir a um posto de saúde; de ter alimentação e de como educar a criança; da escola e do ambiente familiar não ter violência; no desenvolvimento da criança. (Carlos Henrique de Azevedo)

Outros pontos que apareceram foram: cidadania como solidariedade - uma vez; como ação - duas vezes; como forma de levar informação e conhecimento por duas vezes. O primeiro exemplo fala da ação; já o segundo mistura os outros dois itens.

Katia Regina Queirós da Silva Matos, 29 anos, líder: "É a nossa atuação mesmo, no nosso ramo social".

Maria José da Silva, 36 anos, coordenadora de ramo e líder: "Cidadania, para mim, é você estar levando conhecimentos para as pessoas, integração. Estar sempre junto, buscando conhecer quem é seu vizinho, quem não é, tentando ajudar as pessoas".

Nesse processo, há um despertar para a cidadania, primeiro na liderança, depois nas mães e nas famílias. Como relata a coordenadora de ramo e líder Elizabeth Valente Lorenzano, 61 anos, que atua em Perdizes: “A gente vai andando e conhecendo os cortiços, casas invadidas, pensões. Antes eu não tinha um olhar assim. Eu passava e nunca prestava 
atenção. Só via os edifícios. Agora, prestando mais atenção, vejo muitas crianças que precisam da Pastoral". As líderes também reconhecem o quanto aprendem como vemos na fala da líder de 62 anos de idade e 10 de Pastoral da Criança:

\begin{abstract}
Sempre pensava que quando meus filhos crescessem e eu ainda eu tivesse um pouquinho de saúde, gostaria de participar de alguma coisa como voluntária. Quando abriu a comunidade, a irmã me convidou, mas como não tenho muito estudo, só até a $5^{\mathrm{a}}$. série do antigo ginásio, achava que não estava apta para participar da Pastoral da Criança. Quando, no ano seguinte, ela tornou a me convidar, eu falei - "tudo bem irmã, então, eu vou, mas só por caridade". Foi tão bom. Fiz o curso de capacitação e gostei muito. Estou dando minha pequena contribuição, mais aprendo do que ajudo. (Benedita Batista dos Santos Goulart)
\end{abstract}

É a ação na comunidade como relata o coordenador de ramo e líder do Setor Sé Richard Sanches, 47 anos: "o trabalho do líder é você verificar o que efetivamente está acontecendo na sua comunidade, no seu bairro, na sua paróquia”. Assim se age em prol da cidadania como relata a multiplicadora da mesma região, de 50 anos de idade e 13 de Pastoral da Criança:

\begin{abstract}
A gente está tentando trabalhar com o pessoal esse novo enfoque da Pastoral que é o de conhecer, de preparar, de ajudar as pessoas a se perceberem como cidadãos, com dignidade, com direitos a serem respeitados. Eu vejo que nas capacitações, nas atualizações, quando as pessoas se demonstram, mais ou menos espantadas: "Poxa, mas eu posso isso? Eu sei disso, estou me dando conta agora". A Pastoral da Criança tem uma participação muito grande para o "despertar" do ser humano para sua ação cidadã neste país. As pessoas são motivadas a buscar. (Terezinha Fátima Tomaze)
\end{abstract}

\title{
3.10 - A construção da cidadania no cotidiano
}

O processo educacional e comunicativo da Pastoral da Criança e a percepção de voluntárias e voluntários sobre direitos e deveres mostram como a cidadania pode ser construída a partir do cotidiano. Martín-Barbero, a partir de Foucault, trabalha a questão do poder, disseminado nas práticas cotidianas dos indivíduos e instituições, em um mundo como uma rede que une pontos ${ }^{60}$. Na ação da Pastoral da Criança, as líderes que vivem nas mesmas

\footnotetext{
${ }^{60}$ Mais uma vez usamos o conteúdo da apostila do curso de Jesús Martín-Barbero na ECA. Nesse caso, o seguinte texto: MARTÍN-BARBERO, Jesús. Pensar juntos espacios y territorios.
} 
regiões pobres das famílias atendidas, ganham o respeito da comunidade e é comum ouvir em seus discursos que antes de recuperar a cidadania dos outros, recuperam a de si próprias. $\mathrm{O}$ jornal da entidade funciona como um espaço de reconhecimento desse poder, no qual elas podem ver suas histórias como também as de seus pares.

Nesse mundo em que a escola não é mais o lugar do saber, a organização contribui para a construção do conhecimento na sua rede de voluntárias e voluntários, que divide essa aprendizagem com as famílias atendidas. Nas visitas, ao colocar em prática o conhecimento aprendido no jornal, que aborda diversos temas de saúde e direitos, ou nos diversos cursos de formação, as líderes se deparam com novos problemas. Forma-se uma rede educativa que deve ter uma perspectiva "freireana".

Essa perspectiva deve estar presente não só na ação de cada líder como também nos materiais de comunicação da entidade, sempre levando em conta o saber do povo. As identidades não devem ser reprimidas e sim fortalecidas, e os movimentos sociais devem ser espaço para esse fortalecimento. Há no mundo, como reflete Martín-Barbero ${ }^{61}$, uma separação entre a racionalidade econômica e as identidades que se manifestam de forma brutal com a globalização. Para o autor, não é possível enfrentar a globalização perversa que temos sem assumir o que passa na espacialidade-mundo. Por sua vez, a cidade precisa ter seu espaço apropriado com toda sua diversidade, sendo experimentada e vivenciada pelos cidadãos.

Desvaluado por las lógicas de lo global y por las dinámicas de lo local, desafiado por la pluralidad de los relatos que hoy construyen las etnias, las regiones y las mujeres, lo nacional estalla y se descentra haciendo de la ciudad el estratégico lugar en el que algunos lazos de pertencia aun sobreviven convivendo con el desanclaje que producen los flujos de lo global ${ }^{62}$. (MARTÍN-BARBERO)

Por um lado vivemos um neoliberalismo com "a vitória do consumo como fim em si mesmo" e "a supressão da vida comunitária baseada na solidariedade" (SANTOS, 2007, p.23). "Em lugar do cidadão, formou-se um consumidor ${ }^{63}$, que aceita ser chamado de usuário"

\footnotetext{
61 Ibid.

${ }^{62}$ Texto - MARTÍN-BARBERO, Jesús. Entre urbanias y ciudadanías. - retirado da apostila do curso da ECA, realizado em 2008.

${ }^{63}$ Para Santos (2007, p.49), “ a glorificação do consumo acompanha-se da diminuição gradativa de outras sensibilidades, como a noção de individualidade, que, aliás, constitui um dos alicerces da cidadania. Enquanto constrói e alimenta um individualismo feroz e sem fronteiras, o consumo contribui ao aniquilamento da personalidade, sem a qual o homem não se reconhece como distinto, a partir da igualdade entre todos. Ainda afirma que "o chamado ao consumo busca retardar a tomada de consciência, mergulhando o consumidor numa atmosfera irreal, onde o futuro aparece como miragem. Se cada qual pudesse estar consciente de suas possibilidades reais a partir de sua situação concreta, o mundo da fantasia cederia lugar ao confronto com um mundo incapaz de premiar os esforços individuais" (2007, p. 54). Já Freire $(2005$, p.51) avalia que "para os
} 
(2007, p.25). Assim o "espaço vivido consagra desigualdades e injustiças e termina por ser, em sua maior parte, um espaço sem cidadãos" (2007, p.59). No entanto, o cotidiano pode ser o lugar da desalienação, pois se nele se manifestam os preconceitos, é nele que ocorrem as descobertas (2007, p.71).

Santos (2007, p.81) avalia que "quando o homem se defronta com um espaço que não ajudou a criar, cuja história desconhece, cuja memória lhe é estranha, esse lugar é a sede de uma vigorosa alienação". Mais adiante afirma que a "cultura nos dá a consciência de pertencer a um grupo". Assim acreditamos que a Pastoral da Criança funciona como um espaço em que as pessoas podem ajudar a recriar a comunidade. Trocam experiências, aprendizagens e se desalienam.

Pois a meta da liberdade começa no espírito do homem e a condição de liberdade é a imersão do indivíduo renovado numa sociedade onde o homem é o sujeito e não o objeto. É fundamental, todavia, ultrapassar a reconstrução solidária do indivíduo e transformá-la em ação solidária. A individualidade somente se realiza em grupo.

(...)

Sozinhos, ficamos livres, mas não podemos exercitar a nossa liberdade. Com o grupo, encontramos os meios de multiplicar as forças individuais, mediante a organização. É assim que nosso campo de luta se alarga e que um maior número de pessoas se avizinha da consciência possível, rompendo as amarras da alienação. É também pela organização que pessoas inconformadas se reúnem, ampliando, destarte, sua força e arrastando, pela convicção e o exemplo, gente já predisposta mas ainda não solidamente instalada nesses princípios redentores. (SANTOS, 2007, p.102-104)

Assim podemos pensar os movimentos sociais e suas organizações como peças fundamentais para a manifestação das diferenças e como espaço para a cidadania. A Pastoral da Criança é uma dessas organizações. Essa ação comunicativa e educativa ajuda a construir a cidadania em um país onde "as classes chamadas superiores, incluindo as classes médias, jamais quiseram ser cidadãs; os pobres jamais puderam ser cidadãos" (SANTOS, 2008, p.4950). Isso porque "as classes médias foram condicionadas a apenas querer privilégios e não direitos".

Na ação de voluntárias e voluntários da Pastoral da Criança a comunidade se une em prol de direitos e não de privilégios. Assim buscam construir e exercer a cidadania de que fala Milton Santos ${ }^{64}$ em outro texto: "a cidadania é o exercício de direitos e supõe a ciência

opressores, o que vale é ter mais e cada vez mais, à custa, inclusive, do ter menos ou do nada ter dos oprimidos. Ser, para eles, é ter e ter como classe que tem".

${ }^{64}$ Não temos o ano da publicação, mas trata-se do texto Cidadanias Mutiladas, retirado da publicação da Secretaria da Justiça e da Defesa da Cidadania, de São Paulo: O Preconceito. 
dos direitos que temos e a capacidade de reivindicar seu exercício pleno e também de reivindicar mais". O mesmo autor nos alerta sobre o fato de vivermos uma globalização perversa e de precisarmos construir "uma outra globalização", mais humana (SANTOS, 2008).

Acreditamos que a Pastoral da Criança contribui para essa construção. A percepção do voluntariado sobre a cidadania confirma isso e também a tese defendida por Gentilli (2005), de que o cidadão precisa ter acesso à informação pública e que essa é uma condição para a ampliação de seus direitos. Claro que a falta de democratização da mídia, a face industrial da produção da notícia e o alcance limitado da comunicação popular devem ser considerados, mas isso não deve impedir que se trabalhe em prol do direito da informação e contra essas estruturas limitantes.

O direito à informação, portanto, deve ser compreendido como um direito relacionado diretamente aos outros direitos, incluindo, obviamente, as contradições e os antagonismos destes. É um direito que fomenta o exercício da cidadania e permite ao cidadão o acesso e a crítica aos instrumentos necessários ao exercício pleno do conjunto dos direitos de cidadania.

Daí resulta a formulação da informação pública como um pressuposto indispensável ao exercício da cidadania e, portanto, um fator decisivo no processo de aprofundamento democrático. Como conseqüência do raciocínio, o entendimento de que o acesso à informação é uma porta de acesso a outros direitos: numa sociedade de massas modernas, o acesso à informação jornalística, por parte do cidadão, pode potencialmente vir a consistir num direito que assegura outros direitos, confere condições de igualização de sujeitos e oferece visibilidade ao poder e ao mundo. (GENTILLI, 2005, p.128)

É preciso que o jornalismo cumpra seu dever de informar e que o cidadão receba o direito da informação. Essa função também deve ser cumprida pela comunicação popular. Assim, os cidadãos serão informados sobre seus direitos civis, políticos e sociais; e poderão exercer seus direitos de cidadania. A informação sobre os direitos é matéria-prima para que se realize uma cidadania ativa e se chegue à revolução interna de que fala Manzini-Covre (1993).

Essa revolução interna possibilitará a cidadania plena e vai ao encontro da reflexão de Heller (1989, p.117) sobre um pensamento de Marx:

Marx disse que, transformando o mundo, os homens se transformam a si mesmos. Não modificaremos substancialmente o seu pensamento se alterarmos sua frase e afirmarmos agora que não podemos transformar $o$ mundo se, ao mesmo tempo, não nos transformarmos a nós mesmos. 
Essa transformação deve alcançar espaço na nossa vida cotidiana, como defende Heller (1989), mas também na comunicação, seja ela a comunicação popular ou o jornalismo dos conglomerados de comunicação. Afinal o ser humano é um sujeito histórico que transforma. Freire $(2005$, p.107) afirma que "através de sua permanente ação transformadora da realidade objetiva, os homens" e as mulheres ${ }^{65}$, "simultaneamente, criam a história e se fazem seres histórico-sociais". O autor também recorre a Marx ao dizer que "não há história sem homens, como não há uma história para os homens, mas uma história de homens que, feita por eles, também os faz".

$\mathrm{Na}$ Pastoral da Criança, vimos como mulheres e homens agem como sujeitos históricos e transformam a realidade da comunidade a partir da família e ao mesmo tempo se transformam, auxiliados por uma organização educativa e comunicativa, baseada no diálogo e na práxis. Essa ação se dá nas práticas cotidianas e, dessa forma, caminha-se para a cidadania, construindo-se uma nova realidade,

um outro cotidiano, aquele pelo qual o homem redescobre a consciência e busca ampliá-la Este cotidiano não se defende apenas pela letra de uma Constituição federal, mas igualmente (e mais freqüentemente) pelas regras de convivência no lugar mesmo em que se vive. Esta consciência do homem, que faz dele um verdadeiro cidadão ou nele alimenta a vontade de sê-lo, também faz parte dos desígnios fundamentais e do longo prazo, porque diz respeito à própria essência humana. (SANTOS, 2007, p.137)

\footnotetext{
${ }^{65}$ Acrescentamos a palavra mulheres que vai de acordo com reflexões feitas posteriormente por Paulo Freire em Pedagogia da Esperança sobre a ideologia implícita que há no uso das palavras somente no masculino.
} 


\section{Capítulo IV - O jornal e a voz da comunidade}

\section{1 - Uma construção coletiva}

Nesse último capítulo, apresentaremos a estrutura do jornal, os gêneros presentes, suas seções, mas também analisaremos as respostas das leitoras do Jornal Pastoral da Criança, a partir das entrevistas semiabertas que realizamos com as 61 voluntárias e voluntários da Pastoral da Criança na Arquidiocese de São Paulo. Trata-se de um estudo que olha para a recepção e para a produção do jornal, relacionando o que dizem as líderes com o conteúdo que acompanhamos entre os meses de fevereiro de 2008 até junho de 2009. O intuito é averiguar até que ponto essa comunicação assume um caráter educativo e os seus resultados na prática.

Trata-se de uma análise importante, pois, juntamente com a pesquisa de campo realizada, estamos reconstruindo a história da Pastoral da Criança na Arquidiocese de São Paulo a partir daqueles sujeitos que fazem essa história: o voluntariado. Para Bosi (2003, p.15-17), "a memória oral é um instrumento precioso se desejamos construir a crônica do cotidiano". Isso porque, segundo autora, a história baseada em documentos oficiais não traz em si as paixões individuais que estão presentes em cada episódio. Se por um lado a memória oral pode cair numa ideologização da história do cotidiano, por outro lado, longe da visão unilateral das instituições, ela traz pontos de vistas distintos. No entanto, explica que as testemunhas orais podem seguir estereótipos da memória institucional.

Como arrancar do fundo do oceano das idades um "fato puro" memorizado? Quando puxarmos a rede veremos o quanto ela vem carregada de representações ideológicas. Mais do que o documento unilinear, a narrativa mostra a complexidade do acontecimento. É a via privilegiada para chegar até o ponto de articulação da História com a vida quotidiana. Colhe pontos de vistas diversos, às vezes opostos, é uma recomposição constante de dados. (BOSI, 2003, p.19)

A autora ainda explica que a memória permite a relação do presente com o passado e também "interfere no curso atual das representações". Assim,

Pela memória, o passado não só vem à tona das águas presentes, misturando com as percepções imediatas, como também empurra, 'descola' estas últimas, ocupando o espaço todo da consciência. A memória aparece como 
força subjetiva ao mesmo tempo profunda e ativa, latente e penetrante, oculta e invasora. (BOSI, 2003, p.36)

Recorrer à memória, à percepção e à vivência das voluntárias e voluntários da Pastoral da Criança também é importante porque "a comunidade familiar ou grupal exerce uma função de apoio como testemunha e interprete" das experiências. Se o "conjunto das lembranças é também uma construção social do grupo em que a pessoa vive e onde coexistem elementos da escolha e rejeição ao que será lembrado", acreditamos que, ao ouvir o que pensam aqueles que atuam na Pastoral da Criança, estamos levantando a construção feita pelo grupo sobre si. (BOSI, 2003, p.54) Já começamos a fazer isso ao levantar a concepção que essas pessoas têm da cidadania, no capítulo anterior. Estamos olhando para essa construção coletiva na comunidade e também ouvindo o que ela tem a nos dizer.

Essa importância da liderança é reconhecida pela coordenação da Pastoral da Criança, como podemos ver na fala da coordenadora nacional, em entrevista à autora dessa dissertação em julho de 2008:

O líder é a pessoa mais importante da Pastoral da Criança. Podemos chamálo de coluna vertebral. Sem o nosso líder nós não seríamos capazes de fazer um trabalho com uma abrangência tão grande. É o líder que realmente faz acontecer o trabalho da Pastoral da Criança e consegue ir onde essas mães se encontram, sobretudo o líder deve pertencer a sua comunidade. (Vera Lúcia Altoé)

Essas líderes visitam as famílias e procuram contribuir para o desenvolvimento integral das crianças. Ao fazer isso educam e se educam. As visitas que realizam são o que fazem a Pastoral da Criança acontecer e nos remetem mais uma vez a Bosi (2003, p.195-208). A autora analisa as práticas religiosas e o enraizamento que possibilitam. Em um momento fala das visitas a doentes e também de visitas em festas religiosas. Não é uma análise sobre a Pastoral da Criança, mas certamente serve para pensar a ação da mesma, na qual essa liderança também se vê como missionária:

A visitação é um enraizamento: de Belém à Vila das Mercês, de Osasco à Penha estão os amigos e parentes que um mundo de opressão separou.

(...)

Os crentes populares estendem a visita às casas o bairro, em especial às casas dos doentes, como uma missão, um prolongamento do culto.

Nada na sociedade atual favorece tais encontros: a estafa diária, a jornada intensa de trabalho, a televisão, tudo procura impedir a visitação dos pobres. A visitação que age em sentido contrário do isolamento e desenraizamento. 
No entanto, como no Evangelho de Lucas, Maria visita Isabel, os vizinhos visitam Isabel e Zacarias, os pastores visitam José e Maria, e Maria sobe a Jerusalém. (BOSI, 2003, p.205)

E assim ainda hoje os mais de 260 mil voluntárias e voluntários da Pastoral da Criança vão visitando seus vizinhos, alimentados pelo espírito missionário, mas também pela estrutura educativa e comunicativa da organização. Ouvimos parte desse todo, as 61 pessoas que atuam na cidade de São Paulo, local onde tudo favorece para que essa visitação não aconteça: o trânsito, a distância entre as localidades, o ritmo alucinado, o espaço mal distribuído. Tudo parece ir contra o trabalho comunitário, mas ele acontece e possibilita a construção da cidadania cotidianamente.

\section{2 - O papel da comunicação}

Chaparro (2007, p.33-34) cita o artigo 19 da Declaração Universal dos Direitos Humanos, de 1948, para reafirmar que "todo indivíduo tem direito (...) de investigar e receber informações e opiniões, e o de difundi-las sem limitação de fronteiras”. A definição “estabelece de imediato que esse direito deve ser assegurado aos que não podem exercer". Por sua vez, o jornalismo, para o autor, contribui para que isso aconteça, ao ser o "elo que nos processos sociais, cria e mantém as mediações viabilizadoras do direito à informação".

Vemos a partir da percepção do autor o papel da comunicação para a sociedade e o direito de comunicar dos cidadãos. Nesse sentido, as informações na Pastoral da Criança, levadas pelos programas de rádio e pelo jornal mensal garantem o direito à comunicação a suas voluntárias e voluntários. Isso porque o material não é apenas produzido para essas pessoas, mas também conta com a colaboração delas para a construção das mensagens.

O interesse de um leitor por uma informação, só vai ocorrer, conforme explica Chaparro (2007, p.146-148), quando o relato projeta interesses, desperta interesses ou responde a interesses. Isso é o que define a notícia. Quanto maior "os atributos de relevância social da informação, maior será a dimensão do interesse público atendido”. O que significa que quanto maior for a importância do conteúdo, maior será o interesse que o conteúdo desperta no leitor, no caso do jornal pesquisado, o voluntariado.

Esse processo de comunicação popular tem seu ápice na seção Comunidades do Jornal Pastoral da Criança. Nesse espaço, as informações são enviadas diretamente de comunidades 
dos mais diferentes pontos do Brasil. O jornal, como vimos, caracteriza-se pela comunicação popular ao ser produzido para as líderes que vivem nas comunidades carentes em que atuam e criar ferramentas de participação para as mesmas, enviando notícias para a publicação, que é editada por uma jornalista. Receptor e emissor têm a mesma importância no processo, em uma comunicação que não pode ser vista de forma vertical.

Vemos assim a importância do receptor no processo comunicativo. Algumas características a respeito do leitor são trabalhadas por Chaparro (2007) que usa a pragmática, a qual trabalha as relações entre os signos e os usuários nos processos sociais, para pensar o jornalismo. Ele cita Lamiquiz, que afirma: "as propriedades pragmáticas da mensagem da mensagem dependem das experiências anteriores do emissor e receptor, e de suas circunstâncias atuais" (2007, p.23). Outra fonte do autor é Cherry, que a partir de Peirce, diz: "cada signo significa algo para alguém - logo, o usuário está essencialmente implicado" (2007, p.25).

Interpretação é um processo complicado de atribuição de significados, e vai além do autor, porque aos leitores cabe dar sentido aos textos. Não há texto sem intenção nem leitura sem atribuição de sentidos. E nessa interação entre intenções de autoria e intenções de leitura, talvez os principais intérpretes sejam os que lêem, não os que escrevem. (CHAPARRO, 1998, p.104)

Já Dines (1986, p.54) afirma que “cada emissor é simultaneamente um receptor e viceversa, o que caracteriza o sistema como múltiplo, funcionando em todas as direções”. Cabe ao jornalista sentir as necessidades dos leitores, por sua vez, os leitores são "domesticados" para receber o material. No caso de um jornal de comunicação popular como o da Pastoral da Criança, é essencial que haja essa troca, no sentido de que as necessidades informativas sejam atendidas. Também essas informações devem ser compreendidas e colocadas em prática pela liderança. A identidade entre emissor e receptor, ou entre uma equipe de emissores e o
respectivo grupo de receptores, é chamada pelos teóricos de comunicação de
Campo de Experiências Comuns. É o campo magnético onde se estabelece a
sintonia e a identidade entre os dois pólos. Com o material extraído deste
C.E.C. processam-se os códigos. Esse campo unificado transforma cada
jornalista num leitor e o leitor num foco inspirador de temas. (DINES,1986,
p.59)

Por sua vez o papel do jornalismo, para o Chaparro (2007), está no "relato veraz", aquele em que "foi visto, ouvido e sentido pelo mediador". A "razão ética primordial do 
jornalismo" seria a de "viabilizar, asseverando, o acesso ao direito de informação", até se chegar nesse "relato veraz".

A ação jornalística se esgota no seu ato de asseverar, quando a mensagem é lida. Os derivados, em forma de comportamentos ou novas ações sociais, fazem parte da esfera criativa e livre do receptor, inserto em suas próprias circunstâncias sociais e seus interesses. Os comportamentos e as ações sociais derivados dos atos comunicativos do jornalismo realimentam o processo social, provocando transformações nos cenários da atualidade e da ordenação ética e moral da sociedade. (CHAPARRO, 2007, p.143)

Nesse sentido, Ramadan (2000, p.17) aponta "o jornalismo como uma atividade de interferência social, além de ser um dos espaços para a construção da cidadania”. Essa capacidade de interferência social pode ser vivenciada em um jornal com características de comunicação popular como o Jornal Pastoral da Criança. As informações levadas aos leitores possibilitam que eles tenham instrumentos para construir a cidadania em suas comunidades. Percebe-se um caráter educativo na publicação.

A interferência possibilitada pelo jornalismo também é apontada por Endler (1998): “o jornalismo é, igualmente, um discurso ativo e, portanto, que interfere na própria realidade". Da mesma forma, o autor destaca a importância do espaço como relação de sujeitos: "não deveria haver comunicação sem sujeito da autonomia".

Nesse processo de interferência social e educativo, que vemos se viabilizar no Jornal Pastoral da Criança, percebe-se o cumprimento de um dos papéis do jornalismo. O que é explicitado por Dines (1986, p.118) ao falar do jornalista: "Sabe-se que o processo de informar é um processo formador, portanto, o jornalista, em última análise, é um educador".

Essa educação através do jornalismo, em um veículo de comunicação popular, deve ocorrer numa perspectiva "freireana". O jornal da Pastoral deve fornecer subsídios para os seus leitores e aprender com eles. Essa aprendizagem alimentará a escolha das pautas do jornal, quais questões de saúde e cidadania que serão abordadas. As próprias reuniões e capacitações podem oferecer subsídios para orientar o trabalho jornalístico assim como a seção Comunidades.

A comunicação é um processo múltiplo, funcionando bilateral e simultaneamente entre emissor e receptor. Quando se pretende uma comunicação na direção única emissor-receptor, sem retorno (ou feedback), temos apenas a etapa primária da divulgação. E mesmo quando ocorre um retorno, mas do qual não participa toda a audiência potencial, persiste a disfunção. (DINES,1986, p.132) 
Outro ponto importante a considerar, principalmente ao se tratar de um jornal de comunicação popular, é o aspecto levantado por Kunczik (1997, p.387) “o jornalismo deve estar sempre em harmonia com o ambiente social em que opera". Nesse sentido, podemos pensar o Jornal Pastoral da Criança como o espaço para apresentar os desafios das comunidades, as soluções encontradas para os problemas, informações educativas que possam ajudar as comunidades na busca pelas soluções.

Isso significa falar da realidade das comunidades, dos líderes e sua ação em relação à saúde. Como afirmou Abramo (1988, p.113), “jornalismo é, em grande parte, o registro histórico cotidiano - ou do cotidiano histórico, como se queira -, é preciso ter pontos referenciais sobre o universo em que se vive”. Esse registro, para o autor, é mediado por uma ética do cidadão: “Gosto de fazer móveis, cadeiras, e minha ética como marceneiro é igual à minha ética como jornalista - não tenho duas. Não existe uma ética específica do jornalista. Sua ética é a mesma do cidadão" (1988, p.109). Assim como o jornalista deve ser guiado pela ética do cidadão, um jornal que tenta ser uma fonte de comunicação popular deve fazer o mesmo.

\section{3 - Um olhar sobre gêneros}

Abramo (1988, p.109) defende não só a ética do cidadão como a necessidade de que o jornalista tenha opinião: "É preciso ter opinião para poder fazer opções e olhar o mundo da maneira que escolhemos. Se nos eximimos disso, perdemos o senso crítico para julgar qualquer outra coisa".

A presença da opinião no fazer jornalístico também é defendida por Chaparro (2007), que critica a separação entre textos informativos e opinativos:

No ofício de fazer reportagens, entrevistas, notícias e editoriais, o jornalista exercita a arte de narrar ou argumentar. E o faz associando os fatos às idéias, os dados às emoções, os acontecimentos à reflexão, os sintomas ao diagnóstico, a observação à explicação, o pressuposto à aferição.

Não há, pois, como definir uma fronteira entre opinião e informação. Pela simples razão de que não existe essa fronteira.

Existe, sim, uma relação interativa, dialética, estratégica, criativa, permanente entre informação e opinião. E nessa relação se constrói o jornalismo, tanto nos esquemas da narração (para relatar os fatos) quanto no esquema da argumentação (para comentar os fatos). (CHAPARRO, 2007, p.13) 
Chaparro (1998, p.94) aponta que a categorização de gêneros jornalísticos em Opinativo e Informativo não tem eficácia, pois a pesquisa que realizou nos principais jornais brasileiros e portugueses mostrou que o "relato jornalístico consistente acolhe cada vez mais a elucidação opinativa e que o comentário da atualidade exige cada vez mais a sustentação de informações qualificadas". Ele conclui que esse é um falso paradigma, pois o "jornalismo não se divide, mas constrói-se com informações e opiniões" (1998, p.100).

Pena (2005, p.66) conta que essa classificação remete ao início do século XVIII, quando o editor inglês Samuel Buckley separou o conteúdo do jornal Daily Courant em news (notícias) e comments (comentários). "Para se ter uma idéia da dificuldade em estabelecer um conceito unificado de gênero, essa divisão demorou quase duzentos anos para ser efetivamente aplicada pelos jornalistas e, até hoje, causa divergências".

$\mathrm{O}$ autor explica ainda que muitos autores seguiram "essa dicotomia" e utilizaram a forma e o conteúdo como critério de separação. Dessa forma, chegou-se a "divisão por temas e pela própria relação do texto com a realidade (opinião x informação), contribuindo assim para uma classificação a partir da intenção do autor”. É dessa forma que José Marques de Melo propõe a seguinte divisão: Jornalismo Informativo (nota, notícia, reportagem e entrevista) e Jornalismo Opinativo (editorial, comentário, artigo, resenha, coluna, crônica, caricatura e carta).

No entanto, Chaparro (1998) avalia que a própria valoração jornalística e a interferência dos sujeitos do processo impossibilitam a existência de uma fronteira que faça essa separação:

Não há como ajustar as formas discursivas do jornalismo ao critério que divide os textos em informativos e opinativos - até por serem coisas de esferas diferentes: na teoria dos gêneros, a divisão dos textos em classes e tipos (artigo, notícia, reportagem, entrevista, crônica...) resulta da diversidade nas estruturas externas, identificando formas; já as propriedades informativas e opinativas das mensagens são como que substâncias na natureza do jornalismo, no sentido em que se constituem suportes que permanecem na totalidade da acção jornalística, quer se relate ou se comente a atualidade.

A apuração e a depuração, indispensáveis ao bom relato, são intervenções valorativas, intencionadas por pressupostos, juízos, interesses e pontos de vista estabelecidos. Como noticiar ou deixar de noticiar algum fato sem a componente opinativa? Por outro lado, o comentário - explicativo ou crítico - será ineficaz se não partir de factos e dados confiáveis, rigorosamente apurados. (CHAPARRO, 1998, p. 110)

Para Chaparro (1998, p.113-123), há o texto com uma estrutura formal argumentativa e o texto com uma estrutura formal narrativa, ambos contendo informação e opinião. $\mathrm{O}$ que 
não existe é uma estrutura rígida que faça com que quesitos que andam juntos possam ser separados para classificar os textos. Por exemplo, para relatar acontecimentos, avalia que a narração é mais eficaz, o que não impede que juízos de valor estejam no texto e nas escolhas que gerou a produção.

A partir dessas constatações, o autor propõe a classificação de gêneros a partir das formas de discurso e das duas formas de ação jornalística - "relatar a atualidade" e "comentar a atualidade". Assim propõe dois gêneros de discurso jornalístico: Comentário e Relato. Cada gênero agrupa dois tipos de espécies que foram elaboradas a partir da leitura qualitativa de jornais. Apresenta o seguinte quadro de classificação:

\begin{tabular}{|l|l|l|l|}
\hline \multicolumn{2}{|c|}{ Gênero Comentário } & \multicolumn{2}{c|}{ Gênero Relato } \\
\hline $\begin{array}{l}\text { Espécies } \\
\text { Argumentativas }\end{array}$ & $\begin{array}{l}\text { Espécies Gráfico- } \\
\text { Artísticas }\end{array}$ & $\begin{array}{l}\text { Espécies } \\
\text { Narrativas }\end{array}$ & Espécies Práticas \\
\hline Artigo & Caricatura & Reportagem & Roteiros \\
\hline Crônica & Charge & Notícia & Indicadores \\
\hline Cartas & & Entrevista & Previsão do Tempo \\
\hline Coluna & & Coluna & Cartas-consulta \\
\hline & & & Orientações Úteis \\
\hline
\end{tabular}

Usaremos a classificação proposta por Chaparro (1998) para analisar o Jornal Pastoral da Criança quanto ao uso dos gêneros de discurso jornalístico e a utilização das espécies definidas pelo autor. Ao mesmo tempo iremos apresentando as seções existentes na publicação.

Criado em 1985, o Jornal Pastoral da Criança é mensal desde setembro de 2003 (antes era bimestral), quando contava com 16 páginas. Em formato tablóide, atualmente, a publicação costuma ter 16 ou 24 páginas. Observamos os jornais publicados entre os meses de fevereiro de 2008 e junho de 2009, totalizando 16 publicações, pois para os meses de dezembro de 2008 e janeiro de 2009 houve uma única edição. A partir de fevereiro de 2009, apresentou uma nova diagramação e textos com frases mais curtas. As edições com 24 páginas foram as de fevereiro, maio, agosto e setembro de 2008; já em 2009, apenas a edição de abril. Esses meses trouxeram encartes: em fevereiro/2008, oito páginas com o tema a participação da comunidade na política/rodas de conversa sobre as eleições e círculos bíblicos; em maio/2008, círculos bíblicos com quatro páginas; em agosto/2008, saneamento 
básico e círculos bíblicos, oito páginas; em setembro/2008, duas páginas sobre os 25 anos da Pastoral da Criança; já em abril/2009, reflexão sobre visitas e a bíblia, com quatro páginas. Todas as outras edições tiveram 16 páginas

Com 280 mil exemplares distribuídos mensalmente por todo o Brasil, o Jornal Pastoral da Criança apresenta tanto o gênero comentário quanto o relato. No entanto, não são todas as espécies catalogadas por Chaparro (1998) que aparecem. Especificaremos, nesse trabalho, quais são as espécies utilizadas, de que forma e quais têm mais destaque ${ }^{66}$.

Das edições de fevereiro de 2008 a junho de 2009, apenas cinco apresentam a espécie argumentativa carta através da seção denominada Espaço do Leitor: fevereiro/2008, março/2008, junho/2008, julho/2008, agosto/2008 e dezembro-janeiro/2009. Em cada edição, só há espaço para o comentário de um leitor, trazendo sempre manifestações elogiosas como na edição de junho de 2008: “Meu nome é Helena Figueiredo. Sou de Janaúba, Minas Gerais, da Comunidade Cerâmica. Sou líder da pastoral da Criança e adoro trabalhar na minha comunidade. Um abraço e parabéns pelo Jornal da Pastoral da Criança".

Percebe-se uma falha nesse direcionamento, pois como veículo de comunicação popular, essa deveria ser uma espécie privilegiada para os leitores e leitoras manifestarem uma perspectiva crítica. Também se avalia que houve um retrocesso na publicação. Em análise das edições de setembro de 2003 até agosto de 2004, verificamos que a seção era um espaço para a manifestação crítica, o que se repetia em diversas edições:

Observando-se a questão educativa, o "Editorial" de janeiro de 2004 destaca
as dicas sobre prevenção contra a dengue no jornal. Nessa mesma linha, o
"Espaço do Leitor" traz uma redação de uma menina de 9 anos, mandada por
sua mãe, voluntária da Pastoral, que fala sobre os problemas que atingem as
crianças: "Segundo a carta dos direitos humanos, toda criança tem direito à
felicidade, mas o que vemos é o contrário. A situação das crianças hoje em
dia é apavorante." A partir disso, a menina faz um contraponto com
exemplos negativos, como a chacina da Candelária, e positivos, como o
trabalho da Pastoral da Criança. Esse espaço caracteriza de forma positiva a
comunicação popular, dando espaço a uma criança e, ao mesmo tempo, com
uma perspectiva crítica. (REIMBERG, 2006, p.97)

Vemos que atualmente não há essa perspectiva crítica. Para Dines (1986), o espaço de “cartas de leitores" é importante porque

O leitor não é fato isolado e singular, é fração de universo. O que acontece com um leitor está acontecendo simultaneamente com o conjunto que ele representa. É por isso que a seção de "Cartas de Leitores" tem tamanha importância num jornal, pois não atende apenas àqueles que se armaram de

\footnotetext{
${ }^{66}$ Os textos dos encartes não foram analisados.
} 
paciência e coragem para escrever ao jornal, mas a todos aqueles que não tiveram a mesma disposição, mas assim pensam. (DINES, 1986, p.55)

Outra seção existente é o Editorial, sempre na página 2, presente em todos os exemplares observados. Segundo Abramo (1988, p.117), geralmente, o editorial é o espaço no qual os jornais manifestam suas opiniões. Ele acredita que os editoriais "funcionam, na medida em que o jornal explicita cada vez mais o seu ponto de vista em relação às questões que afetam a vida do cidadão". Usando a classificação de Chaparro (1998), podemos afirmar que o editorial, em geral, é uma espécie argumentativa artigo, pertencente ao gênero Comentário.

No entanto, o Editorial do Jornal Pastoral da Criança ganha característica da espécie coluna, pois as edições de fevereiro até março de 2008 são assinadas pelo coordenador nacional adjunto da Pastoral da Criança, Nelson Arns Neumann. Já nas edições de abril de 2008 até junho de 2009, a seção passa a contar com a assinatura da nova coordenadora nacional da Pastoral da Criança, irmã Vera Lúcia Altoé. A partir de fevereiro de 2009, a seção ganha mais destaque visual ao ser colocada em um box, com fundo em cor salmão.

Chaparro (1998, p.113) explica que o "artigo, no plano da linguagem, identifica um tipo de texto organizado em esquemas argumentativos, adequados para a estruturação de comentários". Já sobre a coluna (1998, p.88-89), o autor diz que é uma espécie híbrida, que pode ser eficaz tanto para a argumentação (comentário da atualidade) quanto para a narração (relato da atualidade). "Nas características da Coluna, tem relevância a capacidade de potencializar a credibilidade dos conteúdos, pois, por ter autoria reconhecida e especializada, a espécie agrega a respeitabilidade do autor à do jornal”.

No caso do Jornal Pastoral da Criança, o texto do editorial apresenta comentários sobre os principais temas do jornal, fazendo uma relação com a necessidade de que os conteúdos sejam utilizados, como nesse trecho de março de 2009: "Gostaria ainda de indicar a leitura das dicas sobre alimentação. Líder, leve essas orientações a todas as famílias para que a alimentação enriquecida e de baixo custo possa fazer parte do dia-a-dia de nossas comunidades".

Observando os textos, percebemos a hibridez de que fala Carlos Chaparro e classificamos a seção Editorial como coluna, uma espécie que pode se apresentar tanto como espécie argumentativa como espécie narrativa. Essa mistura pode acontecer até em um mesmo texto. Acreditamos que o fato do editorial ser assinado pelos mais altos representantes da coordenação nacional da entidade, agrega ao texto o valor da credibilidade do autor. 
O Jornal Pastoral da Criança apresenta outras duas colunas fixas de grande destaque. São as seções Palavra do Pastor e Conversando com você. A primeira é assinada por algum bispo da Igreja. A outra pela fundadora da Pastoral da Criança, Zilda Arns.

A coluna Palavra do Pastor tem um forte caráter argumentativo. Geralmente apresenta conselhos, perspectiva crítica sobre determinada situação e busca a reflexão do leitor. Tudo aliado a uma avaliação sobre a importância da ação da Pastoral da Criança. Algumas vezes os autores recorrem a um recurso narrativo, usando uma história para exemplificar uma questão, tendendo ao gênero relato como na edição de maio de 2008 com o bispo de Registro/SP, Dom José Luiz Bertanha:

Entre a minha vida e a do meu filho, salvem a criança”! Esta afirmação chegou a nós por Santa Gianna Beretta Molla, uma médica, mãe de família, que no dia do seu casamento propôs e assumiu junto a seu noivo: "queremos formar uma família verdadeiramente cristã, um pequeno cenáculo onde o Senhor reine em nossos corações, ilumine as nossas decisões e os nossos programas, como projeto de vida.

No entanto, na maioria das vezes, o uso do recurso da narração serve como base de sustentação argumentativa. É a partir das histórias que se caminha para argumentação. Esses textos também trazem reflexões sobre os problemas sociais como na edição de fevereiro de 2009, quando Dom Aldo Di Cillo Pagotto, presidente do Conselho Diretor da Pastoral da Criança e arcebispo da Paraíba fala sobre a campanha da fraternidade de 2009, que apresentamos abaixo. O texto inclusive atua contra a forma estigmatizante que o jovem envolvido com drogas é visto e traz uma discussão voltada para a falta de políticas públicas:

Primeiro, a violência se espalhou de tal forma que o povo está chamando de
'violência generalizada'. A violência começa em casa, quando damos mais
importância às exterioridades do que às pessoas. (...)
Segundo, a violência está vinculada ao narcotráfico. A droga está presente
em todo canto. O tráfico de droga alimenta o crime organizado. Por falta de
políticas de educação e capacitação para o trabalho e renda, muitos
adolescentes e jovens ficam sem perspectiva na vida. O mundo do crime os
recruta e os adota. (...)
(...) O que mais temos que fazer é visitar as famílias e educar as pessoas para
uma cultura de paz.

Já a coluna de Zilda Arns, começa sempre como se fosse uma carta com a frase “Querido (a) líder, Querido (a) coordenador (a), Paz e Bem!” O estilo busca uma aproximação com o leitor, como se fosse uma conversa, o que se percebe até mesmo pela utilização de temos como “Está de acordo?” (edição de junho de 2008), "Não é assim?” (edição de maio de 2008). Estimula-se o leitor e a leitora a refletirem sobre os comentários expostos. Os textos 
trazem relatos de histórias, dados informativos e teores argumentativos, mostrando a hibridez da espécie coluna. Também há um forte estímulo à mobilização nos textos de Zilda Arns, como vemos na edição de maio de 2008:

Todos temos que lutar para que os serviços públicos de saúde, como o prénatal e a assistência ao parto, tenham boa qualidade e funcionem bem. Assim como as crianças, as pessoas idosas também devem receber atenção especial, conforme determina o estatuto do Idoso. Os avós são muito importantes para nossas crianças. Você concorda comigo?

Vale relembrar a importância da coluna de Zilda Arns no jornal, pois como Faxina (2001, p.216) constatou em sua pesquisa de mestrado, todos os seus entrevistados, voluntários da Pastoral da Criança, liam os artigos de Zilda Arns. Isso se deve a credibilidade da autora junto aos voluntários, por ser a fundadora da Pastoral da Criança e vista como a grande responsável pela Pastoral ter ganhado a dimensão que tem.

Outra seção de relevo no jornal é Comunidades, bastante destacada pelos entrevistados e entrevistadas de Faxina (2001) como também em nossa pesquisa, já que foi a parte do jornal mais citada nas entrevistas. Nessa parte do jornal, concentram-se as notícias enviadas por comunidades de diversos locais do Brasil. É o espaço no qual se concentra o gênero relato com a espécie narrativa notícias. Abaixo uma tabela que mostra a distribuição dos textos. Não fizemos diferenciação entre nota e notícia.

\begin{tabular}{|c|c|c|c|}
\hline Mês & $\begin{array}{c}\text { Número de } \\
\text { páginas da } \\
\text { seção }\end{array}$ & $\begin{array}{c}\text { Número de } \\
\text { Notícias } \\
\text { enviadas pelas } \\
\text { comunidades }\end{array}$ & Outros \\
\hline Fevereiro/2008 & 8 & 35 & $\begin{array}{c}\text { Mural de recados }-5 \\
1 \text { Comentário especialista }\end{array}$ \\
\hline Março/2008 & 8 & 36 & $\begin{array}{c}\text { Mural de recados }-6 \\
1 \text { Artigo de comunidade }\end{array}$ \\
\hline Abril/2008 & 8 & 34 & $\begin{array}{c}\text { Mural de recados }-5 \\
1 \text { Orientação Útil da } \\
\text { Coordenação }\end{array}$ \\
& & & $\begin{array}{c}\text { Mensagem Nelson Arns } \\
\text { Neumann }\end{array}$ \\
\hline Maio/2008 & 10 & 43 & $\begin{array}{c}\text { Mural de recados }-6 \\
3 \text { poesias das }\end{array}$ \\
\hline
\end{tabular}




\begin{tabular}{|c|c|c|c|}
\hline & & & $\begin{array}{c}\text { Comunidades } \\
1 \text { nota Coordenação } \\
\text { Nacional }\end{array}$ \\
\hline Junho/2008 & 8 & 40 & $\begin{array}{c}\text { Mural de recados }-4 \\
1 \text { Artigo de comunidade } \\
2 \text { Notas da Coordenação } \\
\text { Nacional } \\
1 \text { Citação de Madre Tereza } \\
\text { de Calcutá }\end{array}$ \\
\hline Julho/2008 & 8 & 32 & $\begin{array}{c}\text { Mural de recados - } 4 \\
1 \text { Orientação Útil da } \\
\text { Coordenação } \\
1 \text { Comentário especialista } \\
1 \text { Nota da Coordenação } \\
1 \text { Citação do Documento } \\
\text { de Aparecida }\end{array}$ \\
\hline Agosto/2008 & 8 & 31 & $\begin{array}{l}\text { Mural de recados }-4 \\
1 \text { carta de comunidade } \\
1 \text { Artigo de comunidade }\end{array}$ \\
\hline Setembro/2008 & 12 & 50 & Mural de Recados -6 \\
\hline Outubro/2008 & 8 & 33 & Mural de Recados - 5 \\
\hline Novembro/2008 & 8 & 32 & Mural de Recados -4 \\
\hline $\begin{array}{c}\text { Dezembro/2008- } \\
\text { Janeiro/2009 }\end{array}$ & 8 & 35 & $\begin{array}{c}\text { Mural de Recados - } 5 \\
1 \text { Comentário } \\
\text { Coordenação Nacional } \\
1 \text { Artigo estadual (SP) } \\
1 \text { Mensagem Feliz Natal }\end{array}$ \\
\hline Fevereiro/2009 & 8 & 32 & $\begin{array}{c}2 \text { Poesias } \\
1 \text { Canção } \\
1 \text { Nota irmã Vera Altoé } \\
1 \text { Nota Coordenação - } \\
\text { Mutirão das gestantes }\end{array}$ \\
\hline Março/2009 & 8 & 32 & Mural de Recados - 3 \\
\hline
\end{tabular}




\begin{tabular}{|c|c|c|c|}
\hline Abril/2009 & 10 & 31 & $\begin{array}{c}\text { Mural de Recados - } 3 \\
2 \text { Perguntas e respostas } \\
1 \text { Orientação útil } \\
\text { Coordenação Nacional } \\
1 \text { Opinião do leitor } \\
1 \text { Poesia } \\
1 \text { Artigo de Comunidade }\end{array}$ \\
\hline Maio/2009 & 8 & 28 & $\begin{array}{l}1 \text { Nota Coordenação - } \\
\text { Mutirão das gestantes } \\
1 \text { Poesia }\end{array}$ \\
\hline Junho/2009 & 8 & 25 & $\begin{array}{c}\text { Mural de Recados - } 3 \\
1 \text { Nota Equipe Jornal } \\
1 \text { Relato de uma mãe de } \\
\text { comunidade } \\
1 \text { Notícia Coordenação } \\
\text { Nacional }\end{array}$ \\
\hline
\end{tabular}

Percebe-se a grande quantidade de notícias enviadas pelas comunidades, de diferentes locais do Brasil. Uma média mensal de 34 notícias foi enviada pelas comunidades nas 16 edições, entre os meses de fevereiro de 2008 e junho de 2009, e um total de 549 notícias. As comunidades também são livres para mandar o texto em formato de artigo ou poesias, o que ocorreu por quatro e sete vezes, respectivamente, no período estudado. Já o Mural de Recados traz mensagens enviadas pela liderança. Foram 63 notinhas enviadas durante o período estudado, com uma média de 4 recados por edição. No entanto, no mês de fevereiro e maio de 2009 não houve essa seção.

Destacamos ainda a mensagem de Nelson Arns Neumann, na edição de abril de 2008, faz um comentário sobre terem recebido muitas notícias sobre o Natal. O interessante é a forma como começa sua mensagem: "Os professores de jornalismo costumam dizer que 'se o cachorro morde um homem' não é notícia, mas se 'o homem que morde o cachorro' pode colocar no jornal". A partir de então, liga o número de notícias recebidas à importância da data. É a única reflexão que achamos durante o período estudado sobre o significado da notícia.

Segundo Milman (1998), "a notícia é apresentada como a mais adequada expressão narrativa dos fatos, como gênero jornalístico primeiro". Também diz que as "matrizes da 
notícia" são os fatos que despertam interesse na maioria das pessoas. Já Chaparro (1998, p.125) define notícia como "o resumo informativo para a descrição jornalística de um facto relevante que se esgota em si mesmo, e para cuja compreensão bastam as informações que o próprio facto contém".

As notícias das comunidades ocupam a maior parte do jornal. Elas informam sobre atividades realizadas, capacitações, crianças recuperadas, comemorações. Contam as histórias vivenciadas nas comunidades. As duas definições citadas acima podem ser relacionadas à seção Comunidades, que traz fatos locais, mas que despertam o interesse do público leitor. Isso porque apesar de falarem de realidades de lugares diferentes, mostram uma ação comum em prol do desenvolvimento das crianças pela Pastoral.

As últimas páginas do Jornal Pastoral da Criança trazem a seção Aprendendo Mais. São diversos tópicos apresentados, cuja principal característica é apresentar o gênero relato através da espécie prática orientações úteis. Também há artigos nessa seção. Em ambos os casos, as temáticas abordadas são voltadas para a saúde, a educação e a cidadania.

\section{4 - O receptor como produtor}

O papel da recepção na reconstrução das mensagens pode ser dimensionado a partir da afirmação de Bosi (2003, p.115): "sabemos que transfiguramos uma cena por nós assistida, e ela sofre uma distorção causada pelo ponto de vista. Como se a nossa percepção das coisas fosse, mais do que uma recepção, uma construção, uma tarefa sobre o mundo".

Sousa (2002, p.23) explica que na pós-modernidade, “o receptor em comunicação pode ser visto empiricamente como colocado numa zona limite e conflitiva". Isso porque "de um lado é o sujeito-indivíduo, o apelo ao usufruto, ao valor de bens da sociedade disponível; de outro lado, é o sujeito social, mas no limite do aqui e agora, na valorização do tempo e do espaço em que de fato vale a pena investir". É um receptor que "se confunde ora com o consumidor social ora com o desbravador de si mesmo". Assim "não se resume a depositário sedento do irrefletido de desejos, nem a uma busca desesperada de si". Rompe-se "com a primazia do objeto", mas nem sempre se analisa a "pluralidade de tendências".

Há uma rearticulação da relação “indivíduo/sujeito/receptor”. Se por um lado "a ruptura pós-moderna" nega "os parâmetros que sustentavam a utilização de teorias mais generalizantes e macroexplicativas, como o marxismo e a psicanálise freudiana"; por outro, 
vários autores usam esses paradigmas, acrescentando "outros elementos para dar conta das novas e diferentes práticas contemporâneas". Entre esses estudos, há aqueles que "são voltados para o espaço do mundo cotidiano de pessoas e grupos sociais, não se apegando necessariamente à ortodoxia de grandes paradigmas". No geral, nos anos 70 e 80, havia uma busca para compreender o social e a singularidade do indivíduo. (SOUSA, 2002, p.24-26)

Quanto às comunicações, chama atenção a busca de condicionantes do
sujeito, das mediações que ultrapassam a noção de um determinismo entre
emissor e receptor, ou sujeito e objeto. Embora esse "quem" da
comunicação, esse sujeito, teoricamente ainda não esteja configurado, sabe-
se que ocupa um espaço contraditório, o da negociação, o da busca de
significações e de produções incessantes de sentido na vida cotidiana. O
receptor deixa de ser visto, mesmo empiricamente, como consumidor
necessário de supérfluos culturais ou produtos massificados apenas porque
consome, mas resgata-se nele também um espaço de produção cultural; é um
receptor em situações e condições, e por isso mesmo cada vez mais a
comunicação busca na cultura as formas de compreendê-lo, empírica e
teoricamente. (SOUSA, 2002, p.26-27)

Ainda destaca a importância do cotidiano e das mediações. É na prática cotidiana que "as pessoas encontram elos para relacionar-se consigo mesmas" e "constroem sua identidade de sujeito" (2002, p.34). Já a noção de mediação "procura qualificá-la no receptor, no emissor, no processo grupal, social" (2002, p.36).

Baccega e Guimarães (2005, p.409-410), por sua vez, afirmam que nos anos 70, “a recepção começa a ser concebida como ativa, admitindo-se a participação dos sujeitos na reconstrução dos significados das mensagens". As autoras avaliam que para ocorrer a comunicação, os interlocutores precisam ter "uma memória comum" e fazer parte de "uma mesma cultura", o que traçará o percurso de leitura. Assim a comunicação "é uma prática cultural que produz significados". No encontro de emissão e recepção, novos sentidos são produzidos ou reconfigurados, e a interpretação se dá por meio dessa memória comum e das referências culturais. O receptor como sujeito ressignifica o que ouve, vê ou lê para incorporar ou não a suas práticas, agindo como co-produtores.

White (1998, p. 58-59), por sua vez, usa o termo "audiência ativa" e fala de uma "teoria da interpretação da audiência", que procura interpretar o uso que as audiências fazem da mídia e as construções subjetivas de significados. Aponta, assim, quatro linhas de abordagens - Estudos Culturais, Simbólica Interacionista, Consenso Cultural e Abordagens Resultantes de Interesses na Cultura Popular. Essa última abrange os movimentos populares, mídia do povo, democratização da comunicação e pesquisa sobre mídia e desenvolvimento das culturas nacionais. Assim, "muda o foco segundo o qual a mídia é exclusivamente agente 
e fonte de construção do significado, deixando para trás a mídia como mero texto e leitura de textos e prioriza o enfoque da construção do significado por comunidades interpretativas".

Outra autora a avaliar a recepção é Lopes (2005, p.34-43). Primeiro fala sobre os estudos culturais dos anos 70, que "liberaram a reflexão sobre a recepção dos meios do modelo reducionista dos efeitos" e colocaram a recepção "como prática complexa de construção social de sentido". Isso ocorre com uma análise da produção e recepção da mensagem "dentro de um quadro semiológico inspirado no marxismo".

O conceito gramsciano de hegemonia é usado no modelo de codificação/decodificação de sentido (Hall) para examinar os modos concretos pelos quais os significados do meio podem ser negociados ou até eventualmente subvertidos por audiências específicas. A audiência, para os estudos culturais é, então, uma estrutura complexa que reúne indivíduos em classes, grupos ou subculturas, onde cada formação social tem sua própria identidade e seu próprio código. O código funciona através de versões múltiplas que reenvia às tradições culturais particularmente operantes numa determinada sociedade. (LOPES, 2005, p.35)

Sobre os estudos culturais, Lopes (2005, p.35) ainda aponta que "permitem uma problematização mais elaborada da recepção em que as características socioculturais dos usuários são integradas na análise não mais de uma difusão, mas de uma circulação de mensagens no seio de uma dinâmica cultural". A reflexão que era focada nos meios passa para os grupos sociais, os quais fazem parte de práticas sociais e culturais ampliadas.

Segundo Hall (2006, p.365-381), os significados e mensagens circulam através de discursos que se utilizam da linguagem e outras formas de comunicação. Esses discursos são transformados em práticas sociais, produzindo efeitos. Quando um evento histórico é colocado sob a forma de um discurso, ele se sujeita a complexidade de regras da linguagem ou da forma de comunicação. A recepção, por sua vez, passa não só pela compreensão como também pelas relações econômicas, sociais, que moldarão a concretização da recepção e possibilitarão que os significados adquiram valor de uso social. O processo comunicativo pode ser visto como estrutura produzida através de articulação de momentos distintos e interligados - produção, circulação, distribuição, consumo, reprodução.

O autor ainda explica que a diferença entre conotação e denotação é somente analítica e é mantida pelo fato dos signos adquirirem valor ideológico. Na denotação, essa ideologia está fortemente fixada. Já na conotação, as ideologias alteram e transformam a significação. Há uma ordem cultural dominante com domínios discursivos que privilegiam certos sentidos/significados. A codificação produz limites para as decodificações operarem, mas isso 
não é totalmente determinado. No entanto, deve haver certa reciprocidade entre a codificação e decodificação para se ter uma efetiva troca comunicativa.

Hall (2006, p.377-380) ainda enumera três posições hipotéticas sobre a decodificação de um discurso televisivo, mas que serve para pensarmos a decodificação em diferentes meios a partir da mediação do receptor. Uma delas é a "posição hegemônica-dominante", na qual ocorre a apropriação do sentido conotado de forma integral. Já o "código negociado" mistura elementos de adaptação e oposição, pois reconhece a legitimidade das definições hegemônicas, mas também cria regras em nível mais restrito. Por sua vez, o "código de oposição" destotaliza a mensagem no código preferencial para retotalizá-la em um referencial alternativo.

Pensando no Brasil e na América Latina, os estudos de recepção ganham força no início dos anos 80, inseridos na temática das culturas populares. Desenvolve-se, assim, "uma teoria complexa e multifacetada", da qual destacam-se o "deslocamento dos meios às mediações", a partir da reflexão de Martín-Barbero, e "os processos de hibridização cultural", pensado por García Canclini. A mediação é "uma espécie de estrutura incrustada nas práticas sociais e no cotidiano de vida das pessoas que, ao realizar-se através dessas práticas, traduz-se em múltiplas mediações”. (LOPES, 2005, p.35-37)

A abordagem das mediaçães se firma como renovadora em função de que a
noção de mediação em Martín-Barbero emerge de uma visão (re)integradora
dos fenômenos de comunicação a partir do binômio comunicação-cultura
(por sua vez, também renovado), a partir da qual se critica o exclusivismo e
o determinismo dos paradigmas informacional-tecnológico, semiológico e
ideológico que tem marcado a história dos estudos de comunicação na
América latina. Organiza-se, então, como uma perspectiva que pretende
integrar todos os âmbitos da comunicação, tanto a produção, como o produto
e a recepção. (LOPES, 2005, p.40-41)

Já Martín-Barbero (2002, p.39-40) explica que “a recepção não é apenas uma etapa do processo de comunicação. É um lugar novo", no qual se deve repensar "o processo inteiro" e acabar com o modelo mecânico. Nesse não há "verdadeiros atores nem verdadeiros intercâmbios", o que se quer é "fazer chegar uma informação, um significado já pronto, já construído, de um pólo a outro". A recepção, assim, é vista como "um ponto de chegada daquilo que já está concluído". O que o autor considera "uma confusão epistemológica muito grave", pois se confunde "a significação da mensagem com o sentido do processo e o das práticas de comunicação". Dessa forma, as "práticas nas vidas das pessoas" são reduzidas ao significado da mensagem. 
Trata-se de colocar a "iniciativa da atividade comunicativa" toda no emissor. Ao receptor caberia apenas "reagir aos estímulos do emissor". Uma "concepção condutista" fundada no iluminismo para o qual o conhecimento na educação era transmitido para quem não conhece. 'O receptor era 'tábua rasa', apena um recipiente vazio para depositar os conhecimentos originados, ou produzidos, em outro lugar”. (MARTÍN-BARBERO, 2002, p.41)

A crítica que faz Martín-Barbero é a mesma que Freire realiza e teoriza na educação bancária. Outra similaridade é que o primeiro fala em "multiciplidade de histórias, com seus próprios ritmos e com suas próprias lógicas" (2002,p.43); já o segundo destaca o papel do sujeito em construir a história. É de Martín-Barbero que emerge a noção de mediação, como se pode ver abaixo, onde o autor relaciona o conceito com ritualidades para explicar o processo comunicativo.

\begin{abstract}
A mediação das ritualidades remete-nos ao nexo simbólico que sustenta toda comunicação: à sua ancoragem na memória, aos seus ritmos e formas, seus cenários de interação e repetição. Em relação com os FI (discursos, gêneros, programas e grades ou palimpsestos, as ritualidades constituem gramáticas da ação - do olhar, do escutar, do ler - que regulam a interação entre os espaços e tempos da vida cotidiana e os espaços e tempos que formam os meios. O que implica da parte dos meios, uma certa capacidade de impor regras aos jogos entre significação e situação. Porém, uma coisa é a significação da mensagem e outra, aquilo a que alude a pragmática quando faz a pergunta pelo sentido que tem para o receptor a ação de ouvir rádio ou de ver televisão. Vistas a partir das CR, as ritualidades remetem, de um lado, aos diferentes usos sociais dos meios, por exemplo, ao barroquismo expressivo dos modos populares de assistir ao filme frente à sobriedade e seriedade do intelectual, para quem qualquer ruído é capaz de distraí-lo de sua contemplação cinematográfica. Ou ao consumo produtivo que alguns jovens fazem do computador diante do uso marcadamente lúdico-evasivo da maioria. De outro lado, as ritualidades remetem às múltiplas trajetórias de leitura ligadas às condições sociais do gosto, marcadas por níveis e qualidade de educação, por posses e saberes constituídos na memória étnica, de classe ou de gênero e por hábitos familiares de conivência com a cultura letrada, oral ou audiovisual, que carregam a experiência de ver sobre a do ler ou vice-versa. ${ }^{67}$ (MARTÍN-BARBERO, 2006, p.19)
\end{abstract}

Para Martín-Barbero (2002, p.54-55), o estudo da recepção pode resgatar a “complexidade da vida cotidiana, como espaço de produção de sentido". Assim é preciso estudar o que as pessoas fazem com os meios, o que não quer dizer, no entanto, que o leitor "faz o que lhe der vontade". Também não se pode "desligar o estudo da recepção dos processos de produção". "Eu não poderia compreender o que faz o receptor, sem levar em

\footnotetext{
${ }^{67}$ Quando o autor escreve FI quer dizer Formatos Industriais e CR - Competências de Recepção ou Consumo. (MARTÍN-BARBERO, 2006, p.16)
} 
conta a economia de produção, a maneira como a produção se organiza e se programa, como e por que pesquisar as expectativas do receptor". Para o autor, a "recepção é um processo de interação", “de negociação de sentido" (2002, p. 57). Assim, é preciso evitar os extremos:

O primeiro extremo é: quem sabe o que se passa na comunicação é o emissor. Há que estudar as intenções do emissor, se são manipulatórias ou ideológicas. Nem podemos ficar no extremo de pensar que o receptor faz o que quer com a mensagem. O que estamos estudando, com base na recepção, é um modo de interagir não só com as mensagens, mas com a sociedade, com outros atores sociais, e não só com os aparatos. (MARTÍN-BARBERO, 2002, p.58)

Acreditamos que, com nosso estudo, estamos fazendo esse percurso de entender todo o processo comunicativo da Pastoral da Criança. Analisamos as intenções do emissor, a construção coletiva das mensagens e ouvimos as próprias leitoras para ver como a informação do Jornal Pastoral da Criança contribui para a ação das mesmas, podendo inferir a partir da pesquisa a contribuição dessa comunicação para o processo educativo, que leva à construção da cidadania. Essas receptoras das mensagens são também construtoras das mesmas, a partir do processo de comunicação popular e estratégias de participação criadas pela Pastoral da Criança.

Sendo espaço de negociação, apropriação e produção de sentido,

el concepto de recepción renuncia a todo dejo de pasividad e incluso a la asociación de receptor activo en términos de "usos y gratificaciones". Estamos frente a un proceso de recepción que requiere un estudio pormenorizado, entender al receptor como el productor, comprender la influenzia de lo cotidiano y de las modalidades de recepción en la asignación de sentido que "construye" el receptor, sin olvidar que éste está inmerso em un determinado contexto socio-cultural. (CANTÚ e CIMADEVILLA, 1998, p.47)

São sujeitos da comunicação em um processo educativo construído de forma dialógica nas práticas cotidianas. O que não invalida que as informações, tanto das capacitações quanto do jornal, têm uma intenção e um significado pensados pela Coordenação Nacional, ainda que pensado nacionalmente e com canais de participação. Essa intenção é educar e contribuir para a saúde e o desenvolvimento da criança, o que é irradiado a toda a família e leva a um despertar para a cidadania. Em depoimento dado a autora no dia 29 de março de 2008, uma multiplicadora do Estado de São Paulo afirmou sobre a questão da comunicação que:

As informações que são geradas na Coordenação Nacional precisam fluir para chegar ao líder de forma fiel em relação à fonte das informações. Então existe um caminho percorrido que garante no Brasil todo essa multiplicação 
das informações de maneira fiel. Esta maneira idealizada pela Pastoral é para garantir a fidelidade das informações que os líderes têm direito de receber. (Maria Lúcia de Campos Guerra Caldin)

As líderes e os líderes são sujeitos, com direito de receber a informação, mas também de produzi-las e se de se fazer ouvir por meio de seções como Comunidades ou Testemunho.

...sabe-se que todo sujeito reúne as possibilidades de produzir e receber discursos, na medida em que está em contato com o campo do código, enquanto outro, dimensão que lhe fornece as faculdades de construir as "gramáticas de produção" e "gramáticas de recepção" de mensagens. Portanto, esse trabalho de mobilização e apropriação sobre o código não é algo restrito ao chamado núcleo de emissão - como quer o modelo empiricista de comunicação. (FAUSTO NETO, 2002, p.196)

Para Fausto Neto (2002, p.199-200), "as interações entre sujeitos e campos sociais se dão" por meio de "contratos de leitura", os quais são "um conjunto de regras e de instruções construídas pelo campo da emissão para serem seguidas pelo campo da recepção". Mas isso não significa "passividade do leitor" em relação ao discurso. Cabe a ele "efetuar 'percursos' no interior desse campo, fazendo 'elos associativos' baseados" nos seus saberes e nos pressupostos da emissão.

Rigorosamente, tanto os sujeitos da emissão como os da recepção estão subordinados, nas características das posições que lhes são peculiares, ao "outro" (língua, cultura saberes, instituições, imaginários etc.). Como os sujeitos não se tocam, e também como suas relações são mediatizadas pelas formas de linguagem, a única maneira de estimar possibilidades de interações entre os campos é pelo estabelecimento dos contratos de leitura, no interior dos quais estão presentes as marcas dos lugares enunciadores, da especificidade do discurso em produção e em funcionamento e, ainda, dos outros saberes mobilizados como espécie de "condição de produção". (FAUSTO NETO, 2002, p.201)

Concordamos com essa subordinação ao "outro" e acrescentamos que no caso da comunicação popular praticada pela Pastoral da Criança há outras formas de interação, além dos contratos de leituras, pois o sujeito receptor tem possibilidades de ser produtor. Além disso, relacionam-se com os outros leitores nas reuniões e capacitações, assim como com a coordenação e seus representantes.

Esse tipo de comunicação nos remete a Kaplún (1998, p.60-63) que defende a comunicação como diálogo, intercâmbio, relação de compartilhar. Critica, assim, o modelo autoritário em que a comunicação é vista como transmissão (emissor -mensagem - receptor). Classifica isso como comunicação dominadora, baseada no monólogo e no poder, ocorrida de forma vertical, unidirecional e monopolizada, concentrada na minoria. Já a outra comunicação 
classifica como democrática, baseada no diálogo, na comunidade, de maneira horizontal, com mão-dupla, participativa e ao serviço das maiorias.

Los hombres y los pueblos de hoy se niegan a seguir siendo receptores pasivos y ejecutores de ordenes. Sienten la necesidad y exigen el derecho de participar, de ser actores, protagonistas, em la construcción de la nueva sociedad auténticamente democrática.

(...)

La primera acepción - la que reduce la comunicación a transmisión de informaciones - corresponde a una sociedad concebida como poder: unos pocos emisores imponiéndose a una mayoría de receptores. La segunda, a una sociedad construída como comunidad democrática. (KAPLÚN, 1998, p.63)

O autor (1998, p.64-65) defende o retorno de diálogo como característica de comunicação. Esse processo deve permitir a todos a oportunidade de alternadamente serem emissores e receptores. Dessa forma, explica que o canadense Jean Cloutier criou um termo novo para designar um amalgama entre emissor e receptor: "Tal como Freire había dicho 'no más educadores y educandos sino educadores/educandos y educandos/educadores', diríamos hoy: no más emisores y receptores sino EMIRECS; no más locutores y oyentes sino interlocutores". Caracterizar-se-ia, assim, um intercâmbio de mensagens em ciclo bidirecional e permanente.

A partir dessa comparação, é interessante ver o que Freire pensava sobre a recepção. A pequena análise ocorre a partir de uma pergunta feita por Marques de Melo, originalmente para a revista Chasqui, editada pelo Ciespal (Centro Internacional de Estudos Superiores da Comunicação para a América Latina) no Equador, em 1981. O material ${ }^{68}$ é retomado por Soares (1988, p.333-335), que relata o seguinte. Marques de Melo afirma que em Puebla os bispos recomendam "meios alternativos grupais. Mais ainda, decidiram usar os seus próprios meios de comunicação para 'dar voz aos que não tem voz'.” Depois, pergunta a Paulo Freire: "Como você vê essa tentativa de estimular a produção de uma autêntica comunicação popular em que o receptor seja também produtor?" Freire responde:

É interessante que toda a linguagem usada na teoria da comunicação, na cibernética, é uma linguagem puramente ideológica e castrante. Eu confesso que estranho quando um homem ou uma mulher de esquerda usa expressões como transmissor, receptor, meio, conteúdo ou mensagem. Essa linguagem já é em si ideológica; o transmissor é o sujeito que transmite a mensagem; a mensagem é o objeto seu, próprio, pessoal. Isso é profundamente perigoso.

\footnotetext{
${ }^{68}$ Segundo as referências de Soares (1988), ele pega essa entrevista original de 1981 de uma obra de José Marques de Melo: "Para uma leitura prática da Comunicação", que foi publicada em 1985 pelas Edições Paulinas.
} 
O meio adequando-se ao receptor para ser mais eficaz à transmissão. Eu não uso jamais essas expressões. Na minha linguagem político pedagógica não existe receptor que seja só receptor. Ao aceitá-lo, eu usaria o que você usou agora- receptor também como produtor de uma certa mensagem. Isso ai não pode ficar desapercebido por uma liderança revolucionária. Nesse sentido, a revolução vai ter de mudar o ser mesmo do meio. Ela tem de criar os caminhos do retorno. Dar voz a quem era antes um povo paciente. (apud SOARES, 1998, p.334-335)

Kaplún (1998, p.78-79) propõe ainda a necessidade da pré-alimentação no processo comunicativo. Ela se daria através do contato inicial com os destinatários da comunicação para que eles representem e reflitam sobre a mensagem. A comunicação começaria com os destinatários, que mostrariam suas aspirações. Essas seriam formuladas em um meio de comunicação e chegariam novamente aos destinatários. É o que vemos na seção Comunidades do Jornal Pastoral da Criança, pois as informações vêm das próprias comunidades.

Também explica que a função do comunicador em um processo assim concebido já não é a que se entende por fonte emissora, porque não consiste em transmitir somente suas próprias ideias. A principal prática é recolher experiências dos destinatários, selecioná-las, ordená-las e organizá-las e, assim estruturadas, devolvê-las, de tal modo que eles possam se conscientizar, analisá-las e refletí-las. Quando a mensagem é difundida, o sujeito coletivo se reconhecerá nela. A identificação ocorre ainda que não tenham participado diretamente da produção ou que sejam outros atores.

Mais uma vez podemos dizer que isso acontece com a seção Comunidades, as líderes se veem nos relatos, mesmo que seja a história de outra líder, pois ela traz em si semelhanças com todas as comunidades. O receptor é de alguma maneira co-autor da mensagem e começa a se fazer "emirec". No entanto, para o autor, é importante que a equipe de comunicadores procure desenvolver esse processo de forma que a comunidade possa ter uma perspectiva crítica. Os acontecimentos devem ser problematizados para gerar reflexão. Essa parte do processo parece não ser sempre contemplada no Jornal Pastoral da Criança. Muitas vezes a seção se limita a relatar os fatos mandados pelas bases. Por outro lado, são as comunidades que mandam esse tipo de relato, que é publicado e entendido como aquilo que querem falar.

Nesse sentido, o próprio Kaplún (1998, p.80) defende que para a comunidade se envolver na comunicação é preciso que não se veja longe e se reconheça na mensagem assim como a necessidade de se ouvir o destinatário da mensagem, refletindo sobre os interesses deles (1998, p. 94). Também se devem elaborar mensagens abertas, que ativem a decodificação no destinatário (1998, p.251). 
El mensaje no culmina con su difusión sino que es entonces cuando realmente comienza su vida; esto es, cuando sus destinatarios empiezan a reflexionarlo, a discutirlo, a hacerlo suyo, a aplicarlo. Un mensaje que no sea completado, enriquecido, recreado, asumido por aquellos a quienes está destinado, es un poco un esfuerzo caído en el vacío. Nuestros mensajes no son fines em si mismos sino médios; instrumentos para suscitar procesos. (KAPLÚN, 1998, p.250)

\section{5 - O uso do jornal pelo voluntariado}

Segundo Endler (1998), em cada receptor de uma mensagem de jornal, rádio, internet ou TV existe a "possibilidade de início de uma nova rede informativa". Isso fica bem claro na prática comunicativa estabelecida pela Pastoral da Criança. Primeiro, os receptores também podem ser produtores de conteúdo em seções como Comunidades, Testemunho, Pergunta do Líder e Mural de Recados. Além disso, todos os receptores são produtores de sentido para o que leem e formam essa nova rede de informação ao discutirem as matérias e artigos do jornal, seja em reuniões, em capacitações ou até mesmo em conversas informais. Isso ficou claro nas 61 entrevistas que realizamos com esses leitores e leitoras, que são produtores e receptores, na Arquidiocese de São Paulo.

Nos próximos parágrafos, mostraremos como isso acontece a partir das respostas coletadas. Essa análise se baseou nas seguintes questões: Você lê o jornal? De que forma ele é utilizado? Contribui para a sua ação na Pastoral da Criança? Essas perguntas não são fechadas, mas sim serviam para abrir uma conversa, da qual pudemos levantar os pontos em comum. Foram ouvidas 61 pessoas, dez de cada região episcopal e a coordenadora da Pastoral da Criança da Arquidiocese de São Paulo.

A coordenadora Maria do Rosário Gazzola de Souza, por exemplo, afirma que costuma ler a publicação, pois "é uma formação excelente. Sempre traz informações e a gente conhece também o que está acontecendo nas outras comunidades em todo Brasil. Acho muito interessante". Ela ainda acredita que o jornal orienta a liderança: "A gente aprende muito. Às vezes você está com alguma dúvida, vê o jornal e vem a resposta. É um instrumento muito útil para a líder e para quem coordena também.”

A partir das respostas levantamos pontos que se repetiram. Vimos que 57 dos entrevistados fazem a leitura individual do jornal, o que corresponde a 93,5\% das pessoas ouvidas. 56 afirmaram ou deram exemplos de que o jornal contribui para a sua atividade, 
totalizando 91,8\%. Já 21 voluntários e voluntárias costumam ler e discutir o jornal nas reuniões de reflexão e avaliação, 34,8\% do total. Outros aspectos percebidos nas respostas foram:19 disseram mostrar o jornal para as mães - 31\%; 8 mostram para outras pessoas da comunidade $-13 \%$; 6 utilizam na Celebração da Vida - 9,8\%; 5 usam o jornal para elaborar Rodas de Conversa $-8 \%$.

Vale destacar que a circulação do jornal ocorre da seguinte maneira: a Coordenação Nacional da Pastoral da Criança envia os jornais para a coordenação da Arquidiocese e para os setores, no caso de nossa pesquisa: Belém, Brasilândia, Ipiranga, Lapa, Santana e Sé. Na reunião mensal da coordenadora de setor com as coordenadoras e coordenadores de área ou ramo, os exemplares são distribuídos. Esses distribuem para os coordenadores de comunidade, que por sua vez, dão para as líderes. Esse procedimento ocorre dessa forma em todo Brasil. Isso permite que o jornal chegue às comunidades mais distantes ainda que tenha que atravessar rios em barcos até chegar ao seu destino: as líderes. Essas por sua vez, espalham o saber pelas comunidades em que vivem e ainda tem no jornal um espaço para dividir essa vivência.

\begin{abstract}
A líder é muito importante porque ela é a pessoa que multiplica o saber e a solidariedade. É a pessoa mais motivada para a missão. Nós tivemos uma pesquisa que comprovou como os líderes comunitários são os mais comprometidos com a missão, com os resultados. Há líderes que andam 30 $\mathrm{km}$, sobem morro, descem morro, atravessam rios para visitar as famílias. Elas sentem na carne toda a problemática da família e querem fazer a promoção da família, promovendo a criança, cuidando da saúde e da educação, ensinando as famílias a cuidar melhor das crianças. Então a família é comprometida, a líder é comprometida e ela quando escreve uma experiência, isso sai do próprio cerne da questão. (Zilda Arns) ${ }^{69}$
\end{abstract}

Observando os resultados das entrevistas em São Paulo, avaliamos que o jornal é bastante usado e contribui para a formação e atuação da liderança. No entanto, o conteúdo poderia ser mais trabalhado nas reuniões e mais utilizado nas visitas ou Celebrações da Vida, fazendo-se com que as mães e as famílias tivessem contato com o material. Também separamos os resultados por regiões, como relatamos nos próximos parágrafos.

Olhando para as respostas em cada região episcopal vemos que todas as pessoas ouvidas do Belém fazem a leitura individual do jornal e consideram que o jornal ajuda na atividade. O uso em reuniões foi citado quatro vezes. Duas citaram mostrar matérias para as mães, três realizam rodas de conversas com o subsídio do jornal e uma relatou o uso na

\footnotetext{
${ }^{69}$ Entrevista realizada por nós em 25/06, enquanto aguardávamos a gravação do programa do Ronnie Von, na TV Gazeta.
} 
Celebração da Vida. Uma pessoa também disse divulgar o jornal na comunidade (paróquia).

Selecionamos algumas frases que mostram esses usos e a importância do jornal:

Ana Maria de Carvalho Bom Filho, 48 anos: "Ajuda, principalmente, sobre doenças de gestantes e de crianças, quando a gente vê uma situação já lembra que leu e como agir".

Ana Paula de Lima Silva, 28 anos: "Quando veio falando da tuberculose, a gente usou a informação. Também do aleitamento materno, a gente usou reportagem. Uma vez a gente usou uma parte que era para trabalhar as avaliações e reflexões. Também a metodologia, as mensagens, a gente sempre está usando alguma coisa do jornal".

Fernanda Tobias Cipriano, 21 anos: "As ações das brinquedistas sempre têm ideias novas no jornal: novas brincadeiras, ensina a fazer brinquedos. São coisas que a gente usa para nossas capacitações e nossas celebrações da vida".

Também na região Brasilândia todas as pessoas ouvidas fazem a leitura individual do jornal e consideram que o jornal ajuda na atividade. Dessas, seis mostram o jornal para as mães, quatro usam nas reuniões, três mostram para as comunidades e duas utilizam na Celebração da Vida. Selecionamos algumas falas, que explicam como o jornal é utilizado:

Maria Vila Nova de Sousa , 55 anos: "Eu costumo ler e passar para as mães algumas coisas que achei importante, por exemplo, a receita que é bom para criança e rica em vitamina, informação sobre como viver em família e no amor de Deus. Distribuo também na comunidade, dou para outras pessoas.

Débora Mara de Oliveira Soares, 44 anos: "Recebemos todo mês. A gente distribui nas reuniões e sempre tem algum ponto interessante, principalmente a parte que fala sobre alguma doença ou sobre o desenvolvimento da criança. A receita também é sempre usada, algumas passamos para as famílias, porque o custo é baixo e pode aproveitar algo que tenha em casa, que são nutritivos. Geralmente a gente dá um para cada líder, e às vezes, como não dá para dar para as mães, a gente leva nas visitas e mostra alguma coisa interessante para as mães".

Rosangela Maria Santos da Silva, 44 anos: "A gente lê individualmente, mas conversa bastante sobre as matérias, que são muito importantes e servem de diretriz pra gente também, as experiências de outros estados. A gente mostra para as mães, utiliza mais nas visitas"

Já na região Ipiranga, sete das pessoas ouvidas afirmam fazer a leitura individual do jornal e consideram que o jornal ajuda na atividade. As outras três disseram ler pouco. Dessas, uma afirmou usar a receita e a outra usar alguma informação na Celebração da Vida. Das outras sete entrevistadas, que fazem a leitura constantemente, duas mostram matérias para as mães, uma usa em reunião e uma mostra para a comunidade. Selecionamos algumas falas que 
exemplificam como se dá esse uso na prática como também mostra a contribuição do jornal para pessoas de diferentes níveis de escolaridade. Nos exemplos abaixo, as formações são, respectivamente, doutorado em biologia, ensino fundamental incompleto e graduação em administração de empresas.

Solange Martone Rocha, 45 anos: "A gente recebe na reunião que a gente faz uma vez por mês com as coordenadoras e eu como coordenadora repasso para minhas líderes o jornal. Entrego na paróquia também e a gente mostra para as mães. Toda capacitação que a gente faz, a gente trabalha muito com isso e conversa muito com as mães. Usamos as matérias, às vezes as receitas. $\mathrm{Ou}$ a gente orienta a mãe a fazer alguma coisa. Ou alguma experiência por parte das outras líderes".

Edileusa Bispo da Silva, 29 anos: "O jornal ajuda bastante, principalmente, pra gente que é líder e muitas vezes não tem uma informação de saúde para passar para as mães, se a criança tem alguma doença, a gente procura entender o que está no jornal, para poder passar para as mães”.

Cecília Valverde, 43 anos: "Vejo pelas coordenadoras que elas usam muito as receitas na Celebração da Vida. Já eu gosto muito de notícias de outros estados também, vemos fotos, depoimentos de pessoas que a gente conhece pelo Brasil a fora nos encontros que ela realiza como o encontro estadual, a assembleia nacional. É uma forma de a gente matar a saudade do pessoal".

A região Lapa, por sua vez, nove pessoas afirmaram ler o jornal e avaliaram que ele contribui para sua atividade. Como explica Jairo Fedel, 49 anos, “o jornal ajuda na formação do líder e, às vezes, sem perceber, ele está levando aquela informação também para a família”. Uma das entrevistadas não lê o jornal, por não ser alfabetizada, mas pede que o filho leia para ela. Das nove pessoas que leem a publicação, seis utilizam nas reuniões, três costumam mostrar para as mães e uma para a comunidade. Também houve uma citação de roda de conversa. Selecionamos três falas para exemplificar esses usos.

Margot Helena Noske Schutz, 71 anos: "Usamos o jornal. Fazemos debate nas reuniões de avaliação. Às vezes distribuímos alguns artigos para as mães, principalmente, os de nutrição, educação, sobre o sono da criança. Fazemos as rodas de conversa com as mães. É muito bom isso."

Dalila Aparecida da Costa, 54 anos: "Todo mês, a gente lê com as líderes, cada uma delas tem o seu. A gente sempre discute alguma coisa do jornal. A gente aproveita algum tema, fala da receitinha, de repente fazendo uma colocação do que está sendo visto, acho que enriquece bastante. Tem toda a informação possível lá dentro."

Sonia Regina Faila Ferreira dos Santos, 58 anos: "No caso da minha região, distribuo para as minhas coordenadoras. Muitas vezes a gente lê alguma coisa que eu já selecionei ou eu falo esse jornal tem tal coisa. A gente lê e incentiva a coordenadora ler na sua comunidade, ou com mãe, tem gente que faz isso, tem coordenadora que lê no dia de avaliação e reflexão. A 
gente trabalha muito na capacitação esse jornal. O jornal traz bastante coisa e atualiza você. Até que a notícia chega num caderno, numa capacitação, o jornal chega antes. O jornal já vem e já traz a notícia fresquinha."

Outra região observada foi a de Santana. Lá todas as leitoras afirmam ler o jornal, mas uma acredita que o jornal contribuiria mais para a ação se tivesse mais informações para as líderes passarem para as mães, principalmente sobre reaproveitamento de alimento e como orientar pais e mães agressivos. As outras nove acreditam que o jornal ajuda em sua atividade. Dessas, duas citaram mostrar o jornal para mães e duas para a comunidade. Por uma vez, foram citados o uso em reunião, em rodas de conversa e Celebração da Vida. Os três exemplos a seguir mostram como as voluntárias usam ou veem o jornal:

Vera Lúcia Vieira Figliuoleo, 6 anos de Pastoral da Criança: "Uso a parte de brinquedos e brincadeiras. $\mathrm{Eu}$ uso para montar a minha espiritualidade dentro do jornal nas capacitações. Eles têm reportagens muito interessantes como a parte de saúde e mesmo ficar sabendo das novidades que as outras pastorais pelo Brasil a fora têm. $\mathrm{O}$ que elas estão fazendo e o que a gente pode estar fazendo com as nossas. Acho o jornal completo. Ele atinge todas as pessoas, desde a liderança até os multiplicadores, que sabem utilizar o jornal."

Maria Teresa de Abreu, 15 anos de Pastoral da Criança: "O jornal é sempre uma troca. Uma espécie de roda de conversa escrita. Tem muito aprendizado inclusive para a capacitação, para formar novas líderes, é muito criativo."

Maria Cristina Bonfanty, 9 anos de Pastoral da Criança: "Usamos no diálogo, as reflexões sempre me ajudam a fazer a reunião mensal com as coordenadoras. A gente sempre lê e tira os temas para a reunião com as coordenadoras de ramo. A gente lê e discute com elas linha por linha porque é aí que aprendemos mais."

Por último, apresentamos os resultados da região Sé. Todas as pessoas afirmaram ler o jornal e apontaram que ele ajuda na prática. No entanto, uma das ouvidas avaliou que o jornal precisa ser mais contextualizado com a realidade. Cinco disseram usá-lo em reuniões, quatro mostram para as mães e um utiliza na Celebração da Vida.

Elizabeth Valente Lorenzano, 61 anos: "Na verdade eu leio de cabo a rabo. Gosto de tudo, desde a receitinha do bolo a comunidade que formou ou capacitou lideres. Todos os assuntos são importantes. As mães leem atentamente e é uma pena que os exemplares não deem para todas."

Carlos Henrique de Azevedo, 54 anos:"Sempre quando a gente recebe, dá uma lida na reunião de reflexão. Todo mundo vê o que pode ser aproveitado para fazer as visitas e quando faz as visitas, a gente mostra para as mães e comenta alguma coisa a respeito." 
Maria José da Silva, 36 anos: "A gente recebe todo mês. Eu como coordenadora dou uma lida. Nós distribuímos para as famílias que a gente acompanha no dia da Celebração da Vida. Se naquele mês tiver falando sobre um assunto que a família está acostumada a lidar no dia a dia eu falo. Gosto muito da parte das receitas também."

Pelas respostas que utilizamos para exemplificar as opiniões dos leitores e leitoras, podemos perceber uma visão positiva sobre o jornal e sua contribuição para as atividades ao disseminar informações, que muitas vezes a comunidade não tem acesso. Outra questão que procuramos levantar foram as partes que leitores e leitoras mais gostam ou que mais contribuem para a ação. Levantamos algumas seções e temas que vieram não só com as respostas direta a esse questionamento, mas também nos exemplos concretos que entrevistados e entrevistadas davam. Assim uma mesma pessoa podia citar ao longo da entrevista mais de um tema como de seu interesse ou muito importante.

Das 61 pessoas ouvidas, 41 citaram a seção Comunidade, o que dá cerca de $67 \%$ do total. Nessa seção, é possível ver o que se passa em diferentes localidades do Brasil. As respostas mostram que há identificação, mas também uma troca de aprendizagem. $\mathrm{O}$ que é visto sobre outro lugar pode servir de exemplo. Selecionamos uma fala de cada setor da Pastoral da Criança na Arquidiocese de São Paulo, que mostram as razões da escolha:

Belém - Fernanda Tobias Cipriano, 21 anos: "O legal do jornal é que tem muita experiência. A gente vê o que ocorreu lá no Paraná, lá para cima, que ela teve problema com essa família e como ela resolveu. Tem coisa que a gente não sabe resolver porque não aconteceu na nossa comunidade. Vendo no jornalzinho, a gente pode se preparar para resolver."

Brasilândia - Adervisto Mariano Neto, 66 anos: "Vejo o que acontece nas comunidades e com isso a gente aprende cada vez mais".

Ipiranga - Michaele Gonçalves Sousa, 13 anos: "Eu gosto de ler as partes dos estados na Pastoral para saber o que está acontecendo. Isso ajuda porque a gente olha para os estados e tenta fazer um conjunto, tudo igual”.

Lapa - Benedita Lopes Carvalho de Moraes, 68 anos: "Às vezes tem alguma experiência de comunidades que acho interessante, para gente ver o que acontece no Brasil todo. Às vezes a gente fica analisando a Pastoral por onde a gente mora, mas ali a gente vê o quanto é diferente e acaba entendendo certas coisas que a gente não entende."

Santana - Cinira Fidalgo Serafim: "Eu gosto de saber o que está acontecendo nos outros estados. Acho muito legal porque a gente compara como é aqui, como é nos outros. Você às vezes pensa - será que eu to fazendo errado? Ai de repente você vê - nossa, aconteceu isso comigo. Dá um alívio, existe em outro lugar, não é só minha comunidade que está acontecendo isso." 
Sé - Maria da Conceição, 73 anos: "O jornal contribui porque muitas vezes nós encontramos determinadas dificuldades e, através dos relatos, a gente vê situações que nos animam, porque encontro situações piores do que nossa realidade."

Em segundo lugar, as receitas foram apontadas como preferidas ou úteis na ação, por $37,7 \%$ ou 23 pessoas. A saúde foi o terceiro assunto mais citado, por $31 \%$ das entrevistadas e entrevistados (19 pessoas). Esses dois temas são tratados na seção Aprendendo Mais, que também teve outros pontos que aborda em seus diferentes espaços citados: alimento e nutrição - 13\% dos ouvidos ( 8 pessoas); brinquedos e brincadeiras - 11,5\% (7 pessoas); espiritualidade $-9,8 \%$ (6 pessoas). Selecionamos uma fala que fala tanto sobre o uso das receitas do jornal como das informações sobre saúde:

Selma Leite Galindo da Silva, 39 anos: "Nas reuniões, usamos alguma matéria que achamos importantes. Também levamos para as mães as receitas que são bem legais para aproveitar os alimentos, a parte das doenças, as dicas e ideias. É um material muito legal. Com as famílias, usamos nas rodas de conversa. A parte da pneumonia, nessa época de chuva sobre a dengue, a parte de desnutrição, de obesidade. Tem coisas muito boas".

Ainda houve a citação da coluna de Zilda Arns por 14,7\% (9 pessoas) e da Palavra do Pastor por $6,5 \%$ (4 pessoas). Também foi citado por apenas uma vez os seguintes assuntos: cidadania, criança, educação, mural de recados, reflexão e família. No quadro abaixo, colocamos os temas que mais apareceram em cada região e também os levantados pela coordenadora arquidiocesana:

\begin{tabular}{|c|c|c|c|c|c|c|c|c|}
\hline \multicolumn{8}{|c|}{ Temas citados pelas 61 pessoas entrevistadas na Arquidiocese de São Paulo como } \\
\\
\hline
\end{tabular}

\footnotetext{
${ }^{70}$ Como se trata de uma entrevista semiaberta, as pessoas ficavam livres para dissertar sobre o jornal a partir das perguntas elaboradas e citar quantos temas quisessem.
} 


\begin{tabular}{|c|c|c|c|c|c|c|c|c|}
\hline e Nutrição & & & & & & & & \\
\hline $\begin{array}{c}\text { Brinquedos e } \\
\text { Brincadeiras }\end{array}$ & 1 & 0 & 1 & 2 & 2 & 1 & 0 & 7 \\
\hline $\begin{array}{c}\text { Espirituali- } \\
\text { dade }\end{array}$ & 1 & 1 & 0 & 0 & 3 & 1 & 0 & 6 \\
\hline $\begin{array}{c}\text { Palavra do } \\
\text { Pastor }\end{array}$ & 0 & 1 & 0 & 1 & 1 & 1 & 0 & 4 \\
\hline
\end{tabular}

Comparando com pesquisa de Faxina (2001, p.214-221), vemos que o enfoque principal do jornal continua sendo o líder comunitário. Assim como ainda hoje se busca uma troca de experiências entre as comunidades e "uma atualização permanente de informações, criando um processo de formação continuada".

O objetivo é estabelecer um intercâmbio de experiências entre as comunidades e fazer uma atualização permanente de informações, criando um processo de formação continuada. Uma das metas estabelecidas é provocar as próprias lideranças comunitárias para que relatem suas experiências em forma de texto e imagem, a partir de seu próprio olhar, competindo à coordenação nacional a edição desse material, respeitando as características locais. (FAXINA, 2001, p.214)

O autor também concluiu que os leitores, na maioria das vezes, procuram matérias que falem das comunidades, o que serve como motivação. "Eles procuram no jornal aquilo que reflete o próprio trabalho deles, seja para tomar como experiência ou para sua própria motivação pessoal. Percebe-se que, acima de tudo, eles procuram se ver no jornal" (2001, p.214). Isso se manteve em nossa pesquisa, com um índice de $67 \%$ das entrevistadas e entrevistados.

No entanto, para Faxina (2001, p.216), os artigos de Zilda Arns, que saem no jornal, eram lidos por todos os entrevistados do pesquisador. Em nossa pesquisa não chegamos a perguntar se as pessoas liam determinada parte do jornal, optamos por deixá-las livres para falarem das partes que mais utilizavam. Dessa forma a coluna da fundadora da Pastoral da Criança só foi citada por $14,7 \%$ das pessoas entrevistadas em nossa pesquisa.

Já um ponto de coincidência é que na pesquisa de Faxina (2001) é que 90\% dos entrevistados pelo autor, afirmam que ler o jornal contribui para sua ação na Pastoral da Criança. Em nossa pesquisa esse índice foi bem parecido: 91,8\%. O autor entrevistou 60 líderes e coordenadoras locais da entidade, de diferentes locais do Brasil, visando uma análise 
qualitativa da motivação e atuação desses agentes, transpassando, dessa forma, pela questão da comunicação. Já nossa pesquisa, para essa análise da recepção do jornal e percepção da cidadania, ouviu 61 pessoas que atuam na Arquidiocese de São Paulo

Outra verificação sobre a Pastoral da Criança de Faxina (2001, p.218) foi que é constante a reclamação nas reuniões comunitárias da falta de notícias próprias no jornal. "Cada lugar entende que sua região é prejudicada em função da outra". Em nossa pesquisa, apenas cinco entrevistadas ${ }^{71}$ reclamaram de não ver notícias de suas comunidades, totalizando $8 \%$.

Por outro lado, para Faxina (2001, p.221), gostariam também de ver mais matérias que ajudassem em sua ação. Em nossa pesquisa, essa questão só foi levantada por uma entrevistada que queria mais matérias que ajudassem na ação com as mães. Também houve uma reclamação para os seguintes pontos: o jornal deveria chegar mais cedo, pois sempre recebem depois que passou a data comemorativa; as matérias deveriam ser mais contextualizadas com a realidade; o esquema criado para cada setor participar em forma de rodízio é muito demorado e isso faz perder o interesse pelo jornal. Também houve três sugestões apresentadas: trazer reflexões que levem a liderança a compreender as ações e situação do povo carente, como por exemplo, o que leva a família a morar numa favela; dar uma coluna para irmã Vera Lúcia Altoé assim como a da Dra. Zilda Arns; trazer mais informações sobre políticas públicas.

Lima (2007) também estudou a Pastoral da Criança, analisando o jornal da entidade como um "instrumento de promoção da cidadania". Para tanto, entrevistou cinco pessoas que fazem parte da equipe da Coordenação Nacional e 18 voluntárias da organização em comunidades na Arquidiocese de Aparecida (SP), sendo 15 coordenadoras e três líderes. A autora verificou que "a coordenação do Jornal Pastoral da Criança entende o Jornal por um ponto de vista, mais comunitário, mais transformador; a comunidade, por outro, um lado mais informativo, mais animador dos trabalhos pastorais" (2007, p.166). Em sua avaliação, uma das limitações seria que as informações não ultrapassam o nível comunitário além da estrutura da Pastoral da Criança. Assim, é subutilizado.

Apesar disso, a autora acredita que há uma comunicação popular-alternativa na Pastoral da Criança, adequada "às necessidades e demandas de informação", com uma proposta educativa e voltada para a cidadania, com qualidade de produção, profissionalismo e uso de tecnologia. Vê ainda na comunicação da Pastoral da Criança "uma relação direta com a

\footnotetext{
${ }^{71}$ Uma pessoa do Belém, uma da Lapa e três de Santana.
} 
transformação da realidade das comunidades, com a preocupação de uma conscientização e educação política via meios de comunicação, seja na produção dos materiais e conteúdo, seja no estímulo a ação comunicativa das comunidades”. (LIMA, 2007, p.107-108)

Aponta também que a participação das comunidades com o envio de notícias configura um sentido de participação e pertencimento (2007, p.118). Outra característica percebida a partir das entrevistas é o jornal visto "como instrumento de formação contínua" (2007, p.127). A transformação social é apresentada como uma das propostas do jornal (2007, p. 128). Assim percebe que existe na Coordenação Nacional uma

compreensão de que o Jornal não deve se restringir somente à transmissão de informação, mas promover a ação, a mobilização dos voluntários da Pastoral da Criança nos problemas da comunidade, identifica-se uma dupla preocupação cidadã. A primeira função está relacionada à comunicação para a construção do sujeito autônomo; a segunda, pode ser entendida como o conhecimento apreendido com vistas às ações concretas. (LIMA, 2007, p. 129)

Dessa forma, conclui que o jornal pretende ser "motivador da ação e da participação social dos voluntários”. Desperta ainda um sentimento de pertença ao integrar propostas e promover troca de experiências e projetar um pouco de cada líder a partir das realidades apresentadas, "criando uma identidade coletiva" (LIMA, 2007, p. 131-132).

Já entre as falas do voluntariado percebeu um "entendimento do papel interativo que o Jornal oferece às comunidades, possibilitando que uns conheçam o trabalho dos outros e reflitam sobre sua realidade". A comunidade é colocada "como protagonista da comunicação". Mas, por outro lado, vê que há uma atitude passiva frente ao jornal, como receptor sem compreender "a possibilidade de um papel ativo, papel de sujeito participante no processo de comunicação". (2007, p.139-140) As entrevistadas também vêem o papel educativo do jornal, na maioria das vezes. Destacam as informações das outras comunidades e as que contribuem para o desenvolvimento do trabalho (2007, p.143). Mostraram também interesse pela coluna de Zilda Arns (2007, p.147).

Essas opiniões apresentam significados pontuais sobre o conteúdo do Jornal, como: $1^{\circ}$ ) o Jornal Pastoral da Criança é um mecanismo no qual se busca apoio e valorização do trabalho das líderes; $2^{\circ}$ ) o jornal é uma fonte de inspiração e de avaliação para as comunidades devido a apresentação do trabalho das outras comunidades; $3^{\circ}$ ) o Jornal também é visto como fonte de informação e formação para a ação cotidiana dentro da Pastoral, uma vez que as informações trazidas podem transformar-se em novas atividades dentro da pastoral. (LIMA, 2007, p.148) 
Lacerda (2002a,b) é outro pesquisador que estudou a comunicação na Pastoral da Criança. O autor avalia que a seção Comunidades é o " "carro chefe' do Jornal da Pastoral”, caracterizando-a como "o lugar mais estratégico" no "processo de midiatização, para a interação entre a Pastoral da Criança" e o voluntariado. Essa produção midiática tem um discurso pedagógico. Na construção do texto, destaca o uso do verbo no início da frase, buscando a proximidade com o leitor. (2002a, p.11-12) Ainda destaca que no lead, o quem é o ator coletivo da Pastoral da Criança. Constrói-se uma identidade coletiva, e a recepção constitui-se tanto no consumo do jornal como na possibilidade interferir no processo produtivo. Assim "o lugar de fala da Pastoral da Criança é o lugar onde fala o líder comunitário". (2002a, p.16-17)

Já em outro artigo descreve "como se constitui a rotina produtiva do 'Gatekeeper' no processo de produção e veiculação das notícias enviadas pelos líderes” para o jornal (LACERDA, 2002b, p.6). Aponta que o leitor fala em forma de notícias na seção Comunidades, lugar em que os fatos são noticiados de comunidade para comunidade, mas isso ocorre conforme "condições de produção específicas do jornal” (2002b, p.10). O fazer da Pastoral da Criança é notícia (2002b, p.12). O lead tem como item de atualidade as ações realizadas na comunidade, não se obedece a lógica de novidade da mídia massiva e sim os processos de mobilização social da organização. Assim na época de sua pesquisa, em 2001, percebeu que "o processo de seleção, hierarquização e tematização tem mecanismos de regulação estabelecidos: uma linha editorial constituída, cursos de capacitação em produção de notícias, o departamento de comunicação e o profissional jornalista responsável”. Assim, configura-se uma noção de notícia em que "boa notícia é boa notícia. Invertendo a lógica da mídia jornalística de massa que define 'notícia como um problema'." (2002b, 14-16)

Em nossa pesquisa, realizada, principalmente, nos anos de 2008 e 2009, percebemos que algumas características se mantêm ainda hoje como a publicação de boas notícias em Comunidades, ainda permanece a ideia de a seção mostrar as ações das comunidades, que também tem interesse em apresentar fatos positivos que realizam e como venceram determinadas dificuldades. No entanto, novas estratégias de participação foram criadas como foi relatado pela atual jornalista responsável Sonia Prati. A jornalista também parece ter uma consciência da prática de comunicação popular e da diferença em relação à mídia, o que não apareceu na fala da jornalista de 2001 apresentada no artigo. Já na pesquisa de Lima (2007), a jornalista responsável já era Sonia Prati, e a autora também mostra esse viés popularalternativo da comunicação praticada pela Pastoral da Criança a partir das entrevistas que 
realizou. Resultado também visualizado em nossa pesquisa assim como o viés educativo da publicação.

\section{6 - A contribuição do jornal para a cidadania}

Para 55 de nossas entrevistadas e entrevistados, o jornal contribui para a cidadania ao divulgar informações sobre saúde e direito, um índice alto, de 90\%. Dessas pessoas, apenas uma disse que poderia ajudar ainda mais se abordasse em maior quantidade a questão das políticas públicas. As dez pessoas ouvidas tanto no Belém quanto na Brasilândia afirmaram haver essa contribuição. Já nos outros setores, o número foi de sete no Ipiranga (as outras três só liam um pouco o jornal); nove na Lapa (uma pessoa não era alfabetizada), nove em Santana (uma avaliou que só um pouco) e nove na Sé (uma pessoa disse que não sabia responder). Selecionamos uma resposta de cada região para a questão - O Jornal Pastoral da Criança contribui para a construção da cidadania?

Belém - Ana Paula de Lima Silva, 5 anos de Pastoral de Criança: "Acho que sim, porque é uma informação e contribui no aprendizado, porque além da gente estar recebendo essa informação, a gente vai poder passar essa informação para as famílias, para as pessoas. Tudo que a gente recebe de material só vai contribuir para que cada vez mais a informação se alastre".

Brasilândia - Elza Cristina Garcia Dias, 7 anos de Pastoral de Criança: "Sem dúvida porque a gente vive em comunidade muito carente e mesmo devagar a gente dá uma dica aqui, outra ali, sem dúvida é um excelente material".

Ipiranga - Cecília Valverde, 10 anos de Pastoral de Criança: "Certamente, porque, veja bem, agora estamos na campanha de registro de nascimento e isso sai no jornal também. É um alerta para que aquela líder pense - nossa, será que eu tenho trabalhado isso com as mães nas visitas? Então muitas matérias que têm no jornal servem de alerta para a líder e a coordenadora de ramo, para ela ver se está trabalhando aquilo mesmo. São inúmeros os casos que a gente vê resultados. Aqui no Ipiranga mesmo, uma zona totalmente urbana, há dois meses, tivemos um caso de uma criança com quatro anos sem registro de nascimento. A coordenadora desse ramo se deu conta de trabalhar esse tema a partir do Dicas. Ela leu e começou a trabalhar isso e fez essa descoberta."

Lapa - Maria Amélia da Silva, 3 anos de Pastoral de Criança:: "O jornal traz essa informação para nós. É um ótimo veículo para que as pessoas tomem ciência." 
Santana - Maria Cristina Bonfanty, 9 anos de Pastoral de Criança: "Sem dúvida, a gente costuma colocar até nas paróquias para que alguém veja aquilo, que todos têm os seus direitos como cidadão".

Sé - Carlos Henrique de Azevedo, 1 ano de Pastoral de Criança: "Com certeza, é muito bom, contribui bastante e é necessário, porque lá traz muitas informações e mostra o que está sendo feito, a preocupação que a gente tem, o que pode melhorar para a vida das famílias".

Voluntárias e voluntários acreditam nessa contribuição, na maioria das vezes, independentemente do tempo em que estão na Pastoral, da escolaridade ou do local onde moram. Isso mostra a importância da ação educativa e comunicativa da Pastoral da Criança. Como vimos no capítulo anterior, todos voluntários e voluntárias acabam construindo um significado para a cidadania, que vem da formação contínua, mas também é vivenciada na prática. O jornal é uma das fontes dessa formação, que conta ainda com as capacitações, reuniões de reflexão e avaliação, programa de rádio e conversas informais entre o voluntariado e também com as famílias.

Lima (2007, p.155-156 e p.167) também estudou a contribuição do Jornal Pastoral da Criança para a construção da cidadania e viu que as voluntárias entrevistadas na Arquidiocese de Aparecida percebem a cidadania "em função dos assuntos e das questões cotidianas que envolvem o trabalho pastoral, com pouca relação com a vida coletiva como num todo". Há aquelas que refletem sobre os direitos e deveres das crianças e gestantes, buscando no jornal informações que clareiam a noção de cidadania e uma leitura mais crítica da realidade. Por outro lado, "o conceito de cidadania é ambíguo, vago e remete a inúmeras interpretações, o que não impede que todas apontem a função cidadã do jornal associada a "capacidade de trazer informação", sem uma percepção do papel social do jornal de forma mais ampla.

Já em nossa pesquisa, verificamos essa percepção mais ampla, como mostramos ao longo do texto e com o uso do jornal para a ação. Também há variadas interpretações para a cidadania na Arquidiocese de São Paulo, algumas mais ligadas à vivência, outras com noção de direitos e deveres. Os dois estudos percebem a cidadania vivenciada nas práticas cotidianas, e o jornal contribui para isso.

O papel da comunicação para a construção da cidadania nos faz lembrar Gentilli (2005), para quem, o jornalismo supera a mercadoria, típica da sociedade de massa e da indústria cultural, contribuindo para a construção da cidadania. Isso porque a informação jornalística pode possibilitar que as pessoas ajam como cidadãs, saindo da condição de massa. O jornalismo deve oferecer "informações que o cidadão tem o direito de receber para que possa exercer plenamente todos os seus direitos". 
Devemos estender a definição acima também para a comunicação popular, que tem o dever de informar o cidadão para que ele exerça seus direitos. A diferença entre eles é a de que o jornalismo faz isso no âmbito das massas, com um alcance de público maior. Já a comunicação popular faz no âmbito das comunidades, contando até com a participação das mesmas na elaboração das notícias. Não trata apenas do direito de ser informado, mas também do direito de comunicar.

Os jornais, para o autor, são vistos como "organizações voltadas para a produção de informação pública", e o direito à informação pública constitui um direito de cidadania. Quando esse direito não é cumprido, os outros direitos ficam prejudicados:

Nas democracias de massas, marcadas pela expansão de direitos, o direito à informação constitui-se num direito ' em si' e ao mesmo tempo é a porta de acesso a outros direitos. Neste sentido, a informação, conforme seja a necessidade que dela se tenha pode ser entendida como direito social, como direito civil e como direito político. (GENTILLI, 2005, p.24)

Para Lima (2006), é necessária a existência de uma mídia democratizada, condição básica para a realização dos direitos políticos. No entanto, essa democratização da mídia é limitada pela falta de políticas públicas de comunicação e por relações de classe.

As distorções do poder provocadas pelo desequilíbrio histórico entre os sistemas privado, público e estatal (de radiodifusão); pela concentração da propriedade - em boa parte provocada pela ausência de normas que impeçam a propriedade cruzada - e a vinculação dos grandes grupos de mídia com lideranças políticas regionais e locais, são alguns dos problemas que impedem a democratização de nossa mídia e, portanto, a realização da nossa plena cidadania. (LIMA, 2006, p.16)

Acreditamos que ao fazer essa comunicação popular, que é dialógica, educativa, horizontal e participativa, a Pastoral da Criança está contribuindo não só para a construção da cidadania como também atuando em prol da democratização da comunicação. O Jornal Pastoral da Criança muitas vezes é o único veículo de comunicação impresso que voluntários e volúntárias vão ler, debater e apresentar para outras pessoas da comunidade.

Se olharmos para o conteúdo do jornal da Pastoral da Criança, veremos que a cidadania aparece em vários pontos, especialmente na seção Aprendendo Mais. Essa parte do jornal traz diversas subseções que avaliamos contribuir para a construção da cidadania. São informações e reflexões sobre saúde, direitos, educação, conivência comunitária, fé tratadas por especialistas como enfermeira, psicóloga, nutricionista, educadora, gestor em política, 
padre ou pastor. Também há alguns espaços para a prática da comunicação popular com o envio de perguntas, receitas, testemunhos.

É como se juntas as seções Aprendendo Mais e Comunidades formassem a verdadeira práxis. A primeira é a reflexão e vem nas últimas páginas do jornal. A segunda é a própria ação das comunidades, que trazem relatos. Esses, por vezes, podem apenas dizer como vem sendo as visitas, celebrações da vida e capacitações, mas em outras, contam como a comunidade participa da discussão política, realiza debates (rodas de conversas), alfabetização, como vemos no exemplo abaixo, retirado da edição de junho de 2008 (p.7 $)^{72}$ :

\section{Educação de Jovens e adultos}

Bonfim

Bahia

A Educação de Jovens e Adultos na Pastoral da Criança teve seu início quando foi constatado que muitos líderes, apesar da boa vontade, não conseguiam ler e entender o material educativo que vinha até eles. Aos poucos, percebeu-se que também era importante e ajudava muito a comunidade se as mães acompanhadas pela Pastoral da Criança soubessem ler e escrever. Hoje, mais do que nunca, estamos conscientes do amplo desafio que temos a nossa frente. Então, você que ama a educação e luta por essa mudança, ajude-nos nesse mutirão contra o analfabetismo.

$\mathrm{Na}$ nossa diocese durante os dias 22 e 23 de fevereiro foi realizado com aproveitamento uma capacitação para monitores que irão desenvolver esse serviço em suas comunidades e paróquias. Participaram 30 monitores sendo que 3 eram da Diocese de Juazeiro. Da Diocese de Bonfim participaram as paróquias de Cansanção, Senhor do Bonfim, Pindobaçu e Campo Formoso. (...)

Esse exemplo retirado do jornal assim como as entrevistas que realizamos mostram como ver as ações em outras comunidades pode inspirar a atuação da liderança. Vimos que 41 pessoas citaram a seção Comunidades. Essa citação nem sempre era direta. Como as questões eram abertas, elas nem sempre falavam o nome da seção, mas diziam gostar da parte em que apareciam as histórias da Pastoral da Criança de outras comunidades, dos outros estados. Nessas respostas, nenhuma pessoa chegou a citar a seção Aprendendo Mais pelo nome, no entanto, citavam mais de um tema que é abordado nessa parte do jornal. Tanto as receitas com 23 citações, a saúde com 19, a alimentação e nutrição com 8, Brinquedos e Brincadeiras com 7, Espiritualidade com 6, como temas citados apenas uma vez -cidadania, criança, educação, reflexão e família - fazem parte das subseções do Aprendendo Mais. Isso quer dizer que as temáticas dessa seção foram citadas por 68 vezes. Um mesmo entrevistado chegou a citar mais de um tema. Se contarmos por pessoas ouvidas pela pesquisa, 42 chegaram a falar pelo

\footnotetext{
${ }^{72}$ Colocamos a página 7 em nossos anexos para o leitor poder ver uma página da seção Comunidades, como os textos enviados por diferentes locais, e também o Mural de Recados.
} 
menos um desses assuntos como parte preferida ou útil para ação. $\mathrm{O}$ que nos permite afirmar que 68,8\% citaram indiretamente a seção Aprendendo Mais, enquanto que de 67\% do total citou a seção Comunidades (41 pessoas). Logo, essas são as duas partes do jornal que mais contribuem para a ação da liderança e para sua educação continuada.

Por ser a parte que consideramos mais educativa do jornal e também por ter sido bastante abordada durante as entrevistas, apontamos as temáticas abordadas pela seção Aprendendo Mais nas 16 edições analisadas. Também selecionamos exemplos que mostram como se leva a uma reflexão que conscientiza sobre direitos e deveres, educa e contribui para a construção da cidadania no cotidiano.

Para facilitar a visualização dos temas abordados, preparamos quadros com quatro edições de jornais. Vale dizer que a seção conta geralmente com cinco páginas. As exceções foram os meses de maio/08, setembro/08, com sete páginas. Antes do quadro, mostraremos quatro trechos de algumas das subseções do Aprendendo Mais de cada mês, que exemplificam como a questão da cidadania é trabalhada visando à ação prática na comunidade. Começamos apresentando trechos dos meses de fevereiro a maio de 2008:

Jornal Pastoral da Criança - Fev/2008 (p.24) - subseção Cidadania: “A família deve ser a base da saúde, da educação, do amor necessários para a criança se desenvolver. (...) Por isso, todas as pessoas, e também governos, devem defender a vida, a promover os direitos e a prevenir situações que geram sofrimento para a infância, como doenças, ambiente desfavorável, fome, acidentes e atos de violência."

Jornal Pastoral da Criança - Mar/2008 (p.13) - subseção Diálogo: "Ninguém veio ao mundo sabendo o que é certo ou errado. São os pais, mães e familiares que têm essa missão de passar para seus filhos o que pode e o que não pode, sem desrespeitar ou agredir. (...)

Dar limites é:

- ensinar para os filhos que os direitos são iguais para todos;

- ensinar que existem outras pessoas no mundo;

- dizer SIM sempre que possível e NÃO quando necessário;

- (...)

- dar o exemplo - quem quer ter filhos que respeitem as leis e as pessoas, precisa viver seu dia-a-dia dentro desses mesmos princípios." ${ }^{, 73}$

Jornal Pastoral da Criança - Abril/2008 (p.15) - subseção Fé e Vida: “(...) Então, a mística é essa realidade, é essa força maior que nos move, que nos capacita para ouvir, para escutar esse Deus que fala a nós. (...) Quem faz esse trabalho voluntário na Pastoral da Criança o faz por causa de Cristo, porque enxerga Cristo em cada irmãos. É esta espiritualidade que nós temos que cultivar, todos nós que nos dedicamos à Pastoral da Criança".

\footnotetext{
${ }^{73}$ A página 13 se encontra nos anexos desse trabalho.
} 
Jornal Pastoral da Criança - Maio/2008 (p.24) - subseção Trocando Idéias: "Nós na Pastoral da Criança devemos procurar ajudar na transformação de nossas comunidades para que mães e pais não estejam tão exaustos de tanto trabalho e tanta luta pela sobrevivência que não tenham tempo nem vontade de cantar para seus filhos. Fazer nossa parte para que não se ouçam tiros e brigas nas ruas e nas casas, para que o medo e a violência não estejam presentes no dia-a-dia da família. Nós, na Pastoral da Criança, perseguimos o sonho de ver as crianças dormindo e embaladas por cantigas cantadas suavemente, vivendo desde pequenas num ambiente de amor e paz".

Como vemos pelos exemplos acima, os textos da seção Aprendendo Mais tentam contribuir para a ação da líder, trazendo reflexões sobre temas que levam a uma vida melhor na comunidade. A mudança ocorre na vida cotidiana e parte da conscientização das líderes que trabalharão essa consciência nas visitas às famílias. O mesmo ocorre nas outras subseções que trazem informações sobre saúde, prevenção de doenças e de acidentes, direitos, entre outros, como podemos ver na tabela abaixo:

\begin{tabular}{|c|c|c|c|c|}
\hline \multicolumn{5}{|c|}{ Temática Aprendendo Mais* } \\
\hline Subseções & Fevereiro/2008 & Março/2008 & Abril/2008 & Maio/2008 \\
\hline $\begin{array}{c}\text { TROCANDO } \\
\text { IDÉIAS }\end{array}$ & $\begin{array}{l}\text { Brinquedos e } \\
\text { brincadeiras }\end{array}$ & $\begin{array}{l}\text { Brinquedos e } \\
\text { brincadeiras }\end{array}$ & $\begin{array}{l}\text { Brinquedos e } \\
\text { brincadeiras }\end{array}$ & $\begin{array}{l}\text { Brinquedos e } \\
\text { brincadeiras }\end{array}$ \\
\hline FÉ E VIDA & $\begin{array}{l}\text { Campanha da } \\
\text { Fraternidade }\end{array}$ & Páscoa & $\begin{array}{c}\text { Mística e } \\
\text { voluntariado }\end{array}$ & Maternidade \\
\hline $\begin{array}{c}\text { AÇÕES } \\
\text { BÁSICAS }\end{array}$ & $\begin{array}{l}\text { Prevenção de } \\
\text { várias doenças }\end{array}$ & $\begin{array}{l}\text { Viroses - } \\
\text { sintomas }\end{array}$ & Soro Caseiro & Água e doenças \\
\hline DIÁLOGO & $\begin{array}{l}\text { Convivência } \\
\text { familiar }\end{array}$ & $\begin{array}{l}\text { Limites aos } \\
\text { filhos }\end{array}$ & $\begin{array}{l}\text { Bater não } \\
\text { educa }\end{array}$ & $\begin{array}{l}\text { Desapego das } \\
\text { coisas }\end{array}$ \\
\hline SAÚDE & Epilepsia & Tuberculose & $\begin{array}{l}\text { Parceria em SP } \\
\text { - tuberculose }\end{array}$ & Pneumonia \\
\hline $\begin{array}{c}\text { (EM) } \\
\text { DESTAQUE }\end{array}$ & Tétano & - & $\begin{array}{l}\text { Cuidado pós- } \\
\text { parto }\end{array}$ & $\begin{array}{c}\text { Cuidados } 1^{\circ} \text { mês } \\
\text { do bebê }\end{array}$ \\
\hline RECEITA & $\begin{array}{l}\text { Canjica salgada } \\
\text { (CP) }\end{array}$ & $\begin{array}{l}\text { Strogonoff de } \\
\text { Maxixe (CP) }\end{array}$ & $\begin{array}{c}\text { Suco de } \\
\text { mandioca }(\mathrm{CP})\end{array}$ & $\begin{array}{l}\text { Salada de banana } \\
\text { (CP) }\end{array}$ \\
\hline CIDADANIA & $\begin{array}{l}\text { Campanha da } \\
\text { fraternidade }\end{array}$ & SUS & $\begin{array}{l}\text { Direitos das } \\
\text { gestantes }\end{array}$ & Saúde da Mulher \\
\hline ALIMENTAÇÃO & - & $\begin{array}{l}\text { O que faz } \\
\text { criança não } \\
\text { comer }\end{array}$ & $\begin{array}{l}\text { Alimentação } \\
\text { bebê - mais de } \\
6 \text { meses }\end{array}$ & Nutrição infantil \\
\hline TESTEMUNHO & - & - & $\begin{array}{l}1 \text { voluntária } \\
\text { (CP) }\end{array}$ & 3 voluntárias $(\mathrm{CP})$ \\
\hline PREVENÇÃO & - & - & Rede elétrica & $\begin{array}{l}\text { Câncer do } \\
\text { Intestino }\end{array}$ \\
\hline
\end{tabular}




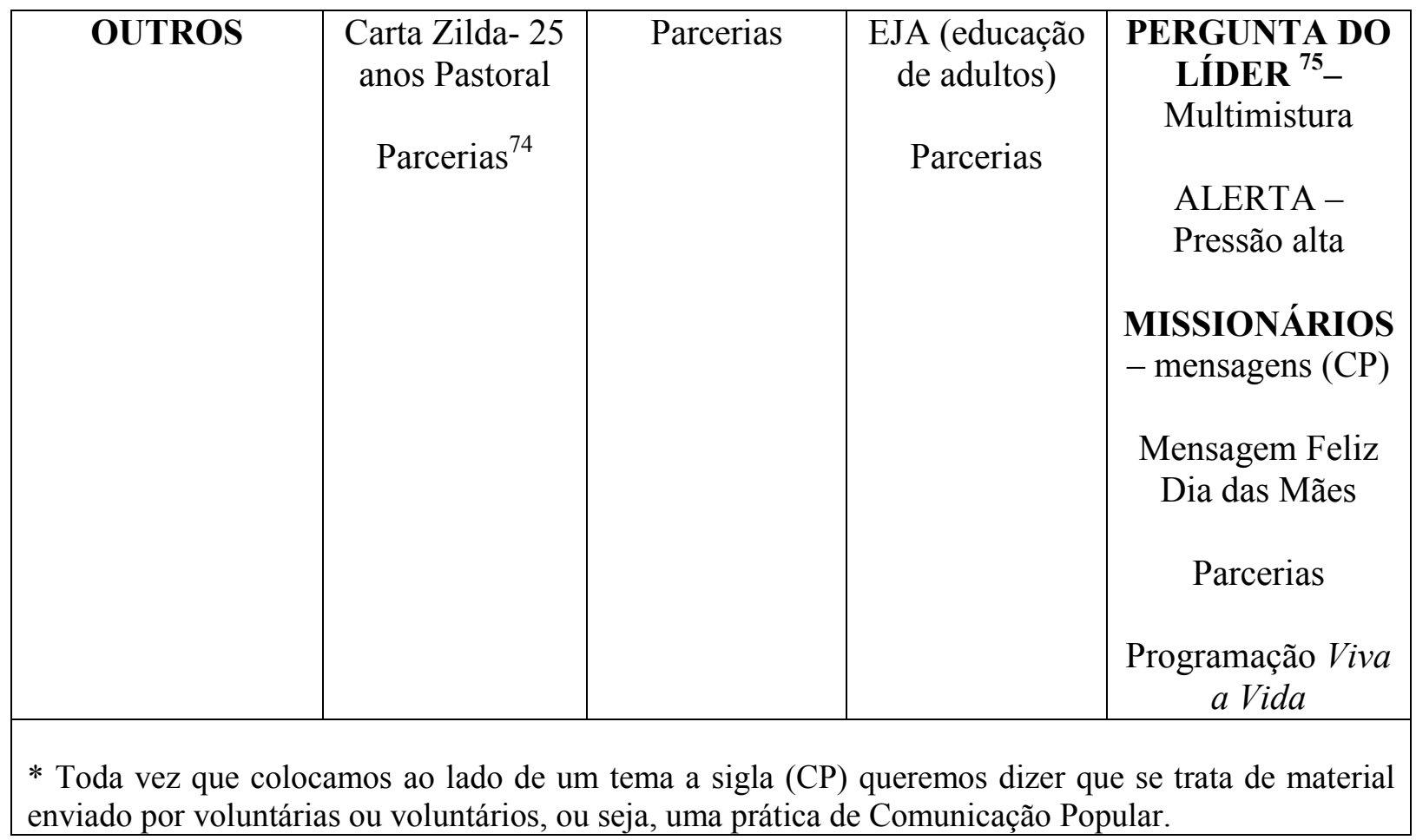

Os textos nos mostram como sujeitos podem agir em prol da cidadania com práticas realizadas no dia-a-dia. Também selecionamos exemplos de algumas subseções de Aprendendo Mais entre os meses de junho a setembro de 2008. A seção, como podemos ver é uma fonte educativa, em que há uma identidade coletiva e uma vontade de mudança que tem a ver com a conscientização, mas também com a fé. A ação na Pastoral da Criança é uma missão.

\begin{abstract}
Jornal Pastoral da Criança - Jun/2008 (p.14) - subseção Saúde: "O soro caseiro só deve ser oferecido para a criança que está com diarréia ou vomitando pouco, por causa de algum problema intestinal. Não se deve oferecer o soro caseiro quando a criança está boa, porque ela vai receber mais substâncias do que precisa e isso força o seu corpo. Lembre que soro caseiro é remédio e remédio só deve ser dado para a criança doente."

Jornal Pastoral da Criança - Jul/2008 (p.13) - subseção Cidadania: "Este ano, o Estatuto da Criança e do Adolescente (ECA) completa 18 anos. Desde que foi instituído como Lei, em 1990, foram muitas conquistas. Mas para que a criança seja prioridade absoluta ainda há muito a ser feito. Por exemplo, como podemos diminuir a violência dentro da família como determina o ECA? A Pastoral da Criança trabalha pela defesa dos direitos humanos, especialmente das famílias e das crianças mais pobres do Brasil. Nossa missão é estar a serviço das pessoas e garantir um dos direitos fundamentais da criança: viver com dignidade."
\end{abstract}

\footnotetext{
${ }^{74}$ Símbolos de organizações que fazem doações para a Pastoral da Criança.

${ }^{75}$ Usamos negrito para os nomes de subseções que se repetem em mais de uma edição, ainda que na tabela só apareça em uma.
} 
Jornal Pastoral da Criança - Ago/2008 (p.20) - subseção Diretrizes: “(...) as Diretrizes da CNBB apontam sinais de esperança, valorizando o trabalho de muitas organizações alternativas não-governamentais e movimentos sociais sem vinculação partidária. E o documento nos faz um alerta: é preciso cobrar dos governos políticas públicas em prol da família, de modo especial devemos tomar iniciativas de solidariedade em relação a pessoas, famílias e grupos atingidos pela miséria, fome e tantas formas de sofrimento."

Jornal Pastoral da Criança - Set/2008 (p.23) - subseção Testemunho: "Essa é uma parte de minha vida que faz todo o sentido continuar vivendo! É a estória de um lutador, ainda que pequenino com apenas quatro anos, que já segue em busca da cidadania, para si e sua irmã; que tem em Deus seu pai e seu protetor e que passa pela vida de algumas pessoas, inclusive a minha, deixando algo de bom. Como dizia Madre Teresa de Calcutá: 'Não devemos entrar na vida de uma pessoa sem que, ao sair dela, ela não se sinta melhor'.",76

Como diz o próprio Jornal Pastoral da Criança (set/2008) na subseção Cidadania, "a articulação comunitária é o ponto de partida para a participação no controle social. Os voluntários da Pastoral da Criança ouvem as pessoas e procuram entender os problemas que afetam a vida das crianças..." Assim lista alguns exemplos: "violência, desemprego, injustiças, falta de moradia, tratamento de esgotos e todas as situações que precisam ser enfrentadas". Certamente as líderes estão atentas a esses problemas por uma série de fatores: elas vivenciam isso ou veem as pessoas passando por esses problemas, elas discutem esses problemas nas reuniões, ouvem falar deles nas capacitações, leem sobre eles no jornal. Assim se formam e informam para enfrentá-los e tentar contribuir para a mudança da realidade, como também vemos na tabela temática das edições abaixo.

\begin{tabular}{|c|c|c|c|c|}
\hline \multicolumn{5}{|c|}{ Temática Aprendendo Mais } \\
\hline Subseções & Junho/2008 & Julho/2008 & Agosto/2008 & Setembro/2008 \\
\hline $\begin{array}{c}\text { TROCANDO } \\
\text { IDÉIAS }\end{array}$ & Festas juninas & $\begin{array}{c}\text { Brinquedos e } \\
\text { brincadeiras } \\
(\text { CP) }\end{array}$ & $\begin{array}{c}\text { Papel do pai } \\
\text { na educação }\end{array}$ & $\begin{array}{c}\text { Desenvolvimen } \\
\text { to integral da } \\
\text { criança }\end{array}$ \\
\hline FÉ E VIDA & - & $\begin{array}{c}\text { Voluntariado } \\
\text { e amor à } \\
\text { comunidade } \\
\text { AÇÕES }\end{array}$ & $\begin{array}{c}\text { Voluntariado } \\
\text { (escrito por } \\
\text { um pastor) }\end{array}$ & $\begin{array}{c}\text { - } \\
\text { BÁSICAS }\end{array}$ \\
\hline
\end{tabular}

\footnotetext{
${ }^{76}$ A íntegra desse texto, que foi escrito por uma voluntária da Pastoral da Criança, encontra-se nos Anexos dessa dissertação. Trata-se da história de um menino de quatro anos que procurou a Pastoral da Criança sozinho para se tornar uma criança acompanhada.
} 


\begin{tabular}{|c|c|c|c|c|}
\hline & & & & meses \\
\hline DIÁLOGO & Ansiedade & $\begin{array}{l}\text { Problemas } \\
\text { gerados pela } \\
\text { fofoca }\end{array}$ & $\begin{array}{c}\text { Pessoas } \\
\text { controladoras }\end{array}$ & - \\
\hline SAÚDE & $\begin{array}{c}\text { Dúvidas de } \\
\text { mães - soro e } \\
\text { amamenta-ção }\end{array}$ & - & - & $\begin{array}{c}\text { Baixo peso ao } \\
\text { nascer }\end{array}$ \\
\hline DESTAQUE & Leptospirose & - & $\begin{array}{l}\text { Gravidez de } \\
\text { alto risco }\end{array}$ & - \\
\hline RECEITA & $\begin{array}{l}\text { Refogado de } \\
\text { jaca (CP) }\end{array}$ & $\begin{array}{l}\text { Lasanha de } \\
\text { mandioca } \\
\text { (CP) }\end{array}$ & $\begin{array}{c}\text { Doce de } \\
\text { chuchu }(\mathrm{CP})\end{array}$ & $\begin{array}{l}\text { Farofa com } \\
\text { banana }(\mathrm{CP})\end{array}$ \\
\hline CIDADANIA & $\begin{array}{l}\text { Melhorar } \\
\text { posto de } \\
\text { saúde }\end{array}$ & $\begin{array}{c}\text { ECA } \\
\text { (Estatuto da } \\
\text { Criança e do } \\
\text { Adolescente) }\end{array}$ & $\begin{array}{l}\text { Eleger } \\
\text { políticos } \\
\text { honestos }\end{array}$ & $\begin{array}{c}\text { Transformação } \\
\text { da comunidade } \\
\text { pelas líderes }\end{array}$ \\
\hline ALIMENTAÇÃO & - & $\begin{array}{c}\text { Preparação de } \\
\text { alimentos }\end{array}$ & $\begin{array}{l}\text { Cuidados na } \\
\text { preparação }\end{array}$ & - \\
\hline TESTEMUNHO & 1 líder $(\mathrm{CP})$ & - & - & 1 líder $(\mathrm{CP})$ \\
\hline PREVENÇÃO & $\begin{array}{l}\text { Acidentes na } \\
\text { infância }\end{array}$ & - & $\begin{array}{l}\text { Envenena- } \\
\text { mento }\end{array}$ & $\begin{array}{c}\text { Segurança em } \\
\text { casa }\end{array}$ \\
\hline ESTADUAL & $\begin{array}{c}\text { Via sacra } \\
\text { crianças (SP) }\end{array}$ & - & $\begin{array}{c}\text { Ação de } \\
\text { brinquedos e } \\
\text { brincadeiras }\end{array}$ & - \\
\hline MISSIONÁRIOS & - & Encontro & - & Encontro \\
\hline $\begin{array}{c}\text { PERGUNTA DO } \\
\text { LİDER / } \\
\text { ESPAÇO DO } \\
\text { LÍDER }\end{array}$ & $\begin{array}{c}\text { Como } \\
\text { participar do } \\
\text { jornal? }\end{array}$ & & $\begin{array}{l}\text { Sugestão de } \\
\text { trabalharem } \\
\text { alimentação } \\
\text { enriquecida }\end{array}$ & \\
\hline OUTROS & $\begin{array}{c}10 \\
\begin{array}{c}\text { Mandamentos } \\
\text { da Paz }\end{array} \\
\text { Parcerias }\end{array}$ & $\begin{array}{c}\text { LÍDER - } \\
\text { carteira de } \\
\text { identificação } \\
\text { ALERTA- } \\
\text { Golpe usando } \\
\text { nome da } \\
\text { Pastoral } \\
\text { Parcerias }\end{array}$ & $\begin{array}{c}\text { DIRETRIZES } \\
\text { - ação evan- } \\
\text { gelizadora } \\
\text { MENSAGEM } \\
\text { - vocação } \\
\text { Parcerias }\end{array}$ & $\begin{array}{c}\text { ESPECIAL - } \\
\text { Zilda recebe } \\
\text { título } \\
\text { Citação de } \\
\text { Documento de } \\
\text { Aparecida } \\
\text { SAÚdDE } \\
\text { BUCAL - } \\
\text { capacitação } \\
\text { Parcerias } \\
\text { Programação } \\
\text { Viva a Vida }\end{array}$ \\
\hline
\end{tabular}


Continuando a análise da contribuição do Jornal Pastoral da Criança para a cidadania, analisamos a seção Aprendendo Mais das edições de outubro de 2008 a janeiro de 2009. São três publicações, já que para dezembro e janeiro foi feita uma única edição. Os exemplos abaixo mostram tanto como as comunidades podem se mobilizar para ter direitos sociais efetivados quanto como cumprir deveres, seja economizando água ou possibilitando que a criança brinque.

Jornal Pastoral da Criança - Out/2008 (p.12) - subseção Trocando
Idéias: “...pensei que seria interessante pensarmos sobre como nossas
cidades, nossas comunidades estão acolhendo essa pessoa especial que vive
nelas - a criança! Isso também se torna importante agora, pois estamos em
tempos de eleição e prefeitos e vereadores estão mais próximos de nós para
que possamos reivindicar necessidades e direitos. Um voto bem dado e um
monitoramento das promessas feitas em campanha podem fazer alguma
diferença na nossa vida diária."

Jornal Pastoral da Criança - Set/2008 (p.23) - subseção Entrevista: "Podemos nos reunir com os vizinhos e associação de moradores para exigir das autoridades que o esgoto seja coletado do bairro ou da cidade seja tratado; Estimular uma pesquisa dentro de casa, na escola, na igreja ou na associação do bairro sobre a utilização da água, discutindo e comparando os vários hábitos, apresentando cartazes e fazendo orientações simples de como diminuir o consumo; Evitar exageros e desperdícios, instituindo hábitos positivos como: evitar banhos demorados; fechar a torneira enquanto escovamos os dentes..."78

Jornal Pastoral da Criança - Dez/08- Jan/09 (p.14) - subseção Trocando Idéias: "Para nós, brincadeira é aquela atividade na qual é a criança que decide quando e como quer brincar. Portanto, não podemos obrigar uma criança a brincar, ela brinca se quiser. A brincadeira é a única hora em que quem comanda a atividade é a criança. Não é como a hora de comer, de dormir, de tomar banho em que ela tem que obedecer ao adulto. É preciso cuidar só para que, na brincadeira, a criança não se machuque, não machuque outra criança e não ultrapasse os limites do que é permitido fazer."

Segue tabela com os temas da seção Aprendendo Mais das edições de outubro de 2008 a janeiro de 2009. É interessante notar que um tema pode se repetir numa mesma edição, um complementando o outro e enriquecendo ainda mais a aprendizagem e a reflexão. É o caso, por exemplo, da hanseníase, em outubro (p.13). Na subseção Saúde, fala-se dos sintomas, da transmissão, da parceria da Pastoral com o governo sobre a doença. Já na subseção Fé e Vida, o texto fala de como devemos nos mobilizar: "Aparecem inúmeras pessoas com esse problema de hanseníase. Nós temos que enfrentar esse problema. (...) exigirmos hospitais,

\footnotetext{
${ }^{77}$ A íntegra desse texto se encontra nos anexos dessa dissertação.

${ }^{78}$ Essa página também foi anexada no final do trabalho.
} 
clínicas, tratamento e quando aparecer esse problema encaminhar imediatamente as pessoas para atendimento." E relaciona a ação das pessoas com a do próprio Cristo: "Nós não podemos nos deixar alimentar com o preconceito. Essa foi uma prática que Jesus condenou tantas vezes no Evangelho. Por isso, Jesus nos mostra o jeito certo. Jesus se aproxima ... e ajuda...; faz com que a pessoa... se reintegre na sociedade".

\begin{tabular}{|c|c|c|c|}
\hline \multicolumn{4}{|c|}{ Temática Aprendendo Mais } \\
\hline Subseções & Outubro/2008 & Novembro/2008 & Dez/08-Jan/09 \\
\hline $\begin{array}{l}\text { TROCANDO } \\
\text { IDÉIAS }\end{array}$ & $\begin{array}{l}\text { Espaço da cidade } \\
\text { para as crianças }\end{array}$ & $\begin{array}{l}\text { Brinquedista e } \\
\text { brincadores }\end{array}$ & $\begin{array}{c}\text { Brinquedista e } \\
\text { brincadores }\end{array}$ \\
\hline FÉ E VIDA & Hanseníase e Jesus & - & Natal \\
\hline $\begin{array}{c}\text { AÇÕES } \\
\text { BÁSICAS }\end{array}$ & - & $\begin{array}{l}\text { Nutrição da } \\
\text { gestante }\end{array}$ & - \\
\hline DIÁLOGO & $\begin{array}{c}\text { Não se ver como } \\
\text { vítima }\end{array}$ & $\begin{array}{c}\text { Ajudar o próximo - } \\
\text { com depoimento } \\
\text { (CP) }\end{array}$ & $\begin{array}{l}\text { Natal, o perdão e a } \\
\text { paz familiar }\end{array}$ \\
\hline SAÚDE & Hanseníase & - & - \\
\hline RECEITA & $\begin{array}{l}\text { Broa de fubá e } \\
\text { milho verde }(\mathrm{CP})\end{array}$ & $\begin{array}{l}\text { Biscoito de amido } \\
\text { de milho }(\mathrm{CP})\end{array}$ & Bolo de banana \\
\hline CIDADANIA & $\begin{array}{l}\text { O direito de acesso } \\
\text { a medicamentos }\end{array}$ & $\begin{array}{c}\text { Convenção Direitos } \\
\text { das Crianças }\end{array}$ & - \\
\hline NUTRIÇÃO & - & Sal na medida certa & - \\
\hline TESTEMUNHO & 1 líder $(\mathrm{CP})$ & 1 líder $(\mathrm{CP})$ & - \\
\hline PREVENÇÃO & Dengue & - & - \\
\hline ESTADUAL & $\begin{array}{l}\text { Homenagem à } \\
\text { Pastoral/ECA }\end{array}$ & $\begin{array}{c}\text { Repetiu mesma } \\
\text { notícia mês anterior }\end{array}$ & - \\
\hline MISSIONÁRIOS & $\begin{array}{l}\text { Reflexão sobre } \\
\text { missionários }\end{array}$ & - & Capacitação \\
\hline ESPECIAL & - & $\begin{array}{c}\text { 1.Zilda ganha título } \\
\text { 2. Natal }\end{array}$ & $\begin{array}{c}\text { Comemoração } 25 \\
\text { anos Pastoral em } \\
\text { Florestópolis }\end{array}$ \\
\hline OUTROS & $\begin{array}{c}\text { COMUNICA- } \\
\text { DORES - Viva a } \\
\text { vida local } \\
\text { ANVISA - parceria } \\
\text { Parcerias }\end{array}$ & $\begin{array}{c}\text { ENTREVISTA - } \\
\text { sobre água } \\
\text { Parcerias }\end{array}$ & $\begin{array}{l}\text { PERGUNTA DO } \\
\text { LÍDER - } \\
\text { amamentação (CP) } \\
\text { DICAS - males do } \\
\text { mel para bebês } \\
\text { Parcerias }\end{array}$ \\
\hline
\end{tabular}

\footnotetext{
${ }^{79}$ Brinquedista é a líder que passou por capacitação de Brinquedos e Brincadeiras, já o brincador é uma pessoa da comunidade preparada pela brinquedista para ajudá-la nas atividades de brincadeiras com as crianças.
} 


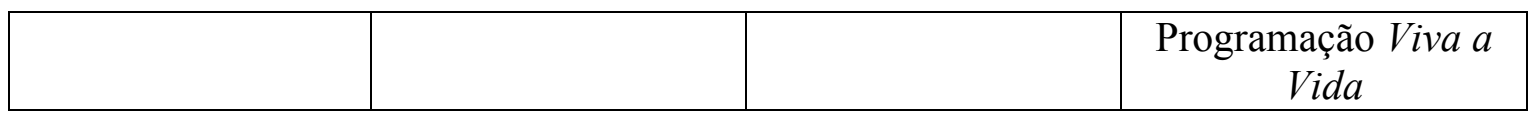

Em fevereiro de 2009, o jornal ganhou nova diagramação. Analisaremos, assim, em conjunto, as edições desse mês até junho de 2009. Sem o uso excessivo de boxes coloridos como ocorria antes, as páginas em fundo branco do Aprendendo Mais facilitam a leitura. Outro ponto positivo é que a programação do Viva a vida passou a ser apresentada fixamente na seção. O que faz com que a líder saiba mais facilmente a temática do programa de rádio. Só falta colocar a página da internet onde eles estão disponíveis, assim como poderiam usar o site para indicar todas as emissoras que retransmitem o programa. Também seria interessante que o espaço destinado para a líder fazer comentário ou pergunta tivesse um único nome. $\mathrm{O}$ mesmo podemos dizer de Estadual e Estado. O ideal seria padronizar, procurar ter apenas nomes fixos. Por exemplo, a subseção Saiba Mais só saiu em março de 2009 e poderia ter sido chamada de Direitos, já usada em outros meses. Abaixo apresentamos a tabela com os temas e subseções das edições.

\begin{tabular}{|c|c|c|c|c|c|}
\hline \multicolumn{6}{|c|}{ Temática Aprendendo Mais } \\
\hline Subsecõos & Fev/2009 & Mar/2009 & Abril/2009 & Maio/2009 & Jun/2009 \\
\hline $\begin{array}{c}\text { TROCAN- } \\
\text { DO IDÉIAS }\end{array}$ & $\begin{array}{l}\text { Brinquedos e } \\
\text { brincadeiras }\end{array}$ & $\begin{array}{l}\text { Dinâmica } \\
\text { para } \\
\text { encontros }\end{array}$ & Dinâmicas & Mãe e amor & $\begin{array}{c}\text { Festa Junina } \\
\text { e } \\
\text { brincadeira }\end{array}$ \\
\hline FÉ E VIDA & $\begin{array}{l}\text { Campanha da } \\
\text { Fraternidade - } \\
\text { segurança } \\
\text { pública }\end{array}$ & $\begin{array}{l}\text { Diversida } \\
\text { de e } \\
\text { preconcei- } \\
\text { to }\end{array}$ & $\begin{array}{l}\text { Páscoa e } \\
\text { vida nova }\end{array}$ & $\begin{array}{l}\text { Mãe e } \\
\text { missão }\end{array}$ & \\
\hline DIÁLOGO & $\begin{array}{l}\text { Reunião de } \\
\text { avaliação e } \\
\text { reflexão }\end{array}$ & $\begin{array}{l}\text { Líder é luz } \\
\text { no mundo }\end{array}$ & $\begin{array}{c}\text { Dificuldade } \\
\text { na missão }\end{array}$ & $\begin{array}{l}\text { Líder e } \\
\text { Deus }\end{array}$ & \\
\hline DESTAQUE & $\begin{array}{l}\text { Perigos do } \\
\text { verão }\end{array}$ & $\begin{array}{l}\text { Direito e } \\
\text { pré-natal }\end{array}$ & & Tabagismo & $\begin{array}{l}\text { Acompanha } \\
\text { nte no parto }\end{array}$ \\
\hline RECEITA & $\begin{array}{c}\text { Bolo de casca } \\
\text { de banana }\end{array}$ & $\begin{array}{l}\text { Suco de } \\
\text { melancia }\end{array}$ & $\begin{array}{c}\text { Bolo de } \\
\text { milho verde }\end{array}$ & $\begin{array}{l}\text { Bolo mexe- } \\
\text { mexe (CP) }\end{array}$ & $\begin{array}{c}\text { Suco de } \\
\text { laranja com } \\
\text { cenoura }\end{array}$ \\
\hline $\begin{array}{l}\text { CIDADA- } \\
\text { NIA }\end{array}$ & $\begin{array}{l}\text { Paz- família e } \\
\text { comunidade }\end{array}$ & $\begin{array}{l}\text { Saiu na pg } \\
2 \text { sobre } \\
\text { tuberculos } \\
\text { e }\end{array}$ & $\begin{array}{c}\text { Políticas } \\
\text { Públicas e a } \\
\text { líder }\end{array}$ & & $\begin{array}{c}\text { Espaços } \\
\text { para as } \\
\text { crianças }\end{array}$ \\
\hline NUTRIÇÃO & $\begin{array}{l}\text { Alimentação } \\
\text { bebês } 6 \text { meses }\end{array}$ & Anemia & $\begin{array}{l}\text { Alimentos } \\
\text { perigosos } \\
\text { para }\end{array}$ & $\begin{array}{l}\text { Alimenta- } \\
\text { ção } \\
\text { saudável }\end{array}$ & Anemia \\
\hline
\end{tabular}




\begin{tabular}{|c|c|c|c|c|c|}
\hline & & & crianças & & \\
\hline $\begin{array}{c}\text { TESTEMU } \\
\text { NHO }\end{array}$ & $\begin{array}{c}2 \text { líderes } \\
\text { entrevistam } \\
\text { uma mãe }(\mathrm{CP})\end{array}$ & $\begin{array}{l}1 \text { líder } \\
\text { (CP) }\end{array}$ & $\begin{array}{l}1 \text { líder } \\
\text { (CP) }\end{array}$ & & 1 líder (CP) \\
\hline $\begin{array}{c}\text { ESTADUAL } \\
\text { / ESTADO }\end{array}$ & & $\begin{array}{l}23 \text { anos - } \\
\text { Pastoral } \\
\text { no Ceará }\end{array}$ & & & $\begin{array}{l}\text { Saúde bucal } \\
\text { (CP) }\end{array}$ \\
\hline $\begin{array}{l}\text { MISSIONÁ } \\
\text { RIOS }\end{array}$ & & Recursos & & $\begin{array}{l}\text { Missão na } \\
\text { Pastoral } \\
\text { (CP) }\end{array}$ & Convite \\
\hline $\begin{array}{l}\text { PALAVRA } \\
\text { DO LÍDER/ } \\
\text { ESPAÇO } \\
\text { DO LIIDER / } \\
\text { PERGUNT } \\
\text { A DO } \\
\text { LÍDER }\end{array}$ & $\begin{array}{l}\text { Opinião de } \\
\text { uma líder } \\
\text { sobre Natal } \\
\text { (CP) }\end{array}$ & & $\begin{array}{l}1 \text { líder fala } \\
\text { de sua ação } \\
\text { na Pastoral } \\
\text { com a ajuda } \\
\text { das filhas } \\
\text { (CP) }\end{array}$ & & $\begin{array}{c}\text { Curva } \\
\text { desenvolvi } \\
\text { mento da } \\
\text { criança } \\
\text { (CP) }\end{array}$ \\
\hline $\begin{array}{l}\text { COMUNI- } \\
\text { CADORES }\end{array}$ & & $\begin{array}{c}\text { Projeto } \\
\text { Comunica } \\
\text { ção } \\
\text { Popular / } \\
\text { RN (CP) }\end{array}$ & $\begin{array}{c}\text { Viva a vida } \\
\text { local / CE } \\
\text { (CP) }\end{array}$ & $\begin{array}{c}\text { Viva a vida } \\
\text { local / AC } \\
\text { (CP) }\end{array}$ & \\
\hline DICA & & $\begin{array}{l}\text { Aleitamen } \\
\text {-to } \\
\text { materno }\end{array}$ & $\begin{array}{l}\text { Hortas } \\
\text { caseiras }\end{array}$ & & \\
\hline DIREITOS & & & $\begin{array}{l}\text { Adolescente } \\
\text { grávida e o } \\
\text { direito à } \\
\text { escola }\end{array}$ & $\begin{array}{l}\text { Direitos da } \\
\text { gestante }\end{array}$ & \\
\hline $\begin{array}{c}\text { REFLEXÃ } \\
\text { O }\end{array}$ & & & & $\begin{array}{l}\text { Ajuda ao } \\
\text { próximo }\end{array}$ & $\begin{array}{l}\text { Solidarie- } \\
\text { dade }\end{array}$ \\
\hline OUTROS & $\begin{array}{c}\text { ESPECIAL - } \\
\text { Pastoral da } \\
\text { Criança } \\
\text { Internacional } \\
\text { Parcerias } \\
\text { Programação } \\
\text { Viva a Vida }\end{array}$ & $\begin{array}{l}\text { SAIBA } \\
\text { MAIS - } \\
\text { direito } \\
\text { parto } \\
\text { Parcerias } \\
\text { Programa- } \\
\text { ção Viva a } \\
\text { Vida }\end{array}$ & $\begin{array}{c}\text { AÇÕES } \\
\text { BÁSICAS - } \\
\text { Saúde bucal } \\
\text { IDÉIAS } \\
\text { CRIATI- } \\
\text { VAS - } \\
\text { brincadeiras } \\
\text { (CP) } \\
\text { PÁSCOA } \\
\text { Parcerias } \\
\text { Programa- } \\
\text { ção Viva a } \\
\text { Vida }\end{array}$ & $\begin{array}{c}\text { Parcerias } \\
\text { Programa- } \\
\text { ção Viva a } \\
\text { Vida }\end{array}$ & $\begin{array}{l}\text { DISQUE- } \\
\text { SAÚDE } \\
\text { (SUS) } \\
\text { Parcerias } \\
\text { Programa- } \\
\text { ção Viva a } \\
\text { Vida }\end{array}$ \\
\hline
\end{tabular}


Também selecionamos um exemplo de cada uma dessas cinco edições para mostrar como a questão da saúde, educação e direitos vêm sendo trabalhada. A mudança no jornal foi mais relacionada à diagramação e à edição do que ao conteúdo, que continuou mantendo características parecidas com as edições anteriores.

Jornal Pastoral da Criança - Fev/09 (p.14) - subseção Cidadania: "Neste mesmo período, convidamos as equipes de coordenação do Setor e de Ramo a convocar os Conselhos e os prefeitos dos seus municípios. Sugerimos que apresentem propostas e cobrem a execução de políticas públicas, por meio de cartas de compromisso ou reuniões, relacionadas aos direitos das crianças e adolescentes." $\$ 80$

Jornal Pastoral da Criança - Mar/09 (p.12) - subseção Saiba Mais: “As gestantes têm direito a indicar um acompanhante para estar com ela durante o trabalho de parto, no parto e no início do pós-parto. É o que determina a Lei Federal número 11.108, de 07 de abril de 2005, que obriga os serviços de saúde públicos ou que atendam pelo SUS (Sistema Único de Saúde), a permitir a presença de um acompanhante junto da gestante ma (sic) hora do parto". ${ }^{81}$

Jornal Pastoral da Criança - Abr/09 (p.19) - subseção Direitos: "Líder, você certamente conhece muitas jovens que engravidaram muito cedo. (...) Uma das conseqüências desta gravidez é o abandono da escola, além da adolescente sofrer com a discriminação... Precisamos enfrentar essa situação e proteger a mãe e a criança. Um bom começo é garantir as condições para a permanência da estudante na escola durante a gestação e após o parto. A licença maternidade escolar está prevista na Lei $\mathrm{n}^{\circ} 6.202$, de 17 de abril de 1975. (...) Líder, fique próximo da gestante adolescente, oriente sobre o prénatal, incentive a estudar..."

Jornal Pastoral da Criança - Maio/09 (p.14) - subseção Reflexão: "Maria vai prestar ajuda. Ajudar não é substituir o outro, não é abafar as potencialidades do outro; é colocar-se ao lado, dar apoio para que as potencialidades do outro venham à tona e aconteçam. Por isso, a verdadeira ajuda precisa de escuta e de observação atenta. Por exemplo, você orientou a gestante a fazer o pré-natal e ela não foi. Qual será o motivo ou os motivos? É preciso escutar atentamente o que acontece, especialmente prestar atenção nos sentimentos da pessoa."

Jornal Pastoral da Criança - Jun/09 (p.15) - subseção Nutrição: “A anemia é um problema muito comum entre crianças e que pode trazer sérias conseqüências para a saúde, como atraso no desenvolvimento mental e psicomotor. A criança com anemia perde o apetite, não tem vontade de brincar, sente muito sono, fica pálida e desanimada. A melhor maneira de evitar a anemia é a prevenção através dos alimentos."

\footnotetext{
${ }^{80}$ Página anexada ao final do trabalho.

${ }^{81}$ Página anexada no final do trabalho.

${ }^{82}$ Também inserimos essa página no anexo. Recomendamos a leitura. A subseção Saiba Mais tem características parecidas com essa subseção Direitos e deveriam ter o mesmo nome.
} 
Acreditamos que esse jornalismo praticado pela Pastoral da Criança contribui para a cidadania. Fisher (2000, p.94) fala sobre a mídia e a prática de um jornalismo comunitário, o que pode ser transposto para a comunicação educativa do Jornal Pastoral da Criança: "Na prática, esse jornalismo começa por colocar uma série de questões, engajando a comunidade na solução de problemas, ajudando leitores e espectadores a enfocar suas próprias soluções e as dos outros."

Ainda podemos destacar o papel da capa que sempre traz fotos e mensagens curtas que estimulam a ação da liderança. Outras seções do jornal que levam a uma reflexão sobre direitos e deveres são Palavra do Pastor e Conversando com você, que a partir de fevereiro de 2009 passou a se chamar Mensagem ${ }^{83}$. Essas colunas, a primeira escrita por um bispo e a segunda por Zilda Arns, misturam temas da realidade, a fé e o estímulo à atuação da líder. Selecionamos ${ }^{84}$ apenas um trecho de cada uma, para exemplificar. O primeiro foi escrito pelo bispo de Cristalândia/TO, Dom Heriberto Hermes. O segundo é a “carta” de Zilda Arns.

Jornal Pastoral da Criança - Nov/08 (p.02) - seção Palavra do Pastor: "O
lema 'Comece em Casa' dá a entender que o lar é fonte, origem, mas insinua
que é para SAIR, compartilhar o que recebeu, ser como uma vela, que não
existe PARA SI, mas para os outros, para iluminar, transformar o ambiente -
é uma MISSÃO para transmitir o que recebeu, partilhar para transformar.
(...) Daí a fantástica oportunidade ... de participar, de propor, de agir, mão só
nas eleições municipais, mas sobretudo acompanhando, fiscalizando,
cobrando, propondo e, se for necessário, denunciando e até cassando as
pessoas que elegemos para o legislativo e executivo municipais. E a maneira
privilegiada para isso é participando ativamente nos Conselhos Municipais,
ou seja nas Políticas Públicas, que afetam os mais diversos setores da vida
coletiva”. Jornal Pastoral da Criança - Fev/09 (p.03) - subseção Mensagem: "A Campanha da Fraternidade é um esforço de toda Igreja em favor da Construção de uma sociedade mais justa e fraterna, a serviço da vida e da esperança, conforme aprendemos nos ensinamentos de Jesus. Vocês já repararam como a violência aumenta dia por dia? E não só a violência nas ruas, mas a violência no trânsito e, o que é muito triste, a violência doméstica. $\mathrm{O}$ que podemos fazer para mudar essa situação? (...) Você sabia que todas as Campanhas da Fraternidade resultam em políticas públicas? (...) Participe você também com idéias, críticas e sugestões nos debates que surgirão na sua comunidade. Só assim poderemos diminuir a violência e construir um mundo melhor para todos."

Essa mobilização incentivada pelas reflexões contidas no jornal com as informações sobre saúde, educação e direitos são importantes para que voluntárias e voluntários desenvolvam ações transformadoras que levam à construção da cidadania. Isso porque

\footnotetext{
${ }^{83}$ Acreditamos que o nome anterior era melhor pois criava uma maior proximidade com o leitor e a leitora.

${ }^{84}$ As duas páginas selecionadas nos exemplos estão anexadas no fim do trabalho.
} 
Para que os avanços políticos saiam do papel e ocorram de fato, a população de cidadãos deve ter informações para a cidadania e praticar ações de cidadania, exigindo e reafirmando a nossa democracia, praticando o aspecto performativo da cidadania. Cidadania necessita de uma sociedade civil organizada que reivindica, aponta soluções e o Estado se obriga a consolidálas. (FARAONE, 2001, p. 40)

\section{7 - Em busca do texto acessível}

Não temos dúvidas de que tanto o jornal como as capacitações, reuniões e programas de rádio contribuem para a construção da cidadania por meio da ação de voluntárias e voluntários da Pastoral da Criança. No entanto, em relação ao jornal, gostaríamos de fazer uma última reflexão, sobre a acessibilidade do texto. Com um texto acessível, a disseminação de informações sobre saúde, educação e direitos pode ainda ser maior.

Como vimos, entre nossas 61 entrevistadas e entrevistados, três afirmaram ler pouco o jornal e uma não sabia ler. No entanto, entre os que costumam ler, quatro falaram que nem sempre veem os outros lendo. Entre essas, a líder e multiplicadora do Belém, Selma Leite Galindo da Silva apontou duas situações. Conhece líderes que leem e uma que até arquiva os exemplares do jornal, mas também percebe que outras têm dificuldades, como pode ser visto no trecho de sua fala:

O líder precisa ter a informação de maneira clara. A informação tem que estar em uma linguagem fácil para ele poder passar para as famílias. Eu graças a Deus não tenho dificuldades, mas conheço pessoas que você precisa sentar e explicar. Tem algumas partes técnicas do jornal que as pessoas têm dificuldades de entender. (Selma Leite Galindo da Silva)

Essas três pessoas que leem pouco, a senhora não alfabetizada e a fala de Selma nos chamam atenção para uma questão: o texto do jornal é acessível ou pode ser melhorado? Trata-se de uma questão fundamental, principalmente, quando pensamos no alfabetismo funcional. Quem realmente consegue ler e entender o que está escrito? Quem se preocupa em escrever da forma mais clara possível para que todos entendam? Essas questões nunca podem ser esquecidas, principalmente quando se faz uma comunicação popular educativa.

As pessoas das classes dominantes têm acesso a praticamente todas as informações relevantes, necessárias para que suas decisões pessoais e para que possam conhecer e exercer seus outros direitos. As pessoas das camadas 
populares não conseguem exercer de forma semelhante seu direito à informação e seus outros direitos de cidadã. (...)

$\mathrm{O}$ analfabetismo, que na prática atinge apenas as camadas populares, impede que milhões de adultos dessas classes tenham acesso a qualquer tipo de comunicação por escrito. Um pouco aquém dessa extrema exclusão estão todos aqueles alfabetizados que não tiveram e não têm a oportunidade de exercitar a leitura, de maneira a se tornarem leitores proficientes. Estão nesse caso as pessoas com poucos anos de escolaridade e pequeno acesso a meios impressos, motivada, esta última limitação, pela pobreza, pela falta crônicas de bibliotecas, por falta de tempo e disposição para leitura após o dia de trabalho. É com estes que me preocupo, pessoas excluídas da leitura, que é o meio mais rápido para obter informações. No mundo de hoje é importante ser proficiente em leitura, principalmente para obter cada vez maior acesso independente à informação, compreendidos aí os conhecimentos essenciais para o desenvolvimento pessoal e o exercício da cidadania. (BOCCHINI, 1994, p.16)

O INAF (Indicador de Alfabetismo Funcional) nos dá uma ideia de como são os leitores no Brasil e as dificuldades que eles apresentam. A pesquisa analisa os níveis de alfabetismo funcional da população brasileira entre 15 e 64 anos de idade. Assim, avaliam-se habilidades em leitura/escrita (letramento) e em matemática (numeramento). O indicador cria diferentes níveis de alfabetismo: analfabetismo, alfabetismo rudimentar, alfabetismo básico e alfabetismo pleno.

Os resultados do INAF, de 2001 a 2005, mostram que houve uma queda do número de analfabetos tanto em relação ao letramento quanto ao numeramento. No entanto, o balanço aponta que se comparando os dados do INAF com os do IBGE, a taxa de escolaridade cresceu em proporção muito maior do que o letramento e o numeramento.

Essas constatações são importantes para entendermos as dificuldades de leitura da população brasileira. Provavelmente, entre as mais de 260 mil voluntárias da Pastoral da Criança, haja essas mesmas dificuldades. Por isso, ao se escrever um material para esse público, deve-se procurar facilitar a leitura, principalmente, diante da possibilidade de leitores pouco proficientes fazerem parte desse universo.

Os dados do relatório do INAF mostram quase 4 milhões de brasileiros analfabetos em relação à habilidade de letramento e escrita. Além disso, 68\% daqueles que estudaram até a quarta série conseguem alcançar o grau rudimentar de alfabetismo (20,8 milhões). Apenas 1/4 dos que estudaram da $5^{\mathrm{a}}$ a $8^{\mathrm{a}}$ série $(7,7$ milhões $)$ pode ser considerado plenamente alfabetizado. Mesmo os que completaram o ensino médio, cerca de 50 milhões, apenas 56\% têm domínio pleno de habilidades de leitura e escrita. 
Outro dado relevante mostra que a maior escolaridade aumenta as chances do indivíduo exercitar suas habilidades. Nesse contexto, a questão econômica e social é primordial, pois isso tem relação direta com a escolaridade.

Os resultados, muitas vezes, parecem reproduzir as estruturas sociais e questões históricas para o desenvolvimento de habilidades em letramento e numeramento e para as diferenças de oportunidade em relação à escolaridade. A região Nordeste traz os piores resultados e a Sul, os melhores. Na comparação capital versus interior, os índices das capitais são melhores. E há diferenças em relação ao centro e periferias das grandes cidades como ocorre no Sudeste.

Todos esses aspectos devem ser pensados ao se tentar criar um perfil das líderes da Pastoral da Criança. Afinal, a Pastoral atua nos locais mais pobres do país, onde há maiores problemas em relação à desnutrição infantil. Como moradoras desses locais, seja no campo ou na cidade, no centro ou na periferia, as líderes vivem essa realidade em relação ao letramento. No caso de nossa pesquisa, na cidade de São Paulo, vimos os problemas e as dificuldades que elas enfrentam ao realizar sua ação seja nos locais mais pobres da periferia ou nos cortiços do centro.

A partir desse cenário, fica clara a necessidade de que o Jornal Pastoral da Criança se preocupe em escrever para os leitores pouco proficientes. Nesse sentido, Kato (1985), Kleiman (2007) e Assumpção e Bocchini (2006) trazem recomendações fundamentais para se construir um texto acessível.

Kato (1985) mostra como se desenvolvem os processos das leituras em diferentes casos. São informações que podem nos guiar a escrever textos mais compreensíveis para leitores pouco proficientes. Por exemplo, a precisão da leitura de uma palavra depende da frequência com que o leitor foi exposto a ela, ou seja, o registro no léxico visual. Isso nos mostra que para escrever para leitores pouco proficientes, precisamos utilizar palavras que façam parte do seu repertório. Assim, a leitura será facilitada.

Para um leitor iniciante, porém, cujo vocabulário visual ainda é muito limitado (...), o processo de leitura envolve muito pouco reconhecimento visual instantâneo, consistindo a leitura, mais freqüentemente, em operações de análise e síntese, sendo a apreensão do significado mediada quase sempre pela decodificação em palavras auditivamente familiares. (KATO, 1985, p.26)

Observando o Jornal Pastoral da Criança, percebe-se que na seção Comunidades é mais recorrente o uso de um vocabulário com palavras de uso cotidiano. Até mesmo porque essa parte do jornal traz as notícias mandadas pelas comunidades. Dessa forma, apresentam-se 
acontecimentos que muitas vezes são parecidos com o que ocorre em diversos lugares. São relatadas atividades de capacitação, parceria, depoimentos de recuperação de crianças desnutridas, informações sobre troca de coordenações.

Kato (1985) nos leva a refletir sobre as limitações dos leitores pouco proficientes. Eles não terão uma grande habilidade para antecipar itens não vistos, pois têm conhecimento limitado. Da mesma forma, não será possível utilizar regras complexas. Para facilitar a leitura, o ideal é utilizar formas mais simples.

A velocidade e a precisão com que uma palavra é percebida, ou lida, depende: a) de a palavra estar registrada no léxico visual pela freqüência com que o leitor já foi exposto a ela e por ter a ela acoplado o seu sentido; do conhecimento de regras e imposições fonotático-ortográficas, sintáticas, semântico-pragmáticas, colocacionais e estilísticas a que a palavra está sujeita e do uso adequado e suficiente dessas restrições para predizer e confirmar sua forma e conteúdo e c) da capacidade de raciocínio inferencial do leitor, que lhe permite também antecipar itens ainda não vistos. (KATO, 1985, p.30)

Dando-nos subsídios para facilitar a compreensão do leitor, Perini (2007, p.152-153) aponta que o texto informativo requer "a construção de uma paisagem mental baseada nas informações do próprio texto". Esse processo conta com inferências baseadas nessas informações e segue operações lógicas, além de expectativas de alta probabilidade. Ele também destaca a importância dos conhecimentos pré-existentes.

(...) entender um texto informativo é retirar dele informações e integrá-las em um sistema de conhecimentos preexistente na memória, de modo a construir uma espécie de "paisagem mental" coerente e ancorada em conhecimentos prévios. Vimos, e cabe relembrar, que esse processo depende crucialmente da participação ativa do leitor, que, longe de ser um simples receptáculo para informação do texto, colabora ativamente na construção da paisagem mental. (PERINI, 2007, p.152)

Novamente voltamos à importância de se considerar o repertório do leitor. Trazendo isso para questão do texto acessível, o texto deverá apresentar conceitos que fazem parte do referencial do leitor ou explicá-los quando o leitor não possuir esses referenciais.

O conhecimento prévio também é trabalhado por Kleiman (2007, p.10). Ela nos mostra que a leitura é um processo interativo: "a leitura é um ato social, entre dois sujeitos leitor e autor - que interagem entre si, obedecendo a objetivos e necessidades socialmente determinados".

Esse processo consiste na interação de diversos conhecimentos: linguístico, textual, de mundo. Devemos nos preocupar com o conhecimento do leitor para que o texto possa ser 
compreendido. O texto deve utilizar palavras do universo desses leitores. Temas que tenham a ver com a realidade dessas pessoas também facilitarão o processo de compreensão. Assim como estruturas textuais simplificadas.

\begin{abstract}
A compreensão de um texto é um processo que se caracteriza pela utilização de conhecimento prévio: o leitor utiliza na leitura o que ele já sabe, o conhecimento adquirido ao longo de sua vida. É mediante a interação de diversos níveis de conhecimento lingüístico, o textual, o conhecimento de mundo, que o leitor consegue construir o sentido do texto. E porque o leitor utiliza justamente diversos níveis de conhecimento que interagem entre si, a leitura é considerada um processo interativo. Pode-se dizer com segurança que sem o engajamento do conhecimento prévio do leitor não haverá compreensão. (KLEIMAN, 2007, p.13)
\end{abstract}

Segundo Kleiman (2007), o conhecimento linguístico possibilitará o processamento do texto. A percepção das palavras e seus agrupamentos formando significados levarão a compreensão. Em relação ao conhecimento textual do leitor, quanto mais ele conhecer as estruturas textuais, mais fácil será a compreensão do texto. Por isso é importante que a Pastoral da Criança incentive a leitura em suas capacitações. Criando-se, assim, novos elementos para se ter acesso à leitura. Também são interessantes os debates entre as líderes sobre a compreensão dos textos informativos do jornal, que vimos pelas entrevistas ocorrer em algumas comunidades. Levar em conta os apontamentos da autora - conhecimento prévio, de mundo, linguístico - na hora de redigir e editar o jornal seria uma forma de dar outros subsídios para a compreensão.

Kleiman (2007) ainda chama atenção para a importância dos esquemas, que determinam nossas expectativas sobre as coisas. Esquemas comuns entre interlocutores também facilitam a compreensão seja em uma conversa ou em uma leitura. Por isso, é importante que o conhecimento seja compartilhado e que as pessoas tenham uma base comum para a compreensão. Através de conhecimentos prévios, os leitores podem fazer as inferências necessárias para a compreensão.

O Jornal Pastoral da Criança consegue fazer isso na escolha dos temas abordados. A seção Comunidades, por exemplo, fala das ações que acontecem em diferentes locais da Pastoral. Isso já gera um referencial comum. A seção Aprendendo Mais tem êxito ao pegar temas de saúde, educação, políticas públicas e direitos, tratando-os de forma explicativa e reflexiva. Parece haver uma preocupação em explicar o que não faz parte do conhecimento prévio do leitor.

Na edição de outubro de 2008, por exemplo, há um texto sobre a hanseníase na seção Aprendendo Mais (pg 15), subseção Saúde. O texto procura usar termos científicos e explicá- 
los como podemos ver na citação do trecho a seguir: "A Hanseníase é uma doença milenar e até bíblica e que se manifesta através de manchas na pele... Esta doença se manifesta nos nervos periféricos, quer dizer, que estão logo abaixo da pele..."

Outros aspectos trazidos por Kleiman (2007) nos ajudam a escrever textos acessíveis. São pontos que deveriam ser melhores observados nos textos do Jornal Pastoral da Criança.

Por exemplo, na leitura de um jornal, já na primeira página o leitor faz uso de mecanismos para a apreensão rápida de informação visual dando uma mera passada de olhos, (processo este chamado de "scanning" ou avistada) geralmente a fim de depreender o tema dos diversos itens a partir das manchetes. Uma vez localizada uma notícia de interesse, é provável que o artigo seja lido procurando detalhes sobre o assunto, comparando o que já se sabe sobre o assunto. Por outro lado, se estamos em dúvida sobre o possível interesse de um artigo, é provável que utilizaremos uma pré-leitura seletiva um processo chamado de "skimming", literalmente, desnatamento, que consiste em ler por exemplo, seletivamente os primeiros ou últimos períodos de parágrafos, as tabelas, ou quaisquer outros itens selecionados pelo leitor, a fim de obter uma idéia geral sobre o tema e subtemas. (KLEIMAN, 2007, p.33-34)

Nesse contexto, é importante que haja uma leitura com objetivos definidos para a compreensão do texto. Esse recurso forma uma estratégia metacognitiva, pois se reflete sobre o próprio conhecimento, regulamentando-o. Também contribui para a formulação de hipóteses pelos leitores. Os autores devem contribuir para esse processo oferecendo elementos que facilitem a compreensão. São títulos, subtítulos, datas, fontes, ilustrações que contribuirão para a leitura. (KLEIMAN, 2007, p.34-43)

Kleiman (2007, p.45-63) ainda fala das estratégias de processamento do texto. A coesão é uma delas assim como o uso de laços coesivos. São pistas que contribuem para a construção do significado pelo leitor. O autor pode usar a regra da recorrência. São repetições, substituições, pronominalização, uso de dêiticos e de frases definidas.

O princípio da parcimônia citado pela autora é outro aspecto que deve ser considerado ao se escrever um texto. Trata-se de um princípio de economia, no qual o leitor tende a reduzir ao mínimo o número de personagens, objetos e eventos do texto. Os textos devem trazer marcas que facilitam essa redução. Sejam através da regra da recorrência, do uso de poucos personagens, de frases curtas, textos em blocos.

A regra da continuidade faz com que o leitor saiba que uma palavra está substituindo outra para falar do mesmo assunto. Outro princípio que faz parte das estratégias cognitivas é o da canonicidade. Ele agrupa nossas expectativas sobre a ordem natural das coisas. Por exemplo, a causa antecede o efeito. 
A autora ainda fala da importância da regra da linearidade para se facilitar a compreensão. Assim, pode-se escrever o texto em uma ordem sequencial, direta. Ainda devem ser considerados o princípio da relevância e a regra da não contradição, para que encontremos as informações mais importantes no texto e para que elas não sejam conflitantes.

Se olharmos para os textos do Jornal Pastoral da Criança, vemos que alguns desses aspectos não são levados em conta. Os textos da seção Comunidades, muitas vezes, apresentam frases muito longas e parágrafos imensos. Com menor intensidade, esse problema também acontece no Aprendendo Mais. Mesmo depois da nova diagramação, o problema ainda ocorreu algumas vezes. Selecionamos alguns exemplos:

Jornal Pastoral da Criança - Jul/08 (p.16) - Aprendendo Mais - subseção Alimentação: "Cuidado muito especial nós precisamos ter com as esponjas, com os panos de pratos, porque eles estão sempre úmidos e a gente acaba passando o pano de prato em cima do fogão, na pia, depois a gente vão e utiliza esse pano de prato para enxugar talheres, enxugar panela e a gente acaba levando a contaminação da pia para os utensílios, para as colheres ou das mãos para esses equipamentos também."

Jornal Pastoral da Criança - Mar/09 (p.13) - seção Aprendendo Mais subseção Comunicadores: "Ser capacitada nas técnicas de comunicação dos Comunicadores Populares da Pastoral da Criança me fez descobrir o potencial dentro de mim que nem eu mesma sabia", expressa a jovem Maria Nice Ferreira, 17 anos da comunidade de Monte Alegre-RN ao ser capacitada com mais 23 jovens na testagem do Projeto dos Comunicadores Populares que aconteceu na Comunidade de Lagoa Salgada-RN, em outubro de 2008, na Arquidiocese de Natal, Nordeste do Brasil."

As duas frases contam com 71 palavras. A primeira trata-se de um trecho de uma entrevista, mas mesmo assim ela poderia ter sido editada com frases mais curtas, usando a ordem direta no início. Já a segunda é o primeiro parágrafo de uma notícia e também poderia ser dividido em mais frases para facilitar a leitura. O uso de dêitcos, substituições e pronomes permite esse tipo de construção.

Assumpção e Bocchini (2006) sugerem frases de até 22 palavras em textos informativos:

A compreensão rápida do que se lê depende da leitura rápida. Para compreender a frase inteira, é preciso manter na memória o trecho já lido. O fato é que a memória imediata tem limite. Ela funciona como um reservatório com pouco espaço: tudo o que entra tem pouco tempo de permanência. As primeiras palavras entram na memória imediata e ficam ali um pouquinho. Se a leitura não for rápida, para completar logo o sentido, a informação parcial evapora-se.

(...) 
Os períodos longos e complicados podem ser considerados ilegíveis, porque quem lê, quando chega ao ponto final, já não se lembra do começo. O leitor tem de reler o trecho que se evaporou para poder compreender o restante. (ASSUMPÇÃO; BOCCHINI, 2006, p.27-28)

Outro ponto que sempre deve ser observado é o título. Para Assumpção e Bocchini (2006), um bom título é aquele que facilita a leitura. Ele funciona como uma lanterna que iluminará nossa memória. Permite assim que reativemos conhecimentos prévios para compreender o texto. Devem informar o leitor sobre o assunto do texto, temas e subtemas abordados.

\begin{abstract}
Além do título, outros elementos em destaque nas páginas iluminam as pastas de conhecimentos do leitor e o ajudam a imaginar os temas e subtemas do texto que vai ler. Quanto melhor a leitora imagina o conteúdo do texto, mais fácil será a leitura.

Num livro de filosofia, por exemplo, as lanternas serão principalmente os títulos dos capítulos e os subtítulos do texto.

Num relatório, as lanternas serão subtítulos, quadros, fotos e legendas das figuras.

Em revistas, jornais, relatórios, manuais, livros didáticos, livros técnicos e científicos, os sinais para o leitor virão também de elementos como: antetítulo, legendas, olho, olhinho, fotos, ilustrações, títulos de quadros e gráficos. (ASSUMPÇÃO; BOCCHINI, 2006, p.17-19)
\end{abstract}

No Jornal Pastoral da Criança, notamos uma melhora nos títulos a partir da reformulação ocorrida em fevereiro de 2009. Pegamos dois trechos. Um exemplo anterior à reforma, de Comunidades, onde o título não diz nada. Outro do Aprendendo Mais, de março de 2009, em que realmente serve como guia e facilitador da leitura. Além disso, é exemplo de uso de frases curtas e informativas. Vale destacar que mesmo antes da reforma, os títulos dessa seção geralmente cumprem essa função. No caso de Comunidades também há mais exemplos positivos do que negativos.

\title{
Jornal Pastoral da Criança - Set/08 (p.16) - seção Comunidades: \\ Título
}

Com muita alegria queremos partilhar a experiência de capacitação de novos líderes, acontecida nos meses de outubro e novembro de 2007, na Comunidade Santa Teresinha, da Paróquia do Santíssimo Sacramento da Eucaristia.

Por dois meses, os líderes enfrentaram longo caminho para poderem participar dos encontros, sendo a comunidade situada no assentamento MST, área rural.

Jornal Pastoral da Criança - Mar/09 (p.15) - seção Aprendendo Mais subseção Nutrição:

Alimentos importantes para evitar anemia em gestantes 
A anemia é a falta de ferro em nosso organismo. É causada porque não comemos a quantidade de ferro suficiente que nosso corpo precisa.

A anemia deixa as pessoas desanimadas, cansadas, pálidas e com mais facilidade de pegar doenças.

Assumpção e Bocchini (2006) apresentam várias recomendações para se escrever bem um texto. Uma das indicações é sempre optar por palavras mais conhecidas e familiares. As siglas também devem ser explicadas. As frases curtas e a ordem direta também são recomendadas pelas autoras. As intercalações devem ser evitadas. Enumerações longas, cheias de vírgulas e ponto-e-vírgulas devem ser reescritas. Uma sugestão é utilizar tópicos.

A utilização de tópicos é um recurso bem explorado pela Pastoral da Criança, tanto antes quanto depois da reformulação. É comum ser usado nos textos do Aprendendo Mais, assim como intertítulos e explicações didáticas. Selecionamos um trecho da subseção Cidadania:

\section{Jornal Pastoral da Criança - Abril/09 (p.19) - seção Aprendendo Mais - subseção Cidadania: Vigilância das prioridades em 2009}

(..) Devemos dar continuidade ao trabalho e ver como vão acontecer as políticas públicas direcionadas à infância. Devemos destacar algumas prioridades:

- atendimento com qualidade às gestantes;

- atividades de prevenção e medicamentos para as crianças na hora e no local adequados;

- acesso à certidão de nascimento;

- erradicação do analfabetismo;

- cultura, esporte e lazer para todas as crianças e adolescentes;

- locais seguros para as crianças brincarem;

- melhoria da qualidade de ensino desde a primeira infância;

- atividades de combate ao desperdício de alimentos;

- organização de hortas domésticas e pomares.

Pegamos ainda dois primeiros e segundos parágrafos da seção Comunidades, depois da reformulação do jornal. Um texto usa frases mais curtas, seguindo a recomendação de até 22 palavras por frase no primeiro parágrafo; no segundo uma das frases ultrapassa um pouquinho essa recomendação com 28 palavras. Também utiliza na maior parte do tempo a ordem direta. Geralmente os textos têm frases que giram em torno de 30 palavras. No entanto, alguns extrapolam esse número. Então pegamos o primeiro parágrafo de outro texto de Comunidades, da mesma edição, com o primeiro parágrafo formado com uma frase de 59 
palavras; no segundo as frases já são menores: 31, 22 e 25 palavras. Já os títulos, nos dois casos, são positivos. ${ }^{85}$

\section{Jornal Pastoral da Criança - Maio/09 (p.09) - seção Comunidades: Comemoração}

A Pastoral da Criança teve presença significativa em duas festas de final de ano. Engenho de Dentro e Penha acolheram as crianças para festejar. Uma festa aconteceu na Paróquia Imaculada Conceição e São Sebastião do Engenho de Dentro. Com 430 crianças inscritas, a festa teve início às $9 \mathrm{~h}$ com animação do grupo de teatro da paróquia chamado Cativarte.

Todas as crianças receberam um brinquedo, uma roupa e um calçado. Enquanto as crianças se divertiam, os pais recebiam orientações da Pastoral da Criança sobre alimentação e desnutrição e uma dentista esclarecia sobre os cuidados com a dentição infantil.

\section{Jornal Pastoral da Criança - Maio/09 (p.11) - seção Comunidades: Feira da Saúde}

Com o objetivo de comemorar o Dia Internacional da Mulher, chamar atenção da Comunidade para o tratamento de algumas doenças e também orientar as famílias sobre a importância da alimentação saudável, a Pastoral da Criança do Ramo Santo Antonio, juntamente com a Pastoral da Mulher Marginalizada e Pastoral da Saúde realizaram no dia 08 de Março uma Feira da Saúde.

No decorrer da feira os participantes puderam encontrar: Alimentos saudáveis, juntamente com a receita; artesanato; pesagem das crianças de zero a seis anos de idade; acompanhamento de gestantes; e medida da pressão arterial. Além disso, aconteceu uma palestra ministrada pela Enfermeira e Obstetra Eliana da Cruz, sobre Câncer do Colo do Útero e da Mama. Eliana fez uma explanação sobre o que é câncer e quais as conseqüências que pode causar, além de orientar sobre a importância dos exames preventivos.

Já um recurso que poderia ser mais bem explorado é o uso da narração para falar dos aspectos técnicos. Segundo Bocchini (1994, p.111), “a estrutura narrativa deve ser a mais acessível a qualquer leitor, porque é a mais familiar, a mais facilmente encontrável nos relatos orais do cotidiano". Na seção Aprendendo Mais, que apresenta informações técnicas, muitas vezes em forma de artigos, a narração só foi usada de forma integral duas vezes em todo o período analisado. Ambas na mesma edição: setembro de 2008. Uma na subseção Testemunho, que geralmente traz um relato curto de uma voluntária: sou voluntário há tanto tempo e gosto do meu trabalho por tal motivo. A outra foi no Trocando Idéias, em que se conta a história do desenvolvimento infantil na Pastoral da Criança. Colocamos, para exemplificar, os primeiros parágrafos desses dois textos ${ }^{86}$ :

\footnotetext{
${ }^{85}$ Colocamos as duas páginas anexadas no final desse trabalho.

${ }^{86}$ Essas duas páginas também fazem parte de nossos anexos.
} 
Jornal Pastoral da Criança - Set/08 (p.20) - seção Aprendendo Mais subseção Trocando Idéias:

Vou contar uma história

Quando contamos alguma coisa, fatos, acontecimentos sob a forma de uma história fica mais interessante e fácil de entender e lembrar. Por isso, vou contar, nesta edição do jornal que comemora os 25 anos de existência da Pastoral da Criança, a história do desenvolvimento infantil na Pastoral da Criança. Quem é "antiga" como eu na instituição vai poder se recorda dela e, quem é mais novo, vai ficar sabendo como foi.

Jornal Pastoral da Criança - Set/08 (p.23) - seção Aprendendo Mais subseção Testemunho:

As crianças nos ensinam...

Numa tarde de sábado, mais precisamente o quarto sábado do mês, numa pequena cidade do interior de São Paulo, um garotinho moreno, franzino e com uma vozinha rouca chega à igreja de Santa Mônica para mais uma celebração da vida, na Pastoral da Criança. O pequeno chega sozinho, sentase frente à uma líder (eu) e neste instante sou informada por outra líder de que devo fazer o seu cartão... e o garoto responde as perguntas de praxe "nome da mãe", "nome do pai", "mama no peito"... O pequeno diz que não, e olhando sério para mim diz: mamo no copo, né, tia... e faz todos caírem na gargalhada...

Bocchini (1994) relata sua experiência na edição do boletim do SOF Mulher e Saúde em que muitas vezes usou o recurso de contar histórias no início de textos que traziam informações técnicas. Era uma forma de se aproximar de leitores e leitoras, de deixar a abordagem mais fácil e o texto acessível. No Jornal Pastoral da Criança, esse recurso às vezes aparece na Palavra do Pastor, seja no início ou meio do texto, lembrando as parábolas contadas por Cristo. Já no Aprendendo Mais, algumas vezes:

- Na edição de Junho de 2008, o Trocando Idéias traz uma história vivenciada pela autora e depois conta a história das festas juninas.

- Na edição de Julho de 2008, o Trocando Idéias fala de capacitações e no meio do texto relata uma experiência de Maringá.

- No mês de agosto de 2008, o Trocando Idéias utiliza exemplos de frases que as mães costumavam usar no passado e narra experiências genéricas de situações familiares sobre a presença do pai na educação.

- Em novembro de 2008, Diálogo traz um box com o depoimento e história de uma líder em um texto reflexivo sobre solidariedade.

- Em maio e junho de 2009, Reflexão usa histórias bíblicas para refletir sobre questões atuais. 
Acreditamos que esse recurso poderia ser usado também nos textos que falam de políticas públicas e saúde. Por exemplo, ao falar dos aspectos da anemia, poder-se-ia contar algum caso ocorrido em uma comunidade e como foi resolvido. O mesmo podemos dizer de um texto que fala de determinado direito. Uma história de mobilização de alguma comunidade deixaria o texto ainda mais atrativo e traria um exemplo concreto para as outras comunidades. É preciso trabalhar essas questões para que o texto fique mais acessível.

Estou certa de que o direito a uma comunicação acessível, pelo menos para textos informativos, deve ser atendido para quem redige para esse público, mesmo que não seja possível dar às pessoas num passe de mágica, os conteúdos e referenciais de anos de escolaridade que não tiveram e a experiência de milhares de páginas não lidas. (BOCCHINI, 1994, p.14)

Não há dúvidas de que as informações trabalhadas pela Pastoral da Criança no jornal, aliada às práticas educativas, contribuem para a conscientização sobre direitos e dá materiais importantes sobre a saúde, além de subsídios para a reflexão sobre os problemas sociais. No entanto, trabalhando-se para a acessibilidade do texto, essa inclusão pode ser ainda maior. Como afirma Bocchini (1994, p.18), “a produção de textos acessíveis às pessoas das camadas populares, embora redigidos ainda nos marcos do dialeto padrão, pode ser um instrumento eficiente contra a exclusão dessas classes da informação mínima por meios escritos". É preciso pensar no todo do grupo formado pela Pastoral da Criança, um grande desafio devido à heterogeneidade que o forma: mais de 260 mil pessoas de todo o Brasil; de cidades pequenas e grandes; de periferias e centro; de diferentes níveis de escolaridade.

Sabemos que cada leitor é um leitor, com características pessoais e intransferíveis. Mas sabemos também que não é possível escrever para cada pessoa em particular, respeitando cada individualidade em separado. Quando pensamos num certo público leitor, estamos fazendo interferências de traços que consideramos comuns a todo o grupo. Essas simplificações e generalizações transformam-se em estratégias que tornam possível a transferência de um certo conhecimento acumulado para um grupo maior do que o alcançado pela comunicação interpessoal. (BOCCHINI, 1994, p.25)

O que une voluntárias e voluntários da Pastoral da Criança apesar das particularidades de cada lugar e pessoa? Elas acreditam na missão da organização e no papel delas como sujeitos na transformação da realidade comunitária. Isso as une e traz a identificação entre todas e todos que fazem parte do grupo. O conteúdo do jornal já é adequado a essa mobilização cidadã. A questão é usar da melhor forma possível os recursos que tornam o texto mais acessível. Segue algumas recomendações: 
1. Ajude o leitor a ativar os reconhecimentos que ele tem sobre o assunto do texto.

2. Ajude o leitor a predizer o texto, imaginar sua estrutura e seus conteúdos.

3. Respeite os limites da memória imediata do leitor.

4. Descubra as palavras que o leitor conhece e use preferencialmente essas. Explique as palavras que o leitor não conhece no próprio texto.

5. Descubra o campo de conhecimentos de mundo do leitor e trabalhe a partir dele para apresentar informações novas.

6. Use a estrutura narrativa sempre que possível: é a que o leitor conhece melhor.

7. Dirija-se ao leitor.

8. Coopere com o leitor na expectativa que ele tem de que o texto seja coerente, parcimonioso, canônico e coeso.

(BOCCHINI, 1994, p.140)

Algumas das recomendações de Bocchini (1994) precisam ser mais bem trabalhadas. Por exemplo, para respeitar a memória imediata do leitor, é preciso estar atento ao uso de frases curtas. Um recurso bem usado é de "dirigir-se ao leitor", isso ocorre com frequência nos textos ${ }^{87}$. O conhecimento de mundo do leitor, de certa forma, já é buscado e percebido devido aos encontros e capacitações realizadas. Além disso, eles possibilitam uma troca de conhecimentos grande, que permite que as pessoas estejam mais preparadas para uma leitura proficiente. Mas é preciso incentivar que isso continue acontecendo e que ocorra em todos os lugares.

Oliveira, R e Oliveira, M (1983, p.126) falam de experiências educativas que viveram e que através delas podem afirmar: "são os movimentos sociais que reinventam a educação, na medida mesma em que só eles são capazes de questionar o modo de organização social

\footnotetext{
${ }^{87}$ Pegamos cinco exemplos de junho de 2009 do uso desse recurso:

Jornal Pastoral da Criança - Jun/09 (p.2) - seção Palavra do Pastor: "Se você, agente da pastoral da Criança, for abordado por um repórter que lhe pergunta: - Na sua percepção, qual é a maior dificuldade que a Pastoral da Criança enfrenta atualmente? Qual seria a melhor maneira de enfrentar a dificuldade, buscando sua solução?”

Jornal Pastoral da Criança - Jun/09 (p.3) - seção Mensagem:

"Querido (a) Líder

Querido (a) Coordenador (a).

Paz e Bem!

Como vai você? Como vai sua família e a sua comunidade?

Hoje gostaria de falar com você sobre um assunto que considero o mais importante em minha vida: a paz. Como você sabe, a Campanha da Fraternidade desse ano teve o lema: 'A paz é fruto da justiça' e não é porque a quaresma já acabou que vamos parar de refletir sobre esse tema. Aliás, esse deveria ser um tema permanentemente discutido em nossas famílias e comunidades."

Jornal Pastoral da Criança - Jun/09 (p.12) - seção Aprendendo Mais - subseção Cidadania: "Os nossos líderes conhecem muito bem como os hábitos das famílias mudaram nos últimos anos."

Jornal Pastoral da Criança - Jun/09 (p.13) - seção Aprendendo Mais - subseção Trocando Idéias: "Chegou o mês de junho e muitas líderes e brinquedistas pedem idéias para fazerem um dia da Celebração da Vida bem bonito e animado. No jornal da Pastoral da Criança de junho de 2005 dei várias idéias sobre brincadeiras, quadrilha, etc. Vocês podem ter acesso a ele pelo site da Pastoral...”.

Jornal Pastoral da Criança - Jun/09 (p.14) - seção Aprendendo Mais - subseção Reflexão: “A solidariedade (outro nome da caridade bíblica) é o mais importante sinal da presença de Deus em nosso meio. Gostaria de refletir com vocês um texto de Lucas."
} 
dominante e de propor a emergência de novos contextos de vida, de trabalho e de conhecimento". Vemos essa capacidade dentro da educação e comunicação construída pela Pastoral da Criança, que vê na liderança o papel de sujeitos transformadores da realidade a partir de suas comunidades. Assim, como dizem os autores a respeito dos atores sociais, "rompem o isolamento e a impotência a que estavam submetidos" e "reconquistam sua autonomia e identidade". Mais do que isso "reaprendem a aprender e a determinar eles mesmos seu perfil, seu percurso e seu destino". Essas voluntárias e voluntários da Pastoral da Criança estão aprendendo e ensinando o tempo todo, partilhando o conhecimento e em conjunto construindo a cidadania. 


\section{Conclusão}

A rede de comunicação criada pela Pastoral da Criança traz informações sobre saúde, direitos e deveres, complementando a formação dos voluntários e das voluntárias. Essa comunicação é popular, porque permite a participação efetiva do voluntariado com o uso da palavra, o envio de textos e a aprendizagem do diálogo. Também é educativa, pois contribui para que o conhecimento se multiplique e auxilia as líderes na ação cotidiana de acompanhar famílias com gestantes ou crianças menores de seis anos. Fica clara uma contribuição para a construção da cidadania. Ainda que a pessoa tenha dificuldade para explicar o conceito, ela vive a cidadania na prática e reflete sobre os problemas sociais que atingem sua comunidade.

É uma ação importante. Como afirmava Santos (2008, p.113, p.114 e p.116): “a possibilidade de cidadania plena das pessoas depende de soluções a serem buscadas localmente". O lugar é o "espaço para o exercício da existência plena". Dessa forma, pessoas descobrem o que são e que podem "desejar ser outra coisa". "Mas ser outra coisa é ultrapassar a descoberta da diferença e chegar à sua consciência”.

$\mathrm{O}$ autor ainda afirma que essa consciência da diferença pode conduzir à defesa individualista. Por isso, é importante ultrapassar o imediatismo das soluções e alcançar uma "tomada de consciência". Acreditamos que a Pastoral da Criança, ao reunir pessoas que se voltam para o desenvolvimento infantil, é um começo para essa tomada de consciência de que fala Santos (2008). O que em princípio pode ter uma motivação de fé e solidariedade vai adquirindo características de transformação social. Isso só é possível pela opção educativa adotada pela organização.

O processo de educação criado e as políticas de comunicação da entidade possibilitam a conscientização sobre direitos e fortalece a ação e o papel da mulher nas comunidades. Essa ação em prol da criança cria uma identidade entre os membros, que muitas vezes falam da Pastoral da Criança e das pessoas que fazem parte dela como uma família. Nesse cenário educativo, as pessoas não aprendem sozinhas. Em uma perspectiva freireana, constroem o conhecimento em conjunto. São educadoras e educandas.

Em relação à comunicação, ao mesmo tempo em que recebem as mensagens, também reconstroem o significado a partir do diálogo na comunidade e contam com meios de participação. Podem produzir os textos e enviá-los para o Jornal Pastoral da Criança, seja obedecendo a uma sistemática de envio, que reveza os setores, na seção Comunidades, ou em 
outras subseções como Pergunta do Líder, Testemunho ou Mural de Recados. Ainda há espaço para envio de informações locais para o site e o blog.

O diálogo é a marca das reuniões e encontros. Tudo é baseado no método "ver, julgar e agir", muito usado nas CEBs (Comunidades Eclesiais de Base) e desenvolvido a partir dos anos 50 em movimentos da Igreja Católica. Acrescenta-se a essa metodologia mais duas etapas: "avaliar" e "celebrar". Assim não basta ver o problema, refletir sobre e achar soluções, para então fazer o que é preciso. Depois de agir, deve-se avaliar o que foi feito, quais foram os resultados, as dificuldades, o que necessita ser melhorado. Mas também é preciso comemorar, dessa forma, o celebrar alcança sua plenitude na Celebração da Vida, quando líderes, crianças e familiares se reúnem para pesar as crianças e fazer uma festa. Essa comemoração pode ter espaço para palestras, brincadeiras, alimentos. Isso vai depender da organização local da comunidade.

Podemos afirmar ainda que, assim como na Teologia da Libertação, a Pastoral da Criança faz uma opção pelos pobres. Atua nas comunidades carentes e fomenta discussões que levam a construção da cidadania. As reuniões também lembram o ritmo de trabalho das CEBs. No entanto, a Pastoral da Criança centraliza suas ações na Coordenação Nacional. Como organização, a entidade recebe verba governamental e doação de empresas. Tem uma estrutura de ONG como as que emergem nos anos 90. Também possui uma estrutura de comunicação externa. A assessoria de imprensa da entidade é responsável por divulgar suas campanhas e articular entrevistas, seja para a mídia impressa, para o rádio ou a televisão. Há uma preocupação com a imagem da entidade para a sociedade.

A Coordenação Nacional é responsável ainda pela preparação dos materiais de comunicação e educativos a partir de sua área de comunicação interna. Mas essa preparação é dinâmica, as bases são ouvidas a partir dos seus representantes (coordenadores), nas capacitações e até mesmo através das FABs (Folhas de Acompanhamento e Avaliação das Ações Básicas de Saúde e Educação na Comunidade). Esses documentos também servem para acompanhar os trabalhos que as comunidades estão realizando e alimentam as estatísticas da Pastoral da Criança. É uma forma de avaliar a ação e o que vem sendo feito. Esses resultados são discutidos nos encontros regionais e nacionais. Do debate, aparecem propostas de melhorias.

Até mesmo o conteúdo técnico e educativo do Jornal Pastoral da Criança passa por discussões com os coordenadores, como também vimos acontecer com o novo projeto de comunicação popular e sua cartilha. A jornalista responsável tem ido aos encontros estaduais apresentar o material, que antes foi debatido com os coordenadores estaduais e jornalistas 
convidados. Por tudo isso, afirmamos que o diálogo é a base da construção do conhecimento na Pastoral da Criança.

Nessa organização da Igreja, ainda vemos nascer um novo sentido para a comunidade, que emerge dentro de uma sociedade de massas. As pessoas se juntam em torno de um projeto comum e se sentem parte de um todo. Não se vive integralmente em comunidade como antes, mas voluntários e voluntárias recuperam a atividade comunitária quando estão agindo pela Pastoral da Criança, com objetivos comuns para transformar aspectos negativos da sociedade capitalista. Não há uma luta de classes, nem uma consciência nesse sentido, mas as pessoas se juntam para agir contra a opressão em que vivem e assim mudar a realidade em sua vizinhança. Essa transformação ocorre também na vida de voluntários e voluntárias e se multiplica nas casas das famílias acompanhadas. A cada reunião, encontro, leitura dos materiais da Pastoral da Criança, como o Guia do Lider ou o Jornal Pastoral da Criança, o conhecimento é ampliado, e essa ampliação vem da partilha, da troca de informações.

Inserida na sociedade de massas, a Pastoral da Criança cria vínculos comunitários ao mesmo tempo em que explora as formas de comunicação da mídia. De um lado, está a prática de comunicação popular na possibilidade de participação no Jornal Pastoral da Criança, na reconstrução a que cada região é estimulada a fazer do programa de rádio semanal Viva a Vida e no projeto de Comunicação Popular, que vem capacitando ainda em fase experimental a liderança para fazer a sua própria comunicação local, seja por meio de teatro, cartazes, boletim ou jornal mural. Do outro, a aparição da Pastoral da Criança na mídia: reportagens no Jornal Nacional; inclusão de campanha da entidade na novela das $21 \mathrm{~h}$ da TV Globo ${ }^{88}$; entrevistas em programas populares da TV Gazeta ${ }^{89}$, em São Paulo; em matéria veiculada no Programa do Gugu, no $\mathrm{SBT}^{90}$.

Não são políticas de comunicação opostas e sim complementares. A Pastoral da Criança é vista, assim, pela sociedade de massas. Isso não tem apenas reflexos na imagem da entidade, que se torna mais conhecida e respeitada. Essa aparição pode resultar em mais voluntários. É o caso de uma multiplicadora da Brasilândia. Evangélica, ela conheceu o trabalho da Pastoral da Criança através de uma entrevista de Zilda Arns no Programa do

\footnotetext{
${ }^{88}$ Foi o caso da campanha para os bebês dormirem de barriga para cima, na novela Caminho das Índias. O bebê da personagem principal vestia uma roupa com o símbolo da campanha. A personagem ainda explicava a posição correta durante a cena.

${ }^{89}$ Nelson Arns Neumann concedeu entrevista sobre essa mesma campanha no programa Mulheres. Já Zilda Arns foi entrevistada durante o programa Todo Seu, apresentado pelo ex-cantor da Jovem Guarda, Ronnie Von, para contar a história da Pastoral da Criança.

${ }^{90}$ A equipe do SBT filmou a inauguração de um espaço de brincadeiras no Lauzane, bairro da região Santana, que foi financiado pela Duracell. Entre os presentes, estava a atriz Gabriela Duarte, que foi entrevistada, assim como foram ouvidos um representante da empresa e duas voluntárias da Pastoral da Criança.
} 
Faustão. Como a fundadora explicou que a organização era ecumênica, Nuri resolveu conhecer a ação e passou a participar.

Essa convivência entre comunicação popular e aparições na mídia também é vista no $\operatorname{blog}^{91}$ da Pastoral da Criança. Voluntárias e voluntários podem enviar notícias e fotos sobre a campanha para os bebês dormirem de barriga para cima. Há imagens de Celebração da Vida em comunidade do Rio de Janeiro, de "curumins" dormindo de barriga para cima em Mato Grosso, da ação da campanha em diferentes locais. No mesmo espaço, são divulgados os vídeos de matérias da TV, da cena da novela da TV Globo e propagandas sobre a campanha feitas por Zilda Arns e pela apresentadora da Globo, Angélica.

Se há uma globalização que "mata a noção de solidariedade", dando ao ser humano a visão de "cada um por si", e temos "a informação centralizada nas mãos de um número extremamente limitado" de empresas (SANTOS, 2008, p.65-66), a Pastoral da Criança mostra que é possível buscar um outro caminho, o da comunicação popular. Mas essa opção não a impede de usar a mídia para consolidar a imagem da organização.

A Pastoral recupera a solidariedade que move a ação, feita pelo voluntariado. Através da multiplicação do conhecimento e dos materiais educativos e de comunicação que produz dá subsídios para que as pessoas passem da solidariedade para a conscientização sobre os problemas sociais. O passo seguinte é a ação concreta, que não se limita as visitas, quando, por exemplo, estimula-se a participação em conselhos. Ao mesmo tempo, a organização busca ser pauta dos veículos que centralizam a informação. O que não impede que continue atuando em prol da democratização da comunicação, o que ocorre na opção pela comunicação popular.

Nesse caminho, deve-se tomar cuidado para que o diálogo continue sendo a base das ações. Também é preciso atenção para que a contribuição do Estado e de empresas não interfira na atuação da Pastoral da Criança, nem guie seus passos. A aparição na mídia também deve ser feita com discernimento, de forma que não vá contra os direitos da criança nem haja qualquer exposição que contrarie os princípios da entidade e de seus voluntários e voluntárias. Acreditamos que a assessoria de imprensa e coordenadores costumam observar essa questão ao participar de programas ${ }^{92}$.

\footnotetext{
${ }^{91} \mathrm{O}$ endereço do blog é http://sig.pastoraldacrianca.org.br/wordpress/

92 Vimos essa preocupação logo que iniciamos a pesquisa de campo. A coordenadora da Pastoral da Criança ao nos convidar para sermos comunicadora da entidade nos explicou que, ao ser convidada para ir a programas, um dos cuidados era observar o tipo de conteúdo que o programa apresentava, se não ia contra os ensinamentos que eram trabalhados pela Pastoral.
} 
Já o formato de multiplicação do conhecimento e as práticas de comunicação popular permitem que essa educação dialógica se mantenha. Possibilitar e incentivar as discussões nos encontros e criar estratégias de participação nas ações comunicativas vão ao encontro da educação defendida por Paulo Freire, que visa à conscientização e à transformação, na qual todos são sujeitos, construindo o saber.

...ensinar não é a simples transmissão do conhecimento em torno do objeto ou do conteúdo. Transmissão que se faz muito mais muito mais através da pura descrição do conceito do objeto a ser memorizado pelos alunos. Ensinar ainda ... não pode reduzir-se a um mero ensinar os alunos a aprender através de uma operação em que o objeto do conhecimento fosse o ato mesmo de aprender. Ensinar a aprender só é válido ... quando os educandos aprendem ao aprender a razão de ser do objeto ou do conteúdo.

(...)

ensinar é um ato criador, um ato crítico e não mecânico. (FREIRE, 1992, p.81)

Outro ponto defendido pelo autor e que é fundamental para a Pastoral da Criança, em nossa avaliação, é a necessidade de inserir na educação "a luta política pela transformação do mundo", pois “a libertação dos indivíduos só ganha profunda significação quando se alcança a transformação da sociedade” (FREIRE, 1992, p.100). A ação da Pastoral da Criança também visa à transformação, que começa com a formação da líder. Primeiro ela se transforma, como pudemos ouvir de várias entrevistadas. Elas ampliam o seu conhecimento, construído nas capacitações e reuniões, em que todas têm a oportunidade de falar, opinar. Essa transformação continua em cada visita, pois ao mesmo tempo em que ensina o que aprendeu para a mãe e a família, ela também aprende com os problemas presenciados, que são discutidos nas reuniões de reflexão e avaliação. Essa líder passa a conhecer direitos, a refletir sobre questões sociais e isso é dividido com as famílias acompanhadas. Assim o conhecimento vai sendo construído e partilhado.

A Coordenação Nacional, para criar diretrizes para esse processo, ouve as bases a partir dos encontros que realiza. Essa base não pode deixar de der ouvida. Mais uma vez recorremos a Freire para explicar a importância de considerar o conhecimento de mundo das voluntárias e das famílias acompanhadas:

ninguém, numa perspectiva democrática, deveria ensinar o que sabe, sem de um lado, saber o que já sabem e em que nível sabem aqueles e aquelas a quem vai ensinar o que sabe. De outro, sem respeitar esse saber, parte do qual se acha implícito na leitura do mundo dos que vão aprender o que quem vai ensinar sabe. (FREIRE, 1992, p.131) 
Certamente em um universo de mais de 260 mil pessoas voluntárias, essa é uma difícil missão. Mas o fato das líderes serem as educadoras da Pastoral da Criança é um facilitador, pois, na maioria das vezes, elas vivem na comunidade e conhecem os problemas da região. Com o diálogo promovido nas reuniões, é mais fácil chegar a uma conscientização e construir o saber. Assim a cidadania é aprendida, sendo vivenciada no cotidiano. As pessoas passam a conhecer seus direitos e deveres e ainda que a conceituação de cidadania varie na concepção do voluntariado, como vimos nas 61 entrevistas que realizamos, o mais importante já acontece: a cidadania é vivenciada na prática. As reuniões servem para refletir sobre a questão, assim como o Jornal Pastoral da Criança possibilita que as pessoas leiam sobre direitos e deveres, saibam como agir para fazer valer esses direitos e ao mesmo tempo executem o direito de comunicar. Elas comunicam enviando notícias. Também reconstroem o material seja através da leitura ou dos usos que se faz do jornal: nas reuniões, utilizando exemplos de outras comunidades, levando às informações para as mães.

Há um despertar para a cidadania, que se aprofunda quando voluntárias e voluntários ultrapassam a ação da Pastoral da Criança e passam a participar de conselhos, ir aos postos de saúde e reivindicar direitos, participar de debates sobre políticas públicas de saúde e voltadas para a criança. São cenas que foram observadas durante a pesquisa de campo e mostram como por meio da Pastoral da Criança essas pessoas vão construindo um caminho rumo à cidadania. É importante que esse caminhar leve para um cenário como o sugerido por Milton Santos:

\begin{abstract}
A educação deveria prover todas as pessoas com os meios adequados para que sejam capazes de absorver e criticar a informação, recusando-se os seus vieses, reclamando contra sua fragmentação, exigindo que o noticiário de cada dia não interrompa a seqüência dos eventos de modo que o filme do mundo esteja ao alcance de todos os homens. O morador-cidadão, e não o proprietário-consumidor, veria a cidade como um todo, pedindo que a façam evoluir segundo um plano global... (SANTOS, 2007, p.157)
\end{abstract}

A Pastoral da Criança ainda não possibilita essa visão global de que fala Santos (2007) sobre a cidade, mas é um começo ao criar um ambiente para que esse despertar ocorra em nível comunitário. Se conseguir ampliar o envolvimento do voluntariado com o desenvolvimento de políticas públicas, isso talvez possa ser alcançado. Já há algumas iniciativas como as reivindicações levadas à secretaria de saúde do município de São Paulo. Mas é preciso ampliar as ações nesse sentido e envolver outras instâncias.

O Jornal Pastoral da Criança é um espaço propício para essa reflexão. A seção Aprendendo Mais apresenta temas como saúde, direitos, deveres, convivência familiar e comunitária. São vários textos que dão subsídios para a ação da líder e também fazem refletir. 
Nele a liderança encontra receitas de alimentos nutritivos; informações sobre a prevenção de doenças; reflexões sobre políticas e problemas sociais; formas de educar as crianças. Apesar de não ser citada nominalmente pelos entrevistados e entrevistadas de nossa pesquisa, os temas que aparecem nessa seção foram citados por 68 vezes. Um mesmo entrevistado chegou a citar mais de um tema. Das 61 pessoas ouvidas pela pesquisadora, 42 apontaram pelo menos um desses assuntos como parte preferida ou útil para ação, ou seja, 68,8\% citaram indiretamente a seção Aprendendo Mais. Já a seção Comunidades foi citada por 41 pessoas, totalizando $67 \%$ do grupo entrevistado. Essas seções são as que mais contribuem para a ação da liderança e para sua educação continuada, segundo a análise das 61 pessoas ouvidas.

Outro item importante é que para $90 \%$ o jornal contribui para a cidadania ao divulgar informações sobre saúde e direito. Essa é a opinião de 55 voluntários ou voluntárias, que nos concederam entrevistas. Já 93,5\%, 57 pessoas, afirmaram fazer a leitura individual do jornal. Dessas, 56 acreditam que o jornal contribui para a sua atividade, o que corresponde a 91,8\% do total. É interessante notar que o uso do jornal é feito em reuniões por $34,8 \%$ e $31 \%$ mostram o jornal para as mães. Esses números mostram que a publicação também contribui para a educação e a formação continuada do voluntariado, como defende a Pastoral da Criança.

No entanto, é preciso se preocupar com a acessibilidade do texto. É essencial que a liderança consiga ler o material e entendê-lo, até mesmo porque o jornal traz algumas informações técnicas sobre saúde, logo, é preciso que esse conteúdo seja apresentado de forma clara, considerando o saber das comunidades e possibilitando a ampliação desse saber. Nesse sentido, algumas considerações são necessárias.

A seção Comunidades é a que mais usa palavras do cotidiano. Isso é motivado pelo fato de ser o espaço em que são publicados os textos enviados pelas comunidades. Outra vantagem dessa parte do jornal é que o fato de apresentar relatos da Pastoral da Criança em diferentes locais do país por si só gera uma identificação entre o voluntariado. São histórias de pessoas e locais que têm um objetivo idêntico, isso já é um referencial comum.

A necessidade de se considerar o repertório do leitor é mais latente na seção Aprendendo Mais, que traz as informações técnicas sobre saúde e também sobre direitos, deveres, reflexões sobre a ação. Dessa forma, é essencial que os conceitos apresentados façam parte do referencial dos leitores e leitoras ou sejam explicados quando não fizerem. No geral, parece haver uma preocupação em explicar o que não faz parte do conhecimento prévio do leitor. 
Um problema que atrapalha a acessibilidade do texto no Jornal Pastoral da Criança são as frases e parágrafos muito longos. Isso ocorre tanto em Comunidades quanto no Aprendendo Mais, ainda que em menor intensidade. Mesmo com a reformulação no jornal, ocorrida em fevereiro de 2009, o problema continuou ocorrendo. Já os títulos, que servem como guia sobre o texto para leitor e leitora, melhoraram após a reforma. $\mathrm{O}$ recurso da narração, por sua vez, poderia ser mais bem explorado para falar dos aspectos técnicos.

Não podemos deixar de destacar a melhoria que vem sendo feito no site da Pastoral da Criança ao longo de 2009. Com a reformulação, foi criado um novo blog, voltado para a campanha que orienta sobre a posição correta dos bebês dormirem. Voluntários e voluntárias, como já dissemos, podem enviar materiais. Já no site, a divisão das notícias entre locais, nacionais e internacionais também facilitou o acesso. Sem contar que o site também está aberto para receber notícias das comunidades, enviadas por comunicadores voluntários. É altamente profícuo que essa interação continue e seja estimula, para ampliar a participação do voluntariado e permitir que exerçam o direito de comunicar.

Ainda é interessante notar que mesmo nos casos em que as pessoas não tinham uma noção clara dos conceitos de cidadania e políticas públicas, esses temas são vivenciados na prática e trabalhados pelo jornal da Pastoral. Também são temas de discussões nas reuniões e encontros. Esse conhecimento é partilhado através de um processo educativo dialógico. Há um caráter democrático nas discussões, e as pessoas aprendem com as experiências divididas. Nessa aprendizagem, começa a se configurar a transformação seja no indivíduo, na família ou na comunidade.

A ação que começa na solidariedade pode ganhar novos significados com a formação e os materiais educativos. O diálogo é fundamental para essa construção do conhecimento. Voluntárias e voluntários da Pastoral da Criança desenvolvem um trabalho que ao agir em prol do desenvolvimento integral infantil acaba gerando outros debates. É como se a outra globalização defendida por Santos (2008) fosse possível através da práxis defendida por Freire, que possibilita a tomada de consciência do sujeito rumo à ação. Essa ação se dá no cotidiano, como pensa Heller, o qual é construído por sujeitos ativos - os cidadãos. Na Pastoral da Criança, esse sujeito tem como motivação inicial ajudar o próximo, mas com a comunicação, o diálogo e a educação, conscientizam-se. Unidos por objetivos comuns e uma mesma identidade, agem em conjunto para mudar os problemas de suas comunidades. Primeiro passam a conhecer seus direitos, depois começa a luta para efetivá-los e mudar a realidade em seu meio, começam a ter voz e o direito a ter direitos, assim, como sujeitos históricos passam a trilhar um caminho para a cidadania. 


\section{Referências Bibliográficas}

ABRAMO, Cláudio. A Regra do jogo. São Paulo: Companhia das Letras, 1988. 270p.

ALVAREZ, Sonia E; DAGNINO, Evelina; ESCOBAR, Arturo. O cultural e o político nos movimentos sociais latino-americanos. In: ALVAREZ, Sonia E; DAGNINO, Evelina; ESCOBAR, Arturo (org.). Cultura e política nos movimentos sociais latino-americanos: novas leituras. Belo Horizonte: Editora UFMG, 2000. p.15-57.

ANDRADE, Ana Maria Cardoso. Um novo contexto da informação popular: os centros de documentação e comunicação. 1989. 202f. Tese (Doutorado em Ciências da Comunicação) Escola de Comunicação e Artes, Universidade de São Paulo, São Paulo, 1989.

ASSUMPÇÃO, Maria Helena Ortega Ortiz; BOCCHINI, Maria Otília. Para escrever bem. $2^{a}$ edição. São Paulo: Manole, 2006.

BACCEGA, Maria Aparecida; GUIMARÃES, Margaret de Oliveira. Da comunicação à educação: a importância dos estudos de recepção. Comunicação \& Educação, Ano XI, Número 3, set/dez 2006, p.409-414.

BOCCHINI, Maria Otília. Formação de Redatores para a produção de textos acessíveis a leitores pouco proficientes. 1994. 236f. Tese (Doutorado em Ciências da Comunicação) Escola de Comunicação e Artes, Universidade de São Paulo, São Paulo, 1994.

Legibilidade visual em cartilhas de política da Igreja católica

destinadas a trabalhadores. 1988. 233f. Dissertação (Mestrado em Comunicação Social) Instituto Metodista de Ensino Superior, São Bernardo do Campo,1988.

BOFF, Leonardo. Teologia como libertação. In: Teologia do Cativeiro e da libertação. $6^{\text {a }}$ edição. Petrópolis: Vozes, 1998. p.71-89.

BOSI, Ecléa. O tempo vivo da memória: ensaios de psicologia social. São Paulo: Ateliê Editorial, 2003. 219p.

BRANT, Vinicius Caldeira. Da resistência aos movimentos sociais: a emergência das classes populares em São Paulo. In: BRANT, Vinicius Caldeira, SINGER, Paul (org.). São Paulo: o povo em movimento. Petrópolis: Editora Vozes, 1980. p.9-27.

BROLHANI, Cristina Aparecida. Consolidação ou mudança? Uma análise feminista da Pastoral da Criança. 2004. 367f. Tese (Doutorado em Ciências da Religião) - Faculdade de Filosofia e Ciências da Religião, Universidade Metodista de São Paulo, São Bernardo do Campo, 2004.

CAMARGO, Candido Procópio Ferreira de; SOUZA, Beatriz Muniz; PIERUCCI, Antônio Flávio de Oliveira. Comunidades Eclesiais de Base. In: BRANT, Vinicius Caldeira; SINGER, Paul (org.). São Paulo: o povo em movimento. Petrópolis: Vozes, 1980. p. 59-81. 
CANTÚ, Ariadna; CIMADEVILLA, Gustavo. Orientación, Consumo, Recepción y Uso de los Médios: una propuesta de articulación conceptual. Revista Brasileira de Ciências da Comunicação, São Paulo, Volume XXI, n ${ }^{0}$ 2, jul./dez, 1998, p. 41-54.

CARDOSO, Ruth. A trajetória dos movimentos sociais. In: DAGNINO, Evelina (org.). Anos 90: Política e sociedade no Brasil. São Paulo: Ed. Brasiliense, 1994. p.81-115.

CHAPARRO, Manuel Carlos. Pragmática do jornalismo: Buscas práticas para uma teoria da ação jornalística. São Paulo: Summus, 2007. 166p.

Sotaques d'aquém e d'além mar: percursos e gêneros do jornalismo português e brasileiro. Santarém: Jortejo,1998. 167p.

COELHO, Marco Antônio. Lições da Pastoral da Criança: entrevista com Zilda Arns Neumann. Estud. av. [online]. maio/ago. 2003, vol.17, $\mathrm{n}^{\mathrm{o}}$ 48, p.63-75. Disponível em: $<\mathrm{http}: / /$ www.scielo.br/scielo.php?script $=$ sci_arttext\&pid=S0103-40142003000200006\&lng= pt\&nrm=iso $>$.

CONSELHO EPISCOPAL LATINO-AMERICANO. Documento de Aparecida: Texto conclusivo da V Conferência Geral do Episcopado Latino-Americano e do Caribe. $3^{\text {a }}$ edição. Brasília/São Paulo: CNBB, Paulinas, Paulus, 2007. 309p.

DAGNINO, Evelina. Cultura, Cidadania e Democracia: a Transformação dos Discursos e Práticas na Esquerda Latino-Americana. In: ALVAREZ, Sonia E; DAGNINO, Evelina; ESCOBAR, Arturo (org.). Cultura e política nos movimentos sociais latino-americanos: novas leituras. Belo Horizonte: Editora UFMG, 2000. p.61-102.

Os movimentos sociais e a emergência de uma nova noção de cidadania. In: DAGNINO, Evelina (org.). Anos 90: Política e sociedade no Brasil. São Paulo: Ed. Brasiliense, 1994. p.103-115.

DALE, Frei Romeu. Igreja e transformação da Sociedade. . In: FLEURY, Reinaldo Matias (org.). Movimento popular, política e religião. São Paulo: Edições Loyola, 1985. p. 88-101.

DINES, Alberto. O papel do jornal: uma releitura. 5a edição. São Paulo: Summus, 1986. $157 \mathrm{p}$.

DUARTE, Jorge. Entrevista em profundidade. In: DUARTE, Jorge; BARROS, Antonio (org.). Métodos e Técnicas de Pesquisa em Comunicação. São Paulo: Editora Atlas, 2005. p.62-83.

ELIAS, Norbert; SCOTSON, John. Os estabelecidos e os outsiders. Rio de Janeiro: Jorge Zahar, 2000. p.19-50.

ENDLER, Sérgio. O saber e a paixão pelo jornalismo. In: RBS/LPM. (Org.). Tendências na comunicação. Porto Alegre: LPM, 1998.

FARAONE, Nadja Antonia Alves. Temas de cidadania em jornais infantis: um estudo dos Suplementos A Gazetinha, Diário Criança, Estadinho, Folhinha. 2001. Dissertação 
(Mestrados em Ciências da Comunicação) - Escola de Comunicação e Artes, Universidade de São Paulo, São Paulo, 2001. p.36-48.

FAUSTO NETO, Antonio. A deflagração de sentido. Estratégias de produção e de captura. In: SOUSA, Mauro Wilton de (org.). Sujeito, o lado oculto do receptor. São Paulo: Brasiliense: 2002. p.189-222.

FAXINA, Élson. Participação e Subjetividade em Movimentos Sociais: um estudo de caso sobre as práticas culturais contemporâneas como espaço de construção e legitimação do ser individual e ator social. 2001. 285f. Dissertação (Mestrado em Comunicação) - Escola de Comunicação e Artes, Universidade de São Paulo, São Paulo, 2001.

FERNÁNDEZ, Adrian José Padilla. Comunicação e cidadania na virada do século. In: DOWBOR, Ladislaw; IANNI, Octavio; RESENDE, Paulo Edgar; SILVA, Hélio (org.). Desafios da Comunicação. Rio de Janeiro: Vozes, 2000. p.297-304.

FERREIRA, Maria Nazareth (org.). Cultura, comunicação e movimentos sociais. São Paulo: CELACC - ECA/USP, 1999. 266p.

FESTA, Regina. Comunicação popular e alternativa: a realidade e as utopias. 1984. 290f. Dissertação (Mestrado em Comunicação Social) - Instituto Metodista de Ensino Superior, São Bernardo do Campo, 1984.

. Movimentos sociais, comunicação popular alternativa. In: FESTA, Regina; SILVA, Carlos Eduardo Lins da (orgs). Comunicação Popular e alternativa no Brasil. São Paulo: Paulinas, 1986. p.9-30.

FISHER, Anthony. Jornalismo e cidadania: uma parceria entre o setor civil e a mídia. Revista Comunicação \& Artes. São Paulo, nº 33, 2000, p.92-96.

FREI BETTO. O que é Comunidade Eclesial de Base. $4^{a}$ edição. São Paulo: Editora Brasiliense, 1981. 115p.

FREIRE, Paulo. Educação como prática da liberdade. $31^{a}$ edição. Rio de Janeiro: Paz e Terra, 2008. $158 \mathrm{p}$.

$93 \mathrm{p}$.

Extensão ou comunicação? 10 edição. Rio de Janeiro: Paz e Terra, 1977.

Pedagogia da Autonomia: saberes necessários à prática da autonomia. São Paulo: Paz e Terra, 1996. 146p.

Pedagogia da Esperança. 14a edição. Rio de Janeiro: Paz e Terra, 1992. $245 \mathrm{p}$.

Pedagogia do oprimido. $46^{\mathrm{a}}$ edição. Rio de Janeiro: Paz e Terra, 2005. 213

p. 
FREUD, Sigmund. Psicologia de grupo e a análise do ego (Além do princípio do prazer, psicologia de grupo e outros trabalhos) In: Edição Eletrônica das Obras Psicológicas Completas de Sigmund Freud. Vol. XVIII. Imago, 1997.

GARCIA CANCLINI, Nestor. Consumidores e cidadãos: conflitos multiculturais da globalização. Tradução de Maurício Santana Dias. 5a . edição. Rio de Janeiro: Editora UFRJ, 2005. 227p.

GENTILLI, Victor. Democracia de Massas: Jornalismo e Cidadania: estudo sobre as sociedades contemporâneas e o direito dos cidadãos. Porto Alegre: EDIPUCRS, 2005. 180p.

GOHN, Maria da Glória. Teoria dos movimentos sociais: paradigmas clássicos e contemporâneos. São Paulo: Edições Loyola, 1997. 383p.

História dos movimentos e lutas sociais: a construção da cidadania dos brasileiros. São Paulo: Loyola, 1995. 213p.

GOMES, Gilberto Pedro. Jornalismo nas Comunidades Eclesiais de Base: estudo de caso do jornal Grita Povo da região episcopal de São Miguel Paulista-SP. 1987. 254f. Dissertação (Mestrado em Ciências da Comunicação) - Escola de Comunicação e Artes, Universidade de São Paulo, São Paulo, 1987.

HALL, Stuart. Codificação/Decodificação. In:

Da diáspora: identidades $\mathrm{e}$ mediações culturais. $1^{a}$ reimpressão. Belo Horizonte: UFMG, 2003. p.365-381.

HECK, Selvino. A Teologia da Libertação está viva. Disponível em: <http: //www.adital.com.br/SITE/noticia.asp?lang=PT\&cod=27859>. Acesso em: 26 abril 2009.

HELlER, Agnes. O Cotidiano e a História. Trad. Carlos Nelson Coutinho e Leandro Konder, $3^{\text {a }}$ ed. Rio de Janeiro: Paz e Terra, 1989. 121p.

INAF - Indicador de Alfabetismo Funcional: Um balanço dos resultados de 2001 a 2005, preparado pelo Instituto Paulo Montenegro e Ação Educativa. Disponível em: $<$ http://www.ipm.org.br/download/inaf_5anos_completo.pdf $>$

IOKOI, Zilda Márcia Grícoli. Diferenças de conteúdo e metodologia na atuação da igreja. In:_ Igreja e camponeses: teologia da libertação e movimentos sociais no campo Brasil e Peru, 1964-1986. São Paulo: Hucitec, Fapesp, 1996. p.211-220.

JOÃO PAUlO II. Carta Apostólica O Rápido Desenvolvimento. São Paulo: Paulinas, 2005.

KAPLÚN, Mario. Una pedagogía de la comunicación. Madrid: Ediciones de La Torre, 1998. 252p.

KATO, Mary. O aprendizado da leitura. São Paulo: Marins Fontes, 1985. p.25-50.

KLEIMAN, Angela. Texto e leitor: Aspectos cognitivos da leitura. Campinas, SP: Pontes: 2007. 82p. 
KUNCZIK, Michael. Conceitos de jornalismo: Norte e Sul: Manual de Comunicação. Tradução Rafael Varela Jr. São Paulo: EDUSP, 1997. 415p.

KUNSCH, Margarida M. Krohling. Repensando a comunicação na Igreja. Revista Comunicação \& Artes, São Paulo, v. 32, p.55-58, 1997.

Comunicação organizacional no Brasil: panorama histórico e perspectivas. In: LABORATÓRIO INTEGRADO DE MARKETING E CULTURA. Políticas de Comunicação Corporativa. São Paulo: ComArte, 2005. p.11-31.

LACERDA, Juciano de Sousa. Jornal d[para]as comunidades: a relação entre a Pastoral da Criança e seu público via processo midiático. Bocc, 2002a. Disponível em: $<$ http://bocc.ubi.pt/pag/lacerda-juciano-pastoral-crianca.pdf $>$. Acesso em: 21 jul. 2009.

LACERDA, Juciano de Sousa. A tematização no jornal da Pastoral. Bocc, 2002b. Disponível em: <http://bocc.ubi.pt/pag/lacerda-juciano-tematizacao-jornal-pastoral.pdf $>$. Acesso em: 21 jul. 2009.

LIMA, Aline Fernanda. O Jornal Pastoral da Criança como Instrumento de Promoção da Cidadania. 2007. 189f. Dissertação (Mestrado em Comunicação Social) - Universidade Metodista de São Paulo, São Bernardo do Campo, 2007.

LIMA, Venício Artur de. Comunicação e Cultura: as idéias de Paulo Freire. Tradução Paulo Kramer. Rio de Janeiro: Paz e Terra, 1981. 167p.

. Comunicação, Poder e Cidadania. Rastros - Revista do Núcleo de Estudos de Comunicação, Joinville, ano VII, No 7, p.8-16, Out 2006. Disponível em: $<$ htpp://redebonja.cbj.g12/ielusc/necom/rastros/rastros07/rastros0701.pdf $>$

MANZINI-COVRE, Maria de Lourdes. O que é cidadania? São Paulo: Brasiliense, 1993. $77 \mathrm{p}$.

LOPES, Maria Immacolata Vassalo de. Estudos de recepção em comunicação. In: LOPES, MIV... [et al.] (org.) Pensamento Comunicacional Brasileiro. São Paulo: Intercom, 2005. p.34-43.

MARQUES DE MELO, José. Comunicação e libertação. Petrópolis: Vozes, 1981. 80p.

Igreja e comunicação. In: SOARES, Ismar O.; PUNTEL, Joana (org.). Comunicação, Igreja e Estado na América Latina. São Paulo: Paulinas/UCBC, 1985. p.59-70.

MARTÍN-BARBERO, Jesús. América Latina e os anos recentes: o estudo de recepção em comunicação social. In: SOUSA, Mauro Wilton de (org.). Sujeito, o lado oculto do receptor. São Paulo: Brasiliense: 2002. p.39-68.

Cultura y nuevas mediaciones tecnológicas. In: América Latina: otras visiones de la cultura. Bogotá: CAB, 2005. (Texto integrante de apostila usada pelo professor doutor Jesús Martín-Barbero no curso "Novas sensibilidades: entre urbanias e cidadanias", ministrado na ECA/USP, entre os dias 15 e 19 de setembro de 2008.) 
. Dislocamientos del tiempo y nuevas topografias de la memória. In: HOLLANDA, Heloisa Buarque de (org.). Arte Latina. Rio de Janeiro: Aeroplano, 2000. (Texto integrante de apostila usada pelo professor doutor Jesús Martín-Barbero no curso "Novas sensibilidades: entre urbanias e cidadanias", ministrado na ECA/USP, entre os dias 15 e 19 de setembro de 2008.)

Dos meios às mediações: comunicação, cultura e hegemonia. Tradução Ronald Polito; Sérgio Alcides. 4a edição. Rio de Janeiro: UFRJ, 2006. 356p.

. Entre urbanías y ciudadanías. Rev. In-Signis, Gedisa, Barcelona, em prensa. (Texto integrante de apostila usada pelo professor doutor Jesús MartínBarbero no curso "Novas sensibilidades: entre urbanias e cidadanias", ministrado na ECA/USP, entre os dias 15 e 19 de setembro de 2008.)

Pensar juntos espacios y territorios. In: HERRERA, D. y PIAZZINI (org.) [Des\}Territorialidades y [No]Lugares. Medellín: Antioquia, 2006. (Texto integrante de apostila usada pelo professor doutor Jesús Martín-Barbero no curso "Novas sensibilidades: entre urbanias e cidadanias", ministrado na ECA/USP, entre os dias 15 e 19 de setembro de 2008.)

MILMAN, Luis. A metodologia do jornalismo: breve excurso sobre a natureza de um conflito. In: RBS/LPM. (Org.). Tendências na comunicação. Porto Alegre: LPM, 1998. p. 28-39.

MORAES, Denis de. Comunicação virtual e cidadania: movimentos sociais e políticos na Internet. Revista Brasileira de Ciências da Comunicação, São Paulo, Vol. XXIII, $\mathrm{n}^{\circ}$ 2, p.142-155, jul/dez 2000.

OLIVEIRA, Rosiska Darcy; OLIVEIRA, Miguel Darcy. A reinvenção da educação: os movimentos sociais como contexto educativo. In: FREIRE, Paulo; OLIVEIRA, Rosiska Darcy; OLIVEIRA, Miguel Darcy; CECCON, Claudius. Vivendo e aprendendo: experiências do Idac em educação popular. São Paulo: Brasiliense, 1983. p.123-127.

O SÃO PAULO. São Paulo: Arquidiocese de São Paulo, 07/06/2008. Semanal.

PAOLI, Maria Célia. Empresas e responsabilidade social: os enredamentos da cidadania no Brasil. In: SANTOS, Boaventura de Sousa (org.). Democratizar a democracia: os caminhos da democracia participativa. Rio de Janeiro: Civilização Brasileira, 2002. p.373-417.

PASTORAL DA CRIANÇA. Faça parte desta rede de amor e solidariedade. Curitiba: Pastoral da Criança, 2007. 16p.

PASTORAL DA CRIANÇA. Promovendo a vida plena para todas as crianças. Curitiba: Pastoral da Criança, 2008. 20p.

PENA, Felipe. Teoria do Jornalismo. São Paulo: Editora Contexto, 2005. p.65-79. 
PERUZZO, Cićlia Maria Krohling. Comunicação nos movimentos populares: a participação na construção da cidadania. Petrópolis: Vozes, 1998. 342 p.

DUARTE, Jorge; BARROS, Antonio (org.). Métodos e Técnicas de Pesquisa em Comunicação. São Paulo: Editora Atlas, 2005. p.125-145.

PERINI, Mário A. Efeito do gênero textual. In: LIBERATO, Yara e FULGÊNCIO, Lúcia. É possível facilitar a leitura: um guia para escrever claro. São Paulo, Contexto, 2007. p. 149158.

PUNTEL, Joana T. A igreja e a democratização da comunicação. São Paulo: Paulinas, 1994. 327p.

RAMADAN, Nancy Nuyen Ali. Jornalismo na era digital: construindo uma filosofia de Ensino. 2000. 222f. Tese (Doutorado em Ciências da Comunicação) - Escola de Comunicação e Artes, Universidade de São Paulo, São Paulo, 2000.

RATZINGER, Joseph. Instrução sobre certos aspectos da teologia da libertação. Disponível em: <http://www.vatican.va/roman_curia/congregations/cfaith/documents/rc_con_cfaith_doc _19840806_theology-liberation_en.html> Acesso em: 27 abril 2009

REIMBERG, Cristiane Oliveira. Dois olhares sobre a relação entre jornalismo e a Pastoral da Criança: a comunicação popular do jornal da entidade e a cobertura jornalística da Folha de S.Paulo. 164f. Monografia (Especialização em Jornalismo Social) - Cogeae (Coordenadoria Geral de Especialização, Aperfeiçoamento e Extensão), da Pontifícia Universidade Católica, São Paulo, 2006.

SADER, Eder. Quando novos personagens entraram em cena: experiências, falas e lutas dos trabalhadores da Grande São Paulo, 1970-80. $2^{\text {a }}$ edição. Rio de Janeiro: Paz e Terra, 1991. $329 \mathrm{p}$.

SANTOS, Milton. As cidadanias mutiladas. In: GOVERNO DO ESTADO DE SÃO PAULO. O Preconceito. São Paulo: Secretaria da Justiça e da Defesa da Cidadania, Secretaria de Estado da Cultura. (sem data) p.133-144.

O Espaço do Cidadão. $7^{a}$ edição. São Paulo: Edusp, 2007. 176p.

Por uma outra globalização: do pensamento único à consciência universal. $17^{\mathrm{a}}$ edição. Rio de Janeiro: Record, 2008. 174p.

SCHERER-WARREN, Ilse. Movimentos Sociais: um ensaio de interpretação sociológica. Florianópolis: Universidade Federal de Santa Catarina, 1987. 89p.

SINGER, Paul. Movimento de bairro. In: BRANT, Vinicius Caldeira; SINGER, Paul (org.). São Paulo: o povo em movimento. Petrópolis: Editora Vozes, 1980. p.83-107.

SOARES, Ismar Oliveira. A comunicação de resistência no movimento popular ligado à Igreja Católica. São Paulo: ECA/USP, 1994. p.267-270. 
. Do Santo Ofício à Libertação: o discurso e a prática do Vaticano e da Igreja Católica no Brasil sobre a Comunicação Social. São Paulo: Paulinas, 1988. 400p.

SOUSA, Mauro Wilton de. Recepção e comunicação: a busca do sujeito.

(org.). Sujeito, o lado oculto do receptor. São Paulo: Brasiliense: 2002. p.13-38.

WANDERLEY, Luiz Eduardo. Movimentos populares, política e Igreja. In: FLEURY, Reinaldo Matias (org.). Movimento popular, política e religião. São Paulo: Edições Loyola, 1985. p. 9-26.

WEFFORT, Francisco C. Reflexões sociológicas sobre uma pedagogia da Liberdade. In: FREIRE, Paulo. Educação como prática da liberdade. $31^{\text {a }}$ edição. Rio de Janeiro: Paz e Terra, 2008. p.9-34.

WHITE, Robert A. Recepção: a abordagem dos estudos culturais. Comunicação \& Educação, São Paulo, maio/ago 1998, p.57-76. 
ANEXOS

Anexo I

\section{Entrevistadas e entrevistados ligados à Coordenação Nacional}

1. Zilda Arns Neumann - Fundadora e Coordenadora Internacional da Pastoral da Criança, médica sanitarista e pediatra.

Datas das entrevistas:

14/03/08 - Quando foi realizada a Via Sacra da Criança e do Adolescente, em São Paulo.

20/09/08 - Após a Romaria da Pastoral da Criança à Aparecida em comemoração aos 25 anos da entidade, na volta para São Paulo.

25/06/2009 - Antes da participação de Zilda Arns no programa Todo seu, de Ronnie Von, na TV Gazeta, em São Paulo.

2. Vera Lúcia Altoé - Coordenadora Nacional da Pastoral da Criança, freira da Congregação das Irmãs da Imaculada Conceição de Castres e pedagoga com pósgraduação em alfabetização e em ensino religioso.

Datas das entrevistas:

07/07/08 - Durante o Encontro da Coordenação Nacional com Coordenadores de Núcleos, de Setores e Estadual da Pastoral da Criança Regional São Paulo.

20/09/08 - Após a Romaria da Pastoral da Criança à Aparecida em comemoração aos 25 anos da entidade, já em São Paulo.

3. José de Anchieta - Coordenador Estadual da Pastoral da Criança em São Paulo.

Data da entrevista:

07/07/08 - Durante o Encontro da Coordenação Nacional com Coordenadores de Núcleos, de Setores e Estadual da Pastoral da Criança Regional São Paulo.

4. Francisca Sonia M. Prati - Jornalista responsável pelo Jornal Pastoral da Criança, especialista em roteiro e mestranda em saúde pública.

Data da entrevista:

10/02/09 - Durante a reunião sobre o novo projeto de Comunicação Popular em Curitiba com a Coordenação Nacional, ocorrido em Curitiba, entre os dias 08 e 10 de fevereiro. 
5. Caroline Caus Dallabona - nutricionista da Pastoral da Criança.

Data da entrevista:

14/03/09 - Durante a Capacitação de Alimentação e Hortas Caseiras, ocorrida no Centro de Formação Sagrada Família, Setor Ipiranga, São Paulo.

6. Isaac Elias Filho - multiplicador estadual da Pastoral da Criança.

Data da entrevista:

29/03/08 - Durante o Encontro de Multiplicadores no Centro Missionário José Allamano, Horto Florestal, Setor Santana, São Paulo.

7. Maria Lúcia de Campos Guerra Caldin - multiplicadora estadual da Pastoral da Criança.

Data da entrevista:

29/03/08 - Durante o Encontro de Multiplicadores no Centro Missionário José Allamano, Horto Florestal, Setor Santana, São Paulo. 
Anexo II

Entrevistadas e entrevistados ligados à Arquidiocese de São Paulo

\section{Coordenação na Arquidiocese de São Paulo}

1. Maria do Rosário Gazzola de Souza - Coordenadora da Pastoral da Criança na Arquidiocese de São Paulo.

Data da entrevista:

05/11/08 - Durante a inauguração do Espaço para Brincadeiras de uma comunidade da Pastoral da Criança, no Lauzane Paulista, Setor Santana, São Paulo.

2. Silvana Aparecida Gonçalves - Coordenadora do Programa de Geração de Renda em Serviços Domésticos da Pastoral da Criança, realizado na Arquidiocese de São Paulo.

Entrevista:

Agosto/08 - na casa que foi montada para a realização da capacitação, próximo a Praça da Sé, em São Paulo.

3. Mari José de Araújo - Mãe de criança acompanhada pela Pastoral da Criança, moradora de Parelheiros, fez a capacitação em serviços domésticos e foi empregada em um hospital em Santo Amaro.

Entrevista:

Agosto/08 - na casa que foi montada para a realização da capacitação, próximo a Praça da Sé, em São Paulo.

4. Roseli Bueno Neri - Avó de criança acompanhada pela Pastoral da Criança, moradora da Casa Verde, fez a capacitação em serviços domésticos e foi empregada em uma residência na Chácara Santo Antonio.

Entrevista:

Agosto/08 - na casa que foi montada para a realização da capacitação, próximo a Praça da Sé, em São Paulo. 


\section{$\underline{\text { Região Episcopal Belém }}$}

- Entrevistas realizadas em 13/12/2008 - na Confraternização da Pastoral da Criança no Belém:

1. Maria Vaz Couto Martine - Coordenadora de ramo e líder - atua na Paróquia Natividade do Senhor, Vila Guarani, Sapopemba - desde 1992 na Pastoral da Criança. Idade: 57 anos

2. Ana Maria de Carvalho Bom Filho - Coordenadora de ramo e líder - atua na Paróquia Divino Espírito Santo, no Conjunto Teotônio Vilela, Sapopemba - 6 anos de Pastoral da Criança.

Idade: 48 anos

3. Maria de Moreira do Amor Divino - Coordenadora de ramo e líder - atua na Paróquia Santíssima Trindade e Comunidade São João Batista, no bairro Terceira Divisão/ Iguatemi - Evangélica, tem 3 anos e 4 meses de Pastoral da Criança.

Idade: 45 anos

4. Ana Paula de Lima Silva - Coordenadora de ramo e líder - atua na Comunidade São José Operário, que fica na Favela da Vila Prudente e faz parte da Paróquia Santo Emídio - 5 anos de Pastoral da Criança.

Idade: 28 anos

5. Fernanda Tobias Cipriano - Multiplicadora de brinquedista e líder - atua comunidade São Pedro Apóstolo, no Jardim Independência - 10 anos na Pastoral da Criança.

Idade: 21 anos

Escolaridade: cursa graduação em educação física.

6. Sandro Morate Ihana - Coordenador de ramo e líder - atua na Vila Califórnia - 3 anos e meio de Pastoral da Criança.

Idade: 35 anos 
7. Irene Lopes Carderine - Coordenadora de ramo e líder - atua na Paróquia São Mateus Apóstolo, em três favelas - 9 anos de Pastoral da Criança.

Idade: 65 anos.

8. Vera Lúcia Rodrigues Mangela - Líder e capacitadora - atua na Paróquia São Sebastião, na Fazenda da Juta - 23 anos de Pastoral da Criança.

Idade: 46 anos

9. Selma Leite Galindo da Silva - Líder e multiplicadora no setor Belém, também é secretária da Pastoral da Criança na Arquidiocese de São Paulo - 7 anos de Pastoral da Criança.

Idade: 39 anos

Escolaridade: Ensino médio / Técnico em secretariado

10. Aparecida Troqui Raffanini - Coordenadora da Pastoral da Criança no Setor Belém - 7 anos de Pastoral da Criança.

Idade: 58 anos

Escolaridade: Ensino Fundamental.

\section{$\underline{\text { Região Episcopal Brasilândia }}$}

- Entrevistas realizadas em 18/12/2008 antes da reunião de coordenadores e multiplicadores local.

1. Maria Vila Nova de Sousa - Coordenadora comunitária e líder - atua na Comunidade Bom Jesus do Morro, Paróquia Cristo Rei, Anhanguera/Morro Doce 6 anos de Pastoral da Criança.

Idade: 55 anos

2. Marilza Damaciano Lopes Barbosa - Coordenadora do Setor Brasilândia - há 11 anos na Pastoral da Criança.

Idade: 55 anos

Escolaridade: cursa graduação em pedagogia. 
3. Eron Gonçalves de Aguiar - Coordenador de área - atua no Jaraguá - há mais de 5 anos na Pastoral da Criança.

Idade: 45 anos

4. Débora Mara de Oliveira Soares - Multiplicadora da região Brasilândia, capacitadora, coordenadora de ramo, líder e faz parte do Conselho Econômico da Arquidiocese de São Paulo - atua na Paróquia Santo Antonio, Comunidade Nossa Senhora da Paz, Brasilândia - na Pastoral há 5 anos.

Idade: 44 anos

Escolaridade: Ensino Médio

5. Nuri Mary de Oliveira Baptista - Multiplicadora da região Brasilândia, capacitadora, coordenadora de área, líder - atua na Paróquia Santo Antonio, Comunidade Nossa Senhora da Paz, Brasilândia - Evangélica, está na Pastoral há 4 anos.

Idade: 48 anos

Escolaridade: Ensino Fundamental

6. Antonieta Felix da Silva - Coordenadora de área e líder - atua na Freguesia do Ó - na Pastoral há 8 anos.

Idade: 51 anos

7. Elza Cristina Garcia Dias - Coordenadora de área, líder e capacitadora - na Pastoral há 7 anos.

Idade: 37 anos.

- Entrevistas realizadas em 28/03/09, durante a capacitação em comunicação popular no Jardim Maggi, na Brasilândia:

8. Marcos Antonio Lopes - Líder - atua na Comunidade Santa Luzia, da Paróquia Santa Terezinha, no Jardim Maggi - na Pastoral há 3 anos.

Idade: 44 anos

Escolaridade: Ensino Médio 
9. Adervisto Mariano Neto - Líder e coordenador comunitário - atua na Comunidade Santa Luzia, da Paróquia Santa Terezinha, no Jardim Maggi - na Pastoral há 3 anos.

Idade: 66 anos

Escolaridade: Ensino Fundamental

10. Rosangela Maria Santos da Silva - coordenadora de ramo na Paróquia Santa Terezinha, no Jardim Maggi, e responsável pela edição do programa Viva a Vida na Rádio Nove de Julho - na Pastoral há 4 anos.

Idade: 44 anos

Escolaridade: Ensino Superior - Gestão de Qualidade e Produtividade

\section{$\underline{\text { Região Episcopal Ipiranga }}$}

- Entrevistas realizadas em 29/11/2008 durante o Encontrão das Líderes do Ipiranga:

1. Solange Martone Rocha - Coordenadora de ramo - atua na Paróquia São Judas, na Saúde - 1 ano de Pastoral da Criança.

Idade: 45 anos

Escolaridade: doutorado em biologia

2. Joana Nepomuceno de Santana - Líder - atua na Comunidade Santo Estevão, na Água Funda - 5 anos de Pastoral da Criança.

Idade: 73 anos

Escolaridade: Ensino Fundamental.

3. Helena de Souza Silva - Líder - atua na Paróquia Santa Cristina, na Vila Cristina, perto do Zoológico - 2 anos e meio de Pastoral da Criança.

Idade: 27 anos

Escolaridade: Ensino Superior. 
4. Adelina da Conceição Rio Branco - Líder - atua Paróquia Santa Cecília, Comunidade Santo Estevão, Saúde - na Pastoral desde 1986.

Idade: 70 anos

Escolaridade: Ensino Fundamental incompleto.

5. Maria de Fátima Rodrigues de Freitas - Líder - atua na Igreja São Judas Tadeu, na Saúde - 7 meses de Pastoral.

Idade: 43 anos

Escolaridade: Graduação em fisioterapia.

6. Michaele Gonçalves Sousa - Apoio - atua em Heliópolis.

Idade: 13 anos

Escolaridade: cursando $7^{\mathrm{a}}$ série

7. Edileusa Bispo da Silva - Líder - atua em Heliópolis - 4 meses na Pastoral da Criança.

Idade: 29 anos

Escolaridade: Ensino fundamental incompleto.

8. Diana Aparecida de Marques - Líder e coordenadora de ramo - atua na Paróquia Santo Antonio, na Vila Carioca - 3 anos de Pastoral da Criança.

Idade: 49 anos

Escolaridade: Ensino médio incompleto.

9. Ana Maria Torres de Barros - Líder - atua na Paróquia Santa Cristina, no Parque Bristol - 4 anos de Pastoral da Criança.

Idade: 48 anos

10. Cecília Valverde - Coordenadora da Pastoral da Criança na região Ipiranga - na Pastoral da Criança desde 1998.

Idade: 43 anos

Escolaridade: Graduada em administração de empresas. 


\section{$\underline{\text { Região Episcopal Lapa }}$}

- Entrevistas realizadas em 22/03/2009 durante a Assembleia da Lapa:

1. Margot Helena Noske Schutz - Coordenadora de ramo e líder - atua na Paróquia São Patrício, do Rio Pequeno - 10 anos na Pastoral da Criança.

Idade: 71 anos

Escolaridade: Ensino Fundamental.

2. Maria Cristina Checchi - Coordenadora de ramo e líder - atua na Paróquia Santo Alberto Magno, em uma comunidade de uma favela no Jardim Pinheiros - 4 anos na Pastoral da Criança.

Idade: 61 anos

Escolaridade: Superior completo.

3. Dalila Aparecida da Costa - Coordenadora do setor Lapa (eleita no dia da entrevista), multiplicadora e líder - atua na Paróquia Santa Maria Gorete, no Butantã - 6 anos na Pastoral da Criança

Idade: 54 anos

Escolaridade: Graduação em relações públicas.

4. Aparecida Gonçalves de Jesus - Coordenadora do setor Lapa (até o dia da entrevista) - atua na Paróquia Sagrado Coração de Jesus, Parque Continental - 6 anos na Pastoral da Criança.

Idade: 62 anos

Escolaridade: Graduação em administração de empresas.

5. Benedita Lopes Carvalho de Moraes - Líder da Paróquia Nossa Senhora do Consolo, no Jardim Felicidade e coordenadora de uma comunidade na aldeia guarani do Jaraguá - 7 anos na Pastoral da Criança.

Idade: 68 anos

Escolaridade: Ensino Fundamental. 
6. Maria Lúcia Bosco Pinheiro - Coordenadora e líder em favela do Jardim Felicidade - 3 anos na Pastoral da Criança

Escolaridade: Ensino Fundamental.

7. Sonia Regina Faila Ferreira dos Santos - Coordenadora de área do Butantã e do Rio Pequeno, líder da Paróquia Santa Maria Gorete e capacitadora, no Jardim Bonfiglioli - 6 anos na Pastoral da Criança.

Idade: 58 anos.

Escolaridade: Graduação em história.

8. Josefa Gonçalves Leite - Líder da Paróquia Santa Luzia, na Vila Jaguari, em Pirituba - 2 anos como líder, mas antes ajudava como apoio.

Idade: 58 anos

Escolaridade: não alfabetizada, faz curso para alfabetização de adultos.

9. Jairo Fedel - Multiplicador e membro do Conselho Econômico tanto do setor Lapa quanto da Arquidiocese de São Paulo - 6 anos na Pastoral da Criança, do Parque Maria Domitila, ao lado do Parque São Domingos.

Idade: 49 anos

Escolaridade: Graduação em contabilidade e administração de empresas.

10. Maria Amélia da Silva - Líder e capacitadora - 3 anos na Pastoral da Criança. Atua em Pirituba, mas mora em Perdizes.

Idade: 45 anos

Escolaridade: técnica em nutrição e bióloga.

\section{$\underline{\text { Região Episcopal Santana }}$}

- Entrevistas realizadas em 05/11/2008 durante a inauguração do espaço para brincadeiras no Lauzane - patrocinado pela Duracell:

1. Cinira Fidalgo Serafim - Coordenadora de ramo - 6 anos de Pastoral da Criança. 
2. Ivone Cataguene Cardoso - Líder - 5 anos de Pastoral da Criança.

3. Maria Aparecida dos Santos Viana - Coordenadora comunitária - 5 anos de Pastoral da Criança.

4. Vera Lúcia Vieira Figliuoleo - Coordenadora do estado de São Paulo da Ação Brinquedos e Brincadeiras, mas é da região Santana -6 anos de Pastoral da Criança.

5. Maria Teresa de Abreu - Líder e capacitadora - na Pastoral da Criança desde 1993.

6. Lucia Maria de Carvalho - Líder - 3 anos de Pastoral da Criança.

7. Maria Cristina Bonfanty - Coordenadora do setor Santana - 9 anos na Pastoral da Criança.

8. Arlete Della Coleto Agostinho - Líder e auxilia Cristina na coordenação - 8 anos de Pastoral da Criança.

9. Maria da Conceição Evangelista - Líder - 4 anos de Pastoral da Criança

- Entrevista realizada em 14/03/09, durante a capacitação em alimentação e hortas caseiras:

10. Irene Pira de Lima - Líder e capacitadora da Paróquia Imirim - 4 anos de Pastoral da Criança.

Idade: 57 anos

\section{$\underline{\text { Região Episcopal Sé }}$}

- Entrevistas realizadas em 14/03/09 após reunião dos coordenadores, no Bom Retiro:

1. Maria da Conceição - Líder e capacitadora - atua Paróquia Nossa Senhora da Paz, na Liberdade - 6 anos na Pastoral da Criança. 
Idade: 73 anos

Escolaridade: Ensino superior.

2. Vilma Brande Miguel - Coordenadora de ramo e líder - atua na Paróquia Nossa Senhora Aparecida dos Ferroviários, Mooca - 4 anos na Pastoral da Criança.

Idade: 60 anos.

Escolaridade: Ensino superior.

3. Richard Sanches - Coordenador de ramo e líder - atua na Paróquia Nossa Senhora de Guadalupe, Brás - 5 anos na Pastoral da Criança.

Idade: 47 anos

Escolaridade: Ensino superior.

4. Elizabeth Valente Lorenzano - Coordenadora de ramo e líder - atua em cortiços de Perdizes -4 anos na Pastoral da Criança.

Idade: 61 anos

Escolaridade: Ensino superior.

5. Carlos Henrique de Azevedo - Coordenador de ramo e líder - atua na Paróquia Divino Espírito Santo, Bela Vista - 1 ano na Pastoral da Criança.

Idade: 54 anos

Escolaridade: Ensino superior.

6. Maria José da Silva - Coordenadora de ramo e líder - atua na Paróquia Nossa Senhora dos Remédios, na Aclimação - 7 anos na Pastoral da Criança.

Idade: 36 anos

Escolaridade: Ensino superior.

7. Rosane Sebben Reis - Coordenadora do Setor Sé - 9 anos na Pastoral da Criança. Idade: 49 anos

Escolaridade: Ensino médio.

8. Terezinha Fátima Tomaze - Multiplicadora do Setor Sé - 13 anos na Pastoral da Criança. 
Idade: 50 anos

Escolaridade: Ensino superior.

- Entrevistas realizadas em 06/06/09 durante Celebração da Vida na Consolação:

9. Benedita Batista dos Santos Goulart - Líder - atua na Paróquia Divino Espírito Santo, Bela Vista -10 anos na Pastoral da Criança.

Idade: 62 anos

Escolaridade: $5^{\text {a }}$ série do ensino fundamental.

10. Katia Regina Queirós da Silva Matos - Líder - atua na Paróquia Divino Espírito Santo, Bela Vista - 10 anos na Pastoral da Criança.

Idade: 29 anos.

Escolaridade: Ensino superior incompleto. 
Anexo III

Imagens de atividades da Pastoral da Criança:

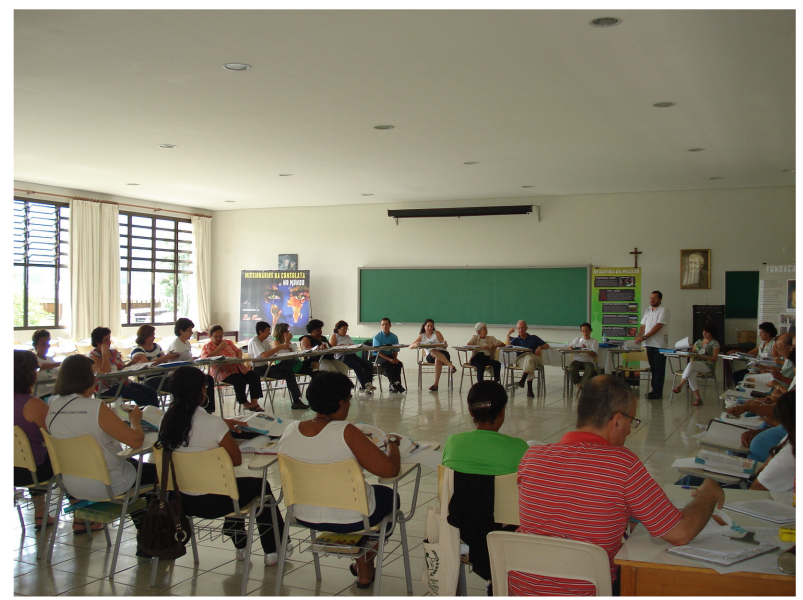

1. Encontro de Multiplicadores - 29/03/2008

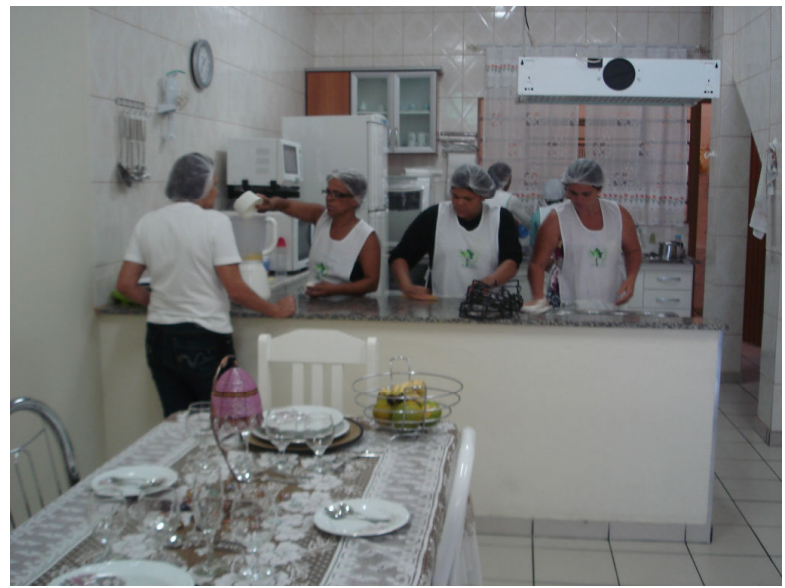

2. Capacitação do Programa de Programa de Geração de Renda em Serviços Domésticos da Pastoral da Criança - Agosto/2008

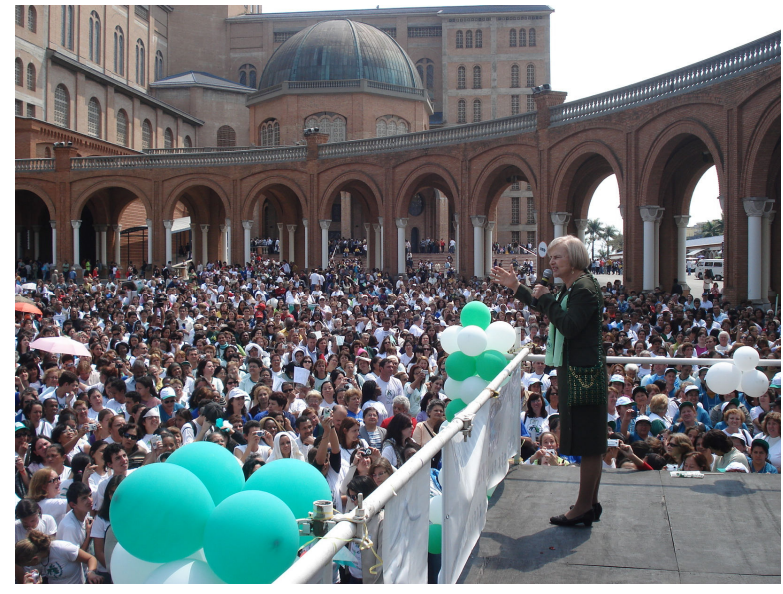

3. Comemoração dos 25 anos da Pastoral da Criança em Aparecida/SP, em 20/09/08. Havia 15 mil voluntários no local. 
Imagens de atividades da Pastoral da Criança:

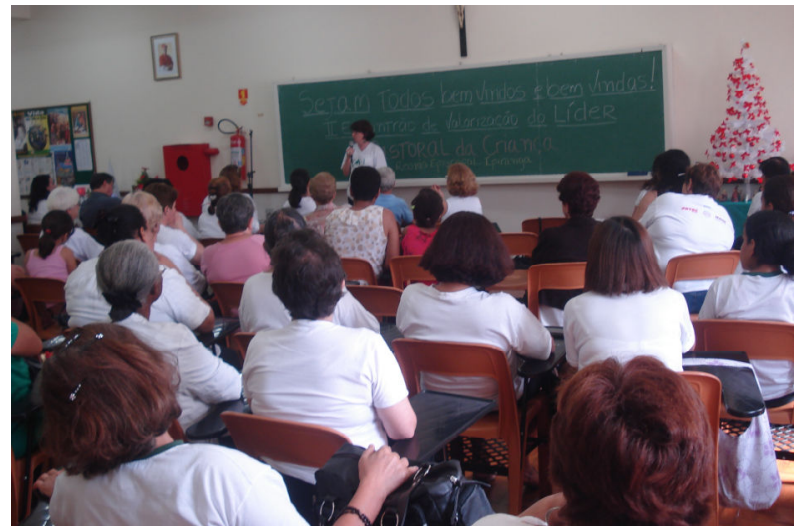

4. Encontrão de Líderes do Setor Ipiranga - 29/11/2008

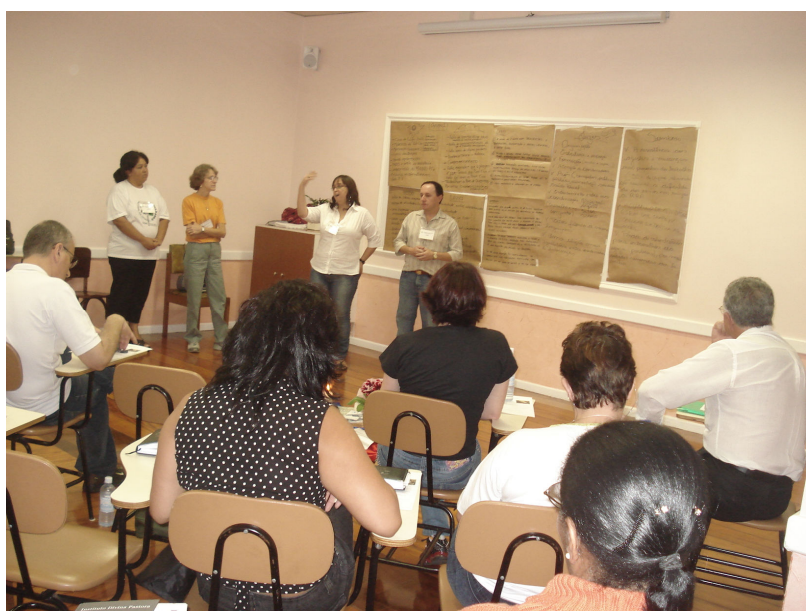

5. Grupo fala sobre formação contínua na Assembleia da Pastoral da Criança na Arquidiocese de São Paulo - 05/04/2009

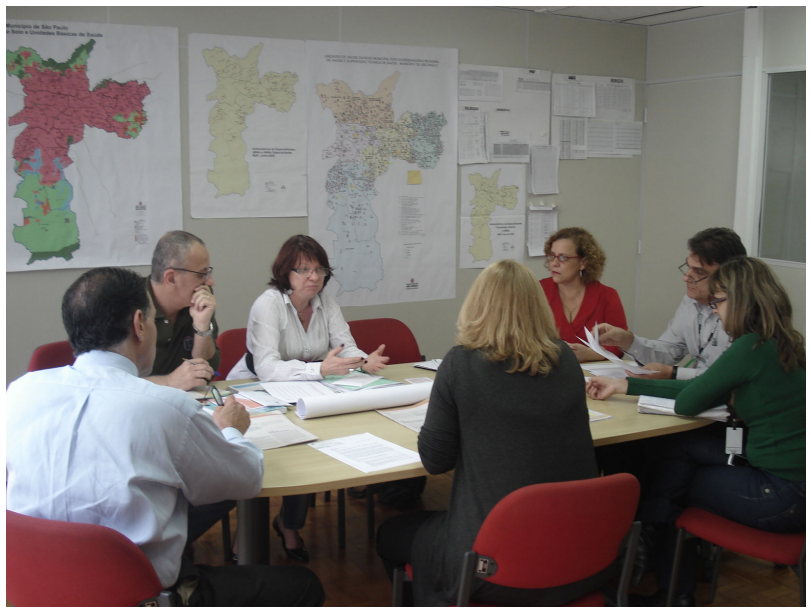

6. A coordenadora da Pastoral da Criança na Arquidiocese de São Paulo, Maria do Rosário (de branco), fala com técnicos da Secretaria de Saúde - 20/05/2009 


\section{Anexo IV}

\section{Algumas páginas do Jornal Pastoral da Criança:}

- Edição de março de 2008 - Seção Aprendendo Mais - p.13

- Edição de junho de 2008 - Seção Comunidades - p.07

- Edição de julho de 2008 - Capa

- Edição de setembro de 2008 - Seção Aprendendo Mais - p.20

- Edição de setembro de 2008 - Seção Aprendendo Mais - p.23

- Edição de outubro de 2008 - Seção Aprendendo Mais - p.12

- Edição de novembro de 2008 - Seção Palavra do Pastor - p.02

- Edição de novembro de 2008 - Seção Aprendendo Mais - p.15

- Edição de fevereiro de 2009 - Seção Mensagem - p.3

- Edição de fevereiro de 2009 - Seção Aprendendo Mais - p.14

- Edição de março de 2009 - Seção Aprendendo Mais - p.12

- Edição de abril de 2009 - Seção Aprendendo Mais - p.19

- Edição de maio de 2009 - Seção Comunidades - p.09

- Edição de maio de 2009 - Seção Comunidades - p.11

- Edição de junho de 2009 - Capa 


\section{Criança precisa de limites, mas sem trauma}

Ninguém veio ao mundo sabendo o que é certo ou errado. São os pais, mães e familiares que têm essa missão de passar para seus filhos o que pode e o que não pode, sem desrespeitar ou agredir.

Dar limites para os filhos é ensiná-los desde pequenos a compreender que as outras pessoas também devem ser respeitadas. A criança precisa entender que pode fazer muitas coisas, mas nem tudo e nem sempre.

\section{Dar limites é:}

- ensinar para os filhos que os direitos são iguais para todos;

- ensinar que existem outras pessoas no mundo;

- dizer SIM sempre que possível e NÃO quando necessário;

- só dizer NÃO quando houver uma razão concreta;

- mostrar que muitas coisas podem ser feitas e outras não podem e explicar o por quê:

- ensinar a criança a agüentar pequenas frustrações do dia-a-dia, para que no futuro possa superar seus problemas com maturidade e equilíbrio;

- desenvolver na criança a capacidade de adiar a satisfação - se não der para hoje, quem sabe amanhã vai dar;

- dar o exemplo - quem quer ter filhos que respeitem as leis e as pessoas, precisa viver seu dia-a-dia dentro desses mesmos princípios.
Ensinar tudo isso não é tarefa fácil e rápida. Mas com calma e paciência, os pais podem dar os limites que a criança precisa, sem traumatizar.

Líder, você pode ajudar as famílias que acompanha orientando que:

Mônica Flügel Hill Psicóloga da Coord. Nacional da Pastoral da Criança.

\section{Dar limites não é:}

- bater nos filhos para que eles se comportem. Limites não significa dar palmadas, bater ou espancar. Isso só ensina a criança a ter medo, mas ela nada aprende. Pior ainda, no futuro pode vir a fazer a mesma coisa com seus próprios filhos;

- fazer só o que nós, pai e mãe, queremos ou temos vontade, sem ceder nunca;

- ser autoritário, dar ordens e impor a lei do mais forte através de ameaças e da força física;

- gritar com a criança para ser atendido.

\section{A Porta de entrada no SUS}

Prezado líder, como você sabe, ainda existem dificuldades de acesso aos serviços de saúde. A espera pelo atendimento ou por uma vaga pode agravar doenças, causar a perda de paciência e a sensação de que 0 Sistema Único de Saúde (SUS) está cada vez pior.

Por um lado, é verdade que estamos longe de um sistema de saúde público que acolha a todos com qualidade no atendimento e nos serviços. Mas todas as pessoas que usam o SUS podem contribuir para que 0 atendimento melhore. Para isso, é preciso considerar e entender a forma de organização dos serviços do SUS, saber quando é melhor se dirigir primeiro ao posto de saúde ou ao hospital.

O conhecimento sobre como funciona o Sistema Único de Saúde pode fazer uma grande diferença na hora de buscar atendimento e ainda pode ajudar a diminuir a sobrecarga de alguns serviços. Nas cidades maiores, muitas pessoas vão diretamente ao hospital ou aos centros de emergência, quando deveriam se dirigir ao posto de saúde mais próximo de sua casa. Como resultado, centenas de pessoas ficam horas nas filas dos hospitais esperando atendimento, com a demora, podem ficar ainda mais doentes. Parte do problema existe porque os postos e unidades básicas têm poucos equipamentos e recursos para 0 atendimento, além da baixa qualidade de alguns serviços, o que gera desconfiança nos usuários.
Onde buscar 0 atendimento adequado

O SUS se organiza conforme a gravidade do problema de saúde. As unidades básicas de saúde ou postos de saúde oferecem a atenção básica. Eles são considerados a porta de entrada do SUS, porque devem estar localizados próximos das comunidades. Devem oferecer consultas, medicamentos básicos, vacinas e serem o centro de referência para as atividades das equipes do Programa Saúde na Família (PSF). Essa equipe é formada por médicos, enfermeiros, auxiliares de enfermagem, agentes comunitários de saúde, cirurgiões-dentistas, auxiliares de consultório dentário ou técnicos de higiene dental. As pessoas que não conseguem se locomover devem ser atendidas pelo PSF em casa. A unidade de saúde deveria ser capaz de resolver $80 \%$ das demandas de serviços da comunidade e, principalmente, promover ações de saúde e prevenção de doenças. Muitos municípios pequenos dispõem somente desses serviços básicos e levam as pessoas que precisam de tratamento para outros municípios.

Nos casos em que há necessidade de atendimento especializado, exames ou tratamentos mais complexos, as pessoas são encaminhadas para os serviços de baixa ou média complexidade. Isso acontece quando há necessidade de internamentos hospitalares, cirurgias, partos, exames laboratoriais, ultrasonografia, serviços de raio- $x$, entre outros. Os serviços de alta complexidade, como transplantes, tratamentos de câncer, cirurgias do coração são ofertados em grandes centros.

Um exemplo da forma adequada de buscar serviços, é a orientação que a Pastoral da Criança faz às gestantes sobre os sinais de perigo na gravidez. Quando a mulher grávida sente dor ao urinar, deve procurar primeiro o posto de saúde, onde costuma fazer o pré-natal. Se for uma infecção, ela poderá ser tratada pelo médico do posto. Somente se houver sintomas de complicações é que ela será encaminhada a um hospital, isso ajuda a diminuir as filas nas emergências nos hospitais, que podem se dedicar a atender os casos mais graves e complexos.

Líder, converse com as famílias sobre a organização dos serviços do SUS, informe a elas onde podem encontrar os serviços que precisam. Converse com as outras lideranças da comunidade e com o Conselho Municipal de Saúde sobre como todos podem contribuir para melhorar os serviços públicos. Vamos continuar nossa luta para que a atenção básica receba mais investimentos, tenha trabalhadores da saúde bem preparados e motivados, além de medicamentos disponíveis, com prioridade de atendimento para crianças, gestantes e idosos.

Clóvis Boufleur 


\section{Mural de Recados}

"Oi, eu sou líder da Pastoral da Criança há seis anos e me sinto muito feliz em olhar para esses rostinhos tão carentes e levar carinho e esperança. Os líderes daqui fizeram uma reciclagem para começar o guia novo. Achei ótimo, muito bem esclarecido. Vocês estão de parabéns pelo conteúdo do livro. Peço a Deus que me ajude a transmitir tudo que sei para as famílias que acompanho. Sou da Paróquia do Senhor Bom Jesus, de Monte Aprazível, São Paulo." (Gislaine Zanin)

"Olá, turma da Pastoral da Criança. Sou Rânia Amaro Pereira, de Cerro Corá, Rio Grande do Norte Setor Caicó. Sou muito feliz por ter sido escolhida por Jesus para fazer parte da Pastoral da Criança dando minha contribuição, ajudando a salvar vidas, para que todas as crianças tenham vida em abundância! Hoje, sou outra pessoa fazendo parte da querida Pastoral da Criança! Abraços para todos!"
"Tenho uma cunhada maravilhosa, é como minha irmã. Ela ama muito o que faz pelas crianças, juntamente com a equipe. Eles são de Carlos Barbosa. O nome dela é Alexandra. Ela atua na Pastoral da Criança juntamente com a Noemi e Adelino".

"Sou líder da Pastoral da Criança há 15 anos, na cidade de Tabira, comunidade do Bairro de Fátima II. Fiz muitos convites a algumas mães para elas serem líderes e graças a Deus consegui 2 pessoas. Estou muito feliz, pois o nosso grupo da Pastoral da Criança está muito animado e temos 20 famílias cadastradas, por enquanto, e 24 crianças. Se Deus quiser esse ano vamos aumentar o número de famílias visitadas. Posso dizer que a Pastoral da Criança está de parabéns.... Abraço dos líderes: Lourdinha, Socorro e Ailson”.

\section{Educação de Jovens e Adultos}

\section{Bonfim} Bahia

A Educação de Jovens e Adultos na Pastoral da Criança teve seu início quando foi constatado que muitos líderes, apesar da boa vontade, não conseguiam ler e ententer o material educativo que vinha até eles. Aos poucos, percebeu-se que também era importante e ajudava muito a comunidade se as mães acompanhadas pela Pastoral da Criança soubesssem ler e escrever. Hoje, mais do que nunca, estamos conscientes do amplo desafio que temos a nossa frente. Então, você que ama a educação e luta por essa mudança, ajude-nos nesse mutirão contra o analfabetismo

$\mathrm{Na}$ nossa diocese durante os dias 22 e 23 de fevereiro foi realizado com aproveitamento uma capacitação para monitores que irão desenvolver esse serviço em suas comunidades e paróquias. Participaram 30 monitores sendo que 3 eram da Diocese de Juazeiro. Da Diocese de Bonfim participaram as paróquias de Cansanção, Senhor do Bonfim, Pindobaçu e Campo Formoso.
Segundo Ir. Olga Confalonieri, coordenadora diocesana, "a tarefa do Supervisor e Monitor da Educação de Jovens e Adultos é extraordinária, pois dá luz a quem não pode ler nem os nomes dos ônibus, interpretar o tão importante Guia do Líder e ir avante na sua carreira para melhorar sua vida e dos seus filhos. Como Jesus, vocês também são solidários, pois transformam em ação concreta, dar do pouco que tem aos que têm menos ainda. Assim, vão adiante na tarefa de educadores".

Segundo os monitores, a capacitação foi mais um momento de conhecimento, troca de experiência e aprendizado. Vai aqui o meu agradecimento aos supervisores e monitores pela colaboração com a Pastoral da Criança em suas comunidades e paróquias. Que todos sigam o exemplo dos protagonistas, para termos um mundo mais justo, solidário e fraterno, com uma mística que dá maior sentido as nossas vidas.

Colaboração: Geraldo Mangabeira da Silva Capacitador/Supervisor da EJA da Pastoral da Criança na Diocese de Bonfim.

\section{Capacitadores}

\section{Guiratinga}

Mato Grosso

Primavera do Leste - Nos dia 6, 7 e 8 de julho de 2007 nos reunimos em Primavera do Leste para a capacitação dos capacitadores do Guia 2007. Participaram líderes de quase todas as paróquias da Diocese de Guiratinga. Foi um momento muito proveitoso com a presença da capacitadora Marlene Francisca, que veio de Ribeirãozinho.

O encontro se desenvolveu com muita atenção e participação por parte de todos os líderes. No encerramento, tivemos a graça de ter junto conosco o nosso bispo Dom Sebastião que com palavras de encorajamento nos anima para continuar nossa missão. Junto com o Padre André, responsável diocesano das Pastorais Sociais, ele nos abençoou com a imagem de Nossa Senhora.

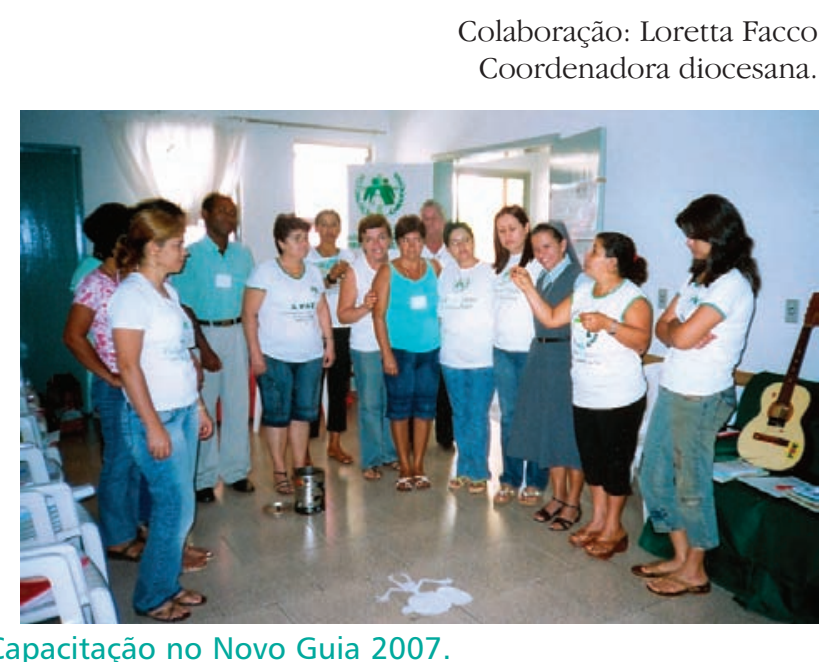

\section{Festa na comunidade}

\section{Governador Valadares}

Minas Gerais

A Pastoral da Criança de Conselheiro Pena, da Paróquia de São José, comemorou no dia 25 de janeiro de 2008 os 15 anos de Amor à Vida. Para comemorar a data, foi Celebrada uma Missa em Ação de Graças, presidida pelo pároco Padre Sebastião Carmo Pereira, que tem dado muito apoio e carinho à Pastoral da Criança. Fizemos um Ofertório no qual ofertamos os Líderes, as gestantes e nossos instrumentos de trabalho como a balança, o Caderno do Líder, o Guia do Líder, FABS, Cartão de Vacina, Soro caseiro, alimentação enriquecida e também o programa de rádio Viva a Vida. Estiveram presentes os líderes da comunidade Barra do Cuieté, Rochedo Nossa Senhora de Fátima e de Conselheiro Pena. Logo após a Santa Missa, servimos um jantar de confraternização.

Colaboração: Sônia Maria Batista da Silva.

Líder, nas visitas você pode ajudar a gestante e a família a aproveitar melhor os alimentos e melhorar seu estado nutricional. 

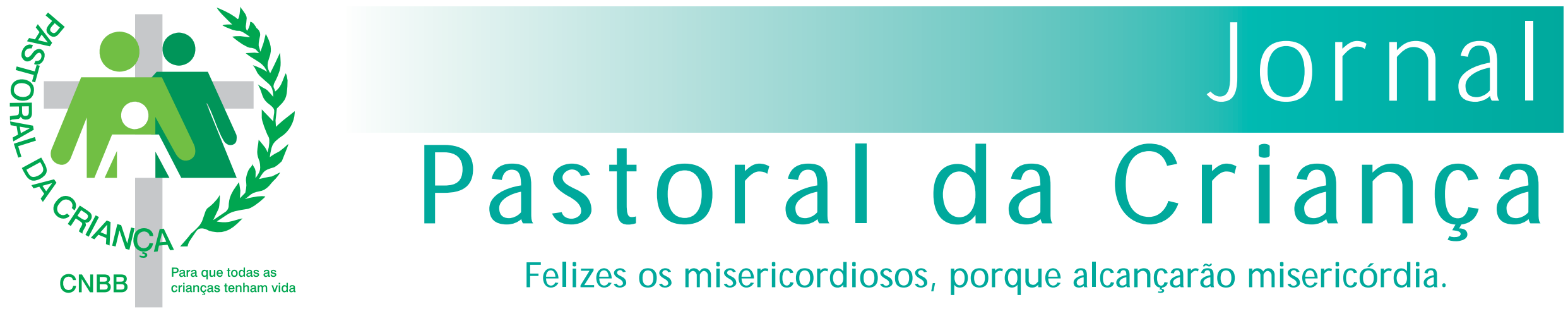

Felizes os misericordiosos, porque alcançarão misericórdia.

"As praças da cidade se encherãa de meninas e meninas que nelas brincarãa".

(Zacarias 8,5)

Por que valorizamos e incentivamos tanto a brincadeira na Pastoral da Criança? Por acreditar que o brincar é uma necessidade para o desenvolvimento infantil, estando inclusive assegurado como um direito no Estatuto da Criança e do Adolescente - ECA.

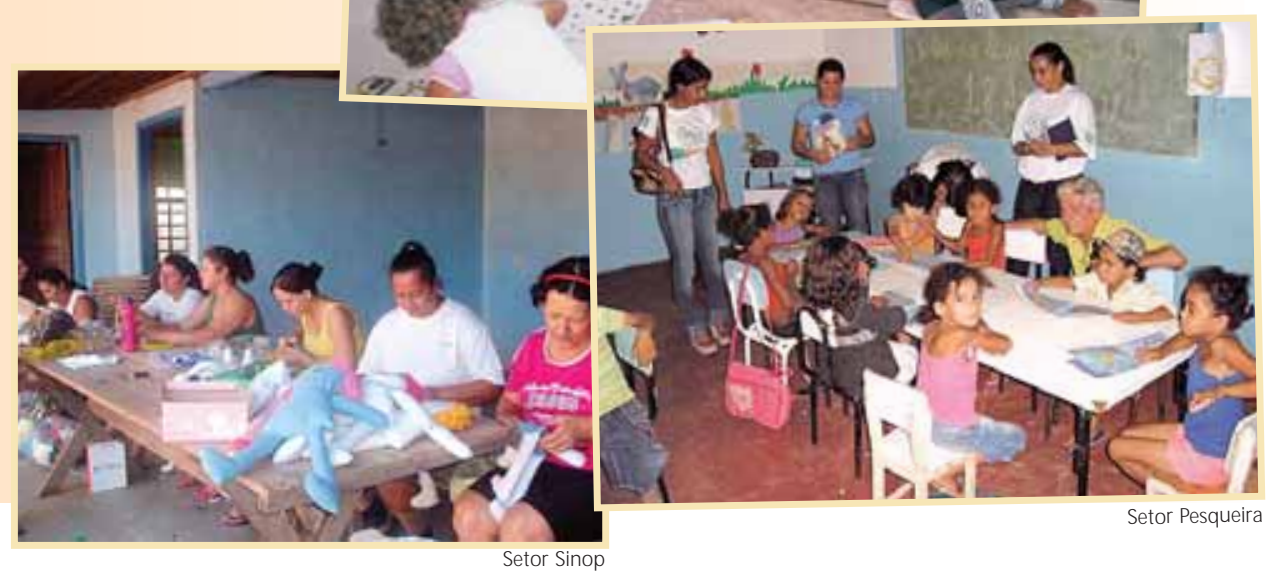

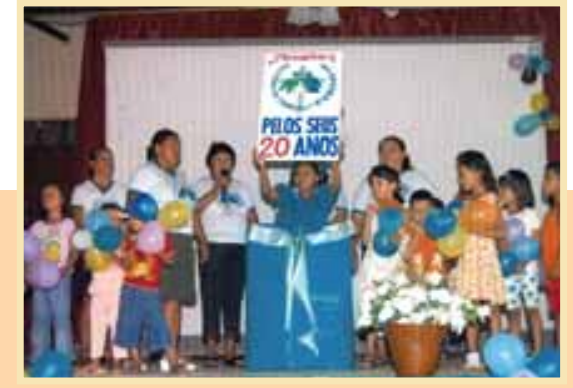

Saiba mais sobre as ações da Pastoral da Criança no Setor Óbidos - Pará, na página 05.

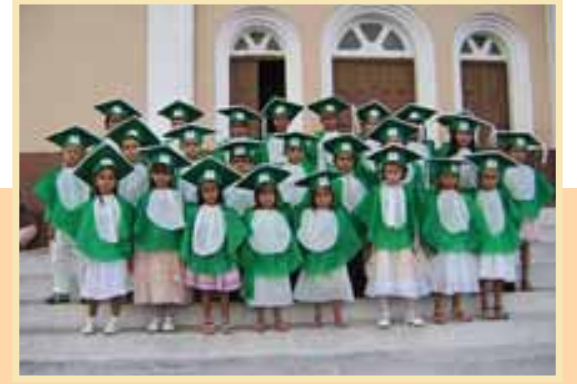

Conheça o trabalho da Pastoral da Criança no Setor Natal - Rio Grande do Norte, na página 10.

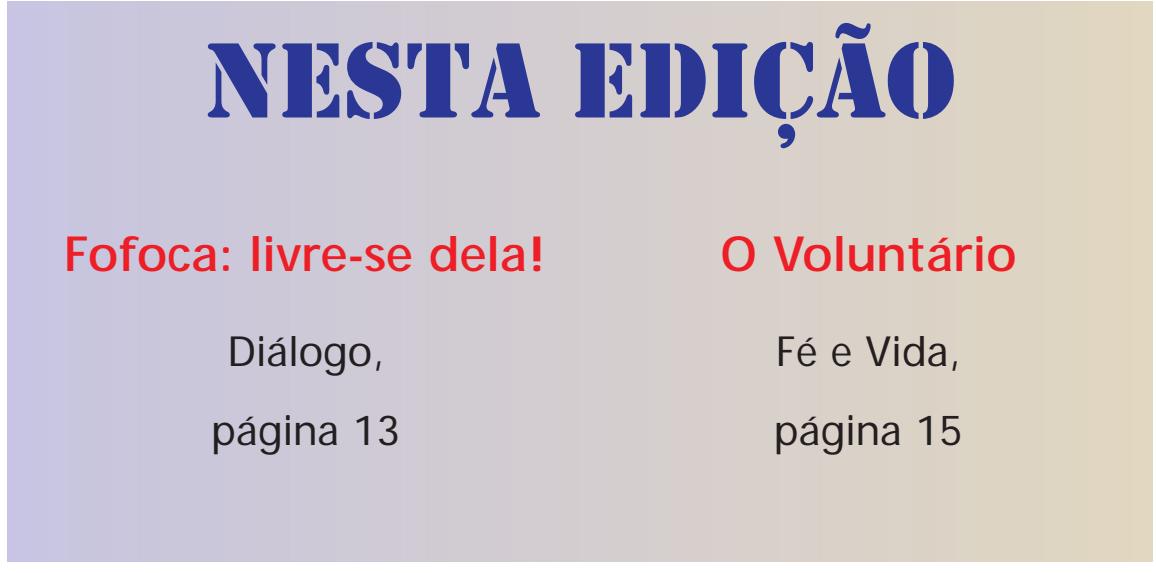

Ĺder:

No mês que vem tem Mutirão em Busca das Gestantes!
Mutirão em Busca das

Gestantes 


\section{Trocando Idélas - Educação da Criança no 107}

\section{Vou contar uma história...}

Quando contamos alguma coisa, fatos, acontecimentos sob a forma de uma história fica mais interessante e fácil de entender e lembrar. Por isso, vou contar, nesta edição do jornal que comemora os 25 anos de existência da Pastoral da Criança, a história de como começou-se a trabalhar com uma abordagem integral do desenvolvimento infantil na Pastoral da Criança. Quem é "antiga" como eu na instituição vai poder se recordar dela e, quem é mais novo, vai ficar sabendo como foi.

Desde o início da Pastoral a Dra. Zilda, mesmo frente ao desafio enorme de ajudar a diminuir a mortalidade infantil por diarréia e desidratação, tinha a preocupação de sempre estar chamando a atenção dos líderes e coordenadores para outros aspectos do desenvolvimento infantil como a aprendizagem da criança, a importância das brincadeiras e a vivência da espiritualidade na família.

Em 1986, por intermédio de consultores do UNICEF, fui apresentada a ela, pois era uma pedagoga que trabalhava com a educação da criança na família. A partir daí, quando a Dra. Zilda conseguia recurso para minha passagem, eu a acompanhava em alguns encontros da Pastoral da Criança para falar sobre a educação, a aprendizagem e o desenvolvimento da criança. Na primeira vez, em Santo Antonio da Patrulha, no Rio Grande do Sul, ela me avisou que eu iria falar para umas 40 ou 50 pessoas. Quando chegamos lá, só no primeiro grupo, eram mais de 100 líderes e outras pessoas. E ela, junto com a coordenadora local, ainda arrumou mais encontros com estudantes, professores, pessoal do serviço de saúde. Falei de manhã, de tarde e de noite. Fiquei logo "batizada" em como trabalhar com a Pastoral. E gostei muito, pois senti que podia compartilhar com pessoas interessadas e atuantes o que eu tinha tido a oportunidade de aprender. E assim estou até hoje, praticando, estudando, aprendendo e trabalhando na Pastoral da Criança.

Em janeiro de 1991, Dra. Zilda me chamou para ajudar numa modificação no Guia do Líder, a fim de incluir aspectos de educação e aprendizagem da criança e para preparar os capacitadores dos líderes. Foram também criados outros indicadores, além dos de saúde, para acompanhar como as crianças se desenvolviam. Comecei, então, um trabalho regular na Pastoral da Criança e, desde esse tempo, contamos também com a colaboração da psicóloga/doutora Elizabeth Tunes, que vem atuando como consultora do desenvolvimento infantil até hoje. A Ana Ruth, atual secretária do Conselho Diretor, fez parte da primeira turma de capacitadores que preparei, na qual ela ajudou chamando atenção para a relação saúde e desenvolvimento e a espiritualidade no trabalho da Pastoral da Criança.

Essa primeira mudança já foi feita com base na visão de desenvolvimento infantil como um processo de mudanças que ocorrem em condições sociais de vida, por isso não existe um padrão de desenvolvimento infantil, cada criança tem seu tempo e seu modo de se desenvolver. No entanto, as informações no Guia do Líder ainda continuaram separadas por assunto em seis cadernos chamados: Missão do Líder/ Cuidando da gestante e do nenê nas primeiras semanas de vida/ Aleitamento materno/ Acompanhando o desenvolvimento/ Incentivando a imunização/ Salvando vidas com o soro oral. Apesar de querermos fazer uma redação que mostrasse como o desenvolvimento da criança começa desde a gestação e todos seus aspectos como físicos, mentais, emocionais são ligados não conseguimos nessa primeira mudança. Então, as informações sobre o desenvolvimento foram introduzidas no caderno, que antes se chamava "Acompanhando 0 crescimento" o qual mudamos o nome e acrescentamos os indicadores de acompanhamento da criança junto com uma parte para o líder conversar com os pais e familiares, que eram chamadas de "Atividades de Educação Essencial" para orientar os pais. Mas tanto a Prof. Beth Tunes quanto eu, ainda não estávamos plenamente satisfeitas com a forma, nem com o tipo de indicadores que criamos, mas na época foi o melhor que conseguimos fazer.

Testamos o material com líderes do nordeste, em Salvador, na Bahia, e no sul, em Curitiba e Jacarezinho (área rural) no Paraná, e ele foi aprovado. Na área rural fui com o Dr. Nelson, ficamos cinco dias hospedados em casas das líderes de lá. E desde esse momento, ele foi conquistado pelo trabalho com desenvolvimento infantil e, dizemos, a Beth Tunes e eu, que não tem médico que entenda e fale melhor sobre desenvolvimento infantil do que ele.

Depois, em 1998, quando houve necessidade de introduzir novas e atualizadas informações no Guia, conseguimos fazer a modificação para escrever as informações sob uma forma que acompanha o bebê desde sua concepção até os seis anos e, conseqüentemente, a gestação de sua mãe. Os indicadores também foram mudados e agora estavam de acordo com a idéia de desenvolvimento adotada pela Pastoral da Criança, pois segundo a professora Beth Tunes “...não se pode avaliar desenvolvimento sem levar em conta as condições sociais e, principalmente, os fundamentos éticovalorativos da vida social: compromisso, responsabilidade e respeito ao outro. Não é isso o que significa essa frase maravilhosa: Eu vim para que todos tenham vida e a tenham em abundância?" Agora tínhamos os Indicadores de Oportunidades e Conquistas, os quais observam o ambiente em que a criança vive e as conquistas que ela pode fazer em decorrência das oportunidades que tem. Mas ainda ficamos com o Guia dividido em três partes: A missão do líder da Pastoral da Criança/ Acompanhando a gestante e a criança/ $O$ dia-a-dia do Líder.

Na testagem desse novo Guia, fiquei muito feliz quando uma líder falou: "Eu estou vendo no Guia uma gestante inteira, uma criança inteira. Agora gostei, fica mais facinho de explicar para as mães". Em relação aos indicadores, outra líder falou: "Já entendi, esses indicadores são um 'pé de conversa' pra gente falar com os pais." Isso nos deixou felizes, pois vimos ter conseguido corresponder ao que elas viam na realidade.

Em 2006, novas mudanças no Guia do Líder. Tiveram que ser atualizados alguns conteúdos e conseguimos fazer com que a espiritualidade, que dá sentido e deve permear tudo o que fazemos na Pastoral da Criança, estivesse presente em todo o livro e as ferramentas, que o líder usa no seu dia-a-dia, ficaram junto do texto que explica sua importância e seu uso. Outra modificação foi na própria apresentação do texto, que foi escrito sob a forma de etapas que são acompanhadas por tarefas de casa para ficarem juntas a teoria e a prática e assim reforçar a aprendizagem . Procuramos neste Guia do Líder 2007 (como ele foi "batizado", pois começou a ser implantado em janeiro de 2007) explicar mais sobre o desenvolvimento e os indicadores, conforme o pedido dos líderes. Esperamos que ele seja uma ferramenta importante na melhoria da qualidade do trabalho da Pastoral da Criança.

E assim está sendo a história da abordagem integral do desenvolvimento infantil na Pastoral da Criança. Uma história escrita e feita com muito amor, dedicação e empenho de todos nós que trabalhamos nesta instituição que, ao completar 25 anos de existência, se mantém fiel à missão que Jesus nos apresentou quando diz: "Eu vim para que todos tenham vida e a tenham em abundância" conforme escrito no evangelho de João 10,10.

Márcia Mamede

Assistente Técnica da Pastoral da Criança. 
"Numa tarde de sábado, mais precisamente 0 quarto sábado do mês, numa pequena cidade do interior de São Paulo, um garotinho moreno, franzino e com uma vozinha rouca chega à igreja de Santa Mônica para mais uma celebração da vida, na Pastoral da Criança. O pequeno chega sozinho, senta-se frente à uma líder (eu) e neste instante sou informada por outra líder de que devo fazer seu cartão... e o garoto responde às perguntas de praxe "nome da mãe", "nome do pai", "mama no peito"... O pequeno diz que não, e olhando sério pra mim diz: "mamo no copo, né, tia"... e faz todos caírem na gargalhada...

Ficamos fascinadas pela inteligência e graciosidade do menino que descobriu sozinho a Pastoral da Criança, e que instantes depois, após ter passado pela pesagem, e já tomado seu suco e comido sua pipoca, vai buscar a irmãzinha e a mãe, e num gesto de proteção e zelo, nos apresenta as duas e instrui a mãe sobre como fazer para "pesar" a irmã...

Fascinadas, procuramos saber mais deste garoto e Ihe fizemos uma visita, para melhor sabermos de sua história e de sua intensa satisfação em participar das reuniões. 0 que soubemos nos fez reavaliar valores e acreditar ainda mais em Deus.

A história deste pequeno é feita de superações e pudemos constatar isto assim que adentramos em sua casa, onde um cachorrinho veio recepcionar-nos. Assim que

\section{As crianças nos ensinam...}

nos apresentamos à sua mãe e elogiamos seu filho, ela nos contou que Tiago, ainda bebê, sofreu um acidente de carro...deste acidente seu avô faleceu e nosso pequeno foi internado às pressas, tendo fraturado gravemente a cabeça, acidente este que deixara seqüelas e, enquanto sua mãe falava sobre estas seqüelas, fiquei ainda mais surpresa, pois nunca reparei em nada, nada, nada... porém, ouvi de minhas companheiras que haviam sim, seqüelas visíveis e que elas já haviam notado...

Mas não eu. Nada pude perceber nos momentos em que estive com o nosso Petrê, apelido que dei a ele carinhosamente...é como se o Petrê não quisesse mostrar o que a realidade Ihe dera de forma tão cruel. Ele apenas nos mostrou a alegria, suas músicas "cantadas de qualquer jeito", mas de forma muito engraçada, seu sorriso tão contagiante e sua enorme vontade de participar de nossas reuniões e, acreditem, certa vez ele nos pediu para abrir as portas da igreja para que ele pudesse falar com seu Pai Deus... ele desfruta de uma certa intimidade com nosso Pai, a qual ainda me falta...

0 que tem este garoto que me fez repensar a vida e meus valores eu não sei, mas quando quero simplificar sua aparição e parar de teorizar sobre meu amor por ele, penso que Deus mandou-me este anjinho, para que eu entendesse um pouco mais do próximo e aprendesse com ele um pouco mais sobre humildade, alegria, amizade...
Durante algum tempo, tenho ajudado em alguns projetos sociais, mas nunca soube se 0 que fazia era certo, se estava indo bem, mas ouvir deste garoto que eu sou sua amiga para sempre, sou também bonita e bacana me faz seguir com este propósito de servir ao próximo sem jamais querer desistir!

Na última vez que nos vimos, eu 0 presenteei com um bolo de chocolate, seu favorito. Quando dei as costas para ir embora, pensei "Ele vai ficar entretido com o bolo...", mas tudo o que ouvi, assim que me despedi, foi "Espera, tia, vou com vocês"... Deus, que garoto mandaste na minha vida!

Esta é uma parte de minha vida que faz todo o sentido para continuar vivendo! É a estória de um lutador, ainda que pequenino, com apenas quatro anos, que já segue em busca de cidadania, para si e para sua irmã; que tem em Deus seu pai e seu protetor e que passa pela vida de algumas pessoas, inclusive a minha, deixando algo de bom. Como dizia Madre Teresa de Calcutá: "Não devemos entrar na vida de uma pessoa sem que, ao sair dela, ela não se sinta melhor".

Senhoras, no dia 18 de julho o Petrê fez anos, e eu completei muitos anos no dia 21 de julho! Que este seja um presente a ele, ter o relato de sua vida, já que ensinou tanta coisa a uma mulher que não sabia que precisava aprender tanta coisa..."

Colaboração: Claudia Sinibaldi

\section{A Comunicação como ferramenta de mobilização Social}

Marilene Ribeiro, coordenadora da área central do Setor de Tocantinópolis, em Tocantins, depois de muitas tentativas sem sucesso para reanimar coordenadoras (paroquiais, de ramo e comunidade) e líderes, resolveu priorizar a comunicação sistematizada, organizada pelos grupos de apoio que surgiram nas comunidades.

A primeira capacitação foi realizada ainda em 2007, para comunicadores em rádio. Pouco tempo depois atendendo a novas solicitações, foi realizado o encontro de assessoria de imprensa e mobilização social, e de lá pra cá, houve uma nítida mudança nas relações interpessoais, o que conseqüentemente resulta na melhoria das ações básicas voltadas às crianças de 0 a 6 anos e suas respectivas famílias.

"Eu sentia as coordenadoras e as líderes com a auto-estima em baixa, desmotivadas, mas graças a Deus, a comunicação tem unido mais as pessoas tornando-as mais fortes. Os comunicadores têm sido nossos parceiros" - disse Marilene Ribeiro. Como ação concreta, além de veicular o Viva a Vida na programação da Rádio Local, os comunicadores da comunidade Alto Bonito, em Tocantinópolis, agora produzem o Jornal da Pastoral da Criança, canal direto entre as ações básicas (de saúde, nutrição, educação e cidadania), os voluntários da Pastoral da Criança e sociedade em Geral.

Islaiana Ferreira chegou para somar esforços com os líderes da Vila Pe. Cesare. Foi por meio das ações de comunicação que ele teve seu primeiro contato e consequentemente se apaixonou pelo trabalho que salva e contribui com a melhoria na qualidade de vida das crianças. "A Pastoral da Criança passou a fazer parte da minha vida também, agradeço ao pessoal da equipe de comunicação que me apresentou a esta missão" - concluiu emocionada.

Como se vê, muito mais que simplesmente informar, a comunicação efetivamente torna as ações comuns, envolve e encanta, possibilitando que outras pessoas também se unam a esta rede de amor e solidariedade. 


\section{Trocando Idéias - Educação da Criança no 108}

\section{Cidades e comunidades amigas da criança}

Neste mês de outubro, para homenagear as crianças, pensei que seria interessante pensarmos sobre como nossas cidades, nossas comunidades estão acolhendo essa pessoa especial que vive nelas - a criança!

Isso também se torna importante agora, pois estamos em tempos de eleição e prefeitos e vereadores estão mais próximos de nós para que possamos reivindicar necessidades e direitos. Um voto bem dado e um monitoramento das promessas feitas em campanha podem fazer alguma diferença na nossa vida diária.

Vou fazer essas reflexões com base em um texto que li e gostei muito. Coloco a indicação dele aqui para quem quiser saber mais sobre o assunto. 0 texto é "Uma cidade que acolhe as crianças: políticas públicas na perspectiva da infância", escrito por Didonet, V. \& Redin, E. no livro Infâncias- cidades e escolas amigas das crianças. Porto Alegre: Editora Mediação, 2007.

Faço, então, algumas perguntas para pensarmos:

- o que há nessa fase da vida de uma pessoa que a distingue da vida adulta e precisa da atenção do administrador público, dos encarregados de fazer as leis, das pessoas que vivem em determinado local?

- as cidades de hoje em dia são ambientes favoráveis à vida e ao desenvolvimento infantil, no nosso caso específico, de crianças até os seis anos?

- é possível uma cidade, uma comunidade, na qual a infância tenha um papel importante na organização do espaço urbano?

A primeira resposta todos nós da Pastoral da Criança sabemos bem. A vida da criança até os seis anos precisa de atenção e cuidados especiais, pois ela é totalmente dependente dos adultos. E uma infância bem amada e cuidada forma uma base de sustentação para toda a vida de uma pessoa. Ela dá mais possibilidades de integração social, de segurança afetiva, de facilitação de aprendizagens.

Para ajudar nas reflexões, vou levantar alguns pontos para nossos líderes, brinquedistas e coordenadores observarem:

- existem quintais, pátios nas casas ou edifícios; praças, parques, jardins com árvores e plantas para as crianças poderem tomar sol, correr, pular, subir e descer, jogar bola e fazer muitas brincadeiras em conjunto?

- as ruas e calçadas são limpas, sem lixo e esgoto a céu aberto, sem tiros e violência?

- existem postos de saúde, hospitais em número suficiente e com atendimento de qualidade para atender às famílias?

- há instituições de educação infantil (as que eram chamadas creches e pré-escolas) para atender bem a todas as crianças que necessitem delas?

- existem no local centros comunitários, igrejas, onde as pessoas possam se encontrar para conviver, conversar sobre suas necessidades, compartilhar conquistas, vivenciar sua fé?

existem teatros, cinemas, clubes, locais para a prática de esporte?

existem entre as pessoas que habitam a comunidade, o bairro, a cidade, laços sociais de respeito, sensibilidade e solidariedade? Elas procuram participar das discussões que afetam a vida na comunidade?

- as crianças participam da vida com os adultos? Elas são vistas e escutadas realmente?
Esses são alguns pontos e vocês podem destacar outros também. Infelizmente, o quadro que olhamos hoje, na imensa maioria de nossas cidades e comunidades, está longe de responder a esses pontos levantados.

Sendo assim vocês podem achar que conseguir tudo isso é uma utopia, ou seja, algo impossível de atingir. E o que fazer então, desistir, deixar para os outros fazerem algo?

Ou será que podemos e devemos ser formiguinhas esforçadas, fazendo um pouco de cada vez, perseverantes e lutadoras? E ser também cigarras que cantam e alegram para animar o trabalho e a luta de cada dia?

Acredito que nós, que escolhemos trabalhar numa instituição com a missão da Pastoral da Criança, temos que saber e aprender cada dia mais como estabelecer uma corrente de interação humana para dar sentido e melhorar o nosso dia-a-dia.

Vou citar aqui um poeta, daqueles que olham a realidade com sensibilidade e se emocionam. Alguém acostumado a enfrentar o papel vazio e, de repente, como um pequeno milagre, criar. É uma pequena poesia para nos animar, nos ajudar a ser construtores e construtoras de comunidades e cidades que digam SIM a suas crianças.

\section{Das Utopias}

Se as coisas são inatingíveis... ora! Não é motivo para não querê-las... Que tristes os caminhos, se não fora A mágica presença das estrelas! Mário Quintana

Márcia Mamede Assistente Técnica da Pastoral da Criança.

\section{Broa de fubá e milho verde}

$\begin{array}{ll}\text { Ingredientes } & \text { - Óleo } \\ \text { - } 1 \text { lata de milho verde } & \text { - } 2 \text { ovos } \\ \text { - Açúcar } & \text { - Fermento em pó } \\ \text { - Fubá } & \text { - Queijo ralado } \\ \text { - Leite } & \text { - Coco ralado. }\end{array}$

\section{Ingredientes}

- Fubá

- Leite

\section{Modo de fazer:}

Use a lata de milho como medida. Coloque numa tigela o milho, a mesma medida (da lata) de açúcar de fubá e de leite. Coloque $1 / 4$ da lata (de milho) de óleo, 2 ovos, 1 colher de sopa de fermento em pó, 1 colher de sopa de queijo ralado e 100 gramas de coco ralado. Bata tudo no liquidificador. Coloque numa forma untada e asse em forno quente.

Colaboração: Lúcia de Fátima Teixeira Líder da Comunidade S. J. Tadeu Eldorado - Contagem

Setor N. S. Aparecida - Belo Horizonte/MG. 
Caros amigos:

É com grande alegria que me dirijo a vocês neste mês de novembro, mês do Mutirão em Busca das Gestantes. Pedimos aos líderes da Pastoral da Criança para aproveitarem as visitas às famílias e envolverem todas as pessoas da comunidade da importância de encontrar a gestante o quanto antes e cadastrá-la na Pastoral da Criança.

Neste mês recomendo especialmente que os líderes organizem junto com as famílias acompanhadas o Dia de Oração pela Criança. A oração está na capa desta edição e também pode ser ouvida no Site da Pastoral da Criança (Publicações Spots - Oração da Criança). Não deixem de aproveitar esse momento maravilhoso de unidade com outras religiões e de fortalecimento da espiritualidade.

Aproveitem para refletir sobre o artigo de Dom Heriberto Hermes, bispo de Cristalândia, sobre a importância de atuarmos nos Conselhos e nas Políticas Públicas. Além disso, gostaria que vocês refletissem sobre o texto que escrevi para a preparação da festa de Natal nas comunidades, lembrando sempre que o Menino Jesus é o centro da festa.

Por fim, amigos, continuem animados nessa maravilhosa missão de salvar vidas. Sabemos que a luta é grande, mas sabemos também que a esperança que os líderes levam às famílias acompanhadas ajuda a transformar vidas e comunidades.

Um grande abraço a todos.

Ir. Vera Lúcia Altoé da Congregação das Irmãs de Nossa Senhora da Imaculada Conceição de Castres. Coordenadora Nacional da Pastoral da Criança.

\section{Ornal Pastoral da Criança}

Este jornal é mensal e de responsabilidade da Coordenação Nacional da Pastoral da Criança, Organismo de Ação Social da CNBB Conferência Nacional dos Bispos do Brasil. O Jornal da Pastoral da Criança também está disponível na Internet, no endereço www.pastoraldacrianca.org.br

\section{Conselho Editorial}

Dra. Zilda Arns Neumann Dr. Nelson Arns Neumann Ir. Vera Lúcia Altoé

Jornalista Responsável:

Francisca Sônia M. Prati - DRT: 5365

Diagramação:

Fernando Artur de Souza

Revisão:

Aldiza Soares da Silva

Impressão:

Esdeva Indústria Gráfica S.A. Impresso com apoio do:

Criança Esperança, um projeto Rede Globo em parceria com a Unesco

Tiragem: 280.000 exemplares
Cartas ou artigos para a redação devem ser remetidos à: Coordenação Nacional da Pastoral da Criança

Rua Jacarezinho, 1691 - Mercês 80810-900 - Curitiba/PR Telefone: (41) 2105-0250 E-mail:

jornal@ pastoraldacrianca.org.br 0 informativo da Pastoral da Criança não pode ser comercializado. Os artigos e impressões pessoais nele publicados são de responsabilidade exclusiva de seus autores e comunidades. Fax: (41) 2105-0201 / 2105-0299

\section{Palavra do Pastor}

\section{Políticas Públicas}

A Campanha da Fraternidade de 1977 tinha por lema: "Comece em Casa". No cartaz havia a imagem de um lar, de porta parcialmente aberta, bem iluminado por dentro, e fora uma escuridão muito forte. A imagem sugeria que dentro havia alegria, paz, acolhida. E fora medo, insinuando "cuidado ao sair". E a porta parcialmente aberta significava liberdade para entrar e sair. Porém, liberdade com respeito e participação dentro e para sair reforçado, mas com responsabilidade. A luz de dentro penetrava a escuridão lá fora: mais perto da porta, luz forte, facilitando a saída; mais longe, luz mais fraca, ambiente mais escuro, mais difícil para caminhar com segurança.

O lema "Comece em Casa" dá a entender que o lar é fonte, origem, mas insinua que é para SAIR, compartilhar o que recebeu, ser como uma vela, que não existe PARA SI, mas para os outros, para iluminar, transformar o ambiente - é uma MISSÃO para transmitir o que recebeu, partilhar para transformar.

Uma expressão muito comum hoje em dia expressa mais ou menos a mesma idéia: "Pensar globalmente, mas agir localmente". É como uma mina d'água que nasce, que brota "localmente", num lugar às vezes escondido, praticamente insignificante, mas que tende a ir para um córrego, que despeja num rio e procura desembocar na imensidão do mar onde "desaparece". Mas o mar imenso é o resultado de milhões de nascentes, córregos e rios!

Assim é nossa atuação no lar, no bairro, no município, no estado, no país, no mundo das nações, no planeta!

Daí a fantástica oportunidade, a suma importância, a responsabilidade - eu diria até "sagrada" - de participar, de propor, de agir; não só nas eleições municipais, mas sobretudo acompanhando, fiscalizando, cobrando, propondo e, se for necessário, denunciando e até cassando as pessoas que elegemos para o legislativo e executivo municipais. E a maneira privilegiada para isso é participando ativamente nos Conselhos Municipais, ou seja nas Políticas Públicas, que afetam os mais diversos setores da vida coletiva.

Um abraço,

Dom Heriberto Hermes Bispo de Cristalândia -Tocantins programas "Viva a Vida" no mês de novembro. Líder, ouça e divulgue o Programa "Viva a Vida" em sua comunidade. Converse sobre os temas dos programas com as mães e famílias acompanhadas.

$\begin{array}{lll}\text { Programa 891 } & \text { Gestação gemelar } & \text { (de 27/10 a 02/11/2008). } \\ \text { Programa 892 } & \text { Gravidez no } 1^{\circ} \text { trimestre } & \text { (de 03/11 a 09/11/2008). } \\ \text { Programa 893 } & \text { Exames preventivos } & \text { (de 10/11 a 16/11/2008). } \\ \text { Programa 894 } & \text { Gestante e pré-natal } & \text { (de 17/11 a 23/11/2008). } \\ \text { Programa 895 } & \text { Nutrição da Gestante } & \text { (de 24/11 a 30/11/2008). }\end{array}$

*Estes programas radiofônicos foram produzidos com o apoio do Ministério da Saúde 


\section{A água é um bem essencial?}

Devemos sempre enxergar a água como fonte da vida. É só a gente perceber que desde a nossa gestação, ainda no ventre da mãe, estamos em um meio líquido. E depois que nascemos, muito do nosso corpo é água, aproximadamente $75 \%$. Então, é sempre importante reconhecer que a gente depende dela pra viver.

\section{Os rios estão doentes?}

Alguns já estão hospitalizados e quase que mortos. A água de boa qualidade tem se tornado cada vez mais rara. É possível perceber que a cada dia, principalmente nas cidades, estamos tendo que buscar água para abastecer a população, em locais mais distantes e gastando muito mais para tratar essa água e levá-la até as torneiras das casas. É fato que as cidades têm cuidado muito mal de seus rios, retirando a mata protetora das margens, construindo casas sem infraestrutura de saneamento e ainda lançando a maior parte do esgoto doméstico e industrial sem tratamento adequado.

\section{Dá para mudar essa situação?}

É preciso criar um sentimento de responsabilidade e organizar campanhas de conscientização. A gente, enquanto cidadão, pode se mobilizar e fazer pressão, para exigir das autoridades responsáveis medidas que dêem conta da situação. Correr atrás do prejuízo e não deixar que os rios morram ou que os mananciais sequem.

É preciso não poluir e não desmatar. A mata tem a finalidade de proteger tanto os

\section{Água: fonte da vida}

animais e as nascentes que vão formar os rios.

\section{E a poluição?}

Desde um papel de bala que a gente jogue na rua até mesmo uma garrafa plástica, um pneu velho, seja o que for se eles não forem recolhidos eles vão acabar atingindo os rios e isso pode ocasionar muitos problemas.

\section{O que a comunidade pode fazer} para que não falte água e água de boa qualidade?

Podemos fazer várias coisas:

- Uma bem importante é verificar se o nosso esgoto está ligado adequadamente a uma rede coletora. Não pode ser ligado na galeria de águas de chuva;

- Podemos nos reunir com os vizinhos e associação de moradores para exigir das autoridades que o esgoto coletado do Bairro ou da cidade seja tratado;

- Estimular uma pesquisa dentro de casa, na escola, na igreja ou na associação do bairro sobre a utilização da água, discutindo e comparando os vários hábitos, apresentando cartazes e fazendo orientações simples de como diminuir o consumo;

- Evitar exageros e desperdícios, instituindo hábitos positivos como: evitar banhos demorados; fechar a torneira enquanto escovamos os dentes ou fazemos a barba; usar a descarga do vaso sanitário somente para fezes e urina; juntar bastante roupa antes de usar a máquina de lavar; usar pano úmido e balde ao invés de mangueira para limpar corredores e varandas; varrer a calçada ao invés de lavá-la; evitar lavar o carro com freqüência e quando fizer utilizar balde e mangueira de gatilho; usar um regador para regar as plantas;

- Remover todos os restos de alimentos dos pratos antes de lavá-los;

- Nunca jogar gordura ou óleo no vaso sanitário, se possível estimular a reciclagem no bairro, para fazer sabão;

- Verificar se existe vazamentos dentro de sua casa (torneiras, válvula de descarga, tubulações) e consertá-los;

- Em hotéis, evitar a troca diária de toalha solicitando à camareira que a mesma não seja substituída;

- Sempre que notar um vazamento na rua informar o mais rápido possível 0 responsável para o conserto;

- Não jogar lixo nas ruas, pois vai acabar indo para bueiros e bocas de lobo atingindo algum rio e poluindo;

- Organizar uma visita à Estação de Tratamento de Água (ETA) da sua cidade para conhecer o Controle de Qualidade e saber como anda a qualidade do manancial abastecedouro.

Essas atitudes podem fazer muita diferença num futuro próximo. É só mudarmos alguns pequenos gestos do nosso dia a dia.

Entrevista com José Nishihara Pinto, Chefe da Divisão de Vigilânci sobre o Meio Secretaria de Estado de Saúde do Paraná.

\section{Assembléia homenageia Pastoral da Criança}

Ceará: A Assembléia Legislativa do Estado do Ceará homenageou a Pastoral da Criança por sua atuação em defesa do Estatuto da Criança e do Adolescente, ECA, na passagem dos 18 anos de aprovação do Estatuto. A homenagem aconteceu dia 14 de julho, por iniciativa da deputada Raquel Marques, em sessão especial, proposta pela deputada Lívia Arruda, presidente da Comissão da Infância e Adolescência.

A Coordenadora Estadual da Pastoral da Criança, Marister Pereira Guimarães, recebeu a homenagem acompanhada de Dom Edmilson Cruz, bispo Emérito da Diocese de Limoeiro do Norte, cuja voz sempre destaca o trabalho da Pastoral da Criança em seus pronunciamentos e que, atualmente, se têm dedicado ao trabalho de combate à corrupção eleitoral, numa iniciativa da Comissão de Justiça e Paz da CNBB.

Na ocasião, a deputada destacou a atuação da Pastoral da Criança na defesa dos direitos das crianças no seio da família e o papel de outras instituições também homenageadas. Ela lembrou a importância do ECA e suas conquistas, lamentando que a lei tenha chegado a maioridade sem ver cumprir, em plenitude, suas determinações, principalmente no que tange às ações cujo objetivo é a recuperação de crianças em situação de risco, que cometeram atos contrários à lei. 


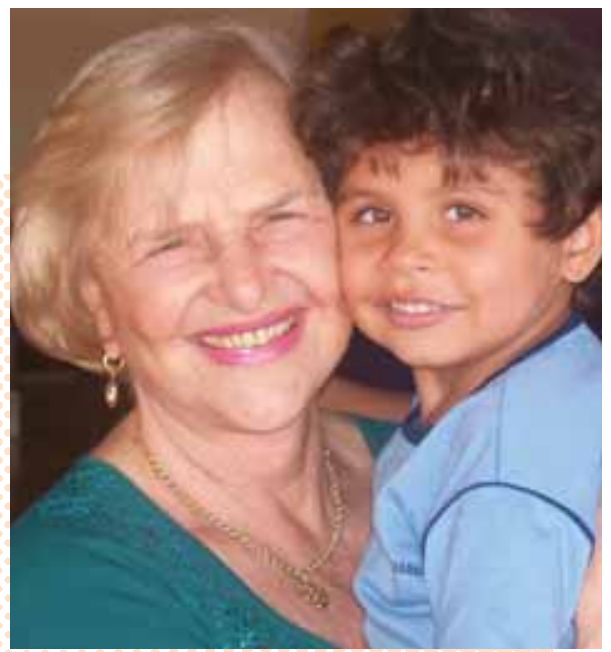

Dra. Zilda Arns Neumann Fundadora e Coordenadora Internacional da Pastoral da Criança. Coordenadora Nacional da Pastoral da Pessoa Idosa. Representante Titular da CNBB no Conselho Nacional de Saúde Conselheira do Conselho de Desenvolvimento Econômico e Social da Presidência da República.
Querido(a) Líder

Querido(a) Coordenador(a)

Paz e Bem!

É com muita alegria e esperança que lhe escrevo esta carta.

Como vai você? E como vai sua família?

Hoje, gostaria de trocar idéias sobre a Campanha da Fraternidade de 2009: "Fraternidade e Segurança Pública"

A Campanha da Fraternidade é um esforço de toda Igreja em favor da construção de uma sociedade mais justa e fraterna, a serviço da vida e da esperança, conforme aprendemos nos ensinamentos de Jesus. Vocês já repararam como a violência aumenta dia por dia? E não só a violência nas ruas, mas a violência no trânsito e, o que é muito triste, a violência doméstica. O que podemos fazer para mudar essa situação?

A Pastoral da Criança, desde já alguns anos, vem fazendo permanentemente a Campanha pela paz nas famílias. Certamente você já deve ter recebido aquele folheto com os "Dez Mandamentos para a Paz na Família”. É muito importante você ler estes Mandamentos junto com as famílias nas reuniões da comunidade, no Dia da Celebração da Vida. Oriente as famílias que em um lar em que existe amor, respeito, diálogo as crianças crescem mais saudáveis e felizes. Todos se sentem bem, porque a vida em harmonia reforça os laços de amor e torna a família mais forte e unida.

Quando participei da Reunião de Cúpula da ONU, em maio de 2002, como representante oficial do Brasil, a conclusão dos 180 países presentes foi que para construir a paz é preciso começar com a criança desde a gestação. Os primeiros anos de vida são os principais para que a criança adquira valores culturais e se transforme em semente de Paz.

"Felizes os que promovem a Paz"; talvez seja esse o segredo da Pastoral da Criança: milhares e milhares de líderes comunitários dizem que são tão felizes nesse trabalho cotidiano de fé e vida, em busca da transformação de suas comunidades.

Você sabia que todas as Campanhas da Fraternidade resultam em políticas públicas? Quem sabe essa Campanha gere transformações muito importantes na sociedade. Colabore. Participe você também com suas idéias, críticas e sugestões nos debates que surgirão na sua comunidade. Só assim poderemos diminuir a violência e construir um mundo melhor para todos.

Por hoje termino, enviando a você e a todas as famílias que você acompanha, o meu carinhoso e especial abraço.

Especial

\section{Dia da Pastoral da Criança}

\section{Em todos os estados do país, mais de 260 mil voluntários celebraram as ações de promoção da vida e da cidadania entre as famílias pobres. Em 2009, municípios da região da Transnordestina recebem atenção especial}

A Coordenação Nacional da Pastoral da Criança encerrou sua $14^{\mathrm{a}}$ Assembléia Anual, realizada em Curitiba, no dia 05 de dezembro, dia em que foi comemorado o Dia do Voluntariado e, desde 2007, também o Dia Nacional da Pastoral da Criança (lei no 11.583 , de 28/11/2007).

Entre as resoluções da $14^{\mathrm{a}}$ Assembléia da Pastoral da Criança estão a atenção ao desenvolvimento integral da criança, que além dos cuidados com a saúde e a educação, estende-se a outros aspectos como políticas públicas que priorizem a infância, a saúde bucal, o acesso à alimentação em quantidade e qualidade adequadas, as hortas caseiras, e o direito ao brincar, com o projeto Brinquedos e Brincadeiras.

Transnordestina - Em 2009, a Pastoral da Criança também dedicará atenção especial aos municípios da região Nordeste, que serão afetados pela construção da Ferrovia Transnordestina. A ferrovia irá ligar os portos de
Pecém (CE) e Suape (PE) ao cerrado do Piauí, no município de Eliseu Martins, com o objetivo de elevar a competitividade da produção agrícola e mineral da região. Porém, além dos benefícios para o desenvolvimento econômico, obras como essa trazem problemas sociais. A Pastoral da Criança contribuirá impulsionando as ações básicas de promoção da saúde e da cidadania entre as famílias empobrecidas da região através do trabalho dos Missionários Leigos da Pastoral da Criança. 


\section{A Cultura de Paz no Ambiente Familiar!}

Líder, como é do seu conhecimento, a atuação da Pastoral da Criança previne a violência no ambiente familiar. O tema da Campanha da fraternidade deste ano, Fraternidade e Segurança Pública, está em perfeita sintonia com um lema da Pastoral da Criança: a paz começa em casa! Por meio das visitas domiciliares, o líder conversa sobre o relacionamento dentro da família e previne a violência.

O primeiro passo para viver a Campanha da Fraternidade é pessoal. Jesus ensinou a amar o próximo como a si mesmo, isso significa que cada pessoa deve ter amor e cuidar bem de si para poder ajudar melhor o outro. Com mais auto-estima podemos conhecer o problema da violência ao nosso redor e aprender como prevenir a agressão no ambiente familiar, especialmente contra a criança, a mulher e o idoso.
Líder, neste período da Quaresma, faça o esforço de visitar todas as familias cadastradas e passe mais tempo com elas em suas casas. Além de acompanhar a criança, coloque-se à disposição para ouvir e ensinar práticas cotidianas de prevenção da violência e educação para a paz. Nestas visitas utilize os 10 mandamentos que estão na contra capa do Guia do Líder.

Neste mesmo período, convidamos as equipes de coordenação de Setor e de Ramo a convocar os Conselhos e os prefeitos dos seus municípios. Sugerimos que apresentem propostas e cobrem a execução de políticas públicas, por meio de cartas de compromisso ou reuniões, relacionadas aos direitos das crianças e adolescentes.

Entre os assuntos da convocação para a construção de uma Cultura de Paz podem ser incluídos os seguintes itens:
- O cumprimento do Estatuto da Criança e do Adolescente.

- O fortalecimento da participação e o controle social das políticas públicas, com ênfase na prevenção da violência.

- A Implantação de espaços de lazer nas comunidades.

- O Combate à exploração sexual e ao trabalho infantil.

- A capacitação dos policiais para desenvolver atividades de prevenção do crime e de proteção à população.

Juntos podemos prevenir a violência e construir ambientes de paz para todos!

\section{Reunião de Reflexão e Avaliação - Valorize e participe!}

Na Pastoral da Criança, a missão principal do líder é partilhar com amor o que aprende.

Por isso, precisa aprender sempre mais, para poder orientar as famílias nos cuidados com seus filhos e ajudá-las a construir um ambiente de amor e paz.

Para o líder, esse aprendizado pode acontecer em vários momentos na comunidade. Mas a Reunião para Reflexão e Avaliação é a melhor oportunidade!

Nessa reunião, além de preencher a FABS, os líderes podem discutir os resultados da FABS do mês, conversar melhor sobre a situação das famílias acompanhadas e animar-se com as soluções encontradas.

Para ajudar nessa reflexão, o método VER,
JULGAR, AGIR, AVALIAR e CELEBRAR, que está explicado no Guia do Líder 2007, é muito útil. Ele ajuda a organizar a reunião e a planejar ações mais concretas para ajudar as famílias a transformar suas realidades.

Como bom pastor, o líder conhece suas ovelhas e elas o conhecem. Por isso, as Reuniões para Reflexão e Avaliação devem acontecer na própria comunidade.

Ao refletir em conjunto com outros líderes, todos se fortalecem na missão evangelizadora e se apóiam uns aos outros "para que todas as crianças tenham vida, e a tenham em abundância”. (Jo 10,10).

Monica Flugel Hill Psicóloga

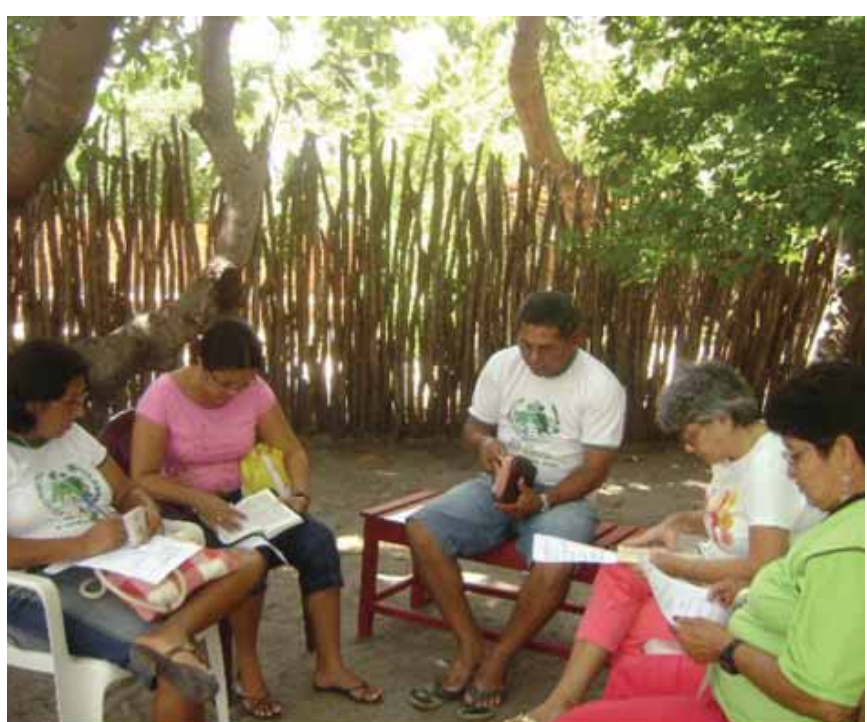

Reunião de Reflexão e Avaliação na Diocese de Parnaíba, Piauí. 


\section{Acompanhante no parto}

As gestantes têm direito a indicar um acompanhante para estar com ela durante o trabalho de parto, no parto e no início do pós-parto. É o que determina a Lei Federal número 11.108, de 7 de abril de 2005, que obriga os serviços de saúde públicos ou que atendam pelo SUS (Sistema Único de Saúde), a permitir a presença de um acompanhante junto da gestante ma hora do parto.

Segundo a Organização Mundial de Saúde, permitir que uma pessoa acompanhe a gestante no momento do parto traz muitos benefícios para a mulher: como diminuição do desgaste emocional, melhoria nas condições de amamentação, porque a mulher se sente mais segura e tranquila com alguém conhecido por perto.

A mulher que for impedida de ter garantido seu direito a um acompanhante durante o parto e o pós-parto em qualquer hospital público ou da rede do Sistema Único de Saúde deve comunicar o fato às autoridades para que as devidas providências sejam tomadas e a lei seja cumprida.
Toda a comunidade deve participar das decisões sobre a saúde das suas gestantes e se unir para que o Serviço de Sáude possa oferecer atendimento e um parto acolhedor. É a partir da participação de toda a comunidade, fazendo o controle social dos serviços de saúde, é que o SUS pode oferecer um verdadeiro atendimento humanizado e cada mulher ter seus direitos respeitados.

\section{Fé e Vida}

\section{Amor solidário}

Amigos e amigas, uma das características do tempo em que estamos vivendo hoje é a diversidade. E aquilo que mais fere a diversidade é o preconceito. Às vezes, nós dizemos que não temos preconceito, mas no fundo temos atitudes que revelam o preconceito que está escondido dentro de nós. Isso se dá quando nós olhamos com diferença para as pessoas que são diferentes de nós, pior ainda quando nós olhamos diferente para as pessoas que são portadoras de alguma enfermidade, de alguma doença. Precisamos quebrar o preconceito e a melhor forma de romper com o preconceito, é o amor que se faz solidário. Deus se fez solidário com a humanidade inteira e quando nós olhamos a prática de Jesus, que é Deus feito homem, vemos que Ele conviveu com os doentes, com os aflitos, com os empobrecidos, com os sofredores, se aproximou deles, tocou, coisa que naquela época era quase vista como um pecado. Jesus não teve nenhuma forma de preconceito. Se nós somos discípulos Dele precisamos quebrar todas as formas de preconceito para que o amor de Deus se revele no rosto de todos, também no rosto daqueles que sofrem e trazem a marca da enfermidade.

Padre Angelo Carlesso Assessor da Pastoral da Criança

\section{Diálogo}

\section{A vela}

"Vós sois a luz do mundo", disse Jesus. Quando Jesus Cristo designou seus discípulos como sendo a luz do mundo, deu-lhes uma grande tarefa: iluminar os caminhos, afastar as trevas e salvar vidas. E para fazer isso, é necessário energia, amor. A chama da candeia gasta o óleo do pavil. Cristão sem espírito de sacrifício, é lâmpada morta. Uma imagem que pode verdadeiramente explicar o sentido de quem ama o próximo é a vela. A vela quando não é acesa, ela pode até ser bonita, mas não serve para nada. Para ela poder desempenhar o seu serviço, é preciso que se acenda e quando se acende ela se derrete, mas aí ela ilumina, aí ela se torna útil, aí ela brilha, aí ela se torna luz. Assim é o líder da Pastoral da Criança, uma luz que fundamenta seu apostolado missionário no amor. Quantas lágrimas enxuga, quantas famílias consola, quantas pessoas aproxima de Deus com sua palavra amiga e de fé! São muitos os casos que cada líder acompanhou e iluminou. A claridade é segurança, discernimento, esperança e alegria. Pensando nisso, se você ainda não encontrou um sentido para a sua vida, disponha-se, doe um pouco de você a quem precisa e dando um pouco de você para o crescimento e o bem de toda a comunidade, você vai ser muito mais feliz. Busque o irmão e você no irmão encontrará a Deus. 


\section{A adolescente grávida tem direito ao estudo!}

Lider, você certamente conhece jovens que engravidaram muito cedo. No Brasil, segundo o Ministério da Saúde, a cada cinco crianças que nascem, uma tem a mãe com menos de 20 anos de idade. Normalmente, estas jovens tem atividade sexual precoce, vivem em áreas pobres e com pouca atenção durante o prénatal. A situação pode gerar o nascimento de crianças com baixo peso, mortalidade neonatal (primeiros 28 dias de vida) e infantil (menores de um ano). Na adolescência, o corpo da mulher não está totalmente preparado para gerar um filho, o que exige mais cuidados com relação à saúde. Além disso, as adolescentes sofrem com a insegurança no que se refere às responsabilidades da maternidade.

Uma das consequências desta gravidez é o abandono da escola, além da adolescente sofrer com a descriminação de colegas, familiares, o medo e a vergonha. Como sabemos, quanto mais anos de estudo a mãe tem, menores são os índices de mortalidade infantil e doenças dos filhos.

Precisamos enfrentar esta situação e proteger a mãe e a criança. Um bom começo é garantir as condições para a permanência da estudante na escola durante a gestação e após o parto. A licença maternidade escolar está prevista na Lei no 6.202, de 17 de abril de 1975. Está escrito na lei que "a partir do oitavo mês de gestação e durante três meses, a estudante em estado de gravidez ficará assistida pelo regime de exercícios domiciliares instituído pelo Decreto-lei no 1.044, de 21 de outubro de 1969. E "em casos excepcionais, devidamente comprovados mediante atestado médico, poderá ser aumentado o período de repouso, antes e depois do parto. Em qualquer caso, é assegurado às estudantes em estado de gravidez o direito à prestação dos exames finais."

Líder, fique próximo da gestante adolescente, oriente sobre o pré-natal, incentive a estudar, e converse sobre as responsabilidades e cuidados na gravidez. Leve esse assunto para outras lideranças e articuladores da Pastoral da Criança. Juntos procurem a prefeitura com propostas de ação que envolvam as áreas da saúde, educação, cultura e lazer para diminuir o número de adolescentes grávidas, melhorar a auto-estima dos jovens e garantir o acesso à educação.

Clóvis Boufleur Márcia Mamede

\section{Vigilância das prioridades em 2009}

Prezada Líder, como cidadãos e cidadãs voluntários e integrantes dos conselhos, as pessoas ligadas à Pastoral da Criança devem priorizar a discussão e o acompanhamento de políticas públicas que garantam o direito à vida, à saúde, à educação, à alimentação e o exercício da cidadania.

Nossas prioridades para 2009 estão voltadas para o acompanhamento das propostas apresentadas pela Pastoral da Criança como compromissos para os candidatos a prefeito, vice-prefeitos e vereadores, nas últimas eleições. Devemos dar continuidade ao trabalho e ver como vão acontecer as políticas públicas direcionadas à infância. Destacamos algumas destas prioridades:
- atendimento com qualidade às gestantes;

- atividades de prevenção e medicamentos para as crianças na hora e no local adequados;

- acesso à certidão de nascimento ;

- erradicação do analfabetismo;

- cultura, esporte e lazer para todas as crianças e adolescentes;

- locais seguros para as crianças brincarem;

- melhoria da qualidade de ensino desde a primeira infância;

- atividades de combate ao desperdício de alimentos;

- organização de hortas domésticas e pomares.
Juntos somos mais fortes para acompanhar e fiscalizar as políticas públicas. Esperamos que o resultado desse esforço seja o acesso com atendimento de qualidade para a população, especialmente nossos idosos, gestantes e crianças.

Clóvis Boufleur Gestor de Relações Institucionais da Pastoral da Criança 


\section{Caçador • Santa Catarina}

\section{Atividades}

$\mathrm{Na}$ diocese de Caçador buscamos, com atividades promovidas pela Pastoral da Criança, reduzir a mortalidade infantil e materna, também a desnutrição e a violência. Ao mesmo tempo, buscamos favorecer o desenvolvimento integral das crianças desde a sua concepção, no seu contexto familiar e comunitário.

No dia 13 de dezembro de 2008, aconteceu a assembleia eletiva paroquial na Paróquia Santa Cruz de Canoinhas, com a participação de todas os líderes das comunidades e equipe da Coordenação de Setor, sendo que a autoridade eclasiástica responsável pela paróquia, Padre Remigio Sita, ratificou Marli dos Santos como coordenadora do Ramo. Nesse encontro, tivemos um momento de mística e espiritualidade, reflexão e avaliação da caminhada e troca de experiências. O encontro encerrou com uma confraternização entre os participantes. (Colaboração: Irmã Rejane Gricoleto.)

\section{Outra notícia}

Nos dias 18 e 19 de outubro de 2008 aconteceu a assembleia do Setor de Caçador

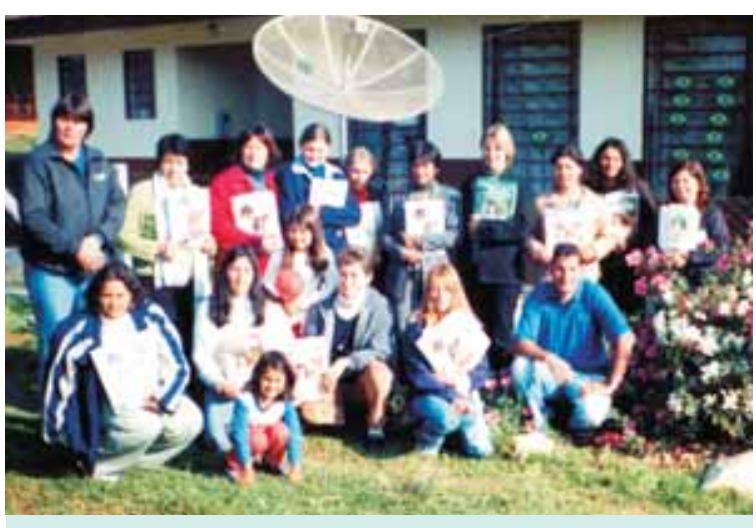

Assembléia da Pastoral da Criança.

- Santa Catarina. A Assembléia contou com a presença da coordenadora de núcleo, Mirialva, Salete, Padre Rogério Esmeraldino, os coordenadores de Ramo e de área e os capacitadores. Foi um momento forte de mística e espiritualidade. Com alegria e motivação, todos participaram da dinâmica apresentada pela capacitadora Cleuza trazendo presente como centro de tudo Deus e a família. O momento propiciou aos coordenadores de Ramo apresentarem os esforços realizados, as conquistas e dificuldades encontradas durante a caminhada de 2008.
Rio de Janeiro - Arquidiocese Rio de Janeiro

\section{Comemoração}

A Pastoral da Criança teve presença significativa em duas festas de final de ano. Engenho de Dentro e Penha acolheram as crianças para festejar. Uma festa aconteceu na Paróquia Imaculada Conceição e São Sebastião do Engenho de Dentro. Com 430 crianças inscritas, a festa teve início às 9 horas com animação do grupo de teatro da paróquia, chamado Cativarte.

Todas as crianças receberam um brinquedo, uma roupa e um calçado. Enquanto as crianças se divertiam, os pais recebiam orientações da Pastoral da Criança sobre alimentação e desnutrição e uma dentista esclarecia sobre os cuidados com a dentição infantil.

A Paróquia Nossa Senhora Aparecida, que fica no Conjunto Marcílio Dias, na Penha Circular, fez uma festa natalina para 500 crianças carentes e gestantes. Acompanhadas pela Pastoral da Criança e pela Conferência Vicentina todas essas crianças receberam um kit completo de roupas, calçados, objetos de higiene e brinquedos. A confraternização natalina contou ainda com momentos de evangelização através do teatro, mostrando o verdadeiro sentido do Natal.

\section{Duque de Caxias • Rio de Janeiro-}

\section{Encontro de líderes}

No dia 25 de Fevereiro de 2009 aconteceu a primeira reunião do ano dos líderes da Pastoral da Criança, no Salão Paroquial da Paróquia São Luiz Gonzaga. O encontro reuniu as líderes do Ramo 3, que inclui as Vilas Marcos, Duque de Caxias, Trinta, Flores, Trevo e Vila Mário. No mesmo dia, aconteceu também o Encontro com as líderes do Ramo 1, correspondentes às vilas Harmonia, Paz, Jauri, Loureiro, Auxiliadora, Ferrari e Vila União. Com as líderes estava presente a Coordenadora Diocesana, Marli.
Curitiba - Noroeste • Paraná

\section{Promoção da mulher}

A Pastoral da Criança da área de Almirante Tamandaré, que reúne as paróquias Anjo da Guarda, Santa Gema Galgani, Nossa Senhora da Conceição e Santa Ana, decidiu organizar uma Feira da Mulher e da Criança, em comemoração ao Dia da Mulher. A Feira aconteceu no dia 06 de março e abordou temas de saúde, alimentação saudável e desenvolvimento infantil. Os líderes, além de orientar os visitantes da Feira sobre como melhorar a alimentação do dia-adia com sucos naturais, hortas caseiras e aproveitamento total dos alimentos, repassaram informações importantes sobre a hanseníase e a tuberculose. A população foi informada sobre a importância de detectar precocemente os casos dessas doenças, o encaminhamento ao Serviço de Saúde e o tratamento que não pode ser abandonado até ser constatada a cura.

O Setor Noroeste está também intensificando a capacitação de novos líderes para atender a outras comunidades carentes da região.

Colaboração: Coordenação do Setor. 


\section{Coari • Amazonas}

\section{Implantação}

Gostaríamos de compartilhar nossa alegria com todos, pois estamos felizes por implantar a Pastoral da Criança em mais duas comunidades de nosso município de Beruri, que faz parte do Setor Prelazia de Coari - Amazonas.

Devido a nossa região ser de uma área geográfica muito extensa e de difícil acesso, para nós essa foi uma grande conquista da Pastoral da Criança. E em junho de 2008, começamos a implantar a Pastoral no interior do nosso município, ou seja, na zona rural - Arumã, que fica a 16 horas de viagem de barco longe da cidade e, em dezembro de 2008, foi realizada a primeira pesagem das crianças daquela localidade.

Esse foi apenas mais um passo dos muitos que virão se Deus assim nos permitir.

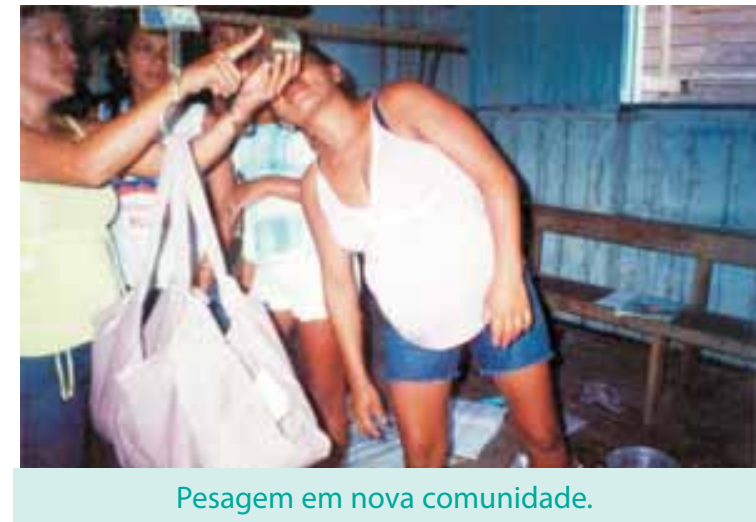

Só temos a agradecer a Deus e a todos que nos apóiam e em especial a coordenadora diocesana da Prelazia de Coari, Maria Cleunice.

Colaboração:Abigair Marinho e Marlene Lopes. coordenadoras do ramo Nossa Senhora de Nazaré de Beruri -

Juazeiro • Bahia

\section{Feira da Saúde}

Com o objetivo de Comemorar o Dia Internacional da Mulher, chamar atenção da Comunidade para o tratamento de algumas doenças e também orientar as famílias da importância da alimentação saudável, a Pastoral da Criança do Ramo Santo Antonio, juntamente com a Pastoral da Mulher Marginalizada e Pastoral da Saúde realizaram no dia 08 de Março uma Feira de Saúde.

No decorrer da feira os participantes puderam encontrar: Alimentos saudáveis, juntamente com a receita; artesanato; pesagem das crianças de zero a seis anos de idade; acompanhamento de gestantes; e medida da pressão arterial. Além disso, aconteceu uma palestra ministrada pela Enfermeira e Obstreta Eliana da Cruz, sobre Câncer do Colo do Útero e da Mama. Eliana fez uma explanação sobre o que é câncer e quais as conseqüências que pode causar,

além de orientar sobre a importância dos exames preventivos.

Este evento contou com a organização das três Pastorais envolvidas e com o apoio da Paróquia Santo Antônio, Secretaria Municipal de Saúde, Prefeitura Municipal e do PAFIR que é um plano de Assistência Familiar.

\section{Jaboticabal • São Paulo}

\section{Dedicação}

O núcleo da Pastoral da Criança da Comunidade de Santo Agostinho, da Paróquia Santa Teresa de Jesus, em Luzitânia, preocupase, todos os meses, em acompanhar as crianças cadastradas segundo a metodologia própria da Pastoral da Criança. Com muito interesse e dedicação da parte de seus líderes e membros e com auxílio dos líderes da Comunidade Matriz Santa Teresa, é possível sempre organizar muitas coisas bonitas em favor das crianças.

Paróquia Santa Teresa de Jesus - Jaboticabal SP

\section{Itapetininga • São Paulo}

\section{Comemoração}

A comunidade Bom Pastor da Vila Labrunnetti, Paróquia Nossa Senhora dos Prazeres, Itapetininga, São Paulo, comemorou no dia 22 de dezembro de 2008 um Natal cheio de alegria e encantamento. "Natal sem criança não tem graça" e "criança sem natal tem menor graça ainda”. A Pastoral da Criança caprichou na festa. As líderes Elizabeth, Francisca, Giovana e Tatiana agradecem a comunidade e a boutique Karina que doou os brinquedos para as crianças. Natal sempre é época de confraternização e a Pastoral da Criança se alegra em comemorar junto esse momento especial com as famílias.

\section{Campinas • São Paulo}

\section{Comunidade em festa}

A comunidade São Benedito da Paróquia Santa Luzia, de Hortolândia, realizou uma Celebração da Vida, com festa de natal e entrega dos diplomas para as crianças que completaram seis anos. Foram entregues 20 diplomas. Agradecemos a Deus por mais essa tarefa cumprida e pedimos a Ele que nos anime e nos dê coragem sempre. 


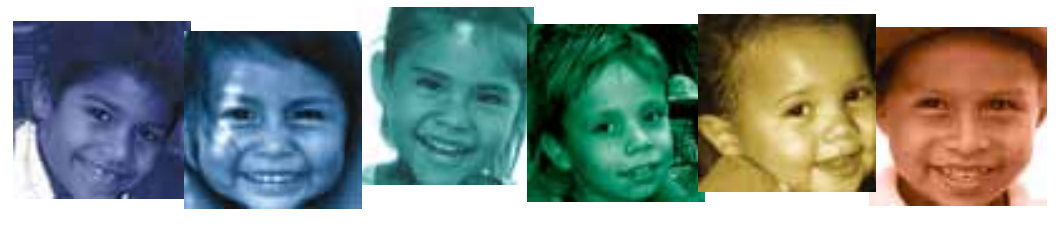

\section{Pastoral da Criança \\ Ano XIX • No 151 • Junho/2009}

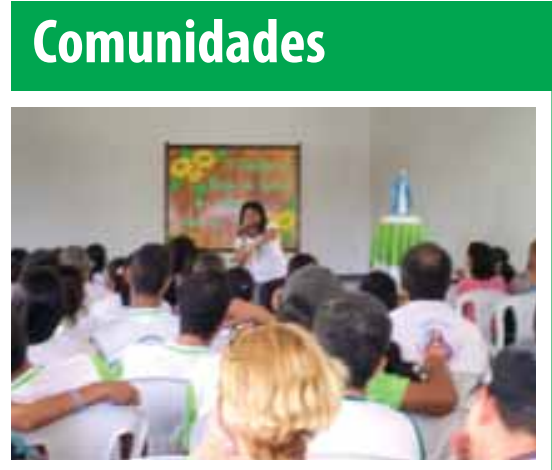

Leia mais sobre 0 grande

encontro de líderes promovido

pelo Setor Uruaçu, Goiás.

página 06

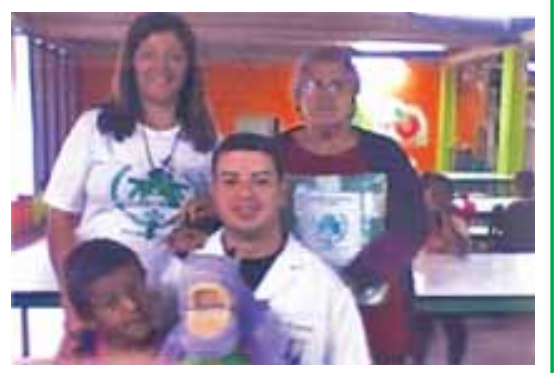

Acompanhe 0 trabalho

realizado pelos voluntários do

Setor Juiz de Fora, Minas Gerais.

página 09

\section{Aprendendo Mais \\ Viva Santo Antônio, São Pedro e São João} Saiba como organizar algumas

brincadeiras juninas em sua comunidade.

página 13

Solidariedade Samaritana

Leia como podemos viver a

solidariedade em nossas comunidades.

página 14
Jornal
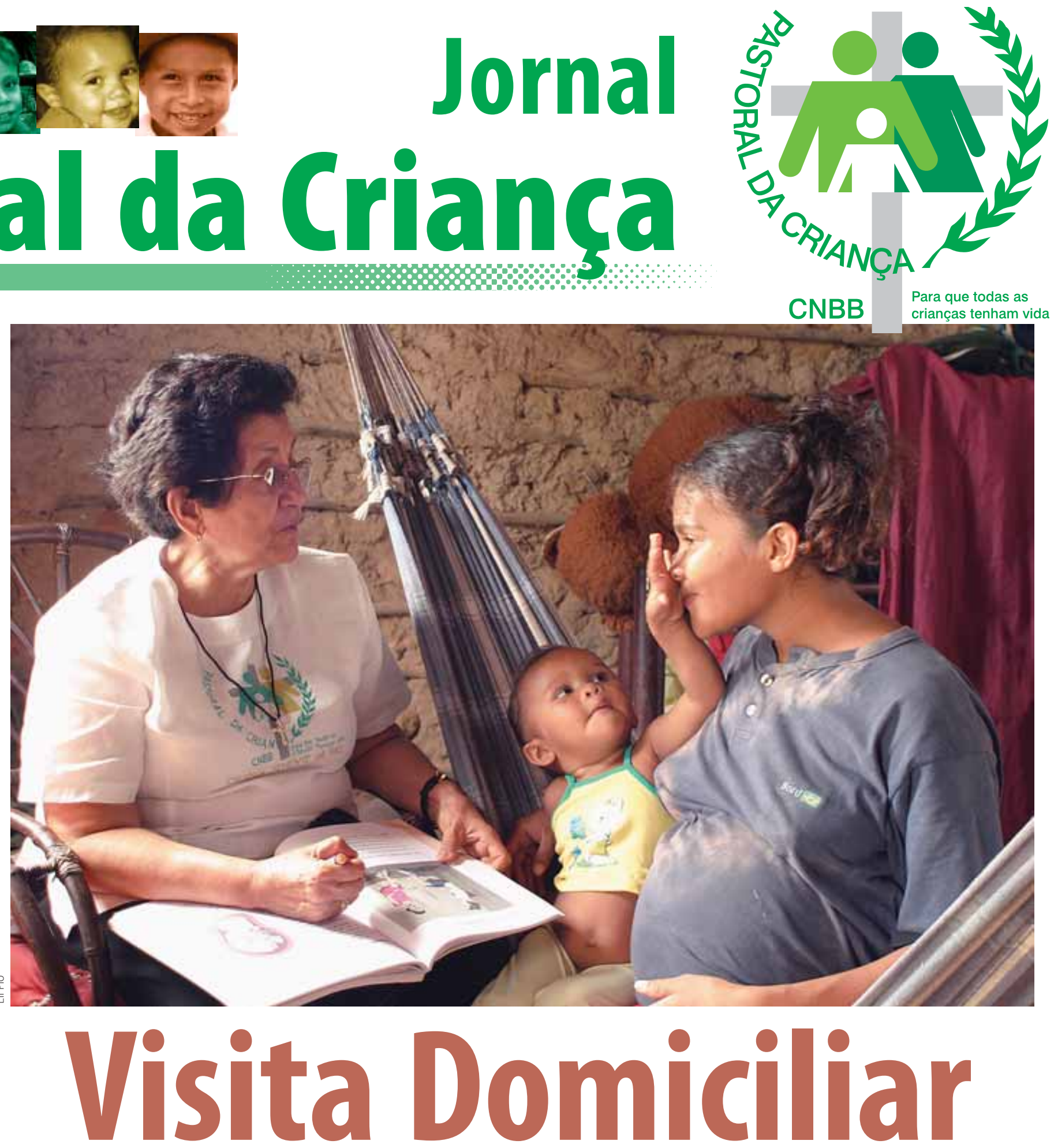

\section{A visita domiciliar é um momento especial de encontro do líder com as famílias.}

\section{Bebês devem dormir de barriga para cima}

Até completar um ano de idade o bebê deve ser colocado para dormir de barriga para cima. Isso reduz a chance do bebê morrer por morte súbita ou morte do berço. Leia mais na página 09. 